UNIVERSIDAD DE SALAMANCA

FACULTAD DE DERECHO

DEPARTAMENTO DE DERECHO PÚBLICO GENERAL

PROGRAMA DE DOCTORADO ADMINISTRACIÓN, HACIENDA Y JUSTICIA

EN EL ESTADO SOCIAL

TESIS DOCTORAL

\title{
DERECHO ADMINISTRATIVO ECONÓMICO Y DE LAS FINANZAS PÚBLICAS EN LOS MODELOS POLÍTICOS Y ECONÓMICOS DE ECUADOR (1990 - 2017)
}

$\mathrm{V}^{\mathrm{o}} \mathrm{B}^{\mathrm{o}}$

ELABORADA POR: VÍCTOR GRANDA AGUILAR

DIRIGIDA POR:

PROFESOR DOCTOR: RICARDO RIVERO ORTEGA

SALAMANCA 2018

Fdo.: Dr. Ricardo Rivero Ortega 


\section{AGRADECIMIENTOS}

Expreso mis agradecimientos a todos quienes han colaborado generosamente para la elaboración de este trabajo de investigación, que recoge $\mathrm{mi}$ experiencia docente $\mathrm{y}$ mis reflexiones sobre las modificaciones y transformaciones en la Constitución económica y en el derecho administrativo y de las finanzas públicas de Ecuador, en el contexto de la globalización y de los modelos y políticas económicas adoptados para la reproducción del sistema capitalista entre 1990 y 2017.

Mi gratitud cordial para los profesores y amigos de la centenaria Universidad de Salamanca, en especial al director de la tesis y Rector Ricardo Rivero Ortega por sus valiosas observaciones y sugerencias y a Lorenzo Bujosa Vadell por su permanente cordialidad en la dirección del programa doctoral “Administración, Hacienda y Justicia en el Estado Social”.

Gracias a la Universidad Andina Simón Bolívar sede Ecuador en la persona de su Rector César Montaño y del Director del Área de Derecho Ramiro Ávila; al fondo de investigaciones que auspició la elaboración de los capítulos sobre derecho de control y de las finanzas públicas y a los colegas del área por su constante estímulo en la culminación de este trabajo.

Mi reconocimiento permanente para Hilda Díaz y otros colaboradores directos en mis distintas actividades universitarias, a mi esposa y compañera Silvia Vega y a mis hijos Paúl, Gabriela, Daniel, y en especial a María Paula, por su comprensión, sugerencias y afectuoso apoyo.

Quito, 21 de junio de 2018.

Víctor Granda Aguilar. 
ÍNDICE

INTRODUCCIÓN 1

CAPÍTULO I: LA GLOBALIZACIÓN CAPITALISTA, LOS MODELOS Y POLÍTICAS ECONÓMICAS Y LAS TRANSFORMACIONES EN EL DERECHO 19

1. LA GLOBALIZACIÓN CAPITALISTA (1990-2017) 19

2. POLÍTICAS Y MODELOS ECONÓMICOS EN LA GLOBALIZACIÓN ACTUAL 33

3. LOS ORGANISMOS FINANCIEROS INTERNACIONALES Y LA

INCIDENCIA EN LOS MODELOS O POLITÍCAS ECONÓMICAS 54

4. TRANSFORMACIONES EN EL DERECHO PÚBLICO, EL DERECHO ADMINISTRATIVO ECONÓMICO, FINANCIERO Y DE CONTROL 66

CAPITULO II: LA CONSTITUCIÓN ECONÓMICA-FINANCIERA Y LOS MODELOS ECONÓMICOS Y POLÍTICOS EN ECUADOR (1990-2017)

1. LA CONSTITUCIÓN ECONÓMICA Y EL CONTENIDO ECONÓMICO Y FINANCIERO DE LA CONSTITUCIÓN 85

2. LOS CONTENIDOS ECONÓMICOS Y FINANCIEROS DE LAS CONSTITUCIONES EN ECUADOR HASTA 1998 97

3. LAS CONSTITUCIONES DE 1998 Y 2008 103

3.1. La Constitución de 1998 104

3.2. La Constitución de 2008 y las enmiendas de 2015 110

3.2.1. El contenido económico y financiero de la Constitución 2008. 112

a) El régimen de desarrollo y el sistema económico 113

b) El papel o función del Estado en la economía 119

c) La soberanía en las políticas y finanzas públicas. 123

d) Autoritarismo e hiperpresidencialismo 129

3.2.2. Las enmiendas constitucionales de 2015 132

CAPÍTULO III: LAS TRANSFORMACIONES EN LA HACIENDA PÚBLICA ECUATORIANA Y EN LA LEGISLACIÓN FINANCIERA Y TRIBUTARIA ACTUAL 136

1. EL DERECHO DE LA HACIENDA PÚBLICA O DERECHO FINANCIERO PÚBLICO EN LA HISTORIA Y LOS MODELOS ECONÓMICOS Y POLÍTICOS DE ECUADOR. 136

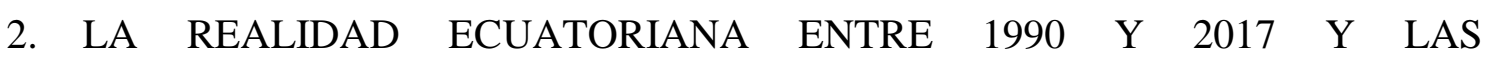
TRANSFORMACIONES EN EL DERECHO FINANCIERO PÚBLICO Y DE LAS INSTITUCIONES FINANCIERAS 156

3. EL DERECHO FINANCIERO VIGENTE SOBRE GASTOS E INGRESOS PUBLICOS, ESPECIALMENTE TRIBUTARIOS 173 
CAPITULO IV: EL DERECHO DE LOS INGRESOS TRIBUTARIOS EN LOS MODELOS ECONÓMICOS DE ECUADOR ENTRE 1990 - 2017 .................... 188

1. PANORAMA HISTÓRICO DEL DERECHO TRIBUTARIO EN ECUADOR..... 188

2. LOS PRINCIPIOS DOCTRINARIOS, CONSTITUCIONALES Y LEGALES

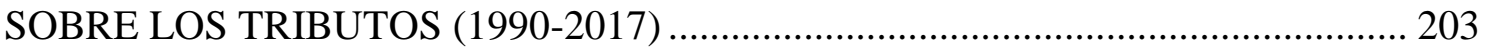

2.1. El principio de legalidad y de seguridad jurídica ............................................... 206

2.2. El principio de justicia tributaria y capacidad económica contributiva ................ 212

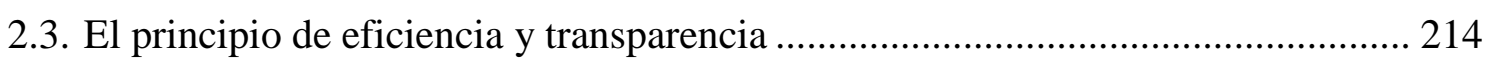

3. LA POTESTAD Y LA ADMINISTRACION TRIBUTARIA EN EL ECUADOR 216

4. RESOLUCIONES Y FACULTADES DE LAS ADMINISTRACIONES

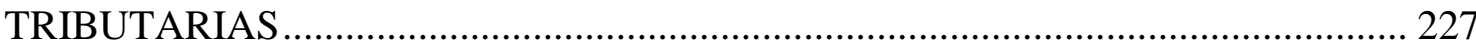

5. PROCEDIMIENTO ADMINISTRATIVO Y CONTENCIOSO - TRIBUTARIO. 233

6. EL DERECHO Y LA LEGISLACIÓN TRIBUTARIOS EN ECUADOR (19902017).

7. CONTENIDO Y PROYECCIONES DE LA REFORMA Y TRANSFORMACIÓN TRIBUTARIA EN EL MODELO ECONÓMICO ACTUAL (2007-2017) 242

CAPITULO V: EL DERECHO DEL GASTO Y DEL PRESUPUESTO EN ECUADOR ENTRE 1990-2016 Y ENTRE 2007-2017 …................................. 255

1. DERECHO DEL GASTO Y DERECHO PRESUPUESTARIO......................... 255

2. EL PRESUPUESTO Y EL GASTO EN LA HISTORIA Y EN LOS MODELOS

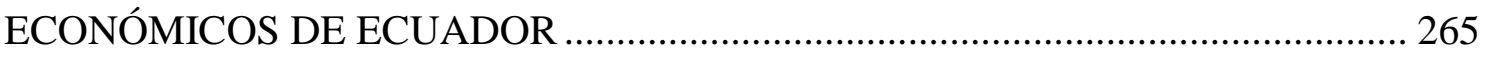

3. LOS PRINCIPIOS CONSTITUCIONALES, LEGALES Y DOCTRINARIOS SOBRE EL GASTO Y EL PRESUPUESTO ENTRE 1990 y 2017 ............................ 276

4. NORMATIVA CONSTITUCIONAL Y LEGAL SOBRE EL GASTO Y EL PRESUPUESTO EN EL PERIODO NEOLIBERAL 1990-2005 Y EN EL

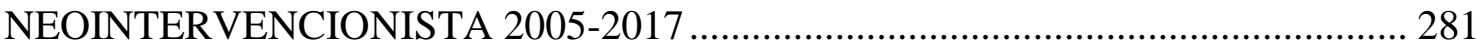

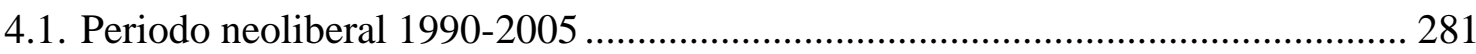

4.2. Etapa neointervencionista: 2005-2017 ….......................................................... 287

CAPÍTULO VI: PLANIFICACIÓNY DERECHO DE LAS FINANZAS PÚBLICAS EN LAS POLÍTICAS Y MODELOS ECONÓMICOS DE ECUADOR (1990-2017)

300

1. LA PLANIFICACIÓN, SU NATURALEZA JURÍDICA Y SU CONTEXTO

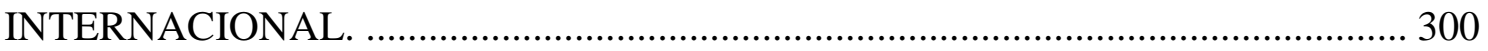

2. LA PLANIFICACIÓN: SU PROCESO HISTORICO Y LEGISLACIÓN EN

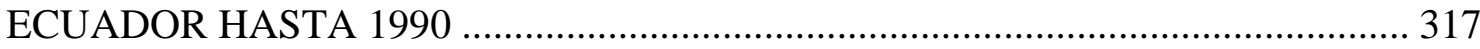

3. LA PLANIFICACIÓN EN LAS NORMAS CONSTITUCIONALES Y LEGALES

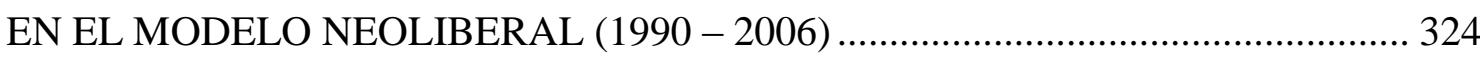

4. LA PLANIFICACIÓN EN LAS NORMAS CONSTITUCIONALES Y LEGALES EN EL MODELO NEOINTERVENCIONISTA Y NEODESARROLLISTA (2006 -

2017). 333 
CAPITULO VII: EL DERECHO DE CONTROL Y SU RELACIÓN CON LAS MODIFICACIONES CONSTITUCIONALES Y JURÍDICAS EN LOS MODELOS POLÍTICOS Y ECONÓMICOS EN ECUADOR (1990-2015).......... 344

1. LOS MODELOS ECONÓMICOS Y LAS CATEGORÍAS DE CONTROL Y

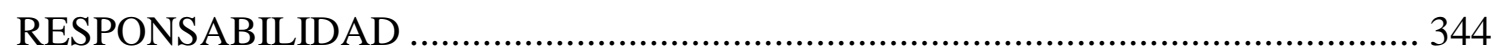

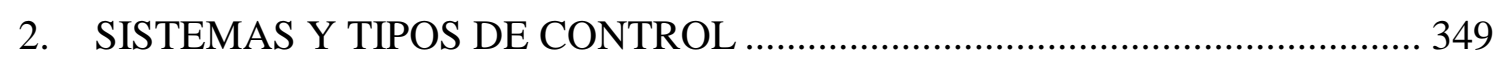

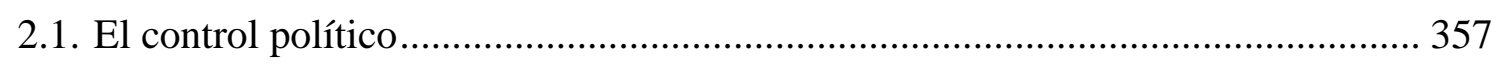

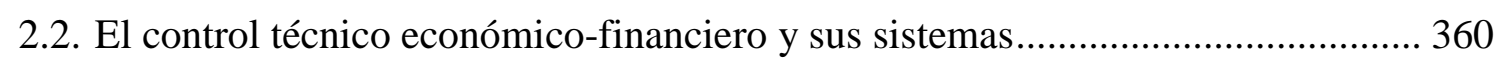

2.2.1.Sistema pluripersonal (o europeo) de Tribunal de Cuentas................................. 362

2.2.2. Sistema externo unipersonal de evaluación y auditoría o Contraloría. ................. 366

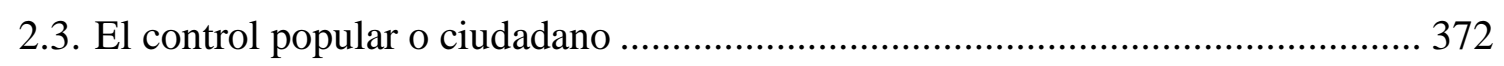

3. EL CONTROL EN LAS CONSTITUCIONES Y EN LA LEGISLACIÓN DE ECUADOR EN LOS MODELOS ECONÓMICOS (1990-2017) .............................. 377

3.1. El control en la transición al modelo neoliberal 1990-1998 ................................ 379

3.2. El control en la Constitución y la legislación de 1998-2007.................................. 386

3.3. El control en la Constitución y la legislación de 2008 - 2017 .............................. 402

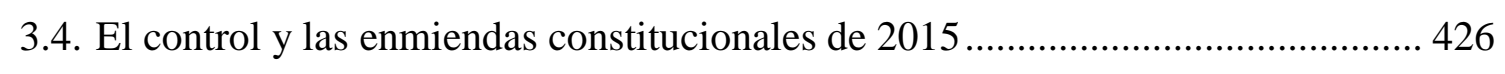

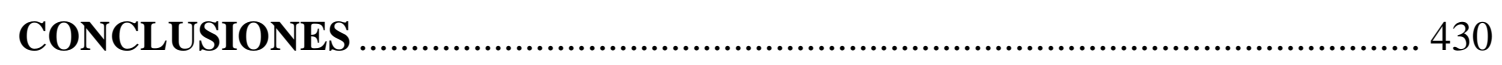

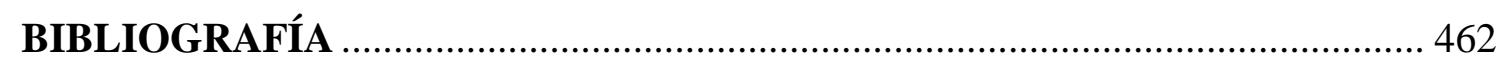




\section{INTRODUCCIÓN}

El presente trabajo desarrolla una investigación sobre los aspectos más sobresalientes de los cambios, transformaciones y perspectivas en las normas administrativas económicas y financieras, que regulan la Hacienda o las finanzas públicas de Ecuador en casi tres décadas (1990-2017). El estudio está fundamentado en la Constitución económicafinanciera y en el proceso de articulación de la economía nacional al sistema capitalista mundial, mediante la aplicación de los modelos o políticas públicas neoliberales y neointervencionistas.

Esta investigación evidenciará, en el contexto de la globalización capitalista y de la creciente hegemonía del capital financiero, la incidencia en el ámbito jurídico no solo de los fenómenos económicos transnacionales y de los poderos intereses a ellos vinculados, sino también los de los grupos de poder local y de los gobiernos y expresiones políticas que los representan.

Los grandes intereses transnacionales que se imponen a los países dependientes y a sus estados y gobiernos, entre ellos al del Ecuador, por medio de regulaciones administrativas y financieras, aparentemente informales, provenientes de los organismos multilaterales (FMI, BM, BID) y aún privados, han sido, para ese propósito, adecuadas, desconocidas, negociadas, sustituidas o convenientemente "interpretadas", pues se encuentran frecuentemente al margen o en contradicción con lo dispuesto en las normas de las constituciones nacionales.

El tema de las transformaciones administrativas y financieras a las que nos referiremos tiene enorme trascendencia y gran utilidad académica e interpretativa, pues hoy en día, el Estado de cualquier país adopta bajo cualquiera de sus formas un evidente protagonismo fiscal con la finalidad de ejercer sus potestades financieras -en cuanto ingresos, gastos, crédito- y las de planificación y control, como instrumentos principales de asignación de recursos, regulación e impulso al desarrollo, para cumplir con su papel en las coyunturas económicas internacionales y alcanzar los fines establecidos en la Constitución y en el pacto social que ella representa. Además, la actividad financiera pública y las regulaciones y decisiones internacionales y locales al respecto, inciden directamente en la formación, ampliación y distribución del producto interno bruto, marcan la orientación y contenido de todas las políticas públicas de los Estados y expresan las diversas modalidades de articulación de las economías nacionales o regionales al sistema mundial.

En este período el sistema económico y político ha transitado por diversos momentos o etapas, también denominados modelos que inspiran políticas públicas, formuladas y articuladas a la globalización capitalista y a los intereses dominantes externos, que luego se imbrican con los de los grupos de poder nacional, pero en cuya adopción o sustitución participan a la vez tanto los tradicionales y nuevos actores sociales 
dominantes como los populares, que luchan por satisfacer sus derechos o para mantenerlos, ampliarlos o evitar su disminución o deterioro.

Esos cambios, transformaciones e innovaciones se inscriben en un inestable sistema constitucional y jurídico local, por un renovado y constantemente quebrantado pacto social entre sectores del poder dominante y los que representan a grupos sociales dominados y alternativos. Con su movilización y lucha introdujeron en las constituciones regionales y en la actualmente vigente en Ecuador todo el elenco universal de derechos y garantías, incluyendo los innovadores de plurinacionalidad y de la naturaleza, pero no alcanzaron transformaciones institucionales que trastoquen la estructura de poder vigente. ${ }^{1}$ Los movimientos sociales se utilizaron por los nuevos grupos de poder económico y político progresistas, para consolidar o estabilizar el sistema económico y social vigente, pero los contenidos alternativos en las nuevas constituciones, bien podrían ser un instrumento inicial para una acumulación de fuerzas e impulsar la construcción de un nuevo orden económico y social.

Las prácticas cambiantes de los organismos internacionales y del nuevo ordenamiento jurídico internacional se ha constituido también en un precedente habitual para que el mismo comportamiento inveterado de irrespeto al derecho y a la jerarquía de las normas constitucionales, de acuerdo a los intereses hegemónicos, se adopte a nivel interno en el ordenamiento jurídico nacional por parte de los grupos de poder político y económico, en desmedro de los derechos conquistados por los sectores sociales mayoritarios que respaldaron los textos constituyentes y que, frente a su constante irrespeto o tergiversación, se movilizan constantemente, en la actualidad, para exigir su cumplimiento o su ampliación y beneficiar a la mayoría de la población. ${ }^{2}$

Las etapas o modelos económicos implementados en las últimas décadas y en varios países, entre ellos Ecuador, son: el estatismo o desarrollismo hasta 1990; el neoliberalismo o políticas neo competitivas hasta 2006 y el neo estatismo o neo keynesianismo o neodesarrollismo hasta la actualidad. Las medidas o políticas públicas de estos modelos y en especial los dos últimos, no son radicalmente opuestas y se encuentran debidamente combinadas o priorizadas, según las circunstancias de la realidad. Todos los modelos y políticas referidos fueron y son impulsados u observados por los organismos económicos internacionales, en asocio con las empresas transnacionales, especialmente financieras, y adoptados luego, con las debidas modificaciones, por los grupos económicos y políticos dominantes de cada país conforme a sus intereses.

Pero también, en la sustitución, modificación y combinación última de los modelos económicos y políticas públicas indicados, desempeñaron un importante papel la

\footnotetext{
${ }^{1}$ Roberto Gargarella, Pensando sobre la Reforma Constitucional en América Latina, en El derecho en América Latina, César Rodríguez Garabito, coordinador, (Buenos Aires: Siglo Veintiuno Editores, 2011).

${ }^{2}$ Víctor Granda Aguilar, Contenido económico de las Constituciones de Bolivia y Ecuador, (Quito: Ediciones Legales EDLE, Universidad Andina Simón Bolívar sede Ecuador, 2015).
} 
resistencia social y la lucha social y popular que han estado presentes en el proceso de reclamar sus derechos o denunciar la utilización de las políticas públicas económicas y financieras para satisfacer los intereses rentistas de los grupos de poder externos e internos, sin que puedan formular o articular propuestas e iniciativas alternativas. Tampoco se ha podido sumar a ellas la emergencia política y social de nuevos grupos económicos medios y tecnoburocráticos, conducidos por líderes populistas para la restructuración autoritaria del capitalismo local y regional, con visos aparentemente democráticos o sociales y redistributivos, en el contexto de la integración regional y de las renovadas crisis que enfrenta el sistema mundial.

El ejercicio del poder político por parte de las élites tradicionales y de las nuevas, con el respaldo institucional de la fuerza pública para desarrollar los modelos económicos indicados y consolidar el sistema vigente, se ha ejecutado de manera similar mediante un marcado autoritarismo y concentración del poder en manos del Ejecutivo y un creciente presidencialismo o híperpresidencialismo, que recorta la independencia de las funciones del Estado, especialmente de la legislativa y la judicial, y copa y burocratiza las instancias de control y aún las de participación ciudadana.

El autoritarismo en el neoliberalismo y en el neointervencionismo, como se podrá advertir en la investigación, explica la mantención y expedición de normas administrativas y financieras comunes y similares que permanecen vigentes tanto en los dos modelos como en la combinación de ambos, con las variaciones impuestas por la coyuntura económica internacional y nacional, para apuntalar con ellos el proceso de acumulación del capital, lo que incluye algunos subsidios y medidas redistributivas para controlar la reacción y la movilización social.

De igual manera, el disciplinamiento administrativo, económico y de las finanzas públicas, en los modelos o etapas indicadas, está acompañado por una reformulación de las políticas penales, la criminalización de la lucha social y la violación de derechos humanos, especialmente colectivos, para acallar exigencias, dividir, anular y reprimir a las organizaciones sociales y sus dirigentes y, en general, a todas las expresiones políticas alternativas.

Esta investigación dará cuenta, por lo tanto, de los señalados intereses externos e internos en juego, con los cambios que se han propuesto y realizado, tanto en la modernización y transformación del neocapitalismo regional y ecuatoriano como en la modificación o negociación "operativa" del derecho, expresados en las decisiones y recomendaciones de los organismos económicos y financieros internacionales y en la adopción o reforma de normas constitucionales, administrativas y financieras, relacionadas con la planificación, las finanzas públicas y el control de los recursos públicos y financieros del país.

Este trabajo académico de contenido crítico en el desarrollo de las ciencias jurídicas, tiene como justificación principal la necesidad de tener una interpretación lo más certera 
y objetiva posible de las modificaciones económicas, políticas y especialmente jurídicas, operadas en el último cuarto de siglo en Ecuador, para entender el contexto en que ellas se inscriben, con la finalidad de establecer de qué manera contribuyen a fortalecer las actuales estructuras de poder internacional y nacional y de iniciar una reflexión posterior sobre la necesidad de impulsar el ejercicio o la ampliación de los derechos ciudadanos que constan en la Constitución, como punto de partida para la transformación de la realidad existente, proyecto al que no se puede renunciar, en las nuevas circunstancias internacionales, regionales y locales.

Si bien la investigación tiene un fundamento económico y político, su propósito se centra en demostrar la operatividad y contradicciones jurídicas en la consolidación del sistema, tomando como referencia a las más importantes normas económicas constitucionales, administrativas y financieras del Ecuador contemporáneo.

En este trabajo se pretende demostrar que los modelos económicos y políticos imperantes en el Ecuador incorporan normas jurídicas y políticas constitucionales, económicas, financieras y administrativas, definidas por los organismos internacionales que son adoptadas directamente o negociadas en nuestro ordenamiento, por quienes gobiernan para, mediante la modernización o transformación del Estado, modifican el sistema jurídico y con el apoyo de un modelo político autoritario, consolidan el actual proceso económico y social de acumulación capitalista internacional y nacional, conservando un cierto equilibrio con las demandas y el ejercicio de los derechos y garantías de los ciudadanos.

Se puede constatar que las principales normas económicas, administrativas de planificación y control y las que rigen las finanzas públicas (especialmente las tributarias), crediticias y del gasto y presupuesto, en los modelos económicos que se implementan en el país (neoliberalismo 1990 - 2006; neodesarrollismo 2007-2017), se encuentran relacionadas con las normas constitucionales pertinentes y tienen su origen en recomendaciones o en informes y documentos de los organismos internacionales (FMI, BM, OMC, CEPAL, BID etc.) y que han sido adoptadas directamente o con cierta modulación, modificación, interpretación o negociación realizadas por gobiernos autoritarios de diferente signo político, con el propósito de facilitar o viabilizar la reproducción y su articulación al sistema capitalista mundial.

Nuestro propósito complementario se basa en analizar también las adecuaciones o cambios en las normas económicas administrativas sobre la intervención del Estado en la descentralización, la planificación y en las finanzas públicas (Hacienda pública), en el período 1990 - 2017, a tono con las normas constitucionales económicas vigentes, los modelos políticos y económicos neoliberal o neocompetitivo, neodesarrollista o mixto, implementados para lograr la restructuración o modernización del capitalismo en el Ecuador contemporáneo, en el contexto de la globalización. 
Para definir el marco teórico y la metodología que hemos utilizado en esta investigación, es necesario preferentemente hacer una referencia a los estudios que existen sobre la materia en Ecuador y a aquellos que, tomados de otros países, fundamentan nuestro análisis. Debemos precisar que utilizamos documentos oficiales de los organismos internacionales y regionales y en cuanto a textos de autores nacionales e iberoamericanos compartimos el criterio de que si bien nuestras culturas jurídicas incluyen conceptos, normas e instituciones híbridas, en todo caso deberíamos relacionar adecuadamente las normas jurídicas vigentes con reflexiones desde adentro y vincular las innovaciones o modificaciones normativas con la práctica social, económica política a la que se refieren. ${ }^{3}$

El Banco Central del Ecuador, por medio de su División de Estudios Económicos y Sociales, lamentablemente desaparecida en los últimos años, publicó una Biblioteca Básica del Pensamiento Ecuatoriano, en la que incluyó algunos estudios introductorios a la reproducción de documentos y materiales de carácter económico de personajes que en la historia republicana de Ecuador estuvieron relacionados con la economía, el sistema monetario y físcal del país y el valioso libro histórico Las Finanzas Públicas en el Ecuador( 1830-1940) de Linda Alexander Rodríguez. ${ }^{4}$

Eduardo Riofrío Villagómez, en los años cincuenta y sesenta del siglo XX, publicó cuatro volúmenes sobre Hacienda pública y sobre las finanzas públicas del Ecuador, en los que se refiere a los fundamentos doctrinarios administrativos y financieros internacionales que inciden en la legislación tributaria, presupuestaria y del crédito público de esa época, demostrando la transformación y adecuación de aquellas a dichos lineamientos que corresponden a la sustitución del liberalismo por el intervencionismos estatal hasta los años 70 del siglo pasado. ${ }^{5}$

Posteriormente, José Vicente Troya impulsó desde los años 80 estudios de derecho tributario que dan cuenta de la conformación y de las transformaciones de esa rama del derecho, relacionándola con el derecho constitucional y las modificaciones y nuevas instituciones jurídicas adoptadas en el país en cuanto a los ingresos públicos. ${ }^{6}$ En una investigación última, realizada en la Universidad de Salamanca, Troya incursionó también en el derecho del gasto público y su relación con las garantías ciudadanas reconocidas por la Constitución vigente, abriendo un nuevo campo de reflexión jurídica sobre la materia. ${ }^{7}$

\footnotetext{
${ }^{3}$ César Rodríguez Garavito, Un nuevo mapa para el pensamiento jurídico latinoamericano, en El derecho en América Latina, César Rodríguez Garavito, coordinador, (Buenos Aires: Siglo Veintiuno Editores, 2011).

${ }^{4}$ Banco Central del Ecuador, Biblioteca Básica del Pensamiento Ecuatoriano, Tomos 2, 3, 15, 17, 20, 21, 27, 40, 41, 49, Linda Alexander Rodríguez, Las Finanzas Públicas en el Ecuador( 1830-1940), (Quito: Banco Central del Ecuador, 1992).

${ }^{5}$ Eduardo Riofrío Villagómez, Manual de Hacienda Pública (Tomos I, II y III), Quito, Casa de la Cultura, Ecuatoriana, 1957; Tratado de Finanzas Públicas, (Quito: Casa de la Cultura Ecuatoriana, 1968).

${ }^{6}$ José Vicente Troya Jaramillo, et al, Estudios de Derecho Económico, (Quito: CEN-UASB, 1998); Manual de Derecho Tributario, (Quito: CEP, 2014).

${ }^{7}$ José Vicente Troya Jaramillo, Derecho del Gasto Público, (Bogotá: Editorial Temis, 2015).
} 
En la Universidad Andina Simón Bolívar, el profesor Marco Antonio Guzmán publicó en los años 90 del siglo pasado dos tomos de derecho económico en los que enfoca desde una nueva óptica reflexiones sobre el contenido económico de la Constitución y de la legislación ecuatoriana, haciendo valiosas sugerencias y observaciones sobre su relación con el desarrollo y el sistema capitalista mundial. ${ }^{8}$

En la misma universidad, profesores como Julio César Trujillo, Agustín Grijalva, César Montaño, Ramiro Ávila, María Elena Jara, Claudia Storini y Eddy de la Guerra han realizado varios estudios sobre el contenido económico de la Constitución en la que establecen vinculaciones con los modelos económicos en Ecuador, sin embargo no se refieren, como nosotros pretendemos, establecer de qué modo se ha producido la articulación de intereses externos e internos y de los modelos económicos recientes, con las normas económicas constitucionales, administrativas y financieras que se han expedido en más de 25 años de nuestra historia reciente. ${ }^{9}$

El profesor colombiano Mauricio Plazas Vega, doctorado en universidades de Colombia y en Salamanca, publicó un extenso trabajo sobre derecho de la Hacienda pública y derecho tributario, con una amplia disertación sobre la relación entre el pensamiento económico y filosófico con la Hacienda pública y en el derecho tributario en la historia, pero que tiene el mérito de relacionar el proceso histórico y las corrientes económicas con los fenómenos financieros y tributarios. ${ }^{10}$

El profesor Modesto Fabra Valls, en la Revista Española de Derecho Financiero, desarrolló una interesante reflexión sobre de qué manera en los modelos económicos actuales tanto el Estado liberal, como del social y en especial del neoliberal o neocompetitivo se mantienen presentes los principios de justicia y solidaridad bajo diferentes formas y objetivos, respondiendo a los intereses de los grupos de poder o para la reproducción del sistema. ${ }^{11}$

De igual forma, para el análisis de la realidad jurídica de Ecuador hemos utilizado los estudios y aportes pertinentes de autores iberoamericanos que citaremos oportunamente, como Sebastián y Lorenzo Martín Retortillo, Luciano Parejo Alfonso, Agustín Gordillo, Ricardo Rivero Ortega, Ariel Casanovas sobre derecho administrativo económico global e internacional; Jorge Witker y Ángel Rojo sobre derecho económico; Jaime

\footnotetext{
${ }^{8}$ Marco Antonio Guzmán, Derecho Económico Ecuatoriano, tomos 1 y 2, (Quito: UASB- CEN, 1996).

9 Julio César Trujillo, "La Constitución económica más allá del neoliberalismo", en Foro: revista de derecho, No. 7, Quito, Universidad Andina Simón Bolívar, Sede Ecuador (UASB.E) / Corporación Editora Nacional, 2007; Agustín Grijalva, "La Constitución económica del Ecuador", en A. Grijalva y otros, Quito, Universidad Andina Simón Bolívar, Sede Ecuador (UASB.E) / Corporación Editora Nacional, 2013; María Elena Jara, "Constitución económica ecuatoriana y desarrollo" en Estado, Derecho y Justicia, Ramiro Ávila, compilador, (Quito: Universidad Andina Simón Bolívar / Corporación Editora Nacional, 2013).

${ }^{10}$ Mauricio Plazas Vega, Derecho de la Hacienda Pública y Derecho Tributario, Las ideas políticas de la hacienda pública, (Bogotá: Editorial Temis, 2000).

${ }_{11}$ Modesto Fabra Valls, Solidaridad y Derecho Financiero en una sociedad neocompetitiva, Revista Española en Derecho Financiero No ${ }^{\circ} 120$, 609-680.
} 
Rodríguez Arana, Baldo Kresalja, Antonio Embid Irujo, Miguel Martínez Lago, sobre derecho administrativo constitucional, constitución económica-financiera y crisis económica y reforma constitucional; Fernando Sáinz de Bujanda, Carlos Giuliani Fonrouge, Héctor Villegas Andrea Amatucci, Sergio de la Garza, Fernando Pérez Royo, Martín Queralt, Álvaro Rodríguez Bereijó y otros sobre derecho financiero, tributario, gasto, presupuesto y finanzas públicas; de Ruth Saavedra, María Arnáez Arce, Esther del Campo, Aldo Ferrer, Sergio Galilea, Aldo Olano, Richard Webb, Carlos Matos, José Moncada, Leonardo Vicuña, Patricio Moncayo, Jorge Mattar, Jorge Leiva, sobre planificación, descentralización y desarrollo; Pilar Jiménez Tello, José Fernández Ajenjo, Miguel Blanes Climent, Enrique Silva Cimma, Enrique Rivero Isern, María Dolores Calvo sobre auditoria, control y responsabilidades.

De la revisión de los indicados materiales académicos, de los autores antes enunciados y de otros, podemos afirmar que no existe en nuestro medio una investigación jurídica contemporánea, de contenido crítico sobre la relación actual entre el sistema económico y sus modelos económicos actuales, salvo las referencias generales antes señaladas, tomando en cuenta las modificaciones adoptadas en las constituciones $y$, fundamentalmente, en la legislación administrativa y financiera relacionada con las transformaciones del Estado y de las finanzas públicas en el Ecuador y que dé cuenta de los intereses externos e internos, representados en los informes y políticas de los organismos económicos internacionales y en las políticas públicas de los gobiernos de turno.

Como la investigación se refiere a la relación del sistema económico capitalista vigente y de sus modelos o etapas en la actualidad, con los intereses de poder externos e internos y las normas constitucionales económicas, administrativas y de finanzas públicas, el marco teórico pertinente debe contribuir a definir cómo o bajo qué concepciones económicas y jurídicas se analizan la realidad mundial, latinoamericana y nacional y de qué manera en ellas se expresan los intereses externos e internos dominantes y dominados en el período de análisis.

Para analizar el papel que han asumido o cumplen las principales normas de derecho constitucional, administrativo y de derecho financiero, en el ámbito económico y social general del Ecuador, en casi las tres últimas décadas, es preciso contar con una visión de los cambios y transformaciones de la economía mundial, latinoamericana y nacional, en esta etapa de la globalización, para identificar la funcionalidad, contradicciones, resistencia o demanda social de esas disciplinas jurídicas con los modelos económicos que se han ensayado para sustentar el proceso de acumulación y dominación capitalista de estos años.

A fines del siglo anterior y en los inicios de este el capitalismo ha reforzado el proceso de globalización y de internacionalización del capital, en el que juega un papel protagónico el capital financiero internacional, subsumiendo a la economía mundial a sus objetivos rentistas, sin dejar de provocar reiteradas crisis que afectan al sistema 
productivo en su conjunto, incluyendo a las principales zonas y países en los que se asienta y distribuye su poder.

Por ello, la presente investigación parte de los análisis que han realizado sobre la globalización capitalista y la hegemonía del capital financiero internacional economistas y estudiosos de la realidad económica mundial como Joseph Stiglitz, Paul Krugman, Samir Amín, Inmanuel Wallerstein, Eric Hobsbwan, Perry Anderson, Thomas Piketty y otros, partiendo de un análisis objetivo de desde una perspectiva crítica y no apologética; así como de los lineamientos y orientaciones que sobre aquella han formulado, mediante informes, los organismos internacionales como Naciones Unidas, Organización Mundial del Comercio (OMC), Banco Mundial (BM), Fondo Monetario Internacional (FMI), la Organización de Cooperación y Desarrollo Económico (OCDE) entre otros. También ha sido necesario incorporar en el análisis las reflexiones y pronunciamientos provenientes de los sectores sociales emergentes que se han expresado, en foros internacionales y en movilizaciones masivas con demandas antisistema, que superan las reivindicaciones y exigencias económicas e incursionan en la formulación de proyectos políticos alternativos.

En cuanto a la realidad económica latinoamericana y ecuatoriana, así mismo, nuestra reflexión se fundamenta en los análisis que sobre ellas han formulado economistas y estudiosos como Juan Carlos Mariátegui, Manuel Agustín Aguirre, Fernando Velasco, Agustín Cueva, ${ }^{12}$ Alejandro Moreano, José Moncada, René Báez, Germánico Salgado, en sus estudios sobre las diferentes etapas de la formación social latinoamericana y ecuatoriana y los autores de la teoría de la dependencia (Theotonio Dos Santos, Ruy Mauro Marini, André Gunder Frank, Fernando Henrique Cardoso) y otros como Raúl Prebisch, ${ }^{13}$ Enrique Iglesias ${ }^{14}$ en sus enfoques que explican la articulación de la región al capitalismo mundial y la subordinación rentista de las élites dominantes al mismo, estableciendo en todo caso los límites que tienen esas explicación sociológica sobre la realidad continental. ${ }^{15}$ Sobre los modelos económicos y políticos neoliberal y neodesarrollistas y sus efectos se deben tomar en cuenta las reflexiones de Boaventura Dos Santos, Claudio Katz, Eduardo Gudynas, Alberto Acosta, ${ }^{16}$ Enrique Ayala, ${ }^{17}$ Juan Paz y Miño, y en el ámbito jurídico y del neoconstitucionalismo latinoamericano y andino Roberto Gargarella, Claudia Storini, Antonio Carlos Wolkmer, César Rodríguez Garabito, Ramiro Ávila, etc.

\footnotetext{
${ }^{12}$ Agustín Cueva, El desarrollo capitalismo en américa latina, (México: Siglo XXI, 1979); Autoritarismo y fascismo en América Latina, (Quito: Centro de Pensamiento Crítico, 2da edición, 2013).

${ }_{13}$ Raul Prebisch, "La teoría económica, el monetarismo y los países periféricos", en Los modelos de la crisis, compilación Sohel Riffka, (Quito: Editorial El Conejo, 1983).

${ }^{14}$ Enrique V. Iglesias, Reflexiones sobre el desarrollo económico", (Washington: BID, 1992).

15 Agustín Cueva, "Problemas y perspectivas de la teoría de la dependencia" en Teoría social y procesos políticos en América Latina, (México: Editorial Edicol, 1979), 15-39.

16 Alberto Acosta, “A modo de prólogo. El correísmo. Un modelo de dominación burguesa”, Fredy Álvarez et al. El correísmo al desnudo, (Quito: Montecristi Vive, 2013); Breve Historia Económica del Ecuador, (Quito: Corporación Editora Nacional, 2012).

${ }^{17}$ Enrique Ayala Mora, Ecuador en el "Capitalismo del Siglo XXI", Quito, Ediciones La Tierra, 2015; ¿Por qué la Asamblea Constituyente?, Quito, Ediciones la Tierra, 2015.
} 
También son importantes, para establecer las orientaciones de las políticas económicas internacionales que inciden en nuestra realidad, los informes principales que sobre aquella han elaborado en los últimos 27 años la CEPAL, el SELA, el Banco Interamericano de Desarrollo, el ILPES, y, en el caso de Ecuador, los informes y planes del Consejo Nacional de Desarrollo, la Secretaría de Planificación de la Presidencia y últimamente la SENPLADES, el SRI y otros organismos estatales del Ecuador.

Para ubicar la realidad económica mundial, regional y nacional en este período en su relación con las normas y cuerpos jurídicos que son de nuestro interés en este estudio, estimamos importante diferenciar las categorías de sistema económico y social y su modelo o etapas ${ }^{18} \mathrm{y}$, desde el punto de vista teórico y político, también para nuestro análisis, es necesario ubicar las transformaciones económicas en el constitucionalismo latinoamericano, andino y ecuatoriano ${ }^{19}$ y en los regímenes políticos que han estado al frente de esta etapa del capitalismo local y de la implementación de los modelos económicos o de sus etapas, definidas por el capital internacional o por los gobiernos locales para relacionarse con este.

Las modificaciones jurídicas en la legislación administrativa y financiera del Ecuador se han producido primero de manera precedente y luego posterior o en oposición a los procesos y normas constitucionales, y se han impulsado luego reformas significativas o de un nuevo constitucionalismo (neoconstitucionalismo) adoptadas para regular el sistema económico de manera más eficiente y que a la vez han incorporado retóricamente postulados que invocan la vigencia plena y directa de los derechos humanos y de los convenios internacionales que los sustentan.

Frente a esa versión neoconstitucional se ha ido germinando en las últimas décadas un neoconstitucionalismo latinoamericano y aún andino que está presente ya en algunas de las constituciones de nuestra región, para ampliar derechos e incorporar las demandas de plurinacionalidad, del buen vivir y la necesidad de construir un nuevo modelo económicos alternativo y solidario, reclamados por sectores sociales populares mayoritarios que, en la actualidad se sienten frustrados por la gestión autoritaria de los gobiernos progresistas que enarbolaron esas demandas, pero que ya en el ejercicio del poder contradijeron su discurso, al no impulsar las modificaciones institucionales para hacerlas realidad y más bien se sumieron en la corrupción y en la criminalización de la protesta social.

\footnotetext{
${ }^{18}$ Víctor Granda Aguilar, Contenido económico de las Constituciones de Bolivia y Ecuador. Reflexiones jurídico-políticas, (Quito: Ediciones Legales y Universidad Andina Simón Bolívar, 2015).

${ }^{19}$ Julio César Trujillo, "La Constitución económica más allá del neoliberalismo", en Foro: revista de derecho, No. 7, Quito, Universidad Andina Simón Bolívar, Sede Ecuador (UASB-E) / Corporación Editora nacional (CEN), 2007; Alfredo Mancero Samán, La Constitución económica del Estado ecuatoriano y las nuevas condiciones de la economía mundial, (Quito: UASB-E / CEN / Fundación Jonrad Adenauer (FKA), 1997); Agustín Grijalva, "La Constitución económica del Ecuador", en A. Grijalva, M.E. Jara y D. Edit Martínez, Estado, derecho y economía, (Quito: UASB-E / CEN, 2013); María Elena Jara, "Constitución económica ecuatoriana y desarrollo" en Estado, Derecho y Justicia, Ramiro Ávila, compilador, (Quito: Universidad Andina Simón Bolívar / Corporación Editora Nacional, 2013).
} 
A día de hoy, se produce además la inicial apariencia de que el sistema económico y social vigente a nivel internacional se recupera y se estabiliza de sus permanentes y constantes crisis, ${ }^{20}$ pero que por la falta de un consolidado sujeto histórico alternativo se afirma la percepción de que nos encontramos ante un fin de la historia y que el sistema impone sus decisiones, directivas e intereses por medio de un "derecho blando" (soft law), ${ }^{21}$ originado en fuerzas corporativas e institucionales o redes sistémicas, que subordinan y subsumen la normativa jurídica constitucional y legal de los estados y de sus pueblos considerada, formal y teóricamente, como estable y "dura" (hard law), pero que al final, cuando es necesario, se desconoce, no se aplica o se interpreta de la manera más insólita, tergiversando aún el contenido gramatical y semántico de sus textos. ${ }^{22}$

A decir verdad, en la relación entre el Estado, la integración y la globalización en la que existe la indicada tendencia a la centralización e imposición de las decisiones del capital internacional, mediante instrumentos infrajurídicos como son las resoluciones, las regulaciones, las directrices o las recomendaciones de los organismos y convenios internacionales, también se ha puesto en evidencia, y con mayor fuerza como resultado de la crisis, que se requiere aún del Estado nacional y de sus instituciones y de los acuerdos regionales. El motivo no es otro que fortalecer las exigencias que se derivan de la globalización y del mercado, lo que abona para la importancia que en este contexto asume en especial el derecho constitucional y de manera específica las normas del derecho administrativo económico y del financiero, al igual que otras ramas del derecho vinculadas a la actividad de la producción y en general a la actividad económica, como articuladoras de los conflictos principales, secundarios, directos e indirectos que existen en la sociedad. ${ }^{23}$

A la vez, dentro del marco constitucional o fuera del mismo, para posibilitar los intereses externos de la globalización capitalista y de los modelos económicos funcionales a ella, en el campo de la estructura del poder y de los intereses y de las políticas públicas internos, durante todo el período de análisis se apuntalan procesos autoritarios mediante regímenes políticos híperpresidencialistas que relativizan la división de poderes y funciones del Estado para satisfacer las exigencias de los grupos de poder internacionales y locales. ${ }^{24}$ Con esa premisa, en el curso y aplicación de la legislación administrativa y financiera de este período, será necesario identificar su relación con las constituciones, la orientación de sus reformas y el papel que finalmente cumple el sistema jurídico en relación con las exigencias internacionales y nacionales

\footnotetext{
${ }^{20}$ Eric Hobsbawn, op. cit.

${ }^{21}$ Javier Barnes, "Reforma e innovación del procedimiento administrativo", en La Transformación del procedimiento administrativo, J. Barnes, editor, (Sevilla: Global Law Press, 2008).

${ }^{22}$ Carlos de Cabo Martín, Dialéctica del sujeto, dialéctica de la Constitución, (Madrid: Editorial Trotta, 2010).

${ }^{23}$ Juan-Cruz Alli Aranguren, Derecho Administrativo y Globalización, (Madrid: Universidad de Navarra, Aranzadi, 2004).

${ }^{24}$ Ramiro Ávila y Luis Fernando Torres, "Debate dos visiones diferentes sobre la Constitución", en $L a$ Nueva Constitución del Ecuador, S. Andrade, A. Grijalva, C. Storini, editores, (Quito: Universidad Andina Simón Bolívar / Corporación Editora Nacional, 2009); Luis Fernando Torres, Presidencialismo constituyente, (Quito, Cevallos, 2009).
} 
del sistema y de qué manera aquellas recogen algunas de las demandas sociales de los actores populares que reclaman justicia y equidad. ${ }^{25}$

Otro asunto teórico jurídico importante es describir y esclarecer, -lo que de manera lógica no debería entrañar conflicto alguno aplicando el principio de jerarquía de la normas-, cómo y bajo cuales circunstancias y conflictos se establece la relación y subordinación entre las normas constitucionales y los cuerpos jurídicos más importantes de un país, relacionados con la organización de la función y actividad económica y financiera del Estado que, evidentemente repercuten en la actividad económica general $\mathrm{y}$ en los modelos implementados por el sistema y las fuerzas económicas y políticas nacionales para su mantención y reproducción.

Se requiere determinar qué regulaciones legales establecidas por el neoliberalismo en el Ecuador, al igual que ocurre en otros países de la región y el mundo, se adoptaron en contradicción con las normas constitucionales del Estado social o de bienestar vigentes $\mathrm{y}$ han requerido muchas veces de torcidas interpretaciones, en el control de constitucionalidad y legalidad, para declararlas compatibles con la norma fundamental. ${ }^{26}$ En el caso ecuatoriano, entre 1990 y 1998, contradiciendo el principio elemental de jerarquía jurídica, las normas constitucionales fueron transformadas $a$ posteriori para establecer armonía con leyes que se oponían a sus principios. ${ }^{27}$

De igual manera, en las recientes crisis, expedida y ya vigente la Constitución del 2008, con normas que restablecieron la centralidad del Estado y un mayor intervencionismo público en las actividades económicas estratégicas, se adoptan, de igual manera que en el modelo anterior, normas administrativas, financieras y económicas que contradicen la supremacía constitucional en materia de endeudamiento y soberanía, para satisfacer compromisos internacionales y necesidades internas de inversión, de equilibrio fiscal y de dispendio de recursos públicos. ${ }^{28}$

También en la presente investigación se podrán advertir cuerpos jurídicos (en materia administrativa y financiera) con idénticas instituciones y normas relativas a la restructuración del Estado, al involucramiento en ciertas actividades económicas públicas de actores privados, a la disciplina fiscal y al endeudamiento público, entre otras, que son utilizadas indistintamente para implementar o reforzar modelos económicos aparentemente contradictorios, pero que en realidad se complementan para

\footnotetext{
${ }^{25}$ Víctor Granda Aguilar, Contenido económico de las Constituciones de Bolivia y Ecuador. Reflexiones jurídico-políticas, (Quito: Ediciones Legales y Universidad Andina Simón Bolívar, 2015).

${ }^{26}$ Ecuador, Ley de Modernización del Estado y su reglamento ( 31 de diciembre de 1993, 29 de noviembre de 1994); Ley General de Presupuestos del Sector Público (1994); Ley General de Instituciones del Sistema Financiero (1994) ; Estatuto del Régimen Jurídico Administrativo de la Función Ejecutiva (Registro Oficial 411 del 31 de marzo de 1994).

${ }^{27}$ Ecuador, Constitución de 1998.

${ }^{28}$ Ecuador, Ley de Alianzas Público- Privadas, Registro Oficial Suplemento No. 652,18 de diciembre de 2015; Decretos del Presidente Rafael Correa $N^{\circ} 489$ y 2218 de 26 de noviembre de 2014 y de 20 de octubre de 2016 para autorizar otra forma de cálculo de la deuda externa y para que ésta pueda ser utilizada en gasto público.
} 
la mantención del sistema de dominación internacional y nacional y para satisfacer los grandes intereses nacionales y extranjeros que se encuentran en juego.

Por ello, se puede constatar que las diferencias en la legislación administrativa y financiera, modificada y adaptada a los modelos económicos que se han sucedido o que coexisten en el Ecuador, son en buena parte coincidentes y hay ejemplos, como se constatará en la investigación, de que cierta legislación se ha mantenido invariable, especialmente aquella que otorga al Gobierno un rasgo más autoritario que el tradicional, para imponer los propósitos y proyectos dominantes externos e internos, recortando sin mayor pudor los derechos y garantías de la población, que fueron generosamente publicitados cuando se luchaba por acceder al poder para sustituir la "larga noche neoliberal".

En definitiva, este estudio está planteado en lo metodológico desde un enfoque lógicosistémico, dialéctico y crítico para analizar las normas económicas constitucionales, administrativas y financieras del sistema jurídico ecuatoriano y sus contradicciones o relaciones formales con los modelos económicos del período de análisis (1990-2017). En cuanto a la identificación de los intereses externos e internos provenientes de los organismos internacionales y de quienes ejercen el poder y de los sectores sociales dominantes y dominados, nos fundamentamos en la teoría del conflicto social y de la contradicción, como ejes fundamentales para la comprensión de los fenómenos de la realidad jurídica, económica, política y social.

Compartimos la convicción, expresada por Witker, de que las ciencias actuales y entre ellas las jurídicas y particularmente las que regulan las actividades económicas y financieras, requieren de un enfoque transdisciplinario, complejo y holístico, pues necesitan, para su cabal comprensión (relación con el conocimiento) y para definir su función en la práctica social de la sociedad y el Estado (relación de conocimiento), del concurso de otras ciencias y en especial de la economía y de la política, a las que se encuentran asociadas tanto por su contenido normativo, como por el papel que cumplen o pueden cumplir en la reproducción o transformación de la sociedad. ${ }^{29}$

El derecho está íntimamente vinculado a las realidades socio-históricas, económicas y políticas, externas e internas que determinan el contenido de las normas y, que a la vez, pueden ser el espacio para la estabilidad y reproducción del sistema o en el que realicen o abran las posibilidades de acciones transformadoras, por lo que la teoría crítica no solo cumple una función deconstructiva sino un papel emancipador y liberador en el que actúan los sujetos de la historia, especialmente los colectivos insurgentes, articulados

\footnotetext{
${ }^{29}$ Jorge Witker, Los derechos humanos nuevo escenario de la investigación jurídica, Boletín Mexicano de Derecho Comparado, nueva serie, año XIX, núm. 149, mayo-agosto de 2017. UNAM, Instituto de Investigaciones Jurídicas.
} 
por sus múltiples necesidades que enfrentan en una realidad identificada con la explotación, dependencia, exclusión y dominación. ${ }^{30}$

Sin embargo, ello no significa que en el análisis e identificación de la naturaleza o contenido de las normas, se requieran aplicar, cuando sea menester y de utilidad para el propósito que se persigue, enfoques iusnaturalistas y formalistas del derecho.

Las concepciones iusnaturalistas están relacionadas con la vigencia, permanencia y extensión democrática de los derechos humanos, sin dejar de reconocer que dichas doctrinas son complejas e históricas y que pueden abarcar contradictoriamente posiciones liberales, absolutistas y también democráticas y antisistema. La escuela iusnaturalista tiene diversas manifestaciones en distintas épocas históricas del derecho, se reivindica de pensamiento crítico y se identifica en la actualidad, como garantismo o como teoría general del derecho" que persigue, mediante el método axiomático y el formalismo jurídico, distanciarse de la realidad objetiva y privilegiar en los ordenamientos jurídicos modernos, las divergencias entre principios y prácticas, para asegurar la tutela de los derechos y la efectividad de los distintos tipos de poder. ${ }^{31}$

Respecto al formalismo jurídico, las categorías principales en el análisis del derecho se establecen o identifican dentro de un sistema jurídico organizado a partir de su norma fundamental, la Constitución. Este enfoque pretende polemizar con la corriente crítica marxista, acusándola de hacer perder al derecho formalidad y racionalidad en sus reflexiones sobre la realidad y sus conflictos.

Las dos matrices del formalismo, como lo indica Carlos de Cabo Martín, tanto la kelseniana que se fundamenta en la autonomía lógica y dinámica interna del derecho, como la de la racionalidad sistémica, inspirada en Luhmann, dicen defender la verdadera configuración de la ciencia jurídica y devolverle su funcionalidad perdida. En las dos corrientes se inscriben también la teoría del derecho respuesta o responsivo y la del derecho reflexivo. Todas las doctrinas jurídicas que se han mencionado se alejan, con un leguaje hermético y preferentemente obscuro, de los fenómenos reales e históricos de la sociedad. El derecho, como producto de los enfoques formalistas, se concentra en su estructura y en el sistema jurídico y aporta significativamente, en todo caso, a la comprensión de la complejidad de las normas, de la producción jurídica y de la configuración de las fuentes. ${ }^{32}$

No se debe dejar de reconocer que otras perspectivas de análisis teórico del derecho como el historicismo, sociologismo y el realismo, contribuyen también para la

\footnotetext{
${ }^{30}$ Antonio Carlos Wolkmer, Teoría crítica del derecho desde América Latina, (México: Ediciones Akal, 2017).

${ }^{31}$ Carlos De Cabo Martín, Dialéctica del sujeto, dialéctica de la Constitución, Madrid, Editorial Trotta, 2010.

${ }^{32}$ Ibídem.
} 
valoración de las ciencias jurídicas y para que estas sean aplicadas en la comprensión de la realidad pasada y presente y para poder vislumbrar la del futuro.

En todo caso queremos insistir que en este estudio vamos a privilegiar la relación sistemática entre la Constitución y las leyes administrativas y financieras y las antinomias que existen o se presentan entre ellas, ya que desde esta perspectiva podremos evidenciar de qué manera los intereses económicos dominantes externos e internos superan la formalidad jurídica y cómo la contradicción social y política se convierte en el eje fundamental de una explicación más integral de los conflictos jurídicos existentes, sin dejar de subrayar que los valores y principios provenientes inicialmente del iusnaturalismo, por su contenido democrático, contribuyen a proyectar la lucha por la ampliación de la democracia y los derechos, protagonizada por sectores sociales alternativos al sistema cuyo propósito permanente es su transformación y superación.

En este contexto, el derecho, en cuanto a interpretación de los fenómenos a los que se refiere, es una expresión de la confluencia, de la diferencia y de la prioridad que se otorgue a los enfoques y propuestas teóricas antes indicados, más allá del formalismo abstracto tradicional y de concepciones que no se agotan en las meras exigencias del mercado, pues, en lo esencial pretende o debe pretender satisfacer los derechos de los pueblos y de los ciudadanos, aprovechando la bondades del desarrollo tecnológico, del conocimiento y de la información, y superando las irracionalidades del sistema y el deterioro ambiental.

Con todas estas consideraciones, no podemos ocultar que nuestra perspectiva teórica fundamental en este y en general en la mayoría de nuestros trabajos académicos, es la que proviene del marxismo y en general de la teoría crítica y de la filosofía latinoamericana del siglo XX. En ellos se promueve un pluralismo transformador que permite, con renovadas perspectivas y explicaciones más precisas de los fenómenos jurídicos, llegar a una explicación objetiva y cabal del contenido normativo y de su relación con el acontecer y los intereses históricos-sociales que se encuentran en juego en la realidad internacional y nacional para impulsar una opción de cambio y transformación en la que se encuentran comprometidos los sectores sociales alternativos al sistema vigente. ${ }^{33}$

Compartimos las opiniones de aquellos que dentro de esta perspectiva teórica-filosófica consideran que el derecho no puede entenderse por sí mismo, sino estableciendo una relación dialéctica de las normas con las condiciones materiales de vida y con el conflicto social y político, descartando visiones dogmáticas y mecanicistas y tomando en consideración que la ideología y la superestructura jurídica juegan también un papel

\footnotetext{
${ }^{33}$ Víctor Granda Aguilar, Didáctica Activa del Derecho", (Quito: Editorial Universitaria-UCE, 2009), 84; Juan Camilo Sala Cardona, conferencia en la Universidad de Salamanca sobre "La Filosofía española del siglo XX en América Latina, 2 de noviembre de 2016.
} 
importante no solo en la configuración o regulación sino en transformación de la realidad económica y social a la que están articuladas.

El derecho (y en general las normas y categorías jurídicas) tienen un carácter eminentemente histórico y al estar además tan estrechamente vinculados con la realidad, permiten, al hacer una crítica de ellas, realizar un balance de las situaciones a las que corresponden. Generalmente, las normas jurídicas contribuyen al ejercicio de la dominación, pero incluyen también aquellas que recogen ciertas exigencias sociales para consolidar el sistema existente y no ponerlo en peligro, lo que en ciertas circunstancias puede ser el punto de partida para nuevas demandas, para ampliar la democracia y para crear una situación alternativa o contrahegemónica o que en ciertas circunstancias apoyen o impulsen una transformación.

Por ello, insistimos en que para interpretar adecuadamente y de manera global, la relación entre la economía, la política y el derecho y su transformación en una estructura superior, nos inspiramos en las nuevas escuelas del marxismo y de la teoría crítica del derecho en Latinoamérica. Todas ellas tratan la ciencia social de forma creativa, tanto en la relación entre la estructura y la superestructura, como en el papel que cumplen los actores sociales tradicionales y los nuevos actores que surgen en la realidad actual del capitalismo y la globalización, así como en la necesidad de definir un proyecto alternativo que se diferencie de interpretaciones, modelos y realidades superadas por la historia e incorpore nuevas cosmovisiones que no son contradictorias sino complementarias.

En el análisis y comparación de la legislación económica constitucional, administrativa y financiera en los modelos del capitalismo contemporáneo, este enfoque teórico contribuye a identificar la naturaleza real de la sociedad capitalista, ocultada hábilmente por la abstracción del sujeto. Nos permite "la comprensión del funcionamiento de un sistema complejo y estructuralmente contradictorio", descubrir y delatar "los secretos de un sistema opaco revestido de un poderoso equipo de apariencia e ideología que lo falsea" e identificar "las vías, también naturales y reales en cuanto están contenidas en esa realidad para su transformación". 34

Nuestra perspectiva de análisis jurídico, en este caso, no se inscribe en separar lo objetivo de lo subjetivo o en el necesario privilegio permanente de uno de ellos, sino en su presencia simultánea y en su interrelación, en la que, en algunos momentos o circunstancias, se privilegia uno a lo otro y viceversa; sin descartar que las instituciones y conceptos económicos del derecho administrativo y del financiero sean un instrumento directo de la realidad internacional y local y representen la contradicción que se encuentra en su interior y expresen los intereses en conflicto o que dichas ramas jurídicas, articuladas a la Constitución o por efecto de la lucha social, pueden jugar

\footnotetext{
${ }^{34}$ Carlos De Cabo Martín, Dialéctica del sujeto, dialéctica de la Constitución, (Madrid: Editorial Trotta, 2010), 14.
} 
también un papel protagónico en la realidad e incidir en su transformación o modificación.

Los aspectos teóricos antes indicados sobre la realidad económica mundial, latinoamericana y nacional; la ubicación y nuevos contenidos de las normas económicas del derecho que pretendemos analizar; la relación problemática con los contenidos económicos de la Constitución y en especial el enfoque ideológico y filosófico y las nuevas reflexiones utilizadas por los grupos de poder y los tradicionales y nuevos actores sociales, tienen un importante impacto en la metodología de análisis y en las técnicas o procedimientos que utilicemos para la comprensión de los fenómenos jurídicos relacionados con los modelos económicos.

En todo caso, resulta importante subrayar que dada la naturaleza del problema de investigación propuesto, de contenido principalmente analítico y comprensivo, se fundamenta y respalda también en los documentos y políticas oficiales de los organismos internacionales a nivel mundial y regional y en los de los organismos nacionales encargados de la planificación y de la definición de políticas oficiales, así como en la opinión autorizada de quienes han reflexionado de manera crítica desde la academia o desde la lucha social sobre su naturaleza, causas y efectos.

Pretendemos metodológicamente utilizar en nuestro análisis el método histórico y el comparativo, estableciendo el contexto económico, social y político de los modelos o fases económicas y la incidencia de fenómenos e intereses externos e internos para identificar similitudes, diferencias e identidades de los contenidos principales de la legislación administrativa económica y financiera, en el modelo o política neoliberal (1900 - 2005); en el neointervencionista o neo desarrollista (2006 - 2015), en los que se pueden diferencias fases internas que privilegian sus políticas propias o se adopta un modelo mixto para acoplarse de mejor manera a las necesidades del desarrollo capitalista local e internacional. El abandono del reformismo constitucional de los denominados regímenes progresistas en los últimos años, es a la vez el punto de partida para la construcción de un posible modelo alternativo por parte de los tradicionales y nuevos actores sociales y políticos populares que actúan en nuestra realidad.

Los asuntos que pretendemos comparar y analizar utilizando el método dialéctico de la contradicción en las recientes etapas o modelos del capitalismo en el Ecuador, se refieren a las iniciativas jurídicas de acoplamiento, transformación o modernización del Estado y de su administración en el ámbito más general de su estructura y sistema jurídico y por ello se refieren a la planificación, las finanzas públicas y control de los recursos públicos, que se encuentran dentro del ámbito del derecho constitucional administrativo económico y financiero.

Evidentemente, como ya hemos señalado, en este ensayo tiene un carácter privilegiado el análisis del contenido económico de las normas de las constituciones vigentes (reformas constitucionales de 1992-1997; constituciones de 1998 y 2008 y enmiendas 
del 2015) y los planes de estabilización económica impuestos por el FMI, en el período neoliberal, y los posteriores orientaciones e informes económicos con contenido o implicación normativo, provenientes del Banco Mundial, OMC, de la CEPAL, el ILPES, el BID. Estos y otros organismos internacionales inciden en las sucesivas modificaciones o en la mantención de las normas del derecho administrativo económico y financiero o de las finanzas públicas expedidas en la implementación o adopción de los modelos económicos y de sus crisis, en los que no existe simetría y subordinación jerárquica al ordenamiento jurídico interno, sino, más bien, una utilización, acoplamiento o acomodo de las normas constitucionales a las leyes secundarias y a las políticas económicas, que son las que finalmente regulan o se adaptan de manera más directa a los intereses externos e internos.

De igual manera la dimensión económica y política del análisis no se puede eludir, ya que se encuentra en el centro de una interpretación cabal de la realidad, tanto para dilucidar el carácter y contenido del autoritarismo impuesto en el ejercicio del poder en los diferentes modelos económicos e identificar los intereses dominantes internos y externos, como para establecer la resistencia y las luchas sociales destinadas a defender y ampliar sus derechos. Por lo tanto, siguiendo la sugerencia de Andrea Amatucci, resulta inevitable, desde nuestro propósito académico, que en el análisis exista un enfoque que contenga una exposición general y fundamentación "prejurídica" $\mathrm{o}$ "metajurídica", de contenido económico y político, sin la cual no es posible entender los aspectos normativos de la actividad administrativa económica y financiera públicos. ${ }^{35}$

La investigación requiere trabajar constantemente, pues con las normas o recomendaciones convencionales y los preceptos constitucionales vigentes (2000 2015) y las normas jurídicas, reglamentarias y decretos ejecutivos expedidos y modificados en el ámbito del derecho administrativo económico y financiero, en la etapa de predominio neoliberal (1900 - 2006), como: la Ley de Modernización del Estado (1993) y las leyes que favorecieron procesos de privatización en el ámbito petrolero, eléctrico y de las telecomunicaciones; El Estatuto del Régimen Jurídico Administrativo de la Función Ejecutiva (1994); Ley General de las Instituciones del Sistema Financiero (1994); Ley de Presupuestos del Estado (1994) Ley de Creación del Servicio de Rentas Internas y Reformas a la Ley de Régimen Tributario Interno; Reformas al ERJAFE (2002); Ley Orgánica de la Contraloría General del Estado (2002). Y luego, en el modelo actual neointervencionista y mixto (2007-2016): las sucesivas reformas tributarias y a la ley del SRI (2007-2014); el Código Orgánico de Planificación y Finanzas (2010); el Código Orgánico Monetario y Financiero(2014); Ley de Alianzas Públicas y Privadas (2015) y el Código Administrativo (2017), entre otros instrumentos jurídicos.

\footnotetext{
${ }^{35}$ Andrea Amatucci, "La enseñanza del derecho financiero en Italia y España”, Quito, Revista de Derecho $\mathrm{N}^{\circ}$ 1, UASB-CEN, 2003.
} 
Este trabajo académico contiene siete capítulos: el primero destinado a analizar el fenómeno de la globalización en estas últimas décadas y su incidencia en las transformaciones jurídicas constitucionales administrativas y financieras en los modelos y políticas económicas desde 1990 hasta la actualidad. El segundo se refiere a las transformaciones en el contenido económico y financiero de las constituciones y sus reformas en el Ecuador en este período histórico de análisis. El tercer capítulo habla sobre las transformaciones en la Hacienda pública y en el derecho financiero a lo largo de la historia ecuatoriana y en especial en los modelos económicos entre 1990 y 2017, en el contexto de la realidad nacional para establecer el régimen jurídico de los gastos públicos y en especial de los ingresos tributarios. El cuarto desarrolla el contenido, evolución, principios y características actuales de la legislación constitucional económica y de la legislación tributaria. El capítulo quinto está destinado a analizar el derecho del gasto y del presupuesto en los modelos y políticas económicas neoliberales y neointervencionistas. Los capítulos sexto y séptimo se refieren a las instituciones, normas administrativas y financieras sobre la planificación y el control que se encuentran relacionadas o forman parte actualmente del derecho de la Hacienda pública contemporánea. En la parte final planteamos algunas conclusiones de nuestro estudio y los desafíos teóricos y jurídicos que para el derecho o legislación de las finanzas públicas o de la Hacienda pública se plantean en la actualidad. 


\section{CAPÍTULO I: LA GLOBALIZACIÓN CAPITALISTA, LOS MODELOS Y POLÍTICAS ECONÓMICAS Y LAS TRANSFORMACIONES EN EL DERECHO}

Este capítulo se refiere a las principales connotaciones y modificaciones en la globalización capitalista y en las políticas y modelos económicos que se han implementado en el ámbito internacional y en especial en la región y Ecuador desde 1990 hasta la actualidad.

Las reflexiones anteriores son el punto de partida para el estudio sobre sus repercusiones y transformaciones en el derecho público, en el derecho administrativo económico, y en el de las finanzas públicas y control, que constituyen el referente inmediato para el análisis de las modificaciones de las normas constitucionales sobre el sistema económico, la planificación, las finanzas públicas y el control en Ecuador entre 1990 y la actualidad, durante la implementación de las políticas y modelos económicos inspirados en el neoliberalismo y el neoestructuralismo o el neodesarrollismo.

\section{LA GLOBALIZACIÓN CAPITALISTA (1990-2017)}

Globalización es el término con el que se identifica, a la mundialización capitalista, si bien esta como fenómeno histórico estuvo presente desde los orígenes del sistema, en los siglos XVII y XVIII. Esta realidad, sin embargo, se hizo más evidente desde fines del siglo XIX con la declinación de la libre competencia y el surgimiento de los monopolios y, a lo largo del siglo XX hasta la actualidad, gracias a la tecnología y las comunicaciones, con el incremento de la productividad y el comercio internacional, una mayor división internacional del trabajo y una intensa integración económica y financiera mundial.

La última fase de la globalización se inicia formalmente desde la finalización de la "edad de oro" del sistema capitalista, a partir de 1970, cuando se promovió el neoliberalismo como doctrina y política económica internacional que generaliza la creciente crítica al intervencionismo estatal y al estado de bienestar. En su tiempo, fueron las salidas a las reiteradas crisis del capitalismo, y que, así mismo, se presentaron como el camino adecuado para superarlas y frenar la tendencia decreciente de la tasa de ganancia.

La globalización contemporánea, especialmente económica, de dimensión ideológica y débilmente política, se presentó como una "nueva era", luego de la extinción de la mayoría de los regímenes conocidos como seguidores de la economía centralmente planificada, y se identificó con el desarrollo de nuevas relaciones comerciales internacionales y regionales, mediante las regulaciones de la OMC y el GATT; la renovada imposición de las políticas económicas del FMI y el Banco Mundial a los países del tercer mundo; los efectos de la revolución científica y tecnológica; la 
transformación de los procesos laborales y la reorganización del mundo, retomando las ventajas comparativas y la radicalización del intercambio desigual. ${ }^{36}$

Samir Amín identifica como globalización al período más reciente del capitalismo desde 1990, cuando se presenta un deterioro o una erosión del estado-nación y cuando desaparece el vínculo entre la esfera de la producción y la de la acumulación capitalista y se marca el auge del sector financiero sobre el conjunto de la economía. En esta fase del sistema, según este autor, se establecen nuevas relaciones internacionales y una mayor polarización entre las economías de los centros industrializados y de las regiones periféricas del mundo. Los países centrales pugnan por imponer su capacidad de competir y controlar el mercado mundial y en ellos se advierte la acción directa de las empresas transnacionales y de los monopolios tecnológicos que controlan las principales actividades productivas, financieras y comerciales y los más importantes recursos naturales del planeta, los medios de comunicación y la fabricación de armas de destrucción masiva. ${ }^{37}$

En todo caso, la globalización y la revolución científica y tecnológica en las últimas décadas, con la introducción creciente de la microelectrónica, la biotecnología y la transformación en la información y las comunicaciones, marcan el inicio de esta nueva época, que consolida a nivel mundial el sistema capitalista o neocapitalista o de capitalismo tardío, liderado por el capital financiero internacional, afianzado por el complejo militar-industrial norteamericano y por un nuevo orden de relaciones económicas, políticas y jurídicas, caracterizadas por la multipolaridad regional, la deslocalización productiva, la sobreexplotación salarial y la homogenización de instituciones de regulación internacional.

Las transformaciones ocasionadas en la reciente fase de la globalización, según lo indica Héctor Villegas, son resultado de la convergencia de las siguientes variables: las preferencias de los consumidores; la tendencia a diseñar y distribuir productos estandarizados para países distintos; la apertura de mercados y la caída de barreras comerciales; la creciente coordinación de las funciones de las empresas internacionales y la evidente interdependencia de las políticas económicas entre países y el aumento espectacular de los flujos de bienes, servicios, capitales e inversión directa entre ellos. Esto es posible gracias a la reducción de los costos de transportes y comunicaciones y a la extensión generalizada del libre comercio, que permite a las empresas multinacionales modificar sus planes comerciales y su estrategia de deslocalización física, integrándose vertical y horizontalmente con prescindencia de sus fronteras geográficas originales.

Los estudiosos enfocan el proceso actual de la globalización capitalista desde dos perspectivas principales: la convencional de la economía clásica con una teoría de la

\footnotetext{
${ }^{36}$ Jorge Witker V., Introducción al derecho económico, (México: Ediciones Harla, 3ra. Edición, 1995).

37 Samir Amin, Transnacionalización de la economía, el reto de la mundialización en Globalización, mundialización y modernización capitalista, (Dakar: Thierd World Forum, 1999).
} 
modernización que la presentan como una convergencia de países, regiones y del mundo para alcanzar un acercamiento de todos los seres humanos en un proceso de desarrollo y bienestar y la de los exponentes del pensamiento crítico (neokeynesianos y neomarxistas) que analizan, desde la óptica de sus resultados, la profundización histórica de la polarización y los desencuentros entre los países de los centros desarrollados con las regiones y los países subdesarrollados y dependientes. ${ }^{38}$

Los promotores del primer enfoque, denominado también neoinstitucionalismo o institucionalismo neoliberal, plantean que la globalización es esencialmente un paso tecnológico que permite el crecimiento de todos los países mediante acuerdos comerciales y de inversión y normas comunes de regulación internacional. Esta corriente se expresa mediante los informes, recomendaciones y orientaciones de los organismos financieros internacionales que no dejan de reconocer, a la vez, la sobrevivencia y en algunos casos el aumento de los índices de pobreza e indigencia mediante evidencias empíricas de cifras y datos, con los que se legitiman sus propósitos articulados a los enormes intereses que gobiernan el mundo. ${ }^{39}$

Existe, sin embargo, la tendencia innegable a la caída de la tasa de ganancia y a la contracción de la inversión productiva. Se acumulan activos líquidos que buscan ser rentabilizados, mediante portafolios financieros de alto y fácil rendimiento y la titularización de derivados, lo que se identifica como financiarización de la economía, que es gestionada por los bancos más poderosos del mundo y por nuevos agentes financieros internacionales como fondos de inversión y otros.

En la globalización, evidentemente, se profundiza en la desigualdad de la distribución de ingresos y en la concentración de la riqueza a nivel mundial. Se consolidan los monopolios, asentados especialmente en los países centrales y, a la vez, se anulan, bloquean o manipulan a su favor, los procesos de industrialización de los países periféricos, devaluando su trabajo productivo, sobrevalorando el valor agregado de los monopolios externos y convirtiéndolos en complementarios en la fabricación de partes que requieren fuerza de trabajo de manera intensiva.

Otro fenómeno clave de la globalización, según Villegas, es el efecto que produce en el conjunto de la economía mundial, la desregulación, innovación e inestabilidad del sector financiero, combinado con la disminución de controles sobre el movimiento de capitales, los avatares del sistema monetario internacional y la aplicación de nuevas tecnologías en productos y en el proceso productivo, lo que genera economías de escala y una nueva revolución industrial, siempre expuestas a los efectos de la crisis. La globalización ha permitido también una creciente participación en el comercio internacional de los países en vías de desarrollo por la similitud y complementariedad de sus productos; bajos costos de transporte para enfrentar la separación geográfica

\footnotetext{
${ }^{38}$ Olga Pérez Soto, La Globalización, www.videotecamarxista.blogspot.com, 8 noviembre 2013.

${ }^{39}$ Banco Mundial, Índices de desarrollo humano, PNUD, Barcelona, 2000.
} 
entre los sitios de producción y los mercados finales y la creciente participación de los servicios. $^{40}$

La Organización Mundial de Comercio (OMC) y sus rondas desde 1996, así como las decisiones del Grupo de los 20, han promovido amplios acuerdos comerciales entre los Estados, en los que se preservan los subsidios agrícolas e industriales a favor de los países industrializados y se protege su propiedad intelectual, que beneficia especialmente a las transnacionales que controlan las patentes y la producción final y la calidad de los bienes ofrecidos al mercado. En todo caso, en la ronda de Doha en 2001, 142 países demandaron el acceso universal a ciertos productos como los medicamentos esenciales (genéricos) y el derecho a proteger la salud básica de los seres humanos. En 2011 se dispuso que en los años siguientes se ofrecería tratamiento antirretroviral a 15 millones de seropositivos en países de ingresos medios y bajos.

La mundialización de las finanzas internacionales transformó inicialmente la realidad de los mercados financieros, pues se produjo su desregulación en el orden internacional y nacional y se limitaron, no sin ciertas dificultades coyunturales, los obstáculos para el libre movimiento de capitales entre los países, modificando la situación anterior en la que los Estados controlaban con cierta rigidez a los agentes financieros para proteger el ahorro y los intereses del público.

La hegemonía del capital financiero en la globalización se manifestó agresivamente con la creación de nuevos instrumentos financieros; el crecimiento y poder desmedido de los bancos internacionales y otras instituciones financieras; el incremento del comercio mundial de divisas y los bonos del tesoro norteamericano y la pérdida de la capacidad de los estados para aislar las economías individuales del entorno global. El sistema monetario actual de cambios flexible es diferente al papel que tenía, en décadas anteriores, el ordenamiento de Bretton Woods, pues ahora las fuerzas del mercado global determinan el valor de una moneda específica. ${ }^{41}$

La globalización del sistema y la liberalización y desregulación de los mercados financieros en la década de los noventa del siglo pasado, sacudieron, la economía mundial por sus impactos negativos en importantes economías nacionales, como resultado de los altos niveles de actividad especulativa que provocaron los flujos de entradas y salidas de capital de corto plazo y de su alto grado de volatilidad. Sirvieron para "disciplinar" a los Estados, cambiando su control de mando hacia los "circuitos internacionales de capital". ${ }^{2}$ Ello ocurrió en México en 1994; en los tigres asiáticos en 1997; en Rusia y Brasil en 1998; en Ecuador con la crisis bancaria en 1999; en Argentina en 2002; en Estados Unidos en 2007-2008 y en Europa, desde 2009 hasta

\footnotetext{
${ }^{40}$ Héctor Villegas B., Manual de Finanzas Públicas, (Buenos Aires: Ediciones Depalma, 2000).

${ }^{41}$ Manuel Guitian y Félix Varela, Sistemas financieros ante la globalización, (Madrid: Ed. Pirámide, 2000).

${ }^{42}$ Pablo Dávalos, La democracia disciplinaria, el proyecto posneoliberal para América Latina, (Quito: Gráficas Iberia, 2010).
} 
2013, cuando explotó la burbuja inmobiliaria y de derivados y se hizo tangible el manejo fraudulento de los administradores y dueños de entidades financieras.

En el caso europeo, la opacidad, inestabilidad y abusos del sistema financiero no pudieron ser detenidos por la fragmentación política regional, ya que cada Estadonación "no tiene el peso necesario para imponer reglas fiscales y prudenciales apropiados a las instituciones financieras y a los mercados globalizados", además de las dificultades que ocasionó la moneda común al no tener un eficaz control político que, finalmente, tuvo que ser acordado para enfrentar la crisis de un posible colapso financiero en varios países. ${ }^{43}$

Frente a esas crisis y posibles colapsos financieros y económicos se requirió, de inmediato, el apoyo de los organismos financieros internacionales y de los bancos regionales y estatales, así como de las autoridades políticas y de los estados locales, lo que puso en evidencia que esas instancias internacionales y de poder nacional siguen siendo útiles y aún indispensables para la ejecución de medidas colectivas, el sostenimiento del sistema y la socialización de las pérdidas.

Surge o se fortalece, por tanto, la necesidad de una estructura y de normativas y regulaciones comunes para el control de la economía mundial y, en especial, para la supervisión y regulación de las entidades financieras internacionales y nacionales, como lo son los Acuerdos de Basilea y otros, con la finalidad de obligarlas a contar con las correspondientes reservas de capital y adoptar las medidas básicas de prudencia financiera para evitar desajustes y sus posibles colapsos de gran impacto social y en las finanzas públicas de los estados.

Se han creado, adicionalmente, nuevos parámetros para medir el nivel de confianza internacional en la economía mundial, tanto de las corporaciones como de los países, mediante las cotizaciones y márgenes de rentabilidad en la bolsa y el denominado riesgo país, un índice con el que se percibe el déficit fiscal, el saldo negativo de la balanza de pagos, el aumento del gasto no productivo, la protección a la inversión extranjera y el crecimiento y pago oportuno de la amortización y servicio de la deuda externa de cada uno de los estados nacionales.

Las finanzas internacionales tienen cada vez mayor peso institucional con la internacionalización de los bancos y entidades financieras que cuentan con una infraestructura institucionalizada y muy avanzada en tecnologías de información y comunicación, para realizar transacciones que se efectúan en las 24 horas del día y en cualquiera de las latitudes del planeta. Por ello, resulta objetiva la observación que "la globalización financiera contemporánea representa una nueva etapa distinta en la organización y la administración del crédito y del dinero en la economía mundial, que

\footnotetext{
43 Thomas Piketty, La crisis del capital en el Siglo XXI, Anagrama, Colección Argumentos, (Barcelona: Siglo Veintiuno Editores, 2015).
} 
está transformando las condiciones en las cuales se establece la prosperidad inmediata de los Estados y pueblos de todo el mundo". "Pero es evidente también que esta mundialización financiera genera importantes riesgos sistémicos que es preciso advertir para adoptar los correctivos correspondientes y las precauciones de carácter internacional, regional y local.

En todo caso, dada la financiarización de la economía y su naturaleza principalmente especulativa, el sistema es incapaz de generar un orden político y social estable, pues queda propenso a reiteradas crisis como la norteamericana en 2008 y la de la zona del euro de 2009 a 2013, y se crea una situación permanente de inseguridad, incertidumbre y caos. ${ }^{45}$ Por ello es válida la apreciación de Joseph Stiglitz de que tenemos un sistema de "Gobierno global sin Estado global" que exige "repensar cómo se toman las decisiones a nivel internacional y en el interés de quien..."46

Otro fenómeno que se hizo evidente con la globalización fue el cuestionamiento a los poderes y el papel de los Estados nacionales que parecían haber llegado a su ocaso o se presentaban totalmente disminuidos e innecesarios. En otros, como resultado de las crisis y la necesidad de la reactivación económica y el salvataje de las instituciones financieras, resurgen con su poder normativo y de fuerza que les permite, eficazmente, trasladar el costo a los sectores mayoritarios de la población e intervenir en la economía con la explotación de los recursos públicos, generación de empleo y provisión de servicios.

Algunos consideran también que el Estado ya no tiene futuro como forma de convivencia política local o nacional, pero sí como gobierno de la globalización para definir políticas económicas mundiales, establecer responsabilidades económicas, políticas, sociales y ecológicas a las empresas transnacionales y a los organismos multilaterales como el Banco Mundial y el Fondo Monetario Internacional, para establecer instrumentos contra el crimen organizado y la corrupción, además de controlar los abusos de poder de los agentes económicos internacionales, si bien en la actualidad habría ya una suerte de gobierno global sin estado global. ${ }^{47}$

Antes de la crisis de 2008 existía ya (en esferas académicas y de los propios organismos financieros internacionales) la percepción de que la globalización actual y en especial el control hegemónico del capital financiero y de los tratados de comercio injustos afectaban drásticamente a los países en desarrollo para beneficiar a los desarrollados. Stiglitz denunció también en 2007, que la globalización "no está funcionando" puesto que no beneficiaba a todos pues existía en ella "liberalización del mercado y del capital pero no el de la mano de obra"; que en los "tratados de libre comercio" no se negociaba

\footnotetext{
${ }^{44}$ David Held y otros, Transformaciones globales, (México: University Press, Oxford, 2002), 274.

45 Perry Anderson, "Neoliberalismo: un balance provisorio" y "Más allá del neoliberalismo", en La Trama de Neoliberalismo, Emir Sader y otros, (Buenos Aires: CLACSO, 2da edición, 2013).

${ }^{46}$ Joseph Stiglitz, El malestar de la globalización, (Buenos Aires, Taurus, 2003).

47 Baldo Kresalja, César Ochoa, Derecho constitucional económico, (Lima: Fondo Editorial de la Pontificia Universidad Católica del Perú, 2009).
} 
"nada", pues los países más pobres del mundo quedaban en una "situación peor"; que en aquellos había "reuniones mas no negociaciones" y, que en los mercados financieros, su liberalización había provocado una mayor inestabilidad, puesto que el dinero fluía de manera equivocada, no de los países ricos a los pobres sino de manera inversa y sin distribuir equitativamente el riesgo. ${ }^{48}$

En septiembre de 2008, denominado "septiembre negro", se tambaleó la arquitectura financiera mundial y el sistema apareció con un notable riesgo sistémico. Como lo indicó Ignacio Ramonet, ${ }^{49}$ en octubre de 2008 se acabó la "edad de oro" de Wall Street y la etapa de exuberancia y despilfarro de una aristocracia de "banqueros de inversión" que obtenían beneficios exorbitantes de corto plazo con una "burbuja financiera" compuesta por ventas de hipotecas basura del mercado inmobiliario, la manipulación de instrumentos financieros opacos, la titulación de activos de dudoso respaldo y contratos virtuales de cobertura de riesgos. El desastre de la banca de inversión y del aparato financiero de Estados Unidos y Europa afectó a las actividades productivas y de consumo y, en especial, a los salarios de los trabajadores; aumentó el desempleo y subempleo y disminuyó el trabajo y los ingresos de los migrantes y las remesas que enviaban a sus países de origen, uno de los principales componentes de su reactivación en los primeros años del nuevo siglo.

Los gobiernos que desestimaron inicialmente la regulación y la prevención de los excesos financieros de la banca e instituciones de intermediación privadas, adoptaron medidas drásticas para evitar el colapso y, si bien les exigieron parcialmente que asumieran sus responsabilidades, procedieron a su salvataje ilimitado para defender al público, disminuyendo las ejecuciones hipotecarias, reduciendo los riesgos de pérdidas y otorgando a los afectados créditos fiscales con intereses subsidiados. Tanto Bush como Obama en Estados Unidos y, a su tiempo, los gobiernos europeos liderados por Alemania y los latinoamericanos como Ecuador enfrentaron la crisis con la intervención y regulaciones del Estado, renegando de la difundida convicción neoliberal de que el mercado y la empresa privada se autorregulan y lo arreglan todo. El enorme peso del salvataje, inicialmente estimado en varios miles de millones de dólares y euros, fue trasladado finalmente por el Estado a los contribuyentes de sus países y a los ciudadanos del mundo, mediante los artificios del sistema monetario internacional, que es uno de los pilares de la globalización capitalista.

La crisis financiera antes indicada no afectó dramáticamente de manera inicial a las economías latinoamericanas, que tenían una reactivación económica importante, sostenida en los últimos años por una mayor participación en el comercio internacional, el boom de los precios de las materias primas, un importante ingreso de remesas de divisas de sus migrantes a Estados Unidos y Europa y por los correctivos de control y

\footnotetext{
48 Joseph Stiglitz, "Globalización y Desarrollo", Conferencia dictada en FLACSO-Ecuador el 14 de diciembre de 2007.

${ }^{49}$ Ignacio Ramonet. El fin de una era del capitalismo financiero: la crisis del siglo, en el periódico Le Monde Diplomatique de 7 de octubre de 2008, https://mondiplo.com/la-crisis-del-siglo-4024
} 
estabilidad que se introdujeron a las actividades financieras, a fines del siglo XX e inicios del presente.

Después de la recesión que se inició entre 2007 y 2009 se han formulado varias interpretaciones de la crisis y del futuro de la globalización capitalista, por parte de: teóricos neoliberales ortodoxos como Gary Becker y Alan Greenspan que estiman que el fenómeno es transitorio y que se avecina una recuperación económica progresiva; neokeynesianos heterodoxos como Paul Krugman, Joseph Stiglitz, George Soros y Nouriel Roubini y poskeynesianos como Philip Arestis, Gerald Epstein, Miguel Aglietta, Robert Bayer y Thomas Palley, que ponen reparos al neoliberalismo radical y a la liberalización y demandan mayor regulación financiera y los neomarxistas que argumentan sobre los desequilibrios intrínsecos del capitalismo actual, como Michel Husson y Alain Bhir; la obstrucción de la demanda con la flexibilización laboral por parte de Robert Brenner, que analiza también la sobreoferta y la sobreproducción que corroe al capitalismo; Andrew Kliman, Chris Harman y Guglielmo Carchedi sobre el descenso de la tasa de ganancia y la rentabilidad; Francis Chesnais y John Bellamy Foster respecto a la crisis en función de la hipertrofia financiera y el fenómeno de la financiarización, para referirse a las transacciones especulativas y a capitales sobreacumulados que copan los mercados con montos superiores al promedio de la circulación bancaria y Costas Lapavitsas y otros, que plantean el desequilibrio financiero como resultado del dinamismo de la reestructuración neoliberal. Todos ellos coinciden en que existe conexión entre las turbulencias financieras y los desajustes estructurales del capitalismo. No obstante, en la mayoría de planteamientos, no existe tampoco una formulación alternativa y estructural al sistema mundial. ${ }^{50}$

Si bien en el informe anual del FMI del año 2008 se replantea su misión como organismo financiero internacional y, de esta manera, se concluye que la supervisión es clave para dar seguimiento de las políticas económicas de los países miembros y garantizar que estos cumplan con sus obligaciones, pues "al ingresar en el FMI, cada país se compromete, en virtud del Artículo IV del Convenio Constitutivo de la institución, a aplicar políticas que estimulen un crecimiento económico ordenado con estabilidad de precios y a evitar manipular los tipos de cambio para obtener ventajas competitivas desleales. Otro compromiso que adquieren los países es el de proporcionar información exacta y oportuna sobre su economía al FMI” (pág. 20).

En el referido informe se aclara que la supervisión puede ser bilateral, multilateral y regional y se detalla sobre las implicaciones de la globalización en la política fiscal, ya que esta debe ser capaz de afrontar y responder ante las presiones de la globalización y tolerar la deuda externa. Se establece también en el documento una serie de recomendaciones a los gobiernos, entre las cuales destacan: mejores prácticas de gestión de riesgos; una estructura sólida para tomar decisiones bien definidas y adecuadas; excelente calidad en la evaluación, divulgación y contabilidad de los datos de la

\footnotetext{
${ }^{50}$ Claudio Katz, Interpretación de la crisis, Buenos Aires, 6 de octubre de 2010.
} 
economía interna de cada país y que los bancos tengan suficiente liquidez para el otorgamiento de préstamos sin descuidar los riesgos en los créditos. ${ }^{51}$

La visión neoliberal u ortodoxa insiste, por medio de los organismos internacionales y los gobiernos de los países poderosos, luego de la crisis de 2008, que el excesivo gasto público y social, el intervencionismo estatal y el poder de los sindicatos que defienden salarios y prestaciones muy altas, siguen siendo, de todas maneras, los causantes de la inestabilidad económica del sistema y de la crisis y, que, por lo tanto, se requiere salvar y dinamizar a los bancos y al sector financiero mediante el incremento de la inversión extranjera, la captación de fondos previsionales, las privatizaciones, la reducción de salarios y la introducción de políticas de austeridad. Los neokeynesianos, a la vez, acusan a las políticas inadecuadas de excesos del sector financiero de falta de control y de ser los responsables de la pervivencia de la crisis. Demandan también que el Estado incremente el gasto público y el consumo, que se active el sector productivo y que se llegue a la convicción de que el mercado no puede funcionar por sí sólo. Los sustentadores de una opción crítica - marxista sostienen, en cambio, que en el capitalismo las crisis son recurrentes y que obedecen a causas estructurales, producto de la naturaleza misma del sistema como resultado de la contradicción entre producción cada vez más social y la apropiación privada cada vez más agresiva.

En la crisis, los bancos centrales (norteamericano y europeo) jugaron un papel crucial para evitar las quiebras de las instituciones financieras y la depresión económica y estabilizar los mercados, pero con un alto costo social y el aumento de la desigualdad entre ricos y clases populares y medias. ${ }^{52}$

Luego de la crisis en Estados Unidos y de la zona del euro entre 2009 y 2013, y frente a la inestabilidad financiera y amenaza de nuevos colapsos, se provocó una manifiesta desaceleración de la globalización económica por la caída del auge comercial, el deterioro de los precios de productos básicos y de las remesas de divisas de los migrantes; la salida de capitales de los mercados emergentes y la caída de la actividad internacional y negocios de las empresas en otros mercados, lo cual obviamente repercutió de manera negativa en los años siguientes en la economía de países dependientes como los latinoamericanos. Pero el mayor impacto de la crisis financiera se manifestó primero en la adopción de medidas de control por parte de los gobiernos al capital financiero y al mercado de derivados y luego en la adopción en las políticas públicas restableciendo el proteccionismo y limitando la actividad de las empresas en otros países. ${ }^{53}$

\footnotetext{
${ }^{51}$ Fondo Monetario Internacional: por una economía mundial para todos: Informe anual 2008, www.imf.org

${ }^{52}$ Thomas Piketty, La Crisis del Capital en el siglo XXI, Anagrama, Colección Argumentos (Barcelona: Siglo XXI editores, 2015).

53 Jordi Canals, La globalización después de la crisis financiera, 2003, https://www.bbvaopenmind.com/wp-content/uploads/static/pdf/080_JORDI_CANALS.pdf
} 
Al describir la "nueva era" poscrisis, en la que esta tiene manifestaciones recesivas recurrentes, se advierten varias manifestaciones transformadoras: la erosión y recuperación del dólar, el euro y el yuan; la parálisis del proyecto europeo y el crecimiento de nacionalismos proteccionistas; el auge y deterioro del comercio internacional y de los precios de las materias primas; el ascenso de la economía asiática liderada por China y la ineficacia de las Naciones Unidas. Si desde 1989 hasta 2011 se percibió al mundo como unipolar, desde 2012 se lo concibe como multipolar, con expresiones vacilantes de confrontaciones, pero con manifiestas colaboraciones económicas entre los países más desarrollados y los emergentes.

También se han hecho presentes manifestaciones sociales importantes contra los efectos nocivos de la globalización, como las producidas en Seattle (1999), Davos, Génova y en 2002, en el Foro Social Mundial, reunido en Porto Alegre (Brasil) en los que se demostró la capacidad de los Estados más débiles y de los movimientos sociales para cuestionar el nuevo paradigma internacional del capitalismo mundial. Allí se planteó la necesidad de construir un sistema alternativo y de rechazar el neoliberalismo y la globalización financiera. En los últimos años se han desarrollado también importantes movimientos contra la globalización: en Francia, en Octubre de 2015, se efectuó una movilización (Nuit Debout) de rechazo a los tratados de libre comercio, como el Tratado Transpacífico de Cooperación Económica (TPP) y Tratado Transatlántico de Comercio e Inversión (TTIP), actualmente en revisión por decisión unilateral del actual gobierno norteamericano, y en reuniones paralelas de confrontación a las cumbres presidenciales de las potencias mundiales.

Es obvio que los países latinoamericanos, en los que se ha transitado de gobiernos oligárquicos modernizadores a aquellos que inicialmente se autodenominaron progresistas y posneoliberales y que, finalmente, devinieron en gobiernos pragmáticos que combinan el neoliberalismo con el neoestructuralismo en defensa de la estabilidad y consolidación del sistema, hay fenómenos que están presentes en la realidad y que no han podido ser resueltos. Es el caso de la naturaleza y las "relaciones entre la globalización y el desarrollo", en los que se mantiene la polarización económica y social y la dependencia como resultado de la sobrevivencia del intercambio desigual y de la gran diferencia que existe en los ámbitos del conocimiento y la tecnología. En cuanto al desarrollo mismo, constituyen desafíos no alcanzados: la "capacidad de gestionar el conocimiento en el espacio nacional" y la "cohesión social" para superar las desigualdades internas; la afirmación de la democracia frente a tendencias autoritarias de líderes y "minorías que están cerca de intereses transnacionales"; la "estabilidad institucional de largo plazo, independientemente de la naturaleza del régimen político" y el desarrollo de ideas y propuestas críticas y propias en lo económico y social. ${ }^{54}$

\footnotetext{
${ }^{54}$ Aldo Ferrer, Raul Prebisch y el dilema del desarrollo en el mundo global, Revista de la CEPAL 101, Agosto de 2010.
} 
La estrategia que se sigue en las últimas décadas para la reestructuración capitalista de la región fue descrita anticipadamente por Marcelo Selowsky; jefe para América Latina y el Caribe del Banco Mundial, en tres etapas: la inicial de "ajuste" y "estabilización", la siguiente de "profundización de las reformas estructurales" y la tercera de "consolidación de las reformas y de restauración de los niveles de inversión". 55

Compartiendo la opinión de Beatriz Stolowicz, ${ }^{56}$ en estas décadas se habría cumplido la trayectoria antes indicada con los siguientes escenarios políticos: desde 1970 hasta 1990 se destruyó el patrón de acumulación anterior y sus instituciones con el auxilio de autoritarismos civiles y militares; luego, con regímenes constitucionales, se avanzó con privatizaciones y modernizaciones hasta fines del siglo pasado y, en el transcurso del actual se va implementando y consolidando, con ciertas variaciones intervencionistas, el modelo o política económica neoliberal, incluso con la iniciativa de los denominados gobiernos "progresistas" que utilizaron políticas retóricas antisistema, pero que abiertamente reconocieron, al igual que otros gobiernos del continente, que su misión principal fue la de optimizar el sistema capitalista en este período. ${ }^{57}$

Es necesario advertir la estrecha relación entre los intereses de las más importantes como poderosas corporaciones transnacionales, gestoras de un sistema mundial de dominación para el control de los principales recursos naturales del planeta y de los gobiernos de los países desarrollados y especialmente EEUU, con el FMI y el Banco Mundial y sus instituciones y programas financieros, que son los encargados de definir políticas públicas y de desarrollo y aplicación de modelos de normativas jurídicas que se convierten en directrices obligatorias para todos los países y en especial los latinoamericanos.

Desde 1990 la CEPAL asumió en sus documentos para el desarrollo de América Latina, una orientación neoestructuralista con su conocido documento Transformación productiva con equidad..., que luego fue respaldado por Enrique Iglesias en 1992 desde el BID, por el Banco Mundial en $1998 \mathrm{y}$, finalmente por varios intelectuales y por los presidentes que concurrieron a la Cumbre de las Américas de 1998 en Santiago. Todos ellos identificaron descriptivamente estas orientaciones como un "nuevo consenso posliberal" o "posneoliberales", de igual manera que lo hacen en el presente siglo ciertos gobiernos de origen izquierdista y popular.

La CEPAL insiste también desde 2012 en la necesidad de que la región, diseñe una estrategia de relacionamiento comercial negociado con China y defina alternativas que consoliden la integración regional con una amplia red de infraestructura; fortalezca el mercado interno con mejoras distributivas, reduzca la pobreza; promueva el ascenso de

\footnotetext{
${ }^{55}$ Marcelo Selowsky, "Stages in the Recovery of Latin América's Growth", Finance and Development. Banco Mundial, junio de 1990.

${ }^{56}$ Beatriz Stolowicz, El "posneoliberalismo" y la reconfiguración del capitalismo en América Latina", Universidad Nacional de Colombia, Bogotá, 2010.

${ }^{57}$ Declaraciones de Lula y Correa, a Página 12, el 17 de mayo de 2013 y a El Telégrafoel 15 de enero de 2011.
} 
las clases medias y adopte políticas productivas y tecnológicas más activas e innovadoras orientadas al consumo y a la exportación. ${ }^{58}$

La CEPAL sugiere además, que se consoliden las políticas macroeconómicas que otorgan estabilidad y se adopten, con mejoras tecnológicas consistentes y continuas, medidas "contra cíclicas" para impulsar el desarrollo, la industrialización y una mayor integración en la economía global, sin abandonar las políticas sociales sustentadas en el respeto a los derechos humanos y en el principio de igualdad (2000 y 2002), además de promover la creación de servicios sociales universales de alta calidad, utilizando el sistema fiscal para redistribuir el ingreso con un mayor gasto y una mayor progresividad impositiva, conforme lo propuso también el Banco Mundial en 2013. ${ }^{59}$

Los cambios en el sistema global plantean una serie de cuestionamientos sobre las obstrucciones e intereses políticos y económicos de los Estados nacionales; la revolución tecnológica y su impacto en los procesos productivos, el empleo y subempleo; las crisis económicas; los desafíos medioambientales de seguridad y el crecimiento de la corrupción y de la desigualdad económico y social que están presentes en todas las latitudes y países del mundo, y en especial entre los países desarrollados y en los dependientes, lo que evidentemente incrementa el clima de incertidumbre y de "crisis histórica" que se percibió desde finales del siglo anterior y se mantiene en el presente. $^{60}$

En todo caso hoy, se vive en el mundo un momento de transición en lo económico, político y jurídico, pues se evidencian fenómenos y realidades (worldfalia) que van más allá de las relaciones interestatales y reflejan intereses generales de poderosos actores de la comunidad internacional que transforman al derecho internacional de connotaciones privadas en un auténtico derecho internacional público, con incidencia directa en las normas constitucionales, administrativas y financieras que se adoptan a nivel mundial. ${ }^{61}$

Resulta incontrovertible que la política de los países se sustentó principalmente, hasta la crisis de 2008, en las políticas "socialmente ciegas” del Fondo Monetario Internacional, lo que ha provocado, según lo han reconocido connotados economistas y exfuncionarios de los organismos financieros, mayor inestabilidad y profundas fluctuaciones económicas, como ocurrió no solo en América Latina sino en otros países del mundo.

\footnotetext{
${ }^{58}$ CEPAL: Cambio estructural para la igualdad: una visión integrada del desarrollo, 2012.

59 José Antonio Ocampo, América Latina frente a la turbulencia económica mundial, en Neo estructuralismo y corrientes heterodoxas en América Latina y el Caribe a inicios del siglo XXI, Alicia Bárcena, Antonio Prado, (Santiago de Chile: CEPAL - IDRC - CDRI, 2015).

${ }^{60}$ Eric Hobsbawm, Historia del Siglo XX, (Barcelona: Editorial Crítica, 2003).

${ }^{61}$ Nuria Bouza, Caterina García y Angel Rodrigo, ¿Hacia Worldfalia? La gobernanza política jurídica del interés público global, en La gobernanza del interés público global, XXV Jornadas de la Asociación Española de Profesores de Derecho Internacional y Relaciones Internacionales, Universitat Ponpeu Fabra, Tecnos, Barcelona, 2013.
} 
Los estados nacionales, por su capacidad económica y jurídica, finalmente no se resignaron tan fácilmente a ser sustituidos por las corporaciones transnacionales que participan como actores principales de la globalización económica universal. Por ello les impusieron y les imponen a aquellas su calidad "de propietarios de los teatros nacionales" que ellas necesitan para "sus operaciones". Por lo tanto, los Estados nacionales se presentan como un serio obstáculo para una globalización sin límites, tanto más que resulta difícil consolidar áreas o proyectos regionales, áreas y tratados de libre comercio y casi imposible la aceptación del libre movimiento internacional de la mano de obra para alcanzar un "gobierno mundial" en cuyo propósito no contribuye significativamente el régimen actual de la ONU. ${ }^{62}$

Por otro lado, luego de la crisis norteamericana y europea es evidente que en el nuevo orden liberal internacional no se consolidó el proyecto "imperial" norteamericano de gobernanza unipolar y tampoco el de los regímenes democráticos del Estado social en el primer mundo. Surgió, más bien, un sistema internacional conflictivo e inestable con múltiples poderes e intereses en los que actúan los Estados, las multinacionales y diversas organizaciones de todo tipo.

En Europa se planteó la necesidad de reformar en cada uno de los países y a nivel regional las normas constitucionales y comunes para resolver los desequilibrios presupuestarios, modernizar y reformar las políticas fiscales y asegurar la estabilidad financiera-monetaria con la finalidad de asegurar una mayor calidad en los servicios y un buen gobierno.

Hay que recordar que, una vez más, "la crisis financiera puso de manifiesto la necesidad de contar con normas internacionales más sólidas que posibiliten la "resiliencia" financiera. El Banco Mundial contribuye a la formulación de dichas normas y ayuda a sus clientes a cumplirlas. En el ejercicio de 2015, el Banco, junto con el Fondo Monetario Internacional (FMI), realizó 10 análisis en el marco del Programa de Evaluación del Sector Financiero con el objetivo de ayudar a los países a detectar y corregir los aspectos vulnerables de sus sistemas financieros. También es parte esencial de la labor del Banco la lucha contra el lavado de activos y el financiamiento del terrorismo, en lo que se incluye la recuperación de los activos robados. En el ejercicio de 2015 el Banco trabajó con más de 20 países para llevar adelante evaluaciones de alcance nacional sobre el riesgo en estas áreas y para diseñar estrategias que permitieran mitigar posibles vulnerabilidades". ${ }^{63}$

El cuestionamiento a la globalización económica se manifiesta recientemente no sólo en los países dependientes sino en los centrales, con la adopción de decisiones desintegradoras regionales como el Brexit (2016) o con el ascenso al poder, en los países desarrollados, de opciones políticas nacionalistas retrógradas, racistas y

\footnotetext{
${ }^{62}$ Eric Hobsbawn, Después del siglo XX: Un mundo en transición, http://www.letraslibres.com/mexicoespana/despues-del-siglo-xx-un-mundo-en-transicion

${ }^{63}$ Banco Mundial, Informe Anual 2015, 7, http://www.bancomundial.org/es/about/annual-report-2015.
} 
xenófobas, que se oponen frontalmente a la migración y cuestionan la globalización promoviendo el restablecimiento del proteccionismo, sin que se afecte el libre comercio de sus productos y obstaculizando la deslocalización de las actividades industriales para proteger o ampliar las plazas de trabajo en los países centrales.

Estas realidades, que cuentan con el apoyo de sectores rurales, de la clase obrera y de la población de zonas empobrecidas por el desempleo y la desindustrialización en los países desarrollados, explican el resultado de las elecciones presidenciales en Estados Unidos con el triunfo de Donald Trump y el fortalecimiento de similares opciones de extrema derecha en Europa. El presidente norteamericano anunció en abril de 2017, pese a la objeción de los organismos multilaterales como el FMI, la disminución de las regulaciones y la supervisión financiera, adoptadas por Barack Obama luego de la crisis de 2008, la repatriación de capitales almacenados en el exterior y la disminución de impuestos a las empresas, lo que podría poner en mayor peligro la estabilidad de la economía mundial, ${ }^{64}$ en función de lograr una nueva hegemonía norteamericana como en el mundo.

Si bien la globalización es un fenómeno económico, tecnológico y cultural cada vez más presente en la realidad del sistema imperante, no es menos cierto que enfrenta serias dificultades para construirse como una realidad política para consolidar una economía mundial fluida e interconectada que otorgue iguales oportunidades a todos los países y a sus protagonistas para alcanzar el bienestar de los pueblos.

La propia globalización y el desarrollo económico desigual del sistema, en las diferentes latitudes del mundo, no solo provoca las referidas reacciones nacionales, sino que su dinamia lleva a que se presenten otras realidades como el traslado del centro de gravedad de la economía mundial de EEUU y Europa hacia China y el sur y el sureste asiático.

Nos encontramos en la actualidad en un escenario en movimiento y en el que la globalización no resulta el mundo idílico o fácil de alcanzar, como lo pensaban los ideólogos del neoliberalismo o el neoinstitucionalismo, pues se trata de una situación compleja que no se puede abstraer del conflicto económico, social y político internacional y en la que es preciso definir su gobernanza, el interés público global, sus actores o participantes, las normas jurídicas necesarias para regular los intereses en juego y las posibilidades que ofrece el régimen internacional económico en lo financiero, inversiones, derechos humanos, defensa del medioambiente, lucha anticorrupción, etc. ${ }^{65}$

\footnotetext{
${ }^{64}$ Informe a la asamblea de primavera del FMI y el Banco Mundial, en el Foro Estratégico Mundial reunido en Miami, 19 de abril de 2017.

${ }^{65}$ Noe Cornago, "De la Filosofía político a la Gobernanza Global: un acercamientos crítico a la noción del interés público global", en XXV Jornadas de AEPDIRT, Universitat Pompeu Fabra, Tecnos, Barcelona, 2013.
} 


\section{POLÍTICAS Y MODELOS ECONÓMICOS EN LA GLOBALIZACIÓN ACTUAL}

Durante la globalización, desde el siglo XX hasta hoy, se pueden advertir procesos de ajuste al patrón de acumulación capitalista, a la tendencia decreciente de tasa de ganancia y a la legitimación social, en los ámbitos comercial, productivo, financiero, social, político y jurídico, para lo cual se utilizan "políticas" o "modelos", que al ser implementados con cierta coherencia económica y argumentativa, favorecen el crecimiento, la racionalidad y la estabilización del sistema en su conjunto. ${ }^{66}$

Las políticas públicas y los modelos económicos propiamente dichos, no son sino medidas adoptadas por el Estado, por medio del gobierno, a partir de una simplificación teórica estructurada de la realidad en un momento determinado; se trata de contar con una representación abstracta del sistema y de definir medidas coherentes que requieren de interrelaciones entre sus varios componentes; tienen un sustento macro y microeconómico para identificar las soluciones y normas que se adoptan dentro del régimen imperante en un momento determinado de un país o de varios, bajo la orientación de una doctrina o de formulaciones o recomendaciones de los organismos financieros internacionales. ${ }^{67}$

Las políticas o modelos económicos que se han definido e implementado a nivel internacional en el siglo XX y en el actual, son: liberales hasta los años treinta; intervencionistas, estructuralistas o desarrollistas hasta inicios de los años setenta; neoliberales o neocompetitivas propiamente tales hasta fines del siglo $\mathrm{XX}$ y neointervencionistas o neoestructuralistas y neodesarrollista, desde inicios del siglo XXI hasta el momento.

En la reciente globalización, desde 1990, se han adoptado en términos descriptivos los modelos neoliberal (estabilización y ajuste) y neoestructural o neodesarrollista. Este último combina o prolonga en lo esencial las políticas neoliberales iniciales con formas o modalidades distintas cercanas al desarrollismo del pasado, conforme a las necesidades económicas y políticas del momento en los distintos países latinoamericanos, con la finalidad de afianzar el sistema imperante o para dinamizarlo, por lo que algunos más bien identifican al último como "posneoliberal" o como "posliberal".

En algún momento se argumentó que en América Latina, con los gobiernos "progresistas", se inició la construcción de un modelo "alternativo" identificado como del "socialismo del siglo XXI", pero incluso sus propios protagonistas, finalmente

\footnotetext{
${ }^{66}$ Lucas Pacheco Prado, Política Económica, sus fundamentos en la economía política, (Quito: Pontificia Universidad Católica del Ecuador, quinta edición, 2015).

${ }^{67}$ Víctor Granda Aguilar, Contenido económico de las constituciones de Bolivia y Ecuador, (Quito: Colección profesional Ecuatoriana, Universidad Andina Simón Bolívar, Ediciones Legales, 2015); William J. Barber, Historia del Pensamiento Económico, (Madrid: Alianza Editorial, 1980).
} 
reconocieron que sus esfuerzos políticos y económicos se encontraban dirigidos, en lo principal, a fortalecer o renovar el sistema capitalista imperante. ${ }^{68}$

El neoliberalismo, como modelo económico o conjunto de políticas económicas, se inició en las décadas del 70 y 80 a nivel internacional, con los gobiernos de Margaret Tatcher y de Ronald Reagan y en América Latina con la dictadura de Pinochet. El modelo neoliberal de entonces se fundamentó en el pensamiento liberal neoclásico y en el monetarismo y luego en la visión de los pensadores que se identificaron como "institucionalistas" o "neoinstitucionalistas" y que son los que promueven la proliferación de acuerdos comerciales y de inversión privados, el predominio del mercado, la reducción al mínimo de la intervención de los estados en lo mercantil y lo financiero y que difunden o justifican la visión y las instrucciones de los organismos financieros internacionales.

Desde 1982, los organismos financieros multilaterales, como el FMI y el Banco Mundial y los gobiernos de los países desarrollados, inspirados además en el pensamiento neoconservador norteamericano, plantearon que se adopte en los países subdesarrollados o en vías de desarrollo se adoptaran "programas de estabilización" y "políticas de ajuste estructural" que en lo principal debían asegurarles la liberalización del comercio y el pago de la deuda externa. Entre las acciones que se impulsaron con esos contenidos, se encuentran: la Iniciativa para la cuenca del Caribe en 1983; el Plan Baker en 1985; el Plan Brady en 1986; Iniciativa Andina sobre drogas y desarrollo alternativo, en 1990; el Tratado de Libre Comercio (México, Estados Unidos y Canadá) en enero de 1991 y el Disenso de San Antonio sobre drogas y desarrollo en febrero de $1992 .^{69}$

El neoliberalismo y sus políticas hacen del mercado el centro y fuente de lo económico, social y cultural, si bien su visión se restringe a los mercados y especialmente a los del sector financiero y bursátil, en torno a los cuales giran los bienes y servicios. El Estado debe ser, para esta doctrina, un mero complemento de las normas mercantiles y financieras, pues entre menos Estado mejor actúan los mercados para configurar lo social y llegar espontáneamente a un equilibrio general.

Se conoce como "Consenso de Washington"70 a la sistematización de esa política económica impulsada por los organismos financieros internacionales, que plantea,

\footnotetext{
${ }^{68}$ Los presidentes Lula y Correa, reconocieron que su política y gestión, finalmente estuvo orientada a mejorar el funcionamiento del sistema capitalista introduciendo algunos correctivos redistributivos y ampliando las ganancias de los poderosos grupos de poder económico nacional y extranjero. (Entrevista a Lula, en Página 12, el 17 de mayo de 2013 y entrevista a Rafael Correa en diario El Telégrafo de 15 de enero de 2011).

69 "Proyecto Propio frente al Proyecto Ajeno". Conclusiones y acuerdos del seminario taller, de partidos y movimiento de izquierda de América Latina, Lima, 26 al 29 de febrero de 1992.

${ }^{70}$ Desde 1990, John Williamson, del Instituto de Economía Internacional de Washington D.C., denominó así al conjunto de recomendaciones de política económica, formuladas por el Fondo Monetario Internacional (FMI), el Banco Mundial (BM) y el Departamento del Tesoro de Estados Unidos, para optimizar la economía y la gobernabilidad de los países de América Latina.
} 
teniendo como ejes la globalización del mercado, las empresas transnacionales y el capital financiero internacional: las privatizaciones de los activos públicos; la reducción del tamaño del Estado; la flexibilización laboral; el saneamiento y la liberalización económica, comercial y financiera y políticas de estabilización, con severos ajustes económicos de impacto regresivo en los sectores sociales más pobres de la población y como resultado de esa política, se vieron deteriorados los ingresos de los sectores más vulnerables de la población, si bien se aseguraron, principalmente, la estabilización macroeconómica de las economías nacionales y el pago y amortización de la deuda externa.

La políticas neoliberales tuvieron inicialmente amplia aceptación, como respuesta a problemas objetivos de la realidad de nuestros países en los años setenta y ochenta, al estabilizar sus economías frente al descalabro inflacionario, la ineficiencia de la burocracia, los presupuestos desequilibrados, los déficits abultados en sus balanzas de pagos, las emisiones monetarias sin respaldo y los enormes volúmenes de deuda externa e interna que no podían ser servidos oportunamente. Las propuestas neoliberales parecieron inicialmente razonables y no se diga si planteaban, a la vez, la necesidad de una regulación estatal más eficaz y eficiente y que no debían desatender las demandas imperiosas en el campo de la educación, la salud, seguridad social y el desempleo. ${ }^{71}$

Este modelo y sus políticas, dentro del sistema de economía de mercado, como dice Jorge Witker, asignan al Estado y al derecho una cierta función reguladora, "que posibilita el ejercicio de las libertades mercantiles de los ciudadanos", pues al producirse el fenómeno del repliegue del primero, "sus instrumentos de dirección y regulación se simplifican y dejan espacio a la autonomía de voluntad y a la libre contratación de empresarios, trabajadores y consumidores". ${ }^{72}$

El Estado queda pues subordinado al mercado y su política económica de regulación se reduce a cumplir las imposiciones de los organismos multilaterales de crédito, las cartas de intención del FMI y los acuerdos o convenios internacionales económicos que se transforman en las verdaderas constituciones económicas de los países, todo lo cual resulta también conveniente a los grupos de poder local, subordinados al capital transnacional.

Como ya se ha señalado, la privatización de las empresas y los bienes públicos fueron fuente de corrupción y dilapidación de los recursos estatales; se desmanteló la industria nacional para ampliar el espacio de las empresas transnacionales; la desregulación arancelaria en nuestros países dependientes no tuvo como contrapartida la liberalización del mercado y la eliminación de subsidios en los países más desarrollados; creció el desempleo y subempleo; se profundizó la inequitativa distribución del ingreso como resultado de la flexibilización laboral y, en los diferentes países, estalló el impacto de la

\footnotetext{
${ }^{71}$ Héctor Villegas B., Manual de Finanzas Públicas, (Buenos Aires: Ediciones Depalma, 2000).

${ }^{72}$ Jorge Witker, Introducción al Derecho Económico, (México: Ediciones Harla, 1997), 31.
} 
enorme carga de la deuda externa como resultado de las políticas de ajuste impuestas por el FMI. ${ }^{73}$

Si bien el neoliberalismo está asociado a la globalización capitalista, su recetario evidenció, pronto en la realidad, ser un nuevo instrumento de dominio neocolonial para reprimarizar la economía; saquear el ahorro nacional por medio de la liberalización financiera; asegurar el pago de la deuda externa y destruir la deteriorada industria nacional con lo cual avanza la miseria, la pobreza, el desempleo, la marginalidad y la migración de los sectores populares más pobres, como se demostró en las crisis de México, Argentina y Brasil.

La CEPAL en su informe sobre el desarrollo humano de la región del año 2000, registró en sus estadísticas el deterioro económico de América Latina, bajo la ortodoxia neoliberal, la transferencia neta de capitales hacia los países desarrollados y los alarmantes índices alcanzados por la pobreza y la extrema pobreza que afecta a la mayoría de la población. ${ }^{74}$

La desregulación del Estado y de la legislación económica y financiera que se plantearon como solución inicialmente, fueron sustituidas con diferente ritmo, según las circunstancias nacionales y sin desconocer el proceso y las exigencias externas de la globalización en varios convenios y normas internacionales y locales, en los que se reconoce, en todo caso, la necesidad de mantener o reintroducir o incrementar controles financieros más estrictos.

En cuanto a la reforma del Estado y de las finanzas públicas, tanto los organismos internacionales de las Naciones Unidas y la CEPAL a nivel regional, como los entes financieros Banco Mundial, Banco Interamericano de Desarrollo y Fondo Monetario Internacional, formularon inicialmente propuestas para sustituir el intervencionismo estatal y el desarrollismo vigentes hasta los años 70 y 80, por medidas de "estabilización", "ajustes estructurales" y políticas de "shock", que modificaron la dinámica de la acumulación capitalista en América Latina y en los países de la "periferia". De este modo se produjo una transferencia de capital, materias primas y energía de los países subdesarrollados a los países capitalistas centrales, consolidando el sistema mundial, bajo los parámetros neoliberales controlados por el capital financiero internacional y las empresas transnacionales. ${ }^{75}$

El FMI recomendaba, según las circunstancias políticas internas, medidas de shock o gradualistas, que en todo caso llevaron a la recesión y a la regresión económica y social, ya que afectaron a los sectores más pobres y beneficiaron a los grupos de poder de los

\footnotetext{
${ }^{73}$ Víctor Granda Aguilar, Derecho Económico Financiero Ecuatoriano, (Quito: Universidad Central del Ecuador, 2016).

${ }^{74}$ Panorama Social de América Latina 2000 - 2001, CEPAL, Santiago de Chile, 2001.

${ }^{75}$ Pablo Dávalos, La democracia disciplinaria, el proyecto posneoliberal para América Latina, (Quito, Gráficas Iberia, 2010).
} 
países latinoamericanos, lo que permitió a la CEPAL calificar a los ochenta como la "década perdida". El FMI actuó entonces mediante "cartas de intención" confidenciales presentadas por los gobiernos, con las que se pretendían corregir los desequilibrios mediante "condicionalidades", para "ajustar" la demanda a los niveles de producción internos; asegurar el pago de la deuda externa para fortalecer al capital financiero internacional y alcanzar estabilidad macroeconómica, como garantía del crecimiento económico. $^{76}$

Con este propósito, bajo control físico de funcionarios del Fondo, se establecieron medidas y normas estrictas, especialmente para controlar el presupuesto y el gasto estatal destinados a remuneraciones, inversiones y de rubros sociales; se incrementaron los precios de los servicios públicos, de los combustibles y los impuestos regresivos como el IVA y se disminuyeron las capacidades regulatorias del Estado para favorecer la privatización de aquellos. Se introduce el concepto de "superávit fiscal primario", como excedente obligatorio entre el gasto público y los recursos destinados al pago de la deuda y su servicio, que debía ser cumplido estrictamente por los países de la región, los que no podían definir por sí mismos las prioridades de aquel. ${ }^{77}$

En el caso de Ecuador, los 14 programas macroeconómicos y las 10 "cartas de intención" suscritas en las décadas del 80 y del 90, establecieron, en lo principal "condicionalidades" o "terapias de shock" que fueron presentadas como necesidades financieras y técnicas, solicitadas soberanamente por el gobierno nacional para enfrentar la crisis, la inflación y los desequilibrios ocasionados por el derroche del Estado y para favorecer su reforma política monitoreada, a la vez, por el Banco Mundial, mediante el "ajuste estructural" y los "acuerdos de asistencia - país". 78

Entre las condicionalidades de las cartas de intención se encuentran: "Reducción de la inflación a 30\%; disminución del déficit en cuenta corriente al 4.2\% del PBI; inflación inferior al 20\% anual; aumento de exportaciones del 19\% al 25\%; reforma tributaria; control del gasto; asignación equitativa de recursos fiscales más eficientes; aumento de la eficiencia de las empresas públicas con privatización de alguna de ellas; mejora de la capacidad de regulación y supervisión de la Superintendencia de Bancos; reforma del sistema arancelario". ${ }^{79}$

\footnotetext{
${ }^{76}$ Fondo Monetario Internacional: Aspectos teóricos del diseño de los programas de ajuste respaldados por el Fondo, documento interno del FMI, SM/86/162 (S), 1987.

${ }^{77}$ Pablo Dávalos, La democracia disciplinaria, el proyecto posneoliberal para América Latina, (Quito: Gráficas Iberia, 2010).

${ }^{78}$ German Parra Maldonado, "Las condicionalidades de las Cartas de Intención con el Fondo Monetario Internacional y su influencia en la Modernización del Estado Ecuatoriano”, Tesis de Maestría, UASB, 2005.

79 Yesenia Santana, El Rol del Fondo Monetario Internacional en la Economía del Ecuador, http://repositorio.iaen.edu.ec/bitstream/24000/2603/1/EL\%20ROL\%20DEL\%20FONDO\%20MONETAR IO\%20INTERNACIONAL\%20EN\%20EL\%20DESARROLLO\%20DE\%20LA\%20ECONOMIA\%20EC UATORIANA
} 
Las autoridades económicas del gobierno se convirtieron en meros operadores de políticas y recetas impuestas por los intereses internacionales del capital financiero para transferir los costos de la crisis a la periferia y satisfacer sus requerimientos de recursos y bienes baratos desde ella. Las medidas de devaluación, inflación y administración del tipo de cambio, además de perjudicar directamente a los sectores sociales más vulnerables, favorecieron la alianza económica y política entre el capital internacional y las oligarquías locales, replanteando los procesos de industrialización y de su subordinación a los intereses externos, pasando a controlar todos los resortes del poder económico y político nacional.

Se puede decir que la disciplina y austeridad fiscal estuvieron principalmente dirigidas a disminuir los derechos de los trabajadores y servidores del sector público y a limitar la iniciativa económica del Estado tanto en la explotación de recursos naturales como en la provisión de servicios públicos. Cuando ciertos sectores con poder económico, de movilización o de presión nacional o local, demandaron recursos del Estado, el gobierno optó por las "preasignaciones presupuestarias" y otros arbitrios legales o contractuales, como la descentralización o un amplio régimen de concesiones y de otras figuras propias del derecho administrativo. En realidad, el ajuste macro-fiscal y la reforma estructural dirigidos por el FMI y el BM, estuvieron destinados a disciplinar a los mercados, a las exigencias de las corporaciones transnacionales y a los Estados para asegurar el pago de la deuda externa y articular a una nueva etapa de la acumulación capitalista mundial, la de la especulación y financiarización del sistema y a la restructuración de la organización y función del Estado en el contexto del mercado mundial.

La crisis del neoliberalismo y sus efectos desastrosos en países como los latinoamericanos, a los que ya hemos hecho referencia, son el punto de partida para la nueva propuesta del Banco Mundial y del FMI a fines del siglo pasado e inicios del presente sobre el desarrollo, la lucha contra la pobreza y para alcanzar los objetivos del milenio de las Naciones Unidas, si bien en la realidad implican una reformulación para la reconstitución del neoliberalismo, mediante fórmulas neointervencionistas o neoestructuralistas o neodesarrollistas supeditadas a las exigencias del mercado, de las corporaciones y de los estados, que en lugar de debilitarse se fortalecieron como mecanismos de control social, de represión y de transferencia de las pérdidas hacia la población mundial.

Se puede asegurar, siguiendo las observaciones objetivas de Hobsbawn, que el más rápido crecimiento en el PIB, en el mundo capitalista avanzado, no se dio precisamente en los períodos en los que primó el modelo liberal (1870 a 1913) ni en el neoliberal (1973 - 1998), sino en los "años dorados" del sistema (1950 - 1973) que corresponden al período intervencionista del estado de bienestar", y en los últimos años del siglo XX y primeros años del XXI (1999 - 2008), con la extraordinaria revolución industrial y el crecimiento asombroso de las economías asiáticas, que no fueron guiadas por el 
neoliberalismo ni los disciplinamientos del FMI, pues más bien ocasionaron un rápido deterioro de los países que los aplicaron en diversas latitudes del mundo. ${ }^{80}$

Durante el período de la actual globalización, desde los años ochenta del siglo pasado, el modelo neoliberal adoptó dos modalidades: la que contiene reformas radicales de "primera generación", para enfrentar al modelo anterior intervencionista, como las privatizaciones y la liberalización comercial y especialmente financiera en un marco general de desregulación y las reformas de "segunda generación", en los años noventa, impulsadas por el propio FMI y el BM, que pretendieron fortalecer las instituciones y su transparencia mediante regulación de los mercados, los servicios públicos y los sistemas de cohesión social.

Sobre el neoliberalismo se distinguen: una versión radical y conservadora, fundamentada en el pensamiento de Hayek, que plantea la autorregulación del mercado en la actividad económica y social, al margen de la intervención humana y política, pues recompensa a los individuos conforme a su aporte al bienestar social; y otra versión, que admite la necesidad de combinar una justicia distributiva y un activismo del Estado de manera limitada y alto contenido ético, como lo planteó John Rawls, para cubrir las necesidades básicas de los ciudadanos y que puedan satisfacer sus derechos y libertades. ${ }^{81}$

El Banco Mundial por su parte, en el informe de Desarrollo Humano de 1997, partiendo de las políticas impuestas por el FMI pero con una encubierta contradicción con estas, formuló reformas estructurales para cambiar la sociedad y el Estado en su conjunto, partiendo del neoinstitucionalismo económico del que Joseph Stiglitz es uno de sus exponentes, y formuló la preeminencia del mercado y de los agentes económicos, otorgando un papel importante a las exigencias de los consumidores y a la reconstitución del papel del Estado, como Estado social de derecho, descentralizado políticamente y eficiente, o como Estado de "seguridad jurídica" o como "Estado necesario", motor de los "cambios institucionales". 82

Las reformas estructurales de largo plazo planteadas por el Banco Mundial, como dice Pablo Dávalos, se definen en el sistema político, el derecho y las leyes, la participación ciudadana, la lucha contra la corrupción, el desarrollo local territorial, la reducción de la pobreza, la gobernabilidad, etc., e involucran, además, a un "complejo institucional" de organizaciones de cooperación internacional, ONG's, instituciones académicas y del sistema de Naciones Unidas y aún a actores sociales y la acción colectiva, para financiar numerosos proyectos de investigación, asistencia técnica y desarrollo, con el objeto de

\footnotetext{
${ }^{80}$ Eric Hobsbawn, Después del siglo XX: Un mundo en transición, http://www.letraslibres.com/mexicoespana/despues-del-siglo-xx-un-mundo-en-transicion

${ }^{81}$ Jhon Rawls, Liberalismo Político, (México: Fondo de Cultura Económica, 1996); Baldo Kresalja y César Ochoa, Derecho constitucional económico, (Lima: Fondo Editorial de la Pontificia Universidad Católica del Perú, 2009).

${ }^{82}$ Banco Mundial: Informe sobre el desarrollo mundial, 1997. El Estado en un mundo en transformación, Washington, 1997.
} 
privatizar al Estado y modificar drásticamente su "contractualidad social" y convertirlo en un aparato represivo que garantice "seguridad jurídica" a los inversionistas transnacionales y un instrumento coercitivo que discipline a las sociedades en las lógicas mercantiles del capitalismo globalizado. ${ }^{83}$

Los programas y políticas de ajuste y las reformas estructurales promovieron la descentralización y la autonomía territorial para fundamentar las reformas del Estado, las finanzas públicas y la administración, tanto en el Ecuador en la década del 90 del siglo pasado como en otros países. Esas políticas fueron incorporadas en reformas constitucionales y legales para asegurar las transferencias de competencias de interés del capital transnacional y financiero, facilitar la "gobernabilidad" y consolidar el ingreso de nuestros países en la dinámica de la nueva globalización y de los acuerdos de libre comercio de la OMC.

Debe recordarse que el neoliberalismo no sugirió la eliminación del Estado sino la modificación de sus funciones gestoras en la economía. Planteó, más bien, su reconceptualización como instrumento de poder y regulación, lo que implica otra forma de intervención en el conjunto de la sociedad. De allí que en el neoliberalismo y en el neointervencionismo el Estado conserva carácter profundamente autoritario y conservador para conducir las reformas estructurales primero y luego para consolidarlas mediante la renegociación con el capital transnacional y disciplinar a los actores sociales y, cuando es el caso, socializar las pérdidas en las crisis desatadas por el capital internacional y especialmente por la especulación ocasionada por su agresivo sector financiero que ha copado todos los rincones del mundo. Coincidimos con aquellos que puntualizan que la supuesta fobia que el neoliberalismo manifiesta hacia el Estado se transforma en necesidad de utilizar sus instrumentos de poder para consolidarse.

Los organismos internacionales, para estabilizar el sistema capitalista internacional y nacional sin alterar la globalización y el proceso de acumulación internacional del capital, junto al neoliberalismo, las crisis y las reacciones sociales contra sus efectos, recomiendan que se adopten en la región nuevos modelos políticos y se acepte su monitoreo y sugerencias mediante medidas neointervencionistas o neoestructuralistas o neodesarrollistas, o que redefinan o ajusten el papel del Estado, tanto en la regulación de la economía como en el control de los recursos, de los servicios y de las actividades públicas y privadas.

Se argumentó también que si no funcionaba "la mano invisible" del mercado, el sistema requería de continuidad y por lo tanto exigía un cierto intervencionismo estatal para garantizar la capacidad de gasto de los actores sociales, la inversión y la dinámica del mercado. A esta modificación de la estrategia algunos la denominaron "reforma" del modelo neoliberal protagonizada por el FMI y el BM, apoyada por organismos

\footnotetext{
${ }^{83}$ Pablo Dávalos, La democracia disciplinaria, el proyecto posneoliberal para América Latina, (Quito, Gráficas Iberia, 2010).
} 
financieros regionales, que supuestamente habían "aprendido las lecciones del pasado" y que "ya no exigían sacrificios", pues se "respeta la soberanía de las naciones", si bien en la realidad se mantenían las mismas exigencias en los planes de ajuste que se han impuesto en nuestra región y en diferentes latitudes del mundo. ${ }^{84}$

Este proceso se complementa, en el nivel jurídico, cuando las corporaciones transnacionales y el capital financiero logran el rango contractual de "inversionistas" y promueven según su conveniencia, a nivel internacional y en cada uno de los países, mediante la OMC, los organismos financieros y los acuerdos de libre comercio, una armonización normativa con similares leyes y reglas bajo el argumento de una necesaria "seguridad jurídica". 85

El modelo neointervencionista, neoestructuralista o neodesarrollista plantea en cambio la recuperación del Estado como reasignador de recursos y canalizador de parte de la renta obtenida por la explotación pública de los recursos naturales y agresivas reformas tributarias, para construir importantes obras públicas y de servicios y beneficiar parcialmente a sectores populares y medios, garantizando la inversión extranjera y el fortalecimiento de los grupos económicos de poder nacional.

La principales políticas del modelo neoestructuralista o neointervencionista fueron implementadas inicialmente por los "nuevos demócratas americanos" (Bill Clinton), por las laboristas ingleses (Tony Blair) y difundidas en América Latina por la CEPAL y la conferencia de jefes de Estado reunidos en Chile a fines del siglo pasado (1998), que combinaban elementos propios del estado de bienestar y del desarrollismo, con políticas neoliberales de mercado y de liberación financiera y productiva, planteando, en lo principal, el "desarrollo desde dentro".

Uno de los exponentes principales de esta corriente fue también Anthony Giddens, con su obra La tercera vía, en la que planteó como valores la igualdad, libertad, autonomía, responsabilidad y pluralismo y como programa: economía mixta, Estado social inversor, sociedad civil activa, igualdad con inclusión, bienestar positivo, etc. A su vez, Alain Touraine, en su obra ¿Cómo salir del liberalismo? calificó como "pensamiento y contra pensamiento único" a las posiciones extremas de los "liberales" en su defensa a ultranza del mercado y de la "extrema izquierda" que se queda en la denuncia sin plantear opciones, en un marco de defensa "fundamentalista" de las instituciones. El sociólogo francés apeló a la acción de la sociedad civil y especialmente a los intelectuales para promover un "intervencionismo renovado" y propuso: la "mundialización de la economía" sin disolver la "acción política"; que las clases más desprotegidas superen su discurso de "víctimas" y reclamen de manera protagónica sus derechos de manera

\footnotetext{
${ }^{84}$ Pablo Nemiña, "El nuevo FMI”, informe en Página 12, Buenos Aires, 20 de septiembre de 2009.

${ }^{85}$ Ibídem. (Pablo Dávalos, La democracia disciplinaria, el proyecto posneoliberal para América Latina, Gráficas Iberia, Quito, 2010).
} 
innovadora y que la eficacia institucional sea viable si se apoya en reivindicaciones de igualdad y solidaridad. ${ }^{86}$

Los denominados "gobiernos progresistas" en América Latina, instalados en Venezuela primero y luego en Bolivia, Ecuador, Uruguay, Nicaragua y temporalmente en otros países como Brasil y Paraguay, plantearon retóricamente, los más radicales el "socialismo del siglo XXI" y casi todos la necesidad de superar el neoliberalismo inequitativo por un posneoliberalismo, limitadamente redistribuidor, que al final no es sino un giro para adoptar políticas neointervencionistas y neoestructuralistas, recomendadas por la CEPAL y los organismos financieros internacionales (Banco Mundial), para modular y estabilizar las políticas neoliberales transnacionales que, con dichas variaciones y correcciones, siguen vigentes en lo fundamental a nivel mundial.

Este modelo empata con la realidad latinoamericana de fines de siglo, pues las fuerzas de la globalización capitalista y el neoliberalismo no pudieron destruir la independencia de los Estados, ni la libertad y seguridad de los ciudadanos, por lo que se consideraba posible y necesaria una mundialización algo diferente a la del mercado, sustentada en la soberanía de los pueblos y de los Estados. Por ello, Soros y el Presidente del Banco Mundial James Welfenson coincidieron en que no debe causar extrañeza que los Estados asuman una responsabilidad en la solución de los problemas sociales que el mercado no puede resolver. ${ }^{87}$

En toda la región latinoamericana se planteó que el Estado hoy, junto a su mayor intervención económica para dinamizar la demanda y el consumo de la población, debe abrir una mayor participación a los sectores privados nacionales y extranjeros, en áreas que antes eran de su total incumbencia, reservándose para sí un eficiente control que proteja los intereses generales y los de los consumidores, a quienes se les reconoce derechos y participación en las empresas de servicios. Todo ello implica una reformulación del Estado intervencionista del pasado, por un neointervencionismo o neodesarrollismo que parte de un cierto equilibrio entre lo público y lo privado y de una mejor combinación entre el Estado y el mercado.

Los gobiernos izquierdistas de América Latina en el presente siglo, tuvieron, con diferentes matices, inspiración neodesarrollista o neoestructuralista, pues se respaldaban en la planificación y en un papel activo del Estado en la economía y en los servicios públicos, con una política redistributiva sostenida por importantes ingresos tributarios indirectos y por el enorme caudal de recursos resultante de los altos precios de las materias primas y de la negociación con el capital transnacional en la explotación de los recursos naturales.

\footnotetext{
${ }^{86}$ Mauricio Plazas Vega, Derecho de la hacienda pública y Derecho tributario, las ideas políticas de la hacienda pública, (Bogotá: Editorial Temis, 2000).

${ }^{87}$ Banco Mundial: Informe sobre el desarrollo mundial, 1997. El Estado en un mundo en transformación. Washington, 1997.
} 
Debemos precisar que el neodesarrollismo difiere del desarrollismo del siglo pasado, pues relativiza, en su planteamiento principal, el creciente deterioro de los términos del intercambio entre el centro y la periferia y considera que el auge de los agronegocios pueden ser aprovechado, en el marco de la globalización y del manejo de los tipos de cambio, para el impulso del desarrollo interno.

El nuevo modelo o reformulación neodesarrollista, siguiendo la experiencia del sudeste asiático, se fundamentó en un mayor intervencionismo estatal en procesos de industrialización o de "cambio de matriz productiva" y en la reducción de la brecha tecnológica. Además, el neodesarrollismo, evidenciando un cierto pragmatismo, fue y es amigable con la inversión extranjera y, en especial, con las empresas transnacionales a las que facilitan libre movilidad de capitales y mercancías, así como a su instalación y accionar en el espacio nacional, por lo cual, algunos lo consideran una variación del neoliberalismo o una forma de adecuar el sistema capitalista mundial a las exigencias políticas locales.

Las principales tesis económicas del neodesarrollismo para explicar un crecimiento sostenido son: intensificar la intervención estatal, compartiendo la tesis de Stiglitz que "no hay mercados fuertes sin estados fuertes" sin obstruir la inversión privada, ${ }^{88}$ definir una política económica para actuar en la coyuntura y como instrumento de crecimiento; retomar la industrialización para multiplicar el empleo urbano; reducir la brecha tecnológica con acuerdos de innovación con las empresas transnacionales e imitar el avance exportador del sudeste asiático, subsidiando a los industriales y comprometiendo a los trabajadores en la productividad. ${ }^{89}$

Estos planteamientos formulados también por varios tratadistas, como Aldo Ferrer y Osvaldo Sunkel, son compartidos por la CEPAL, cuyas formulaciones, en la actualidad, son más bien una continuidad, sin dejar de advertir las diferencias, ruptura radical con las del neoliberalismo, por lo que reafirmamos nuestra tesis de que finalmente en nuestro medio se adoptó una combinación de los dos modelos, con similares políticas macroeconómicas, conforme a las circunstancias económicas y políticas de los diferentes países de la región.

El neodesarrollismo considera que en la globalización tienen una gran oportunidad los países medianos, entre los que si bien no se encuentran todos los latinoamericanos, se podrían beneficiar por imitación o cercanía si se aprovechan las ventajas comerciales de sus productos primarios y si se controlan los peligros del sistema financiero internacional y local y del endeudamiento descontrolado. Esta visión considera al mercado mundial y su inserción con productos primarios agromineros, como una gran

\footnotetext{
${ }^{88}$ Joseph Stiglitz, Caida Libre, (Buenos Aires, Taurus, 2010).

${ }^{89}$ Claudio Katz, Qué es el neo-desarrollismo: Una visión Crítica, Argenpress, 17 de julio de 2014.
} 
oportunidad para el desarrollo y la industrialización, mas no como un obstáculo como lo estimaba inicialmente la CEPAL en el siglo pasado. ${ }^{90}$

El encuentro o la combinación entre neoliberalismo y neodesarrollismo, a nuestro juicio, se da cuando los dos modelos estiman que el sistema capitalista mundial y sus polos regionales ofrecen oportunidades inagotables para el crecimiento económico y el desarrollo; que el Estado, la tecnoburocracia y los empresarios, especialmente los nuevos, pueden cumplir en ese proceso, con connotaciones autoritarias, un activo papel de fomento, de regulación y estabilización de las ganancias para socializar las pérdidas, con distintas modalidades e iniciativas en los países de la región, para lo que es necesario definir e implementar políticas macroeconómicas responsables y equilibradas y una gestión eficiente, adecuada y meritocrática de la administración estatal.

Como lo señalamos, en otra oportunidad, en el panorama político del continente se pueden diferenciar además dos alternativas políticas que concuerdan con los referidos modelos económicos: una más afín y subordinada al esquema internacional neocapitalista en el que se encuentran México, Colombia y Perú, en la que se continúa aplicando con algunas variantes un neoliberalismo ortodoxo y otra que planteó sustituir o reformar al neoliberalismo, en la que se pudo diferenciar una posición más radical, verbalmente antineoliberal o neodesarrollista que se identificó con un ambiguo socialismo del siglo XXI y que se expresó en los gobiernos de Venezuela, Ecuador, Bolivia, Nicaragua, que conjuntamente con Cuba forman parte del ALBA (Alternativa Latinoamericana Bolivariana), y otra menos radical, que puso énfasis en ciertas políticas sociales, dentro de un esquema político de centro-izquierda, y que se expresó en los gobiernos de Brasil (Lula, Roussef), Argentina (Kirchner, Fernández), Uruguay, Paraguay (Lugo) y Chile (Bachelet).

Los denominados gobiernos "progresistas" o conocidos también como "socialdesarrollistas" (2000-2017), han impulsado en estos años, en lo fundamental de su política económica y social, la formación y consolidación de un nuevo intervencionismo estatal, la explotación con mayores réditos para sus países, de los recursos naturales, especialmente del petróleo, gas y minería; una cierta redistribución de la riqueza para ampliar la infraestructura y los servicios de salud y educación; y la formación o consolidación de una burguesía regional que se inserta en la globalización capitalista y

\footnotetext{
90 En la orientación de la CEPAL se pueden distinguir tres etapas: la del desarrollismo inicial o estructuralismo (1960-1980), en la que se explicaba el subdesarrollo como resultado de las relaciones desiguales entre el centro y periferia y se planteaba como necesidad la sustitución de importaciones; la redistribución del ingreso y las reformas sociales; la del neoestructuralismo (1980- 2000), en la que se abandonan las concepciones iniciales y se pone énfasis en la explicación de la realidad otorgándole primacía en el desarrollo a factores internos, a la apertura comercial, flexibilización laboral, etc. y la tercera, la del neodesarrollismo o endogenismo (2000 y siguientes), muy cercana en concepciones y políticas conservadoras propias del neoliberalismo cada vez más distantes del pensamiento crítico, pues promueve el desarrollo interno de nuestros países, en concordancia con los intereses transnacionales, del capital financiero y los del agro-negocio.
} 
se hace fuerte en la exportación de productos primarios, en la rentabilidad financiera de corto plazo y en su vinculación o subordinación a las empresas transnacionales. ${ }^{91}$

El social-desarrollismo, según Claudio Katz, como una variante del neo-desarrollismo, se plantea como un modelo de crecimiento del capitalismo con inclusión social, enfatizando en la necesidad de incrementar el consumo como un mecanismo de redistribución del ingreso y la producción para reactivar la demanda y el poder adquisitivo de la población. Esta corriente promueve también un intervencionismo y una primacía estatal que le permite captar renta agraria y minera y ejecutar políticas monetarias activas con tipos de cambio competitivos y controlar déficits presupuestarios financiables, con la finalidad de incentivar el consumo y financiar obras públicas y servicios en beneficio nacional.

En todo caso, los planteamientos neodesarrollistas y los socialdesarrollistas no han logrado tampoco estructurar una alternativa sólida al modelo neoliberal, que sigue siendo en nuestra región, "el principal organizador de las concepciones y prácticas de los capitalistas" y de los gobiernos de América Latina, pues sus planteamientos ambiguos se presentan con numerosos "vasos comunicantes a la matriz neoliberal" y tan solo han logrado atenuar las ideologías nacionalistas y bajar el tono a las actitudes y luchas antimperialistas contra el sistema imperante, constituyendo, finalmente, una especie de un capitalismo de Estado, como lo puntualiza Claudio Katz, ${ }^{92}$ o un capitalismo del siglo XXI, como lo manifiesta Enrique Ayala. ${ }^{93}$

Con la finalidad de consolidar al sistema y evitar conflictos políticos y sociales, manifiestos, también los organismos internacionales como la ONU y la CEPAL y especialmente los financieros (BM, FMI, BID, etc.), así como los órganos de integración regional (UE, CAN, MERCOSUR, UNASUR) promueven losdiferentes modelos económicos antes indicados o su combinación, con la finalidad de equilibrar y controlar las finanzas públicas y los agregados macroeconómicos; impulsan acuerdos y convenios internacionales que persiguen ampliar la liberalización del comercio y regular ciertos excesos del mercado (OMC, GATT) y los del capital transnacional y financiero (Comité de Basilea) y reforman la eficiencia, eficacia y calidad de los servicios y las administraciones públicas, además de proteger los derechos de los consumidores y de los usuarios de bienes y servicios y el combate a la corrupción y el crimen organizado que amenazan con desestabilizar, económica y políticamente, a los estados y a las clases dirigentes de los países del mundo.

Los recientes modelos económicos (neoliberal o mercadocéntrico y neoestructural y neo desarrollista o estadocéntrico o su combinación) se adaptan en cada país de acuerdo a su correlación de fuerzas económicas, políticas y sociales, para acoplar los estados nacionales a los requerimientos del capital transnacional, por medio de regímenes

\footnotetext{
${ }^{91}$ Víctor Granda Aguilar, La situación actual y la alternativa socialista en América Latina, Brasilia, 2011.

${ }_{92}^{92}$ Claudio Katz, ¿Qué es el neo-desarrollismo? Una visión crítica, Argenpress, 4 de julio de 2014.

${ }^{93}$ Enrique Ayala, Hacia el Capitalismo del Siglo XXI, Quito, Periódico Opción Socialista, Junio 2014.
} 
políticos que aplican los convenios, normas, instructivos y recomendaciones, aparentando inicialmente un derecho blando (soft law), pero que terminan imponiéndose finalmente, en la estructura jurídica de aquellos, al pasar a formar parte de su ordenamiento constitucional y legal obligatorios (hard law). Dichos instrumentos jurídicos fortalecen el control y la subordinación de los actores económicos y la intervención o regulación del Estado en la actividad económica para ajustarse a las exigencias del capital transnacional y de los grupos o élites de poder local. ${ }^{94}$

En los últimos treinta años, los organismos internacionales promovieron diferentes políticas sobre el papel del Estado y la función administrativa y el contenido del derecho constitucional, administrativo y financiero y de control que los regula, para adaptar las instituciones públicas a los intereses transnacionales. Inicialmente, los organismos multilaterales plantearon el término "gobernabilidad" para referirse a las indispensables modificaciones institucionales compatibles con el modelo neoliberal, promovido en los años ochenta y noventa del siglo pasado y luego el de "gobernanza", que según nuestra percepción, puede tener dos lecturas: una "liberal" para apuntalar directamente los intereses del mercado y del capital transnacional y otra "democrática" o "incluyente", que enfatiza, en la necesidad de incorporar en las mismas reformas económicas liberales, la vigencia de los derechos humanos y la participación de la sociedad civil en ciertas decisiones económicas y políticas internacionales y nacionales". 95

De igual manera ocurre con el derecho, que cumple un papel clave en la conformación y funcionamiento del Estado moderno en todas sus etapas, estableciendo las normas jurídicas, constitucionales y contractuales que finalmente se imponen para controlar las relaciones y la subordinación de los ciudadanos al poder y a los intereses del mercado y de sus principales actores hegemónicos tanto a nivel internacional como local.

También debe considerarse que desde la adscripción de nuestros países a la OMC en 1995-96 y la celebración de tratados de inversión, de libre comercio y de sometimiento a centros de arbitraje internacional dependientes de los organismos financieros internacionales, los actores de la globalización pasan a jugar un papel más directo y determinante en las políticas de los estados a nivel internacional, reduciendo en la práctica su soberanía y su autodeterminación, propósito en el cual también participan el BID, la CAF, FLAR, organismos en los cuales se encuentran presentes los intereses transnacionales que inspiran una normativa común para los estados de la región. Se pasa, entonces, de una etapa en la que el papel de quienes gobiernan y sus decisiones se conjugan con la participación de actores económicos, políticos y sociales, lo que se

\footnotetext{
${ }^{94}$ Carlos de Cabo Martín, Dialéctica del sujeto, dialéctica de la Constitución, (Madrid: Editorial Trotta, 2010); Juan-Cruz Alli Aranguren, Derecho Administrativo y Globalización, (Madrid: Universidad de Navarra, Aranzadi, 2004).

${ }^{95}$ Víctor Granda Aguilar, "Los principales desafíos del Derecho administrativo hoy", Universidad de Salamanca, 2015.
} 
conoce como "gobernanza", pues se trata de una nueva forma de ejercitar la política en los espacios públicos y de permitir la "participación ciudadana" y el "diálogo social". 96

Pero si las políticas del FMI, del Banco Mundial y de la OMC provocaron inestabilidad económica, política y social a fines del siglo pasado, los gobiernos latinoamericanos, unos de derecha, otros de centroizquierda y otros identificados con la "izquierda" o con el "progresismo", coincidiendo con la bonanza económica de altos precios en el mercado internacional de las materias primas, anunciaron al asumir el poder, en la primera década del siglo XXI, que su propósito era abandonar el neoliberalismo o la "larga y triste noche neoliberal" por un nuevo modelo posneoliberal y algunos manifestaron incluso que pretendían construir en sus países y en la región un socialismo del siglo XXI o un comunitarismo andino-amazónico. Previamente los organismos internaciones, previendo el nuevo ciclo político, morigeraron su discurso neoliberal e introdujeron en sus análisis y propuestas la necesidad de promover un neodesarrollismo que consolide la estabilización y las reformas estructurales y que le reasignen al Estado funciones y atribuciones para la regulación, el disciplinamiento social y aún incentivos para la inversión.

Todos los gobiernos latinoamericanos, incluidos los identificados con la izquierda y el socialismo del siglo XXI, se esmeraron en culminar los ajustes macrofiscales, las políticas de estabilidad macroeconómica, las reformas estructurales regionales, las reformas normativas y jurídicas comunes y en general las recomendaciones del consenso de Washington, por lo que, finalmente, con diferentes discursos se persiguió y criminalizó la lucha social por cuestionar las medidas antipopulares; se crearon convenios y nuevos contratos con las empresas transnacionales para controlar los recursos naturales y mineros de la región; se impulsó el libre comercio, la constitución de mercados comunes y se adoptaron normas homogéneas que favorecen los intereses transnacionales y la reproducción del sistema, sin dejar de desconocer que en algunos países se adoptaron, a la vez, limitadas medidas redistributivas para combatir la extrema pobreza, impulsar la construcción de infraestructura vial, eléctrica y de comunicaciones y mejorar los servicios públicos de salud, educación y seguridad social.

La recuperación del Estado que se plantea abiertamente por parte de algunos gobiernos latinoamericanos en el siglo XXI no significa, sin embargo, el retorno al Estado intervencionista y burocrático, que fue desmantelado o reducido por los programas de ajuste y las reformas estructurales del siglo pasado. El Estado se fortalece en sus potestades de "rectoría pública" en los ámbitos de la planificación, control, supervisión, fiscalización, negociación y regulación, propios del modelo neoliberal, y asume a la vez, cuando los recursos y los ingresos públicos se lo permiten, con la negociación en la explotación de recursos naturales, actividades económicas de subsidio y promoción

\footnotetext{
${ }^{96}$ Clemente Navarro Yáñez, La nueva gobernanza local, en IX Congreso Internacional de la CLAD sobre Reforma del Estado y la Administración Pública, Madrid, 2004.
} 
productivos y la provisión y control de ciertos servicios públicos, que finalmente el sector privado los depredó o los mercantilizó.

La definición de Estado social de derecho, adoptada con ciertas variaciones en todas las constituciones de América Latina a fines del siglo pasado y en el presente, expresa la forma en la que el neoliberalismo y sus reformas, monitoreadas por el BM y el FMI, han asignado al Estado una seguridad jurídica que enfatiza en su carácter de defensor de derechos, coercitivo y de rectoría asignado en la etapa actual de la globalización y de financiarización internacional.

Es evidente que las labores fundamentales que cumplen este Estado y los gobiernos, de diferentes matices instalados en la región, son: defender los derechos de los actores económicos y sociales, entre ellos las corporaciones y los financistas y sus inversiones; criminalizar la lucha social y las resistencias a los modelos económicos que al sistema le convienen, según las circunstancias de cada país y abrir las puertas para que la soberanía nacional pueda ser subastada y se impongan los instrumentos institucionales y jurídicos de una nueva gobernanza global.

Para todo ello se requiere la convergencia o adaptación normativas locales a las de la gobernanza mundial, en las que actúan directamente las corporaciones transnacionales y el capital financiero especulativo, que en su calidad de inversionistas se convierten en actores privados con potestad de incidir en la negociación y definición de las políticas más importantes que adoptan los gobiernos de la región, si bien negocian con ellos un margen de redistribución de sus ingresos o utilidades, con la finalidad de proporcionales recursos destinados a la sobrevivencia política de los gobernantes y a la implementación de sus políticas populistas y clientelares.

Dicha convergencia normativa, creada y desarrollada por las normas y procedimientos de la OMC, permite la consolidación con las correspondientes reformulaciones de nuevos espacios de regulación jurídica como los tratados de libre comercio, tratados de protección de inversiones, los tribunales de conciliación y arbitraje" (CIADI y otras instancias arbitrales y jurisdiccionales), que dejando de lado el concepto de soberanía ponen en el mismo marco a los inversionistas y a las corporaciones transnacionales con los estados-nación, otorgándoles a aquellos nuevas garantías de seguridad y posibilitando el establecimiento de sanciones y de acciones de control contra los estados y muy residualmente a los otros actores de la globalización.

A las políticas económicas, administrativas y financieras que se imponen a los estados nacionales y como una forma adicional de cuestionarlos, se suman una serie de orientaciones para combatir y controlar la creciente corrupción internacional, ya que el mismo sistema y los intereses del capital financiero transnacional han generado oportunidades para que interactúen los actores públicos y privados en actividades económicas y de servicios de alta rentabilidad, que crean ocasiones para el abuso de fondos y bienes públicos y el enriquecimiento ilícito, utilizando espacios institucionales 
y nacionales, generados a nivel mundial, como los denominados paraísos fiscales, en los que tradicionalmente sectores poderosos del ámbito público y privado, gobernantes, funcionarios públicos y personas o empresarios, de diferente signo político, han evadido sus obligaciones tributarias y en los que se han depositado y depositan enormes recursos, la mayoría de los cuales provienen de actividades delictivas y de manejos administrativos dolosos.

Si bien la corrupción, desde mucho tiempo atrás, ha estado presente asociada tradicionalmente al manejo y abuso de fondos públicos, es en estas últimas décadas en las que los ciudadanos, afectados por la crisis y las secuelas de un sistema de concentración ilimitada de la riqueza, se movilizan y reaccionan en contra de las élites políticas y altos funcionarios que se enriquecen y abusan de bienes que se han extraído de la empobrecida economía popular y de la explotación de los recursos naturales y de los servicios que pertenecen a la población.

La OEA aprobó en 1996 la Convención Interamericana contra la Corrupción, en la que se definieron: medidas preventivas; las figuras de actos de corrupción, soborno transnacional y enriquecimiento ilícito; la necesidad de que las entidades fiscalizadoras superiores (EFS) en cada país adopten instrumentos modernos para prevenir, detectar, sancionar y erradicar las prácticas corruptas y establezcan mecanismos para estimular la participación de la sociedad civil y las organizaciones no gubernamentales, en la prevención de la corrupción, para enfrentar el secreto bancario y promover la extradición, la confiscación y el decomiso de los bienes obtenidos por corrupción. ${ }^{97} \mathrm{Y}$ para enfrentar la crisis de gobernabilidad en América Latina y fortalecer el control de las desviaciones de poder expidió también el 11 de septiembre de 2001 la Carta Democrática Interamericana de la OEA y en la Cumbre de la Américas, reunida en México en enero de 2004, la Declaración de Nueva León, que tienen a la vez el seguimiento de los organismos de desarrollo regional y del BID. ${ }^{98}$

En Europa, a propósito del reconocimiento del derecho de los ciudadanos a un "buen gobierno" y a una "buena administración" y para alcanzar la "gobernabilidad" y la "gobernanza" o un "gobierno relacional" y ubicar al "ciudadano europeo en el centro del proyecto de integración", se fue afirmando la convicción de que esos derechos y propósitos estaban íntimamente relacionados con la necesidad de una profunda reforma administrativa y el combate a la corrupción. ${ }^{99}$ En el informe Nolan en Gran Bretaña, sobre las Normas de Conducta en la Vida Pública, en 1995, se propuso adoptar "códigos de conducta" para nombrar directivos calificados en las empresas y entidades públicas; realizar en ellas auditorías que permitan descubrir irregularidades en asuntos financieros

\footnotetext{
${ }^{97}$ Convención Interamericana contra la Corrupción, suscrita en Caracas, Venezuela, 29 de marzo de 1996.

${ }_{98}^{98}$ Ricardo Rivero Ortega, (ed.), "Reforma del Estado en América Latina... en A. Ferraro, En busca del buen gobierno: Nuevas perspectivas sobre política y gestión del Estado en América Latina, (Barcelona: Ediciones Bellaterra, 2007).

99 Ricardo Rivero Ortega, "El derecho a la buena administración en Europa y el procedimiento administrativo de la Comunidad Autónoma de Castilla y León", Revista de Administración y Función Pública de Castilla y León, $N^{\circ}$ 1, abril 2004.
} 
y en el mal manejo del dinero público y establecer procedimientos para aceptar y tramitar denuncias internas o externas, incluso anónimas, sobre actos de corrupción y la práctica de aceptar, en las esferas directivas, presentes y regalos para obtener algún favor o beneficio de la administración.

Luego, en 1997, la Unión Europea impulsó un convenio sobre la lucha contra los actos de corrupción y en el mismo año, el 21 de noviembre, la Organización de Cooperación y Desarrollo Económicos (OCDE), promocionó también un convenio sobre la lucha contra el soborno de funcionarios públicos extranjeros en las transacciones comerciales internacionales y, en junio de 2001, el Informe del Comité de Gestión Pública, plantea reformas para fomentar la conducta ética de gobernantes y burócratas y la necesidad de incorporar el empleo de la transparencia y la participación en la gestión pública. ${ }^{100}$

Posteriormente, en 2002, tanto en la Conferencia Internacional sobre la Financiación para el Desarrollo, reunida en Monterrey, como en la Cumbre Mundial sobre el Desarrollo Sostenible en Johannesburgo, se expresó la decisión política mundial de luchar contra la plaga de la corrupción y de sus efectos devastadores en el desarrollo.

Como consecuencia del proceso anterior, en 2003, la Asamblea general de la ONU, en Nueva York, aprobó la Convención de las Naciones Unidas contra la Delincuencia Organizada Transnacional y la Convención de las Naciones Unidas Contra la Corrupción, que establecen sistemas de evaluación sobre el respeto a los derechos humanos, la transparencia en el ejercicio de la función pública y el control de la corrupción. Según lo señala el secretario general Kofi A. Annam, en el prefacio de aquella: "La corrupción es una plaga insidiosa que tiene un amplio espectro de consecuencias corrosivas para la sociedad: socava la democracia y el estado de derecho, da píe a violaciones de los derechos humanos, distorsiona los mercados, menoscaba la calidad de vida y permite el florecimiento de la delincuencia organizada, el terrorismo y otras amenazas a la seguridad humana". ${ }^{101}$

Tras la Convención, los organismos internacionales como la ONU y especialmente los financieros (BM, FMI), impulsaron (e impulsan) el control y la lucha contra la corrupción con mayor fuerza, pues, desde fines del siglo anterior, ya habían incluido en sus agendas estos temas, tanto para implementar sus proyectos de cooperación, como para sus operaciones crediticias; con ese fin se demanda a los países: informes de transparencia fiscal y buenas prácticas en las políticas monetarias y financieras; rendición de cuentas e investigación de denuncias de corrupción y fraude; el cumplimiento de indicadores (WBI); medidas de buena gestión, etc. ${ }^{102}$

\footnotetext{
100 José Antonio Fernández Ajenjo, El control de las administraciones públicas y la lucha contra la corrupción, (Pamplona: Civitas - Thomson Reuters, 2011).

${ }^{101}$ Convención de las Naciones Unidas Contra la Corrupción, Naciones Unidas, Nueva York, 2004.

102 FMI: Código de buenas prácticas de transparencia fiscal, 1998; Código de buenas prácticas de transparencia en las políticas monetarias y financieras, 1999.Banco Mundial: Informe Helping Countries Combat Corruption: The Role of de World Bank, Poverty Reduction an Economic Management Network, 1997.
} 
Además, en junio de 2004 en las Naciones Unidas se agregó un Décimo Principio al Pacto Mundial en relación con la Responsabilidad Social Corporativa, para que las empresas se comprometan también en la lucha contra la corrupción, el soborno y la extorsión.

En la Cumbre de Jefes de Estado y el Grupo de los 20 (G-20), que agrupa a las economías más desarrolladas del planeta y que controlan el 80 por ciento del comercio mundial y en los que mayoritariamente se registran políticas corruptas internacionales, se encuentran constantes referencias a la necesidad de impulsar una cultura de evaluación y de combate frontal a la corrupción y sus desastrosos efectos en la gobernabilidad y gobernanza internacionales que impiden la consolidación y equilibrio del sistema económico y provocan devastadores efectos en los procesos de desarrollo y de marginación social, especialmente en las economías subdesarrolladas del tercer mundo.

En dichas reuniones y en los informes de Transparencia Internacional, ${ }^{103}$ organismo no gubernamental vinculado al Banco Mundial, que ofrece anualmente índices y mediciones de percepción de corrupción en las diferentes regiones y países del mundo, se puede observar que en ellos, incluyendo a los más poderosos, como EEUU y China, no han podido cumplir sus compromisos de luchar contra la corrupción. En especial, ocurre en los denominados paraísos fiscales, ubicados en países marginales y en el mismo corazón de Europa y Norteamérica. En ellos no se ha abolido el secretismo sobre operaciones financieras obscuras; no se ha erradicado la práctica de los sobornos en la adjudicación de contratos y construcción de grandes obras públicas por parte de países ricos y empresas transnacionales; no se ha detenido el pago ilícito de poderosas empresas a funcionarios ni el lavado de dinero que cuentan con el apoyo de gobiernos, bancos, abogados y contadores y no se han recuperado significativamente los bienes y recursos provenientes de la corrupción pública y privada.

Por ello, en la Cumbre Anticorrupción que tuvo lugar en Londres el 12 de mayo de 2016, se establecieron nuevos compromisos de los gobiernos para combatir con mayor eficacia la corrupción y para proteger a sus denunciantes, lo que se evaluó por la ONU en septiembre de 2017, siguiendo sus iniciativas globales de promover un Código anti soborno común, la FEM como iniciativa mundial contra la corrupción y el proyecto RESIST para enfrentar extorsiones y transacciones internacionales ilícitas. También en la cumbre del G-20 en China, el 2 de septiembre de 2016, se planteó el tema del crecimiento de la corrupción y la difícil recuperación de activos, operación "Foxhunt", para promover la cooperación internacional transfronteriza que asegure el retorno de los

\footnotetext{
${ }^{103}$ Transparencia Internacional, es una organización no gubernamental, sin fines de lucro que se fundó en la Haya (Holanda), el 9 de febrero de 1993 por iniciativa del ex funcionario del Banco Mundial Peter Eigen y se registró en Alemania el 15 de junio de 1993 en cuya capital, Berlín, tiene su Secretaría Internacional. Registra capítulos en 100 países y su finalidad es la de dar seguimiento, con el apoyo de instituciones internacionales como el Banco Mundial y nacionales como gobiernos, empresas y entidades de la sociedad civil, a los actos de corrupción y sus nefastas secuelas en el orden público y en el desarrollo social en todos los países del mundo. www.transparency.org
} 
corruptos y de sus capitales a sus países de origen para que sean procesados por la justicia. De igual manera, se discutieron temas relacionados con los "visados de oro" que proporcionan los propios países más desarrollados a personajes que ofrecen o realizan grandes inversiones de dudosa procedencia en los países de acogida, y la detección de empresas secretas, paraísos fiscales, banqueros, abogados y compañías de bienes raíces para ocultar o manejar dinero proveniente de la corrupción. ${ }^{104}$

Por lo tanto, en el contexto de la crisis y del fomento de una conciencia mundial sobre la plena vigencia de los derechos humanos y el reconocimiento del derecho ciudadano a una "buena administración" y a un "buen gobierno", eficiente, eficaz y libre de corrupción, se van dictando normas internacionales y conformando una red institucional que demanda transparencia y acceso amplio a la información pública y privada, así se puedan vulnerar algunas garantías individuales, pues se ha llegado a la convicción de que "el derecho a la intimidad de las personas se utiliza con demasiada frecuencia como escudo perfecto para transmutar la democracia abierta en una democracia opaca y oscura", como lo señala Miguel Blanes Climent. ${ }^{105}$

Se plantea de igual modo, siguiendo al Tribunal Constitucional español, que el Derecho a la transparencia y el acceso a la información pública, si bien no es un derecho fundamental, es un derecho de tercera generación en beneficio de los ciudadanos que requieren de ley expresa para ejercer su prerrogativa a saber; a controlar (legalidad y oportunidad en el uso y destino de fondos públicos) y a ser actores y no solo espectadores de la vida pública. Este derecho también se fundamenta en la convicción de que el poder público se legitima en la misma proporción que se imponen altos estándares de transparencia y que esta, al igual que la rendición de cuentas, constituyen la esencia de la democracia.

Resulta evidente, por tanto, que el Estado social de derecho y la consolidación o ampliación de la democracia son los escenarios adecuados para posibilitar la transparencia, el control, la rendición de cuentas y la responsabilidad. Silva Cimma afirmaba acertadamente hace ya varios años: "El control no tiene cabida sin democracia”, pues el autoritarismo y la concentración de poderes limitan y anulan el control y la responsabilidad pública estatal y de funcionarios. ${ }^{106}$

En el caso de la Unión Europea, para hacer efectivo el derecho a una buena administración, consignado de manera definitiva en la Carta de Derechos Fundamentales del 7 de diciembre de 2000 y en el Tratado de Lisboa, se establecieron instrumentos de evaluación, autoevaluación y calidad, adoptando los modelos internacionales ISO y EFQM. Se expidió también en 2001, por parte del parlamento

\footnotetext{
${ }^{104}$ www.transparency.org

105 Miguel Blanes Climent, La transparencia informativa de las Administraciones públicas, (Aranzadi: Editorial Thomson-Reuters, 2014).

${ }^{106}$ Enrique, Silva Cimma, Derecho Administrativo Chileno y Comparado, el Control Público, (Santiago: Editorial Jurídica de Chile, 1994).
} 
regional, un Código Europeo de Buena Conducta Administrativa, que se complementó más tarde con la directiva 2006/123/CE, sobre la calidad de los servicios en el mercado interior y los derechos de los consumidores.

En los diferentes países de la Unión Europea -y particularmente en España- se efectuaron modificaciones en su legislación interna para dar cumplimiento a estas urgentes transformaciones administrativas (Real Decreto 95/2005 de 29 de julio; Real Decreto 1418/2006 de 1 de diciembre; Ley 28/2006 de 18 de julio; Ley 11/2007 de 22 de junio; Ley 17/2009 de 23 de noviembre), para lo que se crearon agencias estatales y adoptaron medidas para mejorar la calidad de los servicios públicos, el libre acceso a las actividades de servicios y se instrumentaron otros mecanismos y normas para evaluar las políticas y programas públicos, facilitar el acceso a los servicios públicos mediante el acceso informático y electrónico, sustituir controles gravosos y simplificar trámites.

Es así como se ha ido instaurando en el mundo un nuevo "modelo globalizado de administración" y una "nueva cultura de gestión" que requiere de transparencia, libre acceso a la información y renovados instrumentos de control y de evaluación. Lo que ocurre en Europa se impulsa también en el sistema de las Naciones Unidas para favorecer a la vez lo que se denomina una "nueva cultura internacional de auditoría y evaluación", para lo cual se realizan ya exámenes periódicos a nivel universal sobre el respeto y protección de los derechos humanos y se elaboran, a la vez, informes detallados sobre su ejercicio en los campos de salud, educación, ingresos, protección del medioambiente y sistemas de control y colaboración para combatir la corrupción y otros delitos internacionales. Se está forjando, por tanto, un "Estado evaluativo" o una "audit society", que hacen de las técnicas de la evaluación y auditoria, "mecanismos de autorregulación" e "instrumentos de reforma social y de progreso" para ser aplicados, tanto a nivel interno como externo, para que la gestión de las instituciones públicas y aún de las entidades privadas, especialmente aquellas que ofrecen servicios y productos de consumo masivo, alcancen sus objetivos. ${ }^{107}$

De manera activa, a nivel internacional concomitan instancias y agrupaciones de las instituciones fiscalizadoras que han ejercido y ejercen el control en el marco regional y nacional en todos los países del mundo. Así se constituyó en 1953 en la ONU, la International Organization of Supreme Audit Institutions (INTOSAI), que agrupa a las entidades fiscalizadoras superiores (EFS) de control financiero, con la finalidad de intercambiar entre ellas experiencias, proyectos y normas. Complementariamente se han organizado secciones de la INTOSAI, como la europea (EUROSAI) que agrupa a las instituciones nacionales de control financiero y al Tribunal de Cuentas de las comunidades europeas, y en América Latina la OLACEFS, fundada el 9 de abril de 1963, de la que forma parte la Contraloría General del Estado de Ecuador.

\footnotetext{
107 Pilar Jiménez Tello, "Valores de la auditoria y la evaluación en las administraciones Públicas", en Nuevas formas de control de las administraciones públicas y su repercusión sobre consumidores y usuarios”, Enrique Rivero Ysern y M. Dolores Calvo Sánchez, (Coord.), (Salamanca: Ratio Legis, 2013).
} 
En el caso de nuestro país, las normas constitucionales y legales y sus reformas, expedidas en los últimos 27 años, reflejan la misma tendencia internacional de perfeccionar y mejorar formalmente los sistemas técnicos y sociales de control y de combate a la corrupción, en desmedro de un indeterminado "control político" que se encuentra, en algunos países, cada vez más restringido, cuestionado y muchas veces desprestigiado o bloqueado. La Contraloría, sin embargo, ha perfeccionado sus sistemas de auditoría incluyendo el análisis de eficiencia, eficacia y resultados de la gestión pública, lamentablemente sin mayores resultados prácticos para controlar los más grandes escándalos públicos de corrupción, si bien la última enmienda constitucional de diciembre de 2015 pretende eliminarla, para trasladarla totalmente al control interno, ejercido por el propio gobierno por medio de la Secretaría de la Administración Pública (SNAP) o directamente por la Secretaría de la Presidencia y la Secretaría Nacional de Planificación y Desarrollo Social (SENPLADES) desde 2017, ${ }^{108}$ mediante normas y procedimientos que acompañen la gestión, desde el inicio hasta su conclusión.

Frente al deterioro del control político y la manipulación de los controles externos por parte de la autoridad ejecutiva, las organizaciones sociales y la sociedad civil promovieron en Ecuador importantes iniciativas ciudadanas para conocer y analizar denuncias de corrupción y para entregar información al respecto a la Contraloría General del Estado, a la Fiscalía y a la Función Judicial, como lo fue la Comisión de Control Cívico de la Corrupción en 1996, lo pretende ser el Consejo de Participación y Control Social que la sustituyó en 2008 y lo es, con muchas limitaciones y actitudes hostiles por parte del régimen, la Comisión Nacional Anticorrupción conformada, el 30 de mayo de 2015, por las organizaciones sociales de manera independiente a la estructura estatal, como lo analizaremos más adelante.

Es en este contexto en el que se modifican las principales instituciones constitucionales económicas, políticas, las leyes administrativas y financieras y sus principales políticas públicas en los diferentes países de la región.

\section{LOS ORGANISMOS FINANCIEROS INTERNACIONALES Y LA INCIDENCIA EN LOS MODELOS O POLITÍCAS ECONÓMICAS}

Especial incidencia tienen también, en las transformaciones económicas y jurídicas a nivel internacional y en Ecuador, las principales políticas de los organismos financieros mundiales y en concreto la necesidad de lograr equilibrios macroeconómicos como fundamento para alcanzar el desarrollo, la estabilidad y la sostenibilidad de la economía mundial y de cada uno de los países del mundo.

\footnotetext{
108 Presidencia de la República, Decreto Ejecutivo Nro. 40, el Presidente Lenin Moreno, eliminó la Secretaria General de la Administración y transfirió sus amplias atribuciones a la Secretaría de la Presidencia y a la Secretaría Nacional de Planificación y Desarrollo, publicado en el Segundo Suplemento del Registro Oficial 16 de 16 de junio de 2017.
} 
En los modelos y políticas económicos adoptados por el sistema capitalista internacional, desde los años 30 del siglo XX y en especial luego de la segunda guerra mundial hasta la actualidad, se asumieron los contenidos más importantes de las doctrinas económicas más influyentes en cada período, para que los países, conducidos por los organismos internacionales y los estados nacionales, observen ciertos parámetros comunes que garanticen la estabilidad macroeconómica, comercial y financiera mundial y local, con la finalidad de evitar los efectos de las crisis y garantizar un desarrollo armónico, acorde con los intereses de las empresas transnacionales y la acelerada e indiscutible hegemonía del capital financiero.

Las potencias mundiales, luego de la Segunda Guerra Mundial y del descalabro económico que la provocó, pretendían crear entonces un nuevo orden económico internacional, fundamentado en un nuevo sistema monetario y financiero, un marco regulador del comercio internacional y las condiciones apropiadas para impulsar el crecimiento económico y el pleno empleo.

Para monitorear las economías locales y garantizar su desarrollo, la estabilidad monetaria y la expansión del comercio, el pago de la deuda externa y el cumplimiento de sus obligaciones económicas y financieras internacionales, se conformaron inicialmente el FMI y el Banco Mundial (1944) y, más tarde, la OMC (1995) y otros entes comerciales y financieros de cobertura mundial o regional. Las normas jurídicas regulatorias de dichas entidades y de su actividades asumieron inicialmente un carácter referencial y posteriormente obligatorio, conforme a las exigencias y crisis internacionales, regionales y locales.

El FMI era inicialmente un órgano interestatal para regular y supervisar principalmente el sistema monetario mundial, tomando como eje al dólar de los Estados Unidos de América, con tipos de cambio fijos para las monedas nacionales, para impulsar el desarrollo del comercio internacional y las transferencias monetarias libres entre los estados, sin dejar de mantener ciertas restricciones a los otros movimientos de capital que no correspondían a las operaciones mercantiles. La creación del FMI "se planteó en julio de 1944 en una conferencia de las Naciones Unidas celebrada en Bretton Woods, Nuevo Hampshire (Estados Unidos), cuando los representantes de 44 países acordaron establecer un marco de cooperación económica destinado a evitar que se repitieran las devaluaciones competitivas que contribuyeron a provocar la Gran Depresión de los años treinta". ${ }^{109}$ Este organismo tiene como principal objetivo la estabilización financiera internacional, pues "el principal propósito del FMI consiste en asegurar la estabilidad del sistema monetario internacional, es decir el sistema de pagos internacionales y tipos de cambio que permite a los países (y a sus ciudadanos) efectuar transacciones entre sí”. 110

${ }^{109}$ Fondo Monetario Internacional, página oficial, http://www.imf.org/es/About/Factsheets/IMF-at-aGlance

${ }^{110}$ Fondo Monetario Internacional, página oficial, http://www.imf.org/es/About/Factsheets/IMF-at-aGlance 
La preocupación principal del Fondo, y de los países desarrollados que controlaban sus recursos y sus políticas en el período inicial, era la de garantizar la estabilidad del sistema monetario y los requerimientos del comercio mundial, más no la regulación estricta de los mercados financieros que se circunscribían en esos años, principalmente, a las normas de los estados nacionales, pues en ese entonces, no operaban intensamente a nivel internacional $\mathrm{y}$, por lo tanto, no se requerían normas imperativas ni una organización que lo controlaran.

En cuanto al Banco Mundial, surgió inicialmente (1945) como Banco Internacional de Reconstrucción y Fomento (BIRF) para apoyar la reconstrucción de Europa; luego, sus programas y sus organismos asociados regionales se fueron especializando en iniciativas y en la provisión de recursos para fomentar el desarrollo y promover reformas estructurales especialmente en los países pobres.

Debemos resaltar que "el Banco Mundial es una fuente de asistencia financiera y técnica para los países en desarrollo en todo el mundo. El Grupo del Banco Mundial está constituido por cinco instituciones: el Banco Internacional de Reconstrucción y Fomento (BIRF), que otorga préstamos a gobiernos de países de ingreso mediano y de ingreso bajo con capacidad de pago; la Asociación Internacional de Fomento (AIF), que concede préstamos sin interés o créditos, así como donaciones a gobiernos de los países más pobres; la Corporación Financiera Internacional (IFC) proporciona préstamos, capital y asistencia técnica para promover inversiones del sector privado en los países en desarrollo y el Organismo Multilateral de Garantía de Inversiones (MIGA) proporciona seguros contra riesgos políticos o garantías contra pérdidas ocasionadas por riesgos a inversores en los países en desarrollo". ${ }^{111}$

A partir de 1973, con la crisis del dólar y las transformaciones monetarias en EEUU, el FMI adoptó la política de flotación de las monedas y sus funciones principales se orientaron a la supervisión y vigilancia de las economías de los países miembros, a la asistencia técnica en cuestiones fiscales y monetarias y al apoyo financiero a países con problemas en la balanza de pagos, para todo lo cual se concibieron "programas de ajuste" y de "reforma económica" que debían adoptarse obligatoriamente para obtener su aval y acceder al mercado internacional. ${ }^{112}$

Tanto en los años en los que predominaban las políticas intervencionistas, como en las que se dio privilegio a las de mercado o nuevamente al protagonismo del Estado, los organismos financieros internacionales y sus reflexiones doctrinarias recomendaban mantener una economía sólida para observar los equilibrios macroeconómicos, como fundamento para el cumplimiento de las obligaciones comerciales y crediticias internacionales, la sostenibilidad fiscal, la ampliación del comercio y el crecimiento y el desarrollo económico y social.

\footnotetext{
${ }^{111}$ ONU, Página oficial, http://www.un.org.ec/?page_id=821

${ }^{112}$ Marta Arias y José María Vera, Banco Mundial y Fondo Monetario Internacional ¿una ayuda para los países pobres?, Departamento de Estudios de Intermón-Oxfan, Barcelona, 2002.
} 
El término "equilibrios macroeconómicos" se refiere a un conjunto de identidades contables de carácter general, para asegurar que el desempeño económico de un país discurra en un marco de razonable estabilidad, si se toma en cuenta el predominio de una economía mixta entre el sector público y el sector privado, con intercambios económicos con el resto del mundo. En ese caso los equilibrios tienen que ver principalmente con impedir o controlar la brecha fiscal, la privada y la externa, si bien otras construcciones teóricas consideran también el riesgo y la incertidumbre en el ciclo, el crecimiento y el desarrollo económicos y otras dimensiones como las lógicas institucionales del poder, el medioambiente, la biofísica, la cultura, etc.

En medio del neoliberalismo, como enfoque de mercado céntrico y de Estado mínimo, entre los años ochenta y noventa del siglo pasado, se priorizaron los equilibrios macroeconómicos, tanto en la fase inicial de estabilización como en la posterior del ajuste estructural. En la primera se pretendía corregir los desequilibrios (inflación, déficit fiscal y de cuenta corriente) del modelo "de orientación hacia adentro" (estructuralismo o desarrollismo) y en la segunda apuntalar la "orientación hacia afuera" mediante el programa de privatizaciones, de desregulación, de reformas estructurales y de flexibilización laboral.

Para superar los enfoques neoliberales radicales se replanteó, desde la CEPAL y de varios autores y estudiosos de la realidad regional, nuevamente el concepto de "estabilidad macroeconómica", en cuanto a conseguir no sólo baja inflación y equilibrio fiscal en la política macroeconómica, para que esta juegue un efectivo papel anticíclico y pueda impulsar la actividad productiva real y el crecimiento y el pleno empleo, en el contexto de la globalización comercial y financiera. La estabilidad macroeconómica definida para diseñar políticas de desarrollo, según José Ocampo, implica estabilidad de precios y equilibrio en las políticas fiscales, pero debe incluir también variables reales y financieras, para incentivar los ciclos económicos productivos, mediante tasas de cambio competitivas, sistemas financieros confiables, carteras de deuda externa y balances del sector privado sanos, entre otras. ${ }^{113}$

Sin embargo, durante la fase posneoliberal o neoestructuralista o neodesarrollista en América Latina desde inicios del presente siglo hasta la actualidad, en la que se reestatiza la economía, no se desmonta lo esencial del modelo o de las políticas neoliberales antes indicadas, sino que se las matiza o negocia manteniendo la reprimarización de la economía, aprovechando los altos precios internacionales de las materias primas e introduciendo una parcial redistribución social de los ingresos, para lo cual resulta crucial mantener los necesarios equilibrios macroeconómicos.

Pero además, a inicios de los años 70 se presentaron episodios de inestabilidad financiera que podían afectar los sistemas y a las entidades bancarias nacionales. Los

${ }^{113}$ José Antonio Ocampo, "Una visión amplia de la estabilidad macroeconómica”, en Narcis Serra y J. Stiglitz (eds), El consenso de Washington reconsiderado. Hacia una nueva gobernanza global, Oxford (New York: University Press, 2008). 
Estados y las estructuras financieras más importantes, desde 1974 conformaron un Comité de Supervisión Bancaria en Basilea, como un organismo técnico para deliberar y elaborar normas y reglamentos no vinculantes, que se recomienda que sean adoptados por los Estados y las entidades financieras nacionales en su derecho interno, con la finalidad de garantizar un manejo prudente y eficiente de las actividades financieras públicas y privadas.

De igual manera, más tarde se conformaron, con el mismo propósito de regulación financiera, otras organizaciones internacionales de carácter técnico complementarias, como son la Organización Internacional de Comisiones de Valores (OICV - IOSCO, 1984) para la supervisión de mercados de valores y futuros y la Asociación Internacional de Supervisores de Seguros (AISS - IAIS, 1994) que agrupa a las autoridades que supervisan a entidades aseguradoras. También se estructuraron otras asociaciones privadas de carácter internacional, para elaborar normas técnicas en materia financiera como la Federación Internacional de Contadores (FIC - IFAC, 1977) y el Comité de Normas Internacionales de Contabilidad (CNIC - IASC, 1977) que luego se transformó en la Junta de Normas Internacionales de Contabilidad (JNIC IASB, 2001). ${ }^{114}$

Desde fines de los años setenta y hasta terminar el siglo XX, con la sustitución del sistema de cambios fijos por el de fluctuación monetaria; el desarrollo de las comunicaciones y la informática; una mayor mundialización del comercio y la hegemonía del capital financiero, se produjo una acelerada liberalización, diversificación y movimiento de capitales y productos en la creación de un poderoso mercado financiero, sin que ello signifique la creación de un sistema normativo e institucional imperativo que controle y sancione los excesos de quienes encontraron la oportunidad perfecta para maximizar sus ganancias.

Como se indica, las circunstancias y las exigencias internacionales señaladas permitieron el surgimiento de toda una red poco ordenada y planificada de las referidas entidades técnicas que agrupan a entes públicos y privados, cuya finalidad es la regulación y la supervisión financieras. Sus decisiones, si bien en principio no son vinculantes, terminan transformándose en obligatorias, no solo por decisión de la legislación interna sino por su impacto técnico y moral, en la búsqueda de seguridad y estabilidad para las actividades financieras mundiales y no se diga después de las agudas crisis que en este siglo afectaron especialmente a los países más desarrollados y sus centros financieros.

El FMI se concentró principalmente, desde la reforma de su tratado constitutivo en 1978 hasta fines de siglo, en vigilar las políticas macroeconómicas de los estados miembros

\footnotetext{
${ }^{114}$ IOSCO, International Organization, of Securities Comissions, con sede en Madrid; IAIS, International Association of Insurance Supervisors, con sede en Basilea; IFAC, International Federation of Account; IASC, International Accounting Standards Committee; IASB, International Accounting Standards Board. Manuel López, "La protección de la estabilidad financiera como bien público global", en La Gobernanza del Interés Público Global, XXV jornadas de la AEPDIRI, Universitat Pompeu Fabra, Tecnos, Barcelona, 2013.
} 
$\mathrm{y}$, en especial, las de los países subdesarrollados, para contribuir a solucionar, con créditos de estabilización, sus problemas de balanza de pagos, mientras que el Banco Mundial y otros organismos financieros regionales canalizaban recursos para impulsar reformas estructurales que permitían la adopción de medidas severas de disciplina fiscal, de reorientación del gasto público, liberalización financiera y comercial, privatizaciones, promoción de la inversión extranjera y financiamiento de programas de desarrollo destinados a sectores vulnerables, con la finalidad de que las reacciones sociales no pusieran en peligro la estabilidad económica, social y política del sistema mundial.

Sin embargo, los programas de ajuste y las reformas estructurales, más el impacto negativo de la deuda externa no lograron, como ya lo hemos señalado, el efecto esperado en materia de crecimiento económico, pues generaron, en la década de los noventa del siglo pasado, enormes costos sociales y medioambientales con consecuencias desastrosas para la población más pobre. Por ese motivo se planteó la necesidad, desde fuera y desde su interior, de que los organismos internacionales modifiquen sus rigurosas políticas de intervención y adopten iniciativas en la lucha contra la pobreza.

Desde 1989 se estableció un acuerdo para asegurar una colaboración eficaz entre el FMI y el BM, en la que al primero le correspondió impulsar la cooperación internacional en materia monetaria; la asesoría y asistencia técnica para que los países construyan una economía sólida y el apoyo a los países para la formulación de programas que resuelvan problemas de balanza de pagos mediante préstamos de mediano y corto plazo, con la finalidad de que accedan a un financiamiento adecuado, para que efectúen pagos internacionales pendientes. Al Banco Mundial y otras entidades financieras regionales como el BID se les asignó la función de fomentar el desarrollo económico y la reducción de la pobreza, mediante apoyo técnico y financiero a los países que promuevan reformas institucionales e implementen proyectos específicos en el ámbito educativo, servicios básicos y de salud, protección del medioambiente, etc. Tanto las evaluaciones como las reformas, proyectos de desarrollo y programas crediticios, en los diferentes países eran debidamente coordinados para definir y aprobar los correspondientes condicionamientos, que finalmente se convirtieron en políticas rectoras de las economías nacionales.

Organismos financieros regionales como el BID (1959), que se constituyeron para satisfacer ciertas aspiraciones de desarrollo e integración de la región por parte de los gobiernos latinoamericanos y de académicos vinculados a la CEPAL y a la OEA, se fueron articulando desde 1990 de manera total, a las definiciones y orientaciones del FMI y del BM y a los intereses norteamericanos, pues la mayoría de sus recursos provenían principalmente de esas fuentes, supeditadas a las empresas transnacionales y a la creciente hegemonía del capital financiero mundial. 
El BID fue inicialmente la principal agencia de desarrollo y cooperación durante el modelo intervencionista, con la finalidad de apuntalar la política norteamericana de la Alianza para el Progreso. En los años setenta y ochenta del siglo pasado su función disminuyó debido al masivo y fácil endeudamiento privado al que recurrieron los países de la región inducidos por el mismo capital financiero internacional.

Como resultado de la crisis de la deuda externa y de los profundos desequilibrios macroeconómicos de la región en los años noventa, EEUU demandó en el BID mayor poder de voto y una mayor subordinación a las políticas del Banco Mundial, para una intensa inserción de América Latina en el mercado global y para garantizar, bajo diferentes modalidades, el pago de la deuda externa. El organismo financiero regional se reactivó y se convirtió en un instrumento adicional de promoción de las políticas neoliberales, financiando reformas institucionales públicas, la modernización de los sistemas judiciales, la desregulación de los mercados de trabajo, la privatización de los servicios públicos y obras del Estado etc. y, obviamente, impulsando los conocidos “ajustes" y "reformas estructurales" definidas por el FMI y el BM, además de financiar, con mayor intensidad, obras de infraestructura y de servicios públicos ejecutadas por el sector privado, al que se le otorgan garantías directas de largo plazo, sin exigir en los créditos garantía soberana de los estados. ${ }^{115}$

Al final del siglo pasado, constatando las crisis financieras y el deterioro social de varios países de la región -incluyendo Ecuador-, que provocaron el salvataje de las instituciones financieras y el saqueo de recursos públicos y privados, el gobierno de Clinton (1999) y la Comisión Meltzer del Congreso de EEUU exhortaron al FMI, al BM $\mathrm{y}$ al BID a redefinir su función para prevenir los referidos eventos traumáticos y promover reformas estatales y una mayor integración y apertura de América Latina a la economía global.

El FMI y el BM aprobaron entonces, como ya lo señalamos oportunamente, varios documentos en los que se define una nueva estrategia para la reducción de la pobreza, con la finalidad de alcanzar los Objetivos de Desarrollo del Milenio, ${ }^{116}$ que fueron asumidos por la comunidad internacional y refrendados por las Naciones Unidas en el año 2000; sin dejar de insistir, en la adopción de sus consabidas "políticas" para obtener "el crecimiento", mediante sus inamovibles "programas macroeconómicos", que además de mantener una extrema rigidez en el gasto público, una radical liberalización comercial y de capitales y la ampliación de privatizaciones, ahora, retóricamente, proclamaron que debían ser consistentes con los objetivos de la lucha contra la pobreza.

\footnotetext{
${ }^{115}$ Ernesto Vivares, El Banco Interamericano de Desarrollo en la década neoliberal, (Quito: FLACSO sede Ecuador, 2013.

${ }^{116}$ Los Objetivos de Desarrollo del Milenio se refieren entre otros a la reducción de la pobreza extrema; la escolarización primaria universal, aumentar el acceso al agua potable; la reducción de la mortalidad infantil; lucha contra la malaria, el VIH/SIDA y la tuberculosis.
} 
Tanto en el modelo intervencionista como en los modelos neoliberal y neointervencionista, los organismos financieros internacionales, en las cartas de intención y en los planes de reestructuración económica, exigen que los países en desarrollo asuman compromisos concretos para establecer en sus presupuestos y políticas públicas equilibrios macroeconómicos y fiscales. Sea en las constituciones, como en las leyes expedidas en las últimas décadas, como lo veremos más adelante, constan la necesidad de alcanzar estabilidad presupuestaria y un manejo del déficit en el mediano y corto plazo. Incluso en Europa se impuso la obligación de alcanzar "estabilidad presupuestaria" y de dictar reglas macrofiscales como ocurrió en Alemania y España, en donde se introdujeron reformas constitucionales para lograr esos objetivos y aplicar el Pacto Europeo de Estabilidad y Crecimiento (PEC) y el Pacto Presupuestario celebrados en 1997 y que fueron reglamentados en ese mismo año y luego reformados en 2005 y en la crisis económica y financiera del año 2008. ${ }^{117}$

En Alemania se reformó en 2009 la Ley Fundamental de Bonn con la finalidad de prohibir el endeudamiento excesivo que ocasionó el incumplimiento del Pacto Europeo de Estabilidad y Crecimiento, para lo cual se exigió que en los presupuestos de la Federación y de los länders se observe el principio de equilibrio, reglas fiscales estrictas y planes de amortización de los créditos, para mantener la sostenibilidad fiscal en el corto plazo, bajo la supervisión y consentimiento de un "Consejo de Estabilidad". ${ }^{118}$

En 2011, la confluencia de los partidos políticos mayoritarios en España (PP y PSOE) autorizó la reforma constitucional del Art. 135 de la Constitución, que a la vez se complementó con la expedición de la Ley Orgánica de Estabilidad Presupuestaria y Sostenibilidad Financiera de 2012, con las que se produjo una cesión de la "soberanía financiera" a favor de las decisiones de la Unión Europea, para unificar las políticas económicas y asegurar la sostenibilidad de las finanzas públicas a nivel regional, tal como consta en los mecanismos y reglas de corrección presupuestaria del Tratado de Estabilidad, Coordinación y Gobernanza en la Unión Económica y Monetaria (2012). ${ }^{119}$

Varios tratadistas han observado que estas reformas financieras fueron pasos extraordinarios en la adopción de normas constituyentes en la región, adoptadas sin referéndum y como resultado de un pacto político que puso en entredicho los objetivos del Estado social y democrático de derecho, pues al establecer como "prioridad absoluta" el pago de la deuda pública se dispuso que este era un "valor superior" a los de justicia y equidad que lo caracterizaban, a la vez que se despojó a los estados nacionales de su poder presupuestario. ${ }^{120}$

\footnotetext{
117 Constitución Española del 2 de septiembre de 2011, art. 135 reformado; art. 109 y 115 de la Ley Fundamental de Bonn; Resolución del Consejo Europeo, Ámsterdam, 17 de junio 1997.

${ }_{118}$ Antonio Embid Irujo, La Constitucionalización de la crisis económica, (Madrid: Iustel, 2012).

${ }^{119}$ España, Ley Orgánica de Estabilidad Presupuestaria y Sostenibilidad Financiera de España 2/2012 de 27/04; Tratado de Estabilidad, Coordinación y Gobernanza de la UE, 2 de marzo de 2012.

${ }^{120}$ Miguel Ángel Martínez Lago, "Crisis Fiscal, Estabilidad Presupuestaria y Reforma de la Constitución" en El Cronista del Estado Social y Democrático de Derecho, núm. 24, 2011; Violeta Ruiz Almendral “Estabilidad Presupuestaria y Gasto Público en España, (Madrid: Ed. La Ley, 2008).
} 
En Ecuador, los principios de equilibrio presupuestario y sostenibilidad fiscal se encuentran presentes en las cartas de intención presentadas por los diferentes gobiernos al FMI entre 1980 y 2005. Durante el modelo neoliberal -entre 1990 y 2005-, se introdujeron varias normas, en las reformas constitucionales $(1995,1998)$ y en las leyes de presupuestos y de reforma de las finanzas públicas, con la finalidad de controlar el déficit y los gastos públicos, para que estos no se excedieran en la aprobación parlamentaria del presupuesto y contaran con fuentes seguras de financiamiento. Así, el Ejecutivo observó reglas fiscales para controlar y disminuir el déficit en el corto plazo y limitar el incremento anual del presupuesto en relación con la inflación y el crecimiento del PIB, como lo detallaremos posteriormente.

En cuanto al modelo neointervencionista, tanto en la Constitución de 2008 como en el Código de Planificación y Finanzas Públicas (2010), se estableció, ambiguamente, la obligación de que la política fiscal debería conducirse de forma "sostenible, responsable y transparente", procurando la "estabilidad económica". Se dispusieron reglas más flexibles que las adoptadas en el modelo anterior, para que el equilibrio y la sostenibilidad presupuestarias se alcanzaron mediante "egresos permanentes financiados con ingresos permanentes"; que solo los egresos sociales prioritarios de manera excepcional pudieran financiarse con ingresos no permanentes como los de la deuda; que el gasto público contara siempre con las correspondientes fuentes de financiamiento y que las tasas y contribuciones sólo pudieran destinarse a financiar instituciones de derecho público. ${ }^{121}$

Por otra parte, el Banco Mundial emitió en 2001un documento en el que se analizaron las crisis financieras desatadas en diferentes países en la última década del siglo pasado y en el que advertía que la evolución de los servicios financieros en línea conducían a un "mundo de finanzas sin fronteras" y que los países debían decidir, qué servicios financieros comprar y cuáles construir ellos mismos, con la finalidad de adoptar medidas para reducir la frecuencia y las graves consecuencias de las crisis financieras, que finalmente producen un alto costo social y presupuestario. ${ }^{122}$

Los expertos del organismo internacional desalentaron a los estados a ser propietarios de entidades financieras, que sin embargo fueron asumidas como resultado de los salvatajes bancarios; propusieron apertura al ingreso de bancos extranjeros y la liberalización de la cuenta de capitales, para favorecer la competencia y la eficacia de los servicios financieros y sugirieron la adopción de medidas para impedir la frecuencia y gravedad de las crisis, así como un eficaz control de mercado de los participantes y de los supervisores bancarios y autoridades, además de una aplicación no mecánica de las normas internacionales sobre la materia.

\footnotetext{
${ }^{121}$ Ecuador, Código Orgánico de Planificación y Finanzas Públicas Registro Oficial 306, 22 de octubre de 2010.

${ }_{122}$ Banco Mundial: Finanzas para el crecimiento económico: Opciones de política en un mundo volátil, Gerard Caprio, Patrick Honohan, 2010.
} 
Complementariamente, la ONU y su Consejo Económico y Social, que inicialmente no intervinieron en los problemas de inestabilidad o crisis monetarias y financieras, se vieron obligados, como resultado de las crisis y los graves problemas económicos y sociales que surgieron a fines del siglo XX y en la primera década del siglo XXI, a crear foros políticos (G-7, G-8 y más tarde el G-20) que culminaron en la conformación técnica de un Foro de Estabilidad Financiera (1999) y del Consejo de Estabilidad Financiera (FSB, 2009). Con ellos ejercen una función de coordinación y cooperación entre las principales economías del mundo, cuyas declaraciones y sugerencias, en el campo monetario y financiero, terminan finalmente siendo adoptadas o imponiéndose en todos los países.

Después de la evaluación externa que se realizó en 2007, la labor cumplida por el FMI y el BM en las dos décadas anteriores, se elaboró un Plan Ejecutivo Conjunto de Acción para perfeccionar el intercambio de información sobre los países miembros y así elaborar en conjunto programas de trabajo sobre asuntos de importancia macroeconómica crítica; la reducción de la deuda de los países pobres muy endeudados; el alivio de la deuda multilateral; la estrategia de la lucha contra la pobreza; iniciativas para lograr objetivos de desarrollo sostenible; el refuerzo de sistemas tributarios eficaces en los países en desarrollo; las políticas y medidas para alcanzar los Objetivos de Desarrollo del Milenio y la ejecución de la Agenda 2030 para el Desarrollo.

Las normas financieras que inicialmente surgieron de entes privados técnicos y públicos internacionales, con un carácter de soft law, sin fuerza jurídica obligatoria, se fueron transformando, por exigencias del mercado y por el acceso a recursos y productos financieros internacionales y por los condicionamientos de organismos internacionales como FMI y BM, en sus acciones de supervisión monetaria y financieras y de canalización de préstamos y recursos para el desarrollo, en normas obligatorias o de hard law, que se fueron incorporando a las constituciones y a la Legislación interna de los más diversos países del mundo, cuando no se las convirtió, en numerosos casos, en materia de tratados y convenios internacionales o en normas obligatorias, adoptadas por las máximas instancias políticas de la ONU o por los tribunales internacionales de justicia que emiten decisiones y sentencias vinculantes para las personas, empresas y estados involucrados.

Una vez que las regulaciones referenciales fueron ineficaces para prevenir las crisis financieras de finales del siglo XX, la recesión estadounidense de 2007-2008 y la subsiguiente europea a partir de 2009-10, y de que finalmente a los estados nacionales y a sus bancos centrales les correspondió mitigar sus efectos, las regulaciones indicativas de los organismos técnicos y políticos internacionales se han ido convirtiendo más abiertamente en obligatorias para todos los países del mundo, pues solo en estos últimos años se llegó a concebir que la estabilidad financiera, al igual que la monetaria y macroeconómica de los estados, son bienes públicos globales que deben ser debida, oportuna y eficazmente tutelados y regulados a nivel internacional. 
En los últimos años, han participado en las cumbres del G-20 los mandatarios de los países que lo integran, el secretario general de la ONU, el director general de la OMC, los representantes del FMI, del BM y del Consejo de Estabilidad Financiera (FSB), por lo que ese espacio, monitoreado permanentemente por este último, se va transformando en el principal instrumento de coordinación de la política económica mundial y de regulación y supervisión de los mercados financieros y (de) reforma de la arquitectura de financiera internacional, acogiendo las regulaciones y controles de capital y derivados y de los riesgos de las instituciones financieras en general, pero especialmente para las que tienen impacto sistémico, conforme a las exigencias y normas de Basilea III $^{123}$ que, en el marco de la Unión Europea, sus regulaciones se transponen jurídicamente en la Directiva 2013/36/UE (CRD IV) y el Reglamento UE N 575/2013 (CRR).

En la actualidad, el FMI, el BM y el FSB, realizan también evaluaciones de estabilidad, crecimiento y flexibilidad del sector financiero a nivel internacional, tanto en los países avanzados como en los que están en desarrollo y de mercados emergentes. En dichas evaluaciones se emiten informes que dan cuenta de la aplicación de las normas técnicas, especialmente financieras, antes mencionadas. Por otro lado, vale insistir, sea por acción de los organismos internacionales indicados o por la activa gestión del Consejo de Estabilidad Financiera, las regulaciones técnicas que no tenían de por sí efecto vinculante terminan asumiendo calidad obligatoria cuando sus normas se incorporan a las constituciones económicas de los estados y a las normas administrativas y financieras que expiden las legislaturas de los diferentes países y de sus bancos centrales o de otras entidades que ejercen potestades regulatorias de las finanzas públicas y de las instituciones financieras locales.

Hasta el momento no se ha logrado constituir una entidad que regule y controle las entidades y las actividades financieras del mundo, como ocurre con la OMC en el caso del comercio desde 1995, puesto que los estados nacionales se han reservado la potestad de la intervención y restructuración de las entidades financieras $\mathrm{y}$, en general, la supervisión bancaria, ya que son ellos y sus gobiernos los que disponen de las facultades normativas obligatorias y de los recursos necesarios y presupuestarios para realizar rescates bancarios y de las instituciones financieras en crisis.

En el caso de la Comunidad Europea, en la que las entidades financieras han adquirido una gran magnitud en relación con el mercado y han superado el poder económico de los estados miembros y de sus autoridades locales, se optó por conformar en 2010 un Sistema Europeo de Supervisión y de Vigilancia Financiera para requerir la intervención de las instituciones de la UE, como son el Consejo y el Banco Central Europeo.

${ }^{123}$ Manuel López, "La protección de la estabilidad financiera como bien público global”, en $L a$ Gobernanza del Interés Público Global, XXV jornadas de la AEPDIRI, (Barcelona: Universitat Pompeu Fabra, Tecnos, 2013). 
Mediante reglamentos se creó una Junta Europea de Riesgos Sistémicos y se autorizó que el BCE asumiera una cierta supervisión prudencial sobre las entidades financieras, sin dejar de reconocer la potestad estatal en esas materias de control. Como dichas normas tenían el carácter de soft law reforzado y no lograron detener la crisis bancaria y restablecer la estabilidad financiera, en 2012 se inició la transferencia de las potestades de control financiero de los estados a la Unión Europea, para que esta adoptara normas jurídicas vinculantes (hard law) mediante directivas y reglamentos para proteger la estabilidad financiera, para lo cual se elaboró un código normativo único para los bancos y productos financieros (fondos de inversión y derivados), con la finalidad de promover la unificación o la fusión bancaria entre las entidades de los países de la zona euro, incorporar la aplicación de las normas de Basilea I, II y III, armonizar los regímenes nacionales de garantía de depósitos y resolver las crisis bancarias y las quiebras sistémicas. $^{124}$

Hoy la estabilidad económica y financiera es un tema de relevancia internacional, multilateral y nacional, pues los efectos de las crisis en una economía mundial globalizada e interconectada y la financiarización de la economía internacional, con actores agresivos en la búsqueda de beneficios cuantiosos en período cortos, pueden ocasionar la catástrofe de los países y de las economías más vulnerables. Eso supone por lo tanto, una violación masiva de los derechos humanos y en especial de los sectores de menos ingresos, tanto en los países desarrollados como en los medianamente desarrollados y mucho más en los países pobres, sobre los que recaen los efectos de los ajustes económicos y el pago de los subsidios que los Estados asumen generosamente para evitar la quiebra de las entidades financieras y el colapso de los productores que dependen de aquellas.

La asistencia que ofrecen el FMI y el Banco Mundial, como instituciones del sistema de Naciones Unidas a los 188 países miembros, se refieren a supervisión, asistencia técnica y concesión de préstamos. Con la supervisión el FMI analiza, por medio de consultas periódicas anuales con autoridades y otros sectores de la sociedad, el sistema monetario internacional y las políticas económicas y financieras mundiales y regionales y de cada país, para establecer si las políticas fiscales, monetarias, financieras y cambiarias adoptadas promueven la estabilidad macroeconómica interna y externa y el equilibrio en sus balanzas de pagos. Frente a los problemas detectados, se proponen como asistencia técnica, alternativas para superar los riesgos y las vulnerabilidades que deben ser asumidas en la política gubernamental, en el control del sector financiero local e internacional, en las reformas estructurales y en el ámbito legislativo, mediante códigos y normas. En cuanto a los préstamos y al financiamiento, estos están dirigidos a superar problemas temporales en la balanza de pagos para recobrar la confianza y estabilidad y permitir una articulación del país a los circuitos financieros del mercado internacional.

${ }^{124}$ Ibídem. 
Como se puede advertir, en los diferentes modelos y políticas económicas, que se aplican a nivel internacional, existe coincidencia en la necesidad de que todos los países observen los indispensables "equilibrios macroeconómicos", especialmente en su política fiscal, monetaria y comercial, para su inserción en la economía mundial como lo exige reiteradamente el FMI, organismo cada vez más dependiente de las políticas e intereses norteamericanos y de los conglomerados financieros sistémicos internacionales y para que estos, al igual que las instituciones financieras regionales y locales, adopten de manera obligatoria las regulaciones prudenciales y la "resiliencia" necesaria, ${ }^{125}$ para reaccionar y prevenir los efectos de las crisis, los graves desajustes provocados por operaciones de cofinanciamiento y los agresivos productos financieros y derivados que circulan libremente a nivel mundial, dada la financiarización de la economía mundial, si bien el FMI advierte constantemente que también "debe evitarse el riesgo de una regulación excesiva". ${ }^{126}$

Resulta evidente, sin embargo, que las diferentes políticas adoptadas por los organismos financieros internacionales, en concordancia con los intereses de los países de economías desarrolladas y las entidades financieras internacionales, incidieron en la legislación financiera y administrativa económica de los países latinoamericanos adoptada en los modelos neoliberal y neointervencionista. No obstante, no lograron de manera estable alcanzar los objetivos propuestos, en cuanto a los equilibrios macroeconómicos, la sostenibilidad fiscal y el desarrollo y bienestar de los pueblos a nivel mundial, regional o local, si bien consolidaron o estabilizaron temporalmente y en el mediano plazo, los intereses de dominación del sistema capitalista mundial y de sus poderosos beneficiarios externos e internos.

\section{TRANSFORMACIONES EN EL DERECHO PÚBLICO, EL DERECHO ADMINISTRATIVO ECONÓMICO, FINANCIERO Y DE CONTROL}

Durante el neoliberalismo, en Ecuador -al igual que en otros países de la región y del mundo-, se reportó una crisis del conocido auge del derecho público en los "años dorados" del Estado social de derecho (1950-1970), que se registró como una huida del derecho administrativo, para privilegiar la acción del mercado y de los instrumentos del derecho privado en los asuntos públicos (1990- 2005). En los últimos años (2006 2017), en cambio, se retoman las regulaciones y se produce un nuevo auge del derecho público y del derecho administrativo y financiero internacional y local, con énfasis en sus contenidos de regulación económica y control.

En el actual derecho público constitucional y en el derecho administrativo y financiero tienen un impacto crucial del derecho convencional e internacional y de los

\footnotetext{
${ }^{125}$ La resiliencia es el proceso de adaptarse a la adversidad y la habilidad de recuperarse rápidamente a trastornos en el sistema financiero; la resiliencia implica medidas y de solvencia y fortaleza patrimonial que permiten darle al sistema financiero más resistencia para absorber golpes y shocks negativos provocados por la crisis económica y financiera.

${ }^{126}$ FMI, Informes anuales, 2006, 60 y 2008, 33.
} 
instrumentos e instrucciones de los organismos internacionales públicos y privados, que surgen y prosperan por la consolidación política y económica mundial y regional del capitalismo global, de sus nuevos actores y de los procesos de integración, como los de la Unión Europea, de los países latinoamericanos y de otros. Todos ellos introducen nuevas modalidades y figuras jurídicas, que nacen de la emergencia de nuevos mercados y operadores internacionales y del establecimiento de mecanismos alternativos para la solución de las controversias que otorgan mayor seguridad a la transnacionalización y financiarización del capital, atendiendo la demanda global y adoptando mecanismos de transparencia y lucha anticorrupción por exigencia de los organismos internacionales y en especial de los ciudadanos, frente a la crisis y sus consecuencias socioeconómicas y la manifiesta concentración mundial del poder y de la riqueza.

Debe tomarse en cuenta también que en el periodo previo y, especialmente en el posterior a las recientes crisis norteamericana (2008) y europea (2009-2013), el derecho internacional ha abandonado aceleradamente su connotación de derecho privado, basado en la soberanía de los estados y ha ido asumiendo una dimensión pública global, tanto en el derecho constitucional y en el derecho administrativo y financiero, como en la introducción del pluralismo posnacional y de la doctrina de los bienes públicos y jurídicos locales y globales, que inciden directamente en los nuevos contenidos del derecho público mundial y de cada uno de los estados. ${ }^{127}$

Si bien las recomendaciones y políticas de los organismos internacionales tenían, ya en la realidad, un carácter coercitivo e imperativo para los estados, especialmente de los países subdesarrollados, en la actualidad también las decisiones financieras, consideradas recientemente como prerrogativas nacionales y materia de sugerencias interestatales no vinculantes, se tornan obligatorias, respondiendo a intereses públicos fundamentales de la comunidad internacional, frente a las reiteradas crisis provocadas por agresivos instrumentos financieros y otros derivados, que prolíficamente utilizaron los protagonistas de la financiarización de la economía mundial.

En la Unión Europea, reacia a definir formalmente su Constitución, las normas, regulaciones e instituciones comunes sobre derechos humanos, asuntos económicos y decisiones jurisdiccionales, se han convertido, desde el Tratado de Lisboa, en disposiciones constitucionales de facto o en una virtual "Constitución económica" que obligan a todos los estados y a los ciudadanos de la región. Por ello, se va ajustando, además, una nueva institucionalidad de la Unión para otorgar al Consejo Europeo, mediante procedimientos especiales, no sólo atribuciones políticas sino de regulación

127 Ariel Casanovas, "La dimensión pública del Derecho Internacional actual" en la Gobernanza del interés público global, XXV Jornadas de la AEPDIRT, Universitat Pompeo Fabra y Tecnos, Barcelona, 2013. 
vinculantes, ${ }^{128}$ sobre el control de los desequilibrios presupuestarios, los abultados déficits, los niveles excesivos de endeudamiento y de todos aquellos factores y políticas económicas que provocaron o precipitan reiteradas crisis, que no pudieron ser superadas por cada uno de los Estados de forma aislada.

Cada vez más, la globalización económica y financiera y otros fenómenos, como la exigencia universal de la plena vigencia de los derechos humanos y el combate frontal a la corrupción, el narcotráfico y el terrorismo justifican instrumentos y normas, que entrañan obligaciones y decisiones erga omnes, reconocidos y expedidos por los organismos internacionales y que son aplicados finalmente por todos los estados. ${ }^{129}$

La nueva dimensión que tienen las normas y obligaciones internacionales sobre lo que se denominan bienes jurídicos globales demandan de los estados nacionales acelerar el proceso de su inmediatización y de ampliación de su exigibilidad, mediante la emisión de decisiones de los organismos y de los tribunales internacionales y aún de actores internacionales privados que adoptan "reglas extra estatales" o "para estatales", como ocurre con las normas de los mercados financieros, inversiones, ONGS y otras que aprovechan ágil y eficientemente las innovaciones tecnológicas y la estructura e interconexión del internet. ${ }^{130}$

El actual derecho internacional público abandona su carácter privado de coordinación entre los estados como entes soberanos o de sus instituciones y asume un carácter público para proteger derechos de carácter personal y global y los intereses de la humanidad (ius cogens), lo que se conoce como "constitucionalismo material global fundamentado en los derechos que constan en la Carta de las Naciones Unidas y en la Declaración Universal de Derechos Humanos, sin desconocer que esta formulación podría correr el peligro de imponer un cierto colonialismo constitucional. De igual manera ocurre con la formación de un derecho administrativo global y un derecho financiero global destinados a normar estructuras, procedimientos, potestades normativas y administrativas de órganos de regulación intergubernamental o de carácter económico, social y financiero, como los de las Naciones Unidas o los de coordinación y regulación del Comercio (OMC), supervisión financiera (Comité de Brasilia) o las normas de la Organización Internacional de Estandarización (ISO), etc. ${ }^{131}$

El profesor Agustín Gordillo anticipó hace más de cincuenta años que la progresividad del derecho, al regular nuevas realidades mundiales, era un hecho irreversible y que los

\footnotetext{
128 Antonio Calonge Velázquez, La "nueva” institución de la Unión: El Consejo Europeo, en Derecho Administrativo y Regulación Económica Liber Amicorum Gaspar Ariño Ortiz, coordinadores Juan Miguel de la Cuétara Martínez y otros, (España: La Ley, 2011).

129 Rosario Huesa, "La protección del interés público global" y Pedro A. de Miguel, "Desarrollo y eficacia de reglas transnacionales con participación de actores no estatales", Ministerio de Ciencia e Innovación, Barcelona, 2011-2014.

${ }^{130}$ Ibídem.

131 Ariel Casanovas, "La dimensión pública del Derecho Internacional actual” en la Gobernanza del interés público global, XXV Jornadas de la AEPDIRT, Universitat Pompeo Fabra y Tecnos, Barcelona, 2013.
} 
ciudadanos se encontrarían inmersos en un orden jurídico mundial, pues se han celebrado entre los estados tratados de derechos humanos y de integración económica y se han conformado, para su ejecución, organizaciones y redes formales e informales de carácter internacional. Además afirmó que el derecho aplicable en cada uno de los países del mundo provendrá de dichas normas internacionales y organismos a los que se han sometido voluntariamente y en los que se generan normas de aplicación internas de segundo grado. ${ }^{132}$

Luciano Parejo Alfonso observó también que en la última década del siglo pasado floreció un universo de relaciones más complejas en la economía y en la actividad administrativa de los países del mundo, por lo que se requería de un nuevo modelo de administración y de derecho administrativo para regir las actividades provenientes de la globalización y normar los procesos de desregulación, desmonopolización o privatización de la actividad económica que se les imponía. En la ejecución de la nueva actividad administrativa, agrega, se necesitaba no solamente la voluntad unilateral o la coacción en el ejercicio de las potestades de la administración, sino "soluciones representativas del óptimo social" o "voluntades concurrentes" que se expresen en el consenso y en la cooperación entre los ciudadanos interesados y la autoridad; en formas participativas en los procesos de toma de decisiones administrativas y en "formas blandas" de gestión. Por lo que debía darse un tránsito de la administración autoritaria tradicional a una administración prestacional en la que se debería involucrar activamente a los particulares y en general a los ciudadanos. ${ }^{133}$

Sin embargo, a finales del siglo pasado todavía se consideraba que, al ser la administración una extensión del Estado o de los organismos regionales consolidados, era prematuro hablar de la existencia de un derecho administrativo global, pues era indispensable, como presupuesto, la existencia de un poder ejecutivo internacional consolidado que realizara la actividad administrativa de por sí y no solamente las limitadas acciones de coordinación y de asistencia a los estados. Esta situación solo fundamentaba la existencia de un derecho administrativo internacional, tanto más que la globalización no era aún un fenómeno universal, pues solo involucraba a un grupo de países y no se reconocían todavía, de manera integral, los derechos humanos básicos en la mayoría de estados del mundo. ${ }^{134}$

Por el contrario, en el presente siglo las innovaciones tecnológicas; los riesgos sistémicos provocados por las crisis financieras y productivas; el control de las fuentes de materias primas; la proliferación de la corrupción, lo paraísos fiscales, el narcotráfico y los conflictos étnico-religiosos; los acuerdos de la Organización Mundial de Comercio; las regulaciones monetarias; los tratados bilaterales de protección de

\footnotetext{
${ }^{132}$ Agustín Gordillo, Derecho administrativo de la economía, (Buenos Aires: Ed. Macchi, 1967).

133 Luciano Parejo Alfonso, Antonio Jiménez Blanco y Luis Ortega Álvarez, Manual de derecho administrativo, (Barcelona: Ed. Ariel, 1990).

${ }^{134}$ Pablo Fernández Lamela, El impacto de las redes transgubernamentales en la evolución del Derecho Administrativo Internacional, en Benedit Kingsbury y otros, El Nuevo Derecho Administrativo Global en América Latina (Buenos Aires: Ediciones Rap S.A., 2009).
} 
inversiones, entre otros fenómenos económicos y políticos, impusieron decisiones y acciones a nivel global, pues los estados-nación y sus gobiernos aisladamente no tenían capacidad ni fortalezas suficientes para adoptar medidas eficaces.

Por ello, las normas supranacionales y globales, los códigos modelos; los arbitrajes internacionales y la Carta Iberoamericana de los Derechos Ciudadanos en su relación con la administración condicionan y transforman las leyes nacionales administrativas y obligan a pensar en la necesidad de definir un nuevo modelo de administración y de un derecho administrativo global que permitan la gobernanza global y la regulación de las actividades y los procesos contradictorios externos e internos con normas eficaces, simplificadas, consensuadas y participativas. ${ }^{135}$

Además de los anuncios premonitorios de Agustín Gordillo, las observaciones de Luciano Parejo; los estudios de Ricardo Rivero, Libardo Rodríguez y de los profesores Benedict Kingsbury, Nico Krisch y Richard Stewart del Instituto de Derecho y Justicia Internacional de la Universidad de Nueva York concuerdan o con el surgimiento del derecho administrativo global o con la creación de un orden jurídico global en el que se encuentra como su contenido: la adaptación de instituciones y normas comunes a las exigencias de la globalización; un conjunto de nuevos principios, normas, tratados e instrumentos a los que hemos hecho referencia en los párrafos anteriores y sistemas de control y administración supranacionales. Todos esos instrumentos los emiten o autorizan los principales actores o protagonistas del "espacio administrativo global" como los estados; los organismos de las Naciones Unidas; las agrupaciones regionales o comunitarias estatales; los organismos y cortes internacionales; los organismos de regulación financiera, comercial, de normalización y calidad; los que normas ciertas actividades privadas internacionales; las empresas transnacionales, etc. ${ }^{136}$

A nivel interno de los diferentes países, la función administrativa, ejercida por los órganos del Estado de manera principal y residualmente por personas del sector privado cuando intervienen en actividades públicas, amplía como una de sus actividades especializadas, un control de legalidad más prolijo y del ejercicio de derechos, tanto en las transformaciones de la administración y de las finanzas, como en la eficiencia en la gestión de los órganos y recursos públicos que se encuentran bajo su dependencia y de otras entidades que realizan actividades de control y de interés público en beneficio de los ciudadanos.

\footnotetext{
${ }^{135}$ Ricardo Rivero Ortega y Víctor Granda Aguilar, Derecho Administrativo, (Quito: Universidad Andina Simón Bolívar, Sede Ecuador, Corporación Editora Nacional, 2017).

${ }^{136}$ Ricardo Rivero Ortega, Derecho administrativo económico, (Madrid: Marcial Pons, 2013); Libardo Rodríguez Rodríguez, "El Derecho Administrativo Transnacional o Global: Un nuevo capítulo del Derecho Administrativo", en Derecho Administrativo, en homenaje a Jorge Fernández Ruiz,(México: Universidad nacional Autónoma de México y Asociación Mexicana de Derecho Administrativo, 2013); Benedict Kingsbury, Nico Krisch y Richard Stewart, "El Surgimiento del Derecho Administrativo Global" en Benedict Kingsbury y otros, El Nuevo Derecho Administrativo Global en América Latina (Buenos Aires: Ediciones Rap S.A.
} 
Es necesario enfatizar que todas esas actividades jurídicas se realizan para cumplir fines institucionales, alcanzar equilibrios económicos, prevenir la corrupción y satisfacer los derechos humanos, que son los ejes fundamentales en la renovación actual del derecho administrativo y del derecho financiero y de sus ramas especializadas, sin que ello signifique disminuir o menoscabar las atribuciones y potestades de las autoridades públicas y el control integral externo e interno de los recursos públicos, que deben realizar ellas mismas y principalmente los órganos técnicos y sociales especializados en la materia, conforme a las normas convencionales constitucionales y legales.

La distinción tradicional entre derecho público y derecho privado en el siglo $\mathrm{XX}$ se torna menos radical en el siglo XXI con el auge de la globalización y la referida publicitación del derecho internacional. Este proceso se inició también desde mediados del siglo pasado, cuando como todos sabemos, surgió un campo intermedio de interrelación conocido como derecho económico y social, que amplió el contenido del derecho administrativo y del derecho financiero con el surgimiento del derecho administrativo económico y del derecho financiero económico, que regulan y norman de manera directa la intervención y regulación del Estado, la participación en ellas de los actores privados transnacionales y locales y la administración, y la gestión y control de la actividad económica y de la actividad financiera pública y de las instituciones financieras no estatales que cada día tienen una mayor connotación social y pública.

De allí que se mencionó en la reflexión jurídica un novum principium divitionis en el derecho, para superar la división tradicional de derecho público y privado, inspirada en Ulpiano y en el derecho romano y que había sido considerada como la summa divitionis, para dar paso a un tercer elemento en la clasificación del derecho, el derecho económico y social. La existencia del derecho económico y social, como un nuevo tronco independiente o intermedio del derecho público y privado, parece imponerse en la realidad y en la práctica científica y académica de nuestros días, pues el derecho económico es una diagonal que atraviesa todas las ramas del derecho, utilizando la feliz expresión del profesor Ángel Rojo, y se convierte en "una categoría autónoma, añadida al sistema tradicional, si se admite la idea que el sistema jurídico tiene carácter abierto y que los criterios de sistematización, en razón de su heterogeneidad valorativa de la que parten, pueden dar como resultado categorías jurídicas con materia parcialmente compartida". ${ }^{137}$

Si el derecho económico implica un enfoque interdisciplinar que abarca varios campos de las ciencias jurídicas y en especial de la compleja realidad económica internacional y nacional, involucra normas y cuerpos jurídicos que no se los puede ubicar de manera exclusiva en el ámbito público o en el privado sino en los dos de manera complementaria. Esta amplitud se manifiesta también en el derecho público de la economía, de contenido constitucional, administrativo y financiero, destinado a regular

137 Ángel Rojo, El Derecho Económico como categoría sistemática, (Buenos Aires: Editorial Depalma, 1982), 209-210. 
la intervención del poder estatal no solo en su propio ámbito, sino en el de entes y actividades privadas o comunitarias, que por su naturaleza tienen cada vez más una connotación pública y social.

El profesor Ricardo Rivero nos recuerda que la mayoría de regulaciones e intervenciones económicas públicas o estatales tienen fundamento constitucional y están previstas y normadas por leyes, que precisamente forman parte del derecho administrativo económico, ciencia en la que trabajan de manera significativa varios tratadistas de Alemania, Francia, Italia y Estados Unidos y, obviamente, que los asuntos fiscales son objeto de estudio del derecho financiero y tributario, como disciplinas autónomas pero con profundas implicaciones en el derecho administrativo.

Para nosotros también es el derecho administrativo económico es la disciplina que, en el campo académico, nos ofrece, de manera general, el marco jurídico más pertinente para referirnos e involucrar en las categorías y regulaciones establecidas por el Estado, tanto las acciones, decisiones y procedimientos de sus órganos en el ejercicio de sus funciones y atribuciones económicas, como para regular en la actualidad los aspectos administrativos de la planificación, las finanzas y el control de los recursos públicos; las responsabilidades; la restructuración del Estado y del gobierno nacional o local y de la actividad empresarial; las actividades económicas estratégicas y de servicios y los derechos de usuarios y consumidores. ${ }^{138}$

Si bien la administración puede contar con una multiplicidad de órganos e instituciones y utilizar instituciones del derecho público y del privado y aún instrumentos de administración concertada, según la naturaleza de la actividad o proyectos económicos en curso, en los que pueden estar involucrados también entes privados, las grandes definiciones administrativas y financieras sobre la planificación, las finanzas y el control de los recursos públicos se adoptan formalmente por el gobierno y las instituciones públicas, partiendo de las normas constitucionales y del derecho público interno, en las que sin duda inciden de manera directa los convenios internacionales celebrados con los organismos internacionales y las recomendaciones o decisiones de los organismos multilaterales y otros relacionados con la actividad económica y financiera, regional y mundial.

El nuevo derecho administrativo económico y constitucional se sitúa también en un momento de crítica radical tanto al modelo de estado providencia y estado de bienestar como al Estado neoliberal o neocompetitivo. Al primero se le cuestiona "su estancamiento en la consecución del crecimiento económico y su fracaso en el mantenimiento de la cohesión social", pues no cumplió con "su misión principal” ya que "tras varias décadas de actividades redistributivas no solo no han disminuido las desigualdades, sino que, por paradójico que parezca, ha aumentado la distancia entre

\footnotetext{
138 Ricardo Rivero Ortega, Derecho administrativo económico, (Madrid: Marcial Pons, sexta edición,
} 2013). 
ricos y pobres" y se han profundizado las discriminaciones económicas, raciales, religiosas y de nacionalidad. Al segundo se le cuestionan también sus resultados, pues si bien plantea la "economía social de mercado" o un "liberalismo rampante" para alcanzar la "prosperidad económica", y que el Estado cumpla únicamente un papel regulador para "crear el orden de la competencia, sin entorpecer el proceso económico de la misma", resulta evidente, especialmente en los países latinoamericanos, que la aplicación de las políticas neoliberales propiciaron el descontento social, el desempleo, la violencia, una mayor concentración de la riqueza y la corrupción, ya que las "ventajas económicas no son casi nunca suficientes para producir bienestar". Por eso, como alternativa al fracaso de los modelos anteriores, se plantea una transformación democrática del Estado para alcanzar y ampliar, con "políticas austeras" y reformas eficaces, el bienestar de la población y en especial de sus sectores más desfavorecidos, con la finalidad de promover la libertad, la solidaridad y la participación de los ciudadanos en la satisfacción en general de sus derechos. ${ }^{139}$

El derecho administrativo constitucional y económico actual requiere pues de categorías, principios e instituciones democráticas que no se acoplen irreflexivamente a la situación económica y política externa e interna de la globalización y sus intereses, sino que fundamentalmente promuevan el interés y bienestar general, la satisfacción de las necesidades y el ejercicio pleno de los derechos de la población. La riqueza no puede concentrarse en los monopolios económicos y financieros transnacionales y locales, se requiere de un nuevo orden económico y político internacional, regional y nacional y de una buena administración para que el Estado y la Administración pública, sirviendo al interés general, propendan a su redistribución y garanticen y promuevan la participación ciudadana y el ejercicio de la libertad y solidaridad entre los seres humanos. ${ }^{140}$

En cuanto al derecho y a la legislación financieros tradicionalmente han sido ubicados por la mayoría de los estudiosos de su objeto -la actividad financiera pública o de hacienda pública- en el campo del derecho público, pues sostienen que aquella se refiere específicamente a los ingresos y gastos del Estado para el cumplimiento de su finalidad de servicio público.

En cambio, otros autores, como Néstor Martínez Neira, en su obra sobre Sistemas Financieros, dice que el derecho financiero no es sólo el derecho de las finanzas públicas sino "el conjunto de principios y normas que gobiernan la formación, el funcionamiento, la actividad y la liquidación ordenada de las instituciones que tienen por objeto la captación, el manejo, el aprovechamiento y la inversión de fondos provenientes del ahorro del público, así como el ofrecimiento de servicios auxiliares del

\footnotetext{
139 Jaime Rodríguez Arana, Aproximación al Derecho administrativo constitucional, (México: Editorial Liber Juris Novum, 2011).

140 Jaime Rodríguez-Arana Muñoz, El derecho a la buena administración en las relaciones entre ciudadanos y administración pública, en Aportes para un Estado eficiente, ponencias del V Congreso Nacional de Derecho Administrativo, (Lima: Palestra Editores, 2012).
} 
crédito". ${ }^{141}$ Esto es, sería también el derecho que norma la vida y actividad de las instituciones financieras, sean estas públicas o privadas. No se trata, dice, del derecho bancario que seguiría ubicado en el campo del derecho privado, en cuanto se refiera fundamentalmente a su actividad relacionada con los contratos privados bancarios que son innegablemente contratos mercantiles.

Las dos posiciones se refieren a la actividad financiera pero desde diferente óptica. La primera desarrolla y norma la soberanía del Estado en el campo que le corresponde y la otra se refiere a la acción administrativa que ejerce el Estado en el control de las instituciones públicas, privadas y ahora también en las de la economía popular y solidaria, tanto en la captación de los recursos del público como en su intermediación con los ciudadanos que no los tienen.

Los criterios expuestos evidencian que las clasificaciones tradicionales del derecho no se ajustan a las relaciones jurídicas que regulan en la actualidad al derecho económico y financiero, concebido no solo como el que norma las finanzas públicas, sino también a las instituciones, actividades y productos financieros, que teniendo un origen privado, son ahora regulados y controlados por el Estado, puesto que la actividad financiera no es exclusiva del Estado, sino que constituye también una actividad de origen privado, que ha devenido en pública o semipública y que, por lo tanto, debe ser regulada y controlada por este, para defender y precautelar los intereses de la ciudadanía.

De tal manera compartimos la opinión, que por los nuevos contenidos y nuevas realidades que regula el derecho financiero en su totalidad, se ubica mejor en un campo más amplio, el del derecho económico relacionado con el interés público, por lo que resulta insuficiente el esfuerzo de reducirlo solamente al ámbito público o en el privado o de diferenciarlo artificialmente para tal efecto.

Estimamos pues que tanto el Derecho económico como el Derecho económico financiero y mucho más su legislación, tienen una naturaleza, objeto, sujetos, métodos, procedimientos y contenido que se diferencian de otras ramas del derecho, según lo establecen los importantes aportes que ofrecen al respecto en nuestro medio, el profesor chileno Jorge Witker, que publicó en México en 1995 por primera vez su obra Introducción al Derecho económico ${ }^{142}$ y el profesor de la Facultad de Jurisprudencia de la Universidad Central y de la Universidad Andina en Ecuador, Marco Antonio Guzmán, en su obra Derecho económico ecuatoriano. ${ }^{143}$

La discusión forma parte de una polémica más amplia y de larga data que incluye el debate sobre el contenido y la ubicación en las ciencias jurídicas de las disciplinas:

\footnotetext{
${ }^{141}$ Néstor Martínez Neira, Sistemas financieros, fundamentos jurídicos y económicos para la iniciación de su estudio en América Latina, (Bogotá: Biblioteca Felaban, 1994), 3.

${ }^{142}$ Jorge Witker, Introducción al Derecho Económico, (México: Tercera edición, Ediciones Harla, 1995).

${ }^{143}$ Marco Antonio Guzmán, Derecho Económico Ecuatoriano, Tomos I y II, (Quito: Universidad Andina Simón Bolívar y Corporación Editora Nacional, 1996).
} 
derecho financiero o derecho de la hacienda pública, o derecho financiero público o derecho financiero administrativo y derecho financiero privado o derecho bancario o derecho estatutario financiero.

Mauricio A. Plazas Vega dice que la denominación tiene que ver con la identificación del aspecto jurídico de la actividad financiera pública y si sus contenidos y principios la erigen en una rama autónoma e independiente del derecho o si se la considera una simple subespecialidad del derecho administrativo.

Manifiesta que los más destacados tratadistas sobre la materia prefieren el nombre de derecho financiero, siguiendo la síntesis que al respecto hace Fernando Sainz de Bujanda en su obra Hacienda y derecho, quien argumentó que si la gestión estatal, para captar y asignar recursos en el cumplimiento de sus fines, se conoce como actividad financiera, no se requiere mayor esfuerzo para concluir que la disciplina jurídica que la regula debe denominarse derecho financiero, ya que la palabra financiero, en el Diccionario de la Lengua, es lo pertinente o relativo a la hacienda pública, si bien reconoce que la expresión alude también al conjunto de normas que regulan los mecanismos de financiación del sector privado o cuasi privado, como ocurre con el derecho bursátil o el derecho bancario. ${ }^{144}$

Plazas prefiere el uso de "derecho de la hacienda pública", pues dice que la denominación "derecho financiero" se refiere en su uso preferentemente a la actividad financiera del sector privado y semiprivado, reconociendo que para su país sería más apropiado hablar de "derecho financiero público" y de "derecho financiero privado" si bien dicha distinción "deja enormes vacíos y es, en exceso, relativa". ${ }^{145}$

La obra actualizada de Carlos Giuliani Fonrouge se pronuncia por el uso de la denominación "Derecho financiero" para referirse a la disciplina jurídica que tiene como finalidad estudiar el aspecto jurídico de la actividad financiera del Estado en sus diversas manifestaciones y, dice que, tanto por su naturaleza y contenido como por su objeto, constituye parte integrante del derecho público. ${ }^{146}$

Los autores antes indicados reconocen también que en los últimos años la acentuación de los elementos económicos y sociales en el derecho han relativizado la división clásica entre derecho público y privado, por una especie de simbiosis que permite que ambos aspectos se hallen interpenetrados, generalmente en detrimento de lo privado, dándose lo que se ha denominado la "publicitación del derecho"; sin embargo, manifiestan que si bien los particulares también desarrollan actividad financiera, ella es distinta de la estatal, cualitativa y cuantitativamente, por lo que no podría el derecho

\footnotetext{
${ }^{144}$ Fernando Sáinz de Bujanda, Hacienda y derecho, volumen I, (Madrid: Instituto de Estudios Políticos, 1975).

${ }^{145}$ Mauricio Plazas Vega, Derecho de la hacienda pública y derecho tributario, (Bogotá: Editorial Temis, 2000).

${ }^{146}$ Carlos Giuliani Fonrouge, Derecho Financiero volumen II, actualizada por Susana Navarrine, Rubén Asorey, (Buenos Aires: Ediciones Depalma, 2001).
} 
financiero referirse únicamente a las finanzas privadas de los bancos, sociedades anónimas y consorcios internacionales.

Héctor Villegas argumenta que debe usarse la denominación Derecho financiero que es la más difundida para referirse al conjunto de normas jurídicas que regulan la actividad financiera del Estado, si bien sería más preciso y correcto hablar de Derecho de la hacienda pública pues "el vocablo financiero presenta alguna ambigüedad, puesto que se puede emplear correctamente para aludir a operaciones bancarias, bursátiles y negociables".

El tratadista argentino reconoce que las distintas definiciones que proporcionan los que defienden el concepto de derecho financiero, referido a esa actividad estatal, han ido ampliando sus miras hasta lograr la definición que da Sainz de Bujanda, ya avanzado el siglo XX, como "la disciplina que tiene por objeto el estudio sistemático de las normas que regulan los recursos económicos que el Estado y los demás entes públicos pueden emplear para el cumplimiento de sus fines, así como el procedimiento jurídico de percepción de ingresos y de ordenación de gastos y pagos que se destinan al cumplimiento de los servicios públicos", en la que se advierte que existe un esfuerzo conceptual que va más allá de abarcar únicamente en su contenido la actividad financiera estatal, pues cubre a una más amplia noción de aquella ya que alcanzaría a los "servicios públicos", noción que en la actualidad puede incluir a actores privados concesionarios de ellos que realizan actividades que son considerados como tales. ${ }^{147}$

Para Juan Gorospe, el derecho financiero es la "rama del derecho público interno que organiza los recursos constitutivos de la Hacienda del Estado y de las restantes entidades públicas, territoriales e institucionales, y regula los procedimientos de percepción de los ingresos y de ordenación de los gastos y pagos que tales sujetos destinan al cumplimiento de sus fines". ${ }^{148}$

En el derecho colombiano se usa la denominación "derecho de la hacienda pública" para referirse a la actividad financiera estatal que en otros países usa la denominación genérica de derecho financiero y esta última denominación para referirse a la actividad financiera que realizan los bancos y el mercado de valores.

En Ecuador, Eduardo Riofrío Villagómez sustentó inicialmente la denominación de derecho de la hacienda pública, pero más adelante, influenciado por la doctrina y los tratadistas internacionales más connotados de la materia, denomina "derecho financiero" para referirse exclusivamente a la actividad financiera pública. En nuestro medio, estudios de derecho bancario existen muy pocos y la mayor parte de ellos están enfocados a la actividad contractual privada, si bien en las últimas dos décadas se ha usado de manera ambigua el calificativo financiero para referirse tanto a la actividad

\footnotetext{
${ }^{147}$ Héctor Villegas, Manual de finanzas públicas, (Buenos Aires: Ediciones de Palma, 2001).

${ }^{148}$ Juan Ignacio Gorospe Oviedo, Derecho Financiero y Tributario, (Madrid: Dykinson, 2010).
} 
pública como a la privada, pero en especial a la que se encuentra regulada y controlada por el Estado.

La realidad actual del mundo de la economía capitalista globalizada fundamenta esta necesidad de que el Derecho económico financiero no solo regule la actividad financiera del Estado sino también a aquella actividad financiera privada internacional y nacional que involucra los intereses de la colectividad y que convierte a ciertas instituciones y productos del mercado financiero en públicos o semipúblicos.

En el ámbito público, el tratadista argentino Héctor Villegas cuestiona que el derecho financiero o de la hacienda pública tenga autonomía científica, puesto que se refiere a áreas heterogéneas y disímiles que no permiten un ordenamiento jurídico independiente y autónomo, pero argumenta que, en cambio, sí se justifica su autonomía didáctica, puesto que se puede estudiar en forma separada con fines académicos. Los tributaristas latinoamericanos apoyan esa concepción para argumentar que más bien el derecho tributario posee autonomía científica frente al financiero, mientras que otros tratadistas como Vanoni, Sainz de Bujanda, Calvo Ortega, Gabriel Casado, Simón Acosta, Nicola D’Amati, Benvenutto Griziotti y Carlos Giuliani defienden, con diferentes variantes, la autonomía científica del derecho financiero entendido este como derecho de las finanzas públicas.

Carlos Giuliani, con mayor precisión al respecto, dice que el desarrollo del derecho financiero público, después de la Primera Guerra Mundial, ha suscitado discrepancias sobre su naturaleza y alcances, habiéndose conformado al respecto tres corrientes doctrinales: "una totalmente adversa a su erección en disciplina autónoma; otra en el sentido de reconocer independencia a un sector de aquella y la última a favor de la autonomía completa".

La primera corriente manifiesta corresponde a la escuela administrativa clásica que considera a la actividad financiera estatal como un capítulo o parte especializada del derecho administrativo; la segunda, orientada por la doctrina alemana, suiza y francesa, en la que se inscribe la Primera Jornada Latinoamericana de Derecho tributario reunida en Montevideo en 1956, estima que solo la actividad financiera vinculada con la aplicación y recaudación de tributos, a la que se dedica el derecho tributario o fiscal, se puede considerar como disciplina jurídica independiente y la tercera plantea que el derecho financiero es una rama jurídica autónoma que dispone de principios generales propios, en conexión con las otras disciplinas del derecho (unidad del derecho) y que se refiere a "un conjunto de relaciones sociales" que demandan un ordenamiento especial.

El planteamiento último, esto es el que defiende la autonomía del derecho financiero, fue acogida en su tiempo por Grizziotti para quien este tiene mayor amplitud y dinamismo que el derecho tributario; por Sainz de Bujanda que argumenta su espacio autónomo radical, llegando al extremo de pretender desvincularlo también de la economía y la política, planteando la heterogeneidad de su contenido, con normas de 
naturaleza pública y privada que no le hacen perder unión sistemática, si bien restringe su objeto a la hacienda pública; por D’Amelio que enumera los principios constitucionales y doctrinarios que lo identifican y diferencian y por varios exponentes de la doctrina jurídica de Portugal y Brasil, entre otros. ${ }^{149}$

Sainz de Bujanda, en Hacienda y Derecho, afirma de manera radical que "es urgente que la teoría económica-financiera pueda desenvolverse con absoluta pureza, sin supeditarse al contenido de las normas jurídicas"; que resulta inaplazable "la necesidad de estudiar el derecho financiero despojándole de todos los elementos de naturaleza extrajurídica, económicos, contables, estadísticos, etc., que hasta ahora le han sometido a un verdadero proceso de asfixia" y que solo así se "podrán obtener nociones jurídicas limpias y escuetas que deberán confrontarse naturalmente con los resultados a que se llegue en la investigación de la teoría financiera, pero sin que nunca se confundan con ellos". 150

Si los economistas y los juristas se ocupan de diferente manera y con diferentes métodos de la hacienda pública como dice Mauricio Plazas, de igual manera deberían hacerlo con la actividad financiera pública y la privada y en especial con aquella que tiene connotaciones públicas. Creemos que un enfoque científico verdadero no puede deslindar los estudios jurídicos de la realidad económica, social y política y que la pureza de la ciencia no puede atentar contra una realidad objetiva que contiene diversos elementos económicos, sociales y políticos que se complementan e interrelacionan.

Por otro lado, como lo señala Plazas, la autonomía de una rama jurídica que proviene de un tronco común y que puede originar otras subdivisiones, no contradice la idea del derecho como un todo orgánico e integral pues "la unidad del derecho no se niega sino que se afirma al subdividirlo en ramas interdependientes, ninguna de las cuales puede apartarse de la máxima incontestable e imperecedera: uno universe iure". ${ }^{151}$

En cuanto a las ramas en las que se subdivide el derecho y la legislación económica y financiera, Giuliane Fonrouge, dice que éstas, en lo relacionado con el derecho de la hacienda pública, tienen que ver con el aspecto jurídico de las erogaciones para satisfacer las necesidades generales, que se encuentran comprendidos en el derecho presupuestario, en el régimen jurídico de las inversiones y en el de su control. También trata, manifiesta el autor, sobre la administración del patrimonio del Estado que incluye el régimen de los servicios públicos y de las empresas estatales o con participación oficial. Singular importancia asigna en aquel, la aplicación y recaudación de tributos mediante el derecho tributario o fiscal, que se ha convertido en rama o en disciplina autónoma del derecho financiero, con una intensa actividad doctrinal que eclipsa a otros aspectos de la actividad financiera, como son el crédito público y el derecho monetario

\footnotetext{
${ }^{149}$ Carlos Giuliani Fonrouge, Derecho Financiero volumen II, actualizada por Susana Navarrine, Rubén Asorey, (Buenos Aires: Ediciones Depalma, 2001).

${ }^{150}$ Fernando Sáinz de Bujanda, Hacienda y derecho, volumen II, (Madrid: Instituto de Estudios Políticos, 1962), 121 y 122.

${ }^{151}$ Mauricio Plazas Vega, Derecho de la hacienda pública y derecho tributario, (Bogotá: Editorial Temis, 2000), 258 .
} 
constituidos por un conjunto de normas económicas y jurídicas relacionadas, tanto para los empréstitos internacionales como para la moneda como instrumento de valor y de cambio.

Grizzioti, citado por el autor antes indicado, consideraba disciplinas complementarias e integrantes del derecho financiero público en general: al derecho financiero constitucional, al derecho financiero administrativo, al derecho financiero procesal, al derecho financiero penal, al derecho financiero procesal penal, al derecho financiero internacional y a la filosofía del derecho financiero.

Sainz de Bujanda, según Giuliani, descompone el contenido del derecho financiero público en dos partes; una referida a la constitución u organización de la hacienda que incluye los ingresos públicos (prestaciones tributarias, ingresos monopolísticos, productos de la deuda pública y rendimientos patrimoniales) y las obligaciones de contenido económico que no pertenecen al derecho privado y la otra relativa a sus procedimientos de gestión o administración que sería la parte dinámica de la hacienda. Para este autor son ramas de esta parte del derecho financiero: el derecho tributario, el derecho del patrimonio público, el derecho de la deuda pública, el derecho presupuestario y el derecho de la contabilidad pública. ${ }^{152}$

Calvo Ortega y Simón Acosta cuestionan además que los ingresos patrimoniales, la actividad mercantil e industrial, sanciones pecuniarias y las normas sobre la circulación fiduciaria y acuñación de la moneda formen parte del derecho financiero, ya que su gestión no tiene como fin propio y esencial la obtención de recursos dinerarios. Por su parte, otros autores opinan que esos sectores "de la realidad del Estado deben ser estudiados por el derecho financiero, pues gozan de la nota de instrumentalidad inherente a toda actividad financiera, sin perjuicio de su posible estudio desde otras perspectivas". En la doctrina alemana Klaus Tipke, citado por Sainz de Bujanda y Giuliani, se entiende que el derecho financiero público comprende principalmente el derecho tributario, el derecho presupuestario y el derecho patrimonial público y de la deuda pública. ${ }^{153}$

Plazas Vega, a su vez, luego de definir el derecho de hacienda pública como el "conjunto de normas jurídicas que regulan la actividad financiera del Estado", dice que dada la diversidad de aspectos que involucra la gestión estatal en materia financiera se pueden distinguir subespecialidades que se integran unas con otras, entre las cuales se encuentran: el derecho presupuestario; el derecho monetario, el derecho tributario, el derecho de la deuda pública, el derecho cambiario y el derecho del gasto público. ${ }^{154}$

\footnotetext{
${ }^{152}$ Carlos Giuliani Fonrouge, Derecho Financiero volumen II, actualizada por Susana Navarrine, Rubén Asorey, (Buenos Aires: Ediciones Depalma, 2001).

${ }^{153}$ Ibídem, 41 y 42.

${ }^{154}$ Mauricio Plazas Vega, Derecho de la hacienda pública y derecho tributario, (Bogotá: Editorial Temis, 2000).
} 
Héctor Villegas, hablando del contenido del derecho financiero público, le da una especial importancia a sus fundamentos constitucionales, que algunos denominan Derecho financiero constitucional, así como a los tratados y convenios internacionales y lo estructura haciendo referencia a las leyes que regulan los más importantes regímenes jurídicos prácticos de la actividad financiera estatal. Distingue el régimen legal de los gastos públicos, en el que se incluye la legislación de la administración financiera del proceso presupuestario, control interno y externo de los dineros públicos y el régimen legal de los recursos públicos, tanto el de aquellos que se estima recaudar provenientes de créditos públicos y donaciones y otros, más el de los tributos propiamente dichos en su parte general y especial. ${ }^{155}$

Fernando Pérez Royo ${ }^{156}$ y Luis María Cazorla ${ }^{157}$ plantean que el contenido de la actividad financiera pública comprende: los ingresos públicos y los gastos públicos y su control. Los primeros pueden ser: tributarios; los del crédito como la deuda y otras operaciones; los patrimoniales que provienen de bienes o acciones de empresas públicas o privadas; los no tributarios que se originan en precios públicos y los de categoría impropia de multas y sanciones. Los gastos públicos involucran los mecanismos o procedimientos formales que gobiernan la asignación, desembolso y el control del empleo de los recursos públicos (derecho presupuestario y normas de control).

Para los efectos de esta investigación es necesario precisar que este estudio de derecho administrativo y financiero económicos, se refiere exclusivamente al derecho de la planificación y de las finanzas públicas incluyendo el control, ubicados en el ámbito del derecho público y de la actividad de la hacienda contemporánea o posmoderna, en la que se incluyen no solo los ingresos y gasto públicos sino también las actividades de previsión y financiamiento de las actividades públicas, como la planificación y el control de la eficiencia y eficacia en el uso de los recursos públicos, dejando para otro momento el estudio de otras áreas del derecho financiero público como las relativas al crédito, los ingresos patrimoniales y el régimen interno de las instituciones financieras privadas o las de la economía social y solidaria, que encontrándose inicialmente dentro de la órbita privada, actualmente son también autorizadas y reguladas por el Estado y la administración pública.

Para entender críticamente la actividad financiera pública y el contenido principal del derecho económico financiero en la actualidad y que están regulados y controlados por el Estado y la comunidad internacional, se requiere, ahora más que nunca, estudiar el contexto social, político, económico, convencional y constitucional que los condiciona y los interrelaciona.

\footnotetext{
${ }^{155}$ Héctor Villegas, Manual de finanzas públicas, (Buenos Aires: Ediciones de Palma, 2001).

156 Fernando Pérez Royo, Derecho financiero y Tributario, parte general, (Madrid: Editorial Civitas, 1999).

157 Luis María Cazorla Prieto, Derecho Financiero y Tributario, Parte General, (Navarra: Editorial Aranzadi, 2001).
} 
En definitiva, nosotros sostenemos que el Derecho y la legislación económicos, en el ámbito administrativo y financiero, tienen un contenido, método, principios e instituciones jurídicas que se diferencian de los de otras ramas del derecho. Su heterogeneidad de contenido, en el que existen elementos comunes, no es argumento válido para negar su autonomía, que en las ciencias jurídicas siempre es relativa, ya que ello ocurre también con el derecho público, el derecho privado y sus diferentes ramas.

Así mismo, en lo que se conoce como posmodernidad, con el avance de las ciencias jurídicas que han permitido la identificación de nuevo tronco del derecho, el derecho económico, superando los límites del derecho público y privado, el derecho administrativo y el financiero económicos, encuentran espacios pertinentes en aquel, puesto que su objeto es la actividad administrativa y financiera económica, entendida esta no solo como aquella que lleva adelante el Estado, sino también los delegatarios y concesionarios y las entidades privadas que ejerzan función administrativa, financiera y de la economía popular y solidaria, en cuya organización, control y productos principales interviene el poder público, por tratarse de servicios públicos o semipúblicos, propios o impropios y que, en todo caso, tienen relación con el interés general y no solo con el particular.

Para nosotros, el derecho administrativo y financiero económicos y su legislación tienen sus principios, instituciones y métodos que diferencian de otras ramas jurídicas y si bien su objeto es diverso, tienen identidades generales sobre la obtención y asignación y gasto de los recursos públicos y aquellos que provienen del ahorro de la colectividad y su colocación en la sociedad, procesos que deben ser y se encuentran ya, en su mayoría, tutelados por el Estado de manera especial.

Partiendo de la interrelación histórica que existe, desde sus orígenes, entre el derecho constitucional, el administrativo y el financiero público o de la hacienda pública, ${ }^{158}$ cuya autonomía científica ha sido motivo de la larga controversia a la que hemos hecho referencia, encontramos adicionalmente un punto de confluencia parcial de éstas dos disciplinas en lo que denominamos derecho de control y de la responsabilidad, pues sus categorías principales forman parte, con las correspondientes connotaciones, tanto del derecho administrativo económico como del derecho financiero público y, obviamente, del derecho administrativo en general.

En el derecho administrativo económico, la planificación, el control y la responsabilidad nos remiten a todas las actividades, procedimientos y recursos que se encuentran a disposición de las administraciones públicas y de los ciudadanos en el ejercicio de sus derechos de participación, mientras que en el derecho financiero se limita a los fenómenos que involucran a la actividad financiera propiamente tal, relacionada exclusivamente con la obtención y la utilización de los ingresos y los gastos del Estado,

\footnotetext{
158 Andrea Amatucci, La enseñanza del derecho financiero en Italia y España, Quito, FORO Revista de Derecho $\mathrm{N}^{\circ}$ 1, UASB-CEN, 2003.
} 
que constan en los ingresos y el presupuesto general y en los diferentes presupuestos e instrumentos financieros de otras entidades públicas o de aquellas que reciben recursos públicos.

Entendemos que el derecho de los ingresos públicos (tributarios, patrimoniales, de deuda o crédito), el derecho de los egresos o gastos y presupuesto, de la planificación y del control y responsabilidades de los recursos públicos, como disciplinas, con una inicial autonomía académica dadas las categorías e instituciones jurídicas propias con las que cuentan, son una especialidad dentro del derecho administrativo económico y del financiero y del derecho administrativo en general, pues regulan, según nuestro entender, el régimen actual de las finanzas y la hacienda públicas y sobre la vigilancia y acciones que realizan ciertos órganos competentes del poder público, en cuanto a la legalidad, transparencia, honestidad, eficiencia y eficacia en el uso de los bienes y recursos públicos propios o impropios para, luego de ello, establecer las responsabilidades del Estado y sus instituciones, las de los funcionarios y de quienes ejercen función administrativa tanto en el cumplimiento de sus obligaciones y en el desempeño de sus competencias como frente a las denuncias, demandas y reclamaciones de los ciudadanos.

No hay duda también que en el Estado contemporáneo, las actividades de limitación y control jurídicos se extienden también al ámbito privado y en especial al de los servicios y productos destinados al beneficio de la colectividad, de los usuarios y consumidores, pues se trata de una "forma de intervención pública por excelencia" y por lo tanto de una actividad administrativa que tiene finalidades "predominantemente preventivas" en el manejo de la información y luego con "tintes represivos", cuando el Estado asume su "potestad sancionadora" como lo plantean los profesores Rivero Ortega y Nieto García.

Esto es, las actividades del control jurídico estatal o público no solo se refieren a los diferentes momentos y circunstancias de la múltiple actividad de las administraciones públicas, ad intra o ad extra, sino también a las actividades y operaciones ex ante y ex post de otros actores colectivos, empresariales o individuales, que ofrecen servicios y productos masivos, también de interés colectivo o que se ejecutan con recursos del público, que requieren del Estado el ejercicio de su potestad normativa y de control, sea por la vía regulatoria, autorizatoria o por medio de la declaración responsable, para que tanto los servicios públicos como los que ofrecen a la colectividad los actores privados se los realice en las condiciones óptimas de eficiencia, eficacia y economía. ${ }^{159}$

Amplia y multifacética es la actividad financiera pública en la actualidad. No obstante, en este estudio, nos limitaremos a analizar, en el contexto de la globalización y de las normas constitucionales económicas y financieras vigentes en los últimos 27 años

\footnotetext{
${ }^{159}$ Ricardo Rivero Ortega, "La necesaria innovación de los medios de control administrativo" en Nuevas formas de control de las administraciones públicas y su repercusión sobre consumidores y usuarios, Enrique Rivero Ysern y María Dolores Calvo Sánchez, coordinadores, Salamanca, Ratio Legis, 2013; Alejandro Nieto García, Derecho administrativo sancionador, (Madrid: Tecnos, 2009).
} 
(constitución económica y financiera), las modificaciones o la mantención de las normas del derecho en los asuntos específicos que ya hemos apuntado, si bien la dimensión general de la actividad de control jurídico del poder público cubre muchos otros ámbitos de interés para el derecho administrativo y para los ciudadanos y la colectividad, especialmente en la esfera de los servicios públicos propios e impropios y el de los usuarios, productores y consumidores en general.

Es preciso advertir que la Administración y la hacienda pública clásica, regidas por el derecho administrativo y el financiero, eran controladas por el Congreso o Parlamento, que tenía un papel trascendental, desde el origen de los estados modernos, en la aprobación y control del personal, la actividad administrativa y los ingresos, gastos del presupuesto y del endeudamiento. Esta labor política y técnica se trasladó paulatinamente por la Constitución y las leyes a órganos especializados públicos externos a la Administración, como lo son el Tribunal de Cuentas o la Contraloría, que inicialmente eran considerados instrumentos auxiliares del Parlamento y que luego han ido cobrando, dependiendo de las distintas tradiciones jurídicas en los diferentes países del mundo, una mayor o relativa independencia y autonomía, hasta convertirse, en algunos casos como en Ecuador, en órganos de una función independiente del Estado: la Función de Transparencia y Control.

La hacienda moderna y la contemporánea o posmoderna (en las que se incluyen técnicas empresariales, contables y financieras) incorporan a los órganos de la Administración pública y a los de control, actividades e iniciativas de planificación, ejecución y vigilancia interna y externa sobre el cumplimiento de la ley y el control del uso eficiente y eficaz de los recursos públicos durante la gestión y la realización de las diferentes operaciones y actividades de las instituciones y sus funcionarios.

Además de ello, la gestión y el control financiero actual interno y externo deben agregar las operaciones de planificación y de formulación de metas y establecimiento de objetivos; las actividades de seguimiento y las correctivas, para optimizar el uso de los recursos y el cumplimiento de aquellos, tomando en consideración el contexto político y social en el que se realiza la actividad económica-administrativa y financiera, que se encuentra regulada por los organismos internacionales, regionales y locales conforme a los modelos y al sistema económico imperantes.

La actividad económica administrativa y financiera pública tiene que ver pues, en la actualidad, con el establecimiento y alcance de los índices y agregados macroeconómicos; la contabilidad nacional y la estabilidad económica y jurídica del país, que se definen mediante políticas públicas llamadas a garantizar la racionalidad y equilibrio del presupuesto del Estado y el eficaz y eficiente uso de todos los recursos públicos para satisfacer las demandas y los derechos de los ciudadanos. Por tanto en las normas convencionales constitucionales y administrativas, a las máximas autoridades financieras del Ejecutivo se les otorgan potestades cada vez más amplias en la planificación, en la asignación de recursos y en el control interno sobre el presupuesto, 
el endeudamiento y el equilibrio fiscal, sin desconocer la potestad de control externo, que sobre estos importantes asuntos tienen y deben ejercer los órganos correspondientes y los ciudadanos, para estimar y analizar sus consecuencias en el ámbito técnico económico y financiero y en el ejercicio de derechos.

Coincidimos con los profesores peruanos Kresalja y Ochoa que todos los acontecimientos y las decisiones antes indicadas como resultado de la globalización han generado en la práctica un "constitucionalismo global" para atender las necesidades básicas, el multiculturalismo, la ecología, la democracia y los derechos humanos. ${ }^{160}$ Pero, a la vez, habría que agregar que ese "constitucionalismo global", como resultado de la crisis, tiene una especial dimensión económica-financiera que se expresa en las decisiones internacionales de las Naciones Unidas, de los organismos multilaterales financieros y en otras instancias de coordinación económica que han sido trasladadas a las normas de constitución económica financiera de todos los países del mundo y que en especial inciden en la hacienda pública, que es la encargada de hacer efectivas las regulaciones globales, las obligaciones de los ciudadanos y la satisfacción de sus derechos.

El derecho administrativo económico y el financiero, fundamentados en las normas de la Constitución económica pertinentes, constituyen las disciplinas y enfoque que nos confieren el sustento teórico y jurídico para la comprensión cabal de cómo operan las categorías fundamentales y los límites y alcances con los que se regulan la planificación, las finanzas públicas y el control externo e interno sobre el ingreso, uso, gestión y resultados de los recursos públicos de los que dispone el Estado y sus órganos para el cumplimiento de sus fines y la satisfacción efectiva de los derechos económicos, sociales, políticos y culturales de los ciudadanos.

${ }^{160}$ Baldo Kresalja y César Ochoa, Derecho constitucional económico, (Lima: Fondo editorial de la Universidad Católica del Perú, 2009). 


\section{CAPITULO II: LA CONSTITUCIÓN ECONÓMICA-FINANCIERA Y LOS MODELOS ECONÓMICOS Y POLÍTICOS EN ECUADOR (1990-2017)}

Las características propias de la globalización capitalista desde 1990 hasta la actualidad y las más sobresalientes de los modelos económicos y políticos a los que hemos hecho referencia (que también se adoptaron en Ecuador) explican en buena parte su incidencia en el contenido económico y financiero de las cartas políticas, de sus reformas y de la legislación secundaria financiera y administrativa expedidas en el período de 1990 a 2017.

En la década del 90 del siglo pasado se introdujeron las modificaciones estructurales neoliberales sugeridas por el FMI y el Banco Mundial sobre las reformas del Estado, la planificación, las finanzas públicas y los diferentes tipos de control de los recursos públicos, tanto en las normas constitucionales como en las legales.

Posteriormente, a fines del siglo anterior y a inicios del actual, frente a los resultados sociales y económicos críticos del neoliberalismo, los organismos financieros internacionales cambiaron su orientación e incorporaron en sus propuestas una nueva participación activa del Estado y de los gobiernos en la actividad económica. De igual modo definieron políticas públicas que se negociaron con actores económicos internacionales y nacionales para involucrar de manera activa al sector público en las actividades económicas y en los servicios públicos del país. Estos cambios, expresados en la instauración de un modelo neointervencionista o neodesarrollista, se hicieron presentes desde el Gobierno de Alfredo Palacio (2005-2006) y, especialmente, en el Gobierno del presidente Rafael Correa (2007-2017), con la expedición de la Constitución de 2008 y sus reformas y enmiendas, los planes de desarrollo y la vigencia de códigos y normas sobre las materias que se indican inicialmente.

Nos referiremos, por tanto, luego de una exposición conceptual e histórica sobre el contenido económico y financiero de las constituciones del Ecuador hasta 1990, al de las constituciones y sus reformas del período 1990 - 2006, en los que primó el modelo económico y político neoliberal y al de la Constitución y sus reformas entre 2007-2017, en el que se ensayó un modelo neointervencionista, neoestructural o neodesarrollista, en el que, además de sus características propias, se mantuvieron ciertos aspectos del modelo anterior para articular al país de manera más eficiente al sistema capitalista mundial.

\section{LA CONSTITUCIÓN ECONÓMICA Y EL CONTENIDO ECONÓMICO Y FINANCIERO DE LA CONSTITUCIÓN}

La relación entre la economía y el derecho es notoriamente reconocida en todas las etapas de la historia. Y si bien "la anatomía de la sociedad civil hay que buscarla en la economía política" y "las relaciones jurídicas como las formas de Estado no pueden 
comprenderse por sí mismas", ${ }^{161}$ se ha cuestionado la pertinencia de las interpretaciones reduccionistas, según las cuales la superestructura jurídica y política, en los diversos modos de producción y en las formaciones económicas y sociales, se concibe como un simple reflejo mecánico de las relaciones económicas de la sociedad.

Coincidimos con quienes han observado que la relación entre la infraestructura y la superestructura es dialéctica y que hay que diferenciar entre la relación "determinante en última instancia" y la "dominante" 162 , tanto en un modo de producción como en una formación económica y social, pues es evidente también, que en varias ocasiones históricas ciertas modificaciones políticas y jurídicas han promovido o acelerado cambios importantes en la economía y en la sociedad. Sin embargo, las transformaciones fundamentales en esta, dentro del sistema capitalista, jamás han sido resultado de iniciales cambios radicales en las leyes y en la Constitución, pues por lo general, las modificaciones han estado precedidas por transformaciones objetivas en la economía mundial, cada vez más interdependientes y globalizadas, y en las estructuras e intereses internos de las fuerzas económicas, sociales y políticas dominantes.

En el caso ecuatoriano se puede observar, como lo han hecho varios autores, ${ }^{163}$ que las modificaciones económicas mundiales y locales han precedido a los cambios constitucionales y legales, como ocurrió en 1929, 1968, 1978 y 1998, pues "han tenido efectos más bien de legitimación o consolidación de cambios económicos previos, antes que de efectiva directriz normativa de la vida económica nacional". ${ }^{164}$ Esta situación no la encontramos de manera absoluta en la Constitución de Ecuador de 2008, si bien en ella se recogen modificaciones intervencionistas sugeridas por los organismos internacionales desde inicios de siglo pero, además, se convierte en expresión, en cuanto a reconocimiento de derechos, de un "pacto social" implícito con ciertas reivindicaciones históricas de los pueblos dominados cuando se acepta la preexistencia y coexistencia de diversas formas de organización económica y entre ellas, de manera destacada, la economía comunitaria y popular y solidaria. ${ }^{165}$

Este enfoque de la Constitución vigente (2008) no constituye tampoco el resultado de una transformación social y económica previa o necesariamente en curso, sino una constatación de la realidad y la formulación de un proyecto eminentemente políticojurídico, con una gran dosis ideológica y discursiva, con un tímido intento de introducir reformas al statu quo y la formulación ambigua de la construcción de una alternativa económica y social al neoliberalismo imperante, que se convirtió finalmente en la

\footnotetext{
${ }^{161}$ Carlos Marx, Prólogo de la Contribución a la Crítica de la Economía Política, (Berlín: Erstes Helft, 1859).

${ }^{162}$ Marta Harnecker, El Capital: conceptos fundamentales del Materialismo Histórico, (México: Siglo XXI, 1971).

${ }^{163}$ Juan Paz y Mino y Carlos De la Torre, en Asamblea Constituyente y Economía, Quito, THE, 2007 y Agustín Grijalva, en Estado, Derecho y Economía, (Quito: UASB, 2013).

${ }^{164}$ Agustín Grijalva: "La Constitución Económica del Ecuador” en Estado, Derecho y Economía, (Quito: sede Ecuador y Corporación Editora Nacional, 2013).

${ }^{165}$ Ramiro Ávila, El neoconstitucionalismo andino, Universidad andina Simón Bolívar, Quito, 2016.
} 
justificación histórica de un inicial discurso progresista, promotor de cambios y de la necesidad de construir un supuesto socialismo del siglo XXI como el que formuló el presidente Correa y otros líderes latinoamericanos, pero que en los resultados de su gestión terminaron implementando algunas reformas destinadas a consolidar una mejor articulación del país al sistema económico capitalista mundial. Los sectores progresistas y de izquierda que incidieron en el proyecto de Alianza País no abordaron en el texto constitucional los indispensables cambios estructurales e institucionales para compaginar el amplio reconocimiento de derechos, con significativas transformaciones institucionales que pudieran superar la tradicional exclusión y la marginación de la mayoría social. ${ }^{166}$

Las constituciones, como instrumento jurídico fundamental para la organización política, económica y social de los estados modernos, contienen una parte dogmática en la que constan los derechos y las libertades fundamentales como valores universales de la humanidad y que corresponden al ius cogens, y la parte orgánica institucional y territorial de los poderes y órganos del Estado que se pueden separar, como lo manifiesta Ricardo Rivero, de manera vertical (Administración central, gobiernos autónomos descentralizados y entes locales) u horizontal en funciones del Estado y órganos autónomos, siguiendo lo que tradicionalmente se considera el "contenido mínimo" de toda Constitución, conforme al Art. 16 de la Declaración de Derechos del Hombre y el ciudadano de 1789: "Toda sociedad en la cual la garantía de derechos no esté asegurada ni determinada la separación de poderes, no tiene constitución”. ${ }^{167}$

A lo largo de la historia las Constituciones han ido incorporando a sus contenidos esenciales nuevos elementos e instituciones jurídicas que corresponden tanto a la complejidad de las sociedades y del sistema económico mundial, del ordenamiento internacional y de la creciente identificación de bienes públicos comunes, como a la renovada función reguladora e interventora del Estado. De allí que se hable de Constitución económica, Constitución fiscal o financiera, Constitución ambiental, etc.

Para nosotros, siguiendo a Giannini, el derecho financiero público o de la Hacienda pública tiene siempre una doble dimensión: constitucional que fundamenta sus instituciones (tributarias, crediticias, presupuestarias y del gasto) y administrativa, en la ejecución de la actividad financiera-fiscal, de planificación y control. ${ }^{168}$

Por ello, más allá de la discusión de la existencia o no de un derecho constitucional económico, de un derecho constitucional financiero o de un derecho constitucional del gasto o presupuestario, como disciplinas jurídicas específicas relativas a un estudio sistemático sobre los principios, normas y contenidos económicos y financieros de las

\footnotetext{
${ }^{166}$ Roberto Gargarella, Pensando sobre la Reforma Constitucional en América Latina, en El Derecho de América Latina, Coord. César Rodríguez Garavito (Buenos Aires: Siglo Veintiuno Editores, 2011).

${ }^{167}$ Ricardo Rivero Ortega, Derecho Administrativo Económico, (Madrid: sexta edición Marcial Pons, 2013).

${ }^{168}$ Achille Doanto Gianini, Instituciones de Derecho Tributario. Traducción y estudio preliminar de Sainz de Bujanda, Madrid: Giuffre Editores, 1957
} 
constituciones, es indiscutible que en ellas existe siempre dicho contenido, ya sea de manera implícita o poco desarrollada, como ocurre en el primer momento de la vida republicana de los países latinoamericanos, o de manera explícita y más desarrollada, después del establecimiento en estos del Estado social de derecho y mucho más, con el advenimiento del neoliberalismo primero para desmantelar su intervencionismo económico y del neodesarrollismo o neokeynesianismo posteriormente hasta nuestros días, para justificar un nuevo protagonismo del Estado como interventor o regulador de la economía. En todo caso, las diferentes formulaciones son expresión de un pacto o de una hegemonía social que se manifiesta en cada etapa de la historia.

$\mathrm{Si}$ bien a nivel internacional se reconoce que las primeras constituciones que incorporaron en su texto normas relativas a los derechos económicos y sociales y al sistema económico son la de Querétaro en 1917 y la Weimar en 1919, la noción de Constitución económica, para referirse expresamente al conjunto de normas y principios que regulan los derechos económicos de los ciudadanos y la estructura y la actividad económica del Estado, surge en el ámbito europeo en países como Alemania, Italia y España, en dónde se la conceptuó de la manera antes indicada conforme consta en una sentencia del Tribunal Constitucional español de 22 de enero de 1982. ${ }^{169}$

Algunos autores, siguiendo la doctrina europea, han denominado de manera general y más amplia a todos los contenidos económicos de la Constitución como "Constitución Económica". ${ }^{170}$ Esta denominación podría dar la impresión de que se refiere a un texto diferente al que todos identificamos en su totalidad, pero en realidad se trata de una reflexión sistemática o más detenida sobre los aspectos económicos principales de la carta política, que han cobrado mucha más importancia en la fase de intervención y regulación del Estado, en la actividad económica y financiera del país y en las relaciones que surgen a propósito de ellas, entre el Estado, los ciudadanos y diversos sectores y actores sociales de la economía nacional.

Si bien el concepto jurídico, en la dogmática alemana y europea, tiene connotaciones especiales, desde sus raíces ordoliberales hasta los efectos regionales producidos por el Tratado de Lisboa y los problemas desatados en la actual crisis del sistema, ${ }^{171}$ nosotros utilizaremos el término Constitución económica de manera amplia, para referirnos al conjunto de normas e instituciones jurídicas que, teniendo como fundamento un sistema económico, establecen un modelo o forma de funcionamiento de la economía en el que

\footnotetext{
${ }^{169}$ María Elena Jara, "Constitución Económica Ecuatoriana y Desarrollo, en Estado, Derecho y Justicia, Ramiro Ávila Santamaría, compilador, Universidad Andina Simón Bolívar - Corporación Editora Nacional, estudios jurídico 33, Quito, 2013.

${ }^{170}$ Julio César Trujillo, "La Constitución Económica más allá del neoliberalismo", Revista de Derecho Foro, Nro. 7, I semestre, Quito, UASB, 2007; Alfredo Mancero Samán, La Constitución Económica del Estado Ecuatoriano y las nuevas condiciones de la economía mundial, Quito, UASB y Fundación K. Adenauer, 1997; Manuel Arnaldo Castillo Calle, El Derecho Constitucional Económico, (Lima: CLDC, 2012).

${ }^{171}$ Luis Ignnacio Gordillo Pérez y José Ramón Canedo Arrillaga, "La constitución económica de la Unión Europea. Bases de un modelo en constante evolución", en Cuadernos de Derecho Transnacional (Marzo 2013), Vol.5, $\mathrm{N}^{\circ} 1$. ISSN 1989-4570 - www.uc3m.es/cdt
} 
se delimita la actividad estatal, de los individuos y de los grupos sociales, dentro del orden económico establecido.

También varios autores coinciden con la existencia de una Constitución fiscal o financiera como una especificidad de la primera, pero en todo caso, enfatizan también que los dos conceptos, al estar íntimamente relacionados, no deben desligarse del contenido general de las garantías y derechos consignados en la totalidad de la Constitución política, pues las normas y los modelos económicos y las regulaciones financieras son tan solo instrumentos para garantizar los fines del Estado y satisfacer los derechos de los ciudadanos. ${ }^{172}$

La participación e intervención del Estado a partir de los años treinta del siglo XIX es un principio que cruza los diferentes modelos económicos dentro del sistema imperante, si bien difieren en la modalidad o papel que desempeña el Estado en la actividad económica en los respectivos momentos históricos, sea como protagonista y actor directo en el modelo intervencionista, o como patrocinador del libre mercado en el modelo neoliberal o como regulador, redistribuidor y planificador en el modelo neointervencionista o neodesarrollista.

Es necesario diferenciar entre sistema y modelo económico, ${ }^{173}$ aunque para algunos, ambos conceptos significan lo mismo. Tienen razón en la identidad terminológica si los dos se refieren a la forma en la que se pretende describir u organizar la economía nacional, pero en realidad, según nuestra visión, los dos asumen una connotación distinta: el modelo se refiere más bien a una forma simplificada de describir un momento o una política o doctrina que se adopta en el sistema económico para la consecución de determinados objetivos y propuestas, por ejemplo, los modelos liberal, estructuralista o intervencionista, neoliberal, neoestructuralista o neodesarrollista, etc. El sistema económico es, en cambio, una estructura compleja de diferentes modos y relaciones de producción, en las que una de ellas es la dominante y subordina a las otras en su racionalidad. Nos referimos, al sistema feudal, sistema capitalista, sistema socialista, etc.

Carlos de la Torre Muñoz manifiesta que una Constitución no debería "implantar" una definición de "modelo económico", puesto que dicho concepto además de no estar "bien entendido por los economistas y cientistas sociales locales, no corresponde de manera adecuada a una categorización de todo un universo de acciones prácticas que en materia económica se desarrollan en una nación", pues se trata de un "instrumento analítico de

\footnotetext{
${ }^{172}$ Álvaro Rodríguez Bereijó, La Constitución fiscal de España, (Madrid: Centro de Estudios Políticos y Constitucionales, 2015); Juan Cotarelo García, "El concepto de Constitución económica y su aplicación a la Constitución española de 1978" en El Sistema Económico en la Constitución Española, Ministerio de Justicia, Madrid, 1994; Enoch Alberti Rovira, "Criterios constitucionales de la intervención pública en la economía" en La Constitución económica, Asociación de Letrados del Tribunal Constitucional, Madrid, 2012.

${ }^{173}$ Gabriel Loza Tellería, Intervención sobre "El Modelo Económico Plural de Bolivia" en el Foro Andino Amazónico de Desarrollo Rural, La Paz, 18 de septiembre de 2013.
} 
simplificación estructurada de la realidad para el estudio o interpretación de una cierta fenomenología..."174

Para Oscar Olmedo Llanos, "el modelo económico como tal tiene que tener un sustento microeconómico y macroeconómico sintetizados por la teoría económica, punto de partida en la construcción de modelos que describen el comportamiento económico de las unidades individuales: consumidores, empresas, organismos oficiales..." El mismo autor nos trascribe la definición de Marc Guillaume: "un modelo económico representa un sistema compuesto por un conjunto de conceptos y de relaciones; estas últimas quedan especificadas por estimación; proporciona resultados que son a menudo previsiones y que pueden ser comparados con la realidad". ${ }^{175}$

En todo caso, al margen de la discusión académica observada, los términos modelos o sistemas económicos son formas o giros verbales que se adaptan a determinados intereses o para referirse de manera ambigua a fenómenos complejos de la realidad que se deben dilucidar. Con el uso de estos conceptos a los que se agregan calificativos como social y solidario, la nueva Constitución de Ecuador pretende identificar a una alternativa económica y social o encontrar una denominación acorde con el sistema económico y social imperante, en el que se introducen algunas variantes, precisamente para no sustituirlo.

A un mayor nivel de abstracción, en el ámbito económico y social, se diferencian entre los sistemas o formaciones económicas y sociales que existen en el mundo actual: el socialista o de economía centralmente planificado y el capitalista, o como lo distingue Jorge Witker: sistema liberal, sistema de economía centralmente planificada y sistema mixto, que incluye a la vez una modalidad o modelo intervencionista y otro neoliberal. ${ }^{176}$ Siguiendo su línea de análisis para el momento presente habría que agregar la modalidad o modelo posneoliberal o neointervencionista, que se pueden manejar también dentro del mismo sistema capitalista.

En la doctrina y en la jurisprudencia constitucional a nivel internacional se discute sobre la necesidad de una supuesta neutralidad política en las normas de la Constitución económica sobre el régimen económico y financiero, para que estas garanticen seguridad jurídica y puedan cubrir los diferentes modelos o conjuntos de políticas económicas que sean más convenientes y pertinentes, para el desarrollo, en las circunstancias concretas y de sucesivas crisis, del sistema económico dominante. En 1949 los constituyentes alemanes, por ejemplo, establecieron distancias con el intervencionismo propio de la Constitución de Weimar y eludieron la presión política de entonces para que en la Constitución conste la obligación estatal de organizar la

\footnotetext{
${ }^{174}$ Carlos De la Torre, Asamblea Constituyente y Economía, Constituciones en Ecuador, (Quito: AbyaYala, 2007).

${ }^{175}$ Oscar Olmedo Llanos, "Bolivia: Modelos económicos y sistema político". Santa Cruz, Revista Perspectivas, No. 31, abril de 2013.

${ }^{176}$ Jorge Witker, Introducción al Derecho Económico, (México: FCE, edición del 2000).
} 
economía, únicamente mediante procesos privados de producción y distribución, lo cual resumieron en el concepto economía social de mercado.

En España, el Tribunal Constitucional reconoció en 1981 que la Constitución autoriza un sistema económico plenamente liberal, una economía intervenida y una planificada de manera indicativa. Varios autores (Brennan, Casas Pardo, Rojo) opinan que la Constitución española deja un amplio margen político, desde un sistema predominantemente de libre mercado hasta una economía altamente planificada y fuertemente regulada, posibilitando todos los sistemas mixtos imaginables para modificar el modelo económico pero dentro del sistema de economía social de mercado y del Estado social y democrático de derecho. ${ }^{177}$

En el caso de Ecuador, en cambio, las cartas políticas a partir de 1929 adhirieron, bajo diferentes figuras jurídicas, a las políticas o modelos del intervencionismo primero, más tarde del neoliberalismo en 1998 y actualmente del neostructuralismo o neodesarrollismo, sin dejar de sugerir, discretamente en la Constitución de 2008, la posibilidad de promover también, con acción directa del Estado, un modelo alternativo al imperante que no ha podido ser definido o identificado con claridad.

De manera más amplia, los modelos económicos se articulan o se desarrollan también dentro de los períodos y los modelos generales del constitucionalismo latinoamericano desde la fundación de las repúblicas hasta la actualidad. Ramiro Ávila Santamaría los identifica como: liberal-conservador; social; neo constitucionalismo y neo constitucionalismo andino, todos ellos como expresión del sistema imperante y del conflicto y servicio de intereses, disputas de poder y luchas sociales. ${ }^{178}$

Los modelos de constitucionalismo antes indicados, especialmente en el ámbito de sus instituciones y derechos, se encuentran marcados por rasgos similares "elitistas". Las constituciones del siglo XIX y las de las primeras décadas del siglo XX, en América Latina y Ecuador, fueron expresión de las élites conservadoras y liberales que confluyeron en un proyecto estatal y una estructura de poder "contra-mayoritaria" que representaba sus intereses coaligados, especialmente en el ámbito económico, y excluía a los sectores mayoritarios de la población de las decisiones estatales y del ejercicio de sus derechos políticos. ${ }^{179}$

En el constitucionalismo social, los sectores económicos y sociales tradicionales y emergentes, en la segunda y tercera década del siglo pasado, confluyeron en un ordenamiento jurídico que formalmente incorporó los derechos económicos, sociales y culturales de la población, sin que existan los recursos y los medios efectivos para que

\footnotetext{
${ }^{177}$ Álvaro Rodríguez Bereijó, La Constitución fiscal de España, (Madrid: Centro de Estudios Políticos y Constitucionales, 2015).

${ }^{178}$ Ramiro Ávila Santamaría, El neoconstitucionalismo andino, (Quito: Universidad Andina Simón Bolívar, 2016).

${ }^{179}$ Roberto Gargarella, Los fundamentos de la desigualdad, (Madrid: Siglo XXI, 2008).
} 
sean ejercidos, pero que se convirtieron en garantías con reconocimiento estatal, cuya implementación podía ser exigida por la lucha y la movilización social. Dicho reconocimiento constitucional y la movilización y exigencia popular para demandar su cumplimiento se convirtieron en el fundamento de las políticas públicas que pretendían ser implementadas, con diferentes enfoques, por los modelos económicos intervencionista, neoliberal y neo-intervencionista que trataron de implementar los gobiernos entre 1990 y 2017.

El inicial neoconstitucionalismo latinoamericano estuvo relacionado inicialmente con el neoconstitucionalismo europeo que inspiró el ordenamiento constitucional de los diferentes países del viejo continente tras la segunda guerra mundial, con la inclusión de nuevos postulados, como los de: privilegiar principios y el ejercicio directo de los derechos frente a las reglas; interpretar las normas mediante la ponderación en lugar de la subsunción y reconocer el papel activo y protagónico de los jueces en la creación y protección de los derechos frente a la labor de los legisladores en la expedición de las leyes. Estas orientaciones estuvieron dirigidas a consolidar y ampliar el Estado social pero no implicaron una transformación democrática del sistema, ni la superación de la exclusión social, pues favorecieron la acumulación y la superación de las crisis capitalistas con una cierta y limitada redistribución de la riqueza y el robustecimiento institucional del poder de los funcionarios y de los órganos judiciales, que son los sectores más ajenos a la participación y control popular. Se produce, como dice Gargarella, "un potencial desapoderamiento de la ciudadanía, y un trasvasamiento de la autoridad popular hacia los órganos menos democráticos creados por la Constitución". ${ }^{180}$

El neoconstitucionalismo latinoamericano de los noventa del siglo pasado asocia los postulados indicados anteriormente y el respeto a los derechos individuales del modelo neoliberal y a la primacía del mercado, para cuestionar al Estado intervencionista con el impulso de privatizaciones a recursos y servicios públicos y la introducción de procesos judiciales expeditos para el reconocimiento individual de derechos constitucionales conculcados y de procesos de descentralización hacia los gobiernos provinciales y locales. Todo ello con el objetivo de debilitar al Estado central y facilitar la dominación económica y financiera transnacional y de los sectores económicos más poderosos del país.

El neoconstitucionalismo con fundamento neoliberal se transforma por la crisis y fracaso del modelo individualista, centrado en el mercado transnacional, y adquiere, desde inicios del presente siglo un rasgo propio que lo identifica ahora como neoconstitucionalismo latinoamericano. Lo calificaremos de progresista o de popular

\footnotetext{
${ }^{180}$ Roberto Garagarella, Pensando sobre la Reforma Constitucional en América Latina, en El Derecho en América Latina, Coord. César Rodríguez Garavito (Buenos Aires: Siglo Veintiuno Editores, 2011), 97.
} 
como lo denominan varios constitucionalistas: Claudia Storini, ${ }^{181}$ Roberto Viciano, Roberto Gargarella y Pedro Salazar, entre otros.

Esta versión del neoconstitucionalismo latinoamericano tiene características nuevas que lo diferencian de otras versiones europeas o norteamericanas: ampliación y aplicación directa no solo de los derechos individuales sino también de los colectivos, los de la diversidad étnica y cultural de los pueblos y la inclusión de nuevos derechos como los de la naturaleza y de los consumidores y de minorías de diversa índole; la preservación del medioambiente y la reparación integral por su deterioro; el reconocimiento al pluralismo jurídico y jurisdiccional que incluye las normas de pueblos y comunidades ancestrales; la ampliación de las garantías procesales para el ejercicio de derechos constitucionales de los ciudadanos, con la introducción de medidas cautelares, los procedimientos orales en todas las materias y la reparación integral para agilizar las controversias judiciales y la protección efectiva de derechos, etc.

Dentro del neoconstitucionalismo latinoamericano cobra identidad particular lo que Ramiro Ávila denomina neoconstitucionalismo andino. En Constituciones como la de Ecuador (2008) y Bolivia (2009) incluye, además de las reivindicaciones y derechos indicados, las demandas sociales de sectores antes excluidos de los pactos constitucionales y que se expresan en las figuras de: plurinacionalidad, pachamama, sumak kawsai, sumak kamaña, democracia comunitaria, justicia indígena e interculturalidad, que representan las utopías y la inclusión del pacto social inicial implícito o explícito entre el progresismo político latinoamericano y las fuerzas sociales populares alternativas y especialmente las que representan a los sectores sociales excluidos y a los pueblos y nacionalidades.

Tanto el neoconstitucionalismo latinoamericano progresista como el neoconstitucionalismo andino fueron más un ejercicio retórico utilizado por sectores políticos de origen izquierdista, que accedieron al Gobierno en varios países latinoamericanos como Venezuela, Ecuador y Bolivia, para legitimarse en el ejercicio del poder antes que un instrumento práctico de ampliación de la democracia y de inclusión de los sectores sociales a los que dijeron representar. Su modelo político devino en un hiperpresidencialista autoritario y caudillista; las instituciones se mantienen excluyentes a las mayorías; el protagonismo judicial en el reconocimiento de derechos son manipulados totalmente por quienes controlan el Gobierno; los mecanismos de participación social y de consulta popular se encuentran anulados y no son implementados para la ampliación real de la democracia y su modelo económico reproduce los intereses del capital transnacional para una mejor articulación a la globalización capitalista mundial.

${ }^{181}$ Claudia Storini, Pluralismo popular como paradigma de un constitucionalismo de la diferencia, en Constitucionalismo nuevos saberes jurídicos. Construcciones desde las diversidades, (Quito: Corporación Editora Nacional-Universidad Andina Simón Bolívar, 2017), 31-48. 
En las normas de la Constitución económica y financiera inciden directamente asociados al sistema capitalista mundial, además de los intereses económicos y políticos $\mathrm{y}$ las connotaciones jurídicas que se han señalado, los pactos y convenios internacionales, decisiones y recomendaciones económicas de los organismos de integración regional, de las estructuras internacionales multilaterales como el FMI y el BM, de otras instituciones económicas especializadas organizadas por las Naciones Unidas y de otros organismos no oficiales de control y regulación del sistema financiero como el Comité de Basilea, y de principios como los de estabilidad macroeconómica, sostenibilidad fiscal, equilibrio presupuestario y otros, que se han introducido acelerada y universalmente en las normas constitucionales de diferentes países.

En la Unión Europea, por ejemplo, prevalecen normas económicas comunes que conforman su real Constitución económica y consolidan un modelo de economía de mercado en todos los países de la región, con predominantes rasgos neoliberales en la circulación libre de personas, bienes y capitales. De igual manera la política monetaria y la política fiscal son comunes en la Unión y no se diga con la introducción del euro y la creación del Banco Central Europeo. Normas tributarias comunes para un mercado único y normas de estabilidad, coordinación presupuestaria y de limitación del déficit y la deuda, que constan en el Pacto de Estabilidad y Crecimiento (PEC, 1997) y en el Pacto Presupuestario, que se imponen en toda la región y han transformado el contenido de la Constitución económica de cada uno de los países miembros. ${ }^{182}$ Otras normas y recomendaciones, consideradas inicialmente como de soft law, especialmente en el ámbito financiero, terminan finalmente incorporadas en la normativa obligatoria, hard law, de cada uno de los países y no se diga luego de las reiteradas crisis económicas que se han desatado en las economías desarrolladas.

En las constituciones económicas tienen un papel destacado las normas financieras que forman parte de lo que se denomina o se identifica como Constitución financiera, relativa a la Hacienda o a las finanzas públicas, ámbito especial del derecho financiero público que se encuentra relacionado directamente con normas administrativas económicas relativas a la planificación y al control y a ciertas dimensiones de la propia actividad financiera.

Las regulaciones constitucionales sobre la Hacienda pública, que forman parte de la Constitución económica, son esenciales en la actividad y conducción del Estado, tanto para comprender las razones para que la Constitución otorga a las autoridades nacionales y locales la más amplia potestad financiera y la regulación de las actividades de los principales actores económicos, como para que los ciudadanos puedan exigir la cobertura de sus necesidades y sus derechos básicos mediante iniciativas y recursos públicos que deben ser previstos o planificados, equitativamente captados, debidamente gastados y adecuadamente controlados en su eficiente y eficaz uso e inversión.

${ }^{182}$ España, Constitución española, Reforma del art. 135 del 2 de septiembre de 2011. 
Por ello, compartimos la apreciación de Rodríguez-Bereijo de que la Constitución financiera o Constitución fiscal tiene primordial trascendencia en la "arquitectura constitucional" y que es una "fórmula abierta, flexible o indeterminada (aunque no necesariamente ambigua) que permite distintas opciones políticas", ${ }^{183}$ pues los fines del Estado, incluso bajo cualquier modelo según nuestra opinión, se realizan mediante la actividad financiera y las políticas públicas que orientan la Hacienda o las finanzas públicas.

En el propósito de potenciar el avance y el crecimiento económico de todos los países del mundo y de alcanzar una justicia redistributiva de la riqueza, frente a la pobreza y extrema pobreza y los efectos nocivos de las recurrentes crisis económicas, especialmente financieras, y con el propósito de alcanzar los objetivos del milenio y de estabilizar el sistema mundial, las políticas públicas y las normas que rigen o deben regir la Hacienda pública o conformar el derecho financiero tienen importancia capital en la actividad del Estado, pues de ellas dependen otras medidas y acciones para que este pueda cumplir su misión, y los objetivos establecidos en la Constitución política.

La incorporación en el texto constitucional de un modelo de desarrollo que defina el papel del Estado y del mercado y de los actores privados y colectivos en la actividad económica; regule el alcance de la planificación y de los planes de desarrollo; incorpore los principios fundamentales de los tributos, en su dimensión no solo fiscal sino de redistribución de la riqueza; defina el contenido, procedimiento y prioridades del presupuesto, los gastos públicos y la deuda y amplíe las formas y la eficiencia en las diferentes formas de control de los recursos y bienes del Estado, se articulan al contenido global de la Constitución política y al ejercicio eficaz y no solo declarativo de los derechos y garantías ciudadanas recogidas en las últimas cartas políticas del Estado en Ecuador, independientemente de su orientación desarrollista, neoliberal o neoestructuralista.

Las normas constitucionales que regulan la actividad financiera del Estado sobre los ingresos y los gastos son cruciales para diferenciar los modelos económicos dentro del sistema económico o para establecer si existe una pretensión de modificarlo. De allí que se puede distinguir entre la hacienda clásica o de equilibrio propia del régimen liberal, la hacienda moderna que corresponde al Estado social y democrático de derecho y la hacienda contemporánea o posmoderna, tanto en su versión neoliberal como en la neoestructural, que pretende restablecer, de diferente manera y con fines distintos, los equilibrios y la estabilidad económica y social del sistema y la satisfacción de los derechos ciudadanos.

La Constitución financiera $o$ fiscal, sea en el modelo neoliberal $o$ en el neointervencionista, regula la cuantía y los principios de los ingresos públicos

\footnotetext{
183 Álvaro Rodríguez Bereijó, La Constitución fiscal de España, (Madrid: Centro de Estudios Políticos y
} Constitucionales, 2015), 59. 
suficientes para el cumplimiento de las funciones estatales y la cobertura de los gastos, conforme los propósitos y objetivos de aquellos. Los límites o amplitud que se derivan de las normas financieras de la Constitución orientan al quehacer del Estado y los sujetos en el sistema económico vigente.

Las recientes crisis del sistema capitalista mundial y la globalización económica y financiera han colocado en primer plano al debate académico y político sobre los límites en la expansión de los derechos ciudadanos, que para su satisfacción el Estado requiere cada vez de mayores recursos mientras la población se resiste a aumentar la presión fiscal y a recortar los gastos públicos necesarios. Se argumenta que las modificaciones constitucionales y legales de sostenibilidad fiscal ponen en peligro la naturaleza del Estado social o del Estado prestacional o neointervencionista o de derechos y justicia, ya que lo convierten en rehén del mercado de capitales en el cumplimiento de sus obligaciones financieras.

La satisfacción de todos los derechos tienen sin duda una dimensión financiera y un coste que no se puede eludir, ya sea que se trate de derechos constitucionales de prestación, vinculados a los derechos económicos y sociales y a aún los civiles y políticos o si se trata de derechos que tienen los particulares frente al Estado deudor por mandato de la ley o de los contratos o actos que se generen en la ejecución de sentencias judiciales. Por lo tanto, sea en el modelo neoliberal como en el neointervencionista, el derecho financiero regulará los límites que se establezcan a los ingresos y gastos y a las obligaciones que se pretenden cubrir. ${ }^{184}$

Respecto del contenido general de la Constitución económica en Ecuador, esta comprende las normas de la carta política relativas a las definiciones del Estado en esa materia; los derechos y garantías económicos y sociales de los ciudadanos y la normativa que regula el sistema y el régimen económico general que guían la intervención del Estado o del mercado en la actividad económica en general en diferentes ámbitos $\mathrm{y}$, en especial, en aquellos que demandan de su conducción económica, en los ámbitos de la planificación, las finanzas públicas y el control.

En cuanto a las definiciones generales sobre el Estado, en las constituciones de Ecuador entre 1830 y 1929 no se usó la identificación del Estado como Estado de derecho que corresponde al período poscolonial y liberal del siglo XIX. Tampoco en las cartas políticas expedidas entre 1929 y 1979 se introdujo la denominación del Estado como Estado social de derecho, que corresponde al período intervencionista, de bienestar y de transacción de los grupos de poder con los sectores sociales a los que se les reconoció sus derechos económicos y sociales. Más bien la Constitución de 1998, que instauró una economía social de mercado, le dio la definición de Estado de derecho, como una transacción con los sectores sociales que demandaban el reconocimiento amplio de sus

\footnotetext{
184 Álvaro Rodríguez Bereijó, La Constitución fiscal de España, (Bilbao: Centro de Estudios Políticos y Constitucionales, 2015).
} 
derechos en su parte dogmática. Finalmente, la Constitución de 2008 identifica al Estado como un Estado constitucional de derechos y justicia, para diferenciarlo cel Estado intervencionista y neoliberal y para fundamentar un nuevo intervencionismo estatal y la invocación y aplicación directa de los derechos y la política económica neoestructural y neodesarrollista que se ejecutó en los diez años siguientes.

Nuestro estudio sobre la Constitución económica y financiera ecuatoriana se refiere principalmente a las modificaciones y orientaciones que sobre el sistema económico y los modelos neoliberal y neoestructural se expidieron, entre 1990 y 2017, en relación a la planificación, las finanzas públicas y el control, sin desarticular su estudio de los objetivos sociales del Estado, de los derechos de los ciudadanos y de la búsqueda de una alternativa económica y social.

\section{LOS CONTENIDOS ECONÓMICOS Y FINANCIEROS DE LAS CONSTITUCIONES EN ECUADOR HASTA 1998}

Las constituciones latinoamericanas en el siglo XIX y en las primeras décadas del siglo pasado, como las de Ecuador de 1830, 1845, 1851, 1861, 1869, 1878, 1884, 1897 y 1906, no incluían de manera sistemática y expresa las normas de carácter económico sobre el sistema, la propiedad o la actividad de los sujetos económicos, pues suponían que el sistema capitalista de corte liberal se sostenía por sí mismo, fundamentado en el pacto político conservador-liberal local y no requería de la intervención o apoyo directos del Estado, cuya estructura política estaba llamada fundamentalmente a administrar justicia, conservar el orden y la seguridad interna y externa del país. ${ }^{185}$

Varios estudiosos del tema también sostienen que en la etapa liberal de la economía y del Estado en Ecuador, las constituciones del siglo XIX histórico garantizaban per seel sistema interno y externo de dominación imperante y tenían un contenido económico mínimo destinado a preservar los derechos de propiedad y comercio y los aspectos generales de la Hacienda pública liberal, por los que se otorgaba al presidente de la República y al Congreso o a la función legislativa y al presidente, las atribuciones de presentar y aprobar el presupuesto, dictar leyes tributarias y, en algunos casos, definir o autorizar el endeudamiento público. ${ }^{186}$

Luego del período poscolonial del Derecho ecuatoriano, en los inicios de la República, entre 1830 - 1861, en el que se conservaron casi intocables las instituciones jurídicas adoptadas por las reformas borbónicas en la corona española para acoplarse al

\footnotetext{
185 Federico Trabucco, Constituciones de la República del Ecuador, (Quito: Editorial Universitaria, 1975).

186 Juan Paz y Miño: “Constituyentes, Constituciones y Economía”, en Asamblea Constituyente y Economía, Quito, Abya-Yala, 2007 y Agustín Grijalva: "La Constitución Económica del Ecuador” en Estado, Derecho y Economía, Quito, UASB sede Ecuador y Corporación Editora Nacional, 2013.
} 
surgimiento del capitalismo ${ }^{187}$, viene un lapso histórico de más de seis décadas. Hasta 1925, año en el que se consolidó el modelo liberal-conservador, conveniente a los intereses oligárquicos-terratenientes, para asegurar las prerrogativas y atribuciones de hacienda otorgadas al Congreso, en donde se encontraban representados de una forma privilegiada los grupos dominantes del país.

La Revolución juliana de 1925 y el Gobierno de Isidro Ayora, modernizaron al país en los años siguientes con el apoyo de la misión norteamericana dirigida por Edwin Kemmerer. ${ }^{188}$ En ese contexto y con la influencia de la Constitución mexicana (1917) y la de la República de Weimar (1919), se expidió la Constitución de 1929, la primera en el ámbito sudamericano en incluir formalmente un contenido económico para superar la visión liberal tradicional y fundamentar la necesidad de un intervencionismo del Estado en la economía que garantice el acceso a los derechos económicos y sociales de los ciudadanos y la construcción de un estado de bienestar, tal como más tarde lo pregonara el New Deal y el pensamiento económico keynesiano. Estas orientaciones se prolongaron hasta los años ochenta, en los que se reforzó la doctrina intervencionista, con la influencia de los organismos financieros internacionales conformados luego de la segunda guerra mundial y, en nuestra región, con los documentos y planes de la CEPAL inspirados por el pensamiento de Raúl Prebisch.

En la Constitución de 1929 se reconocen como garantías absolutas los derechos económicos y sociales de los ciudadanos, el carácter social de la propiedad, una regulación prolija sobre el presupuesto y el gasto público y el dominio del Estado sobre las minas y yacimientos. Al Consejo de Estado se le otorga la potestad de resolución sobre la nulidad de los actos del Ejecutivo que los contravengan. Con esta Constitución se inicia, según Juan Paz y Miño, un largo proceso histórico de construir instituciones económicas que, desde lo público, superan el régimen oligárquico-terrateniente para promover el desarrollo no satisfecho por el sector privado o las fuerzas naturales del mercado. Las instituciones estatales que se conformaron en los gobiernos julianos permanecieron y se ampliaron hasta los años noventa, cuando se planteó una nueva modernización del país, ya en el contexto de la globalización y de las fórmulas neoliberales del Consenso de Washington. ${ }^{189}$

La Constitución de 1945, expedida después de la "gloriosa" revolución de Mayo de 1944, no solo consignó y amplió los derechos económicos y sociales, la función social de la propiedad y el rol activo del Estado en la economía, sino que además autorizó al

\footnotetext{
${ }^{187}$ Alberto Wray Espinosa, Estudio introductorio a Pensamiento Jurídico Ecuatoriano, Biblioteca Básica del Pensamiento Ecuatoriano, Banco Central del Ecuador - Corporación Editora Nacional N ${ }^{\circ} 42$, Quito, 1997.

${ }^{188}$ BANCO CENTRAL SOBRE KEMMERER EN LOS ANDES, http://biblioteca.bce.ec/cgibin/koha/opacdetail.pl?biblionumber=1820\&query desc $=$ su $\% 3 \mathrm{~A} \% 22 \mathrm{KEMMERER} \% 2 \mathrm{C} \%$ 20EDWIN\%2 0 WAL TER\%22. Y TEXTO DE JUAN PAZ Y MINO SOBRE REVOLUCION JULIANA. En Paz y Miño Cepeda, Juan J. Revolución juliana. Nación, ejército y bancocracia, Quito, EC: Abya-Yala, 2000.

${ }^{189}$ Juan Paz y Miño Cepeda, presentación de Asamblea Constituyente y Economía, Constituciones del Ecuador, Taller de Historia Económica, ADHILAC, Quito: Abya Yala, 2007.
} 
Congreso legislar sobre la moneda, el crédito, la deuda, el Presupuesto General del Estado, la inversión pública y el fomento de la riqueza nacional. Introdujo también, entre otros, el concepto de nacionalización; diferenció el interés nacional del privado, que debe subordinarse a fines públicos y sociales; proscribió el latifundio, la servidumbre y el concertaje y proclamó el cooperativismo como sistema a ser implementado en Ecuador.

Las constituciones de 1946, 1967 y 1978-9, conservaron el contenido económico y financiero antes indicado e incluyeron normas que confieren al Estado un importante rol en la promoción de derechos y en el desarrollo económico y social. El modelo estataldesarrollista incluye el papel de la planificación y una sección específica de las cartas políticas destinada a la economía, al régimen tributario y al régimen monetario y bancario. La Constitución de 1946 creó el Consejo Nacional de Economía para "el estudio de los problemas económicos, su coordinación y planificación" (Art. 79), como paso previo para que el presidente dicte medidas económicas; la de 1967 amplió los organismos de control y constitucionalizó la reforma agraria, la Junta Nacional de Planificación y Coordinación, la expedición de planes plurianuales de desarrollo, la responsabilidad objetiva del Estado, el otorgamiento de concesiones reguladas por ley y el derecho estatal a explotar actividades económicas; y la Constitución de 1979 creó el CONADE (Consejo Nacional de Desarrollo), estableció la función social de la propiedad y reconoció la posibilidad de cogestión de los trabajadores en la conducción de las empresas.

En la Constitución de 1978-79 -aprobada mediante referéndum- y en sus reformas de 1983, se introdujo la definición implícita de Estado social de derecho y se reconocieron a los ciudadanos los derechos de tercera generación que se incorporaron a los derechos económicos y sociales que ya constaban en las constituciones anteriores. La Constitución estructuraba la economía en cuatro sectores respecto de las diversas formas de propiedad y al papel que cumplen en ellos la planificación, el sistema tributario y los presupuestos públicos y la ejecución de los programas de desarrollo, económicos y sociales.

Si bien la Constitución desde 1978-79 expresa desde sus artículos iniciales que "es función primordial del Estado fortalecer la unidad nacional para asegurar la vigencia de los derechos fundamentales del hombre y promover el progreso económico, social y cultural de sus habitantes" (Art. 2), en la regulación de la economía agrega que su organización y funcionamiento "deberá responder a los principios de eficiencia y justicia social, a fin de asegurar a todos los habitantes una existencia digna, permitiéndoles, al mismo tiempo, iguales derechos y oportunidades frente a los medios de producción y consumo". También enfatiza que "el desarrollo en el sistema de economía de mercado propenderá al incremento de la producción y tenderá fundamentalmente a conseguir un proceso de mejoramiento y progreso integral de todos los ecuatorianos" y que "la acción del Estado tendrá como objetivo hacer equitativa la distribución del ingreso y de la riqueza en la comunidad". Como se puede advertir, y así 
lo observa con precisión Marco Antonio Guzmán, las normas indicadas buscaban un equilibrio entre la eficiencia y la justicia, entre la producción, la acumulación y la redistribución de la riqueza y son propias de la concepción del Estado social de derecho y excluyen, en principio, las posiciones liberales o neoliberales. ${ }^{190}$

La Constitución establecía, además, que la estructura de la economía se organiza mediante cuatro sectores básicos: público o de las empresas de propiedad exclusiva del Estado; economía mixta de empresas de propiedad de particulares en asociación con el Estado; comunitario o de autogestión de empresas cooperativas, comunales de propiedad y gestión de una comunidad de personas y privado de empresas pertenecientes a personas naturales o jurídicas de derecho privado. La carta política disponía que las áreas de actividad económica reservadas al Estado estaban conformadas por: los recursos naturales no renovables, los servicios públicos básicos y las empresas estratégicas que por su importancia y magnitud tienen influencia decisoria en el interés social y agregaba que solo por excepción y mediante ley, el Estado podía delegar a la iniciativa privada las actividades antes mencionadas. En cuanto a las empresas mixtas, se podían organizar para promover la inversión en áreas en las que el sector privado requiriera del sector público hasta que aquella pudiera serle transferida y, sobre la regulación y desarrollo del sector comunitario, la Constitución lo asimilaba al sector privado, sin reconocer su naturaleza específica y remitiendo sus asuntos a la ley.

Respecto de las finanzas públicas y la planificación, la Constitución de 1978-79, con la que culmina el modelo económico intervencionista y estructuralista en Ecuador y que se extendió hasta inicios de la década del noventa del siglo pasado, dispuso que el sistema tributario se fundamenta en los principios de igualdad, proporcionalidad y generalidad y que además debe cumplir funciones extra fiscales o "de política económica general", para promover el desarrollo, la inversión, la reinversión, el ahorro para procurar una "justa distribución de las rentas y de la riqueza entre todos los habitantes del país" (Arts. 52 y 67$)$.

La Constitución, acorde con el modelo intervencionista, facilitó los procesos de endeudamiento, pues en ellos no participaba la función legislativa, quedando a la libre decisión del Ejecutivo. Se consideró a la planificación como una regla para la acción del Estado para un crecimiento sostenido y armónico y una equilibrada distribución de recursos en el territorio nacional. Sobre el presupuesto del Estado, la Constitución lo asoció al desarrollo económico y social.

\section{Las reformas constitucionales entre 1990 y 1998}

En la década del ochenta y en los inicios de la del noventa, con la crisis de la deuda y el colapso de economías con sistemas intervencionistas, altamente burocratizados e

\footnotetext{
${ }^{190}$ Marco Antonio Guzmán, Derecho Económico Ecuatoriano I, (Quito: Universidad Andina Simón Bolívar - Corporación Editora Nacional, 1996).
} 
ineficientes por el crecimiento desbordado del gasto público, los organismos financieros internacionales como el FMI y el Banco Mundial radicalizaron sus objeciones a los desequilibrios macroeconómicos de los países en vías de desarrollo y les exigieron, además de los ajustes estructurales y los planes de estabilización, reformas estructurales para sustituir el modelo económico estatista vigente por un modelo neoliberal o mercadocéntrico o empresarial de desarrollo, que trasladara y privatizara las actividades económicas del Estado y los servicios públicos, descentralizara sus funciones en los gobiernos locales y, de esta manera, pudiera satisfacer los intereses empresariales y tener los derechos ciudadanos bajo su control.

La sustitución del modelo económico intervencionista por el neoliberal o de economía privada en Ecuador tiene como antecedentes los planes de estabilización y las cartas de intención acordados con el Fondo Monetario Internacional, que se impusieron a los gobiernos de Osvaldo Hurtado (1981-1984); al de León Febres Cordero (1984-1988) y al de Rodrigo Borja (1988-1992), y que cobraron plena ejecución durante el régimen de Durán - Dahik (1992-1996), el cual, además de la presión externa de los organismos financieros internacionales, formó parte de su propia iniciativa y de su programa político y económico.

A partir de 1992 se inició un proceso de expedición de leyes y normas orientadas a la flexibilización laboral; a la privatización de los recursos y servicios públicos con la Ley de Presupuestos del Sector Público (1992), Ley de Modernización del Estado (1993) y otras que profundizaron en un generoso sistema de concesiones en el sector eléctrico, hidrocarburífero y de telecomunicaciones, la liberación del sistema financiero mediante la Ley General de las Instituciones del Sistema Financiero (1994) y la organización del mercado de valores mediante Ley expedida por primera vez sobre la materia en 1993; al fortalecimiento de las finanzas públicas para asegurar el pago de los vencimientos y servicio de la creciente deuda externa, mediante transformaciones tributarias, presupuestarias y de control de los recursos públicos (Reforma Tributaria de 1989 y 1998 y reformas a la LOAFYC), y a la concentración de las decisiones administrativas y económicas sobre la modernización del Estado en manos del Ejecutivo. Para todo ello se desmanteló la Ley de Régimen Administrativo y se la sustituyó por un Estatuto de Régimen Jurídico Administrativo de la Función Ejecutiva, ERJAFE (1994), que puede ser modificado ágil y discrecionalmente mediante decretos ejecutivos, conforme a la conveniencia del Gobierno. De igual modo se aplicaron las normas de la referida Ley de Modernización del Estado (1993), con la finalidad de acelerar los procesos de transferencia del patrimonio nacional a la iniciativa privada, mediante la privatización y la concesión y otras figuras del derecho administrativo, sustituyendo las potestades legislativas del Congreso Nacional.

El Presidente Sixto Durán propuso dos consultas populares para alcanzar un respaldo político que le permitiera introducir reformas legales de carácter económico y para que tuvieran fundamento constitucional. La primera de ellas, el 28 de agosto de 1994, en la que la mayoría de electores aceptó, entre otros puntos, que los legisladores no deben 
"manejar fondos del presupuesto del Estado" y lo deban "aprobar por sectores de gasto". La otra, el 26 de noviembre de 1995, en la que la respuesta popular fue negativa para todas las preguntas, incluyendo las relativas a profundizar la descentralización, privatizar la seguridad social, disolver el Congreso Nacional y convocar a elecciones anticipadas de diputados, entre otras. ${ }^{191}$

Frente a la resistencia y movilización social a las privatizaciones y particularmente a la de la seguridad social, el Gobierno de Durán Ballén planteó de manera discreta y hábil varios textos de reformas constitucionales al Congreso Nacional el 4 de octubre de 1994, que privilegiaban un enfoque individual sobre lo social y colectivo y que promovían la adopción de normas sobre el ejercicio y protección de derechos, que fueron negociadas con los sectores políticos parlamentarios mayoritarios, a cambio de asignaciones presupuestarias en beneficio de los gobiernos locales y de obras patrocinadas por los legisladores, mientras el Ejecutivo, mediante actos administrativos y con el apoyo técnico del Consejo de Modernización del Estado, modificó y manejó discrecionalmente los procesos de privatización y de concesión del modelo económico y político neoliberal que se pretendía aplicar. ${ }^{192}$

El Congreso tramitó 58 reformas en tres partes que se denominaron bloques: el primero aprobó 11 reformas; el segundo 23 y el tercero 24, todo lo cual culminó el 16 de enero de 1996. ${ }^{193}$ En el primer bloque las reformas relevantes, para efecto de nuestro estudio, son: mayor control del Ejecutivo sobre la formulación y aprobación del presupuesto general del Estado por sectores de gasto, limitación de las potestades que, en la asignación, reforma y control presupuestario tenían al respecto la función legislativa y los legisladores.

En el segundo y tercer bloque de reformas se incorporó en el texto constitucional, con la finalidad de paliar los efectos de la aplicación del modelo neoliberal, que "los derechos y garantías constitucionales son plenamente aplicables e invocables ante cualquier juez, tribunal o autoridad" y se creó una sección "de garantías de los derechos" en las que constan la Defensoría del Pueblo y varios recursos constitucionales para proteger garantías, como el habeasdata y el de amparo, que antes no los contemplaba nuestro derecho constitucional.

Para hacer viable el cambio del modelo económico las reformas apuntaron a una concentración de las decisiones económicas y administrativas en el Ejecutivo, reforzando el presidencialismo, para lo cual se le facultó para dictar su propio régimen jurídico-administrativo; fijar las políticas generales económicas, sociales y

191 Informe del presidente del T.S.E., Consulta Popular 1994 y Consulta Popular 1995, https://Repositories.lib.utexas.edu

${ }_{192}$ Marco Antonio Guzman, Derecho Económico Ecuatoriano I, (Quito, Universidad Andina Simón Bolívar - Corporación Editora Nacional, 1996).

${ }^{193}$ El texto del primer bloque de reformas se publicó en el suplemento del Registro Oficial-S 618 de 24 de enero de 1995; el segundo y tercer bloques se publicaron en el Registro Oficial 863 de 16 de enero de 1996. 
poblacionales del Estado; aprobar los planes de desarrollo; controlar casi de manera total la aprobación y ejecución del presupuesto y definir el proceso de contratación y pago de la deuda externa y la oportunidad y el alcance de las privatizaciones y otras formas de manejo de los recursos, bienes y servicios públicos estratégicos.

Esta concentración de poder en el Ejecutivo estuvo acompañada del despojo al vicepresidente de la República de la atribución constitucional de presidir el Consejo Nacional de Desarrollo a cambio de cumplir las funciones que le asigne el presidente y de disminuir las atribuciones del Congreso Nacional, en cuanto a fiscalización y control, frente a las frecuentes denuncias de corrupción en los procesos de privatización anunciados o en ejecución. Sin embargo, se camuflaron también las decisiones económicas y políticas, fortaleciendo aparentemente las atribuciones de la Contraloría como principal órgano de control externo de los recursos públicos.

\section{LAS CONSTITUCIONES DE 1998 Y 2008}

Las dos constituciones objeto principal de este estudio, siguiendo la tradición de las cartas políticas latinoamericanas del siglo XX, desde la Constitución mexicana en 1919 y desde los años treinta en otros países, incluyen contenidos y lineamientos de carácter económico, introducidos primero en la etapa del Estado socialo intervencionista de los años 30 y luego acentuados por el desarrollismo de los años 60; posteriormente, en la etapa neoliberal esos contenidos proclaman la desregulación y el abandono o la restricción al Estado en su intervención en la economía, para que sea el capital trasnacional y el mercado los que la protagonicen; para que finalmente, en la actualidad posneoliberal o neoestructuralista se restablezcan las atribuciones económicas del Estado con la finalidad de alcanzar el sumak kawsay y para que este sea el constructor de una nueva alternativa al régimen económico imperante o para que lo regule, promueva o modernice.

De la veintena de constituciones que han regido a nuestro país, desde la fundación del Estado en 1830, las dos últimas (1998 - 2008) tienen un más extenso contenido económico. Recordamos que Ecuador es pionero en América del Sur por haber introducido formalmente dicho contenido desde la Constitución de 1929, si bien, como hemos dicho, en el primer siglo de la República (1830 - 1929) se encontraba implícito o parcialmente manifiesto en el tipo de Estado y sistema económico entonces vigentes.

En el caso ecuatoriano, como lo hemos planteado también, el contenido económico de las constituciones está relacionado con los procesos de transformación económica y política del país, en el contexto de cambios en la economía mundial y de los intereses de los grupos de poder económico dominantes.

El contenido económico de las constituciones de Ecuador de 1998 y 2008 se inscribe igualmente en el contexto del Estado social y democrático de derecho, dentro de la 
denominada corriente neoconstitucionalista, que privilegia la aplicación directa de los derechos y garantías de los ciudadanos sin que se requiera necesariamente de ley que los regule, tomando en consideración que se han incluido, como definición del Estado, el de social de derecho (1998) o constitucional de derechos y justicia (2008), en dos procesos o momentos políticos distintos, en los que se propone un modelo económico neoliberal primero y luego uno postneoliberal o neoestruralista o neointervencionista.

Nuestro análisis pretende al mismo tiempo cuestionar si los modelos económicos y las políticas económicas y públicas, y en particular las de planificación, finanzas públicas y control, adoptados por el Estado y sus gobiernos, les otorgan un papel protagónico o subordinando al mercado para incorporarse a la economía capitalista transnacional, o si se encuentran en un proceso real de avance y construcción de un modelo alternativo para edificar en Ecuador un supuesto nuevo sistema económico y social, denominado ambiguamente socialismo del sumak kawsay o socialismo del siglo XXI.

En el segundo momento de los procesos constitucionales indicados, cuando se pregona la instauración de un modelo neoestructural o neointervencionista, por sus resultados objetivos, parece que enfrentamos un esfuerzo más bien retórico con definiciones ideológicas indefinidas que no trascienden la realidad existente. Constatamos, finalmente, que se impone, mediante un manifiesto modelo político autoritario, el neocapitalismo vislumbrado en varias dimensiones a nivel internacional por Sweesy, Baran, Dobb y Hobsbawn, entre otros, y por Manuel Agustín Aguirre y Agustín Cueva en nuestro país y en América Latina y que los gobiernos progresistas de la región y Ecuador, se encuentran empeñados en reconstruir el capitalismo local o "haciendo mejor, mucho mejor pero lo mismo de siempre" o "haciendo mejor las cosas con el mismo modelo de acumulación antes que cambiarlo" como lo manifestara el expresidente ecuatoriano Rafael Correa. ${ }^{194}$

\subsection{La Constitución de 1998}

La gran movilización y resistencia social que se desató contra la aplicación inicial del modelo neoliberal y los casos de corrupción ocurridos a fines de los años noventa fortalecieron la demanda social de que se expidiera una nueva Constitución. La exigencia popular se asumió de inmediato por los sectores económicos y políticos dominantes que mantuvieron el control político del país con el Gobierno interino de Fabián Alarcón en 1997, con la finalidad principal de constitucionalizar las reformas económicas y políticas neoliberales. Convocaron primero una consulta popular para legitimarse en el poder, pues era evidente que habían violentado las normas constitucionales en la sucesión presidencial y en las privatizaciones.

La consulta se realizó el 25 de mayo de 1997 y se preguntó a la población si autorizaba también la reunión de una Asamblea Constitucional para reformar integralmente la

\footnotetext{
${ }^{194}$ Rafael Correa, entrevistas en Perú 20 de octubre de 2012 y a diario El Telégrafo 15 de enero de 2011.
} 
Constitución de 1978, a la que ya se le habían introducido numerosas reformas neoliberales coyunturales, pues aún no se había cambiado sustancialmente el modelo económico, auspiciado por los organismos financieros internacionales y por las fuerzas económicas y políticas dominantes en el país. ${ }^{195}$

Se instalaron dos poderes legislativos: el Congreso Nacional, que cumplía con sus funciones constitucionales tradicionales y una Asamblea Constitucional que de inmediato se proclamó Constituyente y expidió en el lapso de seis meses una nueva Constitución, la de 1998, que en realidad se trata de una extensa codificación de la carta política de 1978, pero sustituye su orientación original estatista o intervencionista e introduce reformas importantes de corte liberal en lo económico, ampliando las garantías individuales y estableciendo un proceso descentralizador que menoscabó las atribuciones económicas del Estado.

En dicha Constitución se reconocen como uno de los deberes primordiales del Estado, "garantizar la vigencia del sistema democrático y la administración pública libre de corrupción" (Art. 3.6); se recopilan todos los derechos y garantías de los ciudadanos contempladas en los instrumentos internacionales de la materia y se modifica sustancialmente el sistema económico y político, denominándolo ahora de economía social de mercado (Art. 244), que es la definición que adoptó preferentemente el neoliberalismo a nivel internacional a partir de la Constitución alemana.

En lo económico, la Constitución de 1998 priorizó el papel del mercado sobre el Estado y se flexibilizaron las normas constitucionales y legales vigentes hasta entonces, para que el sector privado, fundamentalmente transnacional, fuera el principal beneficiario de la copropiedad de recursos públicos, de las concesiones en la explotación de los recursos naturales, de la ejecución de grandes obras de infraestructura y de la provisión de servicios públicos que antes eran de exclusividad del Estado o en los que podía coparticipar el sector privado, mediante expedición expresa de ley. ${ }^{196}$ Este sistema económico fue particularmente reformado por la Constitución de 1998 y, como ya lo indicamos, se adoptó previamente en la legislación anterior a su expedición, (Ley de Modernización del Estado, Ley de Presupuestos, reformas tributarias y administrativas, etc.), para que las transferencias y concesiones no se efectuaran excepcionalmente mediante ley, sino con procedimientos administrativos expeditos, controlados únicamente por la función ejecutiva.

Respecto del papel activo que la Constitución de 1978, asignaba al Estado el reconocimiento de cuatro sectores económicos. En el nuevo texto de la carta política de 1998 ya no se menciona a las "áreas de explotación reservadas al Estado", pues se abren

\footnotetext{
${ }^{195}$ La consulta popular fue convocada por el presidente interino Fabián Alarcón mediante Decreto $\mathrm{N}^{\circ}$ 201. Registro Oficial 38 de 7 de abril de 1997.

${ }^{196}$ Víctor Granda Aguilar, Derecho Económico Financiero Ecuatoriano, (Quito: Universidad Central del Ecuador, 2014); Los principales desafíos del Derecho Administrativo en el Ecuador de hoy, Salamanca, Curso de Especialización en Derecho, 2015.
} 
posibilidades para que el sector privado transnacional o local puedan acceder como propietarios a la explotación de los recursos naturales, a los servicios públicos, a las comunicaciones y a las empresas estratégicas. Como dice Juan Paz y Miño, si bien la Constitución señala que los recursos naturales no renovables son de propiedad "inalienable e imprescriptible" del Estado, en su hábil redacción jurídica dice que esos bienes "serán explotados en función de los intereses nacionales" y que en su exploración y explotación, "podrán ser llevadas a cabo por empresas públicas, mixtas o privadas de acuerdo con la ley" (Arts. 245 a 247). De igual manera la Constitución autoriza el acceso: a las frecuencias, al aprovechamiento de aguas, a la gestión del medio ambiente y su diversidad biológica, al igual que en los servicios públicos y la seguridad social, por parte de la iniciativa privada o a empresas mixtas, "mediante la concesión, asociación, capitalización, traspaso de propiedad accionaria o cualquier otra forma contractual de acuerdo con la ley" (Art. 249). ${ }^{197}$

La Constitución de 1998 recogió en su parte dogmática todos los derechos que en el marco internacional se le han reconocido a los ciudadanos en declaraciones y tratados. El enfoque general de la carta política es de profundo contenido individualista y propende, en lo fundamental, a concentrar el poder en el Ejecutivo y a propiciar una reforma económica neoliberal que limite a las potestades económicas del Estado reduciéndolas al control y vigilancia, mientras traslada al mercado y al sector privado las actividades económicas y los servicios públicos que antes privilegiadamente gestionaban las instituciones públicas nacionales y locales. En el contexto de debilitar el papel y la función intervencionista del Estado, la Constitución promueve además procesos de descentralización y desconcentración, lo que facilita la intervención más agresiva del sector privado en todo el sector público y, de forma específica, en los gobiernos locales.

Sobre la planificación, la Constitución ratificó la reforma parcial que se realizó en 1996 y 1997 para disminuir la importancia y autonomía que en las constituciones anteriores tenían los organismos de planificación y el plan nacional de desarrollo. La Constitución eliminó la competencia del vicepresidente de la República de presidir el Consejo Nacional de Desarrollo y dispuso que esa autoridad ejerciera las funciones asignadas por el presidente y que el organismo se convirtiera en una dependencia o una secretaría del titular de la función ejecutiva, para que los estudios y las políticas de desarrollo formaran parte del plan de acción y de la gestión financiera del presidente de turno. Es sintomática la constatación que al respecto hace Julio César Trujillo, quien afirma que entre 1998 y 2007, con cuatro jefes de Estado, no se formuló plan de desarrollo alguno. ${ }^{198}$

\footnotetext{
${ }^{197}$ Juan Paz y Miño Cepeda, "Constituyentes, Constituciones y Economía" en Asamblea Constituyente y Economía, Taller de Historia Económica, ADHILAC, Quito: ABYA YALA, 2007.

${ }_{198}$ Julio César Trujillo, "La Constitución económica, más allá del neoliberalismo", en Revista de Derecho FORO, $N^{\circ}$ 7, Universidad Andina Simón Bolívar, Quito, primer semestre de 2007.
} 
En el nuevo esquema económico de la Constitución correspondió definir y presentar al presidente de la República, cuando se posesiona en sus funciones, el plan de Gobierno y el informar anualmente a la Asamblea sobre su ejecución para requerirle las leyes y presupuestos que necesita para ese objeto (Art. 171, numeral 7). Esta disposición tiene la trascendencia de que por mandato constitucional se une la política de planificación definida exclusivamente por el presidente, con la de las finanzas públicas, en la que se prevén los ingresos, gastos y el control de los recursos públicos. Tanto la Ley de Presupuestos (1992) como la Ley Orgánica de Responsabilidad, Estabilización y Transparencia Fiscal (2002) establecen la obligación de equilibrio y sostenibilidad fiscal y presupuestaria mediante planes y programas anuales y aún plurianuales definidos por el presidente y no por organismo colegiado alguno.

El Sistema Nacional de Planificación, según lo manda la Constitución, tomando en cuenta las diversidades de edad, étnico-culturales, regionales y aún con enfoque de género, debe establecer los objetivos nacionales de manera permanente en materia económica y social; fijar las metas de desarrollo de corto, mediano y largo plazo que deben ser alcanzadas de manera descentralizada y orientar la inversión de manera obligatoria para el sector público y referencial para el sector privado (Art. 254). Es curioso, pero en el contexto de la frondosa literatura no consta la obligación de formular un Plan Nacional de Desarrollo, sino tan solo planes de desarrollo provincial o cantonal en coordinación con el sistema nacional.

El artículo 247 de la Constitución autoriza la concesión de la exploración y explotación de los recursos naturales a las empresas privadas nacionales o extranjeras o inversionistas, mediante contratos con cláusulas especiales de protección, por las que no podrán ser modificados por leyes u otros actos unilaterales del poder público (271). Otras normas de la Constitución autorizan al sector privado involucrarse a sí mismo en la explotación de bienes de dominio exclusivo del Estado (244.7) y en la provisión y prestación de los servicios públicos.

En cuanto a las finanzas públicas, la Constitución de 1998 establece como obligación del sistema de economía social de mercado "mantener una política fiscal disciplinada; fomentar el ahorro y la inversión; incrementar y diversificar las exportaciones y cuidar que el endeudamiento público sea compatible con la capacidad de pago del país" (244.9). Dedica la carta política, en su Título XII sobre el Sistema Económico: a la política económica, a las finanzas públicas, al endeudamiento, al presupuesto y al régimen tributario. Como dice José Vicente Troya, "existe una estrecha interrelación entre el sistema económico, las finanzas públicas y el sistema tributario que va de lo general a lo particular". 199

\footnotetext{
${ }^{199}$ José Vicente Troya Jaramillo, “Finanzas Públicas y Constitución en el Ecuador”, en Finanzas Públicas y Constitución, Juan Zormoza Pérez, coordinador, serie 6 de Fortalecimiento de la Justicia Constitucional en el Ecuador, Quito: Corporación Editora Nacional, 2004.
} 
En cuanto al régimen tributario se reconocen los principios de igualdad, proporcionalidad y generalidad y la potestad legislativa para establecer tributos, sobre los que el presidente tiene la reserva en su iniciativa; los gobiernos locales tienen competencia para establecer tasas y contribuciones mediante ordenanzas y el Ejecutivo para fijar o modificar las tarifas arancelarias.

Entre los principios tributarios, la Constitución no incluye el principio de progresividad que podría afectar a las personas que cuenten con mayores ingresos y bienes y dispone que los tributos no tengan sólo fines recaudatorios o fiscales, sino que sean instrumentos de política económica, para estimular la inversión, el ahorro, la inversión y su empleo en el desarrollo nacional para procurar una justa distribución de las rentas y la riqueza entre todos los habitantes del país (Art. 256).

Además de los recursos tributarios, constan en la Constitución normas relativas a los provenientes del crédito público, pues en todos los países se los requiere frecuentemente, a diferencia de la escuela clásica, que los consideraba excepcionales. En las finanzas públicas se demandan masivamente recursos que provienen del endeudamiento externo e interno $\mathrm{y}$, dado el impacto que estas operaciones tienen en la economía nacional y en los presupuestos del Estado, es necesario que su autorización, límites y gestión se encuentren debidamente regulados de manera general por la Constitución.

La carta política de 1979, a tono con la política internacional de facilitar el ingreso de capitales financieros y en especial en los países subdesarrollados, suprimió la intervención del Congreso en los procesos de endeudamiento y ello provocó una explosión de los mismos por parte de los gobiernos de turno, desatando crisis agudas por la imposibilidad de pagar y amortizar la deuda. Esta realidad aceleró el colapso de los sistemas estatistas burocráticos en el mundo en la década del ochenta y abrió las puertas a las políticas neoliberales para desmantelar las actividades económicas del Estado y regular sus finanzas públicas con la finalidad de asegurar las exigencias de pago del capital financiero internacional.

La Constitución de 1998 restableció la potestad del Congreso (Art. 130, numeral 14) de fijar el límite del endeudamiento público de acuerdo con la Ley, a la vez que ratificó la competencia del presidente de la República para decidir y autorizar la contratación de los empréstitos. También la Constitución estableció ciertas restricciones al disponer que no se podía financiar gastos corrientes con endeudamiento público (Art. 259); que éste debía ser compatible con la capacidad de pago del país y que el Banco Central no podía conceder crédito a las instituciones del Estado ni adquirir obligaciones emitidas por ellas, salvo en casos de emergencia (Art. 265). ${ }^{200}$ La legislación financiera expedida para aplicar las normas constitucionales antes indicadas serán analizadas más adelante.

${ }^{200}$ José Vicente Troya Jaramillo, "Finanzas Públicas y Constitución" en La estructura constitucional del Estado ecuatoriano, Santiago Andrade y otros, editores, Centro de Estudios Políticos y Sociales de España, Quito: UASB, CEN, 2005. 
En materia presupuestaria, la Constitución de 1998 recuperó las reformas constitucionales de inspiración neoliberal para concentrar en el Ejecutivo la iniciativa de la formulación, asignación de recursos, reforma y ejecución del presupuesto, marginando a la función legislativa y a los legisladores a una dimensión formal en la aprobación del presupuesto y sus reformas, pues no podían modificar los ingresos y mucho menos incrementar los gastos públicos. La Constitución dispone que si no se tramita la proforma dentro de los límites temporales establecidos, entra en vigencia por ministerio de la ley (Art. 258).

La Constitución de 1998 estableció también que en los Presupuestos del Estado debe observarse el principio de universalidad para que consten en él todos los ingresos y gastos del sector público, excepto los que correspondan a los organismos del régimen seccional autónomo y a las empresas públicas; que ningún organismo público puede ser privado del presupuesto necesario para cumplir con los fines y objetivos para el que fue creado; que se debe informar al Congreso de la ejecución y liquidación presupuestaria y que solo para defensa nacional se destinarán fondos de uso reservado (Art. 259).

También la referida carta política dispuso que las asignaciones para el régimen seccional autónomo no podían ser inferiores al $15 \%$ de los ingresos corrientes totales del presupuesto del Gobierno central y que debían ser distribuidos de acuerdo al número de habitantes, necesidades insatisfechas, capacidad contributiva, logros en el mejoramiento de los niveles de vida y eficiencia administrativa (Arts. 231 y 232.2). La Constitución autorizó a los gobernantes cierta amplitud y discrecionalidad en el gasto, a la vez que dispuso una asignación para educación y erradicación del analfabetismo, del $30 \%$ de los ingresos corrientes del Gobierno central (Art. 96).

La Constitución de 1998 ordenó también que el sector bancario y financiero se mantuvieran regulados por el Estado por medio de la Superintendencia de Bancos y, en sus disposiciones transitorias determinó insólitamente, con manifiesta dedicatoria a lo que iba a ocurrir en el corto plazo, que el Banco Central quedaba autorizado para otorgar a las instituciones financieras, en el plazo de dos años y "hasta que cuente con instrumentos legales adecuados para enfrentar crisis financieras", "créditos de estabilidad y de solvencia", "para atender el derecho de preferencia de las personas naturales depositantes en las instituciones que entren en proceso de liquidación". ${ }^{201}$

Aplicando esa norma, el Congreso Nacional, aprobó de inmediato, y por iniciática del Gobierno y de sus aliados parlamentarios, una Ley que eliminó el impuesto a la renta y creó un tributo a la circulación de capitales y una Agencia de Garantía de Depósitos de manera ilimitada, para enfrentar la preanunciada crisis bancaria, cuyo costó, para el

201 Constitución Política de la República del Ecuador 1998, Disposición Transitoria cuadragésima segunda, aprobada el 5 de junio de 1998 y entró en vigencia el 10 de agosto de 1998, Gaceta Constitucional, 2008. 
Estado y los ecuatorianos, fue estimado por la misma entidad, al 31 de diciembre de 2005, en la suma de 8.003 millones de dólares, una tercera parte del PIB. ${ }^{202}$

Para cumplir con su cometido fundamental de adoptar el modelo neoliberal, impuesto por la carta de intención suscrita con el FMI en $1994^{203}$ y las recomendaciones de los organismos financieros internacionales, la Constitución de 1998 reforzó la concentración de las potestades económicas y administrativas en la Función Ejecutiva, como ya lo hicieron inicialmente las reformas constitucionales y legales hasta $1997 \mathrm{y}$ estableció un blindaje a la más alta estructura y cúspide del Gobierno; limitó el control político del Congreso Nacional a los mandatarios del país; eliminó dicho control a la función judicial, para cubrir las apariencias, amplió las atribuciones de control externo de la Contraloría General del Estado y autorizó el funcionamiento simbólico de una instancia para el control social y ciudadano, denominada Comisión de Control Cívico de la Corrupción.

\subsection{La Constitución de 2008 y las enmiendas de 2015}

Rafael Correa fue elegido presidente en 2007 como resultado de un enfrentamiento social e ideológico a las consecuencias económicas y sociales del neoliberalismo, que se expresó en el derrocamiento de Lucio Gutiérrez y numerosas movilizaciones sociales y medidas adoptadas en el Gobierno de Alfredo Palacio. Para implementar un nuevo modelo económico y político posneoliberal o neodesarrollista o neointervencionista que anunció oficialmente el Gobierno, se convocó a una consulta popular el 15 de abril de 2007; luego de la cual se reunió la Asamblea Nacional Constituyente que emitió una nueva Constitución en 2008, la misma que se aprobó en referéndum el 20 de octubre de $2008 .^{204}$

La Constitución y el proceso constituyente se sometieron a una importante movilización social que fue influyente en el contenido de sus textos finales. En las últimas reuniones del poder constituyente se incluyeron textos que eran de conveniencia directa de los sectores de presión y fueron resultado de la imposición de los asesores cercanos al presidente Correa, quienes modificaron los textos en el último momento, tal y como lo denunciaron varios asambleístas constituyentes y en concreto León Roldós, ex candidato presidencial. $^{205}$

\footnotetext{
${ }^{202}$ Granda Aguilar Víctor, y Jorge Rodríguez Torres, Petición de reapertura del sumario en el juicio $\mathrm{N}^{\mathrm{o}}$ 044-2000, presentada en audiencia extraprocesal en la Corte Suprema de Justicia el 14 de diciembre de 2006, con los correspondientes documentos de respaldo.

${ }^{203}$ Carta de Intención del Ecuador con el Fondo Monetario Internacional, marzo 31 de 1994.

${ }^{204}$ Constitución de la República del Ecuador, 2008, Registro Oficial 449 del 20 de octubre de 2008.

205 León Roldós, presentó una denuncia por falsificación ideológica, que buscaba sancionar a los responsables intelectuales del supuesto fraude que se habría cometido en la aprobación de los textos constitucionales en la Asamblea Constituyente, ante el entonces fiscal general, Washington Pesantez, https://www.eluniverso.com/2008/08/27/0001/8/97859FDB3F 774283ABE1 642 1F05A FB8 7.html
} 
En la Constitución existen ampliamente desarrolladas, en forma dispersa, varias normas de contenido económico relativas a garantías individuales y colectivas que se ofrecen a todos los ciudadanos, y de manera sistemática, en las secciones destinadas al régimen de desarrollo y al régimen del buen vivir, se encuentran las principales definiciones y orientaciones para afianzar el régimen o el sistema económico imperante o el alternativo que discretamente se propone, desde el ejercicio de la soberanía económica, la planificación, las finanzas públicas y las normas de control que son el objeto central de esta investigación.

Esta Constitución, reforzando el hiperpresidencialismo y el autoritarismo del Ejecutivo presente en las normas vigentes durante el predominio del modelo neoliberal hasta 2006, dispone, como una atribución expresa del presidente de la República, “dirigir la Administración pública en forma desconcentrada y expedir los decretos necesarios para su integración, organización, regulación y control", lo que sirve de argumento para asumir, igual que en la etapa neoliberal, no solo la potestad organizatoria de la administración pública, sino también ciertas acciones de control interno mediante reformas al Estatuto de Régimen Jurídico de la Función Legislativa, que surgió primero como una ley delegada expresa y luego se transformó en un reglamento autónomo, modificando la potestad de la función legislativa de normar mediante ley orgánica las competencias, los sistemas de organización y los procedimientos administrativos de la Administración Pública que dirige el presidente de la República. ${ }^{206}$

La Constitución de 2008, por las razones políticas y económicas ya indicadas, reduce mucho más las potestades de control político de la Asamblea Nacional, que ahora sustituye al Congreso Nacional, si bien mantiene formalmente una norma general por la que se le atribuye aprobar los Presupuestos Generales del Estado, en la que constará el límite del endeudamiento público y vigilar su ejecución” y amplía, supuestamente para renovar la imagen del régimen en la lucha contra la corrupción, el control técnico y social externo mediante la creación de una nueva función del Estado, la función de Transparencia y Control Social, en la que se integran los órganos técnicos de control como la Contraloría, las superintendencias, la Defensoría del Pueblo y un Consejo de Participación Ciudadana y Control Social con el que se estataliza el control social y ciudadano.

La Constitución declara también como imprescriptibles los delitos de corrupción (peculado, cohecho, concusión, y enriquecimiento ilícito), permite su juzgamiento en ausencia y extiende la responsabilidad a los particulares que hayan participado o se hayan beneficiado de aquellos y amplía significativamente el concepto de responsabilidad, que no solo la tienen todos los funcionarios y personas que manejen recursos públicos, sometidos a los controles internos y externos de los órganos públicos o sociales en el ámbito administrativo, civil y penal, sino también el propio Estado,

\footnotetext{
206 Víctor Granda Aguilar, Proyecto de Código Administrativo (I), Boletín Electrónico Spondylus U.A.S.B., Quito, 30 de junio de 2016.
} 
mediante la denominada responsabilidad objetiva, que puede ser reclamada directamente por los ciudadanos, cuando el Estado y sus agentes les han ocasionado daño.

Esa responsabilidad objetiva no solo la asume el Estado sino también los "concesionarios y todos los que actúen ejerciendo potestad pública", por deficiencia, negligencia en los servicios públicos; deficiencias en el servicio y calidad de productos y "por acciones u omisiones de los funcionarios en el desempeño de sus cargos", incluyendo "el error judicial, detención arbitraria, retardo o inadecuada administración de justicia, violación de derecho a tutela judicial y violación a reglas del debido proceso" o "quebrantamiento de la ley". Según la Constitución, por dichas faltas y violaciones de derechos, el Estado y las instituciones que lo representen estarán obligados a reparar el daño y luego ellos ejercerán el correspondiente derecho de repetición, a los servidores públicos o a quienes ejerzan potestad pública que los hayan ocasionado, pues ninguno de los funcionarios está exento de responsabilidad por su actos y omisiones. ${ }^{207}$

\subsubsection{El contenido económico y financiero de la Constitución 2008}

Como hemos indicado, el contenido económico principal de la Constitución del Ecuador actualmente vigente lo encontramos desde sus primeros artículos en los que se fija como uno de los "deberes primordiales del Estado": promover y planificar el desarrollo sustentable del país de manera "solidaria", con la finalidad de "erradicar la pobreza" y alcanzar "la redistribución equitativa de los recursos y la riqueza" y en otras normas que se refieren a los derechos y garantías de los ciudadanos. ${ }^{208}$

Pero el principal contenido económico de la carta política lo encontramos desarrollado de manera extensa en los títulos VI y VII, relativos al régimen de desarrollo y al régimen del buen vivir.

Para efectos de este estudio nos referiremos del título VI, al régimen de desarrollo y al sistema económico que se pretenden construir en el país; a la intervención y papel del Estado en la economía; al ejercicio de la soberanía en las políticas públicas macro y microeconómicas allí establecidas, especialmente a las relacionadas con la planificación, las finanzas públicas y el sistema de control y a la política autoritaria y de concentración de poder que hizo posible el presente y el anterior modelo económico.

Las regulaciones, potestades y límites sobre la actividad financiera, sobre todo los ingresos, gastos, planificación y control, tienen particular importancia, ya que están relacionadas con el ejercicio directo y pleno de los derechos y con el supuesto objetivo de desarrollar privilegiadamente un sistema económico social y solidario.

\footnotetext{
${ }^{207}$ Ecuador, Constitución de la República del Ecuador 2008, arts. 11, 53, 54, 97, 172, 233.

${ }^{208}$ Ecuador, Constitución de la República del Ecuador 2008, art. 3, num. 5 y 6; arts. 12, 14, 26, 30, 32.
} 
Es necesario enfatizar que el argumento financiero de la Constitución es clave en su real contenido económico, pues en él confluyen las obligaciones de los ciudadanos y del Estado y sus instituciones para satisfacer los derechos económicos, sociales y culturales de la población.

Si bien De la Garza señala que el contenido del Derecho financiero y de las normas constitucionales que lo fundamentan comprende tres fases: la imposición de tributos patrimoniales del Estado y la erogación de los recursos o gastos públicos, nosotros en este estudio nos limitaremos a analizar las normas y políticas relacionadas con las recaudaciones, la gestión y el gasto de los medios necesarios para que el Estado cumpla con sus obligaciones y su relación con la planificación y el control en el período de análisis. $^{209}$ Es necesario también que las referidas normas financieras las articulemos con base en reflexiones sobre el régimen de desarrollo, la intervención del Estado en la economía y el autoritarismo presidencialista utilizado para imponer los modelos económicos y financieros actuales.

\section{a) El régimen de desarrollo y el sistema económico}

El Título VI de la Constitución del 2008 diferencia régimen de desarrollo de sistema económico. Define régimen de desarrollo como "el conjunto organizado, sostenible y dinámico de los sistemas económicos, políticos, socio-culturales y ambientales que garantizan la realización del buen vivir, del sumak kawsay" y no lo hace con el término o el concepto sistema económico, si bien se refiere al sistema que se pretende construir como "social y solidario".

El concepto "régimen de desarrollo" entraña una "definición integral del mismo", conforme lo destacan Agustín Grijalva y María Elena Jara, ${ }^{210}$ pues vincula de manera global los sistemas económicos, políticos, socio culturales y ambientales, todos ellos dentro del proyecto del buen vivir, para lo cual existe una sección de la propia Constitución (la VII) en la que se regulan sus dimensiones y se las relaciona con la equidad y la inclusión (en educación, salud, seguridad social, hábitat, vivienda, cultura, cultura física, tiempo libre, comunicación social, ciencia, tecnología, innovación, saberes ancestrales, gestión de riesgo, población, movilidad, seguridad humana y transporte); con la biodiversidad y los recursos naturales (naturaleza, ambiente, biodiversidad, patrimonio natural, ecosistemas, suelo, agua, biósfera, ecología urbana y energías alternativas).

El régimen de desarrollo, según la Constitución vigente, tiene que alcanzar los objetivos estratégicos de mejorar la calidad y esperanza de vida; construir un sistema económico justo, democrático, productivo, solidario y sostenible; fomentar la participación y

\footnotetext{
${ }^{209}$ Sergio de la Garza, Derecho Financiero Mexicano, (México: Porrúa, 1985).

${ }^{210}$ Agustín Grijalva y María Elena Jara, en Estado, Derecho y Economía, (Quito: Estudios Jurídicos 35 y 33, UASB, CEN, 2013).
} 
control social; recuperar y conservar la naturaleza; garantizar la soberanía nacional, la integración y la inserción en el contexto internacional; promover el ordenamiento territorial equilibrado y equitativo que coadyuve a la unidad del estado y proteger y promover la diversidad cultural, la memoria social y el patrimonio cultural. ${ }^{211}$

En este régimen global de desarrollo se asigna al nuevo sistema económico no solo los calificativos iniciales de social y solidario, sino también de "justo, democrático, productivo y sostenible"; puesto que, según la carta constitucional, se "reconoce al ser humano como sujeto y fin" del mismo y "propende a una relación dinámica y equilibrada entre sociedad, Estado y mercado, en armonía con la naturaleza"; "tiene por objetivo garantizar la producción y reproducción de las condiciones materiales e inmateriales que posibiliten el buen vivir" 212 y está "basado en la distribución igualitaria de los beneficios del desarrollo, de los medios de producción y en la generación de trabajo digno y estable". ${ }^{213}$

Esto es, se plantea que dicho sistema económico social y solidario se construirá no solo mediante la producción y reproducción, sino también mediante una redistribución de beneficios y medios de producción, observando para ello normas de sustentabilidad y equidad, lo que parece ser el mayor esfuerzo para otorgar a dicho modelo económico un carácter alternativo al existente, así sea de manera vaga y sin mayor precisión.

Parece importante subrayar también que el nuevo sistema económico "propende a una relación dinámica y equilibrada entre sociedad, Estado y mercado" y que, en ese contexto, se integran, según la misma norma, las cuatro formas principales de organización económica: pública, privada, mixta, popular y solidaria (sectores cooperativistas, asociativos y comunitarios) y las demás que la Constitución determine.

La Constitución, sin embargo, no define dichas formas de organización económica, pero se entiende que cuando se menciona a la pública se refiere a la ejecutada por el Estado; a la privada por las empresas y los particulares; a la mixta, que combina propiedad pública con la privada y/o comunitaria y a la popular y solidaria que es la efectuada por los sectores cooperativistas, asociativos y comunitarios y a otra formas que serían las que ley regule, sin que queden identificados sus protagonistas.

¿El sistema económico social y solidario de Ecuador a qué sistema real o estructura económica y social identificable en la historia y en la realidad se inscribe? ¿En el capitalista, bajo un modelo liberal, estructuralista o keynesiano o de bienestar, neoliberal o de libre mercado, neoestructuralista o neodesarrollista o posneoliberal? ¿Se trata de un sistema de socialismo de Estado? ¿Se construye en realidad o se puede construir un nuevo sistema alternativo, diferente a los existentes, que podría ser el de un nuevo socialismo, calificado en Ecuador como biosocialismo republicano o socialismo

\footnotetext{
${ }^{211}$ Ecuador, Constitución de la República del Ecuador 2008, art. 276.

${ }^{212}$ Ecuador, Constitución de la República del Ecuador 2008, art. 283.

${ }^{213}$ Ecuador, Constitución de la República del Ecuador 2008, art.276, num. 2.
} 
del buen vivir, o como algunos precipitadamente lo han denominado socialismo del siglo XXI, que cuando se les pregunta en qué consiste el sistema propuesto dicen que es un concepto en construcción?

La Constitución ecuatoriana habla de un régimen de desarrollo y de un sistema económico y no de un modelo económico. La mayoría de constituciones del Ecuador no han definido régimen, sistema o modelo económico, dentro del cual han estado vigentes o que se proponen construir, salvo las de 1998 y 2008. Las constituciones anteriores a las antes indicadas no se han referido a este importante asunto porque lo han dado por supuesto y, en verdad, su propósito tampoco era el de modificarlo o cambiarlo, sino más bien el de apuntalarlo con las normas constitucionales y legales que se llegaron a dictar con esa finalidad.

La Constitución de 1998 es la primera que se refiere de manera abstracta al sistema económico que pretendía implantar, como de economía social de mercado, si bien de hecho sus políticas, esto es propiamente el modelo económico, ya las venían aplicando con las leyes expedidas al respecto, por el Gobierno de Sixto Durán desde 1992. De esta manera quedó justificada, confundiendo intencionadamente sistema y modelo, la orientación neoliberal de la Constitución destinada a favorecer al mercado y a la empresa privada, principalmente transnacional y para consolidar el empeño de los sectores económicos y políticos dominantes de entonces, para limitar o eliminar la intervención del Estado en la economía y en los servicios públicos para privatizarlos a favor especialmente del capital transnacional.

Como ya se mencionó anteriormente, la Constitución del 2008 solo diferencia régimen de desarrollo de sistema económico pero lo identifica a como social y solidario. Para Grijalva la denominación al sistema económico de social y solidario implica un cambio de enfoque en la economía nacional, pues su carácter social "lleva a la regulación del mercado y a la democratización tanto de la propiedad como las decisiones en pos de una economía efectivamente más igualitaria que corresponda a los fines del Estado social" y "la introducción progresiva de la solidaridad en los procesos económicos, incluyendo los de mercado, tiende a generar procesos de eficiencia sistémica o social". ${ }^{214}$

Por otra parte, la Constitución de 1998 en su artículo 242 también disponía que "la organización y el funcionamiento de la economía (social de mercado) responderán a los principios de eficiencia, solidaridad, sustentabilidad y calidad, a fin de asegurar a los habitantes una existencia digna e iguales derechos y oportunidades para acceder al trabajo, los bienes y servicios y a la propiedad de los medios de producción”. Si de declaraciones se trata, como se puede advertir, no hay mucha diferencia entre los objetivos del sistema económico social y solidario y el sistema económico social del mercado.

\footnotetext{
214 Agustín Grijalva, "La Constitución Económica del Ecuador” en Estado, Derecho y Economía, 35, (Quito: UASB, CEN, 2013).
} 
En todo caso, nosotros estimamos que si bien la denominación sugiere reformas o cambios de enfoque en el sistema económico, ello no implica necesariamente una sustitución alternativa; la denominación no deja de ser también una forma camuflada para no referirse abiertamente al sistema imperante y para darle una connotación que lo diferencie de la Constitución anterior.

Según la Constitución, el indefinido sistema económico social y solidario, lleno de lugares comunes, utilizados por todas las corrientes económicas y en especial en los discursos políticos, integra de todas maneras a las diferentes formas de organización económica que existen en el país y persigue "reconocer al ser humano como sujeto y fin" y establecer una relación "dinámica y equilibrada entre sociedad, Estado y mercado, en armonía con la naturaleza", para "garantizar la producción y reproducción de las condiciones materiales e inmateriales que posibiliten el buen vivir".

La Constitución ecuatoriana, según nuestra opinión, utiliza la ambigüedad para conciliar y consolidar las relaciones de producción y las formas de organización económica y de propiedad existentes (pública, privada, mixta, estatal, comunitaria, asociativa y cooperativa o popular y solidaria), poniendo énfasis en la indicada relación equilibrada entre sociedad, estado, mercado y naturaleza, para establecer distancias con la Constitución anterior, que le daba hegemonía al mercado, sin dejar de señalar que, en los dos textos, su finalidad es coincidente: el "buen vivir" (2008) o "asegurar a los habitantes una existencia digna e iguales derechos y oportunidades...” (1998).

En Ecuador podemos constatar que la estructura jurídica de la Constitución del 2008 y las políticas públicas del Gobierno siguen en lo principal los mismos lineamientos que las anteriores constituciones liberales ya que no se crean ni modifican las instituciones necesarias para superar la tradicional exclusión de las mayorías sociales, por lo que tenemos la percepción que otras declaraciones progresistas como la del Estado plurinacional e intercultural fueron una formalidad, sin mayor comprensión política e histórica, y que tienen igual significado que las otras características enunciativas del Estado y que, por lo tanto, no constituye una definición seria que pueda convertirse en el eje de un sistema o de un modelo alternativo, con consecuencias significativas en el campo jurídico y mucho menos en la actividad económica, política e institucional del poder público.

La Constitución ecuatoriana contiene, sin embargo, varias disposiciones orientadas a fortalecer económicamente la economía popular y solidaria en la que se incluye la comunitaria, la asociativa y cooperativa, mediante políticas públicas y recursos financieros, sin que eso signifique que se impongan normas constitucionales claras o categóricas que hagan de aquella el eje de una transformación económica y social. Esto es, la Constitución se queda corta para propender a la definición o a la construcción de un modelo y mucho menos de un sistema económico de desarrollo alternativo al vigente. 
El sistema económico social y solidario, sin embargo, no pretende superar los parámetros y límites fundamentales del sistema capitalista internacional ni alterar el proceso de acumulación mundial en sus diferentes polos de globalización que existen en la actualidad y mucho menos pretende trasformar internamente las relaciones de producción dominantes. En Ecuador se mantienen y reproducen las relaciones económicas y sociales de dominación y exclusión, si bien el Estado y el Gobierno, con sus programas e inversiones, han redistribuido parcialmente la riqueza nacional; han mejorado la infraestructura y los servicios; han atendido de mejor manera la salud, la educación, la seguridad social y han disminuido el desempleo, el subempleo y la migración. Las reformas se convierten en un instrumento para la consolidación y reproducción del sistema imperante.

Está claro que la Constitución de Ecuador se refiere al sistema económico como social y solidario. En ningún momento esa definición se encuentra asociada a la proclamación de la plurinacionalidad ni a una hegemonía de la economía popular y solidaria. Así lo ratifican las acciones y ejecutorias del Gobierno en los últimos años, en las que se advierte su acelerado abandono para construir una alternativa sistémica al capitalismo en Ecuador, ya que no están destinadas a impulsar al desarrollo de las unidades de "la economía popular y solidaria" sino a su control y reglamentación, tal como se advierte en el contenido de los planes nacionales del buen vivir del período 2009-2013 y del 2013-2017. Según Silvia Vega: "las prioridades y el cambio de enfoque de los dos planes muestra un desplazamiento conceptual entre el primero y el segundo, desde concebir la economía social y solidaria como vector de transformaciones más amplias del sistema económico a concebirla como un sector económico más junto con el de la economía pública y privada en el marco del cambio de la matriz productiva que cobra relevancia principal". ${ }^{215}$

Al limitado apoyo del régimen ecuatoriano a la economía popular y solidaria se suma la actitud represiva del régimen hacia las demandas de las comunidades y pueblos indígenas y campesinos, evidenciando también que aquella y la definición de Estado plurinacional e intercultural, se encuentran ideológica, política y materialmente cada vez más lejanas de la realidad. Incluso la definición inicial de Estado constitucional de derechos y justicia paulatinamente resulta incómoda para un modelo económico que en la práctica se torna en excluyente y autoritario, pues pese a la resistencia social va acumulando más poder en la función ejecutiva y se desconocen aceleradamente los derechos de la naturaleza para privilegiar actividades extractivas; se depreda el medioambiente y se propende al uso de genéricos, para lo cual el presidente Correa anunció en el último año de su Gobierno una posible nueva enmienda constitucional que limite esos derechos o para darles lo que según él sería su "verdadero significado".

Si bien el texto constitucional ecuatoriano de 2008 se refiere también a "relaciones dinámicas y equilibradas" entre los diversos sectores de la economía y se reconoce en el

${ }^{215}$ Ibídem, 20 y 21. 
sistema ciertos privilegios a la economía "popular y solidaria", que podrían ser el eje de una supuesta propuesta alternativa para construir un "biosocialismo republicano" o para el "socialismo del buen vivir", el discurso del Gobierno y sus principales ejecutorias han evolucionado en los últimos años hacia la propuesta del "cambio de la matriz productiva" que pretende ser el eje vertebrador del neocapitalismo que en realidad está empeñado en construir. Que el neocapitalismo se disfrace de "socialismo comunitario" o "socialismo democrático" no es ninguna novedad ideológica en la historia política del siglo pasado. ${ }^{216}$

No debemos dejar de reconocer que en torno a la economía popular y solidaria, así como a la economía comunitaria, particularmente en Bolivia, existen valiosos planteamientos como los del brasileño Paul Singer, Aníbal Quijano, José Luis Coragio, que apuntan a construir, partiendo de ellas, un sistema económico alternativo, y que las constituciones de sendos países podrían permitir, con dicha formulación y la gestión de gobiernos genuinamente progresistas, su desarrollo o por lo menos una democratización de la economía o la construcción de una democracia radical.

Hay que recordar que los principales voceros del anterior Gobierno ecuatoriano insistieron en que el país ha realizado "no una sino cinco revoluciones o más", y que ellas sacaron a Ecuador de la "larga noche neoliberal" para avanzar hacia un "socialismo del siglo XXI" que según ello está supuestamente en "proceso de construcción".

Pero las propuestas progresistas que animaron inicialmente el texto constitucional sobre un modelo económico alternativo, paulatinamente han sido desechadas definitivamente de la práctica y de la gestión gubernamental, como se puede advertir en el contenido de las políticas públicas y en los vigentes planes de desarrollo que se han convertido, como hemos dicho, en instrumentos privilegiados de mejoramiento y modernización del sistema capitalista privado transnacional y nativo.

En este sentido, si se revisa a fondo la gestión económica del Gobierno de Correa hasta 2017, se puede llegar a la conclusión de que sus propósitos transformadores al respecto son totalmente limitados, aunque existen declaraciones, normas e instituciones que se han emitido o creado para el efecto. Los proyectos alternativos del régimen han quedado marginalizados de su actividad y gestión económica principal, concentrada más bien en el extractivismo, en la negociación con el capital transnacional, en el cambio de la matriz productiva y en la integración al mercado mundial. ${ }^{217}$

Debe destacarse también que dada la permanencia en el poder del Gobierno de Alianza País por más de diez años, en los que han obtenido repetidos éxitos electorales y

\footnotetext{
${ }^{216}$ Manuel Agustín Aguirre, Dos Mundos dos Sistemas, Quito, Colección Pensamiento Socialista Volumen 1, estudio introductorio de Víctor Granda Aguilar, Ediciones La Tierra, 2006.

${ }^{217}$ Silvia, Vega, ¿Es la Economía Social y Solidaria una Alternativa a la Economía Capitalista?, monografía, FLACSO, 2013.
} 
expedido la nueva Constitución de 2008, Ecuador ha logrado una inédita estabilidad política y económica que, a su vez, ha permitido que los sectores dominantes (financiero y económico) hayan obtenido mayores utilidades que en el pasado y que el nivel de consumo, de ingresos y satisfacción de necesidades de los ecuatorianos sea mayor. ${ }^{218}$

Por tanto, en el siglo XXI se construye en Ecuador, más que un socialismo del siglo XXI, un neocapitalismo nacional, articulado regionalmente a los diferentes polos de la globalización capitalista mundial, pues lo del biosocialismo republicano no es más que un discurso que no tiene sustento en la realidad ni en las acciones o inversiones principales del Gobierno.

Es así que resulta correcta la percepción del tibio papel desempeñado por el progresismo latinoamericano en las modificaciones constitucionales y en la transformación de la realidad de los países en los que su política fue hegemónica, lo que se expresa en su despreocupación por modificaciones democráticas profundas en la institucionalidad estatal y en la no incorporación de la participación social en las decisiones y en la gestión pública. En la gestión de los gobiernos identificados con esa corriente son manifiestas las medidas represivas y de criminalización de la lucha social y sus dirigentes por sus impugnaciones al modelo económico y financiero y al extractivismo de las empresas transnacionales, bajo la égida del caudillismo presidencial y de una retórica izquierdista que no cambia en lo más mínimo la realidad, sino que consolida la dominación externa e interna del capital. ${ }^{219}$

\section{b) El papel o función del Estado en la economía}

Por el contrario, la Constitución de 2008 de Ecuador asigna al Estado un papel protagónico en el campo económico, no solo en la recuperación de las actividades relacionadas con la explotación de los recursos naturales y en especial en materia petrolera y minera, sino también con el campo de la prestación de servicios públicos y la preservación del medioambiente, en pro de lograr el ingreso de mayores recursos que se puedan destinar a los propósitos políticos del régimen y asignarlos al nuevo modelo que se pretende construir, todo ello sin alterar severamente los parámetros de la acumulación capitalista nacional e internacional.

La carta política de Montecristi devuelve al Estado su papel de interventor y regulador de la economía, disminuido por la Constitución de 1998 y en la leyes entonces vigentes, y lo incrementa con nuevas normas de carácter general sobre su función, asignando, en el derecho constitucional ecuatoriano, a la planificación y a las políticas púbicas económicas y sociales un carácter vinculante, antes no establecido para las estructuras, órganos y decisiones del Estado.

\footnotetext{
218 Alberto Acosta y varios autores, Prólogo en "El Correísmo al Desnudo", Quito, 2013.

${ }^{219}$ Roberto Gargarella, Pensando sobre la Reforma Constitucional en América Latina, en El Derecho en América Latina, Coord. César Rodríguez Garavito (Buenos Aires: Siglo Veintiuno Editores, 2011).
} 
Ese papel rector del Estado queda establecido en la Constitución del 2008 en el artículo 277, tanto para "garantizar los derechos de las personas, las colectividades y la naturaleza" como para "dirigir, planificar y regular el proceso de desarrollo". En virtud de esta función económica se le asignan los deberes de "producir bienes, crear y mantener infraestructura y proveer servicios", lo que significa restablecer sus potestades económicas restringidas en el período neoliberal y además de ello ratificar su misión, para impulsar el desarrollo de todas las actividades económicas de los otros sectores comunitarios, cooperativos, asociativos y privados, mediante la legislación y las instituciones estatales, así como en el papel de promotor e impulsor de la "ciencia, la tecnología, las artes, los saberes ancestrales”.

La actual Constitución restablece y amplía la planificación como una obligación general del Estado, cuyos objetivos son: dirigir y regular "el desarrollo del país"; "garantizar el ejercicio de derechos"; la consecución de los objetivos del régimen de desarrollo y los principios consagrados en aquella; propiciar la "equidad social y territorial" y la “concertación". La misma norma enumera las características de la planificación que será "participativa, descentralizada, desconcentrada y transparente". 220

La carta política de 2008 (Art. 279) y luego el Código Orgánico de Planificación y Finanzas $^{221}$ disponen la conformación de un Consejo Nacional de Planificación presidido por el presidente de la República; una Secretaría Técnica desempeñada por el secretario nacional de Planificación y Desarrollo; los consejos de planificación en los gobiernos autónomos descentralizados presididos por sus máximos representantes y los consejos ciudadanos como instancias de deliberación y generación de lineamientos y consensos estratégicos de largo plazo.

El Consejo Nacional de Planificación dicta las políticas que orientan el sistema y, fundamentalmente, el Plan Nacional de Desarrollo, que "es el instrumento al que se sujetarán las políticas, programas y proyectos públicos; la programación y ejecución del presupuesto del Estado; y la inversión y la asignación de los recursos públicos; la coordinación de las competencias exclusivas entre el Estado central y los gobiernos autónomos descentralizados". La misma norma dispone "que el Plan Nacional de Desarrollo es de observancia obligatoria para el sector público e indicativo para los demás sectores". 222

Por ese motivo el instrumento principal de la conducción económica, financiera y política del Estado es el Plan Nacional de Desarrollo, al que se someten obligatoriamente todas las instituciones públicas, no solo de la administración central o institucional, sino las de los gobiernos autónomos descentralizados y todas las entidades que ejercen una potestad estatal incluyendo las universidades y escuelas politécnicas

\footnotetext{
${ }^{220}$ Ecuador, Constitución de la República del Ecuador 2008, art. 275 segundo inciso y 277 num. 2.

${ }^{221}$ Ecuador, Código Orgánico de Planificación y Finanzas, Registro Oficial 306 del 22 de octubre de 2010.

${ }^{222}$ Ecuador, Constitución de la República del Ecuador 2008, art. 280.
} 
cuya autonomía, al igual que la de los GADS, queda reducida a la retórica y limitada para su organización, administración interna y cumplimiento de sus funciones específicas.

Para fortalecer el papel de la planificación en la política gubernamental se la asocia a las finanzas públicas, al quehacer de la totalidad del sector público y, obviamente, a la satisfacción de los derechos individuales y sociales. En Ecuador tiene vital importancia el manejo casi absoluto del presidente de la República en la iniciativa, formulación, aprobación, ejecución y reformas, tanto de los ingresos públicos como del Presupuesto General del Estado, que por mandato constitucional queda íntimamente asociado a la planificación y a los planes de desarrollo definidos por el mismo mandatario.

Se reafirma además el papel soberano del Estado en la economía, en el control de los recursos naturales y en la regulación de la propiedad y uso de la tierra y el agua. De igual manera, la Constitución se refiere a la soberanía alimentaria -entendida esta como la autosuficiencia de alimentos sanos y culturalmente apropiados a la que deben acceder las personas, comunidades y pueblos y nacionalidades del país-, y establece que alcanzarla es para el Estado un "objetivo estratégico y una obligación", por lo que es de su responsabilidad emprender en varias actividades, políticas, fiscales, tributarias, arancelarias, tecnológicas, y en iniciativas de impulso y financiamiento a la producción y transformación agroalimentaria y pesquero nacional, especialmente las que ejecuten las pequeñas y medianas unidades económicas.

En ese mismo contexto, el Estado se propone "fortalecer el desarrollo de organizaciones y redes de productores y consumidores, así como las de comercialización y distribución de alimentos que promuevan la equidad entre espacios rurales y urbanos", impidiendo "prácticas monopólicas", la "especulación con productos alimenticios" y el consumo de "alimentos contaminados". 223

Afirmando el papel rector del Estado y para asegurar ingresos solventes para el cumplimiento de sus crecientes competencias, la Constitución dispone, en normas ubicadas posteriormente, que la propiedad pública de los recursos naturales no renovables y en general de "los productos del subsuelo, yacimientos minerales y de hidrocarburos, sustancias cuya naturaleza sea distinta de la del suelo, incluso los que se encuentren en las áreas cubiertas por las aguas del mar territorial y las zonas marítimas, así como la biodiversidad y su patrimonio genético y el espectro radioeléctrico", es "inalienable, imprescriptible e inembargable". No excluye que esos recursos puedan ser explotados por cualquier empresa nacional o extranjera, siguiendo las normas y principios ambientales establecidos en la Constitución, pero otorgando al Estado una participación "en los beneficios de aprovechamiento de estos recursos, en un monto que no sea inferior a los de la empresa que los explota". 224

\footnotetext{
${ }^{223}$ Ecuador, Constitución de la República del Ecuador 2008, art. 281.

${ }^{224}$ Ecuador, Constitución de la República del Ecuador 2008, art. 408.
} 
Al definir los "sectores estratégicos" que los considera de "decisión y control exclusivo del Estado", se refiere a "aquellos que por su trascendencia y magnitud tienen decisiva influencia económica, social, política o ambiental" y que deben "orientarse al pleno desarrollo de los derechos y el interés social". Ellos son "la energía en todas sus formas, las telecomunicaciones, los recursos naturales no renovables, el transporte y la refinación de hidrocarburos, la biodiversidad y el patrimonio genético, el espectro radioeléctrico, el agua y los demás que determine la ley". Establece también como de responsabilidad del Estado: "la provisión de los servicios públicos, de agua potable y de riego, saneamiento, energía eléctrica, telecomunicaciones, vialidad, infraestructuras portuarias y aeroportuarias y los demás que determine la ley" y dispone que esos servicios respondan a los principios universales que los identifican y que sus precios y tarifas, controlados y regulados por el propio Estado, "sean equitativos". 225

La gestión de los sectores estratégicos y de los servicios públicos estará ahora en manos de "empresas públicas", "con personalidad jurídica, autonomía financiera, económica, administrativa y de gestión, con altos parámetros de calidad y criterios empresariales, económicos, sociales y ambientales", pero autoriza a la vez la delegación de su gestión a "empresas mixtas" en las cuales el Estado tenga la mayoría accionaria" y de "forma excepcional" a las empresas de iniciativa privada y a la economía popular y solidaria "en los casos que establezca la ley". Como se puede advertir, estas normas revierten el modelo de la Constitución de 1998 y retornan a las disposiciones originales de la Constitución de 1978, para que "sólo por ley y de manera excepcional" los sectores estratégicos y los servicios públicos puedan ser gestionados por sectores privados, incluyendo ahora "por los de la economía popular y solidaria". 226

La Constitución establece también una norma crucial para reafirmar el papel rector del Estado en el ámbito agrario sobre la propiedad y uso de la tierra y el agua. Reafirma que le corresponde "normar el uso y acceso a la tierra que deberá cumplir la función social y ambiental" y mediante "un fondo nacional de tierra regulará el acceso equitativo de las campesinas y campesinos"; prohíbe, tal como lo han hecho las constituciones anteriores "el latifundio y la concentración de la tierra" e incluye "el acaparamiento o privatización del agua y sus fuentes", bajo los principios de equidad, eficiencia y sostenibilidad ambiental". 227

Las normas indicadas anteriormente son compatibles también con otras de la propia Constitución, en las que se proclama al agua como "patrimonio nacional estratégico de uso público, inalienable, imprescriptible, inembargable y esencial para la vida" (Art. 12) y a su propiedad como "imprescriptible, inalienable, inembargable e indivisible de las tierras comunitarias", manteniendo su posesión y propiedad y las de los territorios ancestrales y disponiendo su obtención mediante "adjudicación gratuita". 228

\footnotetext{
${ }^{225}$ Ecuador, Constitución de la República del Ecuador 2008. arts. 313 y 314.

${ }^{226}$ Ecuador, Constitución de la República del Ecuador 2008, arts. 315 y 316.

${ }^{227}$ Ecuador, Constitución de la República del Ecuador 2008, art. 282.

${ }^{228}$ Ecuador, Constitución de la República del Ecuador 2008. art. 57, num. 4 y 5.
} 
No obstante, las disposiciones constitucionales anteriores no modifican sustancialmente el sistema y la estructuras de exclusión de los sectores mayoritarios de la población que caracterizan a los modelos económicos y políticos que se han implementado en las diferentes fases del constitucionalismo en América Latina, sino que sirven como un instrumento más eficaz para la reproducción del sistema, cuando aumenta la movilización y la conciencia social de las organizaciones populares y de los pueblos y nacionalidades de nuestra región y país.

\section{c) La soberanía en las políticas y finanzas públicas}

La Constitución ecuatoriana ubica en el capítulo cuarto del título sobre el régimen de desarrollo, con el común denominador de soberanía económica, lo que en realidad son orientaciones generales o políticas económicas, obligatorias por supuesto, sobre las cuales se establecerán las acciones gubernamentales para conducir la economía nacional, que finalmente no son contradictorias sino más bien concordantes con los parámetros internacionales definidos por los organismos internacionales multilaterales y los poderosos conglomerados multinacionales.

La carta política señala los objetivos generales de esas políticas económicas para "asegurar una adecuada distribución del ingreso y la riqueza nacional" sin establecer que es lo que se considera o considerará como "adecuado"; "incentivar la producción nacional, la productividad y competitividad sistémicas, la acumulación del conocimiento científico y tecnológico, la inserción estratégica en la economía mundial y las actividades productivas complementarias en la integración regional", además de "asegurar la soberanía alimentaria"; "el desarrollo equilibrado" social, de regiones y campo-ciudad; "el pleno empleo"; "la estabilidad económica" para alcanzar "el máximo nivel de producción y empleo sostenibles en el tiempo"; "impulsar un consumo social y ambientalmente responsable", entre otras. ${ }^{229}$

Con esos criterios la carta política establece normas generales que orientan la política fiscal, las finanzas públicas y las compras públicas con la finalidad de garantizar la "estabilidad económica", el "financiamiento de los servicios, inversión y bienes públicos"; la "redistribución del ingreso por medio de transferencias, tributos y subsidios adecuados" y "la transparencia", "la calidad" y "responsabilidad ambiental y social", priorizando los "productos y servicios nacionales" provenientes de "la economía popular y solidaria y de las micro, pequeñas y medianas empresas". 230

En cuanto a la política fiscal, las finanzas públicas y en especial al régimen tributario y presupuestario y al endeudamiento público y en general a la política monetaria, cambiaria y financiera; al ahorro y a la inversión se establecen normas cuyo contenido difiere parcialmente de las que estaban vigentes en la Constitución de 1998, puesto que

\footnotetext{
${ }^{229}$ Ecuador, Constitución de la República del Ecuador 2008, art. 284.

${ }^{230}$ Ecuador, Constitución de la República del Ecuador 2008, arts. 285 al 282.
} 
incorporan principios y conceptos relacionados con la nueva orientación y el modelo intervencionista y desarrollista que se pretende implementar, sin dejar de atender las "recomendaciones" de los organismos financieros internacionales dictadas para garantizar "estabilidad económica" y "la sostenibilidad de las finanzas públicas".

Mientras que a lo largo de la historia constitucional de Ecuador se han establecido normas sobre los tributos, el crédito y el presupuesto, en la actualidad la Constitución (2008), dado el modelo económico neointervencionista que promueve, contiene numerosas normas para fundamentar el gasto y asociarlo al deber de contribuir o al de pagar tributos por parte de los ciudadanos y en general de las personas con la finalidad de cumplir los principios de equidad y solidaridad que caracterizan y orientan al Estado.

En todo caso, nuestra carta política enfatiza retóricamente que dichas normas no deben ser el resultado de la imposición externa, sino del ejercicio de la soberanía nacional, en el contexto del régimen de desarrollo, del buen vivir y de la satisfacción de los derechos de los ciudadanos, pues existe entre ellos y, en especial con las finanzas públicas y el sistema tributario un "hilo conductor". 231

El discurso de la soberanía utilizado antes por los gobiernos de inspiración neoliberal para justificar su aceptación incondicional a los planes de ajuste y restructuración impuestos por el FMI y el Banco Mundial, en el Gobierno de Correa se utiliza para subrayar que no acepta sus políticas y sus préstamos, sino que adopta autónomamente políticas económicas similares con cierto contendido social y que accede libremente al mercado externo de capitales y en especial a los créditos ofrecidos por China a países proveedores de materias primas y en los que ingresa a cambio de la ejecución de grandes proyectos de infraestructura.

En las normas que ya hemos señalado, en todo caso se fortalecen las decisiones personales y unilaterales del presidente, tanto en el control de la macroeconomía como en la definición de la planificación, las finanzas públicas y en especial del Presupuesto General del Estado, en cuya formulación, aprobación y control se marginaliza la intervención de la Asamblea Nacional, pues sus atribuciones quedan reducidas a la mínima expresión.

La política fiscal tiene como objetivos: "el financiamiento de servicios, inversión y bienes públicos; la redistribución del ingreso por medio de transferencias, tributos y subsidios adecuados y la generación de incentivos para la inversión en los diferentes sectores de la economía y para la producción de bienes y servicios socialmente deseables y ambientalmente aceptables" (Art. 285 CRE).

\footnotetext{
${ }^{231}$ José Vicente Troya Jaramillo, "El modelo económico, financiero y tributario de la Constitución de 2008" en La nueva Constitución del Ecuador, Estado, derechos e instituciones, (Quito: Universidad Andina Simón Bolívar - Corporación Editora Nacional, 2009).
} 
Las finanzas públicas, según la Constitución, deben observar reglas macro-fiscales claras y obligatorias: perseguir la estabilidad económica; conducirse de forma "sostenible, responsable y transparente". Los egresos permanentes tienen que financiarse con ingresos permanentes y solo los gastos prioritarios, de salud, educación y justicia, se pueden financiar con ingresos no permanentes (Art. 286 CRE). Toda norma que cree una nueva obligación que será cubierta con recursos públicos debe establecer su fuente de financiamiento. Estas disposiciones de estabilidad y de sostenibilidad no son exactamente iguales a las que recomiendan los organismos financieros internacionales.

Las normas constitucionales sobre los ingresos públicos se refieren a los tributos, a los ingresos patrimoniales del Estado originados en la explotación de hidrocarburos, de la minería y en general de los recursos naturales y a los provenientes del crédito y endeudamiento públicos.

Los ingresos tributarios se rigen por varios principios ya contemplados en la Constitución y normas anteriores, como los de legalidad, igualdad, proporcionalidad y generalidad, pero a ellos se agregan los de progresividad, eficiencia, simplicidad administrativa, irretroactividad, transparencia y suficiencia recaudatoria, por lo que es evidente que los nuevos principios persiguen fortalecer el accionar del Estado con mayor eficacia y justicia en la recaudación tributaria, ya que se incluye la noción de "progresividad", y en especial, el mandato de priorizar "los impuestos directos y progresivos" (Art. $300 \mathrm{CRE})$.

De igual manera, la norma constitucional establece que los tributos, más allá de satisfacer una finalidad recaudatoria y de cumplir objetivos de política económica general y de redistribución de la riqueza, deben tener la finalidad de estimular el empleo, la producción de bienes y servicios y conductas ecológicas, sociales y económicas responsables.

Es evidente que con las orientaciones antes indicadas el sistema impositivo debe dar preferencia a tributos que graven la renta y el patrimonio y no al consumo, situación que no corresponde a la realidad pues, luego de diez años de Gobierno, se realizaron limitados intentos de mejorar la recaudación en los grupos económicos más poderosos del país y de establecer tributos más significativos a la plusvalía y a la herencia.

El sistema tributario ecuatoriano tiene que observar además varias disposiciones constitucionales que contienen exenciones en beneficio de sectores sociales vulnerables como adultos mayores, personas con discapacidad y tierras de comunidades, pueblos y nacionalidades. También el mandato de la gratuidad de la justicia, de la educación y de la salud anulan las pretensiones de imponer tasas judiciales y de gravar ciertas actividades o segmentos de los servicios y de prestaciones de la seguridad social. 
En el texto constitucional son importantes e innovadoras las regulaciones sobre el endeudamiento público en lo relacionado a la prohibición que los convenios de renegociación contengan de forma expresa o tácita "anatocismo o usura"; a la prohibición de "estatización de las deudas privadas"; al mandato de que se impugnen "las deudas que se declaren ilegítimas" imponiendo el "derecho de repetición" y al establecer como "imprescriptibles las acciones por las responsabilidades administrativas o civiles causadas por la adquisición y manejo de la deuda pública". ${ }^{232}$ Dichas normas autorizan el control casi total del Ejecutivo sobre el endeudamiento y una participación marginal en las decisiones parlamentarias, lo que permite que el primero defina discrecionalmente las opciones, circunstancias y condiciones del endeudamiento, reforzando una vez más el tradicional hiperpresidencialismo de la función ejecutiva.

José Vicente Troya recuerda que el mensaje de posesión del presidente Rafael Correa (2007) planteó no un desconocimiento de la deuda, sino determinar su legitimidad o ilegitimidad y crear para el efecto un Tribunal Internacional de Arbitraje de la Deuda Soberana, por lo que los países latinoamericanos no necesitarían la condonación de la deuda sino una adecuada reestructuración y financiamiento. ${ }^{233}$

En lo relacionado con el gasto público y el Presupuesto del Estado, la Constitución de 2008 establece que el primero se fundamenta en principios de justicia y solidaridad, con la finalidad de otorgarle una dimensión social y de privilegiar la satisfacción de los derechos de toda la población y en especial de los sectores más vulnerables.

Las normas sobre el Presupuesto General del Estado anual y la Programación Presupuestaria cuatrianual ratifican el control del Ejecutivo sobre todo el ciclo presupuestario. La Asamblea Nacional, de manera simplificada y en los treinta días siguientes a la presentación de dichos instrumentos, solo podrá realizar observaciones por sectores de ingresos y gastos, sin alterar el monto global de la proforma y se establece un sistema de votación y objeciones que imponen la voluntad del Ejecutivo en el contenido y montos del presupuesto.

Se establece también una relación directa del presupuesto anual y de la programación presupuestaria con los contenidos del Plan Nacional de Desarrollo. Las reglas fiscales y de endeudamiento interno que consten en el presupuesto deberán observarse igualmente por los gobiernos autónomos descentralizados. Se mantiene el sistema de preasignaciones únicamente para los gobiernos autónomos descentralizados, salud, educación, educación superior, investigación, ciencia, tecnología e innovación, conforme lo disponga la ley y sus transferencias serán de manera predecible y automática.

\footnotetext{
${ }^{232}$ Ecuador, Constitución de la República del Ecuador 2008, art. 290.

${ }^{233}$ José Vicente Troya Jaramillo, "El modelo económico, financiero y tributario de la Constitución de 2008" en La nueva Constitución del Ecuador, Estado, derechos e instituciones, (Quito: Universidad Andina Simón Bolívar - Corporación Editora Nacional, 2009).
} 
En cuanto a las políticas económicas relacionadas o con las actividades económicas no estatales que desenvuelven todos los otros sectores del sistema y que involucran en especial al sector privado y a la economía social y solidaria, la Constitución vigente se refiere a la política comercial, al sistema financiero y al trabajo y la producción.

En el ámbito comercial, la política del Estado, por medio de aranceles y otras normas de contenido ambiental y preferencial para sectores pequeños, medianos y artesanales, establecidas por el Ejecutivo, se limitan al fomento y a la regulación tanto "para desarrollar, fortalecer y dinamizar los mercados internos" como para "promover y ejecutar las acciones" de "inserción estratégica del país en la economía mundial", evitando "las prácticas monopólica y oligopólicas, particularmente en el sector privado, y otras que afecten el funcionamiento de los mercados". 234

Las actividades financieras provenientes de cualquier otro sector de la economía se conciben "como un servicio de orden público" y, por lo tanto, se ejercen con autorización y control del Estado por medio de los órganos establecidos en la Ley, como lo son las superintendencias de bancos y seguros y de la economía popular y solidaria. La Constitución vigente establece, además, varias disposiciones para el desarrollo de aquellas: la democratización del crédito; la eficiente intermediación para fortalecer "la inversión productiva nacional y el consumo social y ambientalmente responsable"; "la prohibición de prácticas colusorias, el anatocismo y la usura"; la regulación y control no traslada la responsabilidad de la solvencia bancaria ni supone la garantía del Estado, siendo de responsabilidad por dicha solvencia de los administradores y dueños del capital; la prohibición de "congelamiento y retención arbitraria o generalizada de los fondos o depósitos en las instituciones financieras públicas y privadas"; la prohibición de que las instituciones financieras privadas y sus directores o accionistas sean titulares directa o indirectamente de acciones o participaciones, en empresas ajenas a la actividad financiera y en especial en medios de comunicación social y la obligación de que en cada institución financiera se cuente con un defensor del cliente independiente de la institución. $^{235}$

Las normas de la actual Constitución, para establecer distancias con las anteriores, no se refieren directamente al sector mayoritario y hegemónico de la economía en el actual sistema privado y opta por declaraciones para su reconocimiento implícito cuando dice que "se reconocen diversas formas de organización de la producción en la economía, entre otras, las comunitarias, cooperativas, empresariales públicas o privadas, asociativas, familiares, domésticas, autónomas y mixtas", destacando el papel promotor del Estado de todas las formas de producción, alentando "la producción que satisfaga la demanda interna y garantice una participación del Ecuador en el contexto internacional” y que se sujete "a principios y normas de calidad, sostenibilidad, productividad sistémica, valoración del trabajo y eficiencia económica y social.

\footnotetext{
${ }^{234}$ Ecuador, Constitución de la República del Ecuador 2008, arts. 304 al 306.

${ }^{235}$ Ecuador, Constitución de la República del Ecuador 2008, arts. 308 al 312.
} 
De igual manera, el texto Constitucional de 2008, como hemos dicho ya, impone al Estado reconocer y garantizar el derecho a la propiedad, incluyendo la intelectual, bajo todas sus formas "pública, privada, comunitaria, estatal, asociativa, cooperativa, mixta" siempre que cumpla con su "función social y ambiental", además de reafirmar el derecho de las instituciones del Estado "por razones de utilidad pública o interés social”, a la "expropiación de bienes", previa a una "justa valoración, indemnización "prohibiendo "toda forma de confiscación". Al Estado le corresponde también garantizar "la igualdad de derechos y oportunidades de mujeres y hombres "para acceder a "la propiedad"; la "toma de decisiones para la administración de la sociedad conyugal" y para erradicar desigualdades y discriminaciones promover la democratización y redistribución de los factores de la producción y del crédito, evitando la concentración o acaparamiento de factores y recursos productivos. ${ }^{236}$

Las normas constitucionales que constan a continuación ${ }^{237}$ se refieren también a las formas de trabajo y su retribución, en las que se reconocen el derecho al trabajo y como "actores sociales productivos a todas las trabajadoras y trabajadores bajo sus distintas modalidades: en relación de dependencia, autónomas y las labores de sustento y cuidado humano". La definición anterior es importante ya que reconoce como actividad productiva a todas incluyendo "las labores de sustento y cuidado humano", esto es a las labores domésticas y otras de asistencia social informal, antes discriminadas y no medidas en los indicadores económicos del Estado.

Los derechos del trabajo reconocidos en la Constitución se basan en todos los principios históricos y acumulativos de la legislación social y de los convenios internacionales, además de establecer con claridad que la relación laboral "será bilateral y directa", prohibiendo "toda forma de precarización, como la intermediación laboral y la tercerización en las actividades propias y habituales de la empresa y persona empleadora" así como a otras modalidades que afecten los derechos laborales en forma individual o colectiva, bajo prevención de penalización y sanción del "fraude, la simulación y el enriquecimiento injusto en materia laboral". Se incluyen normas sobre remuneraciones que deben ser justas y cubrir las necesidades básicas de la persona y de su familia y si bien se reconoce el derecho a las utilidades por parte del trabajador, se las limita en las empresas de explotación de recursos no renovables y se las prohíbe en las que el Estado tenga participación mayoritaria.

Finalmente, la Constitución incluye disposiciones para promover el empleo, la capacitación, la incorporación de discapacitados y otras personas discriminadas, el respeto a los derechos reproductivos y para proteger "el trabajo autónomo y por cuenta propia realizado en espacios públicos", prohibiendo "toda forma de confiscación de sus productos, materiales o herramientas de trabajo".

\footnotetext{
${ }^{236}$ Ecuador, Constitución de la República del Ecuador 2008, arts. 321 al 324 y 334.

${ }^{237}$ Ecuador, Constitución de la República del Ecuador 2008, arts. 325 al 333.
} 
Este esquema normativo constitucional dibujaba en principio un posible panorama alentador tanto para un socialismo del siglo XXI como para un renovado neocapitalismo, o como lo denomina Enrique Ayala para un capitalismo del siglo $\mathrm{XXI},{ }^{238}$ como efectivamente ocurrió, ya que las normas y regulaciones financieras y fiscales que se han mencionado son la expresión más clara de la ideología y de los intereses dominantes en el país

\section{d) Autoritarismo e hiperpresidencialismo}

La recuperación del papel del Estado en la economía y el supuesto ejercicio de la soberanía en las políticas públicas, según la Constitución de 2008, solo son posibles, según el modelo político actual, mediante el autoritarismo y la mayor concentración de poder en el presidente de la República, tal y como se argumentó para tratar de implementar las políticas neoliberales entre 1990 y 2006.

Una vez más en la historia reciente del país se observa de manera simultánea la consolidación de un poder político concentrado en la función ejecutiva, pasando del tradicional régimen presidencialista a un régimen hiperpresidencialista en el que se asigna, además de las herramientas económicas de la planificación y de las políticas económicas, todo una estructura política que relativiza la división de poderes o de funciones del Estado mediante la imposición de sistemas electorales mayoritarios que disminuyen la representación de opositores y minorías; la estatización de la participación ciudadana que controlan la designación de los órganos de control y justicia y el desarrollo de intensas campañas mediáticas y propagandísticas para controlar a la población y consolidar la imagen y el poder unipersonal del presidente de la República.

Si bien nuestras reflexiones se centran en el campo económico, el proceso histórico que se vivió en América Latina desde el ascenso al poder del presidente Hugo Chávez en Venezuela a fines del siglo pasado y durante todos los años del presente en el que se incluyen los casos ecuatoriano y boliviano, se identifica como un momento en el que habiéndose cuestionando al neoliberalismo económico vigente, se planteó exitosamente en un inicio, un modelo o un proyecto posneoliberal o neoestructuralista, caracterizado por la recuperación del papel del Estado en la economía y en los servicios públicos, pero con un fuerte ingrediente caudillista.

Este proyecto en el ámbito de la dominación política, autoritario y concentrador del poder, estuvo presente ya en el esquema neoconservador-neoliberal, supuestamente fundamentado en la necesidad de asegurar la gobernabilidad y, en la actualidad, para garantizar la gobernanza democrática. El autoritarismo y caudillismo, no sin ciertas resistencias y perjuicios, en un inicio recibieron el beneplácito de los grupos de poder externo e interno, puesto que no afectaron radicalmente al sistema de acumulación mundial, regional y local y lograron estabilidad política y económica en la región, con la

${ }^{238}$ Enrique Ayala, "Hacia el Capitalismo del Siglo XXI", ponencia al Congreso Nacional de la CEDOCUT, Quito: diciembre de 2013. 
finalidad de dar cumplimiento satisfactorio a los objetivos estratégicos del sistema capitalista mundial.

Un modelo político así, en países en los cuales los grupos dominantes no tienen plena hegemonía en la economía, otorgan al Estado y a todos los instrumentos políticos y jurídicos de los que dispone un destacado papel económico frente a los otros sujetos de la actividad productiva para marcar el paso en el desarrollo nacional, sin afectar radicalmente los intereses de los referidos dominadores extranjeros y nacionales.

Si hasta 2006 el Estado en Ecuador, en la variante neoliberal y de mercado, había sido despojado de muchos de sus recursos y activos, para trasladarlos al capital transnacional y a los grupos oligárquicos locales, ahora el mismo Estado reasume sus potestades económicas en la explotación y en la reasignación de recursos y en la distribución de parte de los excedentes provenientes de la explotación minera e hidrocarburífera, sin afectar radicalmente al sistema de dominación, pues más bien con esas políticas lo recompone y reestructura a corto y mediano plazo.

En el marco de la globalización capitalista y de la emergencia de nuevos polos de desarrollo del sistema, como los BRICS, la economía de países como Ecuador, cuyos ingresos provienen de las materias primas y especialmente de la explotación de minerales y de petróleo, depende de la oscilación de precios de esos productos que han enfrentado un período de bonanza y crecimiento inusitados. Si los excedentes estuvieran en manos oligárquicas o neoliberales y los beneficiarios netos del auge de precios de los recursos naturales hubieran sido las empresas transnacionales y sus socios nacionales que controlan el poder político desde la fundación de la República, se habría ocasionado inestabilidad política en la región con la resistencia y movilización social que podían ser conducidas por fuerzas políticas realmente alternativas. ${ }^{239}$

En este proceso de racionalización y recomposición del sistema económico juegan un papel trascendental, como hemos indicado, los planes nacionales de desarrollo y las políticas públicas permanentes y coyunturales autorizadas en los textos constitucionales, que concentran todas las decisiones más importantes del Estado y del Gobierno en el presidente de la República.

El nuevo sistema de planificación, según la Constitución de 2008, es también un instrumento de concentración del poder y de los recursos de todas las instituciones del Estado, incluyendo los denominados gobiernos autónomos descentralizados y de otros órganos del poder público denominados como autónomos. Esa autonomía se reduce a la ejecución de ciertas competencias y de proyectos propios y a ciertas transferencias, bajo el estricto control de los parámetros del Plan Nacional de Desarrollo y de los presupuestos en él asignados. Entre los principios comunes, fijados por el Código

239 Víctor Granda Aguilar, "Los Gobiernos Progresistas y la Alternativa Socialista”, Quito: Opción Socialista, edición especial No. 39-40, Julio de 2013. 
Orgánico de Planificación y Finanzas, consta el denominado "sujeción a la planificación" (Art. 5), en el que se establece que "la programación, formulación, aprobación, asignación, ejecución, seguimiento y evaluación del Presupuesto General del Estado, los demás presupuestos de las entidades públicas y todos los recursos públicos, se sujetarán a los lineamientos de la planificación del desarrollo de todos los niveles de Gobierno...".

En ese contexto la denominada "planificación participativa" y los "consejos de igualdad" son también meros enunciados que no tienen mayor impacto en las decisiones finales que adopta la administración central, que se encuentran reforzadas con poderosos instrumentos informáticos modernos, como el ESIGEF y el SIGOB. En cuanto a las políticas públicas permanentes y coyunturales de control financiero, según la Constitución, están en manos del Ejecutivo luego de despojar de esas potestades a la Asamblea Nacional.

El modelo político y económico autoritario en Ecuador, inspirado ahora en el intervencionismo keynesiano y bajo la retórica del socialismo del siglo XXI, se convirtió en instrumento eficaz para reestructurar el capitalismo local e instaurar un neocapitalismo regional, acorde con la globalización del sistema mundial.

De allí que resulta inexplicable la actitud de ciertos sectores de izquierda y de organizaciones populares latinoamericanas que protagonizaron y contribuyeron a la estructuración y consolidación de regímenes identificados como progresistas y que fueron liderados por caudillos autoritarios, que en el corto plazo las fracturaron y las desplazaron de limitados espacios de poder, persiguiendo a sus dirigentes más connotados con la finalidad de imponer su proyecto de consolidación del sistema vigente.

Según subraya Gargarella, el radicalismo político, tanto en Europa como en Estados Unidos en el siglo XIX, "fue anti presidencialista y partidario de un poder político federalizado, desconcentrado y sensible a las expresiones del pueblo", para "robustecer la capacidad de intervención y el control de los ciudadanos en la política". Los radicales de esa época impulsaron iniciativas "para expandir la soberanía popular, ampliar las oportunidades de participación cívica, reforzar los poderes del Congreso, aumentar los controles sobre el poder, disminuir la extensión de los mandatos o reforzar los lazos entre representantes y representados, a través de medidas tales como las instrucciones obligatorias, la revocatoria de mandatos, la rotación obligatoria en los cargos, las elecciones anuales o la prohibición de la reelección". ${ }^{240}$

A pesar de la tradición antes indicada, ciertos sectores progresistas o izquierdistas latinoamericanos, en el siglo XX y en el presente -con el argumento de un cierto reconocimiento oficial en la ampliación de los derechos en las constituciones y de una

\footnotetext{
${ }^{240}$ Roberto Gargarella, Pensando sobre la Reforma Constitucional en América Latina, en El Derecho en América Latina, Coord. César Rodríguez Garavito (Buenos Aires: Siglo Veintiuno Editores, 2011).
} 
limitada participación burocrática en ciertas esferas del poder-, han apoyado siempre el autoritarismo, la persecución y represión a la lucha sociales por parte de los gobiernos de turno y son "complacientes" o auspician las "iniciativas del fortalecimiento del presidencialismo y de las reelecciones presidenciales" que consolidan en el poder o en el Gobierno a caudillos populistas o a personajes sin una clara definición ideológica, que se han convertido en instrumentos eficaces del sistema, para mantener una institucionalidad estatal tradicional, que discrimina del ejercicio del poder, de la justicia y de la participación a los sectores populares organizados, para facilitar la recomposición del sistema de dominación externo e interno y solventar sus permanentes contradicciones y crisis.

\subsubsection{Las enmiendas constitucionales de 2015}

El modelo económico neointervencionista estatal en la economía, complementado con un régimen autoritario en lo político autorizado por la Constitución, inició su declinación en Ecuador desde finales de 2014, cuando en el ámbito internacional bajaron los precios de las materias primas, particularmente el petróleo, y se revalorizó la divisa norteamericana en el sistema monetario internacional, lo que afectó notoriamente su actividad comercial.

El resurgimiento de la crisis económica y financiera en Europa y Estados Unidos y la paralización de economías como la de China y la de los otros países de los BRICS pusieron en peligro, nuevamente, la estabilidad económica internacional, tanto por el colapso financiero de Grecia, afectada por el sobreendeudamiento y la incapacidad de pagar sus agobiantes créditos, como por los efectos desastrosos de numerosos casos de corrupción que utilizan, a nivel internacional, paraísos fiscales para lavar sus activos de origen ilícito.

Para enfrentar la crisis internacional, el sistema capitalista mundial reaccionó, por medio de los organismos financieros internacionales, liderados por el BM, la OMC y el Fondo Monetario Internacional, con las consabidas fórmulas de ajuste, propias del neoliberalismo, para alcanzar la gobernanza democrática de los países y regiones del mundo. A los programas de ajuste se agregaron algunos medidas de sensibilidad social, de lucha contra la corrupción y un cierto control sobre los paraísos fiscales, en los que se acumulan enormes recursos provenientes de la delincuencia mundial relacionada con las drogas y el abuso de fondos públicos.

El Gobierno ecuatoriano adoptó desde 2015 políticas recesivas en cuanto a la inversión; incrementó los tributos indirectos y para equilibrar el deterioro del comercio adoptó salvaguardas que encarecieron las importaciones y fomentaron la actividad productiva local. 
Frente a la iliquidez de la economía el régimen reavivó, agresiva e ilegalmente,| el endeudamiento externo con crecientes créditos de alto costo con China y la colocación de bonos en el mercado internacional. Siguiendo las recomendaciones de los organismos financieros internacionales y para acceder a créditos parciales, el régimen dio un giro en su política económica y en su orientación neoestatista para favorecer el comercio internacional mediante medidas de corte neoliberal. Así, celebró un Tratado de Libre Comercio con Europa; introdujo un modelo de alianzas públicas-privadas para favorecer la inversión extranjera en grandes obras públicas nacionales y anunció su decisión de restablecer vínculos crediticios con el Banco Mundial y el FMI y de subastar importantes obras de infraestructura, recientemente construidas, como centrales hidroeléctricas, lo que implicó privatizar activos públicos que por casi una década se negó a negociar.

Para la adopción de un modelo económico combinado entre el neoestructuralismo y el neoliberalismo, se fortaleció el modelo político autoritario, requerido sucesivamente para la consolidación y ampliación del sistema neocapitalista imperante en el país. Este modelo político y social persigue mantener y ampliar el presidencialismo, para, mediante actos administrativos y represión, controlar la actividad y la regulación económica del país; efectuar los ajustes y procesos que antes requerirían de leyes para su ejecución; evitar el control político para bloquear la fiscalización y la inestabilidad y la corrupción gubernamental y restringir y aún anular el control técnico-financiero de las grandes operaciones económicas emprendidas por el Gobierno con la finalidad de asegurar los intereses transnacionales y del capital financiero mundial y local.

En ese contexto y por medio de sus asambleístas, en marzo de 2014 el Gobierno del presidente Correa presentó en la Corte Constitucional un proyecto de enmiendas a la Constitución para su correspondiente dictamen, con el pretexto de corregir supuestos errores que existían en ella, cuando en realidad su propósito principal era abrir un camino expedito para introducir en el texto de la carta política la reelección indefinida de los dignatarios principales del Estado y restringir las potestades de control técnico externo de la Contraloría a la gestión y los resultados de la administración, sobre los cuales podía establecer responsabilidades administrativas y civiles culposas e indicios de responsabilidad penal. El paquete de enmiendas fue, en realidad, un grupo de reformas constitucionales, que de acuerdo a la propia carta política exigían un procedimiento diferente que incluía necesariamente en su fase final la ejecución de una consulta popular o incluso en varias de dichas reformas, la convocatoria a una Asamblea Constituyente.

La Corte, controlada en su totalidad por el oficialismo, emitió un dictamen favorable para la casi totalidad de las enmiendas. La Asamblea, en dos debates que culminaron en diciembre de 2015, aprobó, vulnerando y manipulando la Constitución, 16 reformas de las cuales solo dos podrían haberse calificado propiamente como enmiendas: la relativa a disminuir la edad para ser candidato a la Presidencia de la República y la rectificación 
de la palabra provisionales por previsionales cuando la carta política se refiere a los fondos de la seguridad social. ${ }^{241}$

Hacia el futuro, quedó expresamente reconocida, en lo principal, la decisión del Gobierno de Rafael Correa -que difícilmente será alterada por la Corte Constitucional, pues ella emitió previamente el informe favorable para la violación de la Constitución con las enmiendas-, de introducir forzadamente en la carta política, la reelección presidencial indefinida, en contra de la opinión mayoritaria de la población, argumentando que con ella se ampliaban los derechos de los electores y de los elegidos, y la eliminación de la evaluación de gestión de los órganos de la función ejecutiva y del Estado por parte de la Contraloría General del Estado, para encubrir numerosos casos de corrupción. Según el régimen las auditorias de gestión son de responsabilidad de la propia Administración, por medio de la Secretaría Nacional de la Administración Pública, la Secretaría Nacional de Planificación de Desarrollo Social y algunas dependencias del Ministerio de Finanzas, dependencias todas ellas con competencias asignadas por el presidente de la República, mediante simple decreto ejecutivo, que no tienen jerarquía de ley.

Con dichas reformas constitucionales bajo la figura de enmiendas se eludió la consulta popular obligatoria y el Gobierno consolidó el modelo autoritario hiperpresidencialista y anuló las facultades constitucionales que se otorgaban a la Contraloría General del Estado para realizar el control externo de gestión y del cumplimiento de objetivos institucionales a las entidades públicas y establecer responsabilidades personales administrativas, civiles e indicios de responsabilidad penal, no solo por el manejo de los recursos públicos, sino por la mala o deficiente calidad de las actividades y proyectos de la administración y del Estado.

Tras las elecciones presidenciales de 2017, el nuevo Gobierno del presidente Lenin Moreno anunció la convocatoria a una consulta popular con la finalidad de introducir reformas constitucionales, que si bien no cuestionan el modelo económico de la Constitución de 2008, sí lo hacen con el modelo político hiperpresidencialista que se fortaleció con las enmiendas constitucionales de 2015. La consulta pretendía, en lo principal, impedir las reelecciones indefinidas y reestructurar el Consejo de Participación Ciudadana que permitió al ejecutivo copar las designaciones de las máximas autoridades de los órganos de control del Estado. A dicho Consejo Transitorio se le otorgarán la potestad de evaluarlas y de ser del caso destituirlas y sustituirlas, frente a los enormes y numerosos casos de corrupción en los que se encuentran involucradas los máximos personeros del Gobierno anterior, que obviamente recibieron la protección y el auspicio de las autoridades de control designadas, indirectamente, por el propio presidente de la República.

\footnotetext{
${ }^{241}$ Ecuador, Enmiendas a la Constitución de la República del Ecuador, Suplemento Registro Oficial 653, 21-dic-2015.
} 
Con las enmiendas constitucionales de 2015 se fortaleció el autoritarismo presidencial para autorizar la aplicación más intensa de políticas económicas y financieras y planes y proyectos económicos convenientes al capital transnacional y a los grupos de poder interno, a la vez que se mantiene la exclusión de los sectores sociales populares de la institucionalidad estatal para impedir su justa participación en los espacios de poder. En los diez años de Gobierno progresista se manipuló la representación social para estatalizar en su nombre la representación popular y controlar los órganos de control, mediante los cuales se podía haber fortalecido la participación y la democracia. 


\section{CAPÍTULO III: LAS TRANSFORMACIONES EN LA HACIENDA PÚBLICA ECUATORIANA Y EN LA LEGISLACIÓN FINANCIERA Y TRIBUTARIA ACTUAL}

Una vez analizado el contexto de la globalización capitalista contemporánea y su incidencia en los modelos económicos y las transformaciones del derecho público y las normas de la Constitución económica y financiera del Ecuador, nos vamos a referir en este capítulo a las transformaciones en el contenido y alcance del derecho de la Hacienda pública o de las finanzas públicas en sus diferentes etapas de la historia ecuatoriana; a las modificaciones principales en el derecho financiero económico público y privado en la realidad del país entre 1990 y 2017 y a la legislación vigente sobre gastos e ingresos públicos en el ámbito del derecho tributario.

\section{EL DERECHO DE LA HACIENDA PÚBLICA O DERECHO FINANCIERO PÚBLICO EN LA HISTORIA Y LOS MODELOS ECONÓMICOS Y POLÍTICOS DE ECUADOR}

En el marco de la realidad económica, política y jurídica de Ecuador, el derecho de Hacienda o de las finanzas públicas está presente en sus diversas etapas históricas, conforme a las normas constitucionales y legales vigentes y a las esporádicas reflexiones jurídicas y jurisprudenciales que existen desde los inicios de la república hasta la actualidad.

Nosotros distinguimos, de manera general en este estudio, diferentes períodos o etapas en el derecho de la Hacienda pública o de las finanzas públicas en general y en sus principales componentes relativos a los ingresos y gastos y presupuestos públicos, a los que se agregan, en su debido tiempo, la normativa jurídica administrativa de la planificación y el control.

En cuanto a la Hacienda pública como unidad interrelacionada de sus componentes esenciales tenemos: la hacienda poscolonial desde los inicios de la república hasta 1863 , en la que rigieron leyes de hacienda dictadas en la Gran Colombia y en la naciente república; la hacienda de transición al liberalismo desde 1863 hasta 1928, en la que estuvo vigente, en lo fundamental, la Ley de Hacienda de 1863 emitida por el gobierno conservador de García Moreno; la hacienda liberal, con rasgos iniciales intervencionistas, desde 1928 hasta 1975 con la expedición y la vigencia de la Ley de Hacienda elaborada por la misión norteamericana Kemmerer y las normas sugeridas más tarde por Manuel Gómez-Morín y por la misión Triffin; ${ }^{242}$ la hacienda moderna de gerencia financiera que se organizó entre 1976-2009, mientras estuvo vigente la Ley Orgánica de Administración Financiera y Control (LOAFYC), que con reformas y otras normas como la Ley Orgánica de Responsabilidad, Estabilización y Transparencia

\footnotetext{
242 Julio Oleas, La banca central: una historia de cambio, Revista del Banco Central, cuestiones económicas, 1992.
} 
Fiscal (2002) se acoplaron tanto al neoliberalismo (1990-2006) como al inicial neointervencionismo hasta $2010 \mathrm{y}$, finalmente, la actual hacienda contemporánea neointervencionista propiamente tal, que se expresa por medio del Código Orgánico de Planificación y Finanzas expedido en 2010 y que se mantiene vigente hasta la actualidad.

\section{La Hacienda pública neocolonial de inicios de la república}

La primera etapa en la historia de las finanzas públicas de Ecuador es la prolongación de las instituciones hacendísticas y financieras coloniales, reguladas por las Leyes de Indias y ajustada por las reformas comerciales borbónicas de las últimas décadas del siglo XVIII, en la inicial Gran Colombia y en la naciente república (1830) hasta los años sesenta del siglo XIX (1863) cuando se adopta, en el Gobierno autoritario de Gabriel García Moreno, una Ley de Hacienda que inauguró la transición a la fase liberal de las finanzas públicas.

La legislación financiera poscolonial se fundamentó en el concepto de cajas que contenían los recursos físicos financieros con ciertos dispositivos de seguridad. Las cajas eran administradas por una Junta de Hacienda regional integrada por las autoridades locales y que representaban a los grupos del poder regional que a la vez controlaban al tesorero, contador y factor, a los que correspondía la recaudación, custodia, desembolso y registro de los recursos.

Existían también órganos de control con oficiales estatales que integraban tribunales de contadores o de cuentas para juzgar la gestión financiera y revisaban los libros para cobrar los alcances que se establecían. Se podían apelar las decisiones a tribunales superiores de oidores sobre cuentas y alcances locales hasta llegar a la máxima autoridad estatal. ${ }^{243}$

Las Leyes de Hacienda de la Gran Colombia (1821 - 1824) y las primeras de la nueva República del Ecuador (entre 1830 - 1863) heredaron el sistema financiero descentralizado colonial y se sometieron a una serie de reformas que demostraron un constante dinamismo jurídico y económico relacionado con los intereses regionales de los grupos de poder de la naciente república unitaria, en la que tenían el privilegio de mantener tesorerías separadas en sus departamentos de Quito, Guayaquil y Cuenca. En 1830 el 73,9\% del presupuesto se destinó a pagar a militares y hasta 1860 el gasto para ese rubro oscilaba entre el $30 \%$ al $50 \%$ del presupuesto. Entre 1830 y 1878 el servicio de la deuda interna y externa insumía entre un cuarto y un tercio y hasta el $40 \%$ de los ingresos, según Linda Alexander Rodríguez. ${ }^{244}$

\footnotetext{
${ }^{243}$ http://portal.uasb.edu.ec:2165/WebTools/eSilecro/DocumentVisualizer/DocumentVisualizer.aspx?id= HISTORIC-LEY_ORGANICA_DE_ADMINISTRACION_FINANCIERA_Y_CONTROL_1977\&query =LOAFYC\#I_DXDataRow1

244 Enrique Ayala Mora, editor, Historia Constitucional, estudios comparativos, Biblioteca de Historia/36, (Quito: Universidad Andina Simón Bolívar - Corporación Editora Nacional, 2014).
} 
Con dichas normas se estableció una Contaduría General para todo el país y contadurías departamentales que tenían la potestad de glosar y finiquitar las cuentas regionales, que luego podían ser revisadas por la Contaduría General y aún por el Ministerio de Hacienda. Las más importantes fuentes de ingresos del Estado provenían de la aduana, de los impuestos a las importaciones, de los tributos personales a indios y diezmos y de los créditos otorgados por los comerciantes costeños. Los gastos se concentraron en el pago a militares, en el servicio esporádico de la deuda de la independencia, en el pago a acreedores privados internos y mínimamente a los servicios públicos. ${ }^{245}$

En 1854 el país llegó a un acuerdo con los tenedores de bonos de la deuda de la independencia al suscribir el convenio Espinel-Mocatta, que no pudo ejecutarse por los reclamos del Perú sobre las regiones amazónicas que se les ofrecía para la colonización y explotación agrícola. ${ }^{246}$

\section{Transición a la Hacienda pública liberal (1861-1925)}

Desde la Constitución de 1861 se inicia propiamente, con un gobierno conservador a la cabeza, una transición a un modelo de Hacienda liberal en el ámbito de la economía y de las finanzas públicas, si bien ya para entonces la acción estatal también se encontraba dirigida a cubrir los gastos iniciales de educación, obras públicas y comunicaciones.

En lo económico se afianzó una política para fortalecer el comercio exterior y se estableció un régimen tributario fundamentado en impuestos indirectos y aranceles, desestimando paulatinamente los impuestos directos. En 1857 se eliminó de forma inicial el tributo indiano y más tarde los diezmos en 1889, si bien se mantuvo aún el control local-regional sobre los tributos y los gastos. ${ }^{247}$

García Moreno decidió suspender los pagos de los dividendos de la deuda externa en 1862 y los intereses en 1869, con lo que pudo contar con mayores recursos para financiar la obra pública que impulsó su Gobierno.

La Ley de Hacienda de 1863 dictada por el gobierno conservador-terrateniente, luego de la derrota de los regionalismos con la supresión de los departamentos, el establecimiento del sufragio universal para quienes sabían leer y escribir y la nueva representación política por provincias, se prolongó en su vigencia por 64 años hasta 1927, lapso en el cual se expidieron dos codificaciones de aquella en 1912 y 1924.

Pese a la arraigada descentralización fiscal local, la Ley Garciana intentó, sin mayores resultados e incurriendo en crecientes nuevos endeudamientos, centralizar la

\footnotetext{
${ }^{245}$ Linda Alexander Rodríguez, Estudio introductorio a Pensamiento Fiscal Ecuatoriano, 1830-1930, Banco Central del Ecuador-Corporación Editora Nacional, Quito, 1996.

${ }^{246}$ Alberto Acosta, Breve historia económica del Ecuador, Corporación Editora Nacional, Quito, 2012.

${ }^{247}$ Peter V.N Anderson, "La Constitución ecuatoriana de 1861". Enrique Ayala Mora, editor, Historia Constitucional, estudios comparativos, Biblioteca de Historia/36, Universidad Andina Simón Bolívar Corporación Editora Nacional, Quito, 2014.
} 
administración financiera en el presidente y el ministro de Hacienda, tanto en la recaudación como en la distribución de los caudales, para pagar a militares, empleados, acreedores bancarios y a los cada vez más crecientes gastos en actividades de educación, obras públicas, sanidad y bienestar.

La información y las cuentas se centralizaron para su conocimiento permanente en el Ministerio de Hacienda y luego del balance anual se remitían para su examen a las cámaras legislativas y al Tribunal de Cuentas. También se les informaba por separado de la cuenta especial de la deuda pública y el estado de los contratos celebrados y de las obras públicas ejecutadas en el año anterior. ${ }^{248}$

Se ha estudiado el contenido de esas leyes y de las finanzas públicas en el siglo XIX y se observa que hasta la Revolución liberal de fin de siglo se caracterizaron por "ingresos inadecuados, mala administración y mal crédito externo", lo que refleja la desarticulación económica regional, la dispersión del poder político y la incapacidad de las administraciones locales y de los gobiernos para cumplir con sus obligaciones económicas y en particular las provenientes de la deuda externa. Por esta causa recurrieron preferente y constantemente a préstamos internos con los nacientes bancos privados, con la finalidad de pagar el incipiente desarrollo nacional y sofocar las constantes rebeliones internas. ${ }^{249}$

La administración y el control de las finanzas públicas durante el floreciente Estado liberal se fundamentaron en el principio del no intervencionismo económico gubernamental, que otorgaba al sector privado-oligárquico-terrateniente un manejo privilegiado sobre la sociedad y el Estado, pues su representación directa y casi absoluta en el poder o en la función legislativa y en los municipios, les permitió utilizar a las instituciones y poderes en su exclusivo beneficio.

Con la finalidad de obtener recursos para construir la gran obra del ferrocarril que unía la sierra con la costa, al finalizar el siglo XIX se reactivaron gestiones para solucionar los problemas pendientes de la deuda externa. A pesar de todo, las decisiones de los presidentes Flores Jijón y de Luis Cordero elevaron las cotizaciones de los bonos ecuatorianos por lo que, frente a su impacto en el presupuesto nacional, el 24 de julio de 1894 el Congreso Nacional suspendió nuevamente los pagos de la deuda. Ya en el poder como jefe supremo de la República, el 14 de marzo de 1896 Eloy Alfaro suspendió "el pago de la deuda externa hasta que se obtenga un arreglo equitativo y honroso con los tenedores de bonos", pues cuando se encontraba en el destierro la había calificado como "deuda gordiana" que era necesario desatar para promover el desarrollo nacional. En 1898, el presidente Alfaro compró los bonos devaluados de la deuda inglesa, una parte

\footnotetext{
${ }^{248}$ Estudio Introductorio a la Ley Orgánica de Administración Financiera y Control (LOAFYC), http://portal.uasb.edu.ec:2165/WebTools/eSilec ro/DocumentVisualizer/Document Visualizer .aspx?id=HISTORIC-LEY_ORGANICA_DE_ADMINIS

TRA CION_FINANCIERA_Y_CONTROL_1977 \&query =LOAFYC\#I_DXDataRow1

${ }^{249}$ Linda Alexander Rodríguez, Las Finanzas Públicas en el Ecuador (1830-1940), (Quito: Banco Central del Ecuador, 1992.
} 
al contado y otra con la emisión de bonos, para culminar la construcción del ferrocarril que llegó a Quito, luego de adicionales gestiones financieras, el 25 de junio de $1908 .{ }^{250}$

Las normas constitucionales y legales de entonces consolidaron en Ecuador la hegemonía política y económica terrateniente y después de la oligarquía agroexportadora, desde los inicios de la República hasta la revolución juliana de 1925.

En la Hacienda liberal o tradicional, siguiendo la doctrina clásica, los gastos se clasificaban en ordinarios o de funcionamiento y extraordinarios o de inversión y los ingresos en tributarios y en empréstitos, enfatizando en su productividad e igualdad. Los tributos, a la vez, debían ser teóricamente: proporcionales a las rentas y haberes (lo que determina la igualdad o desigualdad de aquellos); ciertos en cuanto debían ser perfectamente identificados; determinados respecto a sus circunstancias y cuantificación y pagaderos dentro del tiempo y modo previamente establecidos, para hacerlos más cómodos y convenientes al contribuyente y al tesoro público, debiendo proveerse lo menos posible de las rentas de los particulares, según Adam Smith. ${ }^{251}$

Recordemos también que las ideas propias del Estado liberal se sintetizan en la exaltación y privilegio de las actividades económicas de los individuos, en la separación del Estado de la sociedad y en la convicción de un Estado mínimo (abstencionista) que requiere recursos fundamentalmente para cumplir con sus labores de orden interno (policía) y seguridad externa y de administración de justicia. Así tenemos que la construcción de un derecho de la Hacienda pública o financiero en esa etapa es meramente instrumental, pues se restringe a establecer la vertiente jurídica positivista de la actividad financiera, autorizada por el Congreso o Asamblea Nacional, para el sostenimiento de los entes públicos en los referidos gastos, con la contribución de los ciudadanos "en función de su capacidad", conforme lo establecía la Declaración de Derechos de $1789 .{ }^{252}$

Ya en el siglo XX en Ecuador, con cierta influencia de las doctrinas marginalista y utilitarista, los ministros de Hacienda liberales manifestaron en diversas oportunidades que el sistema de tributación descentralizado en Ecuador impedía el desarrollo nacional, pues obligaba al Ejecutivo a depender crecientemente de los préstamos bancarios privados para poder atender a las necesidades de los gastos administrativos ordinarios.

Al agravarse la situación económica nacional, como resultado de la Primera Guerra Mundial, el agobiante endeudamiento interno y la crisis monetaria y del cacao, entre 1922 y 1924 se llegó a la conclusión de que se requería modificar urgentemente el sistema tributario y que este debía estar centralizado tanto en su recaudación como en su

\footnotetext{
${ }^{250}$ Alberto Acosta, Breve historia económica del Ecuador, (Quito: Corporación Editora Nacional, 2012).

${ }^{251}$ Adam Smith, Investigación sobre la naturaleza y la causa de la riqueza de las naciones, traducción de José Alonso Ortiz, (Barcelona: Casa Editorial Bosch, 1983).

${ }^{252}$ Modesto Fabra Valls, "Solidaridad y Derecho Financiero en una sociedad neocompetitiva", en Revista Española de Derecho Financiero, Nro. 120, 609 -680, Madrid, 2003.
} 
ejecución. Frente a la negativa del Congreso de atender esta demanda financiera básica para el funcionamiento estatal, los militares derrocaron al Gobierno civil e instauraron una Junta revolucionaria de Gobierno el 9 de julio de $1925 .{ }^{253}$

Los militares julianos facilitaron la modernización del país y el Gobierno civil que designaron adoptó las reformas económicas e institucionales que sugirió la comisión norteamericana de expertos financieros que presidió Edwin Walter Kemmerer. ${ }^{254}$ El presidente provisional Isidro Ayora expidió luego la Ley Orgánica de Hacienda en 1928 y el 9 de octubre del mismo año inauguró las sesiones de la convención que elaboró una nueva Constitución el 29 de Marzo de 1929.

Según Ramiro Borja, la Constitución de 1929 introdujo grandes innovaciones en el derecho constitucional ecuatoriano, estableció "un régimen presidencial mitigado por matices parlamentarios tan subidos que le hacen casi intermedio entre el sistema presidencial puro y el parlamentario" 255 e inició un período de interés por los aspectos sociales y económicos relativos a los derechos económicos y sociales y en especial al derecho laboral, la seguridad social y la reforma agraria, promoviendo una participación activa del Estado en la economía.

\section{De la Hacienda pública liberal a la intervencionista (1925-1945)}

En 1928, en vísperas de la crisis del capitalismo mundial de los años treinta y sus desastrosos efectos sobre el comercio, el empleo y la producción a nivel mundial, en Ecuador se inició una etapa que consolidó la Hacienda y el derecho financiero liberal y comenzó un moderado tránsito hacia la Hacienda moderna del Estado social que, según nuestro análisis, se fue imponiendo en un período de varias décadas.

La primera fase de este período mantuvo vigente por 48 años la Ley Orgánica de Hacienda de 1928 hasta 1976, año en el cual se sustituyó por una moderna Ley Orgánica de Administración Financiera y Control (LOAFYC) cuya vigencia, conjuntamente con modificaciones y otras normas afines, se prolongó por 33 años hasta 2010, resultando útil esta normativa para la implementación con ciertas modificaciones de los modelos económicos: intervencionista, que se consolidó en los años setenta y ochenta; neoliberal desde fines de los ochenta hasta el 2000 y el inicio del neointervencionismo, desde 2005 hasta la instauración y los primeros dos años del gobierno progresista de Rafael Correa.

La Ley de Hacienda de 1928 concentraba la administración financiera en el presidente de la República y el ministro de Hacienda y eliminaba las potestades que al respecto tenían los gobernadores provinciales, las juntas de Hacienda y el Tribunal de Cuentas.

\footnotetext{
253 Juan Paz y Miño, Revolución juliana; Nación, Ejército y bancocracia, (Quito: Abya-Yala, 2000).

${ }^{254}$ Paul W. Drake, Kemmerer en los Andes, (Quito: Banco Central del Ecuador, 1995).

${ }^{255}$ Ramiro Borja (1950), "Derecho Constitucional Ecuatoriano", Quito - Ecuador, Tomo 2. Ed. Cultura Hispánica, 676.
} 
En la nueva Ley se creó también la Contraloría General de la Nación (Art. 199), como órgano de control externo e interno; oficina de contabilidad y de fiscalización de los ingresos y egresos públicos y como órgano independiente del Poder Ejecutivo, con potestades normativas en el ámbito de sus competencias. La Ley organizó la administración tributaria, la recaudación, la tesorería y su control; el régimen y administración del personal público y reguló con mayor detalle el presupuesto nacional en cuanto a su estructura, principios, control y a sus fases de formación, presentación, aprobación, transferencia de asignaciones normales y adicionales, liquidación y reservas del tesoro nacional, diferenciando entre presupuesto ordinario y extraordinario. ${ }^{256}$

Ecuador enfrentó nuevamente una aguda crisis económica y política entre 1931 y 1948. Se alivió con la dinamización del mercado internacional para algunos productos agrarios, durante la Segunda Guerra Mundial y con el auge posterior en la exportación de banano y otros productos agrícolas apetecidos en el mercado internacional. También en estas décadas se introdujeron reformas importantes en el régimen monetario. En concreto, en 1932 con el encargado del poder Alfredo Baquerizo Moreno y en las funciones del Banco Central con las reformas legales sugeridas por el experto mexicano por Manuel Gómez-Morín, y más tarde en 1948, por la misión presidida por Robert Triffin del recientemente inaugurado Fondo Monetario Internacional. ${ }^{257}$

\section{La Hacienda pública intervencionista (1945-1990)}

El derecho y la legislación de finanzas desde mediados de los años cuarenta en Ecuador se inscriben en una clara etapa económica intervencionista (1945 - 1980 y aún hasta 1990) en la que el Estado y el sistema jurídico contrarrestaron las irracionalidades del mercado, regulando el régimen monetario y financiero e incrementando los tributos al conjunto de la sociedad y en especial los directos y progresivos, con la finalidad de obtener una limitada redistribución del ingreso siguiendo los parámetro de la Hacienda moderna.

Con la finalidad de lograr pleno empleo el Estado asume paulatinamente la explotación de los principales recursos naturales; ofrece servicios públicos; regula las relaciones laborales y asigna los ingresos para las obras públicas, la educación, la salud y la seguridad social, con la finalidad de establecer un equilibrio social que permita un funcionamiento racional del sistema para proteger la inversión extranjera y la seguridad y renta de los grupos económicos hegemónicos, articulados o subordinados al capital internacional.

\footnotetext{
256 Estudio Introductorio a la Ley Orgánica de Administración Financiera y Control (LOAFYC), http://portal.uasb.edu.ec:2165/WebTools/eSilec ro/DocumentVisualizer/Document Visualizer .aspx?id=HISTORIC-LEY_ORGANICA_DE_ADMINIS

TRA CION_FINANCIERA_Y_CONTROL_1977 \&query =LOAFYC\#I_DXDataRow1

257 Julio Oleas, La banca central: una historia de cambio, Revista del Banco Central Cuestiones Económicas N¹9, Quito, 1994.
} 
Se introdujeron discretamente, con inspiración en la doctrina keynesiana, ${ }^{258}$ la ciencia de la macroeconomía para el manejo eficiente de las políticas públicas de los gobiernos, con la finalidad de estudiar y establecer "los agregados económicos, el análisis del ingreso nacional, del producto interno bruto, del consumo total, del gasto total, del déficit fiscal y de numerosas variables de orden colectivo y supraindividual". ${ }^{259}$ Esta doctrina que articula política monetaria, fiscal y agregados económicos, plantea que el Estado sea un agente protagónico de la economía y de la demanda global para que se alcance pleno empleo y una redistribución del ingreso y la riqueza, lo que exige preservar los equilibrios macroeconómicos y utilizar el déficit como estrategia para alcanzar ocupación plena. Para ello también se requiere establecer regímenes tributarios apropiados que den prioridad al impuesto sobre la renta con tarifas y alícuotas progresivas; controlar las tasas de interés, los precios, los arrendamientos, etc., y participar activamente en el gasto público y si fuera el caso incentivando la emisión monetaria.

El keynesianismo en América Latina se expresó desde los años cincuenta y sesenta del siglo pasado mediante la doctrina estructuralista de la CEPAL, creada en 1949, y en el pensamiento de Raúl Prebisch con su influyente obra El capitalismo periférico. Ellos promovieron el intervencionismo o regulacionismo estatal, el proteccionismo y la industrialización para la sustitución de importaciones; la liberalización del régimen de cambios y del comercio; un sistema tributario equitativo y redistributivo y un sistema de planificación para racionalizar la inversión y la transferencia de recursos a los gobiernos locales y la expedición de normas jurídicas modernas para la administración financiera y el control. ${ }^{260}$ Desde entonces se inicia un proceso de articulación entre las finanzas públicas, la planificación y el control.

La Junta Militar de Gobierno y la Secretaría Técnica de Administración introdujeron pragmáticamente en 1963 reformas administrativas, tributarias y el concepto y la técnica de "presupuesto por programas, subprogramas, actividades, proyectos y obras" manteniendo a la vez los conceptos de presupuesto de operación y capital ya establecidos mediante Ley en 1951 y que luego se incorporaron a las reformas a la Ley de Hacienda en 1960, con la finalidad de optimizar el uso de los recursos, evaluar servicios y establecer metas en las acciones del Estado. En 1972 se dispuso que las entidades del régimen seccional y las descentralizadas tendrían que aprobar sus presupuestos por programas en la Junta Nacional de Planificación, para lo cual se introdujeron varias reformas en la Ley de Régimen Municipal con la finalidad de que se sometieran a la política de desarrollo establecida por el gobierno nacional. ${ }^{261}$

\footnotetext{
258 John Maynard Keynes, Teoría general de la ocupación, el interés y el dinero, traducción de Eduardo Homedo, (México: Fondo de Cultura Económica, 1992).

259 Mauricio Plazas Vega, Derecho de la hacienda pública y Derecho tributario, (Bogotá: Editorial Temis, 2000), 69.

${ }^{260}$ Raúl Prebisch, El capitalismo periférico, (México: Fondo de Cultura Económica, 1981).

261 Estudio Introductorio a la Ley Orgánica de Administración Financiera y Control (LOAFYC), http://portal.uasb.edu.ec:2165/WebTools/eSilec ro/DocumentVisualizer/Document Visualizer
} 
Por el lapso de más de 30 años las constituciones de 1945, 1946 y 1967 promovieron una legislación financiera, especialmente tributaria y presupuestaria, acorde con sus orientaciones de desarrollo y de creciente intervencionismo estatal.

Las codificaciones de la Ley de Hacienda de 1960 y $1975^{262}$ se sustituyeron por la Ley Orgánica de Administración Financiera y Control (LOAFYC) expedida en 1977, ${ }^{263}$ en la que se integraron las normas financieras de presupuesto, de contabilidad, de determinación y recaudación de recursos, presupuesto y tesorería y las normas de control, conformando un cuerpo jurídico financiero moderno en consonancia con el modelo intervencionista en la economía y en el Estado social consolidado a nivel internacional después de la Segunda Guerra Mundial y en los años cincuenta y sesenta en nuestro país, con la influencia regional de la CEPAL y de otros organismos vinculados a las Naciones Unidas.

Previo a la expedición de la LOAFYC se expidieron los decretos 575, 293, el 1015 y $94^{264}$ que concentraron la actividad financiera pública y su ejecución en el Ministerio de Finanzas que se organizó con una subsecretaría de rentas, otra de presupuesto y crédito público, otra técnica y de tesorería general de la nación y con direcciones de recaudaciones, de contabilidad gubernamental, etc., lo que fue ratificado en el Art. 48 de la nueva ley, que a la vez incluyó en el ordenamiento jurídico ecuatoriano las regulaciones sobre el crédito público que ya en 1957 autorizaron la creación de la Junta de Crédito Público, que se sustituyó por un Comité de Financiamiento en 1963 y por el Comité de Crédito Externo en 1973, que finalmente no solo regulaba a este sino también al crédito interno.

Con la expedición de la LOAFYC se sustituyó también un proceso de administración financiera con trámites excesivos y contradictorios, en los que el Ministerio de Finanzas y la Contraloría participaban en operaciones establecidas o compartidas, como la provisión de recursos para sueldos y salarios y en los que se registraban ingresos y se fijaban cupos y acuerdos de transferencia de recursos públicos, así estos fueran recaudados directamente por las entidades públicas, retardando innecesariamente su desembolso, mientras otros se procesaban directamente en el Banco Central o estaban sujetos a regímenes específicos de excepción.

La LOAFYC se concibió como un cuerpo legal integrado y sistémico para coordinar la administración financiera moderna de las entidades y organismos del sector público y para articular los servicios públicos con el desarrollo socioeconómico, con la finalidad de que pudieran operar de manera eficiente, efectiva y económica. La ley no integra

.aspx?id=HISTORIC-LEY_ORGANICA_DE_ADMINIS

TRA

CION_FINANCIERA_Y_CONTROL_1977 \&query =LOAFYC\#I_DXDataRow1

${ }^{262}$ Ecuador, Ley Orgánica de Hacienda Codificada, Registro Oficia 855 de 29-julio-1975.

${ }^{263}$ Ecuador, Ley Orgánica de Administración Financiera y Control (LOAFYC), Registro Oficial 337, 16mayo-77.

${ }^{264}$ Ecuador, Presidencia de la República, Decreto 1015, Registro Oficial 953, 16-diciembre-1975; Decreto 994, Registro Oficial 232-14 de diciembre-1976. 
formalmente los componentes de la actividad financiera a la planificación pero la presupone y la relaciona con el presupuesto y la gestión financiera de los servicios públicos, para establecer metas, cuantificar efectos y evitar la improvisación y el dispendio de bienes.

La nueva ley concentró los recursos presupuestarios para optimizar los ingresos y gastos y racionalizar su uso, relacionando el sistema presupuestario con la contabilidad y el control fiscales. En cuanto a la determinación y recaudación de los recursos financieros tributarios y no tributarios, la norma centralizó esas actividades en el Ministerio de Finanzas y consideró una cierta descentralización a favor de los gobiernos locales conforme al Código Tributario y las leyes de la materia. El sistema de tesorería preveía la continuidad en la provisión y flujo de fondos, conforme a la recaudación y a las necesidades presupuestarias y el manejo de la cuenta única del tesoro nacional, garantizando siempre una administración financiera unificada. Los sistemas de contabilidad y control formaban parte también del sistema de administración financiera para contar con información gerencial operativa, incorporando los principios de contabilidad generalmente aceptados y los sistemas de control interno y de auditoría moderna que permiten establecer observaciones, correctivos y responsabilidades de los funcionarios públicos en el ámbito administrativo, civil y penal. ${ }^{265}$

La consolidación del Estado social o intervencionista, tanto en la actividad económica como en el reconocimiento y promoción de los derechos económicos, sociales y culturales de los ciudadanos en la provisión de los servicios públicos, tiene repercusiones directas en el contenido del derecho y la legislación financiera públicos. El derecho financiero de contenido meramente instrumental o medial, propio del Estado liberal, es sustituido también en el caso ecuatoriano desde la Constitución de 1929 hasta 1945 de manera paulatina y desde entonces hasta los años 90 de manera más directa, por un derecho financiero público promocional de carácter social e igualitario en el ámbito económico. Está fundamentado en la justicia, tanto en la normativa relacionada con el ordenamiento de los ingresos como de los gastos, ${ }^{266}$ enfatizando en el carácter solidario de la actividad financiera en el Estado social de derecho, concebido como una redistribución de bienes y resultado de una interconexión entre ingresos y gastos.

Con todo, tanto con los fundamentos antes indicados, el derecho tributario como el derecho del gasto adquieren una connotación redistributiva, dado que el primero obliga a contribuir a los que tienen más y el segundo está orientado a los que tienen menos, ${ }^{267}$ con lo que se supera el tradicional interés fiscal recaudatorio liberal, al adoptar

\footnotetext{
265 Estudio Introductorio a la Ley Orgánica de Administración Financiera y Control (LOAFYC), http://portal.uasb.edu.ec:2165/WebTools/eSilecro/DocumentVisualizer/DocumentVisualizer.aspx?id=HIS TORICLEY_ORGANICA_DE_ADMINISTRACION_FINANCIERA_Y_CONTROL_1977\&query=LF YC\#I_DXDataRow1

${ }^{266}$ Modesto Fabra Valls, "Solidaridad y Derecho Financiero en una sociedad neocompetitiva", en Revista Española de Derecho Financiero, Nro. 120, Madrid, 2003, 609 -680.

${ }^{267}$ Alvaro Rodríguez Bereijó, Introducción al estudio del Derecho Financiero. Un ensayo sobre los fundamentos teóricos del Derecho Financiero, (Madrid: IEF, 1976).
} 
principios de justicia tributaria y de solidaridad para cubrir los fines, funciones y gastos crecientes del Estado intervencionista que beneficia a todos los ciudadanos, independientemente de la capacidad y contribución económica de cada uno de ellos, por lo "que se desvincula su financiación de la utilización que cada sujeto efectúa". 268

La crisis del modelo intervencionista y de gobernabilidad del estado de bienestar desde los años 80 del siglo XX a nivel internacional, no solo obedece a una explosión externa e interna de la deuda externa y a una crisis de financiación de los crecientes gastos públicos y de los gastos sociales, sino a la necesidad de buscar una estructura democrática o una alternativa para limitar el gasto público incrementado por la política clientelar de los parlamentos, de los partidos políticos y de los gobiernos. Pero además, fundamentalmente se trata de un cuestionamiento promovido en un marco doctrinario por el neoliberalismo, asumido como política oficial de los organismos financieros internacionales que representan los intereses de las empresas transnacionales y del capital financiero internacional, por el "excesivo aumento del poder del Estado sobre el sistema económico y sobre la propia sociedad" y por la ineficiencia estatal en la provisión de los servicios públicos para beneficiar los intereses corporativos de la burocracia y perjudicar a los actores privados y a los individuos que supuestamente en el mercado pueden ofrecer servicios más eficientes y económicos que los estatales. ${ }^{269}$

Como hemos señalado oportunamente en nuestros análisis sobre la realidad general del país y los modelos económicos, la crisis del intervencionismo estatal y del Estado social en nuestra región y particularmente en el Ecuador, se agudizó en la década del ochenta del siglo pasado como resultado del excesivo gasto público, de la burocratización y del efecto negativo de la enorme deuda externa que creció en los años setenta y ochenta por iniciativa del mismo capital financiero internacional y de los gobiernos de turno para satisfacer la financiación y contratación de grandes obras públicas de infraestructura, en los que se denunciaron enormes sobreprecios y sobornos; por el voluminoso gasto militar contratado a propósito de los conflictos territoriales con el Perú y las crecientes demandas sociales en infraestructura, educación, salud, seguridad social, etc.

La colocación de excedentes financieros en los países subdesarrollados como Ecuador con tasas de interés bajas, inferiores a la inflación, facilitaron el endeudamiento agresivo y la inversión en obras desproporcionadas e ineficientes que constituyeron una pesada carga para el país, como la procesadora de basura en Guayaquil (se pagó pero nunca se instaló por completo); la imprenta del Ministerio de Educación en Quito (permaneció embodegada por más de doce años) o la compra de barcos pesqueros a Noruega por parte de empresarios cuyas deudas se trasladaron al Estado, masivas compras de armas, envío de cuantiosas remesas de utilidades de empresas extranjeras, etc. ${ }^{270}$

\footnotetext{
${ }^{268}$ Modesto Fabra Valls, "Solidaridad y Derecho Financiero en una sociedad neocompetitiva", en Revista Española de Derecho Financiero, Nro. 120, 617.

${ }^{269}$ Modesto Fabra Valls, "Solidaridad y Derecho Financiero en una sociedad neocompetitiva", en Revista Española de Derecho Financiero, Nro. 120, 617.

${ }^{270}$ Alberto Acosta, Breve historia económica del Ecuador, (Quito: Corporación Editora Nacional, 2012).
} 
Los organismos financieros internacionales, FMI, BM y BID, satisfaciendo los intereses y necesidades del capital financiero internacional, alentaron el endeudamiento agresivo de los años ochenta del siglo pasado. Frente a la crisis en el pago de la deuda acelerada por el descenso de los precios del petróleo en el mercado internacional no tuvieron ningún reparo de recomendar o imponer drásticos ajustes "de las economías que ellos contribuyeron a endeudar" o que el Estado "asuma los riesgos de los acreedores y de los deudores privados", como lo observa Alberto Acosta.

En sus estudios, la CEPAL ha reconocido que la crisis de la deuda en América Latina paralizó su desarrollo y que su oneroso costo no se dividió de forma equitativa, ya que los prestamistas sufrieron pérdidas relativas, mientras el impacto lo sufrieron las personas de los distintos países de la región por el deterioro en la producción y en la inversión y el incremento de la pobreza en un 20\%. Los países no pudieron formar un frente común frente a los acreedores internacionales, sobre todo norteamericanos, por lo que aprovecharon esa situación para minimizar las pérdidas y exigirles la adopción de medidas internas devaluatorias, de privatización de bienes públicos y de ajustes fiscales e incremento de tributos para garantizar el pago de sus gravosas acreencias. La reactivación de la región exigió una reducción de la deuda (Plan Brady), pero en mayor medida ajustes fiscales y el aprovechamiento de nuevas oportunidades en el comercio internacional en la década del 90, con el aumento de sus exportaciones y una mejora en el precio de sus productos primarios. ${ }^{271}$

\section{La Hacienda pública moderna neoliberal (1990-2006)}

El modelo neoliberal o nuevo liberalismo ${ }^{272}$ que se adoptó inicialmente desde los años setenta y ochenta a nivel internacional se introdujo de manera tardía y lentamente en Ecuador entre 1990 y el 2000, tanto para enfrentar el burocratismo, la inflación, el masivo y gravoso endeudamiento externo y el excesivo intervencionismo y regulacionismo estatal, y articular al país más intensamente hacia la globalización.

Con la finalidad de impulsar la libre competencia, el comercio y los derechos y beneficios de los consumidores, en este período histórico se redujo el proteccionismo y los aranceles y el país se adscribió (1995-1996) a la Organización Mundial de Comercio (OMC) y al Acuerdo General sobre aranceles y tarifas (GATT), con la finalidad de incorporarse abiertamente a la reciente nueva etapa de la globalización comercial y económica mundial.

En este período también se promovieron: la eliminación de las barreras arancelarias; la disminución y en algunos casos la supresión de los impuestos directos y la generalización y aumento de los indirectos; las privatizaciones y concesiones; se liberalizaron las normas financieras; se reformaron las finanzas públicas para asegurar

\footnotetext{
${ }^{271}$ Bárbara Stallings, y otros en La crisis latinoamericana de la deuda desde la perspectiva histórica, CEPAL, (Santiago de Chile: Cooperación Alemana y Banco de Desarrollo de América Latina, 2014).

${ }^{272}$ Norberto Bobbio, Liberalismo y Democracia, (México: Fondo de Cultura Económica, 1997).
} 
su equilibrio y control de los recursos públicos por parte del Ejecutivo, para asegurar el pago y el servicio de la deuda externa y se fortalecieron las facultades presidenciales para modificar la estructura administrativa y acelerar la transferencia de los servicios públicos y los recursos naturales a favor del sector privado y del capital transnacional.

En el lapso antes indicado, con clara inspiración ideológica en los postulados de la Escuela de Austria $^{273}$ y de Chicago, se desmanteló en Ecuador la estructura de planificación y se organizó para el efecto una oficina secundaria adscrita a la presidencia de la república. Se debe recordar también que el neoliberalismo insiste en construir una "nueva economía de mercado" para sustituir a regímenes de economía planificada o al modelo de economía mixta o intervencionista que utilizan la planificación como política pública de gobierno de manera indicativa en numerosos países capitalistas del mundo y como instrumento de desarrollo, de equilibrio económico, de promoción del empleo y de compromiso político del régimen con sus electores en países periféricos o subdesarrollados. ${ }^{274}$

Ello no significa, según los neoliberales, que el Estado no cumpla un papel económico de justicia y solidaridad, pues controla y promueve subsidiariamente la infraestructura social de salud y educación y mantiene sus competencias básicas de seguridad interna y externa y de administración de justicia.

En cuanto a las finanzas públicas y siguiendo los principios de la hacienda moderna, el neoliberalismo planteó adicionalmente reducir el gasto; restringir la burocracia e incrementar la carga tributaria indirecta sobre el gasto de la mayoría de la población para financiar necesidades esenciales de la sociedad, disminuyendo a la vez los impuestos directos, en concreto sobre la renta de personas y sociedades para favorecer el ahorro, la inversión y el crecimiento de las empresas. En definitiva, en Ecuador jamás llegaron a afectar a los niveles económicos más altos de la sociedad, pues sus regulaciones favorecieron solapadamente la evasión y la elusión. La ventaja de los impuestos indirectos establecidos y en especial sobre el consumo, como el IVA, radica en su invisibilidad, pues se confunde con el precio y la carga del tributo se traslada fácilmente a los compradores o usuarios de los bienes y servicios.

Respecto de los servicios públicos el neoliberalismo prefirió su privatización para que fueran prestados por sectores particulares internos o externos o pagados mediante precios que sustituyen la noción anterior de tasa para garantizar eficiencia, calidad y rentabilidad.

\footnotetext{
${ }^{273}$ Se conoce como Escuela de Austria al pensamiento de Karl Menger, Friedrich von Hayek, Ludwig von Mises y Wilhelm Roepke, que de manera sostenida se enfrentan a los sistemas de economía mixta y al socialismo con la convicción de que el intervencionismo estatal y la planificación atentan contra la libertad de mercado y la libre acción de los actores económicos mundiales.

${ }^{274}$ Friedrich A. von Hayek, Camino de la servidumbre, (San José: Libro Libre, 1989).
} 
Es por eso que se deberá coincidir con quienes afirman que en el modelo de Estado neocompetitivo los cambios se han sentido fundamentalmente en la estructura y composición del sistema tributario, destinado a recaudar lo necesario y suficiente para el sostenimiento de los gastos públicos mediante la imposición indirecta, en desmedro de los tributos personales y progresivos. En cuanto a los servicios públicos, los sistemas de financiamiento se fundamentan en el principio del beneficio o conmutativo, esto es, recae sobre los ciudadanos que se benefician después de establecer el coste que ocasiona a la Administración. Finalmente, en lo relativo a las privatizaciones, si bien las competencias económicas públicas del Estado se trasladan al mercado, ello no significa un abstencionismo de los poderes públicos en cuanto al control de la calidad, empleo y precios de los servicios esenciales que se ofrecen a los ciudadanos por parte de actores privados o públicos, por lo que en realidad se sostiene que existe un tránsito de un Estado providencia a un Estado promotor o de regulación y control. ${ }^{275}$

El sistema tributario en el modelo neoliberal que reduce la progresividad de los impuestos personales, sostiene, no sin fundamento, que el régimen intervencionista tampoco alcanza los efectos redistributivos y de justicia propuestos, porque además de ser ineficiente en el control del fraude y de la elusión produce efectos recesivos y nocivos sobre la población más necesitada, pues aumenta el desempleo. En vista de ello se plantean mecanismos para aliviarlo, fijar un límite máximo o para crear estímulos en caso de generación de empleo. Se trata, por tanto, de aplicar con ductilidad, de acuerdo a las condiciones históricas, los principios tributarios de proporcionalidad, no confiscatoriedad, capacidad económica, etc.

El modelo neoliberal, en todo caso, no pretende eliminar radicalmente el valor de la solidaridad y de la justicia en el que se fundamenta el Estado social, sino reformular el sistema tributario y del gasto público para que aquellos operen eficientemente en el sostenimiento del sistema y de los servicios esenciales para los más pobres, pero sin afectar la sobreacumulación productiva y financiera de los monopolios y de las empresas transnacionales. En lo relativo a la asignación equitativa de los gastos públicos se establece una conexión con el principio de igualdad material y medidas de discriminación positiva, para superar las desigualdades de origen y proveer los gastos sociales más significativos. Pero además, en el campo de las finanzas públicas y de la actividad financiera, el modelo exige alcanzar permanentemente el equilibrio presupuestario, para lo cual los principios de los ingresos y de los gastos públicos deben estar íntimamente relacionados y "tienen sentido si se conectan con los efectos redistributivos del conjunto de la actividad financiera" para "la mitigación de las diferencias y la tendencia hacia una sociedad más justa y solidaria”. ${ }^{276}$

En el caso ecuatoriano, las condicionalidades, imposiciones y sugerencias del FMI y del BM han estado presentes de manera directa o indirecta en la conducción, políticas y

\footnotetext{
${ }^{275}$ Modesto Fabra Valls, "Solidaridad y Derecho Financiero en una sociedad neocompetitiva”, en Revista Española de Derecho Financiero, Nro. 120, 2003.

${ }^{276}$ Ibíd.
} 
modelos económicos que han tenido presencia en el país desde que formamos parte de esos organismos multilaterales. ${ }^{277}$ Las principales políticas y leyes monetarias, financieras, tributarias, presupuestarias, de planificación, gasto, recortes sociales y de subsidios, medidas de control y las que rigen el crédito público adoptadas desde los años cincuenta del siglo pasado, y en especial desde los años setenta hasta la actualidad, han sido sugeridas por esos mismos organismos internacionales o han estado en consonancia con ellos.

Junto a los programas de ajuste y estabilización y las cartas de intención suscritas por los gobiernos de turno, como resultado de las visitas y revisiones de las misiones del FMI en aplicación del punto IV del tratado correspondiente y de los informes del BM, la legislación interna se ha modificado y ajustado con base en dichos documentos, como paso previo para obtener préstamos de estabilización o como carta de presentación para acceder a los mecanismos crediticios internacionales. La intervención era directa en los gobiernos de tendencia neoliberal y solapada en los gobiernos de centro izquierda o de izquierda, ya que estos argumentaban que no adoptaban las políticas y medidas por imposición de los organismos multilaterales, sino que se trataba de iniciativas soberanas adoptadas previamente por los propios gobiernos frente a los desajustes y a la crisis económica. Era por lo tanto una certeza y una fundamentada percepción que las políticas económicas y la legislación financiera adoptadas o reformadas en Ecuador finalmente estaban impuestas por los organismos financieros internacionales y que la acción del gobierno se limitaba a acoplarlas a los intereses de los grupos de poder local de los que dependía de manera directa, buscando la mejor oportunidad para adoptarlas, tratando de controlar y disolver las reacciones sociales que evidentemente provocaban.

Durante la implementación del modelo neoliberal, desde los años noventa hasta inicios del presente siglo, se suscribieron cuatro cartas de intención emblemáticas en la adopción de esas políticas: la suscrita por el gobierno de Sixto Durán, el 31 de marzo de 1994, en la que se evalúan las reformas introducidas entre 1992 y 1993, por sugerencia de dichos organismos internacionales y en la que se prevé las reformas y medidas a ser adoptadas entre 1994-1995 y las cartas de intención del 2000 y 2003, relativas a la reestructuración de la banca privada recientemente colapsada y la última tanto a la política fiscal como a otras reformas y ajustes estructurales. ${ }^{278}$

Entre las medidas que se adoptaron tanto por el Gobierno social demócrata de Borja, quien también suscribió tres cartas de intención con el FMI entre 1989-1991, como en el neoconservador de Durán Ballén, que suscribió la Carta de Intención de 1994, se destacan: las nuevas leyes tributarias, presupuestarias, de modernización del Estado, de

\footnotetext{
${ }^{277}$ Ecuador acepta y ratifica el Convenio Constitutivo del Fondo Monetario Internacional (FMI) mediante Decreto del Congreso Nacional, de 10 de diciembre de 1945. Véase, BANCO CENTRAL DEL ECUADOR "Cartas de Intención suscritas por el Gobierno del Ecuador con el Fondo Monetario Internacional”. Quito. s/e. 1990, 8.

${ }^{278}$ Carta de Intención del Gobierno del Ecuador (presidente Sixto Durán) al FMI, Quito, 31 de marzo de 1994 y cartas de intención del Gobierno de la República del Ecuador (presidente Gustavo Noboa), Quito, 2000, Publicación del Banco Central del Ecuador.
} 
regulación de la administración y de descentralización. Tras suscribir el documento el régimen se comprometió a: realizar acciones para "profundizar las reformas estructurales y los procesos de privatización"; adoptar "políticas macroeconómicas y fiscales sanas" o de "saneamiento de la economía", con medidas de ajuste y "flotación" de los precios de los combustibles, mejorando el cobro de impuestos e incrementando las tarifas de servicios públicos; desinvertir en bienes de instituciones del Estado; fusionar y eliminar entidades públicas; reducir puestos en el servicio público; liberalizar de control al sistema financiero y al mercado de capitales; profundizar el aperturismo comercial ajustes; ajustar la política salarial; reestructurar la deuda, etc.

Es más, el Gobierno de Durán Ballén aceptó al inicio de su mandato un acuerdo para poner en vigencia la deuda a punto de prescribir; renegoció luego la deuda externa en el marco del Plan Brady y expidió leyes económicas para promover las privatizaciones; las concesiones; las reformas administrativas, presupuestarias y tributarias. Durante la vigencia de este modelo se expidieron, como ya lo hemos indicado, reformas a la Constitución vigente de 1978 y, finalmente un nuevo texto de la carta, conocida como Constitución de 1998, con la finalidad de afianzar el modelo neocompetitivo y una nueva legislación para consolidar dichas reformas, la flexibilización laboral, la productividad, la descentralización, la reforma judicial, etc.

Adoptada la dolarización como respuesta de la crisis y del saqueo bancario de recursos públicos y privados, el Gobierno de Gustavo Noboa suscribió con el FMI dos nuevas cartas de intención el 4 de abril de 2000 y en mayo de 2001, con las que se estableció la necesidad de reestructurar la banca privada colapsada en 1999 y fortalecer su solvencia; reestructurar la deuda del sector privado; descongelar los depósitos y apoyar financieramente para fortalecer su liquidez. Se definió también una política fiscal ortodoxa para controlar el equilibrio presupuestario y el gasto en remuneraciones con la finalidad de privilegiar el servicio y pago de la deuda externa; una política de ajuste supuestamente para financiar programas sociales, mediante la adopción de precios internacionales de los combustibles y en las tarifas de electricidad y una política social que flexibilice el trabajo, focalice el bono solidario, apoye la cobertura de salud de los niños y de mujeres embarazadas y la creación de un fondo de desarrollo para comunidades indígenas. A tal efecto se expidieron, además las denominadas Leyes para la Transformación Económica del Ecuador, conocidas como Trole I y Trole II (2000), por su múltiple contenido en relación con los temas antes indicados y la Ley Orgánica de Responsabilidad, Estabilidad y Transparencia Fiscal (2002). ${ }^{279}$

Con la Carta de Intención suscrita en el Gobierno de Lucio Gutiérrez en marzo de 2003, cuyas medidas el presidente las denominó un leve "pinchazo", se impusieron nuevos aumentos en los precios de los combustibles para reducir los subsidios; recortes drásticos a la inversión social y los servicios y medidas de flexibilización laboral para

\footnotetext{
${ }^{279}$ Ecuador, Leyes para la Transformación Económica del Ecuador: Trole I, Registro Oficial 34 de 13 de marzo de 2000 y Trole II, Registro Oficial 144 de 18 de agosto de 2000; Ley Orgánica de Responsabilidad, Estabilización y Transparencia Fiscal, Registro Oficial 589, 4-jun-2002.
} 
favorecer la intermediación y la tercerización laboral. A la vez se acrecentó el monto del presupuesto para pago de la deuda externa de 2.370 millones USD en 2003 a 3.795 millones USD, se incrementó el desempleo abierto del 7,7\% en 2002 al $12 \%$ en 2005 y se elevó la cotización de los bonos global de la deuda externa. ${ }^{280}$

La prevención de la crisis económica y financiera en nuestros países, para afianzar su proceso de desarrollo, no solo demanda una más eficiente regulación del sistema financiero internacional y local, sino también el abandono de políticas económicas rentistas y una configuración macroeconómica sólida y solvente que fortalezca las actividades productivas y de exportación, renueve constantemente la tecnología, defina una política fiscal justa y redistributiva, canalice recursos financieros a los sectores de la pequeña y mediana empresa, el combate frontal a la corrupción, limite las ganancias extraordinarias del capital transnacional y financiero y la fuga de la riqueza humana y material.

\section{La Hacienda pública actual o neointervencionista o neoestructuralista}

El modelo y las políticas neoestructuralistas, neointervencionistas o neodesarrollista, se inspiran en las reflexiones de economistas como Robert Solow, Paul Samuelson, Franco Modigliani y en América Latina en el pensamiento de Osvaldo Sunkel y otros, desde los años noventa. Ya en su implementación en la región, desde fines del siglo pasado y en lo que va del presente, se retoma una participación activa del Estado para modernizar el sistema y optimizar la relación local con el capital transnacional en la explotación de materias primas y recursos mineros; se reintroducen normas y leyes para fortalecer la institucionalidad de la planificación; se reforman las finanzas públicas para ampliar y fortalecer la tributación indirecta, reintroducir la tributación directa y controlar el flujo de recursos públicos para impulsar obras de infraestructura en el campo vial y eléctrico y para mantener o ampliar parcialmente ciertos beneficios en el ámbito de la educación, salud, seguridad social y subsidios para la población más pobre.

El neointervencionismo o neoestructuralismo no implica, sin embargo, desmantelar necesariamente las recetas o las políticas neoliberales, sino matizarlas y adecuarlas a los requerimientos del sistema y del momento económico y político del país, incluyendo en la realidad latinoamericana y ecuatoriana una renovada participación activa del Estado en la gestión o en el control de la economía, con una negociación con el capital extranjero para la explotación de los recursos naturales, sin afectar las reformas estructurales que se introdujeron en la fase neoliberal. Algunos autores discuten, como ya lo hemos dicho, si se trata realmente de un modelo diferente o de una simple variación del mismo. Nosotros los diferenciamos, por razones didácticas de comprensión e identificación de sus principales rasgos económicos y políticos, pues en realidad no se plantea restablecer el Estado providencia controlado por los burócratas, sino una acción conjunta del Estado con la sociedad civil y sus principales actores para

\footnotetext{
${ }^{280}$ Alberto Acosta, Breve historia económica del Ecuador, (Quito: Corporación Editora Nacional, 2012).
} 
renovar las bases institucionales de la sociedad, lo que ha ocasionado que se califique también a este modelo como neoinstitucionalista.

A fin de cuentas, la política fiscal de reducción o control del gasto recomendada por el neointervencionismo no resultó viable cuando se produjo una explosión de ingresos estatales por los altos precios internacionales de las materias primas que favorecieron la expansión del consumo y del empleo estatal, si bien se debió retornar paulatinamente a aquella cuando estos se desplomaron o se deterioraron. Los ajustes estructurales, impuestos inicialmente por el FMI, provocaron violencia y desagrado social, por lo que en esas condiciones fue preferible un ajuste gradual que no llevara al extremo las contradicciones sociales y desequilibrara la estabilidad política e institucional que resulta necesaria para garantizar los intereses globales del sistema.

En el contexto de la globalización, la liberalización financiera y comercial y la concentración del ingreso, se pueden sintetizar las propuestas del neoestructuralismo latinoamericano, en las siguientes: el Estado debe impulsar una estructura productiva competitiva que se inserte en el orden internacional, fomentando los "mercados ausentes" (de capital y divisas a futuro), "mercados incompletos" (tecnológicos), corrección de distorsiones estructurales por la concentración del ingreso y la heterogeneidad del sector productivo y la eliminación de las fallas del mercado.

El Estado puede, además, superar males internos o endógenos que afectan la estructura productiva, propulsando el "desarrollo desde adentro" para consolidar al sector productivo nacional y combatir a la pobreza extrema mediante estímulos a la microempresa y a la generación de empleo y la adopción de medidas para regular el amplio "sector informal", definir una política ambiental, innovar la producción con avances científicos y tecnológicos, estimular la formación de capital y propiciar la diversificación de las exportaciones. El Estado, finalmente, debe impulsar un régimen eficiente de "economía mixta" en armonía con el mercado y el medioambiente, para alcanzar el desarrollo, mediante la planificación y una dirección discreta de la economía que otorgue responsabilidades al sector privado y optimice sus ganancias.

Según el modelo neoestructural, siguiendo los parámetros de la Hacienda posmoderna o neodesarrollista, la justicia social y la redistribución son una condición necesaria para el desarrollo y la estabilidad macroeconómica. Sus propuestas están dirigidas a fomentar primero la oferta y luego al consumo, por lo que sus políticas amplían la inversión pública y fortalecen a las empresas, a los agentes financieros y limitan, sin afectar radicalmente, los derechos laborales. ${ }^{281}$

Fue significativo para la región latinoamericana que las reformas neointervencionistas introducidas desde los inicios del presente siglo por los propios organismos financieros

\footnotetext{
${ }^{281}$ Mauricio Plazas Vega, Derecho de la hacienda pública y Derecho tributario, las ideas políticas de la hacienda pública, (Bogotá: Editorial Temis, 2000).
} 
internacionales y el impacto positivo de los precios de los productos de exportación, no desataran una crisis financiera radical como producto de la crisis global que se inició en 2007 en EEUU y que se prolongó en Europa hasta 2013.

El Gobierno de Rafael Correa comenzó su gestión estableciendo una frontal distancia con el FMI y el Banco Mundial, llegando en los primeros años a adoptar "gestos" publicitarios para "expulsarlos del país" y a no aceptar, inicialmente, sus informes, suspendiendo las visitas oficiales de monitoreo e información. Se proclamó que el régimen había recuperado la soberanía en el manejo de la política económica y que los "ajustes estructurales habían quedado en el pasado". 282

Correa dispuso en 2008 la suspensión parcial en el pago de la deuda externa con la finalidad de renegociarla, luego de nombrar previamente en 2007 una Comisión de Auditoría Integral del Crédito Público que emitió investigaciones y valoraciones importantes que permitían declarar su ilegitimidad total. ${ }^{283}$ El gobierno, finalmente, se abstuvo de realizar acciones legales y de sancionar a los responsables del endeudamiento ilegal y se limitó a recomprar parte de los Bonos Global, dejando vigentes los Bonos a 15 años, con lo que redujo el peso de la deuda en relación con el PIB entre los años 2009 y 2010. Dicho sea de paso, desde 2011 y en 2012 se inició un nuevo proceso de endeudamiento externo que en los años siguientes se tornó agresivo. $^{284}$

Una vez que la Constitución de 2008 entró en vigencia el régimen anunció que su propósito era establecer una nueva relación entre el Estado y la sociedad y adoptar políticas públicas eficientes para defender el interés colectivo. El gobierno aprovechó la coyuntura económica internacional de altos precios de las materias primas y en especial del petróleo para mantener un distanciamiento con los organismos financieros internacionales y promover un nuevo crecimiento burocrático del Estado y de las remuneraciones públicas y mejorar la calidad y extensión de los servicios públicos. Se impulsó igualmente la construcción de obras públicas viales y de grandes proyectos hidroeléctricos. La cuestión es que para financiarlos se prescindió de los créditos de estabilización del FMI, exigidos como requisito para acceder a los mercados financieros tradicionales, y en cambio se recurrió a los ofrecidos por el Gobierno chino, que no demandaban los pronunciamientos de los organismos multilaterales en referencia y que se los efectuó rápidamente, con altas tasas de interés y a corto plazo, facilitando el acceso masivo de las empresas de ese país en la construcción de las referidas obras públicas.

El endeudamiento público interno y externo creció desmesuradamente en los últimos años, con especial incidencia a partir del 2014, como resultado de la crisis financiera

\footnotetext{
${ }^{282}$ Rafael Correa Delgado, Informe a la Nación 2007 - 2017, www.planificacion.gob.ec.

${ }^{283}$ Informe final, resumen ejecutivo, Comisión para la Auditoría Integral del Crédito Público, Quito, diciembre de 2008, www.tce.gob.ec/biblio/opac_css/index.php?lvl=notice_display\&id=2053 ...

${ }^{284}$ Alberto Acosta, Breve historia económica del Ecuador, (Quito: Corporación Editora Nacional, 2012).
} 
internacional, la apreciación del dólar, el deterioro del precio de las materias primas y sobre todo del petróleo y los desastres naturales que afectaron especialmente a las provincias de Manabí y Esmeraldas, ubicadas en la costa ecuatoriana. Para mantener el incremento del gasto y superar los límites establecidos al endeudamiento (40\%) en el Código Orgánico de Planificación y Finanzas (Arts. 134 y 135) el Gobierno de Rafael Correa expidió varias resoluciones y decretos para un manejo discrecional de la deuda, declarar reservadas las negociaciones y ejecución de los contratos de los créditos externos, modificar el destino de los recursos externos y diferenciar la deuda consolidada de la deuda agregada, excluyendo la deuda interna, las ventas anticipadas de petróleo y los certificados de tesorería. ${ }^{285}$

Si se comparan los resultados económicos durante la aplicación del modelo neoliberal hasta 2006 y el modelo neointervencionista, no se advierten diferencias importantes en cuanto a crecimiento económico, redistribución del ingreso y disminución del desempleo y subempleo. En cambio, sí una mejoría que no se debe desestimar en cuanto a la disminución de la pobreza y extrema pobreza, aumento en el salario real y en la cobertura de educación, salud y la seguridad social.

Según el Banco Central del Ecuador la tasa de crecimiento promedio anual entre 1997 2006, fue de 3,2\% y entre 2007 - 2016, fue de 3,4\%. Hasta 2007 los trabajadores captaron el 31,6\% del ingreso nacional mientras en 2016 el 37,4\%. Según el INEC la pobreza por ingresos se redujo de 37,6\% a 22,9\% en el período 2006 a 2016 y la extrema pobreza descendió de 16,9\% en 2006 a 8,7\% en 2016. El Banco Central registra como salario real promedio 240 USD entre 2000 y 2004 y 352 USD entre 2007 y 2016 y el aumento en la cobertura en la seguridad social del 19,8\% en 2007 al 34,1\% de la población económicamente activa. ${ }^{286}$

Las políticas y la legislación económica y financiera que se adoptaron en los diez años del modelo neointervencionista han seguido disimuladamente los parámetros establecidos por los mismos organismos financieros internacionales, tal y como se puede constatar en el contenido del Código Orgánico de Planificación y Finanzas; del Código Monetario y Financiero; en la Ley de Alianzas Públicas y Privadas y en el nuevo Código Orgánico Administrativo que sustituyó a la Ley de Modernización, con regulaciones que amplían y flexibilizan las reformas estructurales y las opciones de privatización y de concesión de las obras y bienes públicos.

Con la disminución de los precios internacionales del petróleo y de los productos agrícolas de exportación, el Gobierno de Correa optó en los últimos cinco años por incrementar su endeudamiento no solo con China sino en el mercado financiero

285 Ecuador, Ministerio de Economía y Finanzas, Resoluciones Ministeriales MF-DM-RD-2010-20012002-2003, 27-abril, 27-octubre y 1-noviembre-2010; Presidencia de la República, Decreto Ejecutivo 489, Registro Oficial 383, 26-nov-2014; Decreto Ejecutivo 2218, 20-oct-2016.

${ }^{286}$ Datos del Banco Central del Ecuador y del INEC, referidos en el Informe a la Nación 2007-2017 del Presidente Rafael Correa Delgado en mayo de 2017. 
internacional con la colocación de bonos con altas tasas de interés, por lo que se favoreció un nuevo acercamiento con el FMI y el BM y se reiniciaron contactos para entregar información y admitir inspecciones con las que prever una regularización en sus relaciones para aliviar la carga de la deuda, propiciar una renegociación y obtener nuevos créditos para proyectos de infraestructura que son de interés del país.

Ya en el gobierno del presidente Lenin Moreno, a fines de 2017, una misión del FMI visitó Quito y se reanudaron oficialmente las visitas regulares de monitoreo de la economía (Artículo IV del Convenio Internacional), con declaraciones, que crean condiciones de una normalización en el cumplimiento de sus funciones tradicionales, una vez que se registró en el mercado internacional una recuperación en los precios del petróleo y de las materias primas y el nuevo régimen anunció que se otorgaría un mayor protagonismo en la economía a la inversión y al sector privado. ${ }^{287}$

\section{LA REALIDAD ECUATORIANA ENTRE 1990 Y 2017 Y LAS TRANSFORMACIONES EN EL DERECHO FINANCIERO PÚBLICO Y DE LAS INSTITUCIONES FINANCIERAS}

Entre 1990 y 2017 se suceden en la realidad ecuatoriana -y a veces se entrecruzan- los modelos económicos y políticos neoliberal y neointervencionista, en los que se insertan, antes o después de las reformas a las normas constitucionales de 1998 y 2008, la legislación económica financiera que, como hemos argumentado inicialmente, no solo cubre a las finanzas o a la Hacienda pública sino también a las normas que regulan la actividad y la instituciones del sistema financiero nacional, que si bien la mayoría de ellas se encuentran en el ámbito privado o de la economía social y solidaria, requieren de regulación pública por tratarse de servicios de interés público en los que se necesita oportunamente la intervención y regulación del Estado, como se ha demostrado en los períodos previos y aún en los episodios dramáticos de crisis, tanto a nivel internacional como nacional.

En el contexto del modelo neoliberal en Ecuador (1990-2005), monitoreado por el FMI y el BM, se pueden distinguir dos fases: la de ajuste y de reformas estructurales, en los últimos diez años del siglo pasado y la que va desde la dolarización en el 2000 hasta el 2005, en las que se dictó una amplia legislación para cumplir entre otros con los siguientes objetivos: modernizar, privatizar y desregular al Estado; disminuir la incidencia de la planificación estatal en la economía; generalizar las concesiones de los recursos y empresas de servicios públicos a favor del sector privado transnacional y local; liberalizar al sector financiero, para precipitar la fuga de capitales y el saqueo de los recursos de los ciudadanos y del Estado; expedir reformas tributarias para elevar el nivel de contribución de los ciudadanos al financiamiento de las actividades básicas del

\footnotetext{
287 Francisco Rivadeneira, delegado del Ecuador ante el FMI, entrevista Diario El Comercio, 3 de diciembre de 2017, 4.
} 
Estado y asegurar el pago de la deuda externa y las obligaciones financieras públicas y facilitar la inversión extranjera para sobreexplotar los recursos naturales del país, especialmente los petroleros.

La Constitución de la República de 1998, exigida primero por sectores sociales alternativos, se expidió finalmente atendiendo los intereses transnacionales y de los sectores económico y políticos dominantes del país, con la finalidad de que el Estado desregule su actividad económica y la traslade, al igual que la prestación de los servicios públicos, al sector privado mediante concesiones y aún la privatización de las de las empresas públicas o de sus acciones.

En el Gobierno socialdemócrata de Borja se aprobaron las primeras normas de modernización del Estado, como la flexibilización laboral, el régimen de la maquila y una reforma tributaria que intensificó y optimizó la recaudación. El grueso de los cambios jurídicos en el campo administrativo y financiero del Estado se produjeron en el gobierno de Sixto Durán (1992 - 1996), a tal punto que chocaron con las normas económicas todavía vigentes de la Constitución de 1978, por lo que se dio el caso de que varios de los instrumentos jurídicos de la modernización entre 1990 y 1998 eran manifiestamente inconstitucionales.

De hecho, en el mismo gobierno de Durán-Dahik se introdujeron reformas fundamentales a la Constitución (1993, 1995 y 1996) para hacerla coherente, -caso insólito en la aplicación de los principios de jerarquía y supremacía de la Constitución-, con las leyes dictadas por un Gobierno que aparentaba no tener brújula ideológica, pero que, en connivencia con los partidos políticos tradicionales, impuso a rajatabla, con mecanismos abiertos de corrupción y negociación legislativa, los intereses del capital transnacional, las exigencias neoliberales del Fondo Monetario Internacional y las de los grupos económicos locales articulados al capital financiero y especulativo transnacional.

Los gobiernos subsiguientes fueron adaptando el nuevo marco jurídico a los efectos nocivos que produjeron en la economía nacional, el saqueo de los recursos públicos y privados que efectuó el sector financiero en 1999, dentro de una agudizada crisis económica y política que enfrentó el país en esos años.

No está por demás insistir que todos estos cambios jurídicos se inscriben en el proceso de globalización o mundialización capitalista de la economía, cuyos momentos más importantes, características y efectos los analizamos anteriormente, por lo que encuentran en ellos una cabal explicación, si bien vale la pena indicar que esos cambios estuvieron determinados por la estructura de poder económico y político del país y por el ritmo con el que nuestra realidad, dentro de un aguda lucha social y emergencia de nuevos actores sociales, los ha ido asumiendo conforme a la correlación de las fuerzas en pugna y a acontecimientos como la guerra con el Perú en el Alto Cenepa (1995), la imposición de la paz, los desastres naturales, los escándalos de corrupción, el creciente 
involucramiento del Ecuador en la guerra interna de Colombia, la conformación de bloques regionales, etc.

Refiriéndose a la globalización o dominio mundial del capital y la hegemonía del capital financiero internacional, tanto en los países centrales como periféricos, Ximena Endara dice: "el papel protagónico de la banca internacional privada y su influencia en la política internacional es evidente, no solamente por las repercusiones políticas y sociales que ha tenido el pago de la deuda externa, sino sobre todo por la nueva función que asumió el FMI de ser guardián de los intereses de la banca internacional privada" y "el capital financiero necesitaba libertad de movimientos para poder cumplir con el proceso de valorización, para ello se implementaron las políticas de liberalización de la economía y las doctrinas neoliberales son el mejor marco teórico. Esto explica la tendencia mundial a la liberalización de los mercados y a la desregulación de la economía en general, lo que vuelve caduco el papel del estado interventor. Es así como en un complejo proceso de readecuación y cambios se va reconstituyendo el capitalismo en medio de la crisis, uno de cuyos resultados más visibles desde mediados de la década pasada (1985) es el funcionamiento de un mercado financiero global". ${ }^{288}$

Durante el Gobierno de Sixto Durán y Alberto Dahik (1992-1996) se impulsaron con mayor fuerza varias reformas y nuevos instrumentos jurídicos que respondían al proceso globalizador controlado por el capital financiero. El régimen expidió un Plan Macroeconómico de Estabilización al inicio de su gestión el 4 de septiembre de 1992 para fundamentar el sobreajuste dictado para controlar la inflación, eliminar el déficit fiscal, liberalizar aún más la economía en las esferas financieras y del comercio exterior, modernizar el estado y acceder a un acuerdo stand by con el FMI (1994), en el que se ofrecía una reducción del déficit fiscal, un estricto control del gasto público, una reducción de 21.000 empleos estatales y un intenso programa de privatizaciones de empresas públicas en las áreas de telecomunicaciones, electricidad, petróleo y seguridad social.

Recordemos que en la parte final del Gobierno liberal-social-demócrata de Rodrigo Borja (1988-1992) se aprobaron la flexibilización laboral, las leyes de la maquila y el nuevo régimen jurídico para el sector monetario, eléctrico y de las telecomunicaciones, que constituyeron el punto de arranque para todo un cuerpo jurídico de claro contenido inconstitucional que se impuso en los primeros años del Gobierno de Sixto Durán y al que ya hemos hecho referencia en el capítulo anterior.

En esos gobiernos también se realizaron varias desinversiones estatales, en empresas como la Cemento Nacional, Aztra, Ecuatoriana de Aviación y otras en las que se dieron escándalos y denuncias de corrupción. No solo eso, mediante decreto ejecutivo,

\footnotetext{
${ }^{288}$ Ximena Endara Osejo, Modernización del Estado y Reforma Jurídica, Ecuador 1992-1996, (Quito: UASB, 1999), 43.
} 
violando normas legales y constitucionales vigentes, se eliminaron varias instituciones y empresas del Estado.

Las reformas legales y estatales antes indicadas deben ser vistas "como una necesidad del capital financiero monopólico transnacional y sus socios criollos, para readecuar la estructura del país a las nuevas modalidades y ritmos de acumulación y centralización capitalista, que requieren de una nueva forma de intervención el Estado en la economía; como una exigencia de los organismos multilaterales, especialmente del FMI, que consideran la reforma jurídica como básica para promover medidas de política económica que cumplan sus programas de ajuste y estabilización; como uno de los espacios de legitimación del régimen, ya que la ley y el proceso de promulgación se ha desarrollado de tal manera que su aprobación es un logro político del sector que la impulsa y como sostén jurídico del modelo neoliberal monetarista, convirtiéndose en el eje central de la acción del presente gobierno (Durán Ballén)". ${ }^{289}$

Con todo y con eso, las modificaciones en la estructura estatal para cuestionar el papel intervencionista del Estado en la economía y en la planificación; la reforma fiscal tanto en lo tributario como en lo presupuestario; la apertura comercial; la reforma en el sector financiero y en el mercado de valores, no dieron los resultados inicialmente esperados. El Estado continuó siendo una institución ineficiente y burocrática, con desiguales remuneraciones que polarizaron a una mayoría mal pagada y a una burocracia dorada con prebendas y beneficios que producían escándalo y rechazo en la población; la disminución de personal y el pago de generosas liquidaciones a funcionarios de alto nivel no produjeron el "adelgazamiento" del Estado propuesto, puesto que se recurrió a "tercerizar" los servicios, o se volvió a contratar a los supuestamente separados, pero esta vez con mayores remuneraciones que no eran las que percibían quienes tenían antes carrera administrativa.

La liberalización financiera limitó los controles a los bancos y otras entidades por parte de la correspondiente Superintendencia, favoreciendo los créditos vinculados y sin garantías suficientes y la fuga de capitales. Todo esto ocasionó quiebras que perjudicaron a los depositantes y al Estado, quienes por medio del Banco Central o la AGD y el Ministerio de Finanzas, asumieron el fraude de los banqueros que fueron procesados, mientras que otros se fugaron del país para gozar de los cuantiosos recursos que trasladaron a su favor en el exterior.

El mercado de valores funcionó limitadamente, sin un aporte significativo al financiamiento de los sectores productivos; la apertura comercial perjudicó a la industria y pequeña industria y se generaron serios problemas para la agricultura frente a precios más bajos y subsidiados de los países industrializados; la modernización de ciertas empresas del Estado, convertidas en sociedades anónimas, permitieron el despilfarro, la corrupción y evitaron el control de los recursos públicos por parte de la

${ }^{289}$ Ibídem, 114. 
Contraloría General del Estado; los procesos de concesión no ocasionaron una real inversión extranjera de riesgo, sino que sirvieron para encubrir los nuevos negocios en los que el Estado corrió los riesgos financieros y los concesionarios recibieron mayores beneficios, transformando la mayoría de veces los contratos de concesión en contratos de construcción, en cuyos precios unitarios se incluyeron los valores de un financiamiento que finalmente asumió el propio Estado; los servicios públicos no mejoraron sustancialmente en su calidad y cobertura, y se atropellaron los derechos de los usuarios y consumidores.

Por aceptación del 85\% de los países miembros, en 1999 el FMI decidió aumentar las cuotas o aportes de cada país. En el caso ecuatoriano el aumento fue de 0.150 por ciento. ${ }^{290}$ Como es de conocimiento general, el FMI, "es una cooperativa financiera y su principal medio de financiamiento son las cuotas, que constituyen un fondo común integrado por las suscripciones de capital que aporta cada uno de los países miembros. Estos recursos permitieron a dichos países corregir desajustes sin tener que recurrir a medidas perniciosas para la prosperidad nacional o internacional". ${ }^{291}$

Como resultado de la inflación, la devaluación, el aprovechamiento desmedido en las operaciones cambiarias y en el entorno de una gran crisis política, ocasionada por la corrupción bancaria y los aportes al Gobierno del presidente Mahuad, el país asumió la dolarización en el 2000 sin la debida preparación y la adopción de medidas adecuadas para evitar una distorsión de precios y el colapso de las actividades productivas.

Como respuesta a esas medidas pronto se desató en el país la corrupción bancaria, que se agravó con los problemas suscitados en la economía internacional y en la producción nacional por efectos de los desastres naturales. Todo ello condujo a una severa crisis económica-financiera, que se profundizó por la falta de control y la complicidad de los grupos políticos de derecha o del populismo que manipularon las instancias de vigilancia del Estado para beneficiar a los grupos de poder a los que se encuentran vinculados.

La crisis se precipitó en el Gobierno de Jamil Mahuad, puesto que permitió a los banqueros y otros propietarios de las instituciones financieras -con el apoyo de otras autoridades estatales- saquear los recursos de los particulares y del Estado mediante préstamos vinculados y la entrega de cuantiosos recursos públicos, sin respaldo alguno, sabiendo que finalmente este, directamente o por medio de la AGD, iba a cubrir los fondos de los ahorristas y difícilmente se iba a cobrar sus acreencias a los beneficiarios de los generosos préstamos del Banco Central.

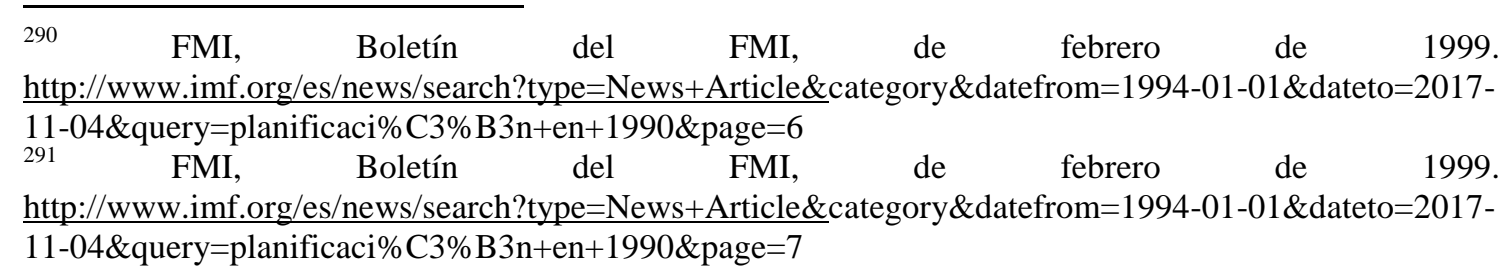


Las leyes de la Agencia de Garantía de Depósitos y el Impuesto a la Circulación de Capitales, ideados por el Partido Social Cristiano y aceptados por el Gobierno de Mahuad, se inscribieron en ese contexto, en la dolarización de la moneda nacional, que estuvo precedida de una gran devaluación que benefició, fundamentalmente, a los grandes deudores en sucres y a quienes desde años atrás manejaron el negocio cambiario y la fuga de capitales. Tan agresivo fue el saqueo de recursos públicos que el propio FMI y el BM, -defendiendo sus intereses y asegurando que el Estado no dejara de cumplir sus obligaciones con los acreedores internacionales-, exigieron límites y correctivos a los atracos bancarios y financieros promovidos por personajes que viven exilio en las grandes metrópolis del mundo.

Obviamente, como resultado de todos estos hechos y de la creciente reacción popular que destituyó al Gobierno, los grupos políticos dirigentes del país dictaron una serie de correctivos a la legislación financiera tanto en la Ley Orgánica de Administración Financiera y Control, como más tarde, la Ley Orgánica de Responsabilidad, Estabilización y Transparencia Fiscal (2002). El objetivo era asegurar el saneamiento de los mecanismos de intermediación hacia el futuro, ponerlos a tono con las regulaciones internacionales y convertirlos en un instrumento más seguro para el funcionamiento racional del país de forma que pueda inscribirse con menos riesgo en la globalización económica y mercantil del mundo que controlan los países industrializados con Estados Unidos a la cabeza. ${ }^{292}$

El sistema monetario dolarizado que se adoptó en esas circunstancias, fue y es tan rígido, que las exportaciones ecuatorianas pierden constantemente competitividad; resulta más barato importar que producir; las devaluaciones de Colombia y Perú benefician su producción y comercio en detrimento de esas actividades en el Ecuador; el desempleo y la migración crecieron luego de la dramática medida monetaria y las condiciones de vida en el país se deterioraron significativamente.

Con ese panorama a la vista, las perspectivas económicas, sociales y políticas del país no fueron alentadoras después de la dolarización y no se diga si a eso se suma la decepción creciente de la población frente a las ofertas incumplidas por los gobiernos de turno, a su incapacidad para gobernar y detener la corrupción y los crecientes compromisos adoptados con el FMI y la política exterior norteamericana que involucró al Ecuador cada vez más en la guerra interna de Colombia.

En este período histórico de deterioro y de aguda crisis política, con la destitución del presidente Jamil Mahuad en 2000 y más tarde la del presidente Lucio Gutiérrez en 2005, surge el proyecto político de Rafael Correa, quien luego de ejercer por corto tiempo en el Ministerio de Finanzas durante el Gobierno de Alfredo Palacio (2005), anunció su participación electoral combatiendo a la "partidocracia" y publicitando la

\footnotetext{
${ }^{292}$ Ecuador, Ley Orgánica de Responsabilidad, Estabilización y Transparencia Fiscal (LORYTF) Registro Oficial 589, 4-junio-2002.
} 
necesidad de convocar a una Asamblea Constituyente, para lo que contó con el apoyo de los movimiento sociales y de las agrupaciones políticas de izquierda.

La nueva Constitución redactada en Montecristi (2008), con amplia mayoría progubernamental, planteó como proyecto político alcanzar el buen vivir o sumak kawsai, para lo cual estableció un régimen económico que distingue entre régimen de desarrollo y sistema económico social y solidario, en el que se privilegia la economía popular y solidaria, que por su ambigüedad, puede ser el marco jurídico para construir a largo plazo un supuesto sistema económico alternativo o para promover una inmediata reestructuración del neocapitalismo internacional y nacional, como en realidad ocurrió en los últimos diez años de Gobierno.

En ese contexto político, el derecho administrativo económico y financiero y su legislación en Ecuador avanzaron significativamente en las últimas décadas. En los años noventa del siglo XX se modificó la legislación administrativa y financiera pública interna por la sugerida por los organismos financieros internacionales, para que el Estado pudiera tener un mayor control administrativo por parte del Ejecutivo y se acoplara a las necesidades macroeconómicas del modelo y a las políticas neoliberales. Así mismo, se expidió una nueva legislación para el ámbito privado financiero que disminuyó el control estatal de los capitales para su liberalización, circunstancia que precipitó la crisis y el saqueo bancario de 1999.

En los seis primeros años de este siglo se introdujeron adicionalmente algunos controles al sistema financiero privado luego de la crisis, observando parámetros internacionales (Basilea I y II). En los diez años siguientes del Gobierno del presidente Rafael Correa, la legislación administrativa y financiera se transformó dentro de los lineamientos de la nueva Constitución y para los propósitos del nuevo modelo y sus políticas neoestructuralistas o neoestatistas y neodesarrollistas.

Entre 1990 y 2006, gobiernos de diferente signo político adoptaron leyes y normas más eficientes en cuanto a la captación de ingresos y al destino de los gastos públicos que son de igual utilidad, tanto para el modelo neoliberal como para el actual neointervencionista o neodesarrollista; los dos modelos son esencialmente concentradores de poder si se toma en cuenta las normas administrativas con las que lo han ejercido, si bien el destino de recursos en el período neoliberal estaba dirigido a asegurar, fundamentalmente, los intereses de las empresas y acreedores transnacionales, mientras en el segundo, sin alterar sustancialmente dichos intereses, se produce una modesta pero innegable redistribución a sectores populares de la sociedad ecuatoriana.

En todo caso, la Asamblea Nacional, inspirada en la actual Constitución de 2008 y para orientar las Finanzas Públicas, expidió el Código de Planificación y Finanzas en 2010, y en la legislación que regula la actividad financiera privada se introdujeron, luego de la crisis, una serie de ajustes de prudencia y control financieros y, en la actualidad, en el segundo período del Gobierno de Rafael Correa, el 2 de septiembre de 2014 se aprobó 
un nuevo Código Monetario y Financiero que transforma declarativamente las actividades financieras, incluyendo a las del sector privado y del popular y solidario, como "un servicio de orden público", según lo dispone la propia carta política vigente (Art. 308).

En cuanto a los ingresos públicos, cabe reseñar que en las tres últimas décadas han disminuido paulatina y porcentualmente el impacto de los recursos patrimoniales provenientes de la explotación hidrocarburífera -como resultado de una deficiente inversión y por la tendencia a deteriorarla para justificar la supuesta inversión extranjera en áreas en las que corriendo un riesgo razonable se obtiene injustificadas y desproporcionadas ganancias- y se han incrementado los ingresos tributarios, para lo cual en la primera etapa se aumentaron principalmente los impuestos indirectos, mientras que en la segunda etapa, además de hacer crecer masivamente el número de contribuyentes reforzando el sistema anterior, también se han incrementado algunos tributos directos, si bien se mantienen prácticas significativas de evasión y elusión.

En las dos referidas etapas tributarias se reforzaron el papel y las atribuciones del SRI, que ha mejorado sustancialmente en su institucionalidad. Durante el actual gobierno los sistemas de recaudación de impuestos con una legislación y mecanismos de recaudación más productivos y efectivos han dado resultados satisfactorios.

Las reformas en la tributación y en la recaudación fueron inicialmente una exigencia del FMI, para dotar al estado de recursos suficientes que le permitan servir un presupuesto en el que más del 40 por ciento estaba destinado al pago del capital e intereses de la deuda externa, pero, en la actualidad, dichas reformas se han perfeccionado e incrementado, con la finalidad de que el nuevo modelo neointervencionista pueda atender el creciente gasto público orientado y en parte a cubrir necesidades sociales y de infraestructura del país.

Los ingresos por deuda pública interna y externa siguen siendo una fuente de financiamiento para la inversión y el gasto, si bien en las últimas dos décadas se establecieron límites y prohibiciones que han sido burladas conforme a las necesidades de los gobiernos de signo neoliberal o neointervencionista. Durante los gobiernos anteriores al actual, muchos de esos controles fueron eludidos como resultado de la corrupción y de las decisiones interesadas de los grupos de poder. Al inicio del Gobierno de Correa se promovió una auditoria de la deuda externa y una renegociación gracias a la cual se redujo sustancialmente; sin embargo en la actualidad, cada año, para enfrentar el creciente déficit fiscal, el régimen optó por un endeudamiento con países como China y otros, que si bien no establecen condicionamientos macroeconómicos en los préstamos, los garantizan con la venta anticipada de petróleo y que, por sus elevadas tasas de interés, resultan altamente gravosos para el fisco.

En lo últimos años el Gobierno neointervencionista del presidente Correa modificó la legislación (2010 COPF) para concentrar en un Comité de endeudamiento -presidido 
por el propio presidente e integrado por sus colaboradores directos- las decisiones sobre la materia y, en los años siguientes, luego de las crisis de liquidez ocasionadas por el deterioro internacional del precio del petróleo, se ajustó más la normativa y aún se la evadió mediante decretos interpretativos de las normas para asegurar el abultado financiamiento presupuestario con nuevos créditos externos e internos, para lo cual se modificó el procedimiento de cálculo de la deuda externa, diferenciado entre deuda agregada y consolidada, con la finalidad de ocultar un tramo de la deuda y eludir la obligación legal (COPF) de que el endeudamiento no podía superar el 40 por ciento del PIB y que si se lo hacía el Gobierno requería autorización parlamentaria asociada a la aprobación previa de un plan de recuperación y sostenibilidad económicas. ${ }^{293}$

Las normas presupuestarias que se dictaron tanto en el período neoliberal (Ley de Presupuestos) como en el neointervencionista (Código de Planificación y Finanzas Públicas), limitaron las atribuciones del Congreso o Asamblea Nacional, para impedir el clientelismo local de los legisladores, pero concentraron las decisiones de todo el ciclo presupuestario y especialmente la ejecución y las reiteradas reformas presupuestarias y las decisiones sobre endeudamiento en manos del Ejecutivo.

Si bien este estudio se refiere a la legislación y al derecho Administrativo y financiero de la Hacienda pública, realizamos a continuación también varias reflexiones sobre la transformación y regulación de las finanzas privadas en la legislación expedida en este período tanto con la Ley General de la Instituciones Financieras (1994) y sus reformas luego de la crisis bancaria, como con la expedición del Código Monetario y Financiero de 2014, pues son útiles por su vinculación con la actividad pública y financiera como contexto para nuestro estudio.

Las actividades financieras en el mercado de dinero y valores, que desarrollaron las empresas privadas, autorizadas por el Estado, mediante regulaciones y controles en los años noventa, fueron depuradas y mejoradas tras la crisis y el saqueo bancario producto de una excesiva liberalización ocurrida entre los años 1994-1999. El propio FMI y organismos multilaterales, a su tiempo, demandaron un control más estricto de la actividad financiera nacional e internacional, mediante medidas y la observación de índices prudenciales con estándares internacionales, para evitar colapsos que pongan en riesgo el sistema y ocasionen pérdidas irreversibles, puesto que finalmente la sed ilimitada de ganancias y dinero conspiran para que los países sean eficientes servidores de sus compromisos de pago por endeudamiento y por otros acuerdos económicos y comerciales a nivel mundial.

Respecto de la Legislación financiera que regulaba a las instituciones privadas, Claudio Monsalve dice que la derogada Ley de Bancos vigente desde 1927 hasta 1994, con varias reformas y codificaciones, resultaba anticuada para los tiempos actuales (se

\footnotetext{
${ }^{293}$ Ecuador, Presidencia de la República, Decreto 1218, presidente Rafael Correa, Segundo Suplemento Registro Oficial 869, 25-octubre 2016.
} 
refiere a 1997) y frenaba el desarrollo del sistema financiero ecuatoriano por una excesiva manía reglamentaria por parte de la Junta Monetaria y la Superintendencia de Bancos.

Aseguraba también que la referida Ley tenía aspectos limitantes del desarrollo financiero, pues fortalecía una banca de depósitos que obligaba a la especialización con una limitada operación en cada sección y que impedía emprender en nuevas operaciones y productos que no estuvieran expresamente permitidos por aquella. Así mismo dicha Ley permitía un cierto paternalismo del estado hacia los bancos, lo que a la larga constituía una carga económica para este; la Junta Monetaria discrecionalmente autorizaba a las entidades financieras para acceder a redescuentos del Banco Central; el control de las entidades financieras no tenía reglas claras, limitándose a análisis contables de cuentas y cupos operativos y existía una inadecuada información al público sobre la situación de los bancos y otras instituciones financieras.

La Ley General de Instituciones del Sistema Financiero dictada en 1994 creó un espacio financiero mayor, mejor integrado y fortalecido, según sus defensores, con una "información confiable y transparente para evitar conflictos de interés" y para hacer posible el crecimiento y solidez de las instituciones financieras, limitando el rol del Estado y eliminando el sistema de autorizaciones y el exceso de formalidades, fortaleciendo a la entidad de supervisión y control. ${ }^{294}$

Examinando estas opiniones, a la luz de los acontecimientos ocurridos entre 1998 y 2000, se puede afirmar que sin lugar a dudas, dicha legislación del período neoliberal tuvo aspectos positivos en cuanto a la modernización e institucionalización de las entidades financieras privadas con relación a la Ley de Bancos; no obstante, no fue cierto que en el colapso bancario las empresas asumieron sus deberes y obligaciones, pues recurrieron una vez más al paternalismo estatal (por obra del poder político vinculado a los intereses y a la corrupción bancaria) y evidenciaron que la reivindicada liberalización se convirtió en el instrumento para el saqueo de recursos hacia el exterior y que las personas que estuvieron frente a los organismos de control fueron partícipes de las irregularidades y delitos cometidos contra el Estado y los ciudadanos.

Luego del colapso bancario, se incluyeron reformas para eliminar los préstamos vinculados y para exigir el cumplimiento de estándares internacionales en cuanto a patrimonio, solvencia y prudencia financiera. Con estas modificaciones, la ley no era formalmente mala; en el manejo de las instituciones y en los organismos de control, la corrupción es la explicación para entender los delitos cometidos y el grave daño que se le ocasionó al país y a muchos ciudadanos.

\footnotetext{
${ }^{294}$ Claudio Monsalve, Legislación Monetaria y Bancaria, (Loja: Universidad Técnica Particular de Loja,
} 1999). 
Desde 1994, la Legislación Financiera que regulaba a las instituciones privadas en el Ecuador se puso a tono con la corriente internacional de transformar las instituciones bancarias tradicionales que estuvieron estructuradas (siguiendo los modelos de especialización de los años 30) por sistemas integrados de multiservicios financieros propios del modelo de banca múltiple o de banca mundial, adoptando un sistema mixto similar al que se ha establecido en otros países de América y del mundo, mediante la organización de grupos financieros y, posteriormente al colapso bancario de 1999 y el saqueo de recursos públicos por parte de banqueros inescrupulosos, de renovados sistemas de control de la Superintendencia de Bancos y del Banco Central, que se fueron tornando más eficientes y oportunos sobre instituciones y operaciones, mediante los seguros de depósitos y el cumplimiento de índices internacionales de solvencia, de liquidez, de reservas, etc.

Alberto Acosta, en su Breve Historia Económica del Ecuador, dice que la estabilidad macroeconómica que tenía el país en 2003 fue ficticia; que la dolarización no aseguró los equilibrios macroeconómicos como ocurrió en Argentina con el manejo de la convertibilidad, tanto más que la primera es mucho más rígida que la segunda, pues "si existe déficit de cuenta corriente o salida de capitales, la defensa de la dolarización conlleva la subida de las tasas de interés y la consecuente disminución de la actividad económica, con el objeto de contener la salida de capitales y de contraer las importaciones".

Otro problema grave que anota el autor es que el modelo monetario rígido que adoptó el Ecuador, acompañado de políticas neoliberales como las adoptadas obsecuentemente por los gobiernos de Noboa y de Gutiérrez, "ahondan las tendencias concentradoras y excluyentes" y, añade, "la eliminación de la especulación cambiaria tampoco es suficiente para que desaparezca la especulación financiera. Esta no es un producto exclusivo del manejo económico ecuatoriano y tampoco se produce por los repetidos vaivenes cambiarios. La especulación se nutre en el mercado financiero internacional y en el Ecuador, como se ve a diario, se reproduce en forma de caricatura. Con la dolarización tampoco desaparecerá el riesgo de corridas bancarias".

Acosta analizó de igual forma y con mucha precisión, la pérdida de competitividad que la dolarización ocasiona en el aparato productivo y el deterioro del empleo. Dice que el equilibrio fiscal no se soluciona con la renuncia de la emisión monetaria; que es necesario el incremento tributario para equilibrar el presupuesto estatal; que es cada vez más difícil acceder al crédito de la banca internacional; que se impone un esquema de sobreexplotación petrolera para financiar los gastos públicos y cubrir la creciente deuda externa; que la producción nacional perderá compradores en el exterior con el consecuente incremento del déficit comercial y que si no existe "la suficiente flexibilidad financiera o laboral el resultado será más desempleo, menor utilización de la capacidad instalada y aún quiebra de empresas". 
Y realizando un balance de esos años, el referido autor argumenta también: "aunque pueda parecer un cinismo, al final, sin importar los elevados costos sociales y económicos, son las condiciones del mercado mundial, los requerimientos del capital internacional y la lógica de las fracciones del capital financiero doméstico, las que emergieron exitosos del ajuste, y aspiran a profundizar y enraizar sus consecuencias a través de la dolarización”. Afirma también que es importante identificar qué nuevas funciones el capital financiero internacional asigna al Ecuador con la apertura, la liberalización y la globalización y que "al Ecuador le toca, como resultado 'natural' de su marcha a una economía 'libre', el retorno a una economía primario-exportadora y maquiladora", con posibilidades de desarrollo del turismo "siempre que las actividades exportadoras no afecten mayormente el entorno natural" o "asumir otros papeles, gracias a las "fuerzas del mercado"; receptar de industrias intensivas en polución, ser 'basurero' de material contaminante, lugar de lavado de narcodólares e, incluso, quizá productor de coca y sus derivados". ${ }^{295}$

La incidencia de la globalización y de sus reglas en la economía, las finanzas y su legislación en el Ecuador, en 2003, fue percibida también por otros académicos y expertos. Uno de ellos indicó: "todo el proceso globalizado ha hecho cambios sustanciales en la legislación económica del país, así como se nos imponen modelos económicos se nos imponen legislaciones que van acordes con los mismos; y las leyes están orientadas todas ellas a sustentar el proceso globalizador y mantener el esquema de distribución de la riqueza como está actualmente...". 296

El Superintendente de Compañías en ese entonces, observó: "la globalización está afectando a la legislación y al derecho financiero doméstico, particularmente en el hecho de que los nuevos mecanismos, procesos e instrumentos financieros se ven frenados por normas obsoletas" y sostiene que "debería permitirse la competencia frente a los sistemas y mecanismos financieros internacionales, mediante libertad de entrada y salida a las instituciones financieras en un mercado informado y transparente". ${ }^{297}$

El intendente del Mercado de Valores manifestó también: "la globalización incide de manera directa en el modelo económico, porque el país busca insertarse en las economías desarrolladas, para lo cual es necesario que el marco jurídico ecuatoriano se rija por parámetros internacionales. Las normas de control y supervisión de los mercados de capitales y financieros son expedidas en función de principios de prudencia, transparencia y solvencia que guíen los mercados internacionales de primer orden y que son emitidos en el caso del Mercado de Valores por el IOSCO (Organización Internacional de Comisiones de Valores) y el COSRA (Consejo de Reguladores de Valores de las Américas), entidades que tienen gran trascendencia en

\footnotetext{
295 Alberto Acosta, Breve Historia Económica del Ecuador, CEN, Quito, 2003.

${ }^{296}$ Oswaldo Tamariz, ex Gerente de la AGD, entrevista del 25 de julio de 2003.

${ }^{297}$ Fabián Albuja, Superintendente de Compañías, entrevista del 22 de julio de 2003.
} 
todo el mundo, pues sus decisiones y principios son adoptadas en la legislación de la gran mayoría de países del mundo". ${ }^{298}$

El Estado en todo caso restableció, entre el 2000 y 2003, un mayor control sobre las actividades de las instituciones financieras públicas y privadas; les impuso parámetros internacionales para asegurar su solidez y confiabilidad y los gobiernos de entonces iniciaron un incómodo proceso de recuperación de ciertos fondos públicos, que antes graciosamente se entregaban a ciertos grupos financieros, más para guardar las apariencias que por convicción, pues estos siempre cuentan con sus agentes políticos en los regímenes de turno.

Según nuestra percepción, en los primeros años del presente siglo se produjo un cierto reordenamiento económico, luego de la crisis, por la necesidad de asegurar recursos para apuntalar la dolarización. Aun así se mantuvo una actividad especulativa de los bancos con altas tasas de interés, resultado de depósitos masivos en el exterior que perciben intereses muy modestos, acordes con la situación internacional de la economía y de la renovada exigencia del FMI para que los gobiernos de entonces sostuvieran una política de ajuste que asegurara el pago de la deuda externa. En todo caso, se presentaron condiciones especiales para una importante expansión de la actividad financiera y para que el Estado y los particulares accedieran a nuevas fuentes de financiamiento, como efectivamente ocurrió en los años siguientes.

En los últimos diez años se propagó en el Ecuador la conciencia de que la actividad financiera del Estado y la de sectores privados debidamente organizados y autorizados por el mismo, incluyendo los de la economía popular y solidaria que luego de la crisis adoptaron algunas iniciativas financieras alternativas, cumplen un servicio de orden público.

En el caso del Estado, el carácter público o de orden público de la actividad financiera es innegable, puesto que la obtención y la colocación de los recursos sirven para cubrir los servicios sociales en su más amplia variedad, tanto aquellos que son inherentes a la organización de la comunidad política, como aquellos que ha ido asumiendo para atender a las necesidades de toda la colectividad y de forma específica de la gran mayoría de ciudadanos que no tienen recursos propios para solventar sus necesidades fundamentales y sus emprendimientos.

La actividad financiera de los entes privados autorizados por la ley y los que surgieron luego de la crisis bancaria (muchas veces al margen de ella) y por iniciativa social y solidaria para captar el ahorro de la ciudadanía y para colocar esos recursos en las actividades que apuntan al desarrollo, a la inversión, a la producción, es considerada, en la actualidad, como un servicio de orden público. Hay quienes lo denominan impropio o semipúblico, que, en todo caso, necesita ser regulado y controlado por el Estado para

\footnotetext{
${ }^{298}$ Diego Garcés, Intendente del Mercado de Valores, oficio № 10529 de 16 de junio de 2003.
} 
evitar que se defraude el esfuerzo honesto de ciudadanos cuando se requiere cubrir una necesidad que ha dejado de ser individual y también es de eminente contenido social.

Reforzando los planteamientos antes expuestos y los enfoques que fundamentan su texto, Antonio Borrero Veintimilla decía, en 1982, muy acertada y visionariamente, que el derecho económico se abre paso como "una nueva dimensión del quehacer jurídico y se le considera como una nueva categoría del derecho, el derecho de la organización del mundo económico (Organización de los Mercados)". Aseguraba también que "es un nuevo tronco jurídico diferente de los dos grandes troncos: derecho público y derecho privado; es por tanto una disciplina jurídica de la actividad llevada a cabo en los mercados bajo la aspiración dominante del interés social; se le reconoce como un tertium genus del cual se desprenden, como capítulo de la ciencia jurídica que tiene autonomía, el DERECHO BANCARIO: una disciplina jurídica con matices propios y que se ocupa de las instituciones dedicadas a toda clase de negocios relacionados con la moneda y el crédito y el mercado financiero que cubre una amplia gama de contratos bancarios". El mismo autor señalaba más adelante: "la función bancaria en una función de interés público y social". 299

A su vez, León Roldós en su obra Banca y Crédito se refiere al "crédito bancario como servicio público" y dice: "en el siglo veinte el poder público de los estados va configurando condiciones en que lo que aparecía como puramente mercantil va transformándose en una figura jurídica y social, en que la mercantilidad de las operaciones bancarias pasa a ser una segunda condición de su naturaleza, porque siendo esencial para la economía y la sociedad que exista disponibilidad de recursos, lo más trascendente es que se dé tal disponibilidad dentro de las prelaciones que convienen a un país y no solo a los sectores que ven en los negocios bancarios una actividad mercantil con fines de lucro". El autor menciona más adelante: "la primera operación bancaria que mostró su naturaleza de servicio público, y por lo tanto asumible por el Estado, es el de la emisión de la moneda" y "hay intereses colectivos y públicos que están por encima de los intereses privados y es el caso de los bancarios, que hacen relación al manejo del crédito del país; y por lo tanto, tienen que ser tratados sus aspectos de calificación y operatividad en el entorno de un derecho de orden público y no de pura privacidad". ${ }^{300}$

La Constitución Política del 2008, dispone al respecto: Art. 308 "Las actividades financieras son un servicio de orden público y podrán ejercerse, previa autorización del Estado, de acuerdo con la ley; tendrán la finalidad fundamental de preservar los depósitos y atender los requerimientos de financiamiento para la consecución de los objetivos de desarrollo del país. Las actividades financieras intermediarán de forma eficiente los recursos captados para fortalecer la inversión productiva nacional, y el consumo social y ambientalmente responsable.

${ }^{299}$ Antonio Borrero Veintimilla, Derecho Bancario Ecuatoriano, (Cuenca: Indugraf, 1982), 8, 10, 18.

${ }^{300}$ León Roldós, Banca y Crédito, (Guayaquil: Escuela Superior Politécnica del Litoral, 1998), 1 y 6. 
El Estado fomentará el acceso a los servicios financieros y a la democratización del crédito. Se prohíben las prácticas colusorias, el anatocismo y la usura.

La regulación y el control del sector financiero privado no trasladarán la responsabilidad de la solvencia bancaria ni supondrán garantía alguna del Estado. Las administradoras y administradores de las instituciones financieras y quienes controlen su capital serán responsables de su solvencia.

Se prohíbe el congelamiento o la retención arbitraria o generalizada delos fondos o depósitos en las instituciones financieras públicas y privadas".

Partiendo de la norma constitucional transcrita se generó un debate sobre el contenido del Código Monetario y Financiero (R. O. N 332 de 12 de septiembre de 2014). Se discutió ampliamente si las actividades financieras son un "servicio público de orden público de potestad del Estado", como se pretendía declararlas en el proyecto inicial o "un servicio de orden público, reguladas y controladas por el Estado", como consta finalmente en el referido Código (Art. 143) para satisfacer las argumentaciones del sector bancario y financiero del país.

Sin duda, la controversia no fue inocente; tenía una dimensión ideológica y política por parte de los actores involucrados, especialmente del sector privado, pues ellos estimaban que si se declaraba a las actividades financieras como un "servicio de orden público de potestad del Estado", estas podrían ser monopolizadas en cualquier momento por el Estado, como ocurre con otros servicios públicos y, por ello, se convino finalmente reiterar en el texto del vigente Código Monetario y Financiero la calculada ambigüedad constitucional antes indicada, para reafirmar que las actividades financieras pueden ser prestadas por el sector público, el privado y el de la economía popular y solidaria, pero en todo caso, solamente controladas, autorizadas y reguladas por el Estado.

El actual Código Orgánico Monetario y Financiero es un complemento de varias leyes y doctrinas definidas en la etapa posneoliberal o neointervencionista para normar a las Instituciones Financieras, las del mercado de valores, las de seguros y, últimamente las de la economía popular y solidaria.

En dicho Código se supedita al estricto control presidencial las atribuciones regulatorias de las superintendencias, de otros órganos de supervisión financiera y del Banco Central, para que estos entes técnicos queden reducidos a ejercer labores sancionadoras y disciplinarias.

El Código otorga casi sesenta competencias de regulación y atribuciones macroeconómicas cruciales a una Junta de Regulación Monetaria y Financiera, integrada por cuatro ministros y un delegado presidencial, para que, contrariando la Constitución, no asuman plena responsabilidad personal en sus decisiones. Esta Junta puede establecer cupos o porcentajes de crédito de fondos privados que las instituciones 
financieras deberán otorgar, para cumplir los planes y proyectos del Gobierno, a cambio de recibir incentivos que serán definidos por ella discrecionalmente.

El Código Orgánico Monetario y Financiero amplía, además, el acceso de las instituciones financieras a los fondos de liquidez del sistema y elimina exigencias para que estos puedan ser invertidos libremente por las autoridades económicas, según la decisión que resulte conveniente al Gobierno de turno.

El Gobierno que prometió transformar la economía y la sociedad ecuatorianas mediante sucesivos planes, según Mario Unda, representa "un nuevo modelo de dominación burguesa" y según Alberto Acosta, aquellos fueron "simplemente un discurso que acompaña una modernización capitalista como pocas veces antes en la historia de la República". Según estos autores, "la globalización capitalista está transitando en la actualidad del "consenso de Washington" al "consenso de los commodities" o "consenso de Beijing", en el que "Ecuador no se resiste a vender sus recursos naturales e inclusive a conseguir financiamiento de quienes quieren comprar". En la financiarización transnacional del país no ha cambiado "la elevada concentración productiva y la elevada tasa de control del sistema financiero por parte de la banca privada", y en ella participan además China, Brasil y Corea y el estado copado por el correísmo "emerge una vez más como palanca de esta lógica de acumulación extractivista", "sumado a programas sociales", caminando por "la senda posneoliberal más no poscapitalista", en la que "ni siquiera se han reducido los mecanismos de explotación de los seres humanos y menos aún de la naturaleza". 301

En el análisis que sobre la crisis financiera mundial y sus impactos en la economía ecuatoriana, realizan a la vez Monika Meireles y Mateo Martínez, se esclarece que uno de los canales de transmisión de aquella es la dependencia de financiamiento externo, en la composición de la deuda privada y pública, ya que para un país dolarizado "la entrada de dólares es vital para que la actividad económica en si exista". Para afrontar la crisis, el Ecuador aumentó la deuda interna tanto pública como privada y tiene ahora, como efecto de la dolarización, serios problemas de iliquidez tanto por el "congelamiento de canales de crédito internacional", el papel hegemónico que tiene la banca privada en la canalización de los recursos del público, como por la "turbulencia de los mercados financieros internacionales". 302

En la evaluación que hizo Acosta en 2013, luego de ocho años de ejercicio del poder de Rafael Correa en un "Gobierno que se autodefine socialista", se consignan hechos positivos y negativos. Dice que se ha logrado, evidentemente, una mejor distribución de los ingresos fiscales que han permitido mejorar la infraestructura vial y las inversiones en educación y salud y reducir la pobreza, pero a la vez, los grupos más acomodados, muchos de ellos vinculados al capital transnacional, "no han visto afectados sus

\footnotetext{
${ }^{301}$ Alberto Acosta y otros, El correismo al desnudo, (Quito, EC: Montecristi vive, 2013), 10 y 14.

302 Monika Meireles y Mateo Martínez, en El correismo al desnudo, Alberto Acosta, editor, (Quito: Montecristi vive, 2013).
} 
mayores privilegios" y han obtenido "jugosas ganancias" y "más utilidades que en los años neoliberales".

Entre los beneficiarios del auge económico producto del precio de las materias primas y del extractivismo, Acosta ubica a las más grandes empresas transnacionales y locales y, en especial, a la banca: "Esta realidad de enorme beneficio para el gran capital es inocultable. Basta ver dos ejemplos: las utilidades de los cien grupos económicos más grandes en el período 2007-2011 crecieron en un 50\% más que en los cinco años anteriores, es decir, durante el período neoliberal. En esta economía dolarizada, las utilidades de la banca en relación a su patrimonio neto llegaron a superar el $17 \%$ en 2011 y habrían bordeado el 13\% en 2012; mientras que las empresas de comunicación (sobre todo las telefónicas) obtuvieron beneficios superiores al 38\% en relación a su patrimonio neto". 303

Por ello, Meireles y Martínez concluyen que "la crisis internacional profundizó tendencias ya instauradas y puso en evidencia que en Alianza País ha sido incapaz de construir de manera efectiva las bases de otro modelo de desarrollo, y -lo que es más preocupante-; se encuentra repotenciando una forma de acumulación de capital que reproduce de manera autoritaria y no sin resistencia de los sectores populares, las mismas derivas del anterior modelo neoliberal". ${ }^{304}$

Resulta pues evidente que la nueva Constitución de 2008, el Código Orgánico de Planificación y Finanzas de 2010, las nuevas normas y regulaciones de las instituciones de control sobre endeudamiento público, tributos, reformas a la Ley General de Instituciones del Sistema Financiero, la Ley Orgánica y su Reglamento sobre la Economía Popular y Solidaria y el reciente Código Orgánico Monetario y Financiero de 12 de septiembre de 2014, otorgan al estado y en especial al presidente de la República, un mayor control sobre las finanzas públicas y privadas y sobre la reasignación de recursos para los programas sociales del gobierno y para permitir que los sectores financieros particulares tradicionales y nuevos, en los que de manera limitada se encuentran los provenientes de la economía popular y solidaria, alcancen una mayor acumulación y participen en el modelo económico del régimen.

Durante el Gobierno autoritario de Rafael Correa muchas decisiones e interpretaciones económicas y financieras importantes de varias leyes y decretos se mantuvieron ocultas y se modificaron discrecionalmente las normas constitucionales y legales vigentes. Así por ejemplo el Ministerio de Finanzas emitió en 2010 tres resoluciones que autorizan ocultar información sobre las condiciones de contratación de deuda externa, utilizando la facultad que le otorga el Art. 137 del COPF. ${ }^{305}$

\footnotetext{
${ }^{303}$ Alberto Acosta y otros, El correismo al desnudo, (Quito, EC: Montecristi vive, 2013), 15 y 16.

${ }^{304}$ Monika Meireles y Mateo Martínez, en El correismo al desnudo, Alberto Acosta, editor, (Quito: Montecristi vive, 2013), 156.

${ }^{305}$ Ecuador, Ministerio de Finanzas, Acuerdos Ministeriales MF-DJM-RD-2010-01; MF-DM-RD-2010002; MF-MD-RD-2010-003 de abril, octubre y noviembre 2010.
} 
El enfrentamiento del Gobierno con las entidades financieras privadas fue más retórico que real, pues se limitó a controlar ciertas tasas de servicio y más tarde, como producto de un enfrentamiento en la campaña electoral presidencial de 2013, se les disminuyó las exoneraciones tributarias que gozaban para la reinversión en las mismas empresas financieras, con la finalidad de solventar el aumento del Bono de Desarrollo Humano de 30 a 50 dólares.

El Código Orgánico Monetario y Financiero (2014) se expidió para ejercer a plenitud la política monetaria, cambiaria, crediticia y financiera del Estado por medio de una Junta de Regulación integrada por altos funcionarios de libre remoción del Ejecutivo, a quienes la ley les concedió inmunidad en el ejercicio de sus numerosas atribuciones y competencias.

Este Código aprobado por la Asamblea Nacional, con un extenso veto presidencial, reafirma el proceso estatista y concentrador de poder y es una respuesta a los posibles problemas de iliquidez de la economía ecuatoriana a corto y mediano plazo y a la dificultad de acceso al crédito internacional, por lo que persigue incidir, con ciertas reglas públicas, en canalizar y comprometer el dinero del público en manos de las instituciones financieras en la reactivación económica dentro del propósito anunciado de "cambiar la matriz productiva". 306

Del análisis antes realizado se desprende que la actividad financiera estatal, privada y de la economía popular y solidaria se amplió en este período neointervencionista sea para enfrentar las secuelas de la crisis anterior, que ha dejado numerosos damnificados en proceso de liquidación definitiva y con conflictos pendientes heredados de aquella, o para asumir y enfrentar nuevos problemas en las nuevas circunstancias de desarrollo de las finanzas y de la economía internacional y nacional.

\section{EL DERECHO FINANCIERO VIGENTE SOBRE GASTOS E INGRESOS PUBLICOS, ESPECIALMENTE TRIBUTARIOS}

El derecho financiero público regula la actividad financiera pública o de las finanzas públicas, o como se denominaba antaño en nuestro medio y se lo sigue haciendo en algunos países, Hacienda pública. Si la actividad financiera del Estado está integrada por las operaciones que se realizan para obtener los recursos y para organizar y autorizar los gastos, el derecho financiero público puede subdividirse, como lo hemos explicado oportunamente, en derecho de los ingresos, derecho de los gastos y del presupuesto y derecho de control de los recursos públicos, con sus correspondientes ramas. La planificación es una actividad pública y administrativa estatal que se encuentra íntimamente articulada al derecho financiero o a la legislación de la Hacienda pública, por lo que si bien no se la considera parte del mismo, nosotros incluimos su estudio en

\footnotetext{
${ }^{306}$ Ecuador, Código Orgánico Monetario y Financiero, publicado en el Registro Oficial, Quito, 12 de septiembre de 2014.
} 
esta investigación ubicándola en el derecho administrativo económico con el que también comparte el derecho de control que, insistimos, tiene una dimensión financiera y otra administrativa.

El derecho de los ingresos públicos se fracciona a la vez en: derecho tributario, que dada su complejidad y desarrollo tiene reconocida y tradicional autonomía al punto que algunos tratadistas lo subsumen en el derecho financiero; derecho del endeudamiento y crédito públicos; derecho patrimonial o de los recursos públicos y derecho o legislación de ingresos públicos impropios, que norma la imposición de multas y sanciones cuya finalidad es la de corregir las conductas de los ciudadanos. A continuación y en el capítulo siguiente, nos limitaremos al estudio de la legislación relacionada con los ingresos tributarios, dejando para otro momento el estudio de la normativa de los ingresos del crédito, patrimoniales y de los impropios a los que hemos hecho referencia.

El derecho de los gastos y egresos públicos comprende, según algunos autores como Fernando Pérez Royo, el derecho presupuestario y el derecho de control de los gastos públicos; sin embargo, debe considerarse que en la actualidad, el control de la actividad financiera no solo se refiere a los recursos desembolsados sino también a la gestión relativa a los ingresos, a las inversiones y a las decisiones y procesos que se dan previo a los gastos, en los gastos propiamente dichos y en los posteriormente a ellos; por ello, nos parece que el derecho de control de los recursos públicos no debería incluirse en el derecho de los egresos públicos, sino que debería considerarse como una rama independiente en la que se vinculan instituciones propias del derecho financiero público o del derecho de las finanzas públicas y del derecho administrativo económico.

Es importante vincular de manera permanente los ingresos y los gastos públicos y para ello, la doctrina internacional y local así como los actuales modelos económicos han enfatizado en su interrelación para el cumplimiento de sus objetivos redistributivos, de solidaridad y de justica social, sea en el Estado social, en el Estado neoliberal o neocompetitivo y en el Estado neointervencionista o neoestructural o neodesarrollista.

Es necesario también, para fines didácticos y de investigación, precisar brevemente las nociones de recursos: ingresos y gastos públicos. Los dos conceptos, además de estar articulados, cuentan con una dimensión eminentemente pecuniaria financiera y tienen, particularmente en el derecho financiero, una función distinta y un propósito común cuando tratan de alcanzar un equilibrio entre ambos; además de que los dos conceptos se relacionan tanto con el requerimiento propio de las instituciones estatales para la provisión de servicios, como con el ejercicio de derechos de los ciudadanos, sea en su obligación de contribuir o de pagar tributos como en el de ser destinatarios de los gastos para satisfacer sus necesidades individuales y colectivas, lo que les otorga a la vez un carácter "redistributivo" y "promocional".307

\footnotetext{
${ }^{307}$ Norberto Bobbio, Contribución a la Teoría del Derecho, (Valencia: Editorial Fernando Torres-Editor, 1980).
} 
Respecto a ingresos, los recursos públicos tienen su propia normativa en el ámbito del derecho tributario y una función de registro financiero en el ámbito presupuestario. El derecho presupuestario no regula los ingresos en cuanto a sus detalles de determinación y recaudación, asunto que corresponde al derecho tributario, sino que los registra y estima como fundamento o referencia necesaria para los gastos que, en cambio, sí tienen un efecto jurídico y obligatorio en su estimación, asignación y autorización.

La teoría de los ingresos es más antigua que la de los egresos, arranca desde la época del "cameralismo", la fisiocracia y el liberalismo clásico. Se concibe como recurso público "al dinero que llega al poder del Estado para atender la necesidad financiera de los servicios públicos". 308

Según el vigente Código de Planificación y Finanzas Públicas (COPFP 2010), los recursos públicos están definidos en el artículo 3 de la Ley Orgánica de la Contraloría General del Estado, que dice:"se entenderán por recursos públicos todos los bienes, fondos, títulos, acciones, participaciones, activos, rentas, utilidades, excedentes, subvenciones y todos los derechos que pertenecen al Estado y a sus instituciones, sea cual fuere la fuente de la que procedan, inclusive los provenientes de préstamos, donaciones y entregas que, a cualquier otro título, realicen a favor del Estado o de sus instituciones, personas naturales o jurídicas u organismos nacionales o internacionales. Los recursos públicos no pierden su calidad de tales al ser administrados por corporaciones, fundaciones, sociedades civiles, compañías mercantiles y otras entidades de derecho privado, cualquiera hubiere sido o fuere su origen, creación o constitución, hasta tanto los títulos, acciones, participaciones o derechos que representen ese patrimonio, sean transferidos a personas naturales o personas jurídicas de derecho privado, de conformidad con la ley". ${ }^{309}$

Los recursos públicos que se registran en el presupuesto provienen, por lo tanto, de las más variadas fuentes y entre ellas principalmente de los tributos, de los ingresos patrimoniales, de las empresas públicas, del crédito y deuda interna y externa y de las multas y sanciones.

Para fines de registro presupuestario, es muy común la clasificación que se hace de ingresos en: corrientes (tributario y no tributarios); de capital (venta de activos, créditos, remanentes y reembolsos) y de financiamiento (adelantos, amortizaciones y servicio de deuda). También es común la clasificación en recursos ordinarios, que como los tributos se perciben de forma regular y continua, y los extraordinarios u ocasionales como lo son ciertos impuestos creados por una sola vez o los obtenidos por deuda.

\footnotetext{
${ }^{308}$ Gustavo Ingrosso, Derecho Financiero, Nápoles 1956, 89.

309 Ecuador, Código Orgánico de Planificación y Finanzas, Registro Oficial 306, Segundo Suplemento, 22-10-2010; Ley Orgánica de la Contraloría General del Estado, Registro Oficial Suplemento 595, 12junio-2002.
} 
Nuestra legislación clasifica los ingresos fiscales en: permanentes, que son los que el Estado recibe de manera continua, periódica y previsible que no sean venta de activos ni endeudamiento y no permanentes, que son los que las instituciones estatales reciben de manera temporal por situación específica, excepcional o extraordinaria y que pueden provenir de venta de activos públicos y endeudamiento. (Art. 78 COPFP).

Los ingresos y la obtención de recursos públicos están asociados estrechamente al principio de legalidad y ocasionan también una serie de efectos económicos y sociales en la sociedad "extrafiscales", conforme al sistema y a los gobiernos imperantes en los distintos momentos históricos. Por ejemplo, los ingresos arancelarios pueden tener no solo efecto fiscal sino proteccionista para alentar ciertas actividades económicas internas.

Los gastos, en cambio, son erogaciones consignadas en el presupuesto para cubrir los servicios públicos en toda la institucionalidad estatal; para cubrir la deuda pública y su servicio y para la inversión patrimonial. Esto es, sirven para satisfacer derechos, adquirir bienes y financiar las actividades productivas y económicas del Estado.

Si el ingreso, como obtención de recurso público, es el momento inicial de la actividad financiera estatal, el gasto público es su culminación o punto final, incluyendo en todo el proceso financiero las actividades de planificación y control. En los gastos se cuantifica y se concreta su destino, las exigencias y necesidades de la colectividad que el Estado y Gobierno han decidido satisfacer, tomando en cuenta sus proyectos y prioridades previamente fijadas en la planificación y en las políticas públicas definidas o reprogramadas por el poder político competente: la función ejecutiva principalmente.

Según Héctor Villegas "son gastos públicos las erogaciones dinerarias que realiza el Estado en virtud de ley para cumplir sus fines, consistentes en la satisfacción de necesidades públicas". ${ }^{310}$ Los gastos tienen también efectos económicos y extrafiscales, conforme al sistema económico y al tipo de estado y coyuntura política en el que se autorizan y ejecutan. Así por ejemplo, en la etapa intervencionista de la economía y el estado, se formuló el principio del multiplicador para explicar el papel que los gastos pueden tener en la reactivación económica, si bien también pueden ser factor de inflación en los precios y de incremento de consumo de importación al no existir una política global de fomento productivo.

Los gastos de acuerdo al Código Orgánico de Planificación y Finanzas de Ecuador se clasifican en egresos permanentes y no permanentes. Los primeros son los que efectúa el estado con carácter operativo, de repetición permanente y permiten la provisión continua de bienes y servicios públicos y que no generan acumulación de capital o activos públicos y los segundos son los que efectúan las instituciones públicas con carácter temporal por una situación específica, excepcional o extraordinaria que no

\footnotetext{
${ }^{310}$ Héctor Villegas, Manual de Finanzas Públicas, Depalma, Buenos Aires, 2000, 128.
} 
requieren repetición permanente y pueden generar acumulación de capital bruto o activos públicos o disminución de pasivos. (Art. 70 COPFP).

En el derecho de los ingresos públicos al que nos referiremos en primer lugar, tiene un papel destacado el derecho y la legislación tributarios. Los ingresos tributarios para el Estado son imprescindibles, ya que de su recaudación depende el cumplimiento de sus objetivos y la amplitud o deficiencia en la cobertura y, consecuentemente, la buena calidad o el deterioro de los servicios públicos que ofrece a los ciudadanos.

El contenido del derecho tributario es sumamente amplio. El establecimiento de la obligación tributaria, los tributos, sus clases, la organización de la administración tributaria estatal, sus potestades y los derechos de las y los ciudadanos como contribuyentes a quienes también no se puede afectar en sus derechos, como en el caso de la confiscación y para interponer reclamos y recursos contenciosos tributarios, son los temas principales de una materia cada vez más compleja y extensa, que ha dado origen al surgimiento de categorías, conceptos y normas convertidas en el fundamento de una rama o disciplina que tiene su propia fisonomía y autonomía en el sistema jurídico.

Si bien el derecho tributario forma parte del derecho financiero en general y más directamente del derecho de las finanzas públicas o del derecho de la Hacienda pública y del derecho de los ingresos públicos, su importante desarrollo ha motivado que algunos autores nieguen la existencia autónoma del derecho financiero o no lo consideren todavía como una disciplina o ciencia autónoma en el campo jurídico y doctrinario, o si aceptan su existencia pongan énfasis en su contenido tributario. Por ello, muchos tratadistas, en la actualidad, titulan sus obras: Derecho de la Hacienda Pública y Derecho Tributario como Mauricio Plazas Vega (Editorial Temis, 2006,); Derecho Financiero y Tributario como Fernando Pérez Royo (Civitas, 1999); Derecho Financiero y Tributario como Luis María Cazorla (Aranzadi, 2001); Curso de Derecho Financiero y Tributario como Juan Martín Queralt y otros (Tecnos, 2011); Lecciones de Derecho Financiero y Tributario como Miguel Ángel Martínez Lago y otros (Iustel, 2004).

En Ecuador se destaca la obra de Eduardo Riofrío Villagómez, quien en las décadas del cuarenta y del cincuenta publicó cuatro tomos sobre el derecho de hacienda y en los años sesenta su Manual de Finanzas Públicas; ${ }^{311}$ luego el texto de Washington Durango sobre Legislación Tributaria Ecuatoriana en 1979; los estudios de José Vicente Troya sobre derecho tributario ecuatoriano en las décadas del noventa del siglo pasado y en la primera del presente hasta la publicación de su libro Lecciones de Derecho Tributario con las últimas reformas de $2015^{312}$ y los textos de Rodrigo Patiño, ${ }^{313}$ de César

\footnotetext{
${ }^{311}$ Eduardo Riofrío Villagómez, Manual de Ciencia de hacienda, Tomos I-IV, (Quito: Casa de la Cultura Ecuatoriana, 1977); Tratado de Finanzas Públicas, (Quito: Casa de la Cultura Ecuatoriana, 1968).

${ }^{312}$ José Vicente Troya Jaramillo, Lecciones de Derecho Tributario con las últimas reformas, (Quito: Ediciones Fausto Reinoso, 2015).
} 
Montaño, ${ }^{314}$ Juan Carlos Mogrovejo, ${ }^{315}$ José Luis Terán, ${ }^{316}$ Álvaro Mejía, ${ }^{317}$ Eddy de la Guerra $^{318}$ y otros sobre la materia.

En cuanto a estudios sobre el endeudamiento público y su legislación, la bibliografía ecuatoriana es más escasa. El Banco Central del Ecuador publicó varios estudios sobre el tema para referirse a la deuda de la independencia y su tratamiento en todo el siglo $\mathrm{XIX}^{319}$ hasta el Gobierno de Eloy Alfaro, quien tuvo que definir una política al respecto para propiciar el endeudamiento para la construcción de su gran obra monumental: el ferrocarril transandino, a principios del siglo $\mathrm{XX} .{ }^{320}$ Sobre la deuda ecuatoriana en el siglo XX destacan los estudios económicos de Alberto Acosta sobre la materia ${ }^{321}$; los informes de la auditoría de la deuda elaborados por una Comisión Internacional designada por el presidente Correa como antecedente para la compra y renegociación de bonos que constituían un gravamen muy pesado en la economía nacional ${ }^{322}$ y las reflexiones que el mismo Alberto Acosta, Fernando Villavicencio y otros estudiosos han realizado sobre el endeudamiento externo con el Gobierno chino durante el mandato del presidente Correa. ${ }^{323}$

Sobre el gasto público en el Ecuador no se han publicado muchos estudios especializados sobre la materia, salvo los trabajos pioneros ya citados de Eduardo Riofrío Villagómez. En la última parte de su vida, José Vicente Troya incursionó en el tema con varios artículos publicados en la Universidad Andina y su tesis doctoral en Salamanca sobre el gasto público. ${ }^{324}$

Concentrando nuestro estudio en esta parte, sobre el derecho tributario como uno de los componentes cruciales del derecho de los ingresos públicos, resulta pertinente que nos refiramos brevemente a la terminología para identificar esta rama jurídica que no es uniforme a nivel internacional. En Francia y México se lo denomina derecho fiscal, como se hacía en el Ecuador hasta 1975; en Alemania se denomina derecho impositivo

\footnotetext{
313 Rodrigo Patiño Ledesma, El cobro de la deuda tributaria y la vía judicial, (Quito: Instituto Ecuatoriano de Derecho Tributario, 2004).

${ }^{314}$ César Montaño Galarza, Manual de Derecho Tributario Internacional, (Quito: UASB - CEN, 2006).

${ }^{315}$ Juan Carlos Mogrovejo, El poder tributario municipal en el Ecuador, Ediciones Abya Yala, Quito, 2010.

316 José Luis Terán, Principios Constitucionales y Jurídicos de la Tributación, (Quito: Editora Jurídica Cevallos, 2014)

317 Alvaro Mejía Salazar, Diccionario de derecho tributario, (Quito: Corporación de Estudios y Publicaciones, 2012).

${ }^{318}$ Eddy de la Guerra, El régimen tributario ecuatoriano, (Quito: CEP, 2012).

${ }^{319}$ Antonio Flores Jijón, La conversión de la deuda anglo.ecuatoriana, Biblioteca básica del pensamiento ecuatoriano, Banco Central del Ecuador, (Quito: CEN, 1979).

${ }^{320}$ Eloy Alfaro, Deuda Gordiana, (Quito: Imprenta Nacional, 1896); Historia del Ferrocarril, (Quito: Editorial Nariz del Diablo, 1931).

${ }^{321}$ Alberto Acosta, La deuda eterna, ALOP, CAP, CECCA, CERG, (Quito: CIUDAD, 1990).

${ }^{322}$ Informe final, resumen ejecutivo, Comisión para la Auditoría Integral del Crédito Público, Quito, diciembre de 2008.

323 Alberto Acosta y otros, El correismo al desnudo, (Quito: Arcoiris Producción Gráfica, 2013); La restauración conservadora, (Quito: Arcoiris Producción Gráfica, 2014).

${ }^{324}$ Jose Vicente Troya Jaramillo, Derecho del Gasto Público, (Bogotá: Editorial Temis, 2014).
} 
y en Italia, España, Colombia, Argentina, Perú y en la mayor parte de América Latina, derecho tributario, nombre que adopta también nuestro país desde la expedición del Código Tributario en 1975-6.

Eduardo Riofrío Villagómez, iniciador de los estudios financieros y de hacienda en el Ecuador, incluyó al derecho tributario en el derecho fiscal y en el derecho financiero, indicando que este es "la disciplina científica que tiene por objeto el estudio de las normas jurídicas que regulan la actividad financiera del Estado, ya en lo que se refiere a la repartición de las cargas públicas y la inversión de los recursos así obtenidos, así como a la gestión de su patrimonio, en lo relacionado a las relaciones jurídicas entre el Estado y sus organismos o los ciudadanos, y a las que surgen entre estos últimos, todo ello en el orden financiero". 325

Fernando Pérez Royo nos dice que se debe tomar en cuenta que el régimen jurídico de los ingresos tributarios y aún los de la deuda pública, a diferencia de los patrimoniales, interesan total y sustancialmente al derecho financiero, ya que, en el caso de los tributos, su finalidad en cuanto institución jurídica es esencialmente contributiva a la cobertura de los gastos públicos. Por esa razón, el autor español identifica para efectos didácticos los conceptos derecho tributario con derecho de los ingresos públicos, si bien reconoce la existencia de ingresos no tributarios. ${ }^{326}$

Washington Durango, exprofesor de esta materia en la Universidad Central, nos recuerda que el derecho tributario es una rama del derecho fiscal o del derecho financiero en el que se establecen las normas que regulan los derechos y actividades del Estado para extraer bienes económicos de la sociedad creando la obligación tributaria, los modos de establecerla y recaudar y las sanciones a los transgresores de estas normas. ${ }^{327}$

En la Guía Práctica de Ediciones Legales de Ecuador se ofrece la siguiente definición de derecho tributario: "es una rama jurídica que, como parte del derecho financiero, regula el nacimiento, aplicación, modificación y extinción de los tributos y, en consecuencia, las relaciones jurídicas que se originan entre la administración (sujeto activo) y el contribuyente o responsable (sujeto pasivo) de la obligación tributaria". 328

Mauricio Plazas define al derecho tributario como "el conjunto de normas jurídicas que regulan los tributos", lo considera una especialidad fundamental del derecho de la Hacienda pública no solo por su impacto cuantitativo "preponderante" en los ingresos públicos (fines fiscales), sino porque cumple un papel cada vez más importante en otros fines y objetivos del Estado y de la economía privada (fines extrafiscales) como en la

\footnotetext{
${ }^{325}$ Eduardo Riofrío Villagómez, Estudios de Derecho Financiero, 1949, CCE, Quito.

${ }^{326}$ Fernando Pérez Royo, Derecho Financiero y Tributario, (Madrid: Editorial Civitas, novena edición 1999).

${ }^{327}$ Washington Durango, Legislación Tributaria Ecuatoriana, (Quito: Editorial Universitaria, 1979).

${ }^{328}$ Ediciones Legales, Régimen Tributario Ecuatoriano, Tomo 1, Guía Práctica, Quito, 2009.
} 
generación de empleo, en la búsqueda de equilibrios macroeconómicos, en la redistribución de la riqueza, etc. ${ }^{329}$

De igual manera, Juan Martín Queralt considera que si bien "el derecho tributario es la disciplina que tiene por objeto de estudio el ordenamiento jurídico que regula el establecimiento y aplicación de los tributos", es tan solo una parte de un ordenamiento más amplio que es el financiero que corresponde al derecho financiero, el que a la vez tiene dos elementos fundamentales, ingresos y gastos públicos, cada uno de los cuales tiene una "riqueza de contenidos y matices" que ameritan ser examinados por separado, dando lugar a lo que podría ser un derecho de los ingresos y un derecho de los gastos públicos. De cualquier manera, dada la conexión entre unos y otros, su análisis científico debe hacerse también en el marco de una disciplina unitaria, el derecho financiero, con una metodología y principios comunes fundamentados en la "justicia financiera" que está presente tanto en la ordenación de los ingresos como de los gastos, pues las prestaciones tributarias son la cuota para la financiación de los gastos públicos. $^{330}$

Como sabemos, el fin de la actividad de la Hacienda pública es cubrir los gastos del Estado para que este cumpla sus fines. El punto de partida será siempre su responsabilidad y potestad de obtener los recursos necesarios y suficientes para el propósito indicado. Fundamentalmente, los ciudadanos integrantes del Estado tienen que aportar los recursos, si bien los ingresos, como hemos dicho, pueden provenir, privilegiada o complementariamente del patrimonio público, cuando los recursos son abundantes y rentables; del endeudamiento o crédito que el Estado, representado por el Gobierno, contrata con proveedores externos o internos; de las empresas estatales de servicios públicos que los ofrecen mediante una tarifa y de los denominados ingresos impropios, como las multas y sanciones, cuya finalidad no es contributiva, sino destinada a corregir y sancionar conductas al margen de la ley.

Del conjunto de ingresos públicos indicados, los tributarios son, o deberían ser, los más importantes, no solo cuantitativamente sino cualitativamente, ya que los integrantes de la comunidad política estatal deben asumir su responsabilidad de financiar las actividades colectivas que son formas eficaces de equidad social y de redistribución del ingreso y de la riqueza. Sin embargo, en un Estado de enorme riqueza patrimonial como es el ecuatoriano, los ingresos provenientes de esa fuente tienen cuantitativamente también mucha trascendencia, lo que ocasiona una cierta laxitud y resistencia en el cumplimiento de las responsabilidades ciudadanas.

El derecho tributario, por lo tanto, es, para nosotros, la disciplina jurídica rama del derecho público y financiero, que regula la obligación tributaria de los ciudadanos con

\footnotetext{
${ }^{329}$ Mauricio Plazas Vega, Derecho de la Hacienda Pública y Derecho Tributario, (Bogotá: Editorial Temis, 2000).

${ }^{330}$ Juan Martín Queralt y otros, Curso de derecho Financiero y Tributario, vigésima segunda edición, (Madrid: Tecnos, 2012).
} 
el Estado y de las relaciones que se establecen entre estos, con la finalidad de garantizar los recursos necesarios para las actividades públicas y los derechos de los contribuyentes.

Es necesario enfatizar que el derecho tributario se encuentra "dominado" por el principio de legalidad y que tiene diferentes dimensiones: la constitucional que establece los principios y el procedimiento para la expedición de los tributos; el derecho material tributario sobre la obligación tributaria y las obligaciones entre los sujetos tributarios; el derecho formal o administrativo tributario sobre la aplicación de tributos, los asuntos contenciosos y el ilícito tributario y el derecho internacional tributario. ${ }^{331}$

El derecho tributario en el Ecuador, según nuestra opinión, tiene una legislación general o común que parte de las normas constitucionales pertinentes en las que se establecen los principios y las normas para la expedición de tributos, que se encuentran acopladas al actual Código Orgánico Tributario, con sus correspondientes reformas y actualizaciones; una legislación orgánica-institucional relativa a la administración tributaria estatal mediante el Servicio de Rentas Internas, el Servicio Nacional de Aduana del Ecuador y la administración tributaria seccional y una legislación especial destinada a regular los diferentes tributos con la Ley Orgánica de Régimen Tributario Interno (LORTI) y otras normas que regulan otros tributos nacionales y los de los gobiernos autónomos descentralizados.

Por otra parte, para efectos didácticos de nuestro estudio es interesante diferenciar las principales categorías del derecho tributario, que es el que más ha profundizado en ellas en el ámbito del derecho financiero y que por lo tanto le da un estatus más reconocido como rama autónoma del derecho.

Si el objeto principal de la actividad financiera es obtener recursos para financiar los gastos estatales nacionales y locales, en el derecho tributario debe distinguirse e identificarse el concepto y los elementos del tributo y de la obligación que los contribuyentes tienen respecto del mismo.

Fernando Pérez Royo define al tributo como "una prestación pecuniaria de carácter coactivo impuesta por el Estado u otro ente público con el objeto de financiar gastos públicos". ${ }^{332}$ Esta definición de manera sintética pone de relieve las tres características fundamentales del tributo: su carácter pecuniario, su coactividad y su carácter contributivo.

La primera determina que el pago de tributos se realiza principalmente en dinero y solo en casos de excepción establecidos en la ley, el pago puede ser en especies o en

\footnotetext{
331 José Vicente Troya Jaramillo, Lecciones de Derecho Tributario con las últimas reformas, (Quito: Ediciones Fausto Reinoso, 2015).

${ }^{332}$ Fernando Pérez Royo, Derecho Financiero y Tributario, (Madrid: Editorial Civitas, novena edición 1999), 33.
} 
servicios apreciables en dinero. La segunda implica que es el Estado, por el poder soberano del que se halla investido y siguiendo los procedimientos establecidos en la Constitución y la ley, el que impone a sus ciudadanos, sin tomar en cuenta su decisión, una erogación económica a propósito de un hecho o circunstancia permanente o reiterativo perfectamente establecido o descrito en la correspondiente normativa.

La tercera característica evidencia que la contribución económica obligatoria tiene por fin satisfacer los requerimientos económicos públicos para solventar las necesidades previstas y definidas por el Estado a través de los procedimientos establecidos en la Constitución y en la ley. El carácter contributivo del tributo lo diferencia de otras prestaciones obligatorias en las que en determinadas circunstancias, debidamente establecidas en la ley, el Estado impone a los ciudadanos como en el caso de las multas o de las sanciones. El carácter contributivo también tiene que considerar los derechos del contribuyente y los límites que en esa calidad prevé la Constitución, las leyes y la doctrina. ${ }^{333}$

Igualmente es necesario precisar que los tributos tienen principalmente fines fiscales, pero que la Constitución y la doctrina les otorgan, al mismo tiempo en su conjunto o en casos especiales, fines extrafiscales. Así, la Constitución de 1998 disponía que "los tributos, además de ser medios para la obtención de recursos presupuestarios, servirán como instrumento de política económica en general"; que "las leyes tributarias estimularán la inversión, la reinversión, el ahorro y su empleo para el desarrollo nacional" y que "procurarán una justa distribución de las rentas y de la riqueza entre todos los habitantes del país" y el inciso segundo del artículo 300 de la Constitución de la República vigente (2008), dispone: "la política tributaria promoverá la redistribución y estimulará el empleo, la producción de bienes y servicios, y conductas ecológicas, sociales y económicas responsables" y, el artículo 285, cuando señala los objetivos específicos de la política fiscal, manda que uno de ellos será la redistribución del ingreso por medio de transferencias, tributos y subsidios adecuados.

Troya enfatiza en que las prestaciones tributarias no tienen de por sí carácter sancionatorio, pues están destinadas a obtener recursos para ejecutar políticas y gastos públicos y si se imponen multas tributarias se hace para sancionar el incumplimiento de las obligaciones formales de los contribuyentes. ${ }^{334}$

Existen varias clasificaciones de los tributos. Una los clasifica en tributos vinculados y no vinculados. Los primeros son aquellos en los que el contribuyente recibe por su pago una contraprestación o un servicio por parte del Estado, mientras que en los no vinculados no se recibe contraprestación alguna y están destinados a solventar de manera general e indistintamente los gastos públicos.

\footnotetext{
${ }^{333}$ Eddy de la Guerra, El deber de contribuir al gasto público, principios que lo informan y derechos del contribuyente, (México: Editorial Porrúa, 2017).

${ }^{334}$ José Vicente Troya Jaramillo, Lecciones de Derecho Tributario con las últimas reformas, (Quito: Ediciones Fausto Reinoso, 2015).
} 
Siguiendo el modelo del Código Latinoamericano, el Código Tributario del Ecuador en su artículo uno y el Código Orgánico de Ordenamiento Territorial Autonomía y Descentralización los clasifica en impuestos, tasas y contribuciones especiales de mejora.

Los impuestos son tributos obligatorios establecidos por ley a un hecho imponible sin que por ellos el contribuyente reciba directamente prestación o servicio alguno por parte del Estado. Los impuestos pueden ser directos (a la renta) o indirectos (al valor agregado, a los consumos especiales); reales (predial) o personales (a la renta), internos o externos (aranceles); ordinarios y extraordinarios y proporcionales y progresivos. ${ }^{335}$

Para los efectos históricos de este estudio, la clasificación que se hace de impuestos directos e indirectos requiere de una precisión doctrinaria. Se denominan impuestos directos a los que gravan "manifestaciones completas de capacidad contributiva del sujeto pasivo", como es el caso del impuesto a la renta, a los activos, al patrimonio, a los bienes, etc. En el primero se toman en cuenta todos los ingresos del contribuyente que son objeto del tributo y se lo considera como progresivo, ya que los sujetos que tienen una mayor base imponible deben aportar un porcentaje mayor de acuerdo a la escala establecida en la ley. También se puede considerar al impuesto a la renta como proporcional cuando a determinados sujetos pasivos (como son las empresas) se les grava por igual un porcentaje único. Los impuestos indirectos son regresivos, ya que deben pagarlos indistintamente los ricos o los pobres, y son los que "imponen gravámenes sin relación con la capacidad contributiva, como el impuesto al valor agregado (IVA), que grava el consumo de bienes o servicios, permitiendo que su carga repercuta en terceros, extraños en la generación de la obligación tributaria". 336

La clasificación de impuestos directos e indirectos pretendía orientar el contenido de política tributaria para determinar si esta perseguía alcanzar una meta de equidad y justicia tributaria o si prefería repartir la carga tributaria a todos los ciudadanos, independientemente de las innegables diferencias de ingresos y de situación económica que tienen. Hay que observar que la distinción se relativiza cuando, en la práctica, es innegable que tanto los impuestos directos como indirectos pueden ser de todas maneras trasladados a los consumidores, con lo que no se consigue la meta de la anhelada justicia tributaria que requeriría otras medidas para ser efectiva.

Otra clasificación para la creación y aplicación de los impuestos, con la finalidad de enfatizar en los efectos económicos de aquellos, distingue entre impuestos sobre las rentas o ingresos, patrimonios, actos de producción y consumo, comercio internacional,

\footnotetext{
${ }^{335}$ Ediciones Legales, Régimen Tributario Ecuatoriano, Tomo 1, Guía Práctica, Quito, 2009, 121-122.

${ }^{336}$ Carlos Licto Garzón, y otros en Comentarios a la Ley Reformatoria para la Equidad Tributaria del Ecuador, Ediciones Processum, Quito, 2008.
} 
contratos, acrecimientos gratuitos como herencias, legados, donaciones, rifas $\mathrm{y}$ loterías. $^{337}$

Una mención conceptual merecen también los aranceles. ¿Son impuestos? Según nuestra opinión se trata de una modalidad de impuesto. Su origen se encuentra en el Código Orgánico de la Producción, Comercio e Inversiones (R. O. 351-S, 29-12-2010) (Ley s/n Segundo Suplemento R. O. 056, 12-VIII-2013) y disponen que quienes operan en el comercio internacional de mercancías están sometidos a los tributos respectivos, entre los cuales constan los derechos arancelarios. El propio Código define los sujetos de la relación tributaria, las exenciones, la base imponible y los procedimientos para regular estos tributos. Los derechos arancelarios, a diferencia a los impuestos que están normados detalladamente por ley, son tarifas que antes eran fijadas por el presidente de la República mediante decreto ejecutivo y ahora, con el Código en referencia, al Comité de Comercio Exterior e Inversiones (COMEX) le corresponde "crear, modificar o suprimir tarifas arancelarias" (Art. 71 literal c), mediante resoluciones que serán publicadas en el Registro Oficial. El Comité será presidido por el Ministerio que determine el presidente ejerciendo a la vez como su Secretaría Técnica.

El arancel es una lista de las mercaderías que van a ser importadas y vendidas en el país, para lo cual se las clasifica sistemáticamente en secciones, capítulos y subcapítulos, que tienen una numeración progresiva, denominada posición arancelaria. A cada posición se señala la tarifa ad valorem que en realidad es el impuesto a pagarse por la importación del artículo correspondiente.

Según nuestra opinión también las patentes y regalías, son una modalidad de tributos, si bien tienen una connotación histórica propia, que autorizan el ejercicio de una actividad económica o la conservación de un recurso con el establecimiento de una contribución obligatoria por la explotación de un recurso natural. Las regalías son obligaciones de origen muy antiguo en el que por la explotación de un recurso natural como una mina se reconocía una participación o un porcentaje al rey, a la autoridad o al estado. Todavía se conservan regalías en la explotación de hidrocarburos y más frecuentemente en la explotación minera.

La Ley de Minería R.O. suplemento 517 (29-I-2009) establece que los concesionarios mineros deben pagar anualmente una patente de conservación por cada hectárea minera y una regalía semestral del $5 \%$ al estado por la explotación de recursos no renovables y su venta además de los otros impuestos que se hayan establecido para el efecto.

Las tasas, según el Código Tributario, son tributos coactivos vinculados a un servicio público general, divisible y cuantificable en unidades mensurables (metros cuadrados, metros cúbicos, impulsos, tiempo de duración, potencia y cantidad de energía, etc.) en

\footnotetext{
337 José Vicente Troya Jaramillo, Lecciones de Derecho Tributario con las últimas reformas, (Quito: Ediciones Fausto Reinoso, 2015).
} 
beneficio del contribuyente, (sea ente público o privado, personal natural o jurídica) mediante tarifas que corresponden al costo del servicio y una estimación adicional razonables para su mantención y ampliación. Las tasas pueden ser de carácter nacional por la utilización de servicios públicos (tasas postales, telegráficas, de servicio aeroportuario o telefónico, del servicio aduanero, peajes, pontazgos, etc.) o seccional (por agua potable, alcantarillado, recolección de basura, comprobación de pesas y medidas, etc.). ${ }^{338}$

Se debe diferenciar entre tasa y precio, pues la primera no tiene equivalencia al valor del servicio público o la utilización de bienes y no se cobran por el beneficio que puede obtener o no el particular. El COOTAD dispone: "las municipalidades y distritos metropolitanos podrán aplicar tasas retributivas del servicio público...”, mediante ordenanza, cuyo monto debe establecerse en "relación con el costo de producción" del mismo, sin incluir en dicho monto "gastos generales de la administración municipal o metropolitana que no tenga relación directa y evidente con la prestación del servicio". Sin embargo, se agrega, que "el monto de las tasas podrá ser inferior al costo, cuando se trate de servicios esenciales destinados a satisfacer necesidades colectivas de gran importancia para la comunidad"... siempre "que la diferencia entre el costo y la tasa pueda cubrirse con los ingresos generales de la municipalidad o del distrito metropolitano" (Art. 566). ${ }^{339}$

Las contribuciones especiales de mejoras son tributos de mejora que pagan los beneficiarios directos de obras públicas por ser propietarios de inmuebles que están dentro de la zona de beneficio o de influencia. El beneficio debe ser mensurable y si bien la obra pública está destinada al bienestar colectivo mejora el valor de mercado o de destino de los bienes de los contribuyentes que se encuentran en su zona de influencia.

El COOTAD dispone al respecto que el "objeto de la contribución especial de mejoras es el beneficio real o presuntivo proporcionado a las propiedades inmuebles urbanas por la construcción de cualquier obra pública" y que "los concejos municipales o distritales podrán disminuir o exonerar el pago de la contribución especial de mejoras en consideración a la situación social y económica de los contribuyentes" (Art. 569). También establece que si los proyectos se desarrollan con la participación pecuniaria o en trabajo de la comunidad no se cobrará a esta contribución por mejoras (Art. 570); que la base del tributo es el costo de la obra a prorrata de las propiedades beneficiadas en la forma y proporción y ubicación que regule la ordenanza (578); que no se pueden incluir en los costos de las obras gastos generales de la administración, de mantenimiento y depreciación (Art. 589); que se puede cobrar las contribuciones especiales fraccionando la obra y en la forma y plazo y hasta un límite establecido en las ordenanzas respectivas

\footnotetext{
${ }^{338}$ Carlos Licto Garzón, y otros en Comentarios a la Ley Reformatoria para la Equidad Tributaria del Ecuador, Ediciones Processum, Quito, 2008.

${ }^{339}$ Ecuador, COOTAD, Registro Oficial 303, Suplemento, 19 de octubre de 2010.
} 
y en la ley (Art. 592) y que los reclamos de los contribuyentes, si no se resolvieren en la instancia administrativa se tramitarán en la vía contenciosa tributaria (Art. 593).

Entre las contribuciones especiales de mejoras tenemos la que se cobra por apertura, pavimentación, ensanche y construcción de vías de toda clase; repavimentación urbana; la construcción de aceras y cercas; obras de alcantarillado; construcción y ampliación de obras y sistemas de agua potable; desecación de pantanos y relleno de quebradas; construcción de plazas, parques y jardines y otras obras que se determinen mediante ordenanza (Art. 577). ${ }^{340}$

También se identifica como "contribuciones especiales por gasto" a aquellas que se establecen para contribuir al financiamiento de las actividades que ejecutan instituciones públicas de control a actividades de entes públicos y privados y "contribuciones parafiscales" a las que no son reconocidas como tales por el Código y leyes tributarios, pero que son obligatorias para las personas involucradas en obras y servicios públicos que prestan entes de naturaleza pública o semipública, como es el caso de las instituciones de Seguridad Social, en las que los aportantes financian la mayoría de prestaciones que se ofrecen bajo diferentes sistemas solidarios o de cuentas individuales con el complemento subsidiario del Estado. ${ }^{341}$

El tributo da origen a la OBLIGACION TRIBUTARIA que nace por mandato de la Constitución al establecer, en el artículo 82 los deberes y las responsabilidades de los ecuatorianos, en el numeral 15: "pagar los tributos establecidos por la ley". El artículo 15 del Código Tributario vigente, define la obligación tributaria como "el vínculo jurídico personal, existente entre el Estado o las entidades acreedoras de tributos y los contribuyentes o responsables de aquellos, en virtud del cual debe satisfacerse una prestación en dinero, especies o servicios apreciables en dinero, al verificarse el hecho generador previsto por la ley".

Según el mismo Código, la obligación tributaria nace cuando se realiza el presupuesto establecido por la ley para configurar el tributo. (Art. 18). De las normas trascritas se desprende que para que surja una relación jurídica-tributaria se requiere de cuatro elementos: la ley, el sujeto activo, el sujeto pasivo y el hecho generador.

La relación jurídico - tributaria implica necesariamente, conforme lo manda la actual Constitución en su artículo 301, la existencia de una ley para establecer, modificar, exonerar o extinguir impuestos y tasas y contribuciones especiales y de acto normativo de órgano competente para establecer, modificar, exonerar y extinguir tasas $\mathrm{y}$ contribuciones.

\footnotetext{
${ }^{340}$ Ecuador, COOTAD, Registro Oficial 303, Suplemento, 19 de octubre de 2010.

${ }^{341}$ José Vicente Troya Jaramillo, Lecciones de Derecho Tributario con las últimas reformas, (Quito: Ediciones Fausto Reinoso, 2015).
} 
La relación debe además ser personal, esto es, entre personas naturales y jurídicas. Las entidades acreedoras de tributos son el sujeto activo, el Estado o cualquier entidad pública (Art. 23 del C. Tributario), y los contribuyentes y responsables (Art. 24 del Código Tributario) son los sujetos pasivos que están obligados a pagar tributos en la forma y con los requisitos de ley, y pueden ser estos personas naturales o jurídicas y, según el Código Tributario, también las herencias yacentes, las comunidades de bienes y otras entidades que constituyan una unidad económica o un patrimonio independiente de los de sus miembros.

El hecho generador, según el artículo 16 del Código Tributario es "el presupuesto establecido por la ley para configurar cada tributo". Se trata no de un presupuesto económico sino en realidad de un hecho, de un acto o situación descrito o tipificada por la ley como generador de un tributo. 


\section{CAPITULO IV: EL DERECHO DE LOS INGRESOS TRIBUTARIOS EN LOS MODELOS ECONÓMICOS DE ECUADOR ENTRE 1990 - 2017}

En este capítulo nos referiremos al derecho tributario y su proceso histórico en el contexto de la Hacienda pública ecuatoriana y a sus principales connotaciones doctrinarias, constitucionales y jurídicas en los modelos y políticas neoliberal y neointervencionista que se han sucedido o combinado en casi tres décadas de su historia en Ecuador (1990-2017).

Analizaremos también las principales modificaciones que se advierten en el mismo período, tanto en las administraciones tributarias del país, como en el ejercicio de sus facultades y procedimientos administrativos y contencioso-tributarios. De igual manera, nos referiremos, estableciendo continuidades y diferencias, a las principales orientaciones y contenidos asumidos por el derecho tributario en los actuales modelos económicos y políticas públicas.

\section{PANORAMA HISTÓRICO DEL DERECHO TRIBUTARIO EN EL ECUADOR}

La legislación y el derecho tributario tienen una íntima relación con el sistema y los modelos económicos y los tipos de Estado y hacienda que se han sucedido en la historia, como fácilmente se puede concluir al revisar rápidamente sus cambios y modificaciones en la historia de Ecuador.

Sin embargo, para Washington Durango, la legislación tributaria en el país tiene dos épocas: una antes de la expedición del Código Fiscal, mediante Decreto - Ley de Emergencia, el 24 de julio de 1963 en el Gobierno de Carlos Julio Arosemena y la que se inicia con la aprobación del actual Código Tributario el 23 de diciembre de 1975 y se prolonga hasta la actualidad.

Nosotros distinguimos, por lo menos, cuatro etapas en la evolución histórica de la legislación y de los sistemas tributarios en Ecuador (liberal, intervencionista, neoliberal y neo-intervencionista) que están relacionados con las etapas de la Hacienda pública a las que nos hemos referido anteriormente, para lo cual examinaremos en el contexto socio-económico y político, los contenidos y connotaciones de los principales tributos y el ejercicio de las garantías ciudadanas para reclamar e impugnar las decisiones de las autoridades en esta materia, siguiendo las investigaciones realizadas inicialmente por Eduardo Riofrío Villagómez y luego por otros tributaristas nacionales.

Si bien se pueden diferenciar las orientaciones de los sistemas tributarios acordes con el modelo económico hegemónico, en cada época de la vida republicana del Ecuador, debemos recordar el carácter medial de los tributos, por lo que los sistemas tributarios y los mismos tributos no se pueden analizar de manera aislada o excluyente. Más bien, resulta evidente que las necesidades que tiene el Estado a lo largo de la historia, 
independientemente del papel que cumpla la economía, absteniéndose de intervenir en ella, como su promotor o ejerciendo su control, requiere de recursos crecientes y suficientes para atender su función y la demanda social, por lo que necesariamente se recurrirá a sus diferentes modalidades, en las que se priorizará uno u otros tributos, de acuerdo al momento histórico y a las corrientes y doctrinas económicas y políticas que se apliquen desde el Gobierno.

En torno al cumplimiento de fines fiscales y extrafiscales en los gobiernos de turno, se ha hablado permanentemente de reformas tributarias y ajustes en los tributos, especialmente, para simplificar su determinación y cobro, para aumentar su recaudación y para que la carga tributaria se amplíe con la finalidad de que un mayor número de ciudadanos contribuya para el financiamiento del Estado. Nosotros diferenciamos los cambios y ajustes rutinarios a los tributos de las reformas o transformaciones tributarias de mayor magnitud (sistemas tributarios) que han provocado cambios en el sistema de determinación, recaudación y ejercicio de las potestades de la administración tributaria y de los derechos de los contribuyentes. Para ser más exactos, deberían denominarse regímenes tributarios, pues no alcanzan a la coherencia y armonía que requiere un verdadero sistema tributario. ${ }^{342}$

\section{Primera etapa: entre 1830 con la fundación de la República, 1863 con la Ley de Hacienda Garciana y la Revolución liberal de 1985 hasta 1926. Del sistema tributario poscolonial al sistema liberal}

En esta etapa se pueden diferenciar dos fases: desde 1830 hasta 1863 (y aún hasta 1864), en la que los tributos que estuvieron vigentes fueron esencialmente los mismos de la época colonial. El sistema tributario de entonces se basaba principalmente en contribuciones directas y personales, con caracteres racistas y discriminatorios, combinadas con el tributo aduanero de efecto indirecto. Así tenemos la "contribución de indígenas" que estuvo vigente hasta los años setenta del siglo XIX; una serie de gravámenes asociados al dominio y subordinación del Estado a la Iglesia: "las temporalidades", "los diezmos", "novenos" y "las primicias" y las aduanas, con los que se financiaba principalmente los gastos del ejército y de las funciones básicas que cumplía el Estado gendarme.

Las clases privilegiadas de entonces, terratenientes y grandes comerciantes, no tributaban, pues se consideraba que hacerlo era deshonroso y denotaba inferioridad.

Conforme lo recoge José Vicente Troya en su artículo "El sistema tributario en el Ecuador", tomado de un estudio denominado El Presupuesto Nacional a través de 115 años, de Alberto Azanza, funcionario del Ministerio del Tesoro en 1946, los ingresos efectivos en 1830, al iniciar la vida republicana, fueron 716.385 pesos, es decir, el equivalente a 840.293 dólares. Las contribuciones aduaneras alcanzaron 311.500 pesos,

\footnotetext{
342 José Vicente Troya Jaramillo, "El Sistema Tributario en el Ecuador”, Libro del Sesquicentenario, IV, (Economía, Segunda Parte, CEN, 1983).
} 
la de indígenas 200.379, la de estancos 48.943, la de timbres 73.098 y 70.465 de diezmos y otros gravámenes compartidos por la Iglesia y el Estado. El diezmo, más tarde, llegó a producir 700.000 pesos de los cuales el fisco recibía 400.000 pesos, hasta que fue suprimido en 1884, luego de un acuerdo con la Santa Sede y reemplazado por un impuesto del 3 por mil a los predios rústicos y un adicional al cacao destinado a sufragar el presupuesto eclesiástico. ${ }^{343}$

La segunda fase va desde el año 1863, en el que se dictó la Ley de Hacienda Garciana, hasta la Revolución juliana de 1926, período en el cual se origina y consolida el Estado liberal hegemonizado por la oligarquía agroexportadora, momento en el que se suprimen algunos tributos directos y se comienzan a priorizar los tributos indirectos, lo que constituiría, según nuestro análisis, el establecimiento de un sistema tributario liberal que implicara una primera y transcendental reforma o transformación tributaria

Conviene recordar que Gabriel Jesús Núñez elaboró en 1884 un proyecto de Código Fiscal para organizar y regular la Hacienda pública que no fue aceptado. A propósito, existía en el Estado (organizado bajo los principios del Estado policía) un Ministerio de Hacienda, un Tribunal de Cuentas que ejercía un control sobre los recursos recaudados y gastados y la posibilidad de plantear en la vía judicial un recurso de queja ante la Corte Suprema de Justicia. ${ }^{344}$

Este período es de modernización liberal y mercantil del Estado y de organización de un sistema tributario nacional, fundamentado en impuestos indirectos. Estamos en la transición del Estado gendarme y mínimo del siglo XIX, al que le interesaba solamente garantizar el orden interno y externo y la administración de justicia, al estado liberal de derecho en el que se requieren recursos para financiar y completar las obras públicas básicas que integren al país (la unión de la costa con la sierra); la educación pública (bajo la inspiración del laicismo); y la asistencia social, y responsabilidades sociales, estas últimas arrebatadas por el Estado a la Iglesia.

Surge entonces un nuevo sistema tributario real de corte liberal, en el que se combinan, primero con cierto privilegio, impuestos directos a los predios rústicos y a los capitales en giro, relacionados con actividades bancarias, industriales y comerciales, con impuestos indirectos que gravan los consumos, las transacciones y el comercio internacional (aduanas). En un inicio de esta etapa no existen impuestos a la propiedad urbana ni a la renta proveniente del trabajo. ${ }^{345}$

A inicios del siglo XX se establecen las juntas de Hacienda para la recaudación y reclamación tributarias y en 1920 se dicta la Ley de Impuesto a las Herencias.

\footnotetext{
343 Ibídem.

${ }_{344}^{345}$ Riofrío Villagómez, Eduardo, "Manual de Ciencia de Hacienda”, Tomo 1, (Quito: CCE, 1949).

${ }^{345}$ Ibídem.
} 
Segunda Etapa: Sistema tributario intervencionista o redistributivo: de la Revolución juliana de 1925 hasta la crisis del Estado intervencionista entre 19801992

En esta etapa, el modelo económico y político del Estado liberal se sustituye paulatinamente por el Estado y el modelo económico intervencionista o social.

Luego de 1925, con el asesoramiento de la misión Kemmerer, se inicia un período en el que Estados Unidos de Norteamérica emergió como potencia económica y militar y, por lo tanto, pretendió orientar a los países latinoamericanos en el ámbito económico, para lo cual Ecuador dictó en 1928 la Ley de Impuesto a la Renta y la Ley Orgánica de Hacienda. Este hecho constituyó el inicio del establecimiento de un sistema tributario intervencionista o social diseñado para consolidar el modelo liberal e iniciar un nuevo modelo económico de carácter social.

En opinión de José Vicente Troya, desde 1925 crece más la tributación indirecta, frente al deterioro de la directa, como lo prueban los datos del referido estudio de Alberto Azanza, pues ya en 1890 la imposición directa rindió 116.353,74 sucres, y la indirecta produjo 3'436.183,76; en 1920 la primera alcanzó a 839.920,29, la segunda llegó a 15'730.090,94 y en 1925, la directa sumó 1'477.973,00 y la indirecta 28'850.988,00 sucres. $^{346}$ Por lo tanto, se puede concluir que desde entonces se reinvierte definitivamente la tendencia inicial y los impuestos indirectos prevalecen sobre los directos.

Siguiendo el sistema norteamericano y la teoría del fisco, los jueces civiles podían conocer y resolver controversias tributarias, aplicando los principios de sumisión del Estado al derecho y el del solve et repete, puesto que primero se debía pagar para luego presentar cualquier reclamo o demanda.

En esta etapa se produce la consolidación del modelo oligárquico exportador, con el auge del banano y el inicio un modelo de sustitución de importaciones, industrialización y de desarrollo con un mayor intervencionismo estatal. La primera fase de este modelo económico se caracteriza por la organización inicial del Estado intervencionista, que en el Ecuador se expresa en la Constitución de 1929; en las reformas sociales que permitieron la expedición del Código del Trabajo en 1938 y otras leyes sociales y en el contenido progresista de la Constitución de 1945.

En esta fase mejoran las normas para la recaudación de tributos entre los que se incluyó el impuesto predial urbano en 1949 y se inició un proceso para establecer procedimientos administrativos y judiciales en materia tributaria para que los ciudadanos pudieran reclamar cualquier exceso o arbitrariedad al Estado. Así, en el caso

\footnotetext{
346 Troya Jaramillo, José Vicente, “El Sistema Tributario en el Ecuador”, Libro del Sesquicentenario, IV, (Economía, Segunda Parte, CEN, 1983).
} 
del impuesto a la renta se permitió la posibilidad de interponer reclamos administrativos ante la Dirección de Ingresos del Ministerio del Tesoro.

El profesor Eduardo Riofrío Villagómez formuló entonces el primer proyecto de Código Fiscal en el que se permitía que las reclamaciones administrativas y tributarias se plantearan ante el Consejo de Estado y luego formalmente las demandas se tramitaran en el mismo organismo administrativo - jurisdiccional. En ese contexto se recibió el aporte de varios profesores y maestros universitarios como los doctores Juan Genaro y Osvaldo Jaramillo Larrea, Pedro Núñez y otros que impulsaron una legislación de justicia tributaria, mediante Ley de Emergencia del 19 de junio de 1959, con la que se creó el Tribunal Fiscal como ente jurisdiccional independiente de la función judicial y de la función ejecutiva, para resolver las demandas en materia tributaria. En 1961 se decidió también que este tribunal resolviera los asuntos aduaneros. Como culminación de este proceso, el 25 de junio de 1963 se expidió el Código Fiscal Ecuatoriano en el Gobierno de Carlos Julio Arosemena. ${ }^{347}$

En la década del 60, luego de la Revolución cubana, Estados Unidos promovió la Alianza para el Progreso y para evitar nuevos acontecimientos insurgentes en su aérea de influencia planteó la instrumentación de varias reformas: agraria, educativa y tributaria. La primera pretendía disminuir las contradicciones sociales y asegurar un proceso de redistribución de la riqueza. En materia tributaria, para asegurar una cierta redistribución del ingreso, se impulsó una serie de conferencias y la elaboración de un modelo de Código Tributario y Fiscal para Latinoamérica, que fue adoptado como sugerencia para todos los países latinoamericanos en una conferencia en Montevideo. El modelo tributario regional perseguía la racionalización y la proporcionalidad tributarias y mecanismos eficientes y modernos de determinación, recaudación y de reclamación en la materia, tanto en el ámbito administrativo como en el judicial.

En ese contexto, la Junta Militar (1963) nombró una comisión de juristas para elaborar un nuevo proyecto de Código Fiscal. La comisión estuvo integrada por los doctores Juan Isaac Lovato, José Ponce Martínez y Eduardo Riofrío Villalones, técnicos del Ministerio de Finanzas, con el asesoramiento del profesor Giuliani Fonrouge, autor del modelo de Código Latinoamericano al que hemos hecho referencia.

La expedición del Código Fiscal de 1963 se complementó con la simplificación del sistema y codificación de algunas leyes que contenían normas dispersas, ineficaces y contradictorias, como la Ley de Impuesto de Herencias, Legados y Donaciones; Ley de Timbres y Tasas Postales; Ley de Impuesto a la Renta; los tributos que contiene la Ley de Régimen Municipal y la Ley a las Transacciones Mercantiles e IVA. ${ }^{348}$

\footnotetext{
${ }^{347}$ Ecuador, Código Fiscal Ecuatoriano, Registro Oficial 490, 25-junio-1963.

348 José Vicente Troya Jaramillo, "El Sistema Tributario en el Ecuador", Libro del Sesquicentenario, IV, (Economía, Segunda Parte, CEN, 1983).
} 
Considerando la experiencia alcanzada en más de 12 años de vigencia del Código Fiscal y la abundante jurisprudencia del Tribunal Fiscal, el proceso anterior culminó el 23 de diciembre de 1976, en la dictadura del general Guillermo Rodríguez, cuando se expidió, en sustitución del Código Fiscal, el Código Tributario que, con varias codificaciones y modificaciones, se encuentra vigente hasta la actualidad. ${ }^{349}$

Para nosotros, la expedición del Código Fiscal, la simplificación legislativa tributaria posterior y fundamentalmente la vigencia del Código Tributario, que ha sobrevivido más de 40 años en nuestra historia jurídica con ciertas modificaciones, nos permite hablar del establecimiento de un sistema tributario intervencionista o social que implicó una segunda gran reforma o transformación tributaria nacional.

En 1980, con el retorno al régimen constitucional que se inspiró en el Plan Nacional de Desarrollo en el que se formuló -como uno de los grandes objetivos nacionales- la reforma estructural a la tributación, podemos hablar que se completó el proceso antes indicado con la expedición de la Ley de Régimen Tributario Interno en 1989el Gobierno social demócrata de Rodrigo Borja.

Esta reforma coincide con la crisis del modelo intervencionista, precipitada por la crisis energética y de la deuda externa, pues demandó mayor rigurosidad y eficiencia en la recaudación tributaria, dado que se consolidaron y ampliaron los mecanismos para mejorar la recaudación del impuesto a la renta. A la vez, crecieron en cobertura e importancia económica los impuestos indirectos y se crearon los impuestos a las transacciones mercantiles y a los consumos selectivos. También se perfeccionaron los mecanismos para simplificar el cobro de tributos y para combatir la evasión y elusión tributarias.

Durante el Gobierno de León Febres Cordero se elevaron los porcentajes de los impuestos a las transacciones mercantiles (ITM); a los consumos selectivos (ICS), a la cerveza y al consumo de bebidas gaseosas, para enfrentar la disminución del precio internacional del petróleo y las exigencias de incrementos salariales.

El proceso que apuntaba a la simplificación tributaria culminó, como hemos dicho, en el Gobierno de Rodrigo Borja en 1989, cuando se dictó, en medio de una gran campaña publicitaria nacional y con la aprobación en el Congreso Nacional, la Ley de Régimen Tributario Interno que disminuyó la frondosidad de los tributos, algunos de los cuales tenían rendimientos insignificantes, unificándolos en el Impuesto a la Renta con una escala que iba hasta el 25 por ciento -porcentaje en el cual se armonizó también la tributación de las empresas nacionales y extranjeras, favoreciendo la supuesta inversión foránea, ya que estas debían pagar hasta entonces un impuesto a la renta del 44\%-; y con los impuestos al Valor Agregado (IVA), a los consumos especiales (ICE) e impuestos a las actividades petroleras y turísticas. Se modernizó notablemente el sistema sin cuestionar el marco general del Código Tributario. Durante este Gobierno,

\footnotetext{
${ }^{349}$ Ecuador, Código Tributario, suplemento, Registro Oficial 958, 23-diciembre-1976.
} 
por imposición del FMI, se inició un proceso de reestructuración de la Dirección General de Rentas que ejercía la Administración Tributaria Nacional para combatir la evasión y elusión tributarias.

Según Jorge Gallardo, exministro de Finanzas, la reforma tributaria que impulsó el gobierno de Borja rebajó los niveles de impuestos "que podían llegar a porcentajes prohibitivos", eliminó una serie de impuestos de bajo rendimiento y difícil recaudación; simplificó la administración de impuestos; incorporó a la banca en la recaudación tributaria, desaparecieron las oficinas de recaudación "que se habían convertido en foco de corrupción" y se generalizaron las retenciones en la fuente para "recaudar impuestos anticipadamente". 350

\section{Tercera etapa: El neoliberalismo, el sistema tributario neoliberal: el auge de la tributación indirecta y la recaudación (1990-2006)}

La crisis capitalista de los años 70, la explosión de la deuda externa y la globalización y mundialización financiera del capitalismo impusieron el neoliberalismo a nivel internacional desde los años 80, bajo las reglas del Consenso de Washington y la imposición de los programas de ajuste del FMI y de los organismos financieros multilaterales.

Si bien en el período presidencial de León Febres Cordero (1984-1988) se publicitó su liberalismo económico, en el Gobierno "social demócrata" de Rodrigo Borja (19881992) se completó la indicada reforma tributaria con la expedición de la Ley de Régimen Tributario Interno y se introdujeron varios mecanismos de flexibilización laboral y de mayor articulación del país al mercado financiero internacional.

Sixto Durán Ballén y Alberto Dahik (1992-1996) dieron los pasos necesarios para desmontar el modelo estatal intervencionista y privilegiar el papel del mercado en la economía, dictando normas (Ley de Modernización del Estado, 1994) para favorecer la privatización de los activos públicos e iniciar el desmantelamiento de todo el aparato de planificación y de intervención del Estado. De igual manera se dictó la legislación para favorecer la liberalización financiera (Ley General de Instituciones Financieras, 1994) y el control fiscal para impulsar supuestamente la inversión extranjera y asegurar el pago puntual de las obligaciones crediticias internacionales.

Con la finalidad de descentralizar la administración de justicia tributaria y de concentrarla en la función judicial, en las reformas constitucionales de 1992 se crearon los tribunales distritales de lo Contencioso Tributario de única instancia, con sede en Quito, Guayaquil, Cuenca y Portoviejo, a los que más tarde se agregó, en 1997, otro en Riobamba (Ambato, Loja) y se dispuso la tramitación de los recursos de casación en materia tributaria en una sala especializada en esa materia, en la Corte Suprema de

\footnotetext{
${ }^{350}$ Jorge Gallardo Zavala, "Impuestos”, El Comercio, 29 de enero de 2012.
} 
Justicia. De esta manera, se sustituyó el sistema autónomo nacional de administración de justicia tributaria que existía en el país y se la adscribió, aplicando el principio de unidad jurisdiccional, a la Corte Suprema de Justicia, tomando en cuenta los principios y las normas especializadas en materia tributaria.

Los planes de ajuste y las cartas de intención de esa época, impuestas por el FMI y otros organismos multilaterales, impulsaron un sistema tributario con orientación neoliberal en el que se incluyen medidas para ampliar el sistema y carga tributarios vigentes y para hacerlo más eficiente en la recaudación de recursos con la finalidad de asegurar el pago de la deuda externa. Subieron nuevamente los impuestos indirectos y se establecieron reglas para controlar el crecimiento del gasto público mediante la Reforma a la Ley de las Finanzas Públicas.

Por su parte, en el gobierno de Fabián Alarcón se expidió en 1998 la Ley del Servicio de Rentas Internas, que eliminó la Dirección Nacional de Rentas y la administración tributaria directa por parte del Ministerio de Finanzas. Desde entonces, sin desconocer el papel político que en materia tributaria tienen el presidente y el ministro de Finanzas, se creó un organismo bajo la dependencia y nombramiento exclusivo del presidente para controlar la ejecución y administración tributaria del Estado de manera más eficiente y profesional.

Estas decisiones para trasladar a la función judicial toda impugnación tributaria, priorizar los tributos indirectos y mejorar y tecnificar el proceso administrativo tributario con la creación del SRI (que ha resultado eficaz en el cobro de tributos en los gobiernos posteriores), son los hitos principales de esta tercera transformación o reforma tributaria nacional.

En el Gobierno de Jamil Mahuad, en el contexto de la crisis y saqueo bancarios que diezmaron los recursos públicos y privados para beneficiar a los círculos que financiaron su campaña electoral, el diputado socialcristiano Jaime Nebot impuso en septiembre de 1998 la eliminación del Impuesto a la Renta. Se sustituyó por un Impuesto a la Circulación de Capitales del 1\%, completando un esquema inequitativo en materia tributaria que traslada todo el peso de la carga tributaria a los sectores de medianos y bajos ingresos. El Gobierno de Gustavo Noboa aprobó en 2002 una Ley de Reforma de las Finanzas Públicas en la que se adoptaron una serie medidas de equilibrio y control fiscal, se restableció el impuesto a la renta y se extendió el IVA a todos los servicios menos salud y educación.

Si bien, como hemos dicho, los tributos tienen principalmente una finalidad fiscal, esto es la de proveer de recursos suficientes para que el Estado pueda cumplir con sus fines y el gobierno con sus planes, también en esta época se enfatiza que pueden tener una finalidad extrafiscal para promover el empleo, la producción y objetivos de justicia redistributiva del ingreso y de la riqueza nacional. 
En el período neoliberal se amplió la base tributaria, se eliminó en su momento culminante el Impuesto a la Renta y se incrementó la recaudación tributaria, pero no mejoró la distribución de la renta ni la equidad, pues el objetivo fundamental del modelo era mantener el equilibrio fiscal, controlar el incremento del gasto público y garantizar el pago puntual de la deuda externa y de su servicio.

El Servicio de Rentas Internas estimó que la recaudación en 1997 en relación con el PIB era apenas del 5,1\% y en 2006, el $10 \%$, estableciendo un promedio en dicho lapso del $8,4 \%$ del PIB y si se compara la participación de los impuestos directos e indirectos en el total de la recaudación entre diciembre de 1997 y diciembre de 2006, los primeros correspondían al 34,34\% y los indirectos al $65,7 \%$, lo que demuestra la prioridad que en el modelo neoliberal se otorgó a la recaudación de impuestos indirectos que son más regresivos y afectan a la mayoría de la población. ${ }^{351}$

\section{Cuarta etapa: El neointervencionismo y el sistema tributario neointervencionista: recaudación y flexibilidad del gasto $(2007-2017)$}

El cuestionamiento académico, político y social de las fuerzas sociales y progresistas del Ecuador al neoliberalismo y a sus efectos se inició activamente desde su instauración a mediados de las décadas del 80 y en la década del noventa y se intensificó desde la quiebra fraudulenta de los bancos y el saqueo de recursos públicos y privados en 1999 y la dolarización en el 2000.

En el sector financiero, luego de la quiebra bancaria de inicios de siglo, se restablecieron paulatinamente los controles estatales, ajustándose a los estándares de Basilea y se paralizaron luego los procesos de privatización, pese a los empeños e intereses presentes en el Consejo de Modernización del Estado dirigidos por el hermano del presidente Gustavo Noboa (CONAM) en 2001 y 2002.

Desde la caída de Lucio Gutiérrez (2003), el gobierno de Alfredo Palacio se vio presionado a establecer límites al saqueo de recursos naturales, estableciendo una participación estatal en los altos precios del petróleo en el mercado internacional y en la prolongada decisión de la caducidad del contrato de concesión en el Bloque 15 con la empresa petrolera norteamericana Occidental.

Con la emergencia de nuevos actores políticos y sociales que triunfaron en la elecciones generales del 2006, se impulsó y aprobó una nueva Constitución en el 2008, que fue imponiendo en el país un nuevo modelo neointervencionista o neokeynesiano, que en el campo tributario planteó optimizar el cobro del impuesto a la renta, estudiar la posibilidad de introducir nuevos tributos directos, combatir frontalmente la evasión y la

\footnotetext{
351 Ecuador, SRI, Presidencia de la República, Rafael Correa Delgado, Informe a la Nación, www.planificación.gob.ec
} 
elusión tributarias y mejorar las instituciones del Código Orgánico Tributario para perfeccionarlas y mejorar la recaudación y la justicia tributarias.

Este proceso en su conjunto, en el que se han dado varios pasos y ajustes, muchos de ellos controvertidos por los sectores económicos de poder y por sectores académicos y sociales de carácter popular, nos permite hablar de una cuarta gran reforma o transformación para imponer un nuevo Sistema Tributario de orientación neointervencionista, que se habría caracterizado por: "el fortalecimiento del SRI; mayor efectividad en el cobro de los impuestos; persecución a la evasión y elusión tributarios; privilegio de los impuestos directos sobre los indirectos; política tributaria para la redistribución de la riqueza; orientación impositiva para el desarrollo de la producción nacional". 352

El 28 de diciembre de 2007 la Asamblea Nacional Constituyente en el Gobierno de Rafael Correa expidió la Ley para la Equidad Tributaria para mejorar la justicia en el sistema tributario y fortalecer la recaudación, si bien se establecieron importantes deducciones en el impuesto a la renta y la eliminación de escudos fiscales, del ICE en telecomunicaciones y se introdujeron nuevos impuestos selectivos, como $0,5 \%$ a la salida de divisas; se incrementó el tributo a las herencias, legados y donaciones con una escala del 5\% al 35\% según el monto y se creó el impuesto a los activos en el exterior. La ley reformó también el Código Tributario, mejorando el sistema de sanciones para optimizar el comportamiento de los contribuyentes y el sistema de recaudación mediante un régimen simplificado. La administración tributaria, además, ha promovido varias iniciativas para tecnificar a su personal y para fortalecer una cultura tributaria que incrementa significativamente el número y calidad de los contribuyentes.

En la memoria bienal 2007-2009 la SENPLADES indica que la referida ley regula los principales impuestos, tomando en cuenta su jerarquía recaudatoria y que por lo tanto define una nueva estructura del impuesto sobre la renta personal, en cuanto a tramos y gastos deducibles y establece un diseño diferenciado del impuesto de consumo específico, sin cambiar el monto del IVA, pero mejorando su rendimiento.

La ley argumenta el organismo de planificación, busca progresividad y mejoramiento en la recaudación y establece una nueva estructura al impuesto a la renta, aumentando su progresividad del 0 al 35\%, incorporando a la tributación a la población manufacturera y comercial de pequeños y medianos ingresos que se somete al RISE, sistema que antes constaba en un reglamento. El IVA y el ICE se generalizan impactando negativamente a la población de menos ingresos, si bien se disminuyen los tributos a las telecomunicaciones. Se establecen sanciones más fuertes para la evasión tributaria y los mecanismos de defraudación. Se crean incentivos a la generación de empleos y para generar puestos de trabajo para los discapacitados. Se fomenta el ahorro mediante 352 Juan Paz y Miño Cepeda, Historia de los impuestos en Ecuador, (Quito: SRI, CEFI, THE, 2015),
2015. 
deducciones para depósitos a plazo fijo por más de un año y se crean tributos para combatir las tierras improductivas y para exonerar a quienes conservan bosques naturales y humedales, debidamente calificadas por las autoridades ambientales.

Estas políticas mejoraron la recaudación tributaria del gobierno en el 2008 y en el 2009, pero desataron también la crítica de varios sectores sociales afectados $\mathrm{y}$, especialmente, de los grupos de poder económico del país.

Según expertos tributarios locales como Mario Prado, la reforma tributaria del Gobierno de Rafael Correa elevó a la categoría de ley varias normas reglamentarias que antes no pudieron incorporarse al ordenamiento jurídico porque la Función Legislativa negó su aprobación. De manera descontextualizada y perjudicial para los sectores productivos incorporó algunos cambios como: el establecimiento de reglas para prevenir y sancionar la subcapitalización de las empresas que operan con créditos externos; la fijación de límites a la deducción de los intereses por créditos externos y el cobro del impuesto a la renta por el pago de intereses al exterior.

También los expertos, al analizar el contenido de las reformas del gobierno, reconocen que estas fortalecen el poder de la Administración y perjudican los derechos y garantías individuales o ciudadanas. Así, dicen que al elevarse la tasa de interés en materia tributaria, en 1.5 veces la tasa activa referencial del Banco Central, cuando antes era de 1.1, se eleva el costo financiero y por lo tanto los sujetos pasivos pagarán los tributos de manera completa, beneficiando a la administración tributaria.

Según esto, el profesor Prado estima que el recargo del 20 por ciento sobre los tributos determinados por la Administración se podría convertir en una sanción adicional a la establecida por la infracción tributaria, con lo que se perjudican al contribuyente. Al analizar otras reformas sobre lo que denomina "aspectos sustantivos", como la responsabilidad de terceros a quienes la administración tributaria requiere información o el nuevo alcance y contenido de la determinación complementaria o sobre el afianzamiento del interés fiscal o sobre las declaraciones sustitutivas, el autor consigna sus reparos y, en algunos casos, califica a las nuevas normas como "abusivas", pues estima que se amplían las atribuciones y discrecionalidad de la administración tributaria en perjuicio del contribuyente, del declarante o de terceros, violando en algunos casos sus derechos y garantías. Afirma, por ejemplo, con respecto al afianzamiento obligatorio de una caución del 10 por ciento de la cuantía para presentar acciones y recursos sobre determinación o recaudación de tributos y sus recargos, intereses y multas: “...el sujeto pasivo queda a expensas de la administración tributaria que ha logrado introducir cambios legales que prácticamente prohíben la impugnación de los actos administrativos por lo oneroso que resulta ejercitar el derecho de defensa". 353

\footnotetext{
${ }^{353}$ Mario Prado, y otros, Comentarios a la Ley Reformatoria para la Equidad Tributaria del Ecuador, Ediciones Processsum, 2008, Quito, Ecuador, 25.
} 
Similares reparos realizan otros autores y los dirigentes gremiales de los empresarios ecuatorianos sobre las reformas a las normas generales de lo penal tributario; a la clasificación de las infracciones y la responsabilidad; al reordenamiento de las reglas de prescripción y del procedimiento penal; a la incorporación de nuevas infracciones y agravamiento de penas; a las reformas a la determinación y declaración del impuesto a la renta y a la deducción de los intereses, cuotas o cánones y el anticipo mínimo. ${ }^{354}$

En realidad, en los diez años del Gobierno del presidente Correa, en el proceso de lo que hemos denominado sistema tributario de orientación neointervencionista, se adoptaron numerosas y sucesivas reformas y ajustes en la legislación tributaria nacional, que se suman a los que se han ejecutado en las leyes de la materia desde que expidieron en el Código Tributario, la Ley de Régimen Tributario Interno, ${ }^{355}$ la ley de Reformas de las Finanzas Públicas y la Ley de creación del SRI. Solo las reformas introducidas en el régimen correísta superan las veinte, además de las que autorizó la Asamblea Nacional Constituyente en diciembre de 2007, a la que ya nos hemos referido anteriormente.

Así, entre las nuevas modificaciones o ajustes de la última década tenemos: la de 30 de julio del 2008 en la que se incrementó, en la Comisión de Legislación y Fiscalización denominada "congresillo", del $0.5 \%$ al $1 \%$ el impuesto a la salida de capitales y se adoptaron medidas que se han considerado como incentivos a la producción nacional y al acceso a los servicios públicos, como la eliminación del ICE para la telefonía fija y celular y la deducción de gastos para el pago del Impuesto a la Renta y de intereses pagados al exterior.

En diciembre de 2009 la Asamblea Nacional aprobó un incremento del 1 al $2 \%$ al ISD (impuesto a la salida de divisas) para transferencias que superan los 1000 dólares en 2010 y desde el 2012 al 5\%; la transformación del anticipo del Impuesto a la Renta como un impuesto a la renta mínimo obligatorio que no será devuelto si la empresa finalmente genera pérdidas en el año fiscal o su impuesto real es menor al anticipo; la tributación de los accionistas de las empresas no solo como empleados sino como beneficiarios de utilidades; la extensión del IVA al papel de periódicos y revistas y cambios en la metodología de cálculo del ICE para cigarrillos, licores y gaseosas.

En julio de 2010 se aprobó una ley reformatoria de la Ley de Hidrocarburos y de la Ley de Régimen Tributario Interno en la que se amplió la cobertura tributaria y se impidió las compensaciones en el impuesto a la renta tanto en los contratos de exploración, explotación y transporte de recursos naturales no renovables en los gastos indirectos, servicios técnicos y administrativos asignados desde el exterior, como en los contratos de prestación de servicios hidrocarburíferos.

\footnotetext{
${ }^{354}$ Jorge Valarezo, Carlos Licto y otros, Comentarios a la Ley Reformatoria para la Equidad Tributaria del Ecuador, Ediciones Processsum, 2008, Quito, Ecuador.

${ }^{355}$ Hasta su codificación del 17 de noviembre de 2004, se reformó cuando menos en 36 ocasiones, como lo dice el doctor Mario Prado, en la obra indicada, a las que habría que sumar las realizadas en el gobierno del Presidente Rafael Correa.
} 
Una vez más, por iniciativa del Gobierno la Asamblea aprobó en diciembre de 2010 el Código Orgánico de la Producción, Comercio e Inversiones (Suplemento del R. O. 354 del 29 de Diciembre del 2010) que contiene un nuevo régimen jurídico sobre las obligaciones tributarias aduaneras, sus operaciones, los regímenes, infracciones y sanciones y la administración aduaneros, con una administración totalmente controlada por el Ejecutivo, por medio de un director, sin ningún nivel de participación de los involucrados en esa actividad, sea como actores o auxiliares de la misma. También se aprobó la exoneración de impuesto a la renta para nuevas inversiones y se elevó el ICE para cigarrillos.

El 24 de noviembre de 2011, antidemocráticamente y "por ministerio de la Ley", el Gobierno publicó en el Registro Oficial un nuevo paquete de ajustes y modificaciones tributarias que esta vez denominó Ley de Fomento Ambiental y Optimización de los Ingresos del Estado. El presidente envió el proyecto tributario por vía urgente para ser debatido, aprobado, modificado o rechazado en 30 días, conforme manda la Constitución. Tanto el gobierno como la "oposición parlamentaria" fueron responsables de enredar e impedir el debate y de crear un clima confuso en el que incluso se aprobó una resolución parlamentaria negando el proyecto. Se contó con la mayoría de los asistentes para la sesión de la Asamblea, pero no reunieron la mayoría establecida en la Constitución. Por ello afirmamos que la nueva ley, formalmente vigente por el mecanismo indicado, no recogió valiosos puntos de vista que podían mejorarla y hacerla más equitativa.

El contenido del referido ajuste tributario, según el gobierno, pretende "por primera vez en la historia del país", según afirmó el presidente Correa, "no recaudar más sino proteger el medioambiente" y agregó "es una reforma ambiental y prosalud". Sin embargo, la nueva ley contiene dos impuestos "verdes", uno a la contaminación vehicular y otro a las botellas plásticas. Tienen rendimientos bastante bajos, y otros, los de mayor rendimiento y que no tienen nada de ecológicos, son: el incremento del ICE a los cigarrillos y bebidas alcohólicas; la exención del ICE para autos híbridos; la reforma al impuesto de tierras; el impuesto del $2 \%$ sobre las ventas brutas de banano y el aumento del 2 al 5 por ciento a la salida de divisas, que permitirán la recaudación entre 450 y 600 millones de dólares adicionales, según el director del SRI si se toman en cuenta los posibles créditos tributarios y más de 1.000 millones de dólares, según voceros de la oposición parlamentaria y dirigentes gremiales de las Cámaras de la Producción.

La ley que entró en vigencia sin intervención parlamentaria tiene la estructura de una norma "trole", pues versa sobre diferentes materias, violando la Constitución. Contiene también asuntos poco socializados: exoneraciones del IVA a transportistas que compren chasis y carrocerías; exoneraciones para la Junta de Beneficencia de Guayaquil y otras entidades; reformas al proceso de cobro de acreencias del Estado modificando en varias partes el Código de Procedimiento Civil; nuevas reglas para la entrega de utilidades a trabajadores petroleros y de la minería modificando la Ley de Hidrocarburos y la Ley de 
Minería y creación de un Comité de Política Tributaria que reemplaza al Directorio del SRI, para establecer los principales lineamientos y definiciones de la materia, eliminado al representante de la Federación de las Cámaras de la Producción y reforzando las atribuciones personales del Director del SRI, a quien se le dan todas las potestades que antes tenía el Directorio, en cuanto manejo de personal, designaciones de directores, gestión presupuestaria y aún para incidir en las definiciones sobre las instancias de control de su gestión.

En diciembre de 2012, por iniciativa del régimen, la Asamblea Nacional aprobó la Ley Orgánica de Redistribución de los Ingresos para el Gasto Social, con la finalidad de financiar el incremento del Bono de Desarrollo Humano de 35 a 50 USD mensuales y otros gastos físcales. En esta normativa se elimina la reducción en diez puntos del impuesto a la renta de los bancos en caso de reinversión de utilidades; se cambia la fórmula de cálculo del anticipo al impuesto a la renta de las entidades financieras; se incluye el IVA a los servicios financieros que se encontraban exonerados; se reforma el impuesto a los activos en el exterior con una nueva tarifa que se incrementa si las inversiones se realizan en subsidiarias en paraísos fiscales, etc. ${ }^{356}$

En 2013 también se aprobó mediante ley una serie de incentivos por medio de abonos tributarios con los que se podía cubrir o pagar obligaciones tributarias pendientes y en 2014 se establecieron en la Ley de Incentivos a la Producción exoneraciones para pymes y empresas de la economía popular y solidaria. ${ }^{357}$

A petición del sector empresarial para reducir costos financieros y de litigios y apoyar la reinversión, eficiencia e innovación, el 6 de mayo de 2015 entró en vigencia la Ley de Remisión de deudas (intereses, multas y recargos) con la administración tributaria, que replicó otra similar en 2008 y recaudó 153 millones USD. En la Ley de 2015 se dispuso la condonación del $100 \%$ de intereses en los primeros 45 días hábiles y del 50 por ciento en los 40 días subsiguientes. Si bien el fisco estimó obtener 500 millones USD que podrían beneficiar a 1,9 millones de personas y empresas que tienen obligaciones pendientes con el SRI, solo dos empresas grandes, Andes Petroleum y Banco del Pichincha podrían ahorrar 263 millones USD de su deudas, lo que evidencia la flexibilidad gubernamental en el cobro de tributos con los más grandes acreedores del fisco. Si se toma en cuenta que para esa misma fecha la cartera pendiente de cobro de la autoridad tributaria suma 6.200 millones de USD, de los cuales el $50 \%$ es capital y $50 \%$ intereses, es evidente que su eficiencia tan publicitada es totalmente relativa. ${ }^{358}$

En junio de 2015, el Ejecutivo envió a la Asamblea Nacional dos proyectos de ley para incrementar el impuesto a las herencias, legados y donaciones hasta un tope del $75 \%$

\footnotetext{
${ }^{356}$ Ecuador, Ley Orgánica de Redistribución de los Ingresos para el Gastos Social, Registro Oficial 847, Suplemento, 10-diciembre-2012.

${ }^{357}$ Ecuador, Ley de Incentivos a la producción del Fraude Fiscal, Registro Oficial 405, Suplemento, 29 diciembre-2014.

${ }^{358}$ Ximena Amoroso, directora del SRI, Entrevista a Revista Vistazo, 21 de mayo de 2015.
} 
(Ley Orgánica para la Redistribución de la Riqueza) y para crear o modificar el impuesto a la plusvalía para combatir la especulación en el precio de tierra y establecer un tributo para la ganancia extraordinaria en la transferencia de bienes inmuebles y por el beneficio directo en el incremento del precio de la tierra como resultado de la obra pública nacional y local. Los proyectos fueron suspendidos en su trámite por la resistencia y movilización social en contra de ellos. ${ }^{359}$

En 2016, luego del terremoto en la costa ecuatoriana en Manabí y Esmeraldas, se aprobó una nueva reforma tributaria mediante la cual durante un año se incrementó el IVA del 12 al 14\%; aumentó el ICE al consumo de cerveza y gravó con ICE la telefonía corporativa, entre otros. En la Ley de Solidaridad se crearon contribuciones en salarios y utilidades. ${ }^{360}$

El expresidente Rafael Correa, realizando una evaluación de sus diez años de gobierno (2007-2017) y fundamentado en datos anuales del SRI, manifestó que durante ese período las referidas reformas tributarias han transformado al sistema en "progresivo" y que los impuestos directos tienen una mayor participación en la totalidad de los ingresos tributarios. Aclaró que la recaudación en porcentaje del PIB tuvo un promedio en la década de su gobierno del 12,3\% del PIB frente al 8,5\% de la década anterior en la que predominó el modelo neoliberal y que los impuestos directos se incrementaron entre 2007-2017 en un promedio de 43,3\% frente a los indirectos que llegaron a un promedio del $56,6 \%$ en el total de la recaudación. ${ }^{361}$

El presidente Lenin Moreno, aplicando el mismo modelo económico neodesarrollista, en los inicios de su Gobierno envió a la Asamblea Nacional (2017) un proyecto de reforma tributaria denominado Ley para la Reactivación Económica Fortalecimiento de la Dolarización y Modernización de la Gestión Económica, aprobada por la Asamblea Nacional en el mes de diciembre. En lo fundamental persigue fomentar las actividades productivas de la pequeña y mediana empresa con ciertos incentivos y exoneraciones, siempre que genere empleo neto y en su proceso de producción incorpore valor agregado nacional. En dicho proyecto se aumentó en tres puntos, del 22 al 25\%, el impuesto a la renta de las empresas más grandes del país; no se aceptó, conforme era su demanda, la eliminación del anticipo de dicho impuesto y el establecido para la salida de divisas; se redujo 10 puntos del impuesto a la renta en la reinversión de utilidades en el sector productivo, turístico y exportadores habituales; se dispuso la reducción de costos en los servicios financieros y el Banco Central dejó de administrar de forma

\footnotetext{
${ }^{359}$ Ecuador, Ley Orgánica para evitar la especulación sobre el valor de las tierras y fijación de tributos, 7 mo. Suplemento, 30 de diciembre de 2016.

360 Ecuador, Ley Orgánica de Solidaridad y corresponsabilidad ciudadana para la reconstrucción y reactivación de las zonas afectadas por el terremoto de 16-abril-2016; Ley Orgánica para evitar la elusión del impuesto a la renta sobre ingresos provenientes de herencias, legados y donaciones, Registro Oficial 802, 2do. Suplemento, 21-julio-2016.

361 Ecuador, Presidencia de la República, Rafael Correa Delgado, Informe a la Nación, www.planificación.gob.ec
} 
exclusiva el sistema de dinero electrónico, de forma que el sector privado será el único autorizado para manejarlo, mientras que el Banco Central solo efectuará labores de supervisión. ${ }^{362}$

La iniciativa presidencial de conformar un Consejo Productivo y Tributario para negociar la política económica y tributaria, se aceptó inicialmente con entusiasmo por los grupos más poderosos del país; posteriormente, la antes indicada iniciativa legislativa recibió muchas críticas por cuanto la política del régimen no se allanó totalmente a sus demandas, demostrando una vez más su tradicional carácter rentista y de dependencia de los subsidios y beneficios estatales.

\section{LOS PRINCIPIOS DOCTRINARIOS, CONSTITUCIONALES Y LEGALES SOBRE LOS TRIBUTOS (1990-2017)}

Examinemos brevemente los principios que la doctrina, la Constitución y la Ley han desarrollado para orientar la legislación y el derecho Tributario en Ecuador entre 1990 y 2017.

Fernando Pérez Royo dice que los principios se refieren fundamentalmente: al reparto de la carga tributaria, en el que se ubican los de capacidad económica, generalidad, igualdad, progresividad y no confiscación; al de justicia material del gasto público; al de legalidad o producción normativa en materia tributaria; al de distribución territorial del poder tributario y a otros de alcance singular que afectan al sistema de fuentes. ${ }^{363}$

El Código Tributario ecuatoriano, que es una ley preconstitucional, en su artículo 5 dispone que el régimen tributario se rija por los principios de legalidad, generalidad, igualdad, proporcionalidad e irretroactividad.

La Codificación de 1998 la Constitución Política de la República del Ecuador de 1978, establecía en sus artículos 256 y 257 que el régimen tributario se regulará por los principios básicos de igualdad, proporcionalidad, generalidad y legalidad. José Vicente Troya advierte que esta Constitución, influenciada con el modelo y las tesis neoliberales, no incluye el principio de progresividad y el de equidad que se encuentran implícitos en su tendencia a disminuir el impacto que en el sistema tributario nacional tiene la eliminación y relativización del impuesto a la renta y en general los tributos directos que se los considera redistributivos y equitativos. ${ }^{364}$

\footnotetext{
${ }^{362}$ Ecuador, Ley para la Reactivación Económica, Fortalecimiento de la Dolarización y Modernización de la Gestión Financiera, segundo suplemento Registro Oficial 150, 29-diciembre-2017.

${ }^{363}$ Fernando Pérez Royo, Derecho Financiero y Tributario, (Madrid: Editorial Civitas, novena edición 1999).

${ }^{364}$ José Vicente Troya, Finanzas Públicas y Constitución, en Estudios sobre la Constitución Ecuatoriana, Roberto Viciano y otros, editores, (Valencia: Tirant lo Blanch, 2005).
} 
La actual Constitución, aprobada en referéndum el 2008 e influenciada por el modelo o la política neointervencionista o neodesarrollista, manda, en sus artículos 300 y 301, que el régimen tributario se regirá por los principios de generalidad, progresividad, eficiencia, simplicidad administrativa, irretroactividad, equidad, transparencia, suficiencia recaudatoria y de legalidad. Como se puede advertir se incluyen los principios relacionados con la redistribución y la equidad y se agregan los de eficiencia, simplicidad y transparencia para otorgar mayor eficacia a la recaudación.

La Constitución prohíbe también la confiscación en la parte final del artículo 323 y en el segundo inciso del artículo 300 dispone que la política tributaria promoverá la redistribución y estimulará el empleo, la producción de bienes y servicios y conductas ecológicas, sociales y económicas responsables.

Los principios formales y materiales de la tributación se condensan en la relación y obligación de los ciudadanos de contribuir o de "pagar tributos" para sostener los gastos públicos con justicia y eficacia, independientemente del modelo económico o político que se encuentre en ejecución.

A lo largo de la historia del constitucionalismo en el estado liberal, intervencionista, neoliberal y neointervencionista consta como obligación o deber de los ciudadanos el pago de tributos con la finalidad de cubrir los gastos públicos. Sin embargo, en cada momento histórico esa relación tiene características especiales conforme a los fines y propósitos que asume el poder público con respecto a los ciudadanos. Si se amplían las funciones del Estado y si se deben satisfacer los derechos colectivos de la población se requiere de recursos suficientes que deben aportar los ciudadanos según su capacidad económica o que se deben conseguir de los bienes patrimoniales públicos que de manera directa o indirecta gestiona el Estado. Si se disminuyen las funciones públicas del Estado en cuanto a servicios y satisfacción de derechos, ello no significa que aquel no requiera de la contribución de los ciudadanos conforme a su capacidad, para que la autoridad pública pueda ejercer las atribuciones de control y regulación del mercado y para satisfacer aquellas prestaciones de seguridad y servicios que son indispensables para beneficio de la colectividad y en especial atender a los sectores populares sociales. La obligación o deber de contribuir de los ciudadanos para satisfacer los gastos que asuma el Estado en cualquiera de los modelos económicos y políticos que se implementen es, por tanto, no solo una obligación sino una necesidad para garantizar una vida social armónica y para que aquel cumpla con sus objetivos constitucionales establecidos. Dicho deber u obligación no solo corresponde a los individuos sino al propio poder público que mediante leyes le impone el mandato de la Constitución. Se trata de deberes constitucionales autónomos que corresponden a la sujeción o subordinación de los ciudadanos al poder, independientemente de los derechos que a la vez les corresponda o puedan exigir. ${ }^{365}$

\footnotetext{
365 Álvaro Rodríguez Bereijó, La Constitución fiscal de España, (Madrid: Centro de Estudios Políticos y Constitucionales, 2015).
} 
En todo caso, el deber de los ciudadanos de pagar tributos conforme a su capacidad económica y a su sistema tributario está asociado a la obligación constitucional de cubrir los gastos necesarios para que el Estado cumpla con los propósitos aprobados en la carta política.

Se discute si existe o pueden existir límites al deber de contribuir. La Constitución ecuatoriana establece un límite máximo cuando prohíbe la confiscación, pero es evidente que existen límites naturales a tal obligación en la que además inciden las decisiones jurídicas y políticas del sistema político tanto en relación con el aumento y calidad de los tributos como en el destino y cobertura de los gastos.

Coincidimos con Álvaro Rodríguez en que el deber constitucional de contribuir o de "pagar los tributos establecidos por la ley" (Art. 83.15 CRE) tiene una doble dimensión: el interés fiscal del Estado para cobrar los tributos consignados en la ley para destinarlos a satisfacer derechos y el interés del contribuyente a que su aportación sea equitativa y de acuerdo a su capacidad económica. ${ }^{366}$ Este "carácter bifronte" de la obligación antes indicada ocurre en el Estado social, ya sea en su fase neoliberal o en la neointervencionista, si bien cada una de ellas otorga a los gastos públicos y a las obligaciones del Estado connotaciones distintas a como ellos entiendan la equidad y solidaridad.

En Ecuador, Eddy de la Guerra reafirma la percepción de que "el deber de contribuir" o de "pagar tributos" nace de una norma constitucional y se debe ejecutar por medio de un sistema tributario justo, lo que implica que este debe respetar los derechos y garantías de los contribuyentes y en especial su capacidad económica, establecida en la Constitución, la ley y también los pactos o acuerdos comunitarios regionales. ${ }^{367}$

Es evidente que formalmente los dos modelos económicos que constan en las constituciones de 1998 y 2008 tienen propósitos distintos en sus formulaciones de "economía social de libre mercado" y de "economía social y solidaria". Ambos establecen como deber y obligación de los ciudadanos el hecho de "pagar los tributos establecidos por la ley" (Art. 97.10 Const. 1998 y Art. 83.15 Const. 2008) y que el Estado se financie de la recaudación tributaria y de la explotación de los recurso naturales con diferentes reglas de juego.

Respecto de la "capacidad económica" para la tributación, la Constitución de 1998 incluye el principio de "proporcionalidad" y la Constitución de 2008 lo omite: no se refiere a la "capacidad económica" de los contribuyentes sino a los principios tradicionales y a la "suficiencia recaudatoria", lo que podría implicar un aumento en la creación y dimensión de los tributos para satisfacer las crecientes necesidades sociales.

\footnotetext{
${ }^{366}$ Álvaro Rodríguez Bereijó, La Constitución fiscal de España, (Madrid: Centro de Estudios Políticos y Constitucionales, 2015).

${ }^{367}$ Eddy de la Guerra, El deber de contribución al gasto público, (México: Editorial Porrúa, 2017).
} 
De la revisión inicial de las normas antes indicadas y de las consideraciones sobre la relación financiera entre ingresos y gastos, nosotros estimamos que los principios tributarios fundamentales que orientan la política $\mathrm{y}$ el sistema tributario, independientemente de los dos modelos económicos vigentes, neoliberal y neointervencionista (entre el 2000 y el 2017) que se entrecruzan con fines coincidentes para optimizar la recaudación tributaria para fortalecer el sistema y consolidar al Estado como instrumento de control del mercado o promotor de la actividad económica, son: el principio de legalidad y seguridad jurídica; el de justicia tributaria y de capacidad económica y el de eficiencia y transparencia. El primero y el tercero son más de carácter formal, pues se refieren a los elementos esenciales de los tributos y a los procedimientos para su expedición, sanción e impugnación. Por su parte, el segundo tiene contenidos materiales, que obviamente presentan diferente dimensión conforme al modelo económico y las combinaciones que se adopten en la realidad económica y social del país.

\subsection{El principio de legalidad y de seguridad jurídica}

Este principio surge en los orígenes del estado de derecho, antes incluso de que este exista formalmente con la separación de poderes, y tiene fundamental importancia en el sistema tributario de un país en el que se persigue la primacía de la justicia, sin arbitrariedades. Este principio que cubre una garantía individual básica se complementa, en la actualidad, con el de seguridad jurídica que regula la estabilidad del sistema legal como una garantía de protección integral a los contribuyentes y a los ciudadanos en general. También es relevante en la actualidad la estrecha relación en los ámbitos jurídico y económico, entre los ingresos públicos y en especial los tributos con el gasto público, ya que los primeros son el antecedente para garantizar la democracia y el cumplimiento de los fines del Estado y el ejercicio de los derechos de los ciudadanos.

En su obra clásica Principios Comunes del Derecho Constitucional Tributario, Víctor Uckmar dice que "la primera exteriorización del principio que ninguna prestación pecuniaria puede ser impuesta si no es deliberada por los órganos legislativos" se encuentra en la carta magna en Inglaterra, si bien antes, tanto en ese país como en Italia, España, Francia y aún en las ciudades, existen antecedentes que evidencian que la imposición y la sanción de tributos requería del "consenso entre los contribuyentes".

El tratadista recuerda también que la Petition of Rights (1628) contenía la referida exigencia y que la resistencia de Carlos I al respecto provocó una rebelión que ocasionó su prisión y más tarde su decapitación. Cuando se restableció la monarquía en 1689, se partió de la aceptación de monarca del Bill of Rights en el que se "ratificó nuevamente el principio de que no podía crearse ninguna imposición sin el consentimiento previo del Parlamento". 368

\footnotetext{
${ }^{368}$ Víctor Uckmar, Principios Comunes del Derecho Constitucional Tributario, (Bogotá: Editorial Temis S.A., 2002), 10-11.
} 
De igual manera en las revoluciones norteamericana (1783) y francesa (1789) quedó asentado el principio en la Constitución y en la Declaración de Derechos: es atribución del poder legislativo la competencia de imponer tributos. De igual manera ocurrió sucesivamente en las constituciones de todos los países que se inspiraron en las referidas revoluciones, tanto en el siglo XIX como en el siglo XX.

Sin embargo, en la historia de los estados modernos, además del reconocimiento de que el poder legislativo es el que tiene la potestad de aprobar normas tributarias, se manda que la iniciativa y la ejecución de esas leyes correspondan a la función o al poder ejecutivo.

En nuestra legislación, el principio de legalidad ex lege parte de la exigencia inexcusable de que el establecimiento, modificación, exoneración y extinción de tributos, particularmente de los impuestos y de tasas y contribuciones especiales de carácter nacional, solo pueden surgir de una ley o de una norma de carácter obligatorio, que son las formas más perfectas con las que se manifiesta la soberanía del Estado. ${ }^{369}$

La Constitución de 1998 sostiene de manera categórica que "solo por acto legislativo de órgano competente se podrán establecer, modificar o extinguir tributos"; que "no se dictarán leyes con carácter retroactivo en perjuicio de los contribuyentes"; que "las tasas y contribuciones especiales se crearán y regularán de acuerdo con la ley" y que solo las tarifas arancelarias se pueden fijar o modificar por acto administrativo del presidente de la República (Art. 257). Luego, inspirada en el modelo neoliberal o neocompetitivo, flexibiliza dicho principio de legalidad cuando agrega que para incentivar la inversión privada nacional y extranjera "destinada especialmente al consumo interno y a la exportación, la ley podrá conceder tratamientos especiales a la inversión pública y privada en las zonas menos desarrolladas o en actividades de interés nacional" $y$, especialmente, cuando dispone que "el Estado, en contratos celebrados con inversionistas, podrá establecer garantías y seguridades especiales, a fin de que los convenios no sean modificados por leyes u otras disposiciones de cualquier clase que afecten sus cláusulas" (Art. 271).

Esto es, el modelo económico presente en la carta política de 1998 impuso que los contratos privados con inversionistas, nacionales y extranjeros, desestimen la aplicación de una ley de cualquier naturaleza posterior a su celebración. De manera explícita la Ley para la Reforma de las Finanzas Públicas estableció que: "para dar cumplimiento a la disposición del segundo inciso del artículo 271 de la Constitución Política de la República, esta Ley autoriza al presidente de la República para que mediante decreto ejecutivo conceda tratamientos tributarios especiales en las zonas menos desarrolladas,

\footnotetext{
369 José Luis Terán Suárez, Principios Constitucionales y Jurídicos de la Tributación, (Quito: Editora Jurídica Cevallos, 2014).
} 
especialmente en las fronteras y Galápagos" que puedan incluir exoneraciones de impuestos o deducciones especiales". ${ }^{370}$

La Constitución de la República del 2008, inspirada inicialmente en el neointervencionismo, ordenó también que "solo por iniciativa de la función legislativa y mediante ley sancionada por la Asamblea Nacional se podría establecer, modificar, exonerar o extinguir tributos"; que "solo por acto normativo de órgano competente se podrá establecer, modificar, exonerar y extinguir tasas y contribuciones" y que estas se crearán y regularán de acuerdo con la ley (Art. 301) que para este caso es el Código Orgánico de ordenamiento territorial, Autonomías y Descentralización (COOTAD), como ya disponía antes el Código Tributario. En otras normas, la Constitución dispone además que "la creación de aranceles y la fijación de sus niveles son competencia exclusiva de la función ejecutiva" (Art. 305) y si bien en principio elimina la disposición expresa que los contratos de inversión puedan contradecir un nuevo ordenamiento jurídico estatal, establece ambiguamente que "la inversión extranjera directa será complementaria a la nacional, estará sujeta a un estricto respeto del marco jurídico y de las regulaciones nacionales..." (Art.339) y que se debe respetar el derecho a la "seguridad jurídica".

Posteriormente (2014), con normas legales secundarias adopta la misma regla constitucional neoliberal antes indicada en el Código Orgánico de la Producción,

Comercio e Inversiones (COPCI), cuando reformó la Ley Orgánica de Incentivos a la Producción y Prevención del Fraude Fiscal (LOIPPFF) y expidió su reglamento, al agregar una norma referente al "incentivo de estabilidad tributaria en contratos de inversión" en la que dispone que el Estado no alterará el tratamiento tributario en cuanto al impuesto a la renta, impuesto a la salida de divisas y otros impuestos directos nacionales como el IVA, durante el plazo del contrato de inversión, siempre que el monto supere los cien millones de dólares.

El Código Tributario, reafirmando el principio de legalidad, hasta en los detalles, incluye una norma titulada reserva de ley, en la que se ordena que las leyes tributarias determinarán el objeto imponible, los sujetos activo y pasivo, la cuantía del tributo o la forma de establecerla, las exenciones y deducciones; los reclamos, recursos y demás materias reservadas a la ley (Art. 4). Esto es, nuestra legislación entre la doctrina de la reserva absoluta o relativa, opta por la primera, para que las leyes tributarias no den margen a la discrecionalidad de la administración en la definición de los aspectos fundamentales del tributo. ${ }^{371}$ La tipificación de infracciones tributarias (delitos, contravenciones e infracciones) debe también constar en la ley por mandato constitucional, así aquella establezca una banda para fijar la cuantía del tributo y sea la

\footnotetext{
${ }^{370}$ Ecuador, Ley para la Reforma de las Finanzas Públicas, Disposición General Tercera, Registro Oficial Suplemento No 181,-30-abril-1999.

${ }^{371}$ César Montaño Galarza, La obligación de contribuir y los primeros de la tributación en las constituciones de los estados miembros de la Comunidad Andina, en Tópicos fiscales contemporáneos, (México: Universidad de Guadalajara, 2004).
} 
administración tributaria (SRI o GAD) la que lo fije dentro de los parámetros establecidos.

Debe enfatizarse que nuestro sistema jurídico en materia tributaria y con la finalidad de simplificar y restringir el sistema, dispone que la iniciativa legislativa exclusiva, tanto en la Constitución de 1998 como en la de 2008, la tenga el presidente de la República y que la aprobación de la Ley corresponda a la Asamblea Nacional, como así lo establecen expresamente los artículos 147 y 130 numeral 6 de la primera y los artículos 301, 132 numeral 3 y 135 de la Constitución de la República vigente, cuando se refieren al régimen tributario y a los procedimientos legislativos. La Constitución prohíbe que la consulta popular se pueda utilizar en materias tributarias (Art. 104) y permite que, en los casos de proyectos de ley calificados como de urgencia económica, como ocurre en los tributarios, si la Asamblea no se pronuncia en 30 días, el presidente de la República los pueda expedir como decreto-ley.

El principio de legalidad entraña también la no retroactividad de la ley. La norma común que consta en el Código Civil y en la doctrina, es que la ley rige para lo venidero. Sin embargo, ese principio, que es indiscutible en el derecho privado, no lo es en el campo del derecho público, en el cual el orden público puede imponer en numerosos casos y circunstancias la retroactividad de la ley. En materia tributaria se parte de la no retroactividad de la Ley para preservar los derechos del contribuyente y para evitar la arbitrariedad y cualquier forma de dedicatoria de la norma.

La no retroactividad de las normas tributarias generalmente se enuncia como principio aparte. La Constitución actual de la República lo incluye expresamente en la enunciación de principios (Art. 300), de igual manera los artículos 30 y el 3 el Código Tributario, también lo mandan, cuando disponen que "no se dictarán leyes tributarias con efecto retroactivo en perjuicio de los contribuyentes".

Nuestro Código Tributario, además de asegurar que las leyes tributarias, sus reglamentos y las circulares de carácter general, regirán en todo el territorio nacional, en sus aguas y espacio aéreo jurisdiccional o en una parte de ellos, manda que entrarán en vigencia desde el día siguiente al de su publicación en el Registro Oficial, salvo que se establezcan fechas especiales de vigencia posteriores a esa publicación. Aclara que las normas que se refieren a tributos cuya determinación o liquidación se realice por períodos anuales o mensuales se aplicarán desde el primer día del siguiente año calendario o del mes siguiente (Art. 11).

En cambio, el mismo Código Tributario establece la excepción al principio de la no retroactividad de la ley tributaria: dispone la retroactividad para las normas penales tributarias cuando son más favorables para el contribuyente, así exista sentencia condenatoria no ejecutada ni cumplida en su totalidad, en el caso de suprimir infracciones, establecer sanciones más benignas o términos de prescripción más breves (Art. 311). Esta excepción tiene fundamento en las normas del debido proceso que 
constan tanto en la Constitución de 1998 como en la actual de 2008 (Art. 76 numeral 5). A saber, es la Ley la que debe establecer de manera expresa el ámbito de la retroactividad, pues, como observa la jurisprudencia española: "la interdicción absoluta de cualquier tipo de retroactividad conduciría a situaciones de congelación o petrificación del ordenamiento jurídico" y "la irretroactividad absoluta de las leyes fiscales podría hacer totalmente inviable una verdadero reforma fiscal".

Según Álvaro Rodríguez Bereijó la capacidad económica es la razón de ser (la ratio) o fundamento que justifica el pedir o aptitud de contribuir y la medida razón o proporción justa por la que cada sujeto aporta para el sostenimiento de los gastos públicos. En otras palabras, se tributa porque se tiene capacidad económica y se hace según la capacidad que se tiene. ${ }^{372}$

También el principio de legalidad nos lleva a las disposiciones sobre la interpretación de la ley o las normas tributarias. El Código Tributario, cuyo origen se remonta al período de intervencionismo estatal que privilegia las prerrogativas de la administración y los intereses públicos a los del administrado y contribuyente, dispone al respecto que las normas tributarias se interpretarán teniendo en cuenta sus fines y su significación económica; que cuando una misma ley tributaria contenga disposiciones contradictorias primará la que más se conforme con los principios básicos de la tributación y que la analogía, admisible como procedimiento para colmar vacíos de la ley, no será aceptable para crear tributos, exenciones y otras materias jurídicas reservadas a la ley (artículos 13 y 14 del Código Tributario).

Otro asunto importante en el principio de legalidad en materia tributaria es el relativo a la supremacía de las normas tributarias sobre otras normas provenientes de leyes generales, y la disposición del mismo Código Tributario de que no se aplicarán por la administración ni por los órganos jurisdiccionales las leyes y decretos que de cualquier manera contravengan dicha supremacía (Art. 2). Antes de la última codificación los artículos 2 y el entonces 447, disponían que las normas tributarias prevalecían sobre toda norma de leyes generales o especiales y que "solo podrán ser modificadas o derogadas por disposición expresa de otra ley destinada específicamente a tales fines".

Finalmente, en la actualidad no se puede desvincular, como ya hemos señalado, el principio de legalidad con el de la seguridad jurídica, incluido durante la vigencia de los dos modelos económicos recientes, como garantía ciudadana en las constituciones de los diversos países del mundo y en nuestro ordenamiento legal en la Constitución de 1998 y la actual de 2008.

La seguridad jurídica implica certeza en la aplicación de las normas vigentes y un freno a la arbitrariedad, lo que particularmente es importante para la legislación tributaria. Al convertirse en una garantía y un derecho constitucional para los ciudadanos es de

\footnotetext{
372 Álvaro Rodríguez Bereijó, La Constitución Fiscal de España, (Madrid: Centro de Estudios Políticos y Constitucionales, 2015).
} 
invocación y aplicación inmediata por parte de toda autoridad y merece todas las protecciones que la carta fundamental del país prevé para el efecto.

La Constitución de 1998 incluyó entre los derechos civiles básicos de los ciudadanos el de la seguridad jurídica (Art. 23.26) y la actual Constitución de la República (2008) lo ratificó en el artículo 82 en los siguientes términos: "el derecho a la seguridad jurídica se fundamenta en el respeto a la Constitución y en la existencia de normas jurídicas previas, claras, públicas y aplicadas por las autoridades competentes". La norma antes indicada es completada por la segunda parte del artículo 84 de la carta política, que manda: "en ningún caso, la reforma de la Constitución, las leyes, otras normas jurídicas ni los actos del poder público atentarán contra los derechos que reconoce la Constitución".

La Constitución de 2008 es garantista de derechos que pueden ser invocados directamente independientemente de que consten o no en una norma secundaria y si la seguridad jurídica es un derecho, en los términos antes indicados, queda reforzado el principio de legalidad en todos los ámbitos y especialmente en materia tributaria, lo que indudablemente también beneficia a los inversionistas extranjeros y nacionales.

Como señala José Vicente Troya con la estabilidad tributaria, el Estado se compromete con las empresas a no ejercer su potestad impositiva mientras existan contratos vigentes de inversión, lo que ha beneficiado especialmente a grandes empresas mineras y de otros sectores económicos productivos. ${ }^{373}$ Como se puede constatar, tanto el modelo neoliberal como el neointervencionista en Ecuador coinciden en definir la misma política tributaria de protección y auspicio a la gran inversión extranjera.

En cuanto a la relación y nexos jurídicos entre los tributos y el gasto público, el mismo profesor Troya manifiesta con acierto que no es suficiente afirmar la relación formal entre estos, sino que es necesario enfatizar que se cobren las contribuciones en la justa medida establecida por la Ley y que el gasto se erogue con honestidad, equidad, transparencia y en forma fructuosa, lo que abona en la convicción de Griziotti y De la Garza sobre dicha relación, pues, sin duda, "el gasto público y los ingresos públicos son elementos y momentos indisolubles" y en la convicción jurídica según la cual un tributo no destinado a cubrir gasto público sería inconstitucional. Eusebio González afirma también correctamente que el tributo es ante todo y sobre todo un instrumento jurídico ideado para cubrir exclusivamente gastos públicos y que una prestación que no tenga esa finalidad deja de ser tributo. ${ }^{374}$

\footnotetext{
${ }^{373}$ José Vicente Troya Jaramillo, Lecciones de Derecho Tributario con las últimas reformas, (Quito: Ediciones Fausto Reinoso, 2015).

${ }^{374}$ José Vicente Troya Jaramillo, El Derecho del Gasto Público. Con precisiones sobre la Constitución de 2008, en Estado, Derecho y Justicia, compilador Ramiro Ávila Santamaría, (Quito: UASB- Corporación Editora Nacional, serie Estudios Jurídicos 33, 2013).
} 


\subsection{El principio de justicia tributaria y capacidad económica contributiva}

A nuestro criterio, este principio sintetiza otros que han sido enunciados en la doctrina y en el derecho constitucional y tributario del Ecuador y de otros países del mundo, sobre el reparto de la carga tributaria. Está relacionado con los de capacidad económica, de igualdad, generalidad, progresividad y de no confiscación. Estos principios tienen su aplicación y connotación especial en los modelos económicos contemporáneos, sea que estos se diferencien en su alcance o se apliquen de manera combinada, como ya lo señalamos anteriormente. ${ }^{375}$

La equidad en materia tributaria implica que las contribuciones de los ciudadanos deben ser justas y corresponden, por lo tanto, a su capacidad económica y la contribución de acuerdo con la riqueza que se convierte en la regla básica para el reparto de la carga tributaria, si bien este no es único criterio de justicia tributaria, ya que ciertos tributos se fundamentan también en las políticas sociales o económicas (fines extrafiscales), en la capacidad de pago del beneficio recibido o por recibir, etc. La capacidad económica se encuentra relacionada con la "progresividad" en los tributos, pues de ella depende el mayor o menor aporte que los ciudadanos deben pagar al Estado para que este cumpla sus metas y se discute como opera y con qué alcance, cuando se trata de imposición directa o indirecta.

Fernando Pérez Royo dice que la capacidad económica para la contribución es "un objetivo al que sirven de manera instrumental los restantes principios o criterios de justicia del sistema tributario", que son los de igualdad, generalidad, progresividad y no confiscación. ${ }^{376}$

José Vicente Troya señala que el principio se refiere no solo a los tributos sino al sistema tributario mismo. Dice que capacidad contributiva significa que solo las manifestaciones directas o indirectas de riqueza son objeto de la tributación y configuran hechos generadores de tributos, por lo que no caben "razones de género, raza, nacionalidad, religión, condición familiar u otras, sirvan de fundamento para crear y aplicar tributos". La capacidad contributiva está, por lo tanto, relacionada con la equidad en la tributación, pues las tarifas progresivas gravan a quienes tienen mayores ingresos, como ocurre con los impuestos directos a la renta y al patrimonio. En el caso de los impuestos indirectos al consumo o al gasto, se establecen tarifas proporcionales que aplican un mismo porcentaje cualquiera que sea la base imponible a todos los contribuyentes sin diferenciar su capacidad económica. ${ }^{377}$ Por eso se consideran equitativamente regresivos.

\footnotetext{
${ }^{375}$ Modesto Fabra Valls, "Solidaridad y Derecho Financiero en una sociedad neocompetitiva", en Revista Española de Derecho Financiero, Nro. 120, 2013.

${ }^{376}$ Fernando Pérez Royo, Derecho Financiero y Tributario, (Madrid: Editorial Civitas, novena edición 1999), 35.

377 José Vicente Troya Jaramillo, Lecciones de Derecho Tributario con las últimas reformas, (Quito: Ediciones Fausto Reinoso, 2015).
} 
El principio de capacidad económica cumple tres funciones: fundamenta la tributación; establece un límite al legislador en el ejercicio de su poder tributario y lo orienta en cuanto al uso de dicho poder. La Constitución actual no se refiere expresamente al principio de capacidad económica, pero lo sobrentiende al disponer que el régimen tributario del país se fundamente, entre otros principios, en los de generalidad, progresividad y equidad. Nuestro Código Tributario, si bien es preconstitucional, dice al respecto: "el ordenamiento tributario se basará en la capacidad económica de los contribuyentes y se regirá por los principios de igualdad y generalidad" (Art. 5).

El principio parte de considerar a los ciudadanos como iguales ante la ley y por lo tanto, esa igualdad sustancial general, que también es un principio constitucional, obliga a los poderes públicos a actuar sin preferencias ni discriminaciones. Las desigualdades económicas reales que existen en la sociedad, obligan al Estado a considerar la capacidad económica de los contribuyentes y a establecer la progresividad en los tributos, sin que esto signifique que consideren a los ciudadanos como desiguales en las categorías económicas en las que se encuentren ubicados.

En materia fiscal no pueden existir discriminaciones y privilegios, lo que implica aplicar además del principio de igualdad, el de generalidad. Entre ciudadanos no se pueden establecer diferencias de nacionalidad, religión, raza, sexo, preferencia sexual y de ningún otro tipo. La generalidad significa también que el pago de tributos es una obligación de todos los ciudadanos y que las exoneraciones no son privilegios sino que tienen fundamento en el interés público que obliga al Estado en beneficio final de la colectividad. Troya dice que este postulado se cumple "irremediablemente" en los impuestos sobre el consumo que se incorporan a los precios de los bienes y servicios. ${ }^{378}$

En materia tributaria, la igualdad y generalidad distinguen la capacidad económica de los contribuyentes, pero en los diferentes estratos económicos se aplicarán nuevamente dichos principios de igualdad y generalidad. Por ello es posible, además, que puedan existir exenciones y beneficios fiscales a una categoría de personas por sus bajos ingresos, pero estos no son intuitu personae, sino que cubren a todos los que se encuentren en la condición económica establecida por la ley.

El sistema y el régimen tributario, fundamentados en la equidad y la capacidad económica, exigen también la progresividad, pues en la medida que aumenta la riqueza y los ingresos de los contribuyentes, aumenta proporcionalmente la contribución para que los que más tienen aporten más en relación con los que menos tienen. Por tanto, la tributación moderna y proporcional cumple también un objetivo extrafiscal: la justicia redistributiva de la que no se pueden abstraer los modelos económicos, ya que de una u otra manera dicen observarla.

${ }^{378}$ Ibídem. 
El principio de progresividad que se incluye en la Constitución de 2008 se debe considerar como complemento político a la proporcionalidad, ya que una mayor capacidad económica aumenta la contribución para propender la redistribución de la riqueza y de la renta. Esto es algo que no tiene aplicación significativa en Ecuador pues, se mantiene la tendencia de establecer límites máximos a la renta personal y a la de sociedades que incluso son más bajas para "incentivar" la inversión. ${ }^{379}$

También los principios de justicia y de capacidad económica fijan un límite constitucional al Estado y a la autoridad tributaria para que no llegue al extremo de la confiscación de los bienes y de los recursos de los contribuyentes. Esto significa que la legislación jamás puede llegar al extremo de imponer tributos confiscatorios. El tributo es una contribución justa, razonable y proporcional a la riqueza y a los ingresos de los contribuyentes, fijada por el Estado mediante normas, pero que jamás puede llegar a los extremos o a tener visos de confiscación, la cual está expresamente prohibida por la Constitución.

Un sistema tributario justo no se agota, pues la aplicación de la capacidad económica de los contribuyentes en la tributación es un deber de solidaridad social, según el cual se aplican un conjunto de principios y técnicas administrativas, sociales y financieras que se reparten entre todos los ciudadanos que forman parte del Estado y están sometidos a su soberanía.

\subsection{El principio de eficiencia y transparencia}

El tercer principio en el que nosotros sintetizamos lo que al respecto ha desarrollado la doctrina y contiene la actual Constitución de 2008 a diferencia de la Constitución de 1998, respecto de los sistemas y los regímenes tributarios, es el de eficiencia y transparencia, que estimamos incluyen dos elementos, también identificados como principios y que son complementarios en la actualidad: los de simplicidad administrativa, economía y suficiencia recaudatoria, a los que se refiere el artículo 300 de la Constitución vigente, que consideramos que son complementarios a la eficiencia para alcanzar resultados eficaces.

Mauricio Plazas Vega, comentando los principios constitucionales del sistema tributario colombiano, manifiesta que su eficiencia debe interpretarse en relación con la administración y con el contribuyente "para procurar un sistema tributario simple, claro y controlado por funcionarios capaces honestos y bien remunerados" en el caso de la primera y en el caso del contribuyente "para comprometerlo con tributos moderados y adecuados que ni desincentiven su gestión económica ni den lugar a la evasión fiscal”. También manifiesta que "la eficiencia en la recaudación y selección de los tributos no

\footnotetext{
379 José Luis Terán Suárez, Principios Constitucionales y Jurídicos de la Tributación, (Quito: Editorial Jurídica Cevallos, 2014).
} 
puede ser desvirtuada por una estructura ineficiente del gasto" que dilapide recursos por el "desorden financiero y una burocracia excesiva". 380

La eficiencia y eficacia asociadas a la transparencia, son términos de mucho uso en la actualidad para exigir de los procedimientos administrativos corrección, publicidad y resultados óptimos con recursos humanos, materiales y tecnológicos de calidad y en el menor tiempo posible. Los ciudadanos tienen derecho a conocer de manera precisa lo que deben pagar como tributos al Estado y este debe aplicarlos sin incurrir en gastos significativos y sin causar molestia a los contribuyentes.

La eficiencia que se refiere más a los procedimientos para alcanzar resultados eficaces incluye, a nuestro juicio, la simplicidad, la economía y la suficiencia recaudatoria. En cuanto a la transparencia, esta es una línea transversal que debe estar presente en todas las fases de un procedimiento administrativo y no se diga en el régimen y en el sistema tributario de un país, uno de cuyos vicios más notorios ha sido el de la corrupción y el quebrantamiento de sus principios para favorecer intereses económicos y políticos.

Tanto en la etapa neoliberal como en la actual neoestructuralista tienen acogida el principio de la eficiencia en cuanto a la moderación y selección de los tributos, observa el tratadista colombiano antes indicado. En la primera, la preferencia tributaria estaba dirigida a los impuestos indirectos, aumentando el universo de contribuyentes y limitando los tributos personales y a la renta para beneficiar a los monopolios, empresas transnacionales y a los grupos y personajes de poder económico en el país y en la segunda, se combinan los impuestos directos con los indirectos.

El Partido Social Cristiano en Ecuador liderado por el diputado Jaime Nebot condicionó facilitar el salvataje bancario, en el que estaba empeñado el gobierno presidido por Jamil Mahuad con el apoyo de León Febres Cordero, si en la Ley que creó la AGD se incluía la sustitución del impuesto a la renta por un impuesto a la circulación de capitales que precipitó la crisis y favoreció la dolarización y el abuso de los fondos públicos del Estado para cubrir el saqueo de recursos por parte de banqueros corruptos y grupos de poder allegados a ellos.

En todo caso, en los dos sistemas o modelos económicos el régimen tributario está integrado por impuestos directos e indirectos y por tributos nacionales y locales, independientemente de las preferencias ideológicas y de intereses y de los grados o radicalidad de los procesos de descentralización y de autonomía administrativas.

Se observa, sin embargo, que la eficiencia y la eficacia tributarias, son metas difíciles de alcanzar, pues los tributos más justos son complejos de administrar en la recaudación y determinación y se prestan a varias circunstancias que favorecen la evasión y la elusión.

${ }^{380}$ Mauricio Plazas Vega, Derecho de la Hacienda Pública y Derecho Tributario, (Bogotá: Editorial Temis, 2000), 606. 
Se requieren métodos modernos para aumentar la eficacia y eficiencia en la administración tributaria en el ejercicio de todas las potestades que tienen conforme a la ley sin que los recursos empleados sean mayores a su recaudación.

Es evidente que los avances de la tecnología y de la información, han impuesto el uso intensivo de los medios virtuales de comunicación no solo para las actividades y negocios de las personas, sino para que los contribuyentes se relacionen con la administración tributaria y para que prueben el cumplimiento o no de sus obligaciones. El sistema de declaraciones y pagos tributarios físicos, en formularios y en las entidades bancarias, han sido casi sustituidos exitosamente por transmisiones y pagos electrónicos que realizan los contribuyentes a las autoridades tributarias.

La eficiencia, eficacia, la descentralización, desconcentración y la coordinación se encuentran relacionadas con la simplicidad administrativa en la administración tributaria y en los trámites de los contribuyentes para respetar sus derechos y optimizar el ejercicio de las potestades públicas. De igual manera, el principio de suficiencia recaudatoria que se incluyó por primera vez en la Constitución ecuatoriana vigente (2008), se relaciona también con la eficiencia y eficacia tributarias, ya que estas deben cubrir los requerimientos del gasto público y de ninguna manera pueden ser instrumentos de exacción de la economía del contribuyente ni tener visos confiscatorios, lo que implica en realidad un límite a la potestad tributaria del Estado en beneficio del ciudadano.

En cuanto a la transparencia como principio, según la Constitución es una exigencia contemporánea tanto para la gestión administrativa tributaria como para los contribuyentes, para que estos puedan acceder de manera libre y exacta a la información del Estado tanto en su gestión tributaria como en el respeto de los derechos ciudadanos, ya que si bien la actuación pública debe ser transparente, la información personal de los contribuyentes es confidencial en la medida en que no afecten intereses de la colectividad. El Centro de Estudios Fiscales del SRI en Ecuador manifiesta que la información de la gestión pública de la administración tributaria debe ser transparente, salvo la de carácter confidencial. ${ }^{381}$

\section{LA POTESTAD Y LA ADMINISTRACION TRIBUTARIA EN EL ECUADOR}

El poder tributario es uno de los poderes fundamentales e inmanentes del Estado. La doctrina tradicional concibe al poder tributario o a la soberanía tributaria como el ejercicio de la supremacía del Estado. El poder originario o soberanía, en el estado moderno, corresponde al pueblo y este lo ejerce por medio de una entidad política jurídica que lo representa, a diferencia del ejercicio del poder originario y soberanía en

381 SRI - CEF, Introducción a la Teoría General de la Tributación, https://cef.sri.gob.ec/virtualcef/mod/book/tool/print/index.phpid=1127 Introducción a la Teoría General de... 
la época monárquica, en la que el rey lo hace en representación del poder divino o de un imaginario "contrato social".

Héctor Villegas define potestad tributaria como una "facultad que tiene el Estado para crear tributos unilateralmente, cuyo pago será exigido a las personas sometidas a su competencia espacial para cubrir las erogaciones que implica el cumplimiento de su finalidad de atender las necesidades públicas". ${ }^{382}$

El poder tributario, en todo caso, es una expresión del poder del Estado y de su supremacía, que se ejerce como una potestad mediante ley y por medio de la Asamblea Nacional, al crear, modificar o suprimir tributos; por medio de las potestades normativas que tienen también los gobiernos autónomos descentralizados o por medio de la competencia constitucional otorgada al presidente de la República para crear aranceles y fijar sus niveles.

La potestad tributaria o de creación de un sistema jurídico tributario se diferencia de la potestad concreta de la ejecución o de la actuación de las normas mediante la Administración Pública Nacional, cuyo titular es el presidente de la República; de los gobiernos locales o de quienes la Constitución y las leyes les atribuyen dicha potestad administrativa con las limitaciones en ellas establecidas. Al estudiar el poder y la potestad tributarios en esta dimensión, no se analiza el fundamento de las imposiciones tributarias, sino la distribución de la capacidad de su ejecución por parte de los entes públicos en la base territorial, conforme a la Constitución y a la Ley. En la aplicación de los tributos se deben considerar pues la conformación de las administraciones tributarias $\mathrm{y}$ sus facultades; los actos y procedimientos administrativos tributarios; las reclamaciones, recursos y consultas en esta materia.

En la aplicación de los modelos económicos neoliberal y neointervencionista o su combinación entre 1990 y 2017, se da un proceso de transformación de la administración y de la justicia tributaria. Se transita de una institucionalidad tributaria dependiente políticamente del Ministerio de Finanzas, como ocurría con la Dirección General de Rentas, a la estructuración del Servicio de Rentas Internas (SRI) como una institucionalidad autónoma y técnica, dependiente del presidente de la República, pero con amplia independencia jurídica y de gestión para cumplir con sus tareas de determinación, de ejecución de los tributos y decisión administrativa sobre los reclamos y recursos que los contribuyentes pueden formular ante dicha autoridad tributaria. Lo propio ocurre con el Servicio de Aduanas del Ecuador, que administra uno de los tributos claves destinados a proveer de recursos al Estado para el gasto público.

En cuanto a la administración tributaria de los gobiernos autónomos descentralizados, esta se rige en la actualidad por normas más claras establecidas en el COOTAD y los procesos contenciosos administrativos en materia tributaria. Tienen dos momentos

\footnotetext{
382 Héctor Villegas, Curso de Finanzas, Derecho Financiero y Tributario, (Buenos Aires: Editorial Depalma, 1980), 14.
} 
importantes en este período (1900-2017) que son: la conformación de los tribunales distritales de lo Tributario y la introducción del recurso de casación en 1992, que se tramita en una sala especializada de la Corte Suprema o Corte Nacional de Justicia, y, actualmente, la transformación procesal, con la expedición del COGEP en 2015, con normas específicas que regulan los litigios contencioso tributarios mediante el sistema oral.

En los modelos económicos antes indicados, con distinta finalidad, el neoliberal para impulsar al mercado, la competencia y el pago de la deuda externa y el neointervencionista, para incrementar el gasto público y una nueva relación negociada con el mercado y los inversionistas internacionales, coinciden en modernizar y hacer eficiente y eficaz la administración tributaria, siguiendo al respecto las sugerencias y documentos de los organismos multilaterales, por lo que en este campo no existen diferencias radicales, sino más bien modificaciones complementarias que perfeccionan el sistema administrativo de regulación y recaudación tributarias.

Nos referiremos en este estudio en particular a las transformaciones en la organización de la administración tributaria, si bien conserva la estructura general inicial establecida en el Código Tributario ecuatoriano (1976), inspirado en el modelo de Código Tributario Latinoamericano promovido inicialmente por la Alianza para el Progreso y la CEPAL. El Título III del Libro Primero del referido Código, clasifica la Administración Tributaria en Central, Seccional y de Excepción.

\section{La Administración Tributaria Central}

Conforme lo establece el Código, la Administración y la dirección de la administración tributaria central corresponde en el ámbito nacional al presidente de la República, quien la ejerce por medio de los organismos establecidos en la ley.

Tanto la Constitución de 1978 que perfeccionó la regulación del modelo intervencionista como la Constitución de 1998 que adecuó el régimen constitucional al sistema neocompetitivo, desde inicios de la década de los noventa del siglo pasado se le asignó a la función ejecutiva la responsabilidad de dirigir e implementar la política tributaria. En un inició la iniciativa tributaria podía provenir del Ejecutivo o de los legisladores para satisfacer requerimiento de gasto nacional y local. Desde la Constitución de 1998, la iniciativa legislativa en materia impositiva es una prerrogativa exclusiva del presidente de la República y, obviamente, la administración tributaria se encuentra bajo su responsabilidad. El Congreso Nacional, que desde 1978 tenía la competencia de "establecer, modificar o suprimir impuestos, tasas u otros ingresos públicos", desde la Constitución de 1998 solo lo podrá hacer "mediante ley", excepto las "tasas y contribuciones" que corresponda crear a los organismos del régimen seccional autónomo. Pero a diferencia del período anterior, los organismos internacionales sugirieron la unificación y simplificación tributarias, limitando la iniciativa legislativa en materia impositiva al Ejecutivo y la creación, bajo el control 
personal del presidente de la República, de un organismos técnico, independiente en lo administrativo y financiero, el SRI, para la administración y gestión tributarias.

La carta política del Estado del 2008 (Art. 301) exige que el poder o potestad tributarios a nivel nacional, se ejerza mediante ley planteada por iniciativa de la función ejecutiva y sancionada por la Asamblea Nacional. Dispone también que solo por medio de ley se pueda establecer, modificar, exonerar o extinguir impuestos; que solo por acto normativo de órgano competente se pueden establecer, modificar, exonerar y extinguir tasas y contribuciones y que las tasas y contribuciones especiales se crearán y regularán de acuerdo con la ley.

Debemos puntualizar que la administración tributaria es parte integrante y especializada de la Administración Pública y que por lo tanto, por mandato constitucional (Arts. 226 y 227) debe someterse a los principios de legalidad, coordinación, goce y ejercicio de derechos, "eficacia, eficiencia, calidad, jerarquía, desconcentración, descentralización, participación, planificación, transparencia y evaluación" que amplían los dos principios enunciados inicialmente (Art. 119) establecidos ya por la Constitución de 1998.

De manera general, la administración tributaria cumple dos funciones: la de aplicar los tributos mediante las facultades y la de resolver reclamaciones y recursos planteados por los contribuyentes, conforme lo dispone el Código Tributario. Complementariamente, también se le confiere a la administración la potestad de absolver consultas para completar la primeramente enunciada. ${ }^{383}$

Según nuestra legislación tributaria común y especial, los organismos nacionales de administración Tributaria son: el Servicio de Rentas Internas; el Servicio Nacional de Aduana del Ecuador y la Dirección Nacional de Avalúos y Catastros.

La Ley Orgánica de Administración Financiera que estuvo vigente desde 1976 hasta el 2010 establecía que la administración financiera del Gobierno comprendía el conjunto de actividades del Ministerio de Economía y Finanzas y de los demás organismos de recaudación y pago; que la dirección general de aquella correspondía al presidente de la República, quien la ejercía por medio del ministro de Economía y Finanzas y los órganos previstos en la ley y que aquella incluía las operaciones de presupuesto, la determinación, recaudación, depósito, administración, inversión, transferencia y registro de los recursos financieros. Conforme a la indicada ley, en la materia tributaria le correspondía al ministro de Economía y Finanzas dirigir las políticas, establecer normas y mecanismos idóneos para el proceso de determinación y recaudación de los recursos financieros. (Artículos 19, 20 y 24 de la LOAFYC).

El Código Orgánico de Planificación y Finanzas Públicas, publicado en el segundo suplemento del Registro Oficial No.306 el 22 de octubre de 2010, establece el Sistema

\footnotetext{
383 José Vicente Troya Jaramillo, Lecciones de Derecho Tributario con las últimas reformas, (Quito: Ediciones Fausto Reinoso, 2015).
} 
Nacional de Finanzas Públicas (SINFIP) que comprende el conjunto de normas, políticas, instrumentos, procesos, actividades, registros y operaciones que las entidades y organismos del sector público deben realizar con el objeto de gestionar en forma programada los ingresos, gastos y financiamiento públicos con sujeción al Plan Nacional de Desarrollo y a las políticas públicas legalmente definidas (Art.70). Según el Código la rectoría del SINFIP le corresponde ejercerla al presidente de la República a través del ministro a cargo de las finanzas públicas.

Entre los componentes del sistema se encuentran los ingresos públicos que la ley califica en permanentes y no permanentes. Se trata de crear y asegurar los mecanismos idóneos para racionalizar y optimizar la determinación y la recaudación tributarias. Para el efecto, la norma antes indicada crea la administración tributaria nacional, la misma que también tiene un gasto tributario, que son los recursos que se dejan de percibir por deducciones, exenciones y otros mecanismos y que se deben estimar en la proforma del Presupuesto del Estado.

\section{Servicio de Rentas Internas}

En el contexto económico neoliberal del Gobierno de Fabián Alarcón se creó el Servicio de Rentas Internas el 2 de diciembre de 1997, ${ }^{384}$ como entidad técnica y autónoma, con personería jurídica, de derecho público, patrimonio y fondos propios, con jurisdicción nacional y sede en Quito para administrar los impuestos internos del Estado, en sustitución de la Dirección General de Rentas que era una dependencia política y administrativa del Ministerio de Finanzas y que correspondía a la estructura tradicional contemplada en las Leyes de Hacienda anteriores a la vigencia de la LOAFYC.

Las facultades y atribuciones del SRI están establecidas en su artículo 2. Entre las principales constan: la ejecución de la política tributaria aprobada por el presidente; efectuar la determinación, recaudación y control de los tributos internos del Estado y de aquellos cuya administración no esté expresamente asignada por Ley a otra autoridad; preparar estudios respecto de reformas a la legislación tributaria; conocer y resolver peticiones, reclamos, recursos, absolver consultas e imponer sanciones; emitir y anular títulos y notas de crédito y ordenes de cobro; solicitar información y documentación y verificarla para la determinación de obligaciones tributarias, etc.

El directorio del SRI estaba presidido por el ministro de Finanzas y lo conformaban la Superintendencia de Bancos y Compañías, el ministro de Industrias, el subsecretario de Presupuestos y Contabilidad y un representante de las Federaciones Nacionales de las Cámaras de la Producción.

\footnotetext{
384 Ecuador, Ley 41 de creación del Servicio de Rentas Internas - SRI-, Registro Oficial 206, 2diciembre-1997.
} 
Las atribuciones y competencias asignadas al directorio del Servicio de Rentas Internas le permitían definir el Orgánico Funcional con direcciones regionales y provinciales y ejercer un control periódico sobre las actividades y responsabilidades de su director general, quien es nombrado por el presidente de la República para ejercer, durante su período de gobierno, la máxima representación legal, todas las potestades de la institución y todas las facultades administrativas para designar y remover al personal de la misma y para solicitar y obtener información en el cumplimiento de sus funciones. El director tiene también potestades normativas de carácter general y obligatorio para la aplicación de la ley y los reglamentos.

El SRI estaba sometido al control externo de la Contraloría con sus propios métodos y procedimientos de control interno. Su patrimonio era el de la Dirección General de Rentas y el que había adquirido desde su constitución y se financiaba, finalmente, con el $1,5 \%$ de los tributos recaudados.

Con la última Ley de Fomento Ambiental y Optimización de los Ingresos del Estado impuesta por el Gobierno "por ministerio de la Ley", el 24 de noviembre de 2011, se ajustó la institucionalidad del SRI al modelo hiperpresidencial y personalista impuesto por Rafael Correa en el contexto del modelo económico neointervencionista. ${ }^{385}$

Se eliminó el directorio del SRI, que como hemos dicho tenía algunas funciones de control institucional sobre las actividades del director, y se lo sustituyó por un Comité de Política Tributaria reducido a definir y establecer los "lineamientos de aspectos de la política tributaria”, tramitar proyectos de ley y reglamentos, conocer y aprobar la proforma presupuestaria del SRI elaborada por su director general y conocer los informes de auditoría de la institución. ${ }^{386}$

Se elimina en su integración al representante de la Federación de las Cámaras de Producción del Ecuador y a los superintendentes de Bancos y Compañías. El nuevo comité queda conformado por funcionarios directos del Gobierno: el ministro a cargo de la Política Económica o su delegado que lo preside; el ministro a cargo de las Finanzas; el ministro a cargo de la Producción y el secretario Nacional de Planificación y Desarrollo o sus correspondientes delegados. ${ }^{387}$

El director del SRI, con la nuevas reformas a su Ley, asume todo el poder administrativo y normativo de la institución; designa a todos los directores nacionales y locales y a los miembros de los comités tributarios internos; tiene la competencia para aplicar todos los tributos nacionales y de los que no se hayan atribuido a otra autoridad; elabora la proforma presupuestaria, conoce todos los reclamos de contribuyentes

\footnotetext{
${ }^{385}$ Ecuador, Ley de Régimen Tributario Interno, art. 10, $\mathrm{N}^{\circ} .18 .2$ reformado.

${ }^{386}$ Ecuador, Ley 41 de creación del Servicio de Rentas Internas - SRI-, Registro Oficial 206, 2Diciembre-1997, art. 3.

${ }^{387}$ Ecuador, Ley 41 de creación del Servicio de Rentas Internas - SRI-, Registro Oficial 206 del 2 de Diciembre de 1997, art. 3.
} 
organizados y solicita a la Controlaría la designación del auditor interno del SRI. La ley y su reglamento autorizan una amplia delegación de las funciones del director nacional a los directores regionales y provinciales, salvo las de expedir regulaciones o circulares de valor nacional, absolver consultas y resolver recursos de revisión. El SRI queda bajo el tutelaje absoluto del director, sin ninguna estructura interna independiente y externa de control normativo, administrativo o financiero. ${ }^{388}$

\section{Servicio Nacional de Aduanas del Ecuador}

La Administración Tributaria Central crea otros servicios con similares parámetros de funcionamiento y autonomía del SRI para administrar los tributos al comercio exterior: el Servicio Nacional de Aduanas del Ecuador (SENAE), una vez que se reconoció a la Aduana como un servicio público para determinar y recaudar las obligaciones tributarias en el comercio exterior, tanto por la entrada como por la salida de productos mercantiles.

La Codificación de la Ley Orgánica de Aduanas (R.O.219-S de 26 de noviembre de 2003) asignó a la Corporación Aduanera Ecuatoriana (CAE)el papel de sujeto activo de la obligación tributaria aduanera del Estado que forma parte de la administración tributaria central y definió como hecho generador de su actuación el ingreso de bienes al país. En dicha ley se estableció que las personas que operan en el comercio internacional de mercancías deben pagar derechos arancelarios, los que son fijados, reformados o suprimidos por el presidente de la República, previo dictamen favorable del Consejo de Comercio Exterior e Inversiones (COMEXI).

El nuevo Código Orgánico de la Producción, Comercio e Inversiones, dictado en el Gobierno del presidente Correa en 2010, ${ }^{389}$ crea el COMEX, Art.71, Comité de Comercio Exterior, como organismo que aprobará las políticas públicas nacionales en materia de política comercial, entre las cuales se encuentra la actividad y servicio aduaneros y la creación, modificación o supresión de las tarifas arancelarias y las tasas no arancelarias vinculadas a los procesos de comercio exterior.

Este Código ${ }^{390}$ define a la obligación tributaria aduanera como "el vínculo jurídico personal entre el Estado y las personas que operan en el tráfico internacional de mercancías, en virtud del cual, aquellas quedan sometidas a la potestad aduanera, a la prestación de los tributos respectivos al verificarse el hecho generador y al cumplimiento de los demás deberes formales." (Art.107). El hecho generador de la obligación tributaria aduanera es el ingreso de mercancías extranjeras o la salida de mercancías del territorio aduanero bajo el control de la autoridad aduanera competente.

\footnotetext{
${ }^{388}$ Ecuador, Presidencia de la República, Decreto Ejecutivo 1026 Registro Oficial Suplemento 23108 ene-1998), art. 23 Reglamento a la Ley de creación del SRI.

${ }^{389}$ Ecuador, Código Orgánico de la Producción, Comercio e Inversiones, Suplemento del Registro Oficial 351 , del 29 de diciembre de 2010.

390 Ecuador, Código Orgánico de la Producción, Comercio e Inversiones, Artículos reformados mediante Ley s/n, Registro Oficial 150-2S, 29 de diciembre de 2017.
} 
Sin perjuicio de lo expuesto, no nace la obligación tributaria aduanera, aunque sí se sujetan al control aduanero las mercancías que atraviesen el territorio aduanero nacional realizando un tránsito aduanero internacional al amparo de la normativa aplicable a cada caso, o las que ingresen como parte de una operación de tráfico internacional de mercancías, con destino a un territorio extranjero, incluido el régimen de transbordo. Tampoco nace la obligación tributaria aduanera, aunque sí la obligación de someterse al control aduanero, respecto de las mercancías que arriben forzosamente, salvo que la persona que tenga el derecho de disponer sobre dichas mercancías exprese mediante la respectiva declaración aduanera su intención de ingresarlas al territorio aduanero nacional (Art. 109). La base imponible de los derechos arancelarios es el valor en aduana de las mercancías importadas y los sujetos de la obligación tributaria aduanera son: el estado como sujeto activo por intermedio del Servicio Nacional de Aduana del Ecuador (SENAE) y como sujetos pasivos las personas naturales o jurídicas que realicen exportaciones o importaciones y/o los responsables del pago de los tributos (Art. 111).

El servicio de aduana, conforme lo establece el artículo 205, es una potestad pública que ejerce el Estado a través del Servicio Nacional de Aduana del Ecuador, sin perjuicio del ejercicio de atribuciones por parte de sus delegatarios debidamente autorizados y de la coordinación o cooperación de otras entidades u órganos del sector público, con sujeción al presente cuerpo legal, sus reglamentos, manuales de operación y procedimientos, y demás normas aplicables.

La Aduana tiene por objeto: facilitar el comercio exterior y ejercer el control de la entrada y salida de mercancías, unidades de carga y medios de transporte por las fronteras y zonas aduaneras de la República, así como quienes efectúen actividades directa o indirectamente relacionadas con el tráfico internacional de mercancías; determinar y recaudar las obligaciones tributarias causadas por efecto de la importación y exportación de mercancías, conforme los sistemas previstos en el Código Tributario; resolver los reclamos, recursos, peticiones y consultas de los interesados; prevenir, perseguir y sancionar las infracciones aduaneras; y, en general, las atribuciones que le son propias a las administraciones aduaneras en la normativa adoptada por el Ecuador en los convenios internacionales.

El Servicio Nacional de Aduana del Ecuador es una persona jurídica de derecho público, de duración indefinida, con autonomía técnica, administrativa, financiera y presupuestaria, domiciliada en Guayaquil y con competencia en todo el territorio nacional. Ejerce las facultades tributarias de planificación, determinación, ejecución, resolución, sanción y reglamentaria en materia aduanera, conforme lo manda el artículo 212 del Código. Se encuentra organizada por un director general y directores distritales para áreas territoriales creadas o suprimidas o modificadas por el director general, quien además define la estructura administrativa y atribuciones de todas las unidades de la institución. 
La legislación permite también la existencia de agentes de aduana, de auxiliares y de operadores económicos autorizados, que son personas naturales o jurídicas registradas, calificadas y controladas por la autoridad para facilitar y agilizar las actividades aduaneras.

El director general, a la vez, es la máxima autoridad de la institución. Su representante legal es nombrado directamente por el presidente de la República, ejecuta la política aduanera, expide las normas para su aplicación y tiene todas las potestades administrativas para el ejercicio pleno de sus atribuciones (artículos 215 y 216).

Los tributos del comercio exterior son: derechos arancelarios; impuestos establecidos en leyes orgánicas u ordinarias sobre el ingreso o salida de mercancías y tasas por servicios aduaneros.

Anteriormente, el Gobierno elaboraba las listas de mercaderías extranjeras que se podían comercializar en el país. Ahora, con el Código, es competencia del Comité de Comercio Exterior crear, modificar o suprimir las tarifas arancelarias, además de aprobar y publicar la nomenclatura para la clasificación y descripción de las mercancías de importación y exportación. A tal efecto se emiten resoluciones que deben ser publicadas en el Registro Oficial (Art. 72 literal g, COPCI). Las tarifas arancelarias son un tipo de tributo (derecho ad valoren) que se debe pagar para importar o exportar determinados productos o mercancías. Para el efecto se clasifican y ordenan en secciones, capítulos y subcapítulos, debidamente numerados de manera progresiva, lo que se denomina posición arancelaria.

En el Código se establecen las exenciones generales (Art. 125) al pago de tributos al comercio exterior, con excepción del pago de tasas por servicio aduanero. Tanto las importaciones como las exportaciones deben ser declaradas, llenando el correspondiente formulario en el que se indicará el régimen aduanero al que se someten y se adjuntarán los documentos que sean pertinentes. En el Código se establecen también las infracciones aduaneras, los delitos (contrabando y defraudación), las contravenciones, las faltas reglamentarias $\mathrm{y}$ las acciones $\mathrm{y}$ recursos que pueden plantear la administración, como los comerciantes o sus agentes, sea en la propia administración aduanera o ante los jueces competentes.

\section{La Dirección Nacional de Avalúos y Catastros}

La Dirección Nacional de Avalúos y Catastros, dependencia que originalmente formaba parte del Ministerio de Finanzas y que actualmente se encuentra fusionada al Ministerio de Desarrollo Urbano y Vivienda bajo la dependencia de su Subsecretaría de Hábitat y Espacio Público, tiene la competencia de avaluar y elaborar el catastro de la propiedad inmobiliaria rural de los municipios y otros servicios relativos a la valoración de bienes inmuebles, observatorio de suelos urbanos y asistencia técnica en la valoración masiva de predios y otros. 
La Ley Orgánica de Régimen Municipal (Arts. 338 y ss.) establecía el impuesto a los predios rurales que gravaba a las propiedades ubicadas fuera de las zonas urbanas, al que se sumaban otros tributos creados mediante ley (Decreto No.126, R.O. 20 del 26 de Abril de 1966).

Actualmente, el COOTAD regula todos los asuntos relacionados con el impuesto a los predios rurales en beneficio de los gobiernos autónomos municipales. A los municipios corresponde el $90 \%$ del tributo y el $10 \%$ a la Dirección Nacional de Avalúos y Catastros, por lo que los dos son los sujetos activos de este tributo, y por lo tanto esta última forma parte también de la administración tributaria nacional.

Mediante Decreto Ejecutivo No 668 (marzo de 2011) se creó el Sistema Nacional de Catastro Integrado Geo-referenciado de Hábitat y Vivienda, cuya rectoría está a cargo del Ministerio de Desarrollo Urbano y Vivienda (MIDUVI) y su objetivo es el de registrar una base de datos integral e integrada de los catastros urbanos y rurales para que sirvan como herramientas en la formulación de políticas de desarrollo urbano.

En la actualidad, la Dirección Nacional de Avalúos y Catastros ha emprendido en la ejecución de otros procesos luego de aprobar y publicar las "Normas Técnicas Nacionales para el catastro de bienes inmuebles urbanos-rurales y el avalúo de bienes...". Se encuentra también en ejecución la metodología de tasación dispuesta en la Ley Orgánica para la Eficiencia en la Contratación Pública. ${ }^{391}$

\section{La Administración Tributaria Seccional}

La administración tributaria seccional o la de los gobiernos autónomos descentralizados, como los denomina la actual Constitución, antes "gobiernos seccionales autónomos" (CRE, 1998), la ejercen los gobiernos regionales, provinciales, municipales y los distritos metropolitanos. El Código Tributario vigente reconoce administración tributaria seccional a los Consejos Provinciales, los que, en verdad, la ejercen esporádicamente, al establecer excepcionalmente contribuciones especiales de mejoras por la construcción de vías rurales y a los municipios. Siendo el Código Tributario un cuerpo jurídico preconstitucional no hace referencia a la potestad tributaria de los gobiernos regionales, que hasta la actualidad no han sido constituidos, de los distritos metropolitanos y de los regímenes especiales que se instauren.

El artículo 240 de la Constitución de 2008 dispone que "los gobiernos autónomos descentralizados de las regiones, distritos, provincias y cantones tendrán facultades legislativas en el ámbito de sus competencias y jurisdicciones territoriales. Las juntas parroquiales rurales tendrán facultades reglamentarias". En el texto de la carta política vigente, solo a los gobiernos municipales y a los gobiernos de los distritos

\footnotetext{
${ }^{391}$ Ecuador, Ley Orgánica para la Eficiencia en la Contratación Pública, Registro Oficial 906, 20-marzo-
} 1917 
metropolitanos les otorga específicamente la competencia de "crear, modificar o suprimir, mediante ordenanzas, tasas y contribuciones especiales de mejoras" (Art. 264 N.5). A los gobiernos regionales y provinciales, la Constitución les asigna la capacidad de dictar normas regionales y ordenanzas provinciales para regular sus competencias y aquellas que les confiera la ley.

El Código Orgánico de Organización Territorial, Autonomía y Descentralización (COOTAD, 2010) reconoce a todos los gobiernos autónomos descentralizados, salvo a las juntas parroquiales rurales, la atribución de "crear, modificar, extinguir tasas y contribuciones especiales para los servicios que preste y obras que ejecute" y a sus ejecutivos la potestad de "presentar con facultad privativa, proyectos de ordenanzas tributarias que creen, modifiquen, exoneren o supriman tributos, en el ámbito de las competencias del gobierno autónomo descentralizado". 392

De acuerdo al Código Tributario la dirección de la administración tributaria está asignada a los alcaldes en el caso de los municipios y de los distritos metropolitanos y al prefecto, en los consejos provinciales. Estas autoridades locales ejercen la administración tributaria mediante las direcciones financieras $\mathrm{o}$ los órganos administrativos determinados en sus respectivas normas. Actualmente el COOTAD dispone que en los gobiernos autónomos descentralizados la recaudación de tasas la efectuará "la tesorería" o "quien haga sus veces".

La Ley Orgánica de Régimen Municipal, ya derogada, en su artículo 69, numeral 30, al hablar de los deberes y atribuciones del alcalde, establecía: "sancionar y promulgar las ordenanzas aprobadas por el concejo y devolver a la corporación las ordenanzas que estimare ilegales o inconvenientes, exclusivamente cuando ellas se refieran a materias económicas, siguiendo el procedimiento y los planes señalados por dicha acción; y en el artículo 153, mandaba: "en materia de hacienda, a la administración municipal le compete... d) Verificar, liquidar y administrar la recaudación, aplicar, interpretar administrativamente los reglamentos sobre tributación expedidos por el consejo y ejercer la jurisdicción coactiva para la recaudación de los impuestos municipales".

La Ley de Régimen Provincial, a la vez, disponía en el artículo 29, literal f) que "son atribuciones y deberes del Consejo Provincial: Recaudar los impuestos a que tenga derecho, por medio de su tesorero, o de los tesoreros municipales u otros funcionarios de la provincia, quienes depositarán diariamente las cantidades recaudadas en las agencias del Banco Central, de los bancos provinciales o de los bancos comerciales, previo informe favorable de la Superintendencia de Bancos, o en las Oficinas de Correos, donde no hubiese oficinas bancarias de ninguna naturaleza, a la orden del tesorero del Consejo Provincial, dando parte de ello al prefecto provincial y a la Contraloría General para los fines de fiscalización". Esta norma se refería a la

\footnotetext{
392 Ecuador, Código de Organización Territorial, Autonomía y Descentralización, R.I. Suplemento 303, 19-oct.-2010, art. 34, 47, 57 y 87.
} 
recaudación de impuestos y tasas a los que tenía derecho el Consejo Provincial, pues el artículo 112 de la misma Ley manda que esta, cuando no se la haga por los referidos agentes de recaudación, se la hará mediante la emisión de títulos de crédito, firmados por el prefecto y el tesorero.

El COOTAD, que sustituyó a las indicadas leyes, ordena que los gobiernos autónomos descentralizados tengan una unidad financiera, cuya estructura, dependencias, funciones y atribuciones serán definidas en los reglamentos respectivos. El ejecutivo del GAD designará a un servidor que reúna requisitos de idoneidad profesional y de experiencia en materias financieras (Art. 339). El Código le confiere a la autoridad financiera las atribuciones del ejercicio de la gestión tributaria, incluyendo las potestades recaudadora y la sancionadora. Para la recaudación la ley establece que bajo el control inmediato de la máxima autoridad financiera, exista un tesorero, investido de la responsabilidad de los procedimientos de ejecución coactiva para lo cual se autoriza recurrir a funcionarios recaudadores y aún recaudadores externos. La Ley del Régimen del Distrito Metropolitano de Quito y su Código Municipal disponen que en el caso de la capital de la República se aplicarán las normas del COOTAD sobre la determinación y recaudación de las obligaciones tributarias. ${ }^{393}$

\section{La administración tributaria de excepción}

La administración tributaria denominada de excepción es la que desempeñan las entidades públicas a las que la ley les concede expresamente la gestión tributaria respecto de sus propios tributos. El sujeto activo, como lo dispone el Art.66 del Código Tributario, serán los órganos que la ley señale y a falta de este señalamiento a las autoridades que ordenen o deban ordenar la recaudación.

En nuestra legislación, los ejemplos más conocidos de administración tributaria de excepción, son: la Dirección General de Aviación Civil (DAC); las universidades; autoridades portuarias; superintendencias; Consejo de la Judicatura, etc., cuando establecen y cobran tasas fijadas en la ley correspondiente o conocen reclamaciones y recursos que propongan los sujetos pasivos de aquellas.

\section{RESOLUCIONES Y FACULTADES DE LAS ADMINISTRACIONES TRIBUTARIAS}

Las autoridades administrativas tributaria emiten, en el desempeño de sus funciones y competencias y facultades, resoluciones que son actos administrativos o actos normativos que producen efectos jurídicos particulares o generales que se agotan o no con su cumplimiento. EL nuevo Código Orgánico Administrativo, expedido en 2017 y que sustituye al ERJAFE y entrará en vigencia en 2018, diferencia entre acto administrativo, acto normativo de carácter administrativo y acto de simple

\footnotetext{
${ }^{393}$ Ecuador, Ley De Régimen Del Distrito Metropolitano De Quito, Registro Oficial 345, 27-dic-1993.
} 
administración interno o de trámite. El primero es "la declaración unilateral de voluntad, efectuada en ejercicio de la función administrativa que produce efectos individuales o generales siempre que se agote con su cumplimiento y de forma directa" (Art.98); el segundo es "toda declaración unilateral efectuada en ejercicio de una competencia administrativa que produce efectos jurídicos generales, que no se agota con su cumplimiento y de forma directa" (Art. 128); y, el tercero es "toda declaración unilateral de voluntad, interna o entre órganos de la administración, efectuada en ejercicio de la función administrativa que produce efectos jurídicos individuales y de forma indirecta". 394

Las resoluciones y actos administrativos tributarios reglados para ser válidos, legítimos y eficaces y no ser nulos deben ser emitidos por la autoridad competente; seguir el procedimiento establecido en las normas; estar debidamente motivados aplicando las normas constitucionales y legales que corresponda y ser debidamente notificados a los contribuyentes. Como todo acto administrativo, los actos tributarios gozan de las presunciones de legitimidad y ejecutoriedad y pueden ser impugnados en vía administrativa mediante reclamaciones y recursos y en la vía judicial mediante las acciones establecidas en el Código General de Procesos.

La administración tributaria, cualquiera que sea, tiene además, conforme al Código Tributario vigente, el ejercicio de las siguientes facultades: reglamentaria o de la de aplicación de la ley; la determinación de la obligación tributaria; la de resolución de reclamos y recursos de los sujetos pasivos; la potestad sancionadora por infracciones a la ley tributaria o sus reglamentos y la de recaudación de los tributos, (Art. 7 Código Tributario).

1) La facultad reglamentaria o de aplicación de la ley

La facultad de aplicación de la ley se denomina también reglamentaria. Conforme a nuestro ordenamiento jurídico, el presidente de la República, como responsable de la Administración pública, tiene la potestad reglamentaria para la aplicación de las leyes "sin contravenirlas ni alterarlas". En ciertos casos, como el de los organismos de control, la Constitución les otorga potestades normativas o regulatorias para el ejercicio pleno de sus funciones

En materia tributaria los reglamentos son de dos clases: reglamentos en estricto sentido jurídico y reglamentos meramente administrativos; los primeros regulan las relaciones tributarias entre el sujeto activo y los contribuyentes o responsables y los segundos son los que regulan el funcionamiento interno de la entidad acreedora del tributo. ${ }^{395}$ Los reglamentos, por supuesto, no pueden contravenir, alterar, adicionar, reformar ni suspender una ley ni crear nuevas obligaciones tributarias, exoneraciones o exenciones

\footnotetext{
${ }^{394}$ Ecuador, Código Orgánico Administrativo, Registro Oficial 31, Quito, viernes 7 de julio de 2017.

${ }^{395}$ Ediciones Legales, guía práctica, 81.
} 
no previstas en ella. El presidente expide los reglamentos a las leyes tributarias y tanto el director general del SRI y el gerente general del Servicio Nacional de Aduanas del Ecuador tienen competencia, como lo manda el Código Tributario, en su artículo 7, "en sus respectivos ámbitos, para dictar circulares o disposiciones generales necesarias para la aplicación de las leyes tributarias y para la armonía y eficiencia de su administración".

\section{2) La facultad determinadora y fiscalizadora}

El Código Tributario vigente dice que la determinación de la obligación tributaria es el acto o conjunto de actos reglados, realizados por la administración activa o por los contribuyentes o sujetos pasivos, tendientes a establecer en cada caso particular la existencia del hecho generador, el sujeto obligado, la base imponible y la cuantía del tributo (Arts. 68 y 87). El ejercicio de esta facultad comprende también: "la verificación, complementación o enmienda de las declaraciones de los contribuyentes o responsables; la composición del tributo correspondiente, cuando se advierta la existencia de hechos imponibles, y la adopción de las medidas legales que se estimen convenientes para esa determinación" (segundo inciso del Art. 68).

La determinación tributaria, como se puede advertir, no es una facultad discrecional sino reglada por parte de la administración activa, ya que por medio de ella se ubican todos los componentes de la obligación tributaria. De esta manera se establece la existencia o no del hecho generador; se identifican los sujetos obligados a cumplir la obligación tributaria y se estiman la base imponible y la cuantía del tributo. Con la determinación se comprueba si surge o no la obligación tributaria frente a un hecho generador. Además, la determinación conlleva los procedimientos de verificación, complementación o enmienda de las declaraciones tributarias por parte de la administración, que tienen varias consecuencias tanto en establecer el monto exacto del tributo como en aplicar sanciones o desvirtuar obligaciones tributarias de los contribuyentes o de los responsables.

Los sistemas de determinación de la obligación tributaria pueden ser: por actuación o iniciativa de la administración cuando ejerce su potestad determinadora, lo que implica un recargo del $20 \%$ de la obligación tributaria; por declaración del sujeto pasivo presentada en el tiempo que corresponda, pudiendo rectificarla dentro del año siguiente cuando se trate de errores de hecho o de cálculo, siempre que la administración no los hubiere detectado con anterioridad o por procedimiento o iniciativa mixtos, cuando la administración la efectúa tomando como base los datos requeridos a los contribuyentes o responsables y proporcionados por estos. La declaración falsa de cifras, datos, circunstancias, antecedentes, mercaderías, que influyan en la determinación se considera defraudación. Cuando la Administración fiscaliza puede establecer glosas y cargos; ratificar si los valores de la liquidación son correctos o determinar valores a favor del contribuyente. 
La determinación tributaria puede ser directa o presuntiva. La primera es objetiva y se fundamenta en la declaración del contribuyente, del responsable o de la propia administración. La presuntiva es subsidiaria, aproximativa, pero no arbitraria, ya que debe ajustarse a las normas establecidas al respecto mediante indicios y coeficientes (Art. 92 del CT).

La facultad determinadora de la administración tributaria puede caducar, esto es, queda sin efecto la potestad de ejercerla, en los siguientes casos: si han pasado tres años luego de la presentación de la declaración del contribuyente o responsable; si han transcurrido seis años desde que venció el plazo para presentar la declaración de todo o parte de los tributos y si ha transcurrido un año para verificar un acto de determinación practicado por el sujeto activo o en forma mixta. La caducidad, en todo caso, puede ser interrumpida por la notificación de la orden de verificación emanada de autoridad competente, aunque la misma no surtirá efecto si no se inicia en los 20 días hábiles siguientes a su notificación o si se suspende por más de 15 días consecutivos (Arts. 94 y 95).

3) La facultad resolutiva en reclamos y recursos administrativos

Las autoridades que ejercen la administración tributaria tienen, además, la obligación de expedir resoluciones escritas y motivadas, debidamente notificadas, frente a las peticiones, consultas, reclamos o recursos formulados por los contribuyentes o lo responsables que se consideren afectados por un acto de la administración tributaria con respecto a ellos.

El derecho de petición, que consta en la Constitución, exige una respuesta oportuna y motivada, debidamente notificada y dentro del plazo establecido por la ley de la materia, que cuando no estaba señalado, era de 15 días término conforme el artículo 28 de la Ley de Modernización y en la actualidad de 30 días, conforme lo dispone el vigente Código Orgánico Administrativo (2017) que entrará en vigencia plena el 7 de julio de 2018 . $^{396}$

Pero en materia tributaria, el Código y sus reformas han señalado el término de 120 días, contados desde el día hábil siguiente al de la presentación del reclamo o al de la ampliación o aclaración que disponga la autoridad administrativa; en materia aduanera, la autoridad Gerente Distrital de Aduana, dispone de 30 días hábiles para pronunciarse. Si no se produce la respuesta opera la aceptación tácita que no excluye el deber de la administración tributaria de dictar la resolución expresa. Las autoridades tributarias que sean responsables de aceptaciones tácitas serán sancionadas con la destitución del cargo sin perjuicio de las responsabilidades civiles, penales o administrativas previstas en otras leyes.

\footnotetext{
${ }^{396}$ Ecuador, Código Orgánico Administrativo, Registro Oficial 31, 7-julio-2017.
} 
La carta política de la República también autoriza a todo ciudadano a impugnar las decisiones de la autoridad en la vía administrativa o en la judicial, para lo cual se interponen las reclamaciones o los recursos administrativos o las acciones contenciosas administrativas y tributarias (Art. $173 \mathrm{CRE}$ ). Y la misma Constitución exige que las autoridades motiven sus resoluciones so pena de nulidad. La motivación es un derecho ciudadano que puede ocasionar la nulidad del acto administrativo que puede ser declarado por la autoridad emanante, por su superior o por los jueces competentes.

En definitiva, esta potestad resolutiva de la administración tributaria, en los términos establecidos en el Código, no es otra cosa que el ejercicio pleno de las garantías constitucionales a las que hemos hecho referencia.

\section{4) Facultad sancionadora}

La administración tributaria, por medio de las autoridades competentes, también se encuentra investida de la facultad sancionadora, administrativa-tributaria, que se ejerce por medio de resoluciones en las que se imponen sanciones conforme a los casos y con los supuestos previstos en la ley.

Dado que esta facultad está asociada con la facultad resolutiva, esta vez se pone énfasis en el contenido de la resolución, que en este caso implica una sanción o una salvedad de ella, ejerciendo la potestad administrativa y disciplinaria que le otorga la ley, en el caso de que el contribuyente o el responsable haya incurrido en un hecho que esté previsto como infracción o para no imponerla si, examinado el asunto, se llega a la conclusión, que no lo es. Conforme a la Constitución vigente, se requiere que el hecho o caso que amerite sanción debe estar tipificado, o perfectamente establecido previamente en la legislación tributaria. Debe aclararse que la actual carta política exige tipificación legal y no acepta la remisión reglamentaria que era común en la legislación preconstitucional.

Según el Código Tributario, las infracciones tributarias son de dos clases: contravenciones y faltas reglamentarias (Art. 315). Las contravenciones son acciones u omisiones de los sujetos tributarios que violen o no acaten las normas legales tributarias u obstaculicen la verificación o fiscalización de los tributos o impidan o retarden los reclamos, acciones y recursos administrativos. Las faltas reglamentarias son inobservancias de normas reglamentarias sobre los procedimientos o requisitos para el cumplimiento de las obligaciones tributarias.

Las sanciones tributarias son: multa, clausura del establecimiento o negocio, suspensión de actividades, decomiso, incautación definitiva, suspensión o cancelación de inscripciones en los registros públicos, suspensión o cancelación de patentes y autorizaciones, suspensión o destitución del desempeño de cargos públicos. Las penas tributarias no excluyen el pago de tributos y de los intereses de mora.

5) Facultad recaudadora 
Finalmente, la autoridad tributaria ejerce la facultad o potestad recaudadora, lo que implica que tiene la capacidad de cobrar los tributos en la forma y por los sistemas que la ley o el reglamento establezcan para cada tributo.

El Código Tributario y las leyes que norman directamente los tributos permiten que su cobro se pueda efectuar por agentes de retención o percepción y por recaudadores que disponga la ley o que instituya la Administración. Los recaudadores no tienen otras atribuciones que las de recibir los valores que los contribuyentes paguen por las obligaciones tributarias y no pueden negarse a hacerlo a no ser que se entreguen en pago valores o títulos diferentes a los que establece el Código Tributario, o lo que es lo mismo, dinero de curso legal, cheques o débitos bancarios debidamente autorizados, libranzas o giros bancarios a la orden del recaudador o de quien fuere facultado por la ley o la Administración para el efecto. También se pueden cancelar obligaciones tributarias con notas de crédito del mismo sujeto activo, o con bonos, certificados de abono tributario u otros similares emitidos por aquel o en especies o servicios cuando las leyes tributarias lo permitan.

Las administraciones tributarias recaudan los tributos mediante empleados y funcionarios en las jefaturas provinciales de recaudaciones y en las tesorerías de los gobiernos municipales o provinciales. La ley prevé también la participación de agentes de retención y de percepción, de bancos e instituciones financieras que deben celebrar convenios y de los notarios en los impuestos que generen actos y contratos celebrados ante ellos. La administración tributaria nacional (SRI), para los impuestos nacionales utiliza formularios identificados con un número.

Entre los sujetos pasivos también vale la pena diferenciar a los contribuyentes y a los responsables. Los primeros son personas naturales o jurídicas, o entes colectivos y entidades que forman una unidad económica con patrimonio propio y autonomía funcional, quienes tienen la obligación tributaria por la verificación del hecho generador; mientras que los responsables solidarios son aquellos que no son contribuyentes pero, por su cargo o función, deben pagar deudas ajenas para cumplir las obligaciones tributarias asignadas a los contribuyentes. Entre los responsables tenemos a los representantes, a los sucesores o adquirentes y a los agentes de retención y percepción. Estos últimos se diferencian así: los de retención son aquellos que están obligados por mandato de la ley, reglamento u orden administrativa para efectuar la retención de tributos, es decir, a liquidar, deducir y pagar el impuesto correspondiente dentro del plazo de diez días del tiempo en el que haya que pagar lo retenido. Los agentes de percepción son las personas naturales o jurídicas que por su actividad están obligados a recaudar tributos y entregarlos al sujeto activo, añadiendo al precio de las mercancías o servicios que se ofrecen el valor del tributo correspondiente.

Si el contribuyente no cumple de manera voluntaria sus obligaciones tributarias, la Administración le cobra coactivamente o compulsivamente, siguiendo el trámite establecido en el Código Tributario y actualmente en el Código Orgánico 
Administrativo aprobado en 2017 y que entra en vigencia en julio de 2018. Se reconoce el derecho de presentar excepciones a la coactiva establecidas en la ley que serán conocidas y resueltas por los tribunales de lo Contencioso Tributario.

Debemos relevar, finalmente, la modernización informática que se ha introducido en los últimos años, tanto en el SRI como en las administraciones tributarias de los GADS más desarrollados del país, en el ejercicio de todas las facultades establecidas en el Código Tributario. Las autoridades tributarias nacionales anunciaron en 2017 que los contribuyentes tienen la posibilidad de acceder mediante servicios en línea en más del 60 por ciento de los trámites que se realizan en el SRI, lo que evidencia un gran avance tecnológico y una simplificación y agilidad en los procedimientos administrativos tributarios. $^{397}$

\section{PROCEDIMIENTO ADMINISTRATIVO Y CONTENCIOSO - TRIBUTARIO}

En la legislación ecuatoriana, no solo la administración, y en este caso la administración tributaria, tiene las prerrogativas que hemos indicado en el ejercicio del poder estatal y del servicio público, sino también los administrados y contribuyentes tienen los derechos establecidos en la Constitución para impugnar las decisiones tributarias. Recordemos que en la actualidad la Constitución es un cuerpo perfecto de derechos que deben ser invocados y aplicados de manera directa e inmediata, independientemente de las normas que constan en el Código y leyes tributarias al respecto.

Los derechos de los ciudadanos en materia tributaria pueden ser ejercidos en la vía administrativa y en la vía jurisdiccional, sea esta constitucional o judicial. El artículo 173 de la Constitución, dispone: "los actos administrativos de cualquier autoridad del Estado, podrán ser impugnados, tanto en la vía administrativa como ante los correspondientes órganos de la función judicial”.

En materia tributaria, la vía administrativa permite a los contribuyentes, a los responsables o terceros presentar reclamaciones y recursos administrativos a la administración tributaria de la cual emanó la decisión que se impugna. Ella tiene también la atribución de absolver consultas sobre la interpretación de la ley y los actos normativos relacionados con los tributos.

La vía contenciosa permite un juicio entre los sujetos pasivos y la administración tributaria ante los tribunales distritales de lo Contencioso Tributario y de sus sentencias se puede interponer recurso de casación ante la Sala correspondiente de la Corte Nacional de Justicia, cuyos fallos producen efecto de cosa juzgada y, por lo tanto, no se pueden modificar o revocar. La Ley de Modernización del Estado y ahora el Código Orgánico Administrativo y el COGEP, no exigen agotar el reclamo o el recurso

\footnotetext{
${ }^{397}$ El Telégrafo, 21 de diciembre de 2017.
} 
administrativo para plantear ante los jueces la controversia que debe formularse dentro del término de noventa días de notificada la decisión tributaria que se impugna.

En la vía administrativa existen tres procedimientos que el contribuyente y otros sujetos pasivos pueden plantear: reclamaciones, recursos y consultas.

Con los reclamos, los contribuyentes, responsables o terceros expresan a la administración tributaria su inconformidad por un acto o resolución que lesiona sus derechos para que sean reformados o revocados. El reclamo debe formularse hasta 20 días después de notificada la resolución tributaria que se impugna. Se presenta ante la Administración tributaria regional o provincial o al SRI para quienes tengan su domicilio en Pichincha, o ante la Gerencia Distrital de Aduanas o en las direcciones financieras de los gobiernos seccionales o de las entidades de los que emanó el acto que se impugna. El art 119 del Código Tributario establece los requisitos que debe contener una reclamación escrita. El trámite es de oficio, puede conceder un período de prueba de 30 días y una audiencia para alegar. La resolución debe expedirse en el término de 120 días desde la presentación del reclamo, y estar debidamente motivada y notificada para que surta efecto obligatorio. Si la administración no resuelve oportunamente la reclamación se produce el silencio administrativo positivo, el mismo que no es aplicable en las consultas y en el recurso de revisión. El funcionario que por negligencia ocasiona el silencio administrativo responde por daños ocasionados al Estado según el Art. 141 del Código Tributario.

En la vía administrativa, los recursos administrativos contra resoluciones tributarias sobre las que se haya presentado reclamo, son: de revisión y de queja, y de la apelación en el procedimiento de ejecución (Art. 140 y 141 del Código Tributario). El primero se tramita ante las máximas autoridades de las administraciones tributarias en los casos establecidos en la ley, de oficio o a petición de parte interesada o afectada si aparecen nuevos documentos, o si los documentos en los que se basó la resolución fueren nulos, erróneos o falsos o si las declaraciones testimoniales fueren falsas o si los actos o resoluciones constituyan delitos declarados en sentencia judicial. El trámite implica abrir un expediente, recibir informes y practicar pruebas entre 5 y 20 días. La administración tributaria máxima o el gerente general de la Corporación Aduanera ecuatoriana, en su caso, disponen de 90 días para emitir la resolución motivada, la cual puede confirmar, invalidar, modificar o sustituir el acto revisado.

El recurso de queja lo puede presentar el afectado, por la falta de atención de una autoridad en los plazos legales, ante la autoridad administrativa jerárquicamente superior, la que a su vez la pone en conocimiento de la autoridad inicial por 3 días y luego en 5 días adopta la resolución que corresponde. El recurso de queja se puede plantear también ante el presidente del Tribunal Distrital Contencioso Tributario, cuando alguna autoridad no ha concedido un recurso ante el Tribunal; en este caso se dispone de 5 días para oír al funcionario y 5 días para que el Tribunal resuelva. El artículo 303 del Código establece los requisitos para formular la queja. 
En cuanto a las consultas sobre la aplicación, sentido o alcance de las normas tributarias, la ley ha regulado el cumplimiento de esta obligación de la Administración tributaria con respecto a los interesados individuales o colectivos. El artículo 136 del Código Tributario establece los requisitos de la consulta y el trámite dura 30 días hasta que se emita respuesta escrita y motivada. La presentación de consultas no suspende la ejecución de las obligaciones tributarias.

El proceso Contencioso Tributario, regula el derecho del interesado a impugnar en la vía judicial -ante el Tribunal Distrital correspondiente-, la decisiones o resoluciones de la Administración tributaria, independientemente de la impugnación administrativa o luego de esta si así se prefiere. En todo caso en el que se presente una acción judicial se suspende el trámite de las impugnaciones administrativas.

Coincidiendo con los procesos de descentralización impulsados por el modelo neoliberal para agilizar la administración y la justicia, los actuales tribunales distritales de lo Contencioso Tributario se crearon con la reforma constitucional de 1992, -para sustituir al Tribunal Fiscal de jurisdicción nacional fundado en 1959-, con sedes regionales en Quito, Guayaquil, Cuenca, Portoviejo y finalmente, en Loja. Son tribunales de única instancia en ciertas materias o de recurso jerárquico en casos de apelación o nulidad. Tienen potestad para resolver controversias entre administraciones tributarias y entre estas y los contribuyentes, responsables o terceros por actos de determinación tributaria o por consecuencias que se derivan de las relaciones jurídicas provenientes de la aplicación de leyes, reglamentos o resoluciones tributarias, según establece el artículo 219 del Código Orgánico de la Función Judicial, el mismo que detalla todas sus competencias en concordancia con las normas pertinentes del Código Tributario vigente.

Los asuntos de competencia de los tribunales distritales de lo Contencioso Tributario son las acciones de impugnación, las acciones directas y acciones especiales, Art. 319, COGEP.

El que se sienta perjudicado por una resolución de la Administración tributaria, luego de un reclamo, la puede impugnar en el Tribunal Distrital de lo Contencioso Tributario presentando una demanda, dentro de los plazos establecidos en el Código Orgánico General de Procesos (60 días hábiles para las acciones directas luego de la notificación del acto administrativo tributario o que se produjo el hecho o acto en que se funde la acción; las acciones de pago indebido, pago en exceso o devoluciones de lo debidamente pagado se propondrán en el plazo de tres años desde que se produjo el pago o desde la determinación según el caso y las otras en el término o plazo determinado en la ley).

La demanda debe estar acompañada de una copia certificada del acto o resolución que se impugna y de los documentos de prueba que se estimen convenientes. Si se impugna un título de crédito, se suspende su ejecutividad hasta que se dicte sentencia. Luego de 
la citación, la autoridad demandada dispone de 30 días hábiles para contestarla. La respuesta también se puede ampliar o complementar si así lo ordena el Tribunal. Siguiendo el procedimiento oral, luego se realizan las audiencias preliminar y definitiva en las que se practican las pruebas, se alega y se emite la sentencia. Si las sentencias del Tribunal están ejecutoriadas son definitivas y producen efecto de cosa juzgada; no obstante, se puede interponer recurso de casación dentro del tiempo establecido en la ley.

Los tribunales distritales de lo Contencioso Tributario conocen, como lo señalamos más arriba, recursos que se interponen contra resoluciones administrativas que se pretende que sean corregidas o revocadas. En el ámbito contencioso tributario los recursos son: de apelación, nulidad y queja.

El recurso de apelación impugna resoluciones que se dictan en la etapa administrativa, especialmente en los procedimientos coactivos, o por conflictos de competencia producidos en la misma. En este caso, la sala distrital competente debe dictar sentencia por el mérito de los autos, dentro de 10 días de recibido el proceso y de haber notificado a las partes.

El recurso de nulidad es una impugnación que se hace respecto a la validez de los actos que se han producido en la etapa administrativa, relativos a omisión de solemnidades sustanciales en la ejecución de créditos tributarios o en los remates, para dejarlos sin efecto y su trámite seguirá el curso de las acciones directas o de la apelación según los casos.

El recurso de queja, finalmente, se puede plantear en la etapa contencioso-tributaria cuando el contribuyente, responsable o tercero no es atendido dentro de los plazos legales respecto de una solicitud o reclamo que ha presentado ante la administración tributaria, especialmente en los procedimientos coactivos o cuando los funcionarios no despachan recursos que debe conocer el Tribunal. El presidente del Tribunal recibe la queja, concede 5 días al funcionario contra la que va dirigida y en los 5 días siguientes debe emitir la resolución, pudiendo imponerse sanciones al que no tiene fundamento en la queja o al funcionario responsable.

Finalmente, contra sentencias que emiten los tribunales distritales de lo Contencioso Tributario se puede interponer el recurso de casación que en realidad es una acción formal y rigurosa contra el fallo de única instancia. En materia de casación esta acción o recursos estuvo previsto, al igual que en materia penal antes que para otras materias. El recurso de casación en materia tributaria se estableció en el Código Tributario desde 1975 y se mantiene en las reformas constitucionales de 1992 y en la Ley de Casación de 1993 para que sea conocido y resuelto por una sala especializada de la Corte Nacional de Justicia, la Sala de lo Contencioso Tributario. 
En la actualidad, los recursos de casación en materia no penal se tramitan conforme al Código General de Procesos y en él se dispone que las sentencias y autos emitidos por los tribunales distritales de lo Contencioso Tributario que ponen fin a las procesos y las providencias que para ejecutar sentencias, resuelvan puntos esenciales, no controvertidos en el juicio ni decididos en el fallo o que contradigan lo ejecutoriado, pueden ser impugnadas mediante recurso de casación o de hecho que será tramitado conforme lo dispone la referida ley y resuelto por la Sala de lo Contencioso Tributario de la Corte Nacional de Justicia. Toda sentencia emitida por la Sala de Casación se debe publicar en el Registro Oficial y, si existe triple reiteración, se convierte en un precedente jurisprudencial obligatorio y vinculante para la interpretación y aplicación de las leyes, excepto para la Corte Nacional de Justicia (Art. 266 COGEP).

Finalmente, contra las sentencias de la Corte Nacional de Justicia se puede interponer la Acción Extraordinaria de Protección sustanciada por la Corte Constitucional que se tramita conforme a la Ley Orgánica de Garantías Jurisdiccionales y Control Constitucional que curiosamente otorga, concede o acepta esta acción a la Administración pública, cuando de las garantías constitucionales solo deberían gozar los ciudadanos o personas naturales y no el propio Estado o la Administración pública, que por su naturaleza ejerce potestades y no derechos. Por medio del uso de esta acción, la Administración tributaria ha logrado revertir sentencias importantes en las que se reconocieron derechos vulnerados a los contribuyentes.

\section{EL DERECHO Y LA LEGISLACIÓN TRIBUTARIOS EN ECUADOR (1990-2017)}

El derecho tributario en Ecuador se ha desarrollado de manera muy significativa en las últimas tres décadas, en la que han predominado los modelos y políticas económicas neoliberales, neointervencionistas o la combinación de los dos: comprende no solo su legislación general, que se ha mantenido relativamente estable desde 1975, en función de optimizar la recaudación indispensable para que el Estado cumpla con su función en los diferentes escenarios económicos y la legislación especial, relativa no solo a las normas que regulan los tributos nacionales y los de los gobiernos autónomos descentralizados, sino también las decisiones, regulaciones y jurisprudencia de los órganos de control administrativos y jurisdiccionales, que corresponden a los rasgos más sobresalientes de dichos modelos económicos y a los que se suman importantes aportes académicos de abogados y docentes que en la actualidad publican importantes textos que continúan la labor científica en la que durante el siglo pasado trabajaron Eduardo Riofrío Villagómez, Washington Durango y José Vicente Troya.

La legislación general a la que ya nos hemos referido corresponde a las normas constitucionales sobre la materia, que son el fundamento de todas las normas legales, y al Código Tributario, en el que se regula: la obligación tributaria en todos sus aspectos; la administración tributaria, sus facultades y potestades y los derechos y acciones de los 
contribuyentes y de otras personas, tanto en la vía administrativa como en la jurisdiccional y que de manera general, con ciertas reformas, se han mantenido estables desde 1975 y en especial durante el período de análisis de este estudio.

La legislación tributaria especial comprende: tanto las leyes y ordenanzas que regulan los tributos nacionales y locales; como a las leyes que norman a los órganos que ejercen la administración tributaria a nivel nacional, como el SRI, la Corporación Aduanera Ecuatoriana y la Dirección Nacional de Avalúos y Catastros, y a nivel regional las ordenanzas financieras emitidas por los gobiernos autónomos descentralizados provinciales o cantonales.

La Constitución de 1998 y la actual Constitución del 2008 correspondientes a los dos modelos económicos neoliberal y neointervencionista que se han aplicado y se aplican combinadamente en materia tributaria y financiera en el país consignan, como ya hemos analizado, los principios que orientan el contenido y la aplicación de las leyes tributarias, así como los objetivos extrafiscales de la política tributaria para promover la redistribución y estimular el empleo, la producción de bienes y servicios y conductas ecológicas, sociales y económicas responsables.

Durante la aplicación de dichos modelos y política económicas, las normas constitucionales enfatizan y coinciden en el principio de legalidad y en la competencia exclusiva de iniciativa tributaria en la función ejecutiva y disponen que solo el presidente de la República puede plantear leyes al Congreso Nacional y actualmente a la Asamblea Nacional, para establecer, modificar, exonerar o extinguir impuestos y que en el caso de las tasas y contribuciones se harán mediante acto normativo por parte del órgano competente y que éstas se crearán y regularán de acuerdo con la ley. Como hemos señalado además durante este período en los dos modelos se insiste también en la aplicación de los principios de justicia y capacidad contributiva de los tributos, si bien los matices en este campo son distintos, ya que se sostiene que bajo diferentes modalidades se pretende asegurar la eficacia de los mismos. ${ }^{398}$

El Código Tributario vigente que sustituyó al Código Fiscal (1963) se dictó el 23 de diciembre de 1975, durante la dictadura militar del General Guillermo Rodríguez Lara. En más de 40 años de vigencia, ha sido reformado en varias ocasiones sin que se haya modificado su estructura inicial. Es y sigue siendo, como lo señaló el profesor Washington Durango en su tiempo, una ley "fundamental que rige las relaciones entre el Estado y los contribuyentes de tributos". 399

El Código, como argumenta el maestro, tiene como ventajas: un mayor ordenamiento, precisión y claridad de las instituciones del derecho tributario; llena los vacíos y lagunas del Código Fiscal; crea y estructura más convenientemente los recursos administrativos

\footnotetext{
${ }^{398}$ Modesto Fabra Valls, Solidaridad y Derecho Financiero en una sociedad neocompetitiva, en Revista Española de Derecho Financiero N ${ }^{\circ}$ 120, 2003, 609-680.

${ }^{399}$ Washington Durango, Legislación Tributaria Ecuatoriana, (Quito: Editorial Universitaria, 1979).
} 
y judiciales; unifica los procedimientos tributarios que se encontraban dispersos y organiza, en lo sustantivo y adjetivo, las cuestiones de lo penal tributario. Pero, sus desventajas, observadas por el mismo profesor, son: no sirve para una mejor distribución y redistribución de la riqueza y rentas nacionales, pues permite su concentración y equipara y, aún, protege supuestamente al contribuyente en relación con el Estado, enfoque que en la actualidad resulta conveniente también, tanto para el modelo o políticas neoliberales que predominaron en el país entre 1990 y 2006 como para el modelo neo intervencionista que se implementa en el país desde 2007.

El doctor Durango, con sus reparos al Código inicial y a varias reformas que se introdujeron en su época, defiende el "interés público" y el "bien común", pues manifiesta que en los denominados derechos del "contribuyente" se esconden, muchas veces, las personas que recolectan o retienen tributos que no son pagados por ellos sino por los consumidores. Por lo que en realidad, esos "contribuyentes" que tienen una serie de privilegios en la legislación inicial y en ciertas reformas que perjudican al Estado, abusan de los fondos públicos en su beneficio particular.

De igual manera, el profesor critica todas aquellas medidas que a su criterio "rompen el justo equilibrio entre los sujetos de la relación tributaria" como el abuso en los recursos administrativos o judiciales o en la manipulación de las excepciones a la coactiva, que son utilizados no tanto para detener el abuso de la autoridad sino para prolongar fechas de pago y para posponer indefinidamente el cumplimiento de las obligaciones tributarias.

Desde otra óptica, varios maestros y profesores de Derecho Tributario, en consonancia con las constituciones de 1998 y 2008, que se inscriben en la corriente neoconstitucionalista, enfatizan en que este debe ser un instrumento garantista de derechos de los contribuyentes y en general de los ciudadanos, que no se pueden considerar como infractores sino como reales contribuyentes para el crecimiento nacional y por lo tanto como elementos indispensables para que el Estado y la sociedad alcancen metas de desarrollo y de servicio público. ${ }^{400}$

En las modificaciones tributarias que se impulsaron en el Gobierno del presidente Correa, exponente de un estatismo agresivo frente a los contribuyentes y de un neointervencionismo estatista supuestamente protector de derechos, se introducen varios cambios en el Código Tributario, planteados para endurecer sanciones a los evasores y evitar el aprovechamiento de ciertos recovecos y recursos jurídicos, especialmente en la coactiva y en sus juicios de excepciones, para supuestamente perjudicar al Estado y a los intereses públicos, no tanto por los contribuyentes que actúan lealmente con el Estado sino por personas, empresas, responsables y otros agentes de percepción y de retención que no cumplen con sus obligaciones y que persiguen beneficios adicionales

\footnotetext{
400 José Vicente Troya Jaramillo, Derecho del Gasto Público, (Bogotá: Temis, 2014); Eddy de la Guerra, El deber de contribución al gasto público, (México: Porrúa, 2017).
} 
que afectan los intereses y derechos de la colectividad. Las reformas al Código Tributario entre 2008 y 2017 han reforzado la protección y las potestades de la administración tributaria y el uso, o mejor dicho, el abuso de la Acción Extraordinaria de Protección, prevista para garantizar derechos de las personas cuando es preciso revertir sentencias que han "afectado el interés público", según voceros del Gobierno.

El Código Tributario, tal como fue expedido, tiene cuatro estructuras (libros) que corresponden a las instituciones jurídicas fundamentales de la actividad financiera del Estado en el orden tributario y a los diversos aspectos que se presentan en las relaciones entre los contribuyentes y el Estado. La primera es de carácter sustantivo, en la que consta todo lo relacionado con la obligación tributaria y la organización, atribuciones y deberes de la Administración tributaria. La segunda estructura se refiere al derecho adjetivo en el campo administrativo; en ella se establecen: los procedimientos tributarios en cuanto a los deberes formales de la Administración y del contribuyente o responsable y el trámite de las reclamaciones, consultas y recursos administrativos que estos pueden presentar a la Administración tributaria. La tercera estructura regula los derechos y obligaciones de los contribuyentes en el proceso contencioso tributario y la competencia del Tribunal Fiscal. La cuarta estructura reúne a todas las disposiciones concernientes al ilícito tributario, a las infracciones tributarias en particular y al proceso penal tributario para la imposición de las sanciones que corresponden.

La estructura general del Código no se ha modificado sustancialmente entre 1975 y 2017, aunque sí se han introducido y reformado varias normas conforme a la orientación ideológica, política y económica de los gobiernos de turno en materia tributaria, según los modelos económicos y políticos que se han definido en las últimas décadas. En cuanto a la legislación especial sobre la organización y facultades de la Administración tributaria nacional y local, ya se explicó en la parte correspondiente de este estudio.

La legislación especial referida específicamente a los tributos en sí, se podría clasificar de la siguiente manera: por los sujetos activos o por su objeto. Si nos referimos a una clasificación de los tributos de acuerdo a los sujetos activos, tendremos que referirnos a los que perciben el Estado, los gobiernos locales y las instituciones que por excepción ejercen administración tributaria.

El Estado percibe, fundamentalmente, impuestos y tasas. La legislación que los regulaba tradicionalmente era numerosa y dispersa hasta los años noventa, incluyendo en el período intervencionista y desarrollista que se consolidó en Ecuador desde la década del cuarenta hasta fines de los años ochenta. En la reforma tributaria que impulsó el gobierno de la Izquierda Democrática en 1990, ya influenciada por las críticas externas e internas al intervencionismo estatista y la necesidad de apuntar un nuevo modelo neocompetitivo en la economía, se trató de simplificar la legislación nacional al respecto. Con ese cometido, se agruparon los impuestos que producen mayor rendimiento en la Ley de Régimen Tributario Interno, en la que constan el impuesto a la renta, los impuestos a las transacciones comerciales (IVA), los impuestos 
a los consumos especiales (ICE) y los impuestos a las actividades hidrocarburíferas y turísticas.

Los gobiernos autónomos descentralizados locales perciben los impuestos establecidos antes en las leyes que regían a los administraciones seccionales, municipales, provinciales y parroquiales, y en la actualidad a los GADS, que cuentan actualmente con una normativa común para ellos el COOTAD (2010), para regular su funcionamiento y en especial su actividad financiera (tanto impuestos a los predios urbanos y rurales, de alcabala, de registro, a la plusvalía, a los vehículos, a los espectáculos públicos, patentes municipales, a los activos totales, al juego, como los gastos), mediante tasas y contribuciones especiales fijadas en la ley y /o creadas o reguladas por ordenanzas.

Las administraciones tributarias de excepción, ejercidas generalmente por organismos de desarrollo local o de carácter nacional para proveer algún servicio especializado, perciben tributos provenientes de tarifas o tasas por servicios.

Una clasificación más completa de los tributos vigentes, en cuanto a la materia u objeto imponible, la tenemos en lo que se considera el Régimen Tributario Ecuatoriano. ${ }^{401}$ En esa clasificación tributaria, independientemente de quien sea el sujeto activo, se distingue:

1. Los impuestos a la renta, al valor agregado y a los consumos especiales que constan en la Ley de Régimen Tributario Interno (LORTI, 1989) que ha sido modificada en varias oportunidades $(2008,2009,2010,2011,2012$, y en especial en los últimos diez años por la Ley para la Equidad Tributaria del Ecuador ${ }^{402}$ y sus reformas (2009), en la que se incluyó el impuesto a la salida de divisas, a ingresos extraordinarios, a las tierras rurales y a los activos en el exterior; por la Asamblea Constituyente de Montecristi en $2008,{ }^{403}$ La Ley Orgánica de Incentivos a la Producción y Prevención del Fraude Fiscal (2014) ${ }^{404}$ Código Orgánico de la Producción Comercio e Inversiones (COPCI) ${ }^{405}$ y la Ley para la Reactivación Económica, Fortalecimiento de la Dolarización y Modernización de la Gestión Financiera. ${ }^{406}$

2. Los demás tributos que constan en otras leyes tributarias y que se clasifican en cinco categorías:

\footnotetext{
${ }^{401}$ Ediciones Legales, Régimen Tributario, IV tomos, última edición, Quito, 2017.

${ }^{402}$ Ecuador. Ley de Equidad Tributaria del Ecuador, Registro Oficial 242, Primer Suplemento No 242 ,29diciembre-2007.

${ }^{403}$ Ibídem, Ecuador, Ley Reformatoria para la Equidad Tributaria del Ecuador s/n, Suplemento Registro Oficial 94, 23-diciembre-2009.

${ }^{404}$ Ecuador, La Ley Orgánica de Incentivos a la Producción y Prevención del Fraude Fiscal, Suplemento del Registro Oficial 405, 29-diciembre-2014.

${ }^{405}$ Ecuador, Código Orgánico de la Producción Comercio e Inversiones (COPCI), Suplemento Registro Oficial 351, 29-diciembre-2010.

${ }^{406}$ Ecuador, Ley para la Reactivación Económica, Fortalecimiento de la Dolarización y Modernización de la Gestión Financiera, segundo suplemento Registro Oficial 150, 29-diciembre-2017.
} 
a) Tributos personales y a la propiedad. Entre los primeros tenemos el impuesto a las personas que salen del país por vía aérea; impuestos y tarifas por el uso de terminales aeroportuarios y los tributos en beneficio del deporte y por la expedición de pasaportes. También son tributos personales los militares (ausencia del país, a remisos, etc.) y por ingreso al área protegida de Galápagos.

En los tributos a la propiedad se encuentran los impuestos al predio urbano, a los predios rústicos, a los vehículos y matrículas de equipos y máquinas para construcción de obras de ingeniería civil.

b) Tributos en los contratos, entre los que se encuentran: el impuesto a las utilidades o plusvalía; en la venta de inmuebles urbanos; impuesto de alcabalas y adicionales.

c) Tributos en las actividades comerciales, industriales y financieras, entre los que se encuentran: contribuciones para el SECAP y el IECE; impuesto sobre los activos totales; impuesto de patentes municipales; contribución a los organismos de control; impuesto del $2 \%$ de las utilidades de Bancos y otras entidades financieras para el desarrollo de la infancia; impuestos a los formularios de cheques, a cuentas corrientes de bancos que operan en Guayaquil; impuesto de salida de divisas, etc.

d) Tributos en el Comercio Exterior, como los derechos de importación (aranceles y otros); derechos e impuestos de exportación (café, banano, etc.) y tasas aduaneras de servicios (control, almacenaje, análisis de laboratorio. inspección, vigilancia aduanera, etc.).

e) Tributos en actividades hidrocarburíferas y mineras: en la comercialización; en la venta de combustibles y lubricantes de aviación, exportaciones de petróleo; transporte de petróleo crudo; por derechos superficiarios, regalías e ingresos extraordinarios e impuesto sobre la facturación a Petroecuador por prestación de servicios; y,

f) Otros tributos, como el impuesto a los espectáculos públicos, al juego, rifas y sorteos; al consumo de energía eléctrica y en beneficio de los bomberos. ${ }^{407}$

\section{CONTENIDO Y PROYECCIONES DE LA REFORMA Y TRANSFORMACIÓN TRIBUTARIA EN EL MODELO ECONÓMICO ACTUAL (2007-2017)}

Luego de analizar los principales temas históricos y de contenido del derecho tributario como parte del derecho económico financiero y administrativo, la organización y potestades tributarias y la estructura de los principales tributos existentes en el Ecuador, se deben realizar algunas reflexiones sobre la política tributaria en la última década y sus proyecciones y desafíos en el futuro.

\footnotetext{
${ }^{407}$ Ediciones Legales, Régimen Tributario Ecuatoriano, Tomos II y IIII.
} 
Debemos saber si las nuevas reformas del gobierno entre 2007 y 2017, que forman parte de lo que hemos denominado el sistema tributario nacional neointervencionista, logran: aportar significativa y suficientemente para financiar el gasto y el cumplimiento de las metas y planes del Estado, al carecer el gobierno de otros arbitrios económicos; revertir los males endémicos del sistema tributario nacional como la evasión, la elusión, las defraudaciones y más ilícitos, respetando las garantías ciudadanas para no caer en la arbitrariedad y en el abuso de la administración tributaria; repartir equitativamente la carga tributaria en una sociedad tan polarizada como la nuestra con la más inequitativa redistribución del ingreso y de la riqueza y, en general, sustituir o, por lo menos, disminuir la tendencia más fácil de aumentar la masa de contribuyentes, incorporándolos al universo de los impuestos indirectos que, obviamente, son regresivos, sin priorizar el cobro eficaz de los tributos directos, proporcionales y progresivos, según los montos de ingresos, bienes y riqueza de los ciudadanos.

Sobre la importancia de la política tributaria en la estabilidad macroeconómica del país, debe tomarse en cuenta que desde que Ecuador adoptó la dolarización en el 2000 renunció a la política monetaria y cambiaria y que la política tributaria se convirtió en uno de los pocos mecanismos de los que dispone el régimen político para conducir la política económica en dolarización, en la que no se pueden adoptar los arbitrios de devaluación y emisión con los que tradicionalmente los gobiernos enfrentaban los desajustes externos.

Vale recordar que desde los años setenta del siglo pasado, los organismos internacionales como la OEA, el BID y la CEPAL, en el contexto del modelo intervencionista en América Latina, comenzaron a impulsar políticas tributarias que alentaban las reformas, la simplificación y la actualización de la imposición indirecta y el fortalecimiento de la imposición directa sobre la renta de individuos y empresas, para corregir la desigual distribución del ingreso y la riqueza de la región. Luego, con el Consenso de Washington en el modelo neoliberal, se planteó priorizar impuestos como el IVA como principal fuente de recursos tributarios, desplazando la importancia que se otorgaba a los tributos directos como el impuesto a la renta, y priorizado objetivos recaudatorios antes que los de equidad o de redistribución de ingresos. Desde inicios del siglo actual, nuevamente los organismos internacionales plantearon que se enfatizara en las políticas tributarias de la región con tributos distributivos como el de la renta. ${ }^{408}$

En Ecuador, tanto las políticas neoliberales que generalizaron la tributación indirecta en desmedro de la directa, con la supuesta finalidad de que los actores económicos privados tomaran iniciativas en la inversión y en la generación de empleo, como las políticas afines al modelo neointervencionista, que otorgan al Estado un papel activo en la economía y en la solución de los problemas sociales, dan importancia legislativa a la institucionalidad y eficiencia técnicas en la recaudación de los entes responsables de la 408 Juan Carlos Gómez Sabaini y otros, Consensos y conflictos en la política tributaria de América
Latina, (Santiago: CEPAL, Naciones Unidas, Cooperación Española, 2017). 
Administración tributaria nacional, el SRI y la SNAE que sustituyeron a la Dirección Nacional de Rentas, dependencia política del Ministerio de Economía y Finanzas.

Las sucesivas reformas en el Gobierno del presidente Correa desde el 2007, concentraron, casi sin ningún control político ni financiero serio, las potestades administrativas de la administración tributaria del SRI en su director. Positivamente, desde nuestro punto de vista, se han adoptado medidas para endurecer las penas y combatir más eficazmente las infracciones y delitos tributarios, que deberían ser más contundentes con las personas jurídicas, los responsables o terceros que recogen o administran recursos que provienen de los contribuyentes y que ipso factose convierten en recursos públicos.

En todo caso, esta necesidad de perseguir las infracciones y delitos tributarios, anotada desde la expedición del Código Tributario por el profesor Washington Durango, no debe avalar la violación de garantías ciudadanas, especialmente las de los contribuyentes que sin dolo incurren en ellas. En relación con la garantía del debido proceso, reconocido por la Constitución y el principio de favorabilidad in dubio pro reo propio del derecho penal en general, deben ser tomados en cuenta en las presuntas infracciones y delitos tributarios, además de la prohibición constitucional de prisión por deudas o por el no pago de tributos. La clave en este asunto es la mayor diferenciación que las leyes tributarias deben hacer entre el contribuyente propiamente dicho y los funcionarios y agentes de retención y percepción o terceros más susceptibles, por su actividad, a la defraudación y al abuso de fondos públicos o privados.

En cuanto a los objetivos de justicia redistributiva y de impulso del desarrollo mediante una activa política tributaria, existen graves contradicciones e imprecisiones. En los anuncios iniciales y en el informe final de 10 años de mandato del presidente Correa, se asegura que se habría producido un giro en la orientación y en la equidad de las políticas tributarias. Se manifiesta que se puso énfasis en el control y en la tributación efectiva del sector financiero, de las grandes empresas y fortunas, de las herencias y de la concentración de la riqueza y de la propiedad. Los resultados en este campo, sin embargo, son magros, pues en realidad la orientación práctica de las reformas tributarias se ha dirigido a optimizar el cobro de los tributos indirectos que son regresivos, incorporando a la tributación a más contribuyentes de menores, bajos y medianos ingresos.

Entre 1990 y 2017, período en el que se aplicaron preferentemente los modelos y políticas neoliberales y neointervencionistas o su combinación, resulta evidente que hasta 2007 se priorizaron los tributos indirectos sobre los directos, hasta el punto de tratar de eliminar temporalmente el impuesto a la renta en 1999 en vísperas del feriado bancario y de la incautación de fondos públicos y privados por parte del sistema financiero privado y con el auspicio del Gobierno del presidente Jamil Mahuad. 
Durante la vigencia de los modelos neoliberal y neointervencionista en América Latina, la estructura media de la tributación entre impuestos directos e indirectos en 1990 fue de $44,9 \%$ y $55,1 \%$; en 2000 , la relación fue de $42,8 \%$ de impuestos directos y $57,2 \%$ de indirectos y en 2014 , los directos representaron $48,3 \%$ y los indirectos $51,7 \%$, lo que no significa tampoco una variación sustancial en la estructura tributaria, pues los impuestos indirectos regresivos son mayoritarios en los dos modelos, frente a los impuestos directos que persiguen relativamente fines de equidad. ${ }^{409}$

La simplificación tributaria sugerida por los organismos multilaterales, aprobada en los inicios de la década del noventa en el Gobierno del presidente Rodrigo Borja permitió finalmente que los impuestos indirectos y regresivos como los del IVA y del ICE, que incorporaron a amplios sectores sociales mayoritarios a la tributación, se convirtieran en los principales proveedores de recursos para el Estado.

Según Rafael Correa, en Ecuador "antes del 2007 el sistema tributario no contemplaba criterios de progresividad y los impuestos indirectos eran la base de la recaudación. Con las reformas tributarias aprobadas en esta década (2007-2017), dicho sistema -dice- se ha vuelto progresivo. Los impuestos directos han ganado mayor participación dentro de los ingresos tributarios, logrando que paguen los que más tienen". Para respaldar sus afirmaciones con datos proporcionados por el SRI, el expresidente indica que entre 1997 y 2006 la contribución tributaria en relación con el PIB alcanzaba a un porcentaje del 8,4\% del PIB y que entre 2007 al 2016, aquella llegó al 12,3\% del PIB. Y, en cuanto a la participación de los impuestos directos e indirectos en el total de la recaudación, entre 1997 y 2006, los directos correspondían al 34,34\% y los indirectos al 65,7 de la misma, mientras entre 2006 y 2016, los directos representaban el 43,3\% y los indirectos el $56,6 \%$ de aquella. ${ }^{410}$

Como se puede observar, durante la implementación del modelo y políticas neointervencionistas (2007-2017), el Gobierno del presidente Correa, si bien está presente como tendencia otorgar prioridad a los principios de justicia, de solidaridad y de redistribución de la riqueza y fortalecer los tributos directos sobre la renta, la propiedad y plusvalía de la tierra, objetivamente tampoco llega al punto de modificar la importancia y la recaudación de los tributos indirectos que siguen siendo porcentualmente mayoritarios respecto de los primeros. Esta política tributaria incorporó a la masa de contribuyentes a amplios sectores de la población de bajos y medianos ingresos; mejorando parcialmente los sistemas de recaudación y de sanción a los evasores.

\footnotetext{
409 CEPAL/OCDE, Estadísticas tributarias en América Latina y el Caribe 1990-2014, Paris, 2016.

410 Ecuador, Presidencia de la República, Rafael Correa Delgado, Informe a la Nación, www.planificación.gob.ec
} 
Respecto de la tributación de los grupos económicos más importantes del país, durante la década neointervencionista se partió de la necesidad de identificarlos para controlar de manera más prolija su creciente actividad económica y el cumplimiento de sus obligaciones tributarias. En 2007, la autoridad tributaria tenía identificados a 17 grandes grupos económicos. El SRI, en los cuatro años posteriores de implementación del nuevo modelo económico y aplicando una metodología especial para su control, anunció que en Ecuador se podían identificar 75 grandes grupos económicos en 2011, a los que el año siguiente se sumó 25 , dando un total de 100 y más tarde se estimó en 117 a los grandes conglomerados económicos, que a su vez, cada uno de ellos agrupa un conjunto de empresas que desarrollan diversas actividades vinculadas a la propiedad accionaria mayoritaria de una persona natural o jurídica.

Según informaciones de la autoridad tributaria en 2012, los 100 grupos económicos representaban 478 sociedades, 115 personas naturales y 102 extranjeras, o sea un total de 695, de las cuales se estiman que solo 108 eran contribuyentes especiales y 36 grandes contribuyentes. Así mismo, se informó que el total de ingresos de los grupos económicos en el 2010 fue de 31.680 millones de dólares y que pagaron por impuesto a la renta y su anticipo la suma de 670 millones, o sea una carga fiscal de $2.01 \%$.

También se indicó que la carga fiscal de los grandes contribuyentes que en 2005 era del $1,78 \%$ pasó a 3,39\% en el 2010; que el impuesto a la renta personal equivalía menos del $1 \%$ del PIB en 2012; que en ese mismo año, los grupos económicos representaban el $30 \%$ del pago total del impuesto a la renta de las sociedades; que los contribuyentes especiales que son más de 5000 pagaban más del $80 \%$ del total del impuesto a la renta y que los 201 grandes contribuyentes pagaron solo 680 millones de impuesto a la renta. ${ }^{411}$ Todos estos datos evidencian, en todo caso, que los incrementos en la tributación directa a los sectores económicos más poderosos de la sociedad siguen siendo poco significativos en cuanto a cobertura de bienes e ingresos, montos de recaudación y combate a la evasión y elusión.

En materia tributaria debemos reconocer que las decisiones son difíciles, pues se pueden tergiversar las intenciones y propósitos redistributivos de las políticas tributarias y crear falsos temores como los difundidos por los opositores al régimen, en sectores de bajos y medios recursos de la sociedad, a propósito del incremento del impuesto a las herencias, la información sobre patrimonio y las rebajas del impuesto a la renta. Los anuncios de su limitación y de los beneficios obtenidos son concesiones publicitarias dirigidas a los sectores medios de la sociedad, pero las rebajas finalmente benefician generosamente a los grupos de poder del país.

El Gobierno negó reiteradamente que los aumentos tributarios afectaron a los sectores populares y medios, pero ciertamente, el incremento de la carga tributaria y la inclusión de nuevos contribuyentes en el conjunto de la sociedad, que provienen precisamente de

${ }^{411}$ Carlos Marx Carrasco, Director del SRI, entrevista a la Revista Vanguardia, 17-febrero-2012. 
esos sectores, afectan de una u otra manera a sus ingresos. Es verdad que varias de las medidas anunciadas están aliviadas contablemente con el crédito tributario, pero en la realidad, además de su difícil acceso, la casi totalidad de los nuevos tributos se trasladan con la inflación y la especulación precisamente a los sectores medios y populares y el régimen poco puede hacer para controlar sus efectos perversos.

Datos proporcionados por analistas económicos registraron que la recaudación tributaria en los primeros 5 años de Gobierno (2007-2011) aumentó en un 143\% y el presidente Correa en su informe final de gestión en 2017 dijo que la recaudación en los últimos 10 años se triplicó. ${ }^{412} \mathrm{Si}$ se compara el monto recaudado por el SRI entre 1999, 2006, 2014 y 2016, se pasó de 1.380 a 4.673 , a 13.617 y a 13.590 millones de USD, respectivamente. ${ }^{413}$

Sin embargo, según Jorge Gallardo, exministro del gobierno de Rodrigo Borja, la recaudación de impuestos fluctuó entre 2000 y 2006 entre $10 \%$ y $11 \%$ del PIB. En 2006, la recaudación neta, deduciendo las devoluciones de impuestos, llegó al 10.8\% del PIB, mientras en 2011 las recaudaciones netas alcanzaron el 13.2\% del PIB, si bien en el 2006 no existía el impuesto a la salida de divisas y el impuesto sobre los activos en el exterior que representan el $0.8 \%$ del PIB. El crecimiento en recaudaciones del IVA e ICE a las importaciones es de más de 10.000 millones entre 2006 y 2011 y representan el $1.8 \%$ del PIB. Gallardo concluye que las cifras anteriores demuestran que ha mejorado la administración tributaria y que la carga tributaria es adecuada, pero sus mismos datos evidencian que no hay un aumento real en la recaudación, pues si se suman los porcentajes últimos de recaudación en tributos, en los que se realiza mayor esfuerzo (2.2\%), la recaudación efectiva, comparada entre el 2011 y el 2006, ha disminuido en $0.2 \%$. Según el mismo exministro, "si se quisieran recaudar más impuestos se deberá disminuir la informalidad incorporando de manera paulatina la economía subterránea a la economía formal ampliando la base tributaria". 414

En un estudio de la Cámara de Industriales de Pichincha en 2012 se dice que para sopesar correctamente la carga tributaria en Ecuador, al 13,57 \% que se pagaba en impuestos al SRI hasta antes de la última reforma, hay que sumar los aranceles, los impuestos a los gobiernos seccionales, la contribución al IESS y las utilidades de los trabajadores. Si a este cálculo se le añade el impacto de la reforma, seguramente la carga tributaria, según los empresarios, supera el 23\%, pues se incluyen como tributos sus obligaciones laborales y a la seguridad social. ${ }^{415}$

\footnotetext{
412 Revista Lideres, Informe sobre las 10 Reformas Tributarias, www.revistalideres.ec/lideres/10reformas-tributarias-impactos.html

${ }^{413}$ Diario El Comercio, Enfoque Económico, fascículo 5, sobre impuestos y recaudación tributaria, 29 de junio de 2015; Valeria Heredia, redactora de El Comercio de Quito, 22 de septiembre de 2016, 5.

${ }_{414}^{4}$ Jorge Gallardo Zavala, Impuestos, columna de diario El Universo de 29 de enero de 2012.

415 Estudio "La carga tributaria en el Ecuador", publicado por la Cámara de Industrias y Producción en noviembre de 2011, revista Líderes de diario El Comercio, 24 de diciembre de 2012.
} 
Frente a esa información, el director del SRI refutó las cifras anteriores y dijo que la carga tributaria en Ecuador era para el año 2010 del 15\%. En los cinco primeros años del Gobierno de Rafael Correa (2012), el mismo director del SRI hizo una evaluación de la gestión tributaria y dijo que había disminuido la brecha entre impuestos directos e indirectos; que en el 2011 aumentó la recaudación tributaria a 9.560,9 millones, esto es, $14,4 \%$ en relación al 2010, que fue de 8.357,2 millones, y que la carga tributaria en el 2011 cerró en 14,8\% del PIB. ${ }^{416}$ En 2014 la directora del SRI informó que la carga tributaria al cierre del año anterior era de $13,7 \%^{417}$ y luego de diez años de ejercicio del poder, el Gobierno de Correa y la Administración tributaria nacional reconocieron que la presión fiscal total llegó a un 12 o 13 \% del PIB entre 2007 y 2016, sin incluir las aportaciones a la seguridad social. ${ }^{418}$

La CEPAL informó en 2007 que la carga tributaria o presión fiscal en Ecuador fue del 14,4\%; que en 2010 llegó a un 19,7 por ciento del PIB (incluyendo a la seguridad social) y que en 2013 al 19,3\% del PIB y sobre la composición de la última carga tributaria informó que el 10,3\% correspondió a tributos a bienes y servicios (impuestos indirectos); $4,8 \%$ a seguridad social; $4,1 \%$ a ingresos (impuestos directos) y $0,1 \%$ a otros impuestos. 419

Según Latin American Economic Outlook, la presión fiscal en 2013, en el caso de Ecuador llegó al 19,3\% frente al PIB, cuando la media para la región se situó en el $21,2 \%{ }^{420}$ En 2014, la CEPAL/OECD registró también que los ingresos tributarios incluidos los aportes a la seguridad social correspondían al $19 \%$ del PIB. ${ }^{421}$

Las estimaciones de los empresarios ponen en evidencia que estos no están acostumbrados a tributar de su riqueza acumulada ni de sus ganancias, sino que trasladan toda la carga tributaria y sus obligaciones a los precios y a los consumidores. En diciembre de 2009, los empresarios criticaron las reformas tributarias del Gobierno, indicando que "las constantes reformas impiden realizar previsiones, frenan la inversión externa y le restan liquidez a los sectores productivos". ${ }^{422}$ El Comité Empresarial Ecuatoriano argumentó reiteradamente que la revisión e incrementos tributarios y las reformas a la legislación que se aprobaron durante el Gobierno de Rafael Correa "no alientan la inversión" y que por lo tanto "subirán los costos de producción para las empresas" y que "el afectado será el consumidor", ${ }^{423}$ pues, como es su costumbre tradicional, dichos grupos de poder trasladan a los consumidores todo el monto que deben pagar por tributos.

\footnotetext{
${ }^{416}$ Diario El Comercio, 29 de enero de 2012,

${ }^{417}$ Ximena Amoroso, directora del SRI, Entrevista, Diario El Comercio, 3 de octubre de 2014, 5.

418 Ecuador, Presidencia de la República, Rafael Correa Delgado, Informe a la Nación, www.planificación.gob.ec

${ }^{419}$ CEPAL, Panorama Fiscal de América Latina y el Caribe. Reformas Tributarias y renovación del Pacto Fiscal, 2013.

${ }^{420}$ El Comercio, Enfoque Económico, fascículo 5, sobre impuestos y recaudación tributaria, 29 de junio de 2015

${ }^{421}$ CEPAL/OECD, Estadísticas tributarias de América Latina y el Caribe 1990-2014, París, 2016.

${ }^{422}$ El Comercio, Revista Líderes, 14 de Diciembre de 2009, 13.

${ }^{423}$ El Comercio, Revista Líderes, informe del 31 de agosto de 2009.
} 
Los mismos sectores indicaron en 2011 que las constantes modificaciones tributarias del régimen aumentan la "continua y nefasta incertidumbre" y que somos el Estado con mayor nivel de gasto, $40 \%$ del PIB, pues además de los incrementos tributarios se consume una mayor cantidad de petróleo, que es también un "aporte de los ciudadanos al Gobierno" sin reparar en su calidad". ${ }^{424}$ También señalaron que con los nuevos tributos "la recaudación de los impuestos crece más rápido que la economía" y catastróficamente anunciaron que "eso reduce la capacidad de gasto de los agentes y las ventas disminuirán y el desempleo aumentará”. 425

Varios expertos en esta materia han indicado también que los "esfuerzos tributarios no se han concentrado en llegar a los que no pagan sino en aumentar las recaudaciones". El economista Wilson Ruales recordó a la Revista Líderes de Diario El Comercio, que la reforma administrativa del Servicio de Rentas Internas que se inició en 1998, mucho antes del actual gobierno, logró un incremento significativo de la recaudación fiscal y que son positivas la existencia de la Ley de Régimen Tributario Interno y la ampliación de la base para el cobro del IVA a más servicios, con excepción de los de salud, vivienda y educación, lo que hace a la norma "más eficiente y aminora la carga de los más pobres". Declaró también que la política impositiva de los últimos años (2009) "muestra un claro retroceso en la gestión" y que existe una manifiesta incapacidad para llegar a más contribuyentes como se manifiesta en el establecimiento último de los impuestos mínimos "que tratan como evasores a personas y empresas que no lo son". 426

El Instituto de Investigaciones Económicas de la Universidad de Guayaquil constató también que "no existe una presión fiscal negativa ni se está desmotivando a la industria, comercio y negocios, simplemente es una racionalización en cuanto a la generación de ingresos para destinar a los gastos sociales. La economía está creciendo por arriba del promedio de la región y eso es bueno". Las cifras indican un crecimiento tributario significativo en el comercio, la industria manufacturera, la intermediación financiera, el transporte y la comunicación, la actividad inmobiliaria, etc., lo que revela que la política tributaria no ha causado recesión. Pero tampoco se puede hablar de un crecimiento real y efectivo de la economía productiva del país, lo cual hace de la supuesta bonanza un fenómeno pasajero y poco sustentable, y no se diga si se mantienen subsidios regresivos como el del consumo indiscriminado de combustibles, mientras que los incentivos a las actividades productivas son bastante limitados.

Hasta el 2011 el SRI definió un plan estratégico para reducir las brechas tributarias a la mitad, consolidar el reconocimiento y aprobación a la gestión del SRI y aplicar de mejor manera los principios constitucionales de la tributación. También se propuso fortalecer el régimen sancionatorio; identificar, cuantificar y actuar sobre la evasión, elusión y fraude tanto en acciones preventivas, concurrentes y reactivas; fortalecer las acciones de cobro y reducir la emisión de cartera de riesgo en los procesos de cobro e incrementar la

\footnotetext{
${ }^{424}$ Pablo Lucio Paredes, El Universo, 22 de octubre de 2011.

${ }^{425}$ Eduardo Peña, Cámara de Comercio de Guayaquil, 25 de octubre de 2011.

${ }^{426}$ El Comercio, Revista Líderes, 14 de diciembre de 2009, 12.
} 
cobertura de control, incorporando nuevos mecanismos de supervisión-control en función del perfil de riesgo e importancia fiscal del contribuyente.

Según voceros del SRI, en los diez años del Gobierno de Correa, la recaudación tributaria se triplicó al pasar de 5.362 millones de USD en 2007 a 13.590 en 2016. Según afirman, el $92 \%$ de la recaudación o presión fiscal se explica por su más eficiente gestión en controlar la evasión y la elusión y solo el $8 \%$ por las reformas que suman más de 22 y han respondido a una búsqueda de la redistribución de la riqueza y disminución de la desigualdad con el aumento inicial -2007- del impuesto a la renta de las empresas del 25 al 35\% y a las herencias del 5 al 35\%, si bien tres años después 2010- se rebajó al 25\% y al 22\%, con la finalidad de crear incentivos para nuevas inversiones, nuevos empleos y plazas para emplear personas con discapacidad; evitar la salida de divisas para sostener la dolarización; luchar contra la evasión fiscal con incrementos impositivos para controlar las inversiones en paraísos fiscales; cobrar anticipos en el impuesto a la renta para gravar en realidad las operaciones de las empresas y ocasionar cambios de conducta en los contribuyentes en el consumo de cigarrillos y licor. $^{427}$

Si se evalúan las proyecciones anteriores, es evidente que el Gobierno de Correa alcanzó su propósito de incorporar mediante acciones y sanciones nuevos contribuyentes, pero estos principalmente provienen de sectores medios y populares. Se aumentó parcialmente la tributación normal en el nivel de los grandes contribuyentes, pero al no haberse modificado la estructura tributaria injusta, ni aumentado significativamente los porcentajes de los ingresos a la renta, ni al haberse establecido por temor un tributo a los grandes patrimonios, la estructura de distribución del ingreso en el Ecuador sigue siendo la más inequitativa de la región. Disminuyó modestamente la pobreza pero no se afectó en lo más mínimo la polarización económica y social y más bien grupos comerciales, de importadores y del sector financiero, ganaron mucho más que antes. La CEPAL manifestó que en los últimos años, tanto Ecuador como Paraguay y República Dominicana, aumentaron la desigualdad económica y social. ${ }^{428}$

Así como la generalización de los impuestos indirectos, especialmente el IVA, fue una de las características del modelo tributario neoliberal desde los años ochenta y noventa del siglo pasado, desde inicios del siglo XXI, en toda América Latina se comenzó a fortalecer el impuesto sobre la renta (ISR) y a introducir nuevos tributos no convencionales o heterodoxos.

Como observan los estudios de la CEPAL, el impuesto a la renta no crece significativamente con los parámetros tradicionales para gravar los más altos ingresos y a las empresas más rentables, sectores caracterizados tradicionalmente por la evasión y la elusión, sino ampliando la base tributaria mediante los denominados "sistemas

\footnotetext{
${ }^{427}$ Valeria Heredia, redactora de El Comercio de Quito, 22 de septiembre de 2016, 5.

${ }^{428}$ CEPAL, Panorama Social de América Latina, 2015.
} 
duales" que diferencian los ingresos del trabajo de los ingresos del capital con tasas especiales, limitando ciertos incentivos tributarios y estableciendo tributos mínimos sobre los ingresos societarios. ${ }^{429}$

En todo caso, si bien los impuestos sobre la renta, utilidades y ganancias del capital en América Latina se estancaron o disminuyeron en las décadas del ochenta y noventa con la adopción del modelo neoliberal; desde el año 2000 hasta el 2014, con el modelo neointervencionista, se incrementaron en un $70 \%$, pasando de un promedio de $3,4 \%$ del PIB en la primera etapa a un promedio del 5,7\% del PIB en la segunda etapa, sin que este incremento haya alterado el mayor aporte que en la tributación tienen los impuestos indirectos. $^{430}$

La subida de los impuestos directos con la adopción paulatina del modelo neointervencionista en América Latina desde los inicios del presente siglo tiene dos momentos: el primero entre 2003 y 2008, en el que crece la recaudación del impuesto a la renta a las sociedades, especialmente a las mineras y petroleras, por el incremento sustancial de los precios de los productos primarios y como resultado de reformas tributarias que incrementaron la participación estatal en los beneficios extraordinarios de dichas actividades. Un segundo momento se inicia en 2011, cuando declinan los precios de las materias primas y se incrementa o mejora la recaudación del impuesto a la renta a las personas físicas y en especial a aquellas que tienen relación dependencia con el Estado y con empresas.

Entre 1990 - 2014, en diez países de América Latina, el aumento de la totalidad de la recaudación del impuesto a la renta correspondió el 71\% (3,4\% del PIB) a las empresas y el 29\% (1,4\% del PIB) a las personas naturales, mientras que en 15 países de la Unión Europea las participaciones son a la inversa, el 79\% (10\% del PIB) corresponde a las personas y el 21\% (2.7\% del PIB) a las empresas. En la región, en 2010, el impuesto a la renta a las personas llegó a un promedio de 1,4\% del PIB y a las empresas al 3,4\% del PIB y en el caso de Ecuador la aportación proveniente de las personas naturales llegó al $0.6 \%$ del PIB y de las empresas al 3,5\% del PIB, lo que representaba $14,8 \%$ de las personas físicas y $85,2 \%$ de las empresas.

Si se revisan los datos de la CEPAL y del Centro Interamericano de Administraciones Tributarias, se puede constatar que en 1985-6 en la región, la alícuota máxima del impuesto a la renta a la personas físicas era del 50,9\%; en la década del ochenta

\footnotetext{
${ }^{429}$ Juan Carlos Gómez Sabaini y otros, Consensos y conflictos en la política tributaria de América Latina, CEPAL, Naciones Unidas, Cooperación Española, Santiago, 2017

${ }^{430}$ Juan Pablo Jiménez, Andrea Podestá, La tributación sobre la renta en América Latina: desafíos y perspectivas, en "Evasión y Equidad en América Latina", CEPAL, Naciones Unidas, Cooperación Española, ${ }^{430}$ Valeria Heredia, redactora de El Comercio de Quito, 22 de septiembre de 2016, 5.

${ }^{430}$ CEPAL, Panorama Social de América Latina, 2015.

${ }^{430}$ Juan Carlos Gómez Sabaini y otros, Consensos y conflictos en la política tributaria de América Latina, CEPAL, Naciones Unidas, Cooperación Española, Santiago, 2017

${ }^{430}$ Juan Pablo Jiménez, Andrea Podestá, La tributación sobre la renta en América Latina: desafíos y perspectivas, en "Evasión y Equidad en América Latina", CEPAL, Naciones Unidas, Cooperación Española, Santiago, 2017.
} 
descendió al 35,2\%; en los años noventa se mantuvo en un promedio de un 30\%; entre el 2000 y el 2012 se sostuvo en un promedio cercano del $29 \%$ y entre 2013 hasta el 2016 bajó a un promedio del 26,5 \% y la tasa mínima pasó de 7,5\% en 1985 a 9,8\%. En Ecuador, la tasa mínima fue en 1985 fue del 19\% y la máxima del 40\%; entre 1992 y 2000, durante el modelo neoliberal, la mínima disminuyó de $10 \%$ al $5 \%$ y la máxima del 25\% al 15\% y, ya en el modelo neointervencionista, entre el 2008 al 2016, la mínima se mantiene en el $5 \%$ y la máxima en $35 \%{ }^{431}$

Lo anterior demuestra que en el modelo neoliberal se disminuyó la imposición y recaudación a la renta a las personas y en el segundo momento en el modelo neointervencionista existe la tendencia, sin alterar la prioridad y el incremento de la recaudación de los tributos indirectos, a mejorar la recaudación y a aumentar las tasas del impuesto a la renta personal y su cobertura a sectores más amplios de la sociedad, no solo a los de más altos ingresos sino a los medianos ingresos que son mayoritarios en la estructura de la población y de los contribuyentes.

Tal y como indican los estudios de la CEPAL, los bajos niveles de recaudación y la estrecha base imponible del impuesto a la renta a las personas físicas en América Latina obedece a la numerosas deducciones y exoneraciones a ganancias no imponibles; a los niveles variables de exención mínimo y máximo en los ingresos de los contribuyentes; a los altos gastos tributarios que favorecen la evasión y elusión; a regímenes especiales, etc., con la finalidad de atraer la inversión extranjera, estimular el ahorro, desarrollar el mercado financiero, la promoción de exportaciones, la generación de empleo, la industrialización y el cambio de la matriz productiva, la transferencia de tecnología y el cuidado del medioambiente.

En cuanto a los altos niveles de incumplimiento por evasión y morosidad de las obligaciones tributarias y particularmente del impuesto a la renta en nuestra región, los niveles son altos en comparación contra regiones del mundo, pues se los estima en el $51 \%$ para el impuesto a la renta y $27 \%$ para el IVA. ${ }^{432}$ Esta realidad afecta a la política fiscal de los estados latinoamericanos en el cumplimiento de sus fines de desarrollo y de redistribución y profundiza la inequidad y la desigualdad en los contribuyentes.

En el caso de Ecuador, hasta antes de 1964 se adoptó el denominado sistema "cedular" para gravar los diferentes tipos de renta provenientes del trabajo, del capital o de los dos, diferenciando las tarifas. Con la expedición de la ley del impuesto a la renta en el año antes indicado, ${ }^{433}$ se adoptó el sistema de "renta global" y de "acrecimiento patrimonial" para sumar todos los ingresos del contribuyente y otros ingresos gratuitos como las herencias, legados y donaciones, con tarifas progresivas. A propósito de esto,

\footnotetext{
${ }^{431}$ Información de la CEPALSTAT, BID, CIAT, OCDE, tomado de Juan Pablo Jiménez, Andrea Podestá, La tributación sobre la renta en América Latina: desafíos y perspectivas, en Consensos y conflictos en la política tributaria de América Latina, (Santiago: CEPAL, Naciones Unidas, Cooperación Española, 2017).

${ }^{432}$ Gómez Sabaini y Morán, capítulo XXI del libro Consensos y conflictos en la política tributaria de América Latina, (Santiago: CEPAL, Naciones Unidas, Cooperación Española, 2017).

${ }^{433}$ Ecuador, Presidencia de la República, Decreto 1283, Registro Oficial 305, 8-septiembre-1971 .
} 
como anota José Vicente Troya, se contemplan "diversos tratamientos que matizan el concepto de renta global" por lo que en realidad el "sistema del país se lo puede calificar de mixto". 434

En estos años también se han generalizado tributos adoptados a nivel internacional sobre precios de transferencia, inversiones en paraísos fiscales y rentas de no residentes, a la vez que se han celebrado convenios entre los países para combatir la evasión mediante un intercambio más fluido de información. Así mismo, en varios países, se han creado nuevos gravámenes "poco convencionales" para obtener ingresos adicionales con finalidad preferentemente recaudatoria en desmedro de la eficiencia y equidad del sistema tributario, como son los dictados por razones de emergencia y los regímenes simplificados de tributación dirigidos a formalizar a los pequeños contribuyentes, como ocurre en Ecuador, con la introducción del RISE desde los inicios del Gobierno de la "revolución ciudadana", sustituyendo en la práctica la progresividad por la regresiva proporcionalidad que afecta finalmente de manera masiva a pequeñas unidades productivas. ${ }^{435}$

De igual manera, en varios países de la región se introdujo de manera generalizada el "anticipo del impuesto a la renta", tomando como base la estimación de los activos o el monto total de los ingresos brutos de las empresas. El anticipo se convierte en un tributo base o mínimo del impuesto a la renta, que si bien es liquidado al final del ejercicio económico, difícilmente es devuelto al contribuyente en su totalidad o en parte, en el caso casi frecuente que los beneficios declarados no alcanzan el monto del tributo previa y referencialmente estimado. Este impuesto es frontalmente combatido por los empresarios, ya que de todas maneras se los obliga, al igual que a las sociedades, a tributar un mínimo de impuesto a la renta sobre los posibles resultados de los que generalmente se evade el tributo total en la declaración anual.

Lo mismo ocurre con el impuesto a la salida de divisas (ISD), que se adoptó en Ecuador en 2008 hasta el monto del 5\%, con la finalidad de "sostener la dolarización" en el país, y que constituye una de las principales fuentes de ingresos tributarios para el Estado, de fácil recaudación, si bien se han introducido algunas modificaciones y exoneraciones selectivas, relacionadas con actividades personales y del comercio exterior.

En todo caso, en el conjunto de los países de América Latina desde inicios del presente siglo, el Impuesto a la Renta sobre las personas naturales y las sociedades se ha convertido en el segundo tributo en importancia recaudatoria luego de la que producen los impuestos indirectos, que se consolidaron y ampliaron durante el modelo neoliberal y que en el modelo neointervencionista siguen teniendo el primer lugar en la carga tributaria. En las reformas tributarias de los últimos años a nivel regional también se

\footnotetext{
${ }^{434}$ José Vicente Troya, Lecciones de Derecho Tributario, con las últimas reformas”, (Quito: Ediciones Fausto Reinoso, 2015), 93.

${ }^{435}$ Ecuador, Ley de Equidad Tributaria, Primer Suplemento Registro Oficial 242. 29-diciembre-2007.
} 
fortalece la imposición de gravámenes sobre la propiedad, sea esta urbana, rural, de vehículos, etc.

Crece, además, la conciencia de la necesidad de que los contribuyentes cumplan a cabalidad sus obligaciones tributarias, siempre que se les otorgue la certeza de que existe justicia en el sistema impositivo y que se usan eficiente, correcta y honestamente los recursos que se entregan al Estado, en un gasto público equitativo y que está dirigido a los sectores más vulnerables y en general a la satisfacción de los derechos económicos, sociales y culturales de la población.

Por ello, una real transformación tributaria, que implique equidad y una efectiva redistribución de la riqueza para impulsar el desarrollo y un gasto equitativo y eficiente requiere de un pacto fiscal democrático entre el Estado y los contribuyentes, lo que todavía está pendiente en el Ecuador, al igual que en otros países de la región y del mundo. 


\section{CAPITULO V: EL DERECHO DEL GASTO Y DEL PRESUPUESTO EN ECUADOR ENTRE 1990-2016 Y ENTRE 2007-2017}

En este capítulo nos referiremos más detenidamente al contenido del derecho del gasto $\mathrm{y}$ del derecho presupuestario y a sus relaciones, con la finalidad de ubicar sus transformaciones en la historia ecuatoriana e identificar las connotaciones y particularidades, que en modelos o políticas económicos (1990-2017), han asumido tanto los principios constitucionales y legales, como la normativa que se ha expedido y se encuentra vigente sobre la materia.

\section{DERECHO DEL GASTO Y DERECHO PRESUPUESTARIO}

Como ya hemos señalado oportunamente, en el derecho de la Hacienda pública o el derecho financiero público se identifican: el derecho tributario, el derecho de la deuda o del crédito público, el derecho cambiario, el derecho monetario y el derecho del gasto y el derecho presupuestario.

No es nuestro objetivo dilucidar las controversias que existen sobre la autonomía científica y/o académica de cada una de las ramas jurídicas indicadas, unas más desarrolladas que otras, pues en esta investigación nos interesa reflexionar sobre la naturaleza jurídica del derecho del gasto, del derecho presupuestario y de uno de los instrumentos claves del ordenamiento financiero y de la política fiscal: el presupuesto, en el contexto de los modelos económicos y políticos, entre los años 2000 y 2017.

En el ámbito académico existe una mayor reflexión doctrinaria y jurídica sobre el presupuesto y la normativa jurídica que lo regula, por razones lógicas y de actualidad. En vista de ello, es necesario que nos refiramos primero al derecho del gasto y a sus relaciones con el derecho presupuestario para desarrollar luego nuestras reflexiones sobre los principios y las normas constitucionales y legales que rigen la materia.

La naturaleza de la Hacienda pública contemporánea es, según nuestra opinión, como ya hemos afirmado, esencialmente política y económica, pues se encuentra vinculada a los diferentes modelos económicos y políticos del sistema capitalista imperante y a las decisiones políticas y regulaciones jurídicas de sus actores internacionales y locales, que a su vez corresponden a los intereses dominantes de la estructura social organizada y representada en la comunidad internacional por los organismos internacionales, los estados nacionales y los gobiernos y estructuras de poder que los representan.

Desde Griziotti, ${ }^{436}$ al igual que otros autores europeos y latinoamericanos, se ha enfatizado que la actividad financiera pública es un "medio" eminentemente político y complejo, sin disminuir la importancia de su dimensión económica, social, técnica y jurídica, para el cumplimiento de los fines del Estado y entre ellos sin duda se

\footnotetext{
${ }^{436}$ Benvenutto Grizziontti, Principios de la ciencia de las finanzas, (Buenos Aires: Depalma, 1949).
} 
encuentran la satisfacción de los derechos de los ciudadanos y en especial aquellos que corresponde cubrir al Estado para alcanzar la estabilidad social, el desarrollo y la equidad.

El derecho del gasto público es una de las ramas importantes y especializadas del derecho de la Hacienda pública o del derecho financiero público. Su fundamento se encuentra en las normas constitucionales y legales y principios que se refieren al gasto público, sea para satisfacer derechos de los ciudadanos, mediante la asignación de recursos humanos y materiales, debidamente planificados, reconocidos y desembolsados; sea para cumplir con una obligación no siempre debidamente satisfecha o que consta, de manera perfectamente establecida, en el presupuesto estatal o de otras entidades públicas; o para motivar la acción y el control del Estado en su uso, gestión, cumplimiento de objetivos o para ejercer su manejo eficiente y honesto.

En el Estado capitalista se acostumbra a diferenciar: el gasto público neutro que corresponde a la hacienda clásica, pues no cambia la distribución de bienes y servicios en la sociedad y no afecta a la economía privada o de mercado que supuestamente con su "mano invisible" alcanza el bienestar general de la sociedad y del gasto público activo que corresponde a la hacienda moderna y contemporánea, en la que su aumento o disminución incide en el conjunto de la economía y se utiliza deliberadamente para la obtención de determinados resultados, como se puede advertir en los modelos intervencionista, neoliberal y neointervencionista.

Se identifican también en la historia, en la doctrina y en el ordenamiento jurídico "principios del gasto público" que se desarrollan, priorizan o reformulan en los diferentes modelos económicos o tipos de hacienda o de políticas públicas adoptadas por los gobiernos y el poder político a nivel internacional, regional o nacional. Entre dichos principios, que en la actualidad son reformulados por la doctrina, tenemos los de legalidad, equidad, eficiencia, eficacia, planificación y otros que tienen connotación y diversos alcances en los distintos momentos históricos y en los ordenamientos constitucionales y jurídicos de los países del mundo.

Evidentemente, entre el derecho del gasto público y el derecho presupuestario y el presupuesto, existe una estrecha relación que ha llevado a algunos autores a identificarlos y a otros a diferenciarlos. A su vez, hay numerosos conceptos de presupuesto y de derecho presupuestario que así mismo reflejan el contexto en el que fueron elaborados y las transformaciones ocurridas en el Estado, la sociedad y el derecho, a lo largo de la historia y en los modelos económicos adoptados en ella en el país y particularmente el neoliberal y el neointervencionista o su combinación entre 1990 y 2017.

Para establecer la relación y la diferencia entre las categorías indicadas es necesario identificar los ámbitos que cubren. Según José Vicente Troya, como punto de partida se debe diferenciar la naturaleza eminentemente pública del tributo y la del gasto, que no 
solo tienen contenido público, sino también efecto privado-contractual. Si bien la potestad del gasto corresponde al Estado, la facultad de beneficiarse por parte de sus destinatarios corresponde a organismos y personas o colectivos públicos y privados, conforme lo dispone la Constitución y la ley. Gastar, además, no es solo una actividad registrable, pues se eroga por "interés público" para satisfacer necesidades colectivas o públicas, sean servicios públicos propios o impropios, establecidos en normas jurídicas, contratos y políticas por parte de las autoridades competentes y que se ejecutan por medio de estas o de otras instituciones estatales e incluso por concesionarios privados. $^{437}$

Es por eso que el derecho del gasto es una rama jurídica instrumental que forma parte del derecho financiero público o de la Hacienda pública, en la que se definen y regulan políticas, sujetos y medios para satisfacer las necesidades públicas que, obviamente, se han modificado y ampliado en los diferentes modelos económico y políticos que han regido y rigen al Estado, y que se hacen mucho más evidentes en nuestra región, con la implementación del modelo intervencionista primero y luego con el neocompetitivo o neoliberal y con en el neoestructural o neointervencionista en las últimas décadas.

El derecho del gasto se fundamenta en principios similares a los del derecho financiero y a los que rigen para el sistema financiero, la política fiscal, presupuestaria y tributaria del Estado y en general para las políticas públicas, como son: reserva de ley, generalidad, justicia o equidad, progresividad, sustentabilidad, sostenibilidad, equilibrio, responsabilidad, seguridad, solidaridad, eficacia, eficiencia, transparencia, razonabilidad, subsidiaridad, solidez, planificación y competencia. ${ }^{438}$ En este conjunto de principios tienen su propia connotación para el caso y, con especial importancia, los de equidad, estabilidad, sostenibilidad, eficiencia, solidaridad y planificación, pues se trata de que el gasto y las políticas públicas, destinados a prestar bienes y servicios y a satisfacer derechos y obligaciones del Estado a los ciudadanos, se realicen con justicia redistributiva, solidaridad, participación, oportunidad y con alta calidad en su satisfacción.

Una preocupación importante, en el ámbito académico, procesal y jurisdiccional, en la aplicación de los principios constitucionales y doctrinarios sobre el gasto y el presupuesto, es la posible vulneración de derechos fundamentales, al expedir leyes, resoluciones y aún sentencias que supediten su ejercicio a la existencia o no de los recursos necesarios, o a la insuficiencia en la asignación de las asignaciones presupuestarias, lo cual resulta inaceptable para un Estado garantista y debería ser fundamento para que sus responsables sean justiciables y responsables.

Durante el período de aplicación de políticas neoliberales, entre 1990 y 2005 en Ecuador, se cuestionó abiertamente la participación activa del Estado en la actividad

\footnotetext{
${ }^{437}$ José Vicente Troya Jaramillo, El Derecho del gasto público, (Bogotá: Temis, 2014).

${ }^{438}$ Ecuador, Constitución de la República de Ecuador, arts. 85, 286, 287, 292, 300, 308, 309, 310.
} 
económica, por lo que desde los organismos internacionales y regionales y en la leyes locales, se planteó reducir el tamaño del Estado e impulsar al sector privado en la inversión y el emprendimiento, considerando que el primero debería tener más bien una función subsidiaria y un papel secundario o no protagónico en el incremento y eficiencia de la economía y el desarrollo.

En el período subsiguiente, en especial en la década 2007-2017, se proyectó recuperar el papel del Estado en el ámbito de la economía, en su crecimiento y en el papel dinamizador del gasto en la inversión, el consumo y el bienestar, para lo cual se argumenta que la tasa promedio de crecimiento anual en dicho período fue de 3,4\% y que el tamaño de la economía se duplicó, al pasar de 51 MMUSD a 97.802,2 MMUSD en $2016 .{ }^{439}$

Concordamos con la afirmación de José Vicente Troya, según la cual, para profundizar sobre la naturaleza del derecho del gasto público se lo debe comparar con el derecho presupuestario, pues su existencia dentro del derecho financiero se reconocido tradicionalmente sin mucha discusión. ${ }^{440}$

Respecto del derecho presupuestario y el presupuesto, Giuliani Fonrouge y sus actualizadores, Susana Navarrete y Rubén Asorey, en su obra Derecho Financiero, ${ }^{441}$ manifiestan que la evolución del concepto de presupuesto se ha dado, sustancialmente, como resultado de la función del Estado en la actividad económica. Así, citando a autores de inicios del siglo pasado como Stourn en 1909, cuando culminaba la fase del Estado liberal, ellos concebían al presupuesto como "un acto que contiene la aprobación previa de los ingresos y gastos públicos" sin que se lo perciba como un instrumento de acción directa sobre la economía.

Cuando el Estado interviene activamente en la sociedad, en la economía y en los servicios públicos, desde los años treinta y con mayor evidencia luego de la Segunda Guerra Mundial, se amplió el concepto de presupuesto y se entendió, según Myrdal, como "el instrumento técnico de control de la contabilidad central al servicio de una red general de previsión y planificación económica del Estado", por lo que su acción debía cumplirse conforme a un plan, cuya noción tradicional se amplió en el tiempo (presupuesto plurianual o cíclico) y en el espacio (presupuesto económico o presupuesto nacional), con alteración de ciertos principios considerados básicos en la ortodoxia financiera.

En otras palabras, el concepto tradicional y en el modelo liberal, el presupuesto es "un acto de previsión de los gastos e ingresos del Estado", según lo afirma Laufenburguer

\footnotetext{
${ }^{439}$ Rafael Correa Delgado, Informe a la Nación 2007-2017, Quito, www.planificacion.gob.ec

440 José Vicente Troya Jaramillo, El Derecho del gasto público, (Bogotá: Temis, 2014).

${ }^{441}$ Carlos M. Giuliani Fonrouge, Derecho Financiero, 7ma.edición actualizada, (Buenos Aires: Depalma, 2001 .
} 
(1948) o por Trotabas: “el presupuesto del Estado ${ }^{442}$ que prevé y autoriza anualmente, en forma legislativa, las cargas y los recursos".

En la época o en el modelo de intervencionismo estatal se diferencia presupuesto financiero de presupuesto económico. El primero lo autoriza el Congreso o la función legislativa, y contiene los ingresos, los gastos y las actividades financieras que desarrollará el Gobierno en un año. El segundo incluye al primero en el contexto más amplio de la actividad económica del país y por ello se lo denomina presupuesto nacional o presupuesto económico de la nación, en el que se establecen fundamentos, lineamientos y políticas sobre el gasto en relación con los objetivos políticos de los gobiernos.

Angelópoulos (1949) definió al presupuesto como "un acto de previsión integral de los ingresos y gastos probables de la nación durante determinado período". ${ }^{443}$ Este concepto descriptivo es útil tanto en los períodos o modelos intervencionistas del Estado, como en el neoliberal y el neointervencionista de los últimos tiempos, ya que en estos son las políticas económicas las que cambian mientras la estructura formal del presupuesto y su técnica se mantienen, con las rigideces e intereses impuestos por los organismos financieros internacionales o por los regímenes políticos de turno.

Jorge Witker, ${ }^{444}$ subrayando la naturaleza política del presupuesto en la época intervencionista del Estado en nuestro continente, nos recuerda las definiciones que sobre el presupuesto nos dan autores como Valdés Costa, para quien "presupuesto es el programa de acción de las fuerzas políticas que gobiernan el Estado, cuyas ideas se van a manifestar en el monto y naturaleza de los gastos, en la relación de estos con los ingresos (teoría del equilibrio y del desequilibrio presupuestal)" y para Gerhard Colm (1971), en su Tratado de Finanzas Públicas: "el presupuesto es, como si dijéramos, el centro nervioso de la economía pública, y desempeña en ella el papel del mercado en la economía privada". 445

Los partidarios de las concepciones liberales, dice el autor antes indicado, coinciden con los exponentes anteriores en el sentido de que la sanción parlamentaria del presupuesto da respuesta a las preguntas: ¿cuánto debe gastar el gobierno?, ¿en qué debe gastar?, y ¿cómo debe financiarse el gasto? De esta manera, agrega, se enfatiza en la naturaleza de decisión política que tiene el presupuesto, para adquirir la legitimidad necesaria en un Estado de derecho mediante procesos jurídicos.

Fernando Pérez Royo, en su Derecho Financiero y Tributario, manifiesta que el presupuesto es en primer lugar un instrumento de racionalización y organización de la

\footnotetext{
${ }^{442}$ Héctor B. Villegas, Manual de finanzas públicas, (Buenos Aires: Depalma, 2000).

443 ANGELOPOULUS, L'Etat et la prosperité sociale, pág.178, cit. por GIULIANI FOUNROUGE, Carlos M. en Derecho Financiero, tomo I, $9^{\mathrm{a}}$ edición, 127.

${ }^{444}$ Jorge Witker Velásquez, Introducción al Derecho Económico, (México: Oxford University Press Harla, 1997).

${ }^{445} \mathrm{http}: / /$ presupuestopublico.blogspot.com
} 
función financiera y en general de la actuación económica del sector público y, además, un instrumento político de fundamental importancia. El documento presupuestario, agrega, al presentar de forma unitaria el plan de actuación económica del sector público al nivel estatal, regional o local, permite emitir un juicio razonado sobre dicha actuación, por lo que se convierte en el instrumento principal de control del Gobierno. $^{446}$

William Leguizamón Acosta, en su texto Derecho Constitucional Económico, nos ofrece varias definiciones de presupuesto: la del diccionario dice que es el "documento contable que, bajo la forma de un acto legislativo, implica una previsión y autorización de ingresos y gastos públicos durante un determinado periodo de tiempo, que coincide normalmente con el año natural"; según la legislación colombiana es un "instrumento para cumplir metas y objetivos fijados en los planes y programas de desarrollo económico y social y en los planes de inversiones públicas"; Álvaro Suárez se refiere a un "acto de autoridad soberana por medio del cual se aprueba un programa de gobierno fijando los ingresos y autorizando los gastos para un período determinado"; en la de René Stourm, "el presupuesto del Estado es un acto de la autoridad soberana que contiene la aprobación previa de los ingresos y gastos públicos" y según Enrique Low Murta, "el presupuesto es una programación de ingresos y gastos públicos". 447

Todas estas definiciones describen aspectos del concepto presupuestario y tienen en común la consideración del presupuesto del Estado como un instrumento o documento producto de su soberanía, que se lo autoriza y prevé para períodos fijos anuales y que los ingresos y gastos públicos son dispuestos para cumplir funciones administrativas y políticas conforme a un plan general de desarrollo e inversiones públicas.

Se debe considerar también que desde la óptica de las finanzas públicas el presupuesto tiene una dimensión técnica asociada a la planificación y a las políticas públicas mientras que en el ámbito del derecho financiero y presupuestario regula la actividad de los egresos públicos para establecer su límite y destino y registrar sus ingresos.

Profundizando en la misma dirección y encontrando su dimensión jurídica, en su Tratado de Finanzas Públicas el maestro ecuatoriano Eduardo Riofrío Villagómez ${ }^{448}$ define al presupuesto como: "documento o acto jurídico-contable por el cual se recuentan, enumeran, estiman y autorizan las entradas y los egresos fiscales, estatales o locales, o de servicios con autonomía financiera, para un ejercicio financiero". En cuanto a su contenido administrativo y constitucional toma las expresiones de Gastón Jeze para señalar que para él, el presupuesto es un acto de

\footnotetext{
446 Pérez Royo Fernando, Derecho Financiero y Tributario Parte General, (Madrid: Editorial Civitas. 9na. edición, 1999).

447 William Leguizamón Acosta, Derecho Constitucional Económico, Ediciones Jurídicas Gustavo Ibáñez, 2002.

${ }^{448}$ Eduardo Villagómez Riofrío, Tratado de Finanzas Públicas, (Quito: Casa de la Cultura Ecuatoriana, 1968).
} 
previsión, un plan administrativo del Gobierno, un acto político y una autorización del poder legislativo al poder ejecutivo.

Héctor Villegas manifiesta en su Manual de Finanzas Públicas que todas las actividades financieras del Estado conducen al presupuesto como único instrumento que les proporciona vida legal. Para concretar sus fines, subraya, este debe realizar gastos y obtener recursos que se tienen que calcular y autorizar de antemano. Define al presupuesto como el plan financiero anual del Estado y dice que "el presupuesto es un acto de Gobierno mediante el cual se prevén los ingresos y gastos estatales y se autorizan estos últimos para un período determinado". Añade, además, que si bien algunos consideran que el presupuesto es una ley y otros una "ley de leyes", la verdad es que implica "un plan político, un plan de acción", es una "herramienta de política y de economía, un vehículo de solidaridad" y una "fuente de armonía entre las clases sociales", ya que es "parte fundamental de un plan de Gobierno con componentes políticos, económicos y sociales". 449

Fernando Pérez Royo indica en su obra Derecho financiero y tributario que el derecho financiero público es el ordenamiento jurídico de la Hacienda pública, en su doble vertiente de ingreso y de gasto público y que el derecho presupuestario es la parte del derecho financiero público que contiene el régimen jurídico de los gastos o egresos públicos en los aspectos que le interesan, esto es, en los mecanismos o procedimientos formales, jurídicos, que gobiernan la asignación, desembolso y control del empleo de los recursos públicos. Estos procesos, agrega, de manera más completa se los conoce con el nombre de ciclo presupuestario y giran en torno a una institución fundamental del derecho financiero, que es el presupuesto del Estado y el de otros entes públicos. ${ }^{450}$

El profesor de la Universidad Central, Eduardo Riofrío, nos recuerda que como culminación de la teoría presupuestaria y su aplicación se configuró una nueva rama del derecho financiero, el derecho presupuestario, que tiene como premisa ordenar todo lo que de básico y regulador tienen las normas constitucionales, legales y contables sobre la materia, constituyendo un cuerpo de ley orgánico que las uniforma en conceptos, métodos y resultados. ${ }^{451}$

Mauricio Plazas Vega, en su obra Derecho de la Hacienda Pública y Derecho Tributario, afirma que si se concibe al presupuesto público no solo como instrumento indispensable de las finanzas sino como una verdadera síntesis de los objetivos financieros y políticos de los estados, el derecho presupuestario es el "conjunto de normas jurídicas que regulan el presupuesto público". ${ }^{45}$

\footnotetext{
${ }^{449}$ Héctor Villegas, Manual de Finanzas Públicas, Capítulo XIV, Editorial De Palma, 2000.

${ }^{450}$ Fernando Pérez Royo, Derecho Financiero y Tributario Parte General, (Madrid: Editorial Civitas. 9na.edición, 1999).

${ }^{451}$ Eduardo Villagómez Riofrío, Tratado de Finanzas Públicas, (Quito: Casa de la Cultura Ecuatoriana, 1968).

${ }_{452}$ Mauricio Plazas Vega, Derecho de la Hacienda Pública y Derecho Tributario, (Bogotá: Editorial Temis, 2000).
} 
A lo largo de la historia, el derecho constitucional ecuatoriano no ha definido de manera expresa lo que es el presupuesto del Estado, sino que se ha limitado a enfatizar de manera indirecta su obligatoriedad, al señalar que en la Ley de Presupuesto que se dictará anualmente constarán todos los ingresos y los egresos del Estado (Constitución de 1945 y 1946). Desde la Constitución de 1967 se deja de denominar ley al presupuesto, pero se lo describe como instrumento de efectos obligatorios para el conjunto del Estado y, además de ello, se dispone que "se destinará a la atención de los servicios públicos y a la ejecución de programas de desarrollo económico y social", con lo que se define además una política para orientar el gasto público.

En la Constitución de 1978 se asocia también el presupuesto al desarrollo económico cuando dispone: "el presupuesto se dictará anualmente y contendrá todos los ingresos y egresos del Estado, incluyendo los de las entidades autónomas, destinados a la atención de los servicios públicos y a la ejecución de los programas de desarrollo económico y social" y manda que en él, como ya lo disponía la Constitución anterior, se debe destinar "no menos del 30\% de los ingresos para la educación y la erradicación del analfabetismo". 453

Además de todas las connotaciones anotadas, el presupuesto tiene un profundo significado y enormes repercusiones jurídicas y políticas que impactan, fundamentalmente, en todas las instituciones públicas sometidas al principio de legalidad en el Estado de derecho. Pese a las limitaciones establecidas en las constituciones de 1998 y 2008, el presupuesto es un instrumento de control político anual por parte del Congreso o de la Asamblea Nacional para registrar ingresos y autorizar los gastos del Estado y para constatar que su contenido sea acorde con el Plan Nacional de Desarrollo y los planes locales para ser cumplidos obligatoriamente.

El profesor Sainz de Bujanda definió en concordancia con otras opiniones expresadas anteriormente que el derecho presupuestario es la "rama del derecho financiero integrada por el conjunto de normas y principios que determinan el régimen jurídico temporal de la gestión, empleo y contabilidad de los caudales que, derivados de la aplicación de los recursos, alimentan el tesoro público". 454

Algunos tratadistas han discutido si el presupuesto es una ley formal o material. La ley, como sabemos, es una norma de carácter general y obligatorio que sigue el trámite constitucional establecido para su validez. En el derecho ecuatoriano, el presupuesto no sigue actualmente el trámite establecido para la formación de la ley, ni en la iniciativa, ni en los debates ni en la promulgación. Pero tiene efectos de ley, pues es general y obligatorio. Por lo tanto, si antes se denominaba de todas formas "ley de presupuesto", en la actualidad, desde la Constitución de 1978 y en especial de 1998, cuando se institucionaliza el modelo neoliberal, solo se lo denomina "presupuesto", pero con

\footnotetext{
${ }^{453}$ Ecuador, Constitución Política del Ecuador 1979, Registro Oficial 800, 27-Marzo-1979, art. 96.

${ }^{454}$ Fernando Sainz de Bujanda, Sistema de derecho financiero, tomo I, (Madrid: Universidad Complutense, 1985).
} 
efecto obligatorio. Su trámite ha sido modificado, restringiendo casi totalmente las potestades de los legisladores en su contenido y aprobación, hasta convertirlo en un instrumento sobre el que tiene control total el ejecutivo en todo su ciclo de formulación, ejecución, reforma y liquidación.

Se debe reconocer que el presupuesto como categoría jurídica es "un documento técnico-jurídico de naturaleza compleja" en el que confluyen actos administrativos de carácter general tanto en su formulación como en su ejecución a cargo del Ejecutivo con una "aprobación legislativa" por parte de la función legislativa que le otorga fuerza normativa obligatoria y general para autorizar el gasto y sus destinatarios. ${ }^{455}$

La Constitución de Montecristi aprobada en referéndum por el pueblo ecuatoriano, en el contexto del modelo económico neointervencionista, el 28 de septiembre de 2008, dice: "el presupuesto del Estado es el instrumento para la determinación y gestión de los ingresos y egresos del Estado, e incluye todos los ingresos y egresos del sector público, con excepción de los pertenecientes a la seguridad social, la banca pública, las empresas públicas y los gobiernos autónomos descentralizados" (Art. 292).

Esta definición constitucional dispone lo que en Ecuador debe entenderse conceptualmente por presupuesto en la actualidad. Esto es, se trata de un instrumento de carácter implícitamente obligatorio, que fija o determina todos los ingresos y egresos del Estado del sector público no financiero, a la vez que autoriza su gestión principalmente a la función ejecutiva. La aprobación corresponde a la Asamblea, cumpliendo ciertos parámetros restrictivos mientras la formulación, la ejecución y la liquidación corresponde a la función ejecutiva. De hecho, la definición entraña también una clasificación de los presupuestos en nuestro país: general del Estado o del sector público no financiero, de la seguridad social, de las empresas públicas y de los gobiernos autónomos descentralizados.

El Código Orgánico de Planificación y Finanzas (2010), también define al Presupuesto General del Estado en su artículo 77 como instrumento, para la determinación y gestión de los ingresos y egresos de todas las entidades que constituyen las diferentes funciones del Estado. No se consideran parte del Presupuesto General del Estado los ingresos y egresos pertenecientes a la Seguridad Social, la banca pública, las empresas públicas y los gobiernos autónomos descentralizados".

La Constitución (2008) y la ley establecen que existirá un Presupuesto General del Estado cada año y una programación presupuestaria cuatrianual, como respaldo de la programación general del sector público no financiero, que es el marco obligatorio para su formulación y ejecución y como fundamento referencial para otros presupuestos del sector público.

\footnotetext{
${ }^{455}$ Eddy De la Guerra Zuñiga, Presupuesto, gasto público y compra pública responsable en Ecuador, en Revista de Derecho Foro, UASB-CEN 25, I semestre 216, Quito.
} 
Por tanto, el presupuesto es un instrumento de efecto jurídico obligatorio aprobado por la Asamblea Nacional pero dominado por la función ejecutiva y que tiene, en la actualidad, una relación y dependencia directa con la planificación estatal y un ciclo de cumplimiento necesario para todas las entidades y organismos del sector público, que incluye las etapas de: programación; formulación; aprobación; ejecución; evaluación y seguimiento y clausura y liquidación presupuestarias. En resumen, el derecho presupuestario es el conjunto de normas y principios jurídicos constitucionales y legales que rigen o regulan el presupuesto del Estado o los presupuestos públicos, desde su formulación hasta su ejecución, control concurrente, liquidación y control posterior.

En todo caso, en la actualidad es necesario y útil diferenciar derecho del gasto del derecho presupuestario, pues en el segundo los créditos o gastos aprobados tienen validez formal y no se refieren a su legitimidad y a los principios o fundamentos o derechos de los beneficiarios en los que se sustenta el primero para que sean cubiertos económicamente por el Estado y las instituciones públicas obligadas.

En otras palabras, la naturaleza jurídica de los gastos-derechos es diferente a la de los gastos-erogación, previstos o autorizados en el presupuesto, ya que los primeros se someten a principios y protecciones previstos en la norma constitucional y la ley para exigirlos o demandar su cumplimiento, mientras que los segundos son establecidos unilateral y discrecionalmente por las autoridades competentes respecto de obligaciones legales con o sin el acuerdo de sus beneficiarios.

Troya nos recuerda, citando a Juan Camilo Restrepo, que desde los años setenta del siglo pasado se ha puesto énfasis en el gasto y en su eficiencia para establecer en qué y cómo se gasta en lugar de la importancia que se da al cómo se aprueban o se ejecutan los gastos del presupuesto, con lo que se puede diferenciar mejor el derecho presupuestario del derecho del gasto, si bien, manifiesta, concordando con otros autores como Menéndez Moreno y Bayona de Perogordo, que el núcleo del derecho de los gastos públicos lo constituye el presupuesto, por lo que según dichos autores el derecho del gasto público se subsume en el derecho presupuestario. ${ }^{456}$

Para nosotros, el derecho presupuestario se refiere específicamente a la autorización y destino de los recursos que se asignan y a la extensa normativa sobre el ciclo presupuestario, mientras que el derecho del gasto involucra los principios y normas constitucionales y legales sobre los recursos que deben destinarse para cumplir con los fines del Estado y la satisfacción de los derechos económicos, sociales y culturales de los ciudadanos.

Sobre los principios y su normativa en la historia y en los modelos económicos entre 1990 y 2017 en Ecuador, nos referiremos a continuación.

\footnotetext{
${ }^{456}$ José Vicente Troya Jaramillo, El Derecho del gasto público, (Bogotá, Temis, 2014).
} 


\section{EL PRESUPUESTO Y EL GASTO EN LA HISTORIA Y EN LOS MODELOS ECONÓMICOS DE ECUADOR}

Existen numerosas referencias jurídicas y doctrinarias sobre la historia, origen y naturaleza jurídica, económica y política del presupuesto a nivel internacional, al que se encuentra asociado inicialmente el gasto en cuanto a su autorización y destinatarios, si bien las principales reflexiones sobre las relaciones de este con los derechos ciudadanos y su finalidad fiscal y extrafiscal surgen en el desarrollo del modelo intervencionista en el estado de bienestar y se expresan, con diferente connotación ideológica, en los modelos económicos subsiguientes, el neoliberal o neocompetitivo y el neoestructural o neointervencionista.

Héctor Villegas afirma en su Manual de Finanzas Públicas que todas las actividades financieras del Estado conducen al presupuesto y que el origen de la palabra presupuesto (budget) es común en el inglés y el francés, puesto que con ese término se denominaba a la carpeta o cartera de cuero del ministro del Tesoro Real, que contenía los documentos con el cálculo de los recursos y el estudio de las necesidades del país.

El referido tratadista también hace memoria política e histórica del presupuesto y asegura que sus antecedentes los encontramos en Inglaterra, en la carta magna de1215, cuando los barones del reino impusieron al monarca que ningún tributo se podía establecer sin el consentimiento del Consejo del Reino, lo cual fue ratificado en la Petición de Derechos de 1628 y en el Hill de Derechos de los Lores y los Comunes en 1689, en los que se ratifica que es ilegal toda cobranza de impuestos sin el consentimiento del Parlamento y se separan las finanzas de la Corona de las de la nación, diferenciando los gastos del Estado de los gastos del soberano y requiriéndose por tanto, que los gastos periódicos del Estado deban ser aprobados anualmente por el Parlamento.

Esta concepción se mantuvo, afirma, hasta el siglo XIX. Por ello, desde este punto de vista el presupuesto es primero el resultado político de las luchas por la supremacía entre el soberano y los representantes del pueblo. Posteriormente, dice, se obtuvo como conquista que la percepción de impuestos fuera autorizada solo por un año y que tanto los gastos como los recursos debían ser autorizados por ese período perentorio de tiempo, en un solo documento sometido a la aprobación del Parlamento. ${ }^{457}$

En su obra Derecho Económico, Marco Antonio Guzmán relaciona los diferentes conceptos que se tienen sobre el presupuesto con la evolución y papel que ha cumplido y cumple el Estado en la sociedad moderna y actual. En el Estado liberal moderno, dice, el presupuesto tenía magnitudes modestas que requerían el menor esfuerzo de los contribuyentes, mientras que en el Estado intervencionista, con un rol activo y dinámico

${ }^{457}$ Héctor B.Villegas, Manual de Finanzas Públicas, Ediciones de Palma, Buenos Aires, 2000. 
en la promoción del desarrollo de un país, el presupuesto se torna complejo y extenso para atender los requerimientos y las necesidades básicas y crecientes de la población.

El autor nos recuerda que Sáinz de Bujanda, en sus Lecciones de Derecho Financiero, afirma que en los inicios del Estado moderno hasta mediados del siglo XIX, en la etapa liberal, el principio de legalidad tributaria se considera inseparablemente unido al principio de anualidad del presupuesto y que por ello, el presupuesto era un acto de autorización simultánea tanto de los ingresos como de los egresos públicos. En cambio, indica, cuando el Estado asume un rol intervencionista en la economía y es protagonista en los servicios públicos y crecen sus necesidades financieras, se desconecta el sistema tributario de la aprobación anual del presupuesto y se manifiesta mediante leyes propias de cada tributo que se aplican independientemente de aquel, con la finalidad que los recursos fluyan con puntualidad y su recaudación sea eficiente, oportuna y sin limitación cuantitativa alguna. ${ }^{458}$

A esta concepción tradicional de presupuesto, dice nuevamente Villegas, deben agregarse, ya en el siglo XX, "las nuevas concepciones financieras traídas generalmente de la mano por las tesis intervencionistas, según las cuales deben operarse profundas transformaciones en la concepción del presupuesto, a causa de la cada vez mayor participación que se asigna al Estado en la actividad económica en general, cualquiera que sea su sistema de gobierno". Según estas ideas se considera al presupuesto como la "ley de leyes" que implica "un plan político", "un vehículo de solidaridad y una fuente de armonía entre las clases", para que "la acción estatal debe cumplirse conforme a un plan, del cual es manifestación esencial el presupuesto cuya noción tradicional se amplía en el tiempo (presupuestos plurianuales o cíclicos) y en el espacio (presupuesto económico) con alteración de ciertos principios considerados básicos en las concepciones clásicas". ${ }^{459}$

En su Introducción al Derecho Económico Jorge Witker ratifica la versión anterior y señala que en sus orígenes el presupuesto no fue otra cosa que un acto esporádico de autorización para controlar al rey; que luego quedó sumergido en la creciente actividad parlamentaria y que, con el desarrollo de esa práctica, adquirió, finalmente, una proyección inusitada que lo ha convertido en el resultado de un proceso de toma de decisiones más importante del Estado, lo cual le confiere una naturaleza eminentemente política. $^{460}$

El desarrollo del presupuesto como derecho presupuestario, esto es su conceptualización jurídica, se produce con la división de poderes y en el Estado liberal cuando su aprobación y el control del gasto los ejerce la función legislativa o el parlamento, como

\footnotetext{
${ }^{458}$ Marco Antonio Guzmán, Derecho Económico Ecuatoriano, Universidad Andina Simón Bolívar y Corporación Editora Nacional, Quito, 1996.

${ }^{459}$ Héctor B. Villegas, Manual de Finanzas Públicas, Ediciones de Palma, Buenos Aires, 2000, página 371.

${ }^{460}$ Jorge Witker, Introducción al Derecho Económico, (México: Oxford University Press Harla, 1997).
} 
instrumento de la soberanía popular para autorizar y vigilar la gestión financiera del Gobierno que no puede gastar sino lo que está previsto y en la cantidades que constan en el presupuesto.

A lo antes indicado habría que agregar, como ya lo hemos argumentado, que es en el intervencionismo estatal, ya en el siglo XX, el momento histórico en el que el gasto no solo es una contraparte de los ingresos en el presupuesto, sino que asume una connotación política y jurídica propia y requiere de reglas especiales, pues el Estado lo destina para atender derechos de los ciudadanos y para cumplir son su finalidad de satisfacer los servicios públicos, lo cual requiere de leyes y contratos y de decisiones administrativas que se expresan, frecuentemente, como políticas públicas o por medio de actos administrativos.

Durante el neoliberalismo, el presupuesto debe cubrir las necesidades mínimas del Estado, para lo que se requiere una política recaudatoria suficiente y eficiente para los ciudadanos; que no afecte a las empresas sobre las que recae la iniciativa económica y la provisión de empleo; que la distribución y captación de recursos se ejerza mediante una ampliación de la descentralización entre el Gobierno central y los gobiernos locales y que asegure el cumplimiento de las obligaciones estatales, especialmente las provenientes del endeudamiento público externo para asegurar el pago de la amortización del capital y el pago oportuno de los intereses. En este período las orientaciones que el poder público otorga al gasto tienen también esa connotación, ya que se asigna al Estado un papel subsidiario del mercado y el control o restricción del gasto público se convierte en factor para dinamizar la economía.

En el neointervencionismo o neodesarrollismo, el presupuesto y el gasto deben atender las necesidades crecientes de la sociedad y el desarrollo, para lo que se requiere una mayor cobertura tributaria aportada por el conjunto de la población y las empresas; la utilización del endeudamientos externo e interno para una mayor intervención en la economía y en la cobertura de las necesidades de infraestructura y servicios, en cuyo contexto las políticas, normas y decisiones sobre el gasto adquieren mayor autonomía frente a las decisiones políticas que están previstas en el presupuesto y en la planificación estatal.

En este contexto podemos distinguir cuatro etapas en la historia del presupuesto y del gasto en Ecuador:

\section{La primera etapa corresponde al Estado liberal (1830 - 1925)}

Esta etapa va desde la fundación de la República hasta la Revolución juliana. El presupuesto era entonces una autorización expresa del Congreso Nacional, para los ingresos y gastos de un Estado cuya actividad principal se reducía a la defensa externa, la seguridad y la administración de justicia. 
Según Eduardo Riofrío, durante los primeros cuarenta años de esta etapa, la erogación principal que contenía el presupuesto estaba destinado al gasto militar y administrativo en un 60 por ciento, por lo que "no quedaba gran cosa para las funciones fundamentales del Estado" sólo los gastos del ejército, en 1830, absorbieron "el $78 \%$ del presupuesto". ${ }^{461}$ Entre 1830 y 1850 los gobiernos destinaron menos del $10 \%$ de sus ingresos para educación, obras públicas y bienestar. Desde la presidencia de García Moreno en 1862 se recortó parcialmente el gasto militar y se destinaron fondos como "gastos ordinarios" del presupuesto para obras públicas y educación.

En la segunda mitad del siglo XIX, las fuerzas armadas consumieron entre un cuarto y un tercio de los ingresos ordinarios del gobierno, si bien en el Gobierno de Caamaño se destinó a los gastos militares, para sofocar rebeliones y conflictos internos, un $50 \%$ del presupuesto nacional. ${ }^{462}$ En la estructura del presupuesto, entre 1830 y 1878 , el servicio de la deuda, contratada especialmente con proveedores privados de la costa y luego con los iniciales bancos de esas región, consumió entre un cuarto y un tercio y hasta el $40 \%$ de los gastos presupuestarios. ${ }^{463}$

En materia presupuestaria, la ley de hacienda garciana (1863) dispuso que el ministro de Hacienda presentara al Congreso Nacional, en el inicio de sus sesiones, un proyecto de ingresos, gastos y de los empréstitos y contratos de crédito público para que fueran aprobados como una ley de presupuesto bianual, que a la vez creaba tributos y una nueva contabilidad por partida doble; autorizaba empréstitos y gastos y limitaba los poderes tributarios regionales.

Si bien se encontraban centralizados los sistemas de tesorería y contabilidad del Estado, para que estos se refirieran estrictamente al presupuesto en vigencia, la ejecución presupuestaria estaba formalmente a cargo del ministro de Hacienda, y en realidad en manos de los gobernadores, tesoreros y colectores que recaudaban, entregaban recursos y realizaban el asentamiento, registro y examen de los documentos y comprobantes de descargo y de los pagos a proveedores, empleados y tropas en cada una de las provincias del país.

En los gobiernos progresistas de Plácido Caamaño y de Antonio Flores Jijón, en la década del ochenta del siglo XIX, se continuó con la reestructuración del Estado y del sistema fiscal basado en tributo aduanero y se destinaron en el presupuesto fondos para la adquisición de armamento para la represión interna, para el pago de la deuda interna y limitadamente para educación y obras públicas, aprovechando el auge de las exportaciones de cacao. Las negociaciones con los tenedores de bonos de la deuda externa y la reanudación del pago del servicio de aquella en el Gobierno de Flores

\footnotetext{
${ }^{461}$ Eduardo Riofrío Villagómez, Tratado de Finanzas Públicas, (Quito: CCE, 1968), 375.

${ }^{462}$ Patricio Ycaza, Vega Silvia, Velasco Marco, Historia crítica de la República, (Quito: 1989.CONUEP, UCE, 1989).

${ }^{463}$ Linda Alexander Rodríguez, Estudio introductorio al Pensamiento Fiscal Ecuatoriano, volumen 41, Banco Central del Ecuador - Corporación Editora Nacional, Quito, 1996.
} 
permitieron la obtención de nuevos créditos para continuar la construcción del ferrocarril, pero se afectó significativamente al presupuesto fiscal.

Entre 1895 y 1925 se mantuvo en los gobiernos liberales una política fiscal fundamentada en la deuda interna con los bancos de la costa, especialmente con el Banco del Ecuador y el Banco Comercial y Agrícola, pues los ingresos estatales, provenientes principalmente del comercio exterior del cacao, no cubrían las crecientes actividades del Estado que asumió la ejecución de importantes obras públicas de infraestructura y las actividades educativas y previsionales que antes eran desempeñadas por la Iglesia católica.

El déficit presupuestario y los gastos crecieron mucho más entre 1910 y 1925 debido a las amenazas externas y los conflictos internos que incrementaron una vez más los gastos militares, todo lo cual se cubrió con agobiantes préstamos bancarios. La estructura del presupuesto en ese período que sobreestimaba los ingresos y subestimaba gastos que no era posible controlar, provocó un constante y abultado déficit. La situación fiscal se complicó durante la Primera Guerra Mundial por la disminución de exportaciones y por los ingentes gastos militares por conflictos internos y por la permanencia del mismo presupuesto en varios años, como resultado de la falta de acuerdo entre los legisladores sobre nuevas estimaciones, como ocurrió entre 1919 y $1924 .^{464}$

La crisis externa, el desplome de las exportaciones y del precio del cacao, las plagas agrícolas que diezmaron las plantaciones, el abuso financiero y de emisión monetaria de los bancos costeños, principales acreedores del Estado y la devaluación monetaria, crearon las condiciones para una transformación política y económica el 9 de julio de 1925, protagonizada por militares jóvenes y sectores medios y artesanales de la sociedad, un hecho que se identificó como Revolución juliana. ${ }^{465}$

\section{La segunda etapa corresponde al estado intervencionista y regulador (1926-1992)}

En materia presupuestaria esta etapa se inicia con la Revolución juliana y la Constitución de 1929 y se consolida más enfáticamente con las constituciones de 1945, 1946, 1967, 1978, hasta las reformas constitucionales y legales de 1992.

Se trata de una coyuntura en la que el Estado asume un papel protagónico en la economía y en la provisión de los servicios públicos, se reconocen los derechos económicos y sociales de los ciudadanos y se otorga una connotación especial a los gastos y los recursos públicos destinados a satisfacer las nuevas finalidades que se le asignan por mandato constitucional, expresando un nuevo pacto entre los grupos de poder y especialmente sus nuevos actores vinculados a la producción y los sectores

\footnotetext{
${ }^{464}$ Linda Alexander Rodríguez, Estudio introductorio al Pensamiento Fiscal Ecuatoriano, volumen 41, Banco Central del Ecuador - Corporación Editora Nacional, Quito, 1996.

465 Juan Paz y Mino, Revolución Juliana: Nación, Ejército y bancocracia, (Quito: Abya-Yala, 2000).
} 
sociales populares del campo y la ciudad que constituyen el sector mayoritario de la población.

Para satisfacer esas necesidades económicas y sociales, en el gasto y la inversión se introducen más tarde sistemas de planificación para la asignación racional de los recursos y una política fiscal intervencionista que requiere de mayores ingresos para cumplir con los nuevos objetivos de desarrollo y la satisfacción de los derechos ciudadanos.

El presupuesto se concibe inicialmente como una ley en la que se deben detallar todos los ingresos y especialmente los egresos del Estado, aplicando ampliamente los principios de unidad y especialidad y asignando las partidas correspondientes primero a las diferentes instituciones y luego a los diversos proyectos, programas y actividades gubernamentales.

Luego de un corto lapso de la inicial Revolución juliana, y ya en la segunda Junta Provisional de Gobierno, presidida por Isidro Ayora, con asesoría de la misión norteamericana presidida por Edwin Kemmerer, se dieron los pasos iniciales para el establecimiento de un Banco Central al conformar una Caja Central de Emisión y Amortización, y se formularon varios proyectos de ley para una organización del Estado, acorde con el contexto internacional, con la finalidad de organizar sus instituciones económicas y financieras y eliminar el sistema presupuestario vigente basado en constantes y crecientes déficits, para lo cual se propuso un nuevo ordenamiento con una revisión profunda del sistema impositivo y de la asignación adecuada de los fondos estatales.

La Ley Orgánica de Hacienda de Ecuador expedida el 27 de septiembre de 1928 bajo la inspiración antes indicada, marca el inicio de una institucionalización del presupuesto como un instrumento técnico y jurídico que debe definir las acciones y programas del Gobierno en un Estado intervencionista, generador de empleo, consumo y proveedor de servicios públicos. Se impone entonces un sistema dualista que divide al presupuesto en ordinario y extraordinario, el primero para cubrir los gastos de las funciones del estado, de organizaciones varias y las amortizaciones ordinarias de la deuda pública y el segundo destinado a cubrir la amortización extraordinaria de la deuda pública, a solventar a empresas u obras productivas de rentas y al fomento extraordinario de la educación pública.

La Constitución de 1929 es la primera en la historia constitucional del país que contiene normas especiales y precisas sobre el presupuesto y su administración, que será presentado anualmente por iniciativa del Ejecutivo con aprobación del Consejo de Ministros y dictamen del Consejo de Estado. Introduce el concepto de equilibrio entre ingresos y egresos que debe observar la ley de presupuesto y se prohíbe que se dicten leyes o modificaciones que lo alteren. Dispone que todos los ingresos y egresos deben constar en la ley de presupuesto; que no se pueden autorizar egresos que no consten en 
ella; que se debe conformar un Fondo General del Tesoro desde el que se asignan los egresos y que con los superávits se tendrá que conformar una reserva del tesoro de la que solo se podrán hacer retiros con disposición legal. La Constitución establece además un procedimiento especial de aprobación de la ley de presupuesto y se dictan normas expresas para prohibir que se destinen o financien egresos administrativos permanentes con empréstitos y se obliga a que en ella conste partida destinada al pago de la deuda pública y que se informe al Congreso sobre las causas de algún déficit que se produzca en la gestión presupuestaria. ${ }^{466}$

Las constituciones de 1945 y 1946 norman la estructuración del presupuesto en cuanto a ingresos y gastos y se asigna un papel gestor a una comisión técnica para elaborar la proforma y la intervención del Congreso en cuanto a su estudio y a la expedición de la ley. La Constitución de 1945 establece de manera expresa, una vez más, que se prohíban cubrir con empréstitos los egresos administrativos permanentes; que no se pueda expedir el presupuesto si no contiene partida destinada al pago de la deuda pública y que se invierta en la educación pública cuando menos el $20 \%$ de los ingresos ordinarios (Art. 123, 124 y 125), si bien la Constitución de 1946 eliminó el indicado porcentaje, estableciendo prioridad para los gastos destinados a defensa nacional y educación.

En los años 50, en el Gobierno de Galo Plaza, se recibe en el Ecuador la visita de una misión de Naciones Unidas integrada por los doctores Sunden y Deperón quienes, con la participación de técnicos nacionales, plantearon una serie de reformas que se recogieron en la Ley Orgánica de Hacienda en el título VI sobre el Presupuesto del Estado y en la Ley Orgánica del Presupuesto, promulgada el 16 de marzo de 1951, que sustituyeron el sistema de presupuesto ordinario y extraordinario, introducido por la misión Kemmerer. Lo dividieron en Presupuestos de Operación y de Capital y en Presupuestos Anexos para las Empresas del Estado, con la finalidad de introducir un régimen especial de principios nuevos de contabilidad y de presupuesto para las empresas estatales. $^{467}$

De igual manera, en los años siguientes, con el apoyo del Punto IV del programa de Alianza para el Progreso de los EEUU de América, se modernizaron los sistemas de contabilidad gubernamental y de control y se proyectaron modificaciones sobre el tratamiento de la deuda y crédito público, los activos generales del Gobierno y la introducción de los nuevos sistemas de auditoría. ${ }^{468}$

\footnotetext{
${ }^{466}$ Ecuador, Constitución Política de la República del Ecuador de 1929, Arts. 101-114, Registro Oficial 138, 26-mar.-1929.

${ }^{467}$ Ecuador, Ley Orgánica de Presupuesto, Decreto de Emergencia Nro. 538, Registro Oficial 769, 21 marzo-1951.

468 Estudio Introductorio a la Ley Orgánica de Administración Financiera y Control (LOAFYC),http://portal.uasb.edu.ec:2165/WebTools/eSilec ro/DocumentVisualizer/Document Visualizer aspx?id=HISTORIC-

LEY_ORGANICA_DE_ADMINISTRACION_FINANCIERA_Y_CONTROL_1977\&query=LOAFYC\# I_DXDataRow1
} 
En esta época se establecieron los principios y normas que regulan el proceso presupuestario, pero como dice la Introducción del Manual de Presupuesto por Programas, publicado por el Ministerio de Economía de entonces, todavía no es posible que el Presupuesto del Estado "constituya un Programa Financiero de la política gubernamental, sino más bien un instrumento que ha permitido llevar la contabilidad del gasto público y lograr el control de los fondos fiscales de una manera general”.

A partir de 1963 se decidió, por parte de la Junta Militar de Gobierno, cambiar el presupuesto tradicional por un nuevo "sistema presupuestario de programas, actividades $\mathrm{y}$ proyectos que permite evaluar los servicios que debe realizar el Gobierno, estableciendo prioridades en la ejecución de sus proyectos y determinando los logros a obtenerse en base a una eficaz utilización de los recursos disponibles", como lo explicó la Secretaría Técnica de la Administración creada para el efecto. Esto es, en este período se trasciende la concepción tradicional de presupuesto financiero a la de presupuesto económico. $^{469}$

En la Constitución de 1967-68, como ya había ocurrido con las constituciones de 1945 y 1946, se relativizó el precedente, existente desde los orígenes de la República, según el cual correspondía al presidente delegar al ministro de Hacienda la elaboración de la proforma presupuestaria, con la finalidad de que fuera una oficina fiscal, la Comisión Técnica de Presupuesto, integrada con representantes de las tres funciones del Estado con las orientaciones del Ministerio de Hacienda, la que elabore el proyecto de Presupuesto del Estado para que sea aprobado en el Congreso Nacional. En 1971, sin embargo, se prescindió también de dicha Comisión Técnica de Presupuesto y el ya entonces Ministerio de Finanzas, se convirtió en el único responsable de elaborar el proyecto de Presupuesto General del Estado. ${ }^{470}$

En la década de los años setenta la explotación petrolera cambió la estructura económica del país y de los ingresos del Estado, pues se modificó la Ley de Hidrocarburos favorable a las empresas extranjeras, con la finalidad de que cumpliera un papel activo en el desarrollo nacional, en la construcción de infraestructura y en la provisión de servicios públicos, mediante empresas y corporaciones estatales. El incremento de recursos petroleros y la liquidez en los mercados financieros internacionales relajó la recaudación de los ingresos tributarios internos y nuevamente aparecieron significativos déficits presupuestarios, financiados preferentemente, esta vez, con deuda externa.

En la dictadura militar progresista del general Guillermo Rodríguez Lara (1972-1976), una vez suprimido el Congreso Nacional, se crearon el Comité Nacional de Presupuesto

\footnotetext{
${ }^{469}$ Ecuador, Secretaría Técnica de Administración, Manual de Presupuesto por Programas, Casa de la Cultura Ecuatoriana. 1964, Quito.

${ }^{470}$ Ecuador, Presidencia de la República, Decreto 575, publicado en el Registro Oficial No. 207, 21 -abril1971.
} 
y la Comisión de Evaluación Presupuestaria ${ }^{471}$ y, dada la importancia que ese Gobierno otorgó a la planificación y al Plan de Desarrollo, se estableció una coordinación estrecha entre ellos, acorde con las doctrinas presupuestarias modernas, vinculadas al intervencionismo y al Estado social, que pretenden racionalizar el gasto, evaluar los proyectos y obras de desarrollo, orientar la política tributaria y financiera (en 1975 se expidió también el Código Tributario) y coordinar la planificación con las políticas fiscal y monetaria. Obviamente, los organismos antes indicados informaban al presidente de la República (dictadura) para que fuera él quien aprobara finalmente el Presupuesto General del Estado.

Esta etapa del intervencionismo estatal en la economía y de amplios subsidios a los grupos empresariales se completó con la expedición de una moderna la Ley Orgánica de Administración Financiera y Control en 1977 y regulaciones en la Constitución de 1978, cuyos propósitos fueron los de ordenar los sistemas gubernamentales de presupuesto, articulándolos al sistema nacional de proyectos y a los planes de corto, mediano y largo plazo, así como concentrar los recursos presupuestarios para optimizar los ingresos y gastos y racionalizar su uso, relacionando el sistema presupuestario con la planificación, la contabilidad y el control fiscales. Sin embargo, todo ello no fue suficiente para conjurar el desequilibrio fiscal, la expansión del gasto, el peso de la deuda externa y la transferencia de capitales al exterior.

La crisis de los años ochenta, monitoreada por los organismos financieros internacionales y particularmente por el FMI, mediante programas de ajuste y cartas de intención, obligaron a los gobiernos de turno, Hurtado, Febres Cordero y Borja (19811992) a la devaluación monetaria, reformas tributarias, reducción de los subsidios de los combustibles, control de los salarios, restricción del gasto público, incremento de las tarifas de los servicios públicos y la "sucretización" indiscriminada de la deuda externa privada primero y luego a su absorción estatal para, supuestamente, fortalecer la industria nacional y preservar las plazas de trabajo.

\section{La tercera etapa corresponde al modelo neoliberal desde 1990 hasta el 2005}

En la etapa de 1990 hasta 2005 las normas constitucionales y legales apuntaron inicialmente a sustituir el modelo intervencionista heredado de la Constitución de 1978 y su legislación por un modelo neocompetitivo con el que desmontar la hegemonía del Estado en la economía y especialmente en los sectores estratégicos y en la explotación de los recursos naturales; promover la descentralización hacia los gobiernos locales para debilitar al Estado central con el fin de controlar y limitar el gasto público y el objetivo de convertir al mercado y a la inversión extranjera en principal motor de la economía. Con esa idea se expidieron reformas constitucionales entre 1995 y 1996 que culminaron en la Constitución de 1998 que consolidó el modelo de "economía social de mercado" con la pretensión de promover la privatización y el traslado de las actividades

${ }^{471}$ Ecuador, Presidencia de la República, Decreto Supremo 293, 21-marzo-1973. 
económicas del Estado y los servicios públicos hacia el empresariado extranjero y nacional.

La normativa secundaria en el ámbito del gasto público y del presupuesto y su contenido y alcance se orientó para consolidar dichos objetivos, como lo veremos más adelante.

Esta etapa se inspiró en la doctrina neoliberal, las recomendaciones de los organismos financieros internacionales y en especial por las cartas de intención presentadas al FMI por los gobiernos ecuatorianos de Sixto Durán, Gustavo Noboa y Lucio Gutiérrez, en 1994, 2000 y 2002, estableciendo con ello un creciente tutelaje extranjero en la política fiscal y presupuestaria ecuatoriana.

Se introdujeron primero reformas y nuevas normas en las leyes económicas del país, con la expedición, en el Gobierno de Sixto Durán, el 26 de noviembre de 1992, de la Ley de Presupuestos y su Reglamento el 26 de febrero de 1993); la Ley de Modernización del Estado y la Ley de Instituciones del Sistema Financiero, etc., con la finalidad de favorecer el protagonismo del mercado en la asignación de recursos y un papel subsidiario del Estado respecto del sector privado. La política fiscal se orientó a la austeridad en el gasto para establecer el equilibrio presupuestario, la ejecución de planes de reducción de personal y de eliminación de subsidios y el incremento del precio de los derivados de los combustibles hasta alcanzar niveles internacionales.

En el Gobierno de Jamil Mahuad en 1998 se adoptaron medidas económicas para incrementar los ingresos y reducir los gastos públicos eliminando los subsidios al precio del gas de uso doméstico y a la tarifas eléctricas; se subieron los precios de los derivados del petróleo incluyendo el diésel y se estableció un "bono solidario" simbólico para compensar a los sectores más pobres de la población. Aceptando la exigencia de los grupos bancarios y financieros del país, representados por la alianza política socialcristiana-democracia popular, se expidió la Ley de Reordenamiento en Materia Económica en el área Tributario-Financiera. ${ }^{472}$

Como resultado de la crisis económica y financiera y de una inflación descontrolada, en enero de 2000 se adoptó la dolarización y un amplio subsidio estatal a los grupos bancarios y financieros. Luego del derrocamiento del gobierno de Mahuad (2000) se aprobó el 13 de marzo, por exigencia del FMI y, fundamentalmente para asegurar el pago de las deuda externa y estabilizar la economía nacional, la Ley de Transformación Económica en el gobierno de Gustavo Noboa. ${ }^{473}$ Y para reforzar la estructura de las finanzas públicas, atendiendo una nueva exigencia del FMI, el 4 de junio de 2002 se expidió además la Ley Orgánica de Responsabilidad, Estabilización y Transparencia Fiscal (LOREYTF), diseñada de manera expresa para controlar más drásticamente el

\footnotetext{
${ }^{472}$ Ecuador, Ley de Reordenamiento en Materia Económica en el área Tributario-Financiera, Registro Oficial Suplemento No. 78, 01-diciembre-1998.

${ }^{473}$ Ecuador, Ley de Transformación Económica, Registro Oficial Suplemento No. 34, 13-marzo-2000.
} 
gasto público y el endeudamiento, equilibrar las finanzas públicas, transparentar las cuentas fiscales y asegurar principalmente el pago de la deuda pública extranjera o su recompra. $^{474}$

Con todas las reformas y normas constitucionales y legales antes indicadas, cuyas repercusiones y contenido analizaremos más adelante, el presupuesto se convirtió una vez más en una iniciativa bajo un mayor control del Ejecutivo con reglas rígidas; el Congreso se limitó a aprobarlo por sectores de gasto sin poder realizar modificación alguna de fondo y se establecieron normas rígidas de aplicación y reglas físcales, impuestas en las cartas de intención con el Fondo Monetario Internacional, con la finalidad de controlar su crecimiento y ejecución para garantizar el control fiscal necesario y asegurar el pago puntual de las acreencias internacionales y su servicio.

\section{La cuarta etapa corresponde al modelo neointervencionista (2005 en adelante)}

Esta etapa, según nuestra opinión, se inicia en el 2005 con el gobierno de Alfredo Palacio y se consolida en el gobierno de la "revolución ciudadana" presidido por Rafael Correa entre 2007-2017, con la expedición de la Constitución de Montecristi en el 2008, que consolida el modelo económico neointervencionista o neoestructuralista $\mathrm{o}$ neokeynesino, que en esencia mantiene ciertos parámetros del modelo o de las políticas neoliberales y que fue ratificado luego por el Código Orgánico de Planificación y Finanzas (2010).

En este período (2005-2017) creció la crítica a los excesos del modelo neoliberal, alentada por la formulada por los organismos internacionales como la CEPAL, el propio FMI y el BM, desde inicios del nuevo siglo, conforme ya lo hemos indicado. Aprovechando el incremento internacional del precio del petróleo se adoptó, con los nuevos recursos, una política fiscal expansionista, para lo cual, en el gobierno de Alfredo Palacio se incluyeron en julio de 2005 reformas a la Ley Orgánica de Responsabilidad, Estabilidad y Transparencia Fiscal, un Reglamento sustitutivo para ella misma y se aprobó una Ley de participación de al menos el 50 por ciento en los excedentes del precio del petróleo, partiendo del monto en el que se negociaron los contratos de participación. ${ }^{475}$

Esta política se consolidó y amplió entre el 2007 - 2017, con la instalación del Gobierno de Rafael Correa, en el que se promueve, como hemos dicho, un modelo estatista neoestructuralista o neokeynesiano que mantiene ciertas políticas neoliberales en el ámbito fiscal, si bien en la renegociación final de los contratos petroleros se realizaron grandes concesiones en los precios de producción a las empresas

\footnotetext{
${ }^{474}$ Ecuador, Ley Orgánica de Responsabilidad, Estabilidad y Transparencia Fiscal, R.O. 589, 4-jun-2002.

${ }^{475}$ Ecuador, Reformas a la Ley Orgánica de Responsabilidad, Estabilidad y Transparencia Fiscal, L20054. Registro Oficial 69, 27-jul-2005; Reglamento Sustitutivo al Reglamento de la LOREYTF, Registro Oficial 131, 24-oct-2005; Ley Orgánica para la Recuperación del uso de las Recursos Petroleros del Estado; Ley No. 42-2006 Reformatoria a la Ley de Hidrocarburos, publicada en el Registro Oficial Suplemento Nro. 257, 25-abril-2006.
} 
transnacionales, con la apariencia de que se incrementó la participación estatal final en la renta petrolera. La Constitución de Montecristi de 2008 contiene en materia presupuestaria, siguiendo el esquema autoritario neoconservador adoptado finalmente por el Gobierno de Correa, un control máximo del Ejecutivo en la formulación, aprobación y ejecución de la proforma y del presupuesto del Estado siguiendo el modelo anterior, pero sometiéndolos al Plan Nacional de Desarrollo formulado por el mismo Gobierno y reduciendo la función legislativa a un papel decorativo de aparente vigilancia de los egresos públicos. El control del Ejecutivo se extiende a las posibles observaciones del Legislativo y a las probables reformas que se extienden a un 15 por ciento del presupuesto, con lo que se imposibilita su control parlamentario.

El Código Orgánico de Planificación y Finanzas Públicas ${ }^{476}$ (2010) que sustituyó a la Ley Orgánica de Administración Financiera y Control (1976), a la LOREYTF, Ley de Presupuestos del Sector Público y otras, dispone la estructuración de un Sistema Nacional de Finanzas Públicas bajo la rectoría del presidente de la República y del Ministerio de Finanzas, para "gestionar en forma programada los ingresos, gastos y financiamiento públicos con sujeción al Plan Nacional de Desarrollo y a las políticas públicas" (Artículos 70 y 71). El sistema y su normativa posterior tiene como componentes: la política y programación fiscal plurianual y anual, ingresos, presupuesto, endeudamiento público, contabilidad gubernamental y tesorería. Más adelante lo desarrollaremos extensamente.

\section{LOS PRINCIPIOS CONSTITUCIONALES, LEGALES Y DOCTRINARIOS SOBRE EL GASTO Y EL PRESUPUESTO ENTRE 1990 y 2017}

Como hemos señalado, existe controversia doctrinaria y jurídica sobre la naturaleza y contenido del derecho del gasto y del derecho presupuestario y también sobre la existencia o no del derecho constitucional del gasto y el derecho constitucional presupuestario.

Si se acepta la existencia del derecho del gasto con autonomía más didáctica que científica, es más difícil sostener la presencia autónoma de un derecho constitucional del gasto público. Así las cosas, la mayoría de tratadistas que ya hemos citado, aceptan la existencia del derecho presupuestario y aún del derecho constitucional presupuestario, pues al igual que el derecho constitucional financiero a diferencia del derecho del gasto y del derecho constitucional del gasto, contienen normas específicas que han sido introducidas en las constituciones a nivel internacional y desarrolladas por cuerpos y reflexiones jurídicos y aún por la jurisprudencia emitida por tribunales ordinarios y constitucionales a nivel regional y mundial. ${ }^{477}$

\footnotetext{
${ }^{476}$ Ecuador, Código Orgánico de Planificación y Finanzas Públicas, Registro Oficial 306 Segundo Suplemento, 22-oct-2010.

${ }^{477}$ José Vicente Troya, El Derecho del gasto público, (Bogotá: Editorial Temis, 2014).
} 
En todo caso, posponiendo discusión antes indicada, para nosotros es evidente que en la Constitución económica existe un contenido, orientaciones y principios sobre las finanzas públicas $\mathrm{y}$, obviamente, sobre el gasto y el presupuesto que se han implementado en el derecho local sobre la materia y que recogen los estudios iniciales de Eduardo Riofrío y los últimos de José Vicente Troya. ${ }^{478}$

En este estudio, que subraya la relación de las instituciones jurídicas financieras y administrativas con los modelos y políticas económicas impulsadas a nivel internacional y local por los sustentadores del sistema internacional, coincidimos con Troya: el derecho y la normativa autónoma sobre el gasto en la actualidad supera el enfoque estrictamente financiero tradicional o de instrumento administrativo, propio del derecho presupuestario, por uno que tiene el rol de instrumento de gobierno, pues se origina en las relaciones del gasto público con los derechos humanos y en especial con los derechos económicos, sociales y culturales de los ciudadanos.

Este enfoque, en el caso ecuatoriano, se inicia con el reconocimiento constitucional de los derechos económicos y sociales en el Estado social o intervencionista; se replantea luego con el modelo o políticas neocompetitivas para hacer prevalecer al mercado y reducir al Estado a un carácter subsidiario en el ejercicio de derechos y se actualiza y desarrolla, con los postulados generales del Estado de "derechos y justicia social" (2008), en el que la asignación de recursos corresponde a su obligación constitucional de satisfacer los derechos ciudadanos, individuales o colectivos, y a su carácter redistribuidor y promotor de la economía, para alcanzar el buen vivir o el sumak kawsay. Estos postulados constan también en la Declaración de Quito sobre la exigibilidad y realización de los derechos económicos, sociales y culturales (DESC) en América Latina y el Caribe (1998), emitida por personalidades y organizaciones de la sociedad civil de la región y que es el antecedente para la Carta Social de las Américas aprobada por la Asamblea General de la OEA en 2012, como instrumento obligatorio para los países y gobiernos de América. ${ }^{479}$

Troya enfatiza que el derecho del gasto tiene una "naturaleza especial" que, estando relacionado con el derecho presupuestario, se fundamenta en una concepción particularizada sobre la equidad y eficiencia para cumplir con su función financiadora del servicio público y del bien común, lo que además autoriza a los beneficiarios de los derechos a exigir que se eroguen los recursos necesarios para satisfacerlos. ${ }^{480}$

Con el principio de responsabilidad fiscal durante el modelo neoliberal se pretendía controlar, mediante fórmulas primero y luego regulaciones, el crecimiento del gasto público, especialmente el social, y asegurar el pago de las obligaciones crediticias

\footnotetext{
${ }^{478}$ Eduardo Riofrío Villagómez, Tratado de Finanzas Públicas, (Quito: Casa de la Cultura Ecuatoriana, 1968); José Vicente Troya, El Derecho del gasto público, (Bogotá: Editorial Temis, Bogotá 2014).

${ }_{479}$ Declaración de Quito de 24 de julio de 1998; Carta Social de las Américas, aprobada en la Cuadragésima Segunda Asamblea General de la OEA, el 4 de julio de 2012 en Cochabamba, Bolivia, reproducidas por José Vicente Troya como anexos en su libro El Derecho del gasto público, (Bogotá: Editorial Temis, 2014).

${ }^{480}$ José Vicente Troya, El Derecho del gasto público, (Bogotá: Editorial Temis, 2014).
} 
internacionales y el costoso servicio de la deuda. Se asociaba este principio al de conservatismo, para que las estimaciones de los ingresos fueran en los montos más modestos para evitar el crecimiento desmedido del gasto y para que este no tuviera sustento y financiamiento.

Durante el modelo neoliberal se introdujo, como dijimos, el principio de responsabilidad fiscal. En la actualidad se lo asocia a la sostenibilidad para procurar la estabilidad económica. El Código de Planificación y Finanzas dispone, como regla fiscal, que la conducción de las finanzas públicas sea de manera sostenible, responsable y transparente, lo que implica, aplicando los principios de unidad y universalidad también, que los egresos permanentes se financien única y exclusivamente con ingresos permanentes, si bien los ingresos permanentes pueden también financiar egresos no permanentes y los egresos permanentes se podrán financiar con ingresos no permanentes en situaciones excepcionales previstas por la Constitución para salud, educación y justicia, previa calificación de la situación excepcional realizada por la Presidencia de la República. (Art. 81)

El principio de transparencia obliga a las autoridades competentes a informar sobre la ejecución presupuestaria y es el que garantiza el derecho de las y los ciudadanos a estar informados de manera veraz sobre el destino y uso de los fondos púbicos.

Para el ejercicio de este principio es indispensable aplicar también el principio de publicidad que obliga a hacer conocer a la ciudadanía la totalidad del presupuesto en el Registro Oficial y toda la información de las etapas del ciclo presupuestario cuando cualquier ciudadano lo requiera, pues se trata del manejo de recursos públicos sobre los cuales no puede existir reserva alguna y constituye uno de los derechos y garantía constitucional. La publicidad y transparencia también deberían permitir a los ciudadanos tener acceso a los debates parlamentarios sobre los informes y la aprobación o formulación de observaciones al Presupuesto y a los fundamentos que el Ejecutivo formule cuando lo reforma o ejecuta. La Constitución de la República vigente dispone que "toda la información del proceso de formulación, aprobación y ejecución del presupuesto será pública y se difundirá permanentemente a la población por los medios más adecuados" (Art. 295 inciso cuarto).

Este principio se mantiene en los dos modelos económicos neoliberal y neointervencionista. La Constitución de 1998 preveía la información detallada al Congreso cada seis meses, la ejecución presupuestaria y su liquidación anual. La Constitución del 2008 dispone, así mismo, que la función ejecutiva informe semestralmente a la Asamblea sobre la ejecución presupuestaria y que la ley establezca las sanciones en caso de incumplimiento.

El Código Orgánico de Planificación y Finanzas, sin respetar la actual Constitución, omite prever las sanciones cuando no se presentan los informes de ejecución presupuestaria tanto a nivel nacional como local y se limita a establecer la obligación 
del ministro de Finanzas de informar semestralmente al presidente de la República y a la Asamblea sobre la evaluación financiera global del Presupuesto General del Estado. El presidente debe informar y no ser informado, ya que él y el ministro son los responsables del Sistema Nacional de Finanzas Públicas. También dice el Código que en los gobiernos autónomos descentralizados se aplicará la misma regla respecto de sus unidades financieras y que el ejecutivo de aquellos también presentará semestralmente un informe sobre la ejecución presupuestaria a sus respectivos órganos legislativos. (Art. 119 COPF).

El principio de anualidad y de plurianualidad. El primero obliga a la aprobación del Presupuesto General del Estado para el correspondiente ejercicio económico de cada año. El período anual se fijó desde antes y luego del surgimiento del estado de derecho, como una exigencia básica para que el soberano primero y luego la función ejecutiva pida autorización para establecer los tributos necesarios que cubran los gastos de la Corona primero y luego del Estado y del Gobierno en doce meses.

Pero ya en la época intervencionista, con la formulación de planes de desarrollo obligatorios en el sistema de economía centralmente planificada, o con planes de desarrollo indicativos en los sistemas económicos capitalistas mixtos, se planteó la necesidad de establecer presupuestos o estimaciones plurianuales, si bien en todos los países del mundo el Presupuesto del Estado se aprueba y rige cada año o por doce meses.

De acuerdo con la Constitución del 2008 se diferencia entre presupuesto con vigencia anual y programación presupuestaria cuatrianual, que es el tiempo de ejecución del Plan Nacional de Desarrollo. El Código Orgánico de Planificación y Finanzas vigente no incluye entre los principios del Sistema Nacional de Finanzas Públicas el principio de la anualidad sino el de la plurianualidad. Antes bien, en otras disposiciones del mismo lo reconoce tácitamente y en el artículo 110 cuando se refiere al ejercicio presupuestario o año fiscal dice que este se inicia el primer día de enero y concluye el 31 de diciembre de cada año.

El principio de oportunidad es aquel que impone que la elaboración del proyecto de presupuesto y el presupuesto mismo se tramiten en los tiempos que permitan recoger todas las necesidades de las instituciones públicas y para que la aprobación y observaciones se encuentren debidamente definidas por la Asamblea o por el cumplimiento de los plazos fijados en la Constitución y la ley, no solo para las etapas indicadas del ciclo presupuestario, sino incluso para la ejecución, el cierre y su liquidación.

Cuando en nuestro país se consideraba que el presupuesto era una ley formal del Estado y no se fijaban fechas o tiempos para su aprobación, los legisladores la prolongaban conforme a sus cálculos y negociaciones políticas en la asignación de los recursos públicos. El desorden fiscal era enorme, ya que en muchas ocasiones el presupuesto se 
aprobaba cuando ya había transcurrido el 60 y hasta el 80 por ciento del nuevo ejercicio económico o el año financiero, mientras se mantenía vigente el presupuesto del año anterior, si bien en la legislación presupuestaria y constitucional anterior establecía como límite final el 10 de septiembre del ejercicio fiscal, fecha en la cual entraba en vigencia el proyecto enviado por el presidente de la República.

Durante el período neoliberal (Constitución de 1998) se impuso un tiempo de sesenta días para la aprobación de la proforma presupuestaria antes de la vigencia del nuevo ejercicio fiscal. Si no se hacía en ese tiempo entraba en vigencia la proforma por ministerio de la ley. En la nueva Constitución del 2008, con la implantación del nuevo modelo neointervencionista, las reglas se restringieron mucho más, ya que el período de aprobación se redujo a 30 días, hasta el 30 de noviembre de cada año y las posibles modificaciones se tornaron imposibles por las reglas de votación que otorgan al Ejecutivo absoluta ventaja para que su decisión se imponga sobre cualquier pretensión parlamentaria. En todo caso, si transcurren los plazos señalados en la Constitución queda vigente el nuevo ejercicio fiscal, la proforma y las reformas que haya aceptado el Ejecutivo antes del inicio del nuevo ejercicio fiscal.

La desconcentración y descentralización operativas representa un principio que introduce una forma de gestión administrativa en el Presupuesto del Estado en lo operativo. La desconcentración se refiere a trasladar a entes jerárquicamente subordinados de las instituciones públicas que forman parte de la administración pública central e institucional y la descentralización a entes autónomos con personería jurídica propia, la capacidad de realizar la gestión financiera en su fase operativa o de aplicación.

Con este principio se pretende agilizar la administración financiera del Estado, que, como hemos visto, está profundamente centralizada en cuanto a políticas y definiciones y decisiones establecidas por las máximas autoridades que ejercen la rectoría de los diversos componentes del Sistema Nacional de Finanzas Públicas.

El Código Orgánico de Planificación y Finanzas prevé, en el contexto de la desconcentración, una amplia delegación de facultades, al disponer que el ministro a cargo de las finanzas públicas podrá delegar por escrito las facultades que estime convenientes. La norma establece, nos parece irresponsablemente, que los actos administrativos ejecutados por los funcionarios, servidores o representantes especiales o permanentes delegados para el efecto por el ministro tendrán la misma fuerza y efecto que si los hubiera hecho el titular y la responsabilidad corresponderá al funcionario delegado (Art. 75).

La participación es un principio que consta actualmente en la Constitución como uno de sus componentes transversales. En materia de las finanzas públicas y más concretamente en materia presupuestaria se trata de otorgar a las y los ciudadanos la posibilidad de incidir en las decisiones y en el control de sus diferentes fases. 
En los niveles de los gobiernos locales se habla de la elaboración de presupuestos participativos con la integración de las juntas parroquiales y las organizaciones de vecinos y sociales. Pero en el nivel nacional no se define con claridad en la Ley Orgánica de Planificación y Finanzas cuáles son los mecanismos concretos para propiciar la participación ciudadana en decisiones que están concentradas en los entes rectores del sistema, esto es en el presidente de la República y en el Ministerio de Finanzas. Parece más un enunciado que se repite constantemente y que es de difícil aplicación en un modelo ultraconcentrado de decisiones políticas y financieras.

De lo visto, si bien existen diferencias en la formulación y aplicación de los principios presupuestarios formulados por la Constitución y en las leyes que regulan las finanzas públicas, en los dos modelos, monitoreados por los organismos financieros (BID, FMI, CEPAL) internacionales, se coincide en la necesidad de que la política fiscal, en manos del Estado, persiga el equilibrio y su sostenibilidad presupuestaria para que sea el mercado el que cumpla su función impulsora de la economía o para que el propio poder público y el Gobierno impulsen el desarrollo mediante el ejercicio de actividades económicas o insuflando los recursos necesarios para el desarrollo nacional en el marco de consolidar el sistema mundial de acumulación capitalista en el que se inscriben.

Las normas, leyes, decisiones de política económica y fiscal, así como la enunciación y conceptualización de los principios presupuestarios sobre el gasto y el presupuesto tienen, sin duda, una especial connotación y continuidad en los modelos económicos y políticos aplicados en el Ecuador de manera sucesiva y simultánea en Ecuador entre 1990-2005 y entre 2006 y 2017.

\section{NORMATIVA CONSTITUCIONAL Y LEGAL SOBRE EL GASTO Y EL PRESUPUESTO EN EL PERIODO NEOLIBERAL 1990-2005 Y EN EL NEOINTERVENCIONISTA 2005-2017}

Para culminar este capítulo nos referiremos al contenido de la normativa constitucional y legal sobre el gasto y el presupuesto y sobre su ejecución, como instrumento clave de la política fiscal, tanto en el período en que se privilegiaron las políticas o modelo neoliberal o neointervencionista entre 1990-2005 como en el modelo o en la aplicación de las políticas neointervencionistas o neodesarrollistas entre 2006 y 2017, año en el que finaliza la década de Gobierno de Rafael Correa.

\subsection{Periodo neoliberal 1990-2005}

En el primer período diferenciamos dos fases que tienen una connotación especial en la política fiscal y en la normativa adoptada para aplicarla: la de antes de la dolarización (1990-1999) y la posterior a la dolarización 2000-2005. 
En el período neoliberal o de políticas neocompetitivas (1990-2005) bajo el auspicio de los organismos financieros internacionales y la carta de intención presentada al FMI por el Gobierno de Durán Ballén en 1992-93 como ya lo hemos indicado, se dictó inicialmente la Ley de Presupuestos del Sector Público y su reglamento; se introdujeron, luego, en 1995-1996, reformas constitucionales para consolidar las modificaciones que la referida ley planteó a las normas para regular el gasto público y el presupuesto en el modelo intervencionista; posteriormente, el proceso de reformas legales e institucionales culminó con la Constitución de 1998, con la finalidad de favorecer la prevalencia del mercado, la descentralización, el desmantelamiento de la actividad económica del Estado y la promoción de las privatizaciones de las actividades económicas públicas, destinadas a explotar los recursos y los servicios públicos.

La Ley de Presupuestos del Sector Público y su reglamento $(1993,1994)$ pretendieron asegurar la ejecución eficiente del presupuesto público, fortaleciendo la capacidad de control en la asignación y en el gasto por parte del Gobierno central por medio del Ministerio de Economía y Finanzas; prohibieron de manera expresa la administración de recursos financieros y donaciones fuera del presupuesto que debía estructurarse con sujeción a los principios de universalidad y unidad. En las reformas fiscales y tributarias consiguientes se fortalecieron los ingresos del presupuesto ampliando la base social media y popular de los contribuyentes y de los agentes del sector informal y restringiendo el acceso del sistema público no financiero al crédito interno del Banco Central. También la Ley de Presupuestos, cumpliendo fines extrafiscales, persiguió manejar el presupuesto en un contexto más amplio que el financiero o de caja, con el objetivo de redimensionar las funciones y el tamaño del aparato del Estado. ${ }^{481}$

En las reformas constitucionales aprobadas en 1995 y 1996 se introdujeron normas para controlar parcialmente el gasto público; se dispuso de manera expresa que la proforma presupuestaria se planteara por el presidente de la República al Congreso Nacional hasta el primero de septiembre de cada año; que el presupuesto se aprobara por sectores de gastos para evitar su manipulación en las partidas y que si existieran discrepancias sobre el contenido presupuestario en la Comisión Legislativa, estas tendrían que ser resueltas por el Pleno del Congreso hasta el 31 de diciembre de cada año, sin que el Ejecutivo las pudiera objetar. ${ }^{482}$

En la Constitución de 1998 (Artículos 258-260) se ratificó que la formulación de la proforma presupuestaria corresponde a la función ejecutiva hasta el 1 de septiembre de cada año con un informe del Banco Central, que según esa carta política es un ente autónomo del Gobierno. Dispuso la Constitución que el Congreso en pleno aprueba o reforma la proforma por sectores de ingresos y gastos hasta el 30 de noviembre y si no

${ }^{481}$ Ecuador, Ley de Presupuestos del Sector Público, 18-PCL, Registro Oficial-S 76, 30-nov-1992; Reglamento a la Ley de Presupuestos del Sector Público, DE-529-A. Registro Oficial-2S 136, 26-feb1993.

${ }^{482}$ Ecuador, Primer bloque de reformas a la Constitución: Registro Oficial-S 618: 24-ene-95; Reformas 2do y 3er bloque: Registro Oficial 863,16-ene-96. 
lo hace hasta esa fecha entra en vigencia por el ministerio de la ley y que en la ejecución presupuestaria se deberá contar con la aprobación del Congreso para incrementar los gastos más allá del porcentaje legal, que puede ser establecido según la conveniencia de los intereses políticos en juego. A las preasignaciones presupuestarias, establecidas para educación, erradicación del analfabetismo y salud, se agregó la del 15 por ciento a favor de los organismos del régimen seccional autónomo, con la finalidad de favorecer la descentralización estatal y reducir el tamaño y los gastos del Estado central dentro del programa de modernización de la Administración pública.

Como se puede advertir, en el modelo neoliberal se restringió mucho más la intervención del Congreso y los legisladores en los asuntos presupuestarios, con la finalidad de controlar la expansión descontrolada del gasto y se fortaleció el papel del Ejecutivo en la definición y ejecución de los gastos, con la finalidad de que este orientara la gestión del Estado según los intereses del modelo económico.

Como paso previo a la crisis financiera de 1999 y 2000, en la que se declaró un feriado bancario y se dispuso el congelamiento y de fondos privados por espacio de un año, se expidió previamente la Ley de Reordenamiento en Materia Económica en el área Tributario-Financiera, ${ }^{483}$ en la que se estableció el impuesto del 1\% a la circulación de capitales para involucrar a todas las transacciones monetarias que realizaban las instituciones del sistema financiero; se suprimió el impuesto a la renta y se creó la AGD para garantizar, sin límite y con recursos públicos, el cien por ciento de los depósitos en el sistema financiero, todo ello como antecedente para favorecer la disposición arbitraria de recursos públicos que se produjo con el congelamiento de fondos privados y la dolarización, decretados por el presidente de la República. ${ }^{484}$

El abuso de fondos públicos y privados en el Gobierno de Jamil Mahuad culminó también con la dolarización y la pérdida para el Estado de la política monetaria, como medida radical para detener la hiperinflación y el total desajuste de la política económica. $^{485}$

Frente a ello, los organismos internacionales y particularmente el FMI, en los condicionamientos establecidos como resultado de la carta de intención presentada por el Gobierno de Gustavo Noboa en 2000, se expidió la Ley de Transformación Económica, en la que se dispuso implícitamente sobreexplotar los campos petroleros y acceder a los ingresos por hidrocarburos y sus derivados, no previstos o superiores a los contemplados en el presupuesto, para conformar un Fondo de Estabilización, Inversión Social, Productiva y Reducción del Endeudamiento Público del que se destinaba $45 \%$

\footnotetext{
${ }^{483}$ Ecuador, Ley de Reordenamiento en Materia Económica en el área Tributario-Financiera, Registro Oficial Suplemento No. 78, 01-diciembre-1998.

${ }^{484}$ Ecuador, Presidencia de la República, Decreto 681 de 9-marzo-1999, Registro Oficial 148, 15 -marzo1999; y Decreto 685, 11-marzo-1999, Registro Oficial No 149, 16-marzo-1999.

${ }^{485}$ Ecuador, La AGD calculó en más de 8.000 millones de USD el impacto negativo que en los recursos del Estado ocasionó hasta 2009, el congelamiento de fondos y el abuso de fondos públicos para enfrentar la dolarización
} 
para el pago de la deuda pública y su servicio, 35\% para financiar la rectificación y pavimentación de la vía troncal amazónica, 10\% para proyectos de desarrollo de las provincias de Esmeraldas, Loja, el Oro y Galápagos y 10\% para el equipamiento y fortalecimiento de la Policía Nacional. ${ }^{486}$

Los gobiernos de turno en Ecuador en la década del noventa del siglo pasado trataron de controlar los problemas de la economía y promover el crecimiento y la estabilidad con hegemonía del mercado, mediante el ejercicio de la política monetaria y cambiaria y mediante el control del gasto y los presupuestos con la legislación antes indicada. A pesar de ello, las metas de crecimiento y estabilidad no se alcanzaron por la persistencia del déficit, al no haber podido articular el gasto con la planificación, la duplicidad de funciones entre las instituciones públicas, la ineficiencia administrativa, la falta de recursos y la mala recaudación y por las consecuencias de acontecimientos especiales como la guerra con el Perú (1995) y el deterioro de los precios internacionales del petróleo (1997-8) y otros.

Si se revisan los presupuestos del Estado en Ecuador, entre 1994 y 1999, en cuanto a sus ingresos existía una dependencia de casi el 50 por ciento de recursos provenientes de la exportación petrolera y comercialización de derivados, en un contexto de variación radical de los precios internacionales del petróleo. En 1994 el precio del barril ascendía a 18,02 USD, mientras que en 1998 bajó a 9,20 USD. La política tributaria, a la vez, se fundamentó principalmente en impuestos indirectos con fines fundamentalmente recaudatorios, sin otorgarle ningún papel a iniciativas que promovieran la redistribución de la riqueza y objetivos de reactivación económica, pues se consideraba que la tributación directa disminuía la inversión y el empleo, tanto que incluso se llegó a sustituir el impuesto a la renta en 1999 por un impuesto a la circulación de capitales.

En cuanto a la estructura del gasto, dichos presupuestos (1994-99), si bien estaban ordenados por la Ley de Presupuestos antes indicada con normas sugeridas por los organismos financieros internacionales, establecieron una composición del mismo en el que se destinó el $48 \%$ a la amortización y servicio de la deuda externa, el $30 \%$ a servicios administrativos y solo el $17 \%$ al gasto social de salud, educación, vivienda y trabajo, en el que a la vez el $72 \%$ fue destinado a gastos corrientes y el $26 \%$ a inversión. ${ }^{487}$

Siguiendo las reglas fiscales del neoliberalismo en estos años el presupuesto creció anualmente en porcentajes menores a la inflación, pues no se lo consideró un instrumento para el desarrollo con metas, actividades y resultados. De las rentas que ingresaron al presupuesto el $75 \%$ tienen destino específico, en el que más del $50 \%$ se asignó para satisfacer compromisos de deuda interna y externa, un tercio para gasto corriente y una décima parte para inversión. Las rentas fiscales estaban predeterminadas en buena parte con fines políticos y tenían destinos específicos y preasignaciones

\footnotetext{
${ }^{486}$ Ecuador, Ley de Transformación Económica, Registro Oficial Suplemento Nº. 34, 13-marzo-2000.

${ }^{487}$ María Elena Haro C, La política Fiscal ecuatoriana a partir de la dolarización. 2002-2002, (Tesis de maestría en relaciones internacionales, mención en economías y finanzas, U.A.S.B., Quito, 2002).
} 
establecidas en la Constitución y la ley. En cuanto al déficit presupuestario, si en 1980, en la época intervencionista, alcanzó el 7,4\% del PIB y se redujo a inicios de la década del 90 a menos del 1\%, en 1999 nuevamente se incrementó al 7,2\%. La deuda externa e interna que en 1992 representó el 101,8\%; en 1996 el 85,4\% y en 1999 el 138,3\% del PIB, si bien en 1996 disminuyó al 65,4\% y en 1997 al 63,2\% del PIB, como resultado de las renegociaciones (plan Brady y el de eurobonos) facilitadas por los mismos organismos financieros internacionales. El servicio de la deuda entre 1996 y 1999 representó el $45 \%$ de los recursos del presupuesto estatal. ${ }^{488}$

Las disposiciones legales y constitucionales antes indicadas, en los dos momentos que se pueden distinguir en la aplicación de las políticas neoliberales -antes y después de la dolarización-, pretendieron superar los reiterados desajustes en la balanza de pagos, el aumento progresivo de precios, el incremento agobiante de la deuda externa y la inflación, etc., para lo cual, con el monitoreo de los organismos financieros internacionales y particularmente del FMI (1993-4; 2000 y 2002), se acordaron primero políticas y programas de reestructuración económica y estabilización financiera y luego, con la dolarización, se adoptaron medidas adicionales para transformar la política fiscal en el principal instrumento de estabilización de la economía y asegurar el pago de las obligaciones internacionales.

Luego de la dolarización en Ecuador, a inicios de 2000, las políticas neoliberales se orientaron fundamentalmente al control de los presupuestos y de la política fiscal. La dolarización significó para el país, en el campo económico, el despojo definitivo de las políticas monetarias y cambiarias como instrumentos a los que constantemente recurrían los gobiernos de turno para lograr los reiterados ajustes en su economía y alcanzar los equilibrios económicos necesarios. En esas condiciones, el ajuste y el equilibrio de la economía se deben conseguir mediante una política fiscal que optimice los recursos con sus ingresos permanentes, con una política de gasto que se ajuste a ellos y que utilice discretamente el endeudamiento público para alcanzar estabilidad y desarrollo.

El Presupuesto del Estado fue reajustado en los primeros meses de 2000, con la autorización de la Ley Reformatoria a la Ley para la Transformación Económica del Ecuador $^{489}$ con la finalidad de adecuarlo al nuevo modelo económico, ajustando las cuentas de ingresos y gastos. Los ingresos se incrementaron como resultado de una mejor recaudación tributaria $(12,5 \%$ del PIB) y con el incremento de los precios del petróleo que llegó al 9,1\% del PIB. Los gastos totales disminuyeron en 29\% en relación con 1999 y el gasto del gobierno bajó del 33,27\% a 23,4\% del PIB en el 2000. La composición del gasto total contempló 46,8\% del presupuesto para amortización e intereses de la deuda, la misma que se redujo con las renegociaciones con el Club de París. La política fiscal se orientó a disminuir el déficit de financiamiento del 13,9\% al

\footnotetext{
${ }^{488}$ María Elena Haro C, La política Fiscal ecuatoriana a partir de la dolarización. 2002-2002, (Tesis de maestría en relaciones internacionales, mención en economías y finanzas, U.A.S.B., Quito, 2002).

${ }^{489}$ Ecuador, Ley Reformatoria a la Ley para la Transformación Económica del Ecuador, Registro Oficial 48, 31-mar-2000.
} 
1,14\%. En la ejecución del presupuesto del primer año de dolarización se destinó el $53,95 \%$ a pago de intereses y amortización de la deuda pública $(24,4 \%$ a la deuda interna y 29,26\% a la deuda externa); $17,1 \%$ al sector social; $5,72 \%$ a defensa; $7,3 \%$ a desarrollo seccional; 4,9\% a inversión y un volumen importante de más de ciento sesenta y cinco millones de dólares para que la AGD cubra las obligaciones de la banca privada que colapsó en el año anterior. ${ }^{490}$

El dramático equilibrio logrado con la dolarización y la devaluación inicial de 25.000 sucres por dólar para convertirla en camisa de fuerza de la economía, reprodujo en los años siguientes los persistentes desequilibrios entre ingresos y gastos y el incremento de estos como resultado del aumento en las demandas regionales y locales, y del déficit y del endeudamiento interno y externo, todo lo cual reproduce los problemas que se tenían antes del macroajuste de la economía nacional, afectando a la desigual distribución del ingreso, al desmantelamiento de los programas sociales y al ejercicio de derechos de la mayoría de la población.

Por ello, adicionalmente se expidió en 2002 la Ley Orgánica de Responsabilidad, Estabilización y Transparencia Fiscal (LOREYTF) que establecía inicialmente porcentajes y fórmulas para limitar el incremento de la proforma presupuestaria en su conjunto y en especial para el crecimiento de los gastos corrientes a excepción de los destinados a la amortización y servicio de la deuda externa. La Ley dispuso también la unificación de las finanzas públicas con la planificación, la elaboración del presupuesto anual y su proyección plurianual; la observancia de reglas macro-fiscales de gasto; el establecimiento de un límite para el endeudamiento que no debía superar el $40 \%$ pues este llegó en el 2001 al 76,7\% del PIB; la adopción de transparencia en las cuentas fiscales y la posibilidad de que se ejerza sobre ellas control ciudadano y la creación de un Fondo de Estabilización y recompra de deuda pública (FEIREP) conformado por los recursos adicionales provenientes del nuevo oleoducto de crudos pesados (OCP) que se construyó en esos años con la inversión de las empresas petroleras y su amortización para el traslado de combustibles que principalmente pagó el Estado.

La LOREYTF también estableció dos reglas fiscales que debían ser observadas por la proforma presupuestaria y el presupuesto del Estado. La primera fue que "el gasto primario del gobierno central, entendido como gasto total excluidas las asignaciones destinadas al pago de intereses de la deuda pública interna y externa (y las amortizaciones), no se incrementará anualmente en más del 3,5\% en términos reales determinados considerando el deflactor implícito del Producto Interno Bruto, el mismo que será publicado por el Banco Central del Ecuador y constará dentro de las directrices presupuestarias”; y, segunda: “ el déficit resultante de los ingresos totales, menos los

\footnotetext{
${ }^{490}$ María Elena Haro C, La política Fiscal ecuatoriana a partir de la dolarización. 2002-2002, (Tesis de maestría en relaciones internacionales, mención en economías y finanzas, U.A.S.B., Quito, 2002).
} 
ingresos, por exportaciones petroleras y menos gastos totales, se reducirá anualmente en 0,2\% del PIB hasta llegar a cero"( Art. 3).

Disponía además dicha Ley: "los presupuestos que contienen los gastos operativos corrientes de cada una de las instituciones del sector público financiero no se incrementarán anualmente en más del $2,5 \%$ en términos reales, determinados considerando el deflactor implícito del PIB, el mismo que será publicado por el Banco Central del Ecuador y constará dentro de las directrices presupuestarias" (Art. 4). ${ }^{491}$

Como se puede observar, en los años siguientes a la dolarización, pese a los correctivos legales antes indicados, la economía de Ecuador y su política fiscal continuó sufriendo un acelerado deterioro en los indicadores económicos, por la mala distribución del ingreso, la inadecuada distribución de los recursos entre los sectores de la economía y en los organismos públicos mediante partidas extrapresupuestarias y dispendios por motivaciones políticas, afectando especialmente a los sectores populares de menos ingresos. Todo ello pone de manifiesto que las diferentes políticas económicas neoliberales, finalmente tuvieron resultados similares en cuanto a inequidad e irracionalidad, a las políticas intervencionistas que se pretendían combatir con el cambio de modelo, pues se mantiene el desequilibrio financiero, económico y social.

\subsection{Etapa neointervencionista: $2005-2017$}

La etapa neointervencionista o neoestructuralista que se inició desde 2005 hasta 2017 matizó la aplicación del modelo neoliberal anterior con las políticas neoestatistas promovidas por los organismos financieros internacionales y de desarrollo, conforme ya lo hemos detallado.

Las políticas fiscales sobre los ingresos, el gasto, el presupuesto y deuda (2005-2017) constan, tanto en la legislación inicial adoptada en el Gobierno de Alfredo Palacio en 2005, como en las normas tributarias y en las políticas de gasto adoptadas por el Gobierno de Rafael Correa desde 2007, que reformaron la entonces vigente Ley Orgánica de Administración Financiera (1976) y la Ley General de Presupuestos del Sector Público (1993) y que culminaron con las normas de la nueva Constitución de Montecristi de 2008 y la nueva legislación sobre la materia que se expidieron hasta la promulgación del Código Orgánico de Planificación y Finanzas Públicas (2010), sobre cuyas normas realizaremos también algunas reflexiones y precisiones, en el contexto de un nuevo momento histórico en la economía mundial, regional y local.

Esta etapa se inicia, como ya lo dijimos, en la presidencia de Alfredo Palacio, con las reformas en 2005 a la Ley Orgánica de Responsabilidad, Estabilización y Transparencia Fiscal -LOREYTF- (2002), que tenían la finalidad de reintroducir un nuevo

\footnotetext{
${ }^{491}$ Ecuador, Ley Orgánica de Responsabilidad, Estabilidad y Transparencia Fiscal, Registro Oficial 589, 4-jun-2002.
} 
intervencionismo estatal para fomentar la inversión y el incremento patrimonial del Estado, modificando y combinando el objetivo inicial de la "estabilización fiscal", propio del neoliberalismo, con el de la "reactivación productiva y social, de desarrollo científico-tecnológico y de la estabilización fiscal", para lo cual se incrementan los ingresos del presupuesto con ingresos petroleros adicionales. Como parte del Presupuesto General del Estado en el Banco Central se creó una cuenta especial con dicho nombre -Cuenta Especial para la Reactivación Productiva y Social (CEREPS)-, autónoma e independiente de la cuenta corriente única del Tesoro Nacional, para destinar sus recursos a líneas de crédito con intereses preferenciales, con el objeto de financiar proyectos productivos; la cancelación de la deuda del Estado con el IESS; la recompra de deuda pública externa o interna y la ejecución de proyectos de infraestructura para elevar la productividad y competitividad del país, proyectos de inversión social, mejoramiento vial, etc. También se creó un Fondo de Ahorro y Contingencia para estabilizar los ingresos petroleros con un directorio de un fideicomiso administrado por el Banco Central, a la vez que se declararon secretos, reservados y punibles, los decretos que autoricen la recompra de deuda pública.

Dichas reformas eliminaron también el Fondo de Estabilización, Inversión Social y Productiva y Reducción del Endeudamiento Público, FEIREP, que inicialmente estaba destinado en un $70 \%$ a la recompra de deuda pública externa e interna, el $20 \%$ para estabilizar los ingresos petroleros y sólo el 10\% para promover el desarrollo humano en educación y salud, si bien se mantuvieron otros fondos como el FEISEH (Fondo Ecuatoriano de Inversión en Sectores Energéticos e Hidrocarburíferos), el FEP (Fondo de Estabilización Petrolera) y el FAC (Fondo de Ahorro y Contingencia) y sus recursos acumulados se utilizaron, posteriormente, para operaciones de recompra de deuda externa por parte del Gobierno de Rafael Correa. ${ }^{492}$

En el presupuesto de 2006 se consideraron las reformas legales antes indicadas, la necesidad de mantener las reglas fiscales y los fondos señalados y las reformas aprobadas a la Ley de Seguridad Social que autorizaron la devolución de los fondos de reserva del IESS a los afiliados, con la finalidad de favorecer la liquidez y reactivar el consumo de la población, proceso apoyado por los recursos provenientes de las remesas de los migrantes, la incorporación de los fondos del desaparecido FEIREP al presupuesto, el repunte de las importaciones de bienes y servicios, todo lo cual determinó un efecto inflacionario, pese a la rigidez de la dolarización. El Banco Central advirtió al Congreso Nacional sobre la necesidad de mantener una política fiscal segura mediante la aplicación de las reglas fiscales indicadas que no afectaban a la inversión y al pago de la deuda pública y una administración de las finanzas públicas con un horizonte de plazo mayor al año, aumentando los gastos de capital y la preservación de

\footnotetext{
${ }^{492}$ Ecuador, Reformas a la Ley Orgánica de Responsabilidad, Estabilidad y Transparencia Fiscal, L20054, Registro Oficial 69, 27-jul-2005; Reglamento Sustitutivo al Reglamento de la LOREYTF, Registro Oficial 131, 24-oct-2005.
} 
los fondos de estabilización para proteger a la economía nacional de la crisis y de los choques externos y desajustes internos. ${ }^{493}$

Para consolidar el modelo neointervencionista y neodesarrollista fundamentado en el gasto, el consumo y la inversión y una limitada redistribución del ingreso, el Gobierno de Rafael Correa expidió en sus primeros años de gobierno la Ley Orgánica para la Recuperación del Uso de los Recursos Petroleros del Estado y la Racionalización Administrativa de los Procesos de Endeudamiento ${ }^{494}$ y en virtud de ella, desde su inicio abolió también los fondos de ahorro (FEISEH, CEREPS, FEP Y FAC) conformados después de la dolarización para asegurar principalmente el pago de la deuda externa y en menor proporción para financiar obras de desarrollo y gasto social.

En los presupuestos de 2007-2012 dictados en los cinco primeros años del Gobierno de Correa se puede observar una consolidación y ampliación de la política neodesarrollista y neointervencionista que fue posible con el incremento de los ingresos hidrocarburíferos por el aumento de precio internacional del petróleo (entre 2000-2006, el precio promedio fue de 31,27 por barril y entre 2007-2012, de 77,51 por barril ) y de la recaudación tributaria que entre 2006 y 2007 pasó de 6.436,5 MUSD a 7.286,5 MUSD y en 2012 alcanzó a la suma de 15.426 millones USD. En cuanto al endeudamiento total, en 2007 fue de 3.036,1 MMUSD (1.356,7 deuda externa y 1.679,4 deuda interna) y en 2012, llegó a 5.724,5 millones USD (1.970,2 deuda externa y $3.754,3$ deuda interna). Respecto al gasto corriente destinado a sueldos y salarios para 356.119 empleados públicos, en 2007 fue de US\$ 3.692,6 millones, con un promedio mensual para cada funcionario de 864,08 USD y en 2012 para 465.000 empleados se destinaron \$ 8.345,5 millones USD, con un promedio mensual de \$1.494,95 USD. Los gastos de capital se incrementaron también significativamente: si en 2000 llegaron a \$782,2 millones USD, en 2012 a \$ 10.359,7 millones USD. En el período 2007-2012 los recursos de capital se destinaron principalmente a vialidad y obras públicas. En cuanto al gasto social (educación, salud, vivienda, trabajo y bienestar social), en el 2000 se destinó 872 millones USD; en 2006, 1.947,1 millones USD; en 2007, 2.597,0 millones USD y en 2012, 6.359,6 millones USD. ${ }^{495}$

El objeto del derecho del gasto y del derecho presupuestario es la orientación del primero para satisfacer los derechos ciudadanos y el cumplimiento de los objetivos del Gobierno y del segundo para regular el presupuesto, con la finalidad de que cumpla con los objetivos antes señalados que constan además en la planificación nacional. El presupuesto y la programación presupuestaria cuatrianual están establecidos en la Constitución (2008) como instrumentos jurídicos de carácter obligatorio, que aprobados

\footnotetext{
${ }^{493}$ Ecuador, Informe del Banco Central del Ecuador sobre la proformas del gobierno central y el límite del endeudamiento externo del año 2006, Congreso Nacional, Quito, 2005.

${ }^{494}$ Ecuador, Ley Orgánica para la Recuperación del Uso de los Recursos Petroleros del Estado y la Racionalización Administrativa de los Procesos de Endeudamiento, Registro Oficial 308, 03 de abril de 2008.

${ }^{495}$ Fabián Cantuña Castillo, La política fiscal como instrumento de estabilidad y crecimiento bajo un esquema de dolarización, caso Ecuador 2000-2012, Tesis de maestría en Relaciones Internacionales, mención economía y finanzas, UASB, Quito, 2015.
} 
anualmente, conforme lo dispone la Constitución y la ley, registran las estimaciones de ingresos y recursos y autorizan los egresos o gastos necesarios del sector público, para el cumplimiento de los objetivos, planes y programas del Plan Nacional de Desarrollo, según lo decida el Gobierno legítimamente constituido en el ejercicio económico y en su período de ejercicio del poder.

La Constitución que impulsó el presidente Correa y se aprobó en referéndum el 28 de septiembre de 2008 en el contexto del nuevo modelo económico neointervencionista, enumera las orientaciones que deben aplicarse a los presupuestos del sector público ecuatoriano:

1. La formulación y aprobación de los presupuestos se someterán al Plan Nacional de Desarrollo, sin menoscabo de sus competencias y autonomía.

2. Los presupuestos del Estado, incluyendo los de los gobiernos autónomos descentralizados, se someterán a las mismas reglas fiscales y de endeudamiento interno.

3. La proforma presupuestaria anual y la programación presupuestaria cuatrianual se elaborarán por el Ejecutivo. La Asamblea Nacional las aprobará y controlará que se ajusten a la Constitución, a la Ley y al Plan Nacional de Desarrollo.

4. El tiempo de aprobación u observación de la proforma y la programación presupuestarias, por parte de la Asamblea, se reducirá a treinta días y se realizará en un solo debate. Si en los treinta días no se pronunciara la Asamblea entrarán en vigencia conforme a la propuesta del Ejecutivo. Las observaciones se realizarán por sectores de ingresos y gastos sin alterar el monto global de la proforma. Si se incluyeran observaciones el Ejecutivo dispondrá de 10 días para aceptarlas, insistir en sus propuestas iniciales o modificarlas. En otros 10 días la Asamblea podrá insistir en sus observaciones en un solo debate y con el voto de dos tercios de sus integrantes, y si no lograran entrar en vigencia, la proforma y la programación entrarán en vigencia con la última propuesta del Ejecutivo.

5. Los aumentos de los gastos en la ejecución presupuestaria que superen los límites establecidos en la ley se aprobarán por la Asamblea Nacional.

6. Todas las fases del ciclo presupuestario, desde la formulación, aprobación, ejecución y los destinatarios de los recursos públicos, serán públicos, se difundirán por los medios de comunicación y se someterán a los principios de transparencia, rendición de cuentas y control. Para ello, la función ejecutiva y los gobiernos autónomos descentralizados informarán semestralmente sobre la ejecución presupuestaria a la Asamblea Nacional o a los órganos de fiscalización respectivos.

7. Los programas financiados por recursos públicos tendrán objetivos, metas y plazos de evaluación en el marco del Plan Nacional de Desarrollo.

8. Se admitirán preasignaciones presupuestarias con transferencias predecibles y automáticas solo en el caso de los gobiernos autónomos descentralizados, de la salud, educación, educación superior, investigación, ciencia, tecnología e innovación, en los términos previstos en la ley. 
9. El Presupuesto del Estado se gestiona en la Cuenta Única del Tesoro Nacional y en las subcuentas correspondientes en el Banco Central.

10. Los recursos públicos se manejarán en la banca pública conforme lo disponga la Ley y se prohibirá que entidades del sector público inviertan sus recursos en el exterior si autorización legal.

Como se puede advertir, las nuevas orientaciones constitucionales recentralizan los recursos y la gestión presupuestaria y la articulan con la planificación y la política pública que sobre el gasto y el desarrollo define el Gobierno central. La autonomía financiera de los gobiernos locales y otras entidades autónomas quedan supeditadas a las reglas fiscales al Plan Nacional de Desarrollo y a las decisiones del Gobierno. Se amplía el papel decorativo del poder legislativo en la aprobación del presupuesto y la programación presupuestaria, facilitando que finalmente se imponga la voluntad del Ejecutivo en las observaciones que se hagan al presupuesto. De igual manera resulta simbólica la supuesta transparencia informativa y el control que deben ejercer los ciudadanos y la Asamblea Nacional sobre la asignación, destino y utilización de los recursos públicos y quedan también en el plano declarativo para que sea la legislación secundaria la que los regule.

Las normas jurídicas que regulan el Presupuesto General del Estado y de todas las entidades públicas en el modelo neointervencionista son: la Constitución de la República (artículos 292 al 299); el Código Orgánico de Planificación y Finanzas (Título II, Capítulo III Del Componente de Presupuesto, artículos 95 - 122), el Plan Nacional de Desarrollo que aprueba finalmente el Ejecutivo y las normas reglamentarias y secundarias obligatorias (manuales, instructivos, directivas, clasificadores, catálogos, glosarios), dictadas por las autoridades rectoras del Sistema de Finanzas Públicas, presidente de la República y ministro de Finanzas-, para las diversas etapas del ciclo presupuestario.

Hoy en día, nuestra legislación se distingue en materia presupuestaria conforme a la programación fiscal obligatoria del sector público no financiero del Estado, la formulación y ejecución anual del Presupuesto General del estado y la Programación Presupuestaria cuatrianual.

El Presupuesto General del Estado tiene un ciclo de cumplimiento obligatorio que se debe observar necesariamente por todas las entidades del sector público y que comprende seis etapas: programación, formulación, aprobación, ejecución, evaluación y seguimiento y clausura y liquidación presupuestarias.

La Programación. Es la etapa del ciclo presupuestario en la que se definen los programas, proyectos y actividades que desarrollarán las instituciones públicas en un año, identificando a la vez metas, recursos resultados y plazos de aquellos. Se fundamenta en los objetivos de la planificación y las disponibilidades de recursos, 
definidos y estimados por los órganos competentes del Gobierno, esto es, la Secretaría Nacional de Planificación y el Ministerio de Finanzas.

En la programación, el Ministerio de Finanzas debe establecer los límites máximos de recursos que se van a asignar a los entes públicos en el presupuesto, conforme a la programación cuatrianual y si los programas y proyectos superan los cuatro años. Además de establecer su límite máximo, se deben incluir en el Programa de Inversiones del Estado. La definición de los límites y del costo total del proyecto son fundamentales para que las entidades públicas puedan establecer compromisos financieros plurianuales.

Las entidades que están fuera del Presupuesto General del Estado definen los límites y compromisos plurianuales, tomando como base las transferencias, asignaciones que se les haga y los recursos que obtengan como resultado de su gestión.

La formulación. Se entiende por formulación a la etapa del ciclo presupuestario en la que se elaboran las proformas o propuestas de las diferentes instituciones que se benefician del Presupuesto General del Estado.

Esta etapa sigue el siguiente procedimiento:

1. El ente rector de las finanzas públicas, el Ministerio de Finanzas, define las normas técnicas, clasificadores y catálogos que obligatoriamente deben cumplir en la formulación de las proformas presupuestarias de todas las entidades del sector público, incluyendo las empresas públicas, los gobiernos autónomos, la banca pública y la seguridad social.

2. Las máximas autoridades de las entidades cuyos presupuestos conforman el Presupuesto General del Estado, deben remitir al Ministerio de Finanzas las proformas institucionales dentro del plazo que este señale, incluyendo todos los ingresos y egresos previstos en el ejercicio fiscal en el que se vayan a ejecutar, sin exclusión alguna.

3. El Ministerio de Finanzas reforma si es del caso las proformas institucionales de acuerdo a las directrices presupuestarias y la disponibilidad de recursos y elabora la proforma o anteproyecto del Presupuesto General del Estado. Si alguna institución no remitió su proforma, el Ministerio realiza las estimaciones que considere pertinentes. El mismo ministerio elabora también la programación presupuestaria cuatrianual.

4. La proforma del presupuesto y el proyecto la programación cuatrianual se remite al presidente de la República junto con una exposición motivada sobre su contenido, financiamiento, ejecución y límites de endeudamiento, para su conocimiento, reforma y posterior presentación a la Asamblea Nacional.

5. El presidente de la República remite, con las reformas y ajustes que estima convenientes, la Proforma del Presupuesto, a la Asamblea Nacional hasta el 60 días antes del inicio del año fiscal o en los 90 días de iniciada su gestión para su análisis y aprobación o en 30 días después de la segunda vuelta electoral en el caso de que el presidente sea reelecto. 
La Aprobación. Es la etapa del ciclo presupuestario en la que siguiendo el trámite previsto en la Constitución, el proyecto o proforma y la programación presupuestaria cuatrianual, reciben finalmente la aceptación de la Asamblea Nacional o la proforma y la programación entran en vigencia por ministerio de la ley.

El trámite de aprobación es el siguiente:

1. Se presenta a la Asamblea Nacional la proforma o proyecto definitivo de presupuesto y la programación presupuestaria por parte del presidente de la República, 60 días antes de inicio del año fiscal, o 90 días después de la posesión de un nuevo presidente o 30 días después de la segunda vuelta en caso de reelección.

2. La Asamblea Nacional dispone de 30 días para aprobar en un solo debate el presupuesto y la programación o para realizar observaciones.

3. Si en los 30 días la Asamblea Nacional no se pronuncia sobre la proforma y la programación presupuestarios, entran en vigencia por ministerio de la ley.

4. Si dentro de los 30 días se realizan observaciones en la Asamblea Nacional, el Ejecutivo dispone de 10 días para aceptar las observaciones, modificarlas o insistir en su planteamiento original. A la vez, la Asamblea dispone de 10 días para aceptar la modificación o para insistir en su observación, en cuyo caso requiere del voto de los tercios de sus miembros. Si en los últimos 10 días la Asamblea no se pronuncia, el prepuesto y la programación presupuestaria quedan aprobados por el ministerio de la ley.

Sobre la aprobación presupuestaria, el Código Orgánico de Planificación y Finanzas, también dispone que en los gobiernos autónomos descentralizados, los plazos de aprobación son los mismos que los que rigen para el Presupuesto del Estado, siguiendo además el procedimiento establecido en sus normas; que en las entidades y organismos que no forman parte del Presupuesto General del Estado se deberá aprobar su presupuesto hasta el último día previo al inicio del año fiscal; que para fines informativos los gobiernos locales enviarán al Ministerio de Finanzas sus presupuestos aprobados en los 30 días siguientes y que las empresas públicas y la banca pública informarán en 30 días luego de la aprobación de sus presupuestos a la Asamblea Nacional; que las entidades y organismos que no pertenecen al Presupuesto General del Estado no pueden aprobar presupuesto que implique transferencias no consideradas en aquel y supuestos diferentes de los que se siguen en la formulación del Presupuesto del Estado y costos e inversiones incompatibles.

La ejecución. Es la etapa del ciclo presupuestario relativa a todas las acciones y decisiones en la aplicación y reforma del Presupuesto General del Estado por parte de las autoridades rectoras del Sistema Nacional de Finanzas Públicas, esto es, el presidente y el Ministerio de Finanzas, a favor de las instituciones públicas y a los derechos y obligaciones de estas para recibir y disponer de los recursos públicos legítimamente asignados. 
Según el COPF (artículo 113), es la "fase del ciclo presupuestario que comprende el conjunto de acciones destinadas a la utilización óptima del talento humano y los recursos materiales y financieros asignados en el presupuesto con el propósito de obtener los bienes, servicios y obras en la cantidad, calidad y oportunidad previstos en el mismo".

Las regulaciones generales de la ejecución, son, según el Código, las siguientes:

1. Corresponde al órgano rector de las finanzas públicas, particularmente al Ministerio de Finanzas, dictar las normas y todo tipo de regulación en la ejecución presupuestaria.

2. Todo compromiso, contrato y obligaciones requiere contar previamente con la emisión de la respectiva certificación presupuestaria

3. Los créditos presupuestarios solo quedan comprometidos en el momento en que la autoridad competente, mediante acto administrativo expreso decida la realización de los pagos, con o sin contraprestación cumplida o por cumplir siempre que exista la antes indicada certificación presupuestaria.

4. Las obligaciones se generan y producen afectación presupuestaria cuando por excepción se deben realizar pagos sin contraprestación siguiendo normas técnicas dictadas por el ente rector de las finanzas públicas y cuando se reciban de terceros obras, bienes o servicios adquiridos por autoridad competente mediante acto administrativo válido haya habido o no compromiso previo.

5. El ente rector de las finanzas públicas, presidente y ministro de Finanzas están facultados para aumentar o rebajar los ingresos y gastos que modifiquen el Presupuesto del Estado hasta en un total del 15\% respecto de las cifras aprobadas por la Asamblea Nacional. Los incrementos deben estar financiados y los aumentos y rebajas de gastos e ingresos no pueden modificar el límite de endeudamiento aprobado por la Asamblea Nacional. Los gobiernos locales no pueden aprobar presupuestos o modificaciones que impliquen transferencias de recursos desde el Presupuesto del Estado que no hubieren estado previstas.

Seguimiento y Evaluación. Es una etapa o fase del ciclo presupuestario que se da simultáneamente con la ejecución del presupuesto. Esta fase, conforme dice el $\mathrm{COPF}$, “comprende la medición de los resultados físicos y financieros obtenidos y los efectos producidos, el análisis de las variaciones observadas, con la determinación de sus causas y la recomendación de medidas correctivas” (Art. 119).

El procedimiento de seguimiento y evaluación debe observar las siguientes normas:

1. La evaluación física y financiera de la ejecución de los presupuestos de las entidades públicas es de responsabilidad de su titular y debe realizarse en forma periódica. 
2. Los informes de los titulares de las entidades públicas son remitidas al Ministerio de Finanzas y a la Secretaría Nacional de Planificación y Desarrollo y deben ser difundidos a la ciudadanía.

3. Cada seis meses el ministro de Finanzas debe efectuar una evaluación financiera global del Presupuesto General del Estado para ponerlo en conocimiento del presidente de la República y de la Asamblea Nacional en 90 días de terminado el semestre.

4. En los gobiernos autónomos descentralizados las unidades financieras y de planificación deben aplicar una regla análoga para que el ejecutivo de aquellos presente el informe semestral sobre la ejecución presupuestaria a sus órganos legislativos.

El ente rector de las finanzas públicas, esto es, el Ministerio de Finanzas, dicta con el carácter de obligatorias para todas las entidades y organismos del sector público las disposiciones adicionales para el seguimiento y evaluación financiera de la ejecución presupuestaria.

Clausura y Liquidación. La clausura es un acto de la fase final del ciclo presupuestario por el cual se cierra el ejercicio del presupuesto el 31 de diciembre de cada año. Después de esa fecha no se pueden contraer compromisos ni obligaciones, ni realizar acciones u operaciones de ninguna naturaleza que afecten al presupuesto clausurado.

El Código de Planificación y Finanzas dispone que los compromisos del presupuesto anual que al 31 de diciembre de cada año no se han transformado total o parcialmente en obligaciones quedarán anulados en los valores no devengados. Los compromisos plurianuales hacia el futuro no se anulan y deben ser reprogramados por las entidades correspondientes. La convalidación de compromiso de ejercicios fiscales anteriores en un nuevo ejercicio fiscal corresponde al Ministerio de Finanzas.

Una vez que se clausura el presupuesto se procede al cierre contable y se inicia el proceso de liquidación, siguiendo normas técnicas establecidas por el Ministerio de Finanzas.

Por lo tanto, la liquidación es el último acto de esta fase del ciclo presupuestario que se expedirá por parte del Ministerio de Finanzas hasta el 31 de marzo del año siguiente, siguiendo las normas técnicas que expida al respecto. De igual manera en la fecha indicada deberán liquidarse los presupuestos de otras entidades del sector público.

Estas normas son aplicadas en los presupuestos públicos y programación presupuestaria en estos años en Ecuador, desde la vigencia de la nueva Constitución (2008) y la plena 
vigencia del Código Orgánico de Planificación y Finanzas (2010) y su reglamento general (2014). ${ }^{496}$

En el informe y resolución aprobados por la Asamblea Nacional se destaca que el Presupuesto del Estado de 2011 y la Programación Presupuestaria 2011-2014 no contienen recomendaciones de fondo, que en ellos se aplica la regla macrofiscal, establecida en el artículo 81 del Código Orgánico de Planificación y Finanzas aprobado el año anterior, según la cual los egresos permanentes se financiarán única y exclusivamente con ingresos permanentes; que los dos instrumentos cumplen con las metas y objetivos del Plan Nacional del buen vivir; que en el presupuesto constan las preasignaciones establecidas en la Constitución; que los ingresos permanentes alcanzan a 15.335 millones USD; que los gastos permanentes suman 14.996 millones USD y que la inversión llega a los 7.375 millones USD; que los subsidios gubernamentales alcanzan a 4.820 millones USD (7,8 del PIB) y que el déficit final para el 2011 es del $15,6 \%$ del presupuesto lo que equivale al $6 \%$ del PIB. ${ }^{497}$

En la programación cuatrianual 2015 -2018 y en la proforma presupuestaria enviadas por el presidente Correa a la Asamblea Nacional a fines de 2014 se ratifica que los dos instrumentos cumplen con las exigencias constitucionales y legales para la sostenibilidad de las finanzas públicas y la consistencia macroeconómica en el mediano plazo, dentro del contexto de la economía mundial y regional y de los objetivos y metas del Plan Nacional de Desarrollo 2013-2017. Para ello se realiza una larga exposición sobre el escenario macroeconómico de mediano plazo en el contexto internacional, analizando en especial los problemas internacionales de la economía y de las políticas y situación de los EEUU y de China, que son los países referentes para nuestras decisiones de política económica, por el uso de la moneda del primero y porque el segundo es nuestro principal proveedor financiero para solventar las principales obras de infraestructura y para la compra de nuestro petróleo a mediano plazo, y con pago de altos intereses en ambos casos.

En la programación a la que hemos hecho referencia se supone que nuestra economía crecerá en promedio de 4,30\% como resultado del consumo doméstico; del incremento de las exportaciones desde 2017; de la puesta en marcha de los proyectos hidroeléctricos, el incremento de la explotación de los recursos naturales y el desarrollo de las telecomunicaciones, si bien se estima que la inflación en Ecuador será ligeramente superior a la de la región y el mundo. Se hace una reflexión sobre la relación entre precios del crudo y la actividad económica en Ecuador en la dolarización y se relativiza su importancia e incidencia en el crecimiento de la economía nacional, sea por el sistema monetario adoptado como por su articulación a la economía mundial.

\footnotetext{
${ }^{496}$ Ecuador, Código Orgánico de Planificación y Finanzas Públicas, Registro Oficial 306, 22-oct-2010; Reglamento General del Código Orgánico de Planificación y Finanzas Públicas, Decreto Ejecutivo 489, Registro Oficial-2S 383, 26-nov-2014.

${ }^{497}$ Ecuador, Informe de la Comisión Especializada del Régimen Económico y Tributario de la Asamblea Nacional, CRET-443-2010, sobre la proforma presupuestaria 2011 y la Programación cuatrianual 20112014, Quito, 19 de noviembre de 2010.
} 
Lo fundamental, se argumenta, es la sostenibilidad y solvencia de la política fiscal por parte del gobierno, con la finalidad de que se puedan servir en el tiempo sus obligaciones de deuda para que no se llegue a un cese de pagos. Por ello, la sostenibilidad fiscal que se plantea para Ecuador depende de si la suma de la deuda no supera el $40 \%$ del PIB, si el crecimiento de la economía llega a un promedio del $4 \%$ anual y si la tasa de interés promedio de la deuda para el período alcanza el 5,47\%. ${ }^{498}$

Sin embargo, en la evaluación y aprobación del Informe de Ejecución Presupuestaria del Ejercicio Fiscal de enero-junio 2016, que realiza la Comisión de Régimen Económico de la Asamblea Nacional, se da cuenta de la desaceleración de la economía y de la actividad productiva desde mediados de 2014, del crecimiento del desempleo, la disminución de la recaudación tributaria en 2016 y las dificultades serias de iliquidez que enfrenta la economía nacional por el deterioro del precio internacional del petróleo, la revalorización del dólar en el mercado internacional, el persistente déficit en la balanza comercial, el terremoto de 16 de abril de 2016 y los fallos internacionales adversos al Ecuador que obligaron a pagar centenares de millones de dólares, como indemnización a las empresas petroleras OXY y Chevron.

El presupuesto codificado a junio de 2016, que se prolongará en su aplicación hasta el 2017 hasta el cambio de gobierno en 2017, totalizó la suma de 32.703,65 millones de dólares, con el incremento discrecional del $9.61 \%$ del presupuesto original gracias al artículo 118 del COPYF que le autoriza reformarlo cada vez hasta en un 15\%. En el informe se registra que en el primer semestre de 2016 los ingresos no permanentes resultaron insuficientes por la caída del precio del petróleo, ocasionando un déficit de 1.919,05 millones de dólares. También los ingresos en general descendieron en 11,59\%, especialmente los tributarios, en relación con el mismo lapso en 2015, si bien se expidieron dos leyes sobre la materia: Ley Orgánica para el Equilibrio de las Finanzas Públicas y la Ley Orgánica de Solidaridad y Corresponsabilidad Ciudadana.

En ese mismo documento se reconoce también que en los primeros seis meses del 2016 la deuda pública externa se incrementó en 5.781,34 millones de dólares, pero se aclara que se trata de que la deuda consolidada tan solo llega a 23.616,2 millones de dólares, esto es el 23,1\% del PIB y que por lo tanto su porcentaje se encuentra distante del límite del $40 \%$ establecido en la ley. Se acepta que la principal variable de ajuste en el gasto en el semestre es la inversión fiscal, la misma que corresponde al 7,92\% del valor devengado; que el monto devengado para el gasto social llegó al 39,09\% del total; que las transferencias a los GADS se ejecutaron en un 34,54\% y que la ejecución de los subsidios al IESS solo corresponde al $9,47 \%$ de lo asignado en el presupuesto codificado. $^{499}$

\footnotetext{
${ }^{498}$ Rafael Correa Delgado, presidente constitucional de la República del Ecuador, Programación Presupuestaria Cuatrianual 2015-2018, Ministerio de Finanzas, Quito, 2014.

${ }^{499}$ Ecuador, Informe de Ejecución Presupuestaria del Ejercicio Fiscal enero junio 2016, Comisión de Régimen Económico de la Asamblea Nacional, Oficio AN-CERET-329-16, Quito, 17 de noviembre de 2016.
} 
Así las cosas, la Asamblea Nacional, controlada por el gobierno, llegó a la conclusión de que la política económica adoptada por el régimen, al implementar salvaguardas desde marzo de 2015 para mantener el equilibrio de la balanza comercial de los últimos años y las reformas tributarias para el equilibrio de las finanzas públicas y para financiar la solidaridad y corresponsabilidad ciudadana frente al terremoto del 16 de abril, fueron las adecuadas para enfrentar la coyuntura económica negativa a nivel mundial e interno.Nada dice el organismo de control político sobre el masivo endeudamiento interno y externo en el que incurrió el gobierno para cubrir el déficit y el gasto corriente que mantiene a la economía nacional a punto del colapso y que se ha puesto en evidencia luego de la terminación de la década de Gobierno del presidente Correa.

En la evaluación de sus diez años de gobierno, Rafael Correa enfatizó que su gestión permitió al Estado recuperar una función activa en la economía que pretendía ser anulada por el modelo anterior neoliberal y que, por lo tanto, su decisión de convertirlo en dinamizador de la economía por medio de la inversión y el gasto público ha permitido que la economía se duplique, al pasar de 51.008 MMUSD en 2007 a 97.802 MMUSD en 2016, cuando en la década previa de signo neoliberal, la economía creció de 28.148 MMUSD en 1997 a 46.802 MMUSD en 2006 y que el PIB per cápita real pase en promedio de 3.230 a 4.011 en los dos períodos indicados. También ofreció datos el expresidente para argumentar que durante su gobierno consiguió una mejor distribución del ingreso, una disminución de la pobreza, de la extrema pobreza y de la desigualdad y que mejoró la estabilidad laboral, los salarios y la seguridad social.

En cuanto a la política fiscal y particularmente la del gasto y la inversión, según Correa, el superávit presupuestario no fue el último fin de la administración de las cuentas públicas, pues su atención se centró en promover grandes transformaciones en vialidad, infraestructura, cobertura y provisión de servicios públicos, telecomunicaciones, generación hidroeléctrica, etc., para convertir la inversión en el gran dinamizador de la economía y para que actúe de forma contra-cíclica, frente al impacto negativo de la crisis financiera norteamericana y europea de 2008-2009 y los choques externos provocados por el deterioro internacionales de los precios de las materias primas, especialmente el petróleo, y la revaluación del dólar en la economía mundial. Según el ex Presidente, además, durante la última década se observaron estrictamente los principios y reglas de sostenibilidad fiscal para que los ingresos permanentes cubran los gastos permanentes y para que el gasto social crezca significativamente, pues pasó del $4,2 \%$ en 2006 , a $9,96 \%$ del PIB en $2016 .^{500}$

Todos los hechos y referencias anteriores contrastan, no obstante, con la mala calidad del gasto y una corrupción generalizada que comenzaron a evidenciarse en la parte final de la década correísta. Durante ese Gobierno, además de aplicar la normativa antes indicada, se adoptaron decisiones de política fiscal que ahora son materia de amplia discusión por el enorme déficit fiscal que ha ocasionado en los últimos años,

${ }^{500}$ Rafael Correa Delgado, Informe a la Nación 2007-2017, Quito. 
particularmente desde 2015 y 2016, como resultado del deterioro acelerado del precio internacional del petróleo y de las materias primas de exportación; la revaluación del dólar en los mercados internacionales lo que ha perjudicado al comercio externo del país; el incremento sustancial del gasto dentro de un ciclo político-electoral si bien ha disminuido en estos años el volumen de la inversión y el aumento desmesurado del endeudamiento público externo e interno que supera el 60\% del PIB. Para disfrazar esta realidad que desquicia la economía el régimen modificó la forma de estimar el monto de la deuda pública, diferenciando deuda consolidada y agregada, con la finalidad de no incorporar en ella las preventas petroleras y el endeudamiento interno para no superar en su cálculo el porcentaje del 40\% establecido como límite en la ley (Art.124 COPFP) y en el presupuesto del Estado.

La regla fiscal aplicada inicialmente por el Gobierno neodesarrollista con la finalidad que el gasto corriente sea financiado por los ingresos presupuestarios permanentes y que la inversión por los ingresos no permanentes, incluidos los provenientes de la exportación petrolera, contribuyó a mantener un precario equilibrio fiscal en los primeros años de su gobierno, ayudado con un incremento progresivo de la deuda externa y especialmente de la interna, absorbiendo los fondos del Banco Central y de la seguridad social. Si bien inicialmente el Gobierno, con la auditoría de la deuda externa, disminuyó su volumen en 2009 (de 10.089,9 millones USD a 7.392,7 millones) con operaciones de recompra en el mercado secundario, posteriormente su crecimiento llegó a más de 60.000 millones USD anunciada por el presidente Moreno en $2017 .^{501}$

Como resultado de esa política fiscal contracíclica, sustentada en el gasto que desestima el ahorro, en los últimos años ha crecido de manera incontrolada el déficit y la iliquidez, llegando a límites similares a los que tenía en los modelos intervencionista y neoliberal anteriores, por lo que, una vez más los recortes del gasto, el exagerado endeudamiento y la manifiesta corrupción en la inversión de las principales obras y proyectos ejecutados en los diez últimos años afectan el equilibrio y sostenibilidad de la economía, el desarrollo y en especial a los sectores más vulnerables de la población.

\footnotetext{
${ }^{501}$ El Comercio, 28 de julio de 2017.
} 


\section{CAPÍTULO VI: PLANIFICACIÓNY DERECHO DE LAS FINANZAS PÚBLICAS EN LAS POLÍTICAS Y MODELOS ECONÓMICOS DEL ECUADOR (1990-2017)}

Partiendo del contexto de la globalización capitalista desde 1990 hasta la actualidad y de la incidencia de los modelos y políticas económicas implementados en Ecuador, en este capítulo pretendemos desarrollar, desde la óptica del derecho público y especialmente de la Constitución económica, del derecho administrativo económico y del derecho de las finanzas públicas, las actividades y las normas relativas a la planificación y su incidencia en los ingresos y egresos públicos, de igual manera que lo haremos en un capítulo posterior con las actividades de control.

Ofreceremos primero una visión general sobre la naturaleza jurídica de la planificación y su contexto internacional y latinoamericano, para referirnos luego a su legislación y orientación en la realidad ecuatoriana y en las principales trasformaciones en las normas constitucionales y legales sobre aquella, tanto en el modelo neoliberal (1990-2006) como en el neointervencionista (2006-2017).

\section{LA PLANIFICACIÓN, SU NATURALEZA JURÍDICA Y SU CONTEXTO INTERNACIONAL.}

Como hemos argumentado en otras ocasiones, ${ }^{502}$ las regulaciones jurídicas sobre la planificación y las de control se ubican, preferentemente, en la órbita del derecho administrativo económico, mientras que las de los ingresos y egresos públicos en el campo del derecho financiero, si bien las actividades administrativas enunciadas se entrelazan con la actividad financiera que es el objeto de estudio del derecho de las finanzas públicas o del derecho financiero que cubre también, como hemos señalado ya, la actividad y las regulaciones de funcionamiento de las entidades financieras privadas y las pertinentes de la economía popular y solidaria.

En esta ocasión nos referiremos únicamente a las actividades de planificación y al Plan Nacional de Desarrollo relacionados con el derecho de las finanzas públicas y en especial con el Presupuesto del Estado en el contexto de los modelos económicos en Ecuador entre 1990-2017.

Si por planificación es una "técnica de intervención pública económica" "503 o una política pública que "permite establecer un sentido de dirección, de rumbo y un ambiente propicio para una gestión empresarial, institucional o social..."504 y los procesos de planificación, y los planes de desarrollo, "procesos políticos que intentan asignar coherencia, racionalidad y conducción a la gestión gubernamental que

\footnotetext{
${ }^{502}$ Víctor Granda Aguilar, Derecho Económico Financiero Ecuatoriana, (Quito: Carrera de Derecho de la Universidad Central del Ecuador, 2015).

${ }_{503}$ Ricardo Rivero Ortega, Derecho administrativo económico, (Madrid: Marcial Pons, 2013).

${ }^{504}$ Ruth Saavedra Y Otros, Planificación del Desarrollo, (Bogotá: EDIT. JORGE TADEO, 2003), 29.
} 
corresponda", se pueden asociar dichos conceptos a las acciones y gestión administrativa de la Función Ejecutiva, en el entorno histórico de los modelos económicos y políticos adoptados sucesivamente dentro del sistema imperante. Por ello, algunos afirman que "planificar y gobernar deben entenderse como tareas simultáneas y armónicas, donde una depende de la otra" y por lo tanto que "planificar es gobernar". 505

De manera general, planificar es toda gestión y decisión gubernamental nacional, seccional o local, con las que los diferentes niveles del gobierno, de manera centralizada o descentralizada, intentan establecer prioridades y conseguir sus objetivos, contando para ello, necesariamente, con buenas herramientas y técnicas para ser ejecutadas y reguladas por el ordenamiento jurídico. La planificación, en realidad, implica inicialmente un conocimiento técnico que "precede y preside" la acción de las instituciones y de las organizaciones públicas y privadas, sean gobiernos, municipios, empresas, universidades, organizaciones no gubernamentales, etc.

Pero además, en el Estado social y en los modelos económicos y políticos adoptados desde los años treinta del siglo XX hasta la actualidad en el sistema capitalista, la actividad pública de planificación requiere aplicar normas jurídicas, por lo que se somete a la Constitución económica y financiera del Estado y al derecho administrativo económico, pues se adopta mediantes políticas públicas y normas que entrañan o regulan actos y decisiones administrativas y económicas de carácter general y son obligatorias para las instituciones estatales y referenciales para las privadas. Más tarde dichas políticas son conocidas y controladas en el ámbito financiero público por la función legislativa cuando aprueba la proforma presupuestaria o cuando ejerce conjuntamente con otras funciones u órganos del Estado el control sobre los gastos y recursos públicos y en especial en la formulación y ejecución del presupuesto. ${ }^{506}$

En la identificación y precisión jurídica, económica y política del concepto de planificación resulta útil diferenciarlo de programación y planeamiento. Este último se utiliza más frecuentemente en el ordenamiento jurídico para referirse al proceso de elaboración de un plan en lo urbano. La programación sirve para definir políticas públicas económicas, mientras que, por lo general, el concepto de planificación, que integra o subordina a los anteriores, identifica al objeto de las instituciones estatales comprometidas en la formulación, aprobación y ejecución de los planes nacionales o locales de desarrollo. ${ }^{507}$ Se debe recordar también, como lo hace Sebastián Martín

\footnotetext{
${ }^{505}$ Sergio Galilea, Los desafíos metodológicos en la planificación latinoamericana: algunas cuestiones básicas. Memorias XVI del Congreso Interamericano de Planificación, Políticas y estrategias. Universidad de Puerto Rico, San Juan, 1988, citado en Ruth Saavedra Y Otros, Planificación del Desarrollo, (Bogotá: EDIT. JORGE TADEO, 2003), 33.

${ }^{506}$ Ecuador, Artículo 292 de la Constitución de la República del Ecuador, Registro Oficial N ${ }^{\circ} 449$ de 20 de octubre de 2008.

${ }^{507}$ Maria Arnáez Arce, La potestad planificadora de las administraciones públicas, (Bilbao: Gomylex, 2013).
} 
Retortillo, que planificación como actividad y plan en cuanto instrumentos son conceptos jurídicos "concurrentes" y no necesariamente "coincidentes". 508

En cuanto a la naturaleza jurídica de la planificación y el plan, en el ámbito de la Constitución económica y del derecho administrativo económico se trata de potestades obligatorias o de competencias administrativas atribuidas jurídicamente al Gobierno nacional y a los gobiernos locales para disponer de los recursos públicos, asignarlos definiendo sus destinatarios y conseguir determinados objetivos de interés general, del bien común o de desarrollo a nivel nacional o local.

Según varios tratadistas españoles, Parejo Alfonso, Jiménez Blanco y Ortega Álvarez, la planificación es una nueva forma de actividad administrativa explícita que se suma de manera diferenciada a las tradicionales de policía, fomento y servicio público, que inicialmente la incluían para que el poder público cumpliera eficientemente su misión de satisfacer el interés general y el bien común. ${ }^{509}$

Esta potestad de planificar produce efectos jurídicos ad intra en el ámbito organizativo de la administración al conformar órganos para el ejercicio de esa potestad o al autorizar que los existentes la ejerzan, y ad extra cuando mediante sus planes tiene repercusiones directas en el ejercicio de los derechos de los ciudadanos y cuando aquellos se tornan obligatorios para todas las entidades públicas, incluyendo para la función legislativa al aprobar el Presupuesto General del Estado o controlar su ejecución.

Sobre la naturaleza jurídica de los planes nacionales o locales y en especial del Plan Nacional de Desarrollo, que se convierten en el Estado contemporáneo y particularmente en los modelos intervencionista y neointervencionista, en columna vertebral de la acción de la Administración pública nacional o de las administraciones regionales y locales, se discute si ellos son la expresión de una ley material o formal y si tienen la connotación jurídica de un reglamento o de un acto administrativo general o específico que a la vez constituya precedente obligatorio para decisiones parlamentarias como la establecida en la Constitución ecuatoriana (2008) en la aprobación y control del Presupuesto General del Estado. ${ }^{510}$

La Constitución antes indicada define como instrumentos, tanto al Plan Nacional de Desarrollo, al Presupuesto General del Estado como a la Programación Presupuestaria cuatrianual. El primero es aprobado con efectos obligatorios para el sector estatal e indicativo para los otros sectores de la economía, por el Consejo Nacional de Planificación presidido por el presidente de la República e integrado en su mayoría por sus subordinados. Los segundos son aprobados $\mathrm{u}$ observados, con una serie de

\footnotetext{
${ }^{508}$ Sebastián Martín-Retortillo Baquer, Derecho administrativo económico, (Madrid: La Ley, 1991).

${ }^{509}$ Luciano Parejo Alfonso, Antonio Jiménez Blanco, Luis Ortega Álvarez, Manual de Derecho Administrativo, vol. I, 5ta edición, (Barcelona: Ariel, 1998).

${ }_{510}$ Maria Arnáez Arce, La potestad planificadora de las administraciones públicas, (Bilbao: Gomylex, 2013).
} 
restricciones, por la Asamblea Nacional y deben sujetarse, en su formulación y trámite a la Constitución, a la ley y al Plan Nacional de Desarrollo.

Evidentemente, ni el Plan Nacional de Desarrollo ni el Presupuesto General del Estado son leyes formales, aunque son "instrumentos" que tienen efecto obligatorio igual que las leyes materiales, de igual manera que lo son los reglamentos y los actos administrativos generales o normativos; con la diferencia de que el PND es aprobado únicamente por la autoridad pública competente controlada por el presidente de la República y el PGE es formulado y ejecutado por dicha autoridad administrativa pero aprobado, en trámite especial, por la función legislativa. Esta situación particular tiene consecuencias jurídicas en cuanto a los medios de impugnación sobre su legalidad o su constitucionalidad.

Si bien el Plan Nacional de Desarrollo tiene efecto obligatorio al ser aprobado cual si se tratara de una ley, en su naturaleza jurídica es diferente, ya que aquella debe ser aprobada por la función legislativa, puede ser general o individual en cuanto a sus destinatarios y tiene duración indefinida, mientras que el PND es aprobado en la actualidad únicamente por la función ejecutiva y tiene vigencia indefinida, sujetos determinables y disposiciones concretas. Al margen de estas diferencias, Armáez Arce, siguiendo a García de Enterría, Villar Palasí, etc., estima que los planes de desarrollo pueden asimilarse por sus efectos a las denominadas "leyes medida, singulares o de caso único" elaboradas para cubrir ciertos objetivos concretos y determinados y que no por ello dejan de ser normas obligatorias, si bien la profesora considera que por su naturaleza jurídica los planes de desarrollo son reglamentos. ${ }^{511}$

Nuestra opinión difiere de la anterior en lo relativo al derecho ecuatoriano, ya que en la actualidad el Plan Nacional de Desarrollo, a diferencia del Presupuesto General del Estado, no es aprobado por la función legislativa, sino únicamente por un órgano controlado por el Ejecutivo y nos parece que su naturaleza objetiva, bajo las condiciones especiales en este caso, se mantiene en la esfera de los actos administrativos generales y obligatorios que también se encuentran previstos en la Constitución y en el Código Orgánico de Planificación y Finanzas.

La doctrina ha discutido mucho sobre si a los planes de desarrollo se los debe considerar reglamentos o actos administrativos. Los reglamentos, desde una perspectiva formal, son instrumentos jurídicos para la aplicación de una Ley y autónomos o independientes si aplican una norma constitucional o legal de manera directa. Desde una perspectiva de contenido administrativo, los reglamentos son organizativos de la estructura administrativa, y son jurídicos si contienen regulaciones normativas para los ciudadanos. Los actos administrativos, por su parte, son expresión de la voluntad unilateral de la autoridad pública competente para resolver o decidir asuntos de

\footnotetext{
${ }^{511}$ Maria Arnáez Arce, La potestad planificadora de las administraciones públicas, (Bilbao: Gomylex, 2013).
} 
naturaleza jurídica o de interés individual o general. ${ }^{512}$ Lorenzo y Sebastián MartínRetortillo y Villar Palasí califican con mayor precisión a los planes de desarrollo como de "categoría mixta" o de "género intermedio", entre las normas reglamentarias y los actos o resoluciones administrativos generales. 513

Si consideramos la diferencia formal y de contenido en la elaboración y aprobación administrativa de un Plan Nacional de Desarrollo o de los planes locales en Ecuador, esos instrumentos no se asimilan, especialmente en la forma, a los diferentes tipos de reglamentos subordinados o relacionados con la ley o al ejercicio normal de la administración, sino que se encuadran mejor, conforme a nuestra Constitución (2008), a los actos administrativos "con efectos generales" que tienen una estructura formal y de contenido diferente a los reglamentos y son directamente impugnables ante la Corte Constitucional, según su artículo 436.4 y 5, pues los actos administrativos de efectos individuales y aún los reglamentos están sometidos inicial y previamente a un control de legalidad. El carácter general y obligatorio para los poderes públicos de estos actos administrativos proviene del Consejo de Planificación que, si bien está controlado por la función ejecutiva, tiene también representación formal de los gobiernos locales y de la ciudadanía, lo que le da un viso de cierta independencia y de legitimidad en su calidad y obligatoriedad social y moral.

Se debe reconocer que la planificación tiene también connotaciones ideológicas, políticas e históricas, en los sistemas y realidades económicas del mundo actual, de América Latina y Ecuador. La planificación inicialmente se encontró asociada al "sistema colectivista-socialista" o "centralmente planificado", en el que predominaba el Estado frente al mercado, pues en el inicial "sistema capitalista liberal", en el que dominaba el mercado, no existían la planificación ni la intervención económica del Estado. Frente a los dos sistemas se instaura en el mundo un "sistema mixto" para superar la gran crisis general del capitalismo de los años treinta del siglo pasado que se mantiene hasta la actualidad, con la aplicación de diferentes modelos o políticas económicas. La planificación se adopta inicialmente también como un instrumento de apoyo a la intervención y regulación del Estado y del Gobierno en la economía, sin desconocer los fundamentos del sistema capitalista imperante. ${ }^{514}$

En las Constituciones de los países del mundo y en la organización de la administración pública, desde el surgimiento del e social o estado de bienestar hasta la actualidad, consta la planificación como instrumento de gobierno con la finalidad de racionalizar su intervención en la economía, el uso eficiente de los recursos y el cumplimiento racional de sus objetivos sociales para proveer eficientemente de servicios públicos a la población.

\footnotetext{
512 Javier Pérez Royo, Las Fuentes del Derecho, (Madrid: Tecnos, 5ta edición, 2008).

${ }^{513}$ Lorenzo Martín-Retortilo, "Actos administrativos generales y reglamentos. Sobre la naturaleza de la convocatoria de oposiciones”, Revista de Administración Pública, No 40, 1963; J. L.Villar Palasí, Apuntes de Derecho administrativo, (Madrid: Villar Palasí, 1977).

514 Jorge Witker, Introducción al Derecho económico, (México: Ediciones Harla, 1997).
} 
La planificación se encuentra estrechamente asociada al desarrollo y, por lo tanto, a la eficiente captación y uso correcto y eficaz de los recursos, por lo que necesariamente está vinculada con los principales instrumentos de la Hacienda pública y en especial con el gasto y el presupuesto del Estado.

El grado de obligatoriedad de los planes de desarrollo, producto principal de la planificación, así como sus formas de elaboración y procedimientos de aplicación, pueden ser históricamente imperativos o indicativos. En la planificación imperativa las medidas son de aplicación obligatoria para todos los sujetos o actores económicos y en especial para los públicos, mientras que en la planificación indicativa, las medidas son flexibles y sus actores privados pueden ajustarse o no a los objetivos del plan.

Se toma como modelo clásico de planificación imperativa el soviético ya desaparecido, pero que tuvo y tiene sus particularidades en Yugoslavia, China, Cuba o Vietnam, y de la planificación indicativa, el modelo francés y el asumido en la actualidad por la mayoría de países capitalistas en los que consta la planificación como un instrumento importante de la política económica de sus gobiernos. ${ }^{515}$

Los procedimientos y métodos de la planificación imperativa del desarrollo, agrupados en forma sistémica, surgieron en la Unión de Repúblicas Socialistas Soviéticas, URSS. $^{516}$ En ella se adoptaron medidas económicas con las que se estatizaron los principales medios de producción, "se decretó (27 de noviembre de 1917) el control obrero para que sean los comités de fábrica los que organicen la actividad productiva; se creó el Consejo Supremo de Economía Nacional (VSNJ) para la organización de la actividad económica nacional y la Hacienda pública, con facultades de confiscación y sindicación forzosa en todas las ramas de la industria y el comercio y se nacionalizaron los bancos (27 de diciembre de 1917) que quedaron integrados, junto con el Banco de Estado, en el Banco Popular de la República Rusa".517

En el sistema de planificación central en la URSS se crearon varios organismos y procedimientos para la elaboración de los planes. Entre los organismos: una Comisión Central del Plan Estatal (Gosplan) que se replicaba en cada una de las repúblicas y tenía varias unidades técnicas e instituciones científicas; secciones de planificación técnicaeconómica en toda entidad que ejercían funciones económicas a nivel central, regional o local; organismos de planificación en la ciudades de más de veinte mil habitantes (Gosplan), en los distritos (Raiplan) y en las regiones (Oblplan) que coordinaban los planes de los establecimientos bajo la dependencia de las autoridades centrales o locales y células de planificación en cada una de las empresas para aplicar los planes de órganos superiores y preparar el plan de las mismas aplicando directivas centrales.

\footnotetext{
515 Marco Antonio Guzmán, Derecho económico, Tomo I, Serie Estudios Jurídicos 11, Universidad Andina Simón Bolívar: Corporación Editora Nacional, Quito, 1996.

${ }^{516}$ Ruth Saavedra Y Otros, Planificación del Desarrollo, (Bogotá: Edit. Jorge Tadeo, 2003), 37.

${ }^{517}$ Tascón Fernández Y Otros, Una visión eurocéntrica de la actividad económica, del Neolítico al siglo XXI, 1era Ed. (Madrid: Biblioteca Nueva, 2012), 132.
} 
En cuanto a los procedimientos de elaboración del plan o de los planes, el Comité Central del Partido Comunista de la URSS establecía las directrices que tenían que cumplirse en el plazo del plan de quince (plan prospectivo), cinco (plan quinquenal) y un año (plan operacional). El Consejo de Ministros debía ratificar dichas directrices. Luego se seguía una fase descendente para que las autoridades políticas y los organismos de planificación de niveles inferiores transmitieran las directrices superiores y perfeccionaran el plan, en sus aspectos concretos, en las empresas específicas; y en la fase ascendente el proceso era a la inversa, para que los proyectos concretos y las actividades a ser desarrolladas por las unidades de gestión fueran considerados y aprobados por las autoridades superiores y los organismos de planificación. Se aprobaba así un plan central único que tenía fuerza de ley y que era controlado en su ejecución por órganos o comisiones estatales y del partido. ${ }^{518}$

Ahora bien, desde 1962 la distribución de recursos y la producción de industrias livianas dejaron de estar controlados por la Agencia de Planificación Central, atendiendo a las sugerencias y reflexiones de Yevsei Liberman, quien planteó al Gobierno que adoptara una política descentralizadora, introduciendo incentivos y beneficios en la producción empresarial para hacer más eficiente la actividad económica y la planificación. Temporalmente la rígida planificación inicial comenzó a incorporar mecanismos flexibles, tanto con la aplicación del séptimo plan, como con la producción de bienes de consumo. Esta orientación dio origen temprano a un sistema híbrido que se denominó "socialismo de mercado dirigido por la demanda del consumidor". 519

Oskar Lange describe el tránsito antes indicado, al señalar que, si bien en las primeras fases de la economía socialista el Estado tenía una fuerza extraeconómica dominante, las leyes económicas de la nueva sociedad se tornaban más funcionales y se requería introducir incentivos económicos para producir los resultados deseados por el nuevo sistema, para lo cual resultaba necesario una separación gradual entre la administración económica y el gobierno político, lo que implicaría un proceso de maduración del sistema socialista. ${ }^{520}$

Estas tendencias "liberalizantes" en la URSS fueron abandonadas desde inicios de los años setenta del siglo pasado, ratificando el control total de la economía por parte del Estado y el papel preponderante de la planificación centralizada sobre el mercado, reforzando la burocratización del sistema que será posteriormente el principal factor de su colapso. La planificación centralizada de los años siguientes, sin embargo, no dejó de considerar la expansión de la producción destinada al consumo, dejando como resultado positivo un procedimiento articulado entre los diferentes niveles de gobierno y una amplia infraestructura estatal para lograr satisfacer ciertas necesidades básicas de la

\footnotetext{
518 Marco Antonio Guzmán, Derecho económico, Tomo I, Serie Estudios Jurídicos 11, Universidad Andina Simón Bolívar -Corporación Editora Nacional, Quito, 1996.

519 José Paschoal Rossetti, Introducción a la economía, enfoque latinoamericano, séptima edición, (México: Harla, 1985).

${ }^{520}$ Oskar Lange, Objeto de la economía política: nociones preliminares.Moderna economía política, 2da edición, (Río de Janeiro: Fondo de Cultura, 1963).
} 
mayoría de la población. En Yugoslavia hubo desde 1960 una experiencia liberalizadora de la economía y de la planificación, mediante procedimientos de descentralización en las decisiones y autoadministración para construir una economía socialista competitiva de mercado.

Es de interés actual por su gran impacto en la economía mundial, el caso de China. En el gigante asiático, inicialmente y hasta la actualidad, las principales decisiones económicas estratégicas y de mediano plazo, para la construcción de su "economía socialista de mercado", se encontraban concentradas por el Estado y el Partido. Su sistema de planificación seguía el modelo rígido e inflexible diseñado por una Central de Planificación, especialmente cuando se adoptaron los principios radicales de la "revolución cultural".

Sin embargo, las diferencias políticas con las URSS, la autosuficiencia y confianza en la civilización tradicional china, su profunda convicción nacional, la necesidad de satisfacer las crecientes demandas de su enorme población y su paulatina y luego creciente incorporación al mercado mundial, determinaron que la economía y la planificación en China se modificaran posteriormente a las reformas impulsadas por Deng Xiaoping en 1978 y, especialmente, en los años ochenta y en los siguientes, cuando se introdujeron progresivamente en la economía mecanismos flexibles de mercado y de competencia, tanto a nivel externo como interno, sin dejar de mantener el control del poder por parte del Partido Comunista Chino y, en la formalidad, una planificación centralizada, en la que se establecieron metas y objetivos generales cada cinco años. La matanza en la Plaza de Tiananmen en 1989, permitió al gobierno chino avanzar en su exitosa política de liberalización económica, luego de aniquilar a sus opositores.

El colapso del sistema económico y político soviético, en la década del ochenta (en 1989 Rusia ya no tenía una plan quinquenal) y en los inicios de la del noventa del siglo pasado, produjo la destrucción de las disímiles redes de dependencia entre los países que de una u otra manera se encontraban subordinados a aquel y los obligó a enfrentarse o integrarse individualmente al mercado mundial, lo que necesariamente implicó una modificación mayor en el uso de las instituciones relacionadas con el establecimiento de políticas públicas, como ocurrió en China en donde se mantiene intacto el sistema de mando centralizado, pero sin una económica única, centralizada y planificada. ${ }^{521}$

El otro modelo de planificación, conocido como indicativo o referencial, se aplicó en la mayoría de países capitalistas del mundo y tiene su origen en la doctrina keynesiana que planteó una participación activa del Estado en la economía en los años treinta del siglo XX. También este modelo tomó como referencia la experiencia francesa de planificación de los años 60, si bien en todos los países del mundo se la asumió como

${ }^{521}$ Eric Hobsbawn, Historia del siglo XX, (Barcelona: Editorial Crítica, 2003). 
un importante ingrediente de programación y regulación económica por más liberal y competitiva que fuera su economía.

El keynesianismo, ${ }^{522}$ antes y luego de la crisis de los años treinta del siglo pasado, fundamentó un nuevo modelo económico para fortalecer el sistema capitalista internacional en el intervencionismo estatal. "Keynes plasma una teoría económica que, tras analizar la fluctuación de los periodos económicos y su influencia en los niveles de empleo e ingresos, propone dotar a los estados y a sus instituciones de mayor poder para intervenir y controlar el mercado, con el objetivo último de lograr una mayor estabilidad social. La herramienta para este control sería una política fiscal redistributiva que asegure el crecimiento económico y la protección social de las clases trabajadoras permitiendo así el aumento del consumo de éstas y su desarrollo como clases medias". 523

Al Estado se le asignó el rol protagónico en la planificación de la nación, pues debía intervenir de manera ordenada y programada en la economía del país. Este intervencionismo y sistema de organización social dispuso que al Estado le correspondía asegurar para toda su población, educación, sanidad, protección social, vivienda, entre otros derechos. Así se pasó de un modelo liberal capitalista de producción a uno que privilegió el consumo y el empleo, dando origen al denominado estado de bienestar (Welfare State).

En la mayoría de países, desde los años cincuenta y sesenta del siglo pasado, la organización de la actividad económica introdujo un papel más o menos importante del Estado en la regulación de la economía y de sus principales actores, con la finalidad de promover el desarrollo y la creciente satisfacción de las necesidades sociales. Las economías modernas combinan mercado y Estado y este es un instrumento útil para el funcionamiento eficiente o por lo menos más racional del primero. Para el cumplimiento de sus funciones el Gobierno adoptaba políticas económicas obligatorias para todos los actores económicos. En cuanto a uno de los instrumentos principales de orientación e intervención del Estado, el Plan de Desarrollo Nacional al igual que otros planes regionales o locales, adoptados por los organismos correspondientes, son obligatorios en cuanto a sus objetivos y decisiones en los organismos del sector público y referenciales o indicativos para los actores privados de la actividad económica.

\footnotetext{
522 "Keynes fue un economista bastante atípico pues de la economía le interesaba fundamentalmente su componente moral. Para él, la economía era un instrumento, no una finalidad; una ciencia moral, no una ciencia natural. Veía el crecimiento económico como un medio para liberar la humanidad de la dependencia del esfuerzo físico y se preguntaba cuándo sería «suficiente» el progreso económico para lograr la finalidad de pasar de la escasez a la abundancia”. Burgaya Riera, Josep, El Estado de bienestar y sus detractores: A propósito de los orígenes y la encrucijada del modelo social europeo en tiempos de crisis, 1ra Edi. (Burgaya Riera, Josep: Octaedro - 2013), 72.

${ }_{523}$ Alberich Nistal, Tomás Y Otros, Planificación y gestión: manual para la acción social, 1ra Edi. (Madrid: Dykinson, 2014), 28.
} 
El sistema de planificación en Francia, tomado inicialmente como referencia para la planificación en los países con régimen parlamentario, estaba conformado por un Comisariado General del Plan, adscrito al Gobierno, que recogía las propuestas de las comisiones de modernización conformadas para negociar los diferentes intereses de los grupos económicos. El Consejo Superior del Plan de 58 miembros preparaba un informe final, luego de conocer los informes técnicos y las opiniones y decisiones iniciales del gobierno, y lo enviaba al Consejo Económico y Social para que emitiera un dictamen que finalmente era conocido por el Parlamento, el cual, luego de los correspondientes ajustes, expedía la ley aprobatoria del Plan. ${ }^{524}$

En varios países europeos, como en España, la Constitución contempla la posibilidad de utilizar la técnica de la planificación en la intervención pública económica, si bien, como dice Ricardo Rivero, en el actual contexto global, no parece pertinente ejecutar una planificación general de la economía pero si la utilización administrativa de planes locales o de iniciativas puntuales, especiales, parciales y aún regionales y nacionales, relativas a asuntos de desarrollo urbano, uso de recursos hídricos, cambio climático, infraestructura, transporte, etc. ${ }^{525}$

En los regímenes presidencialistas, la elaboración, aprobación y aplicación o ejecución de los instrumentos de planificación y los planes son atribuidas a organismos técnicos del Gobierno, unipersonales o pluripersonales, conforme lo dispone la Constitución o la Ley. El presidente de la República tiene la potestad de aprobarlos para su ejecución por parte de la estructura administrativa del Estado y de controlar luego su aplicación, por medio de las instituciones y los instrumentos de control interno o externo establecidos en la legislación.

En cuanto a los principios y etapas de los procesos de planificación global, que se aplican tanto en los planes obligatorios como en los indicativos, se pueden identificar, entre los primeros: la racionalidad, la previsión o visión de futuro, la universalidad, la unidad, la continuidad y la determinación clara de objetivos y metas. ${ }^{526}$ Sobre las etapas de la planificación se distinguen: el análisis previo y prolijo de la realidad a la que esta se refiera la determinación de objetivos y metas viables conforme a medios y plazos de los que se disponga; la elaboración del plan que debe incluir todos los programas, planes locales y sectoriales para que sea integral; la aprobación que debe realizarse en las instancias correspondientes conforme las normas vigentes; la ejecución coordinada y orgánica de los programas, proyectos, obras y actividades que consten en el plan; el control interno y/o externo de ejecución conforme a las normas vigentes de cada país y la actualización, revisión y modificación del plan y la planificación cuando sea

\footnotetext{
524 Marco Antonio Guzmán, Derecho económico, Tomo I, Serie Estudios Jurídicos 11, Universidad Andina Simón Bolívar -Corporación Editora Nacional, Quito, 1996.

${ }^{525}$ Ricardo Rivero Ortega, Derecho administrativo económico, (Madrid: Marcial Pons, 2013).

${ }^{526}$ Jan Tinbergen, Planificación del Desarrollo, Biblioteca para el Hombre Actual, (Madrid: Ediciones Guadarrama, 1967).
} 
necesario, conforme a los recursos de que se dispongan, estableciendo las correspondientes prioridades. ${ }^{527}$

\section{La planificación en América Latina}

La planificación en América Latina se encuentra asociada a su modernización y desarrollo, conforme a los modelos económicos y políticos que se han aplicado en la región durante el siglo XX y particularmente desde 1990 hasta la actualidad.

El modelo primario exportador, fundamentado en los principios del liberalismo económico e inspirado en las teorías clásicas y neoclásicas, se aplicó en las tres primeras décadas del siglo XX. Más tarde se sustituyó por un modelo desarrollista que pregonó una industrialización fundamentada en el proteccionismo y la intervención del Estado en la economía, como una versión regional del pensamiento keynesiano. ${ }^{528} \mathrm{El}$ modelo desarrollista se cambió por el neoliberal que promovió reformas que privilegiaron la acción de mercado y la descentralización y se mantuvo hasta inicios del presente siglo, para dar paso finalmente a un nuevo modelo neoestatista $y$ neodesarrollista que revalorizó el papel del Estado como impulsador de la economía, con la finalidad de favorecer una limitada redistribución del ingreso y estimular su crecimiento.

La planificación fue uno de los instrumentos principales para incentivar el desarrollo, pues al Estado le correspondía esa misión con el aval intelectual y las directrices de los organismos multilaterales (FMI, BM) y de desarrollo (CEPAL) que se conformaron luego de la Segunda Guerra Mundial y que tienen la función de monitorear la economía de los países miembros y en especial de los latinoamericanos.

Según el Instituto Latinoamericano y del Caribe de Planificación Económica y Social (ILPES) de la CEPAL, en los últimos setenta años, conforme a los modelos económicos antes indicados, implementados desde 1945 hasta la actualidad, la planificación ha pasado por tres etapas: la de despliegue hasta 1975; la de repliegue entre 1980 y el 2000 y la de su revalorización desde el 2000 hasta la actualidad.

Los primeros intentos para elaborar planes en América Latina y emprender en acciones económicas y sociales por parte de los gobiernos se dan en varios países como México, Brasil, Argentina y Ecuador.

En la fase del modelo desarrollista (1945-1975), la planificación, como política pública, planteaba que el Estado debía tener un papel central en la economía, mediante su función interventora y empresarial. En los planes de los años cincuenta se hace presente

\footnotetext{
527 Marco Antonio Guzmán, Derecho económico, Tomo I, Serie Estudios Jurídicos 11, Universidad Andina Simón Bolívar -Corporación Editora Nacional, Quito, 1996.

${ }_{528}$ Aldo Olano Alor, "Desarrollo y Planificación en América Latina. Teorías e instrumentos". Revista de Economía Institucional 18, Bogotá, 2016, 135-150
} 
ya la influencia de los organismos internacionales FMI, BM y la CEPAL que aportaron con documentos e investigaciones sobre los problemas económicos y sociales, además de emitir informes y organizar misiones de asesoría en los países de la región, todo lo cual fue de gran utilidad para el desarrollo institucional de la planificación en varios países de la región.

Frente a la revolución cubana, la OEA emitió en Punta del Este (Uruguay), en agosto de 1961, una carta en la que los gobiernos de la región, con la influencia y financiamiento de EEUU, se comprometieron a conquistar importantes metas de desarrollo y crecimiento, para lo cual la planificación se convirtió en el principal instrumento obligatorio previo a la obtención del financiamiento para alcanzarlas. Expresamente la carta estableció que los países de la región "ejecuten...programas nacionales de desarrollo económico y social, amplios y bien concebidos, encaminados a lograr un crecimiento autosuficiente" y "programas de desarrollo de largo plazo" y que conformen una institucionalidad y sistemas para su "preparación, ejecución y revisión periódica". ${ }^{529}$ Estados Unidos, el Banco Mundial y el BID fueron los más activos proselitistas de la planificación en América Latina; exigieron a los países la adopción de planes para el acceso a créditos y financiamiento, capacitaron personal y editaron masivamente manuales técnicos para promoverla. ${ }^{530}$

El auge de la planificación normativa o técnica de los "planes-libro" y de sus instituciones, ${ }^{531}$ así como el modelo económico y político intervencionista, impulsados por las decisiones internacionales antes indicadas, fue monitoreado por la CEPAL, ILPES y BID, reforzada por el pensamiento estructuralista de Raúl Prebisch, ${ }^{532}$ promotor de la industrialización por sustitución de importaciones en los años sesenta y setenta y de un activo papel del Estado para impulsar la reforma agraria, la producción, las industrias pesadas, la energía y los servicios.

Dicho sea de paso, la planificación, los planes y el modelo desarrollista se debilitaron en los años ochenta por el fracaso de las reformas y el intento de replicar el modelo fordista de desarrollo; las propias condicionalidades de los organismos financieros internacionales; las debilidades de las políticas fiscales y de los mercados financieros privados; las malas prácticas administrativas y burocráticas $\mathrm{y}$, finalmente, por los desastrosos efectos de la crisis de la deuda externa. ${ }^{533}$

\footnotetext{
${ }^{529}$ OEA, Carta de Punta del Este, 1961,https://dialnet.unirioja.es /descarga/articulo/ 2048 393.pdf

530 Richard Webb, "Planificar no es mala palabra", Instituto del Perú, Lima, 2009, http://usmp.edu.pe/idp/columna-de-opinion-planificar-no-es-mala-palabra/.

${ }^{531}$ Carlos Matus, Estrategia y Plan,(Santiago: Editorial universitaria, 1972); La planificación posible en la prospectiva socio política de América Latina, Caracas, CENDES, 1980).

${ }^{532}$ El aporte de Raúl Prebisch para el análisis de los problemas de América Latina y sus respuestas frente a los desafíos y oportunidades del orden mundial, se refiere al enfoque centro-periferia, los términos de intercambio, la industrialización para la sustitución de importaciones, la integración regional, la distribución del ingreso y las necesaria políticas públicas.

${ }^{53}$ Sebastián Edwards y Rudiger Dornsbusch, eds, Macroeconomía del populismo en América Latina, (México: Fondo de Cultura Económica, 1992).
} 
Carlos de Matos diferenció en América Latina, en los mismos años también, la planificación normativa o técnica y la planificación proceso o planificación estratégica. La primera se basa en el predominio de la norma sobre el cálculo predictivo expresado en un "plan libro" como elemento clave del proceso de planeamiento. La segunda es un conjunto de políticas coherentes que se fundamentan en una estrategia dinámica para impulsar los cambios necesarios desde un proyecto político, por lo que se trata de una "planificación proceso para una estrategia de desarrollo económico-social". ${ }^{534} \mathrm{El}$ autor, sin dejar de conocer los méritos correspondientes a la planificación normativa, parte de una crítica a los planes, planificadores y procedimientos de la planificación de las décadas anteriores, ya que por su disociación conceptual, los objetivos e instituciones tecnocráticos y desproporcionados hicieron inviable la proyectada planificación para el desarrollo, frente a las condiciones objetivas, económicas, políticas e ideológicas de los países de la región.

Al acelerarse en el sistema mundial el proceso de globalización y la financiarización de la economía, se promovió, ya desde mediados de los setenta a nivel internacional, un nuevo modelo económico neoliberal centrado en el mercado y en el que se asigna al Estado un rol subsidiario al mercado, cuando aquel no podía operar o era manifiestamente ineficiente. La planificación y sus instituciones se replegaron y a partir de los programas de reforma estructural recomendadas por el Consenso de Washington, se redujeron al mínimo; en algunos países se las desmanteló y en otros se convirtieron cada vez más en referencial y sin mayor impacto en las políticas públicas. En algunos países los sistemas y organismos de planificación se sustituyeron por instancias de modernización y descentralización para favorecer la privatización de las actividades del Estado.

Por ello, De Matos decía también que en el modelo económico mercado-céntrico en América Latina, comienza a ser posible una "planificación sin planes" para lograr ciertos objetivos de crecimiento, sin preocupaciones sobre la distribución de los frutos del mismo o para tomar un conjunto de medidas de política económica que restablezcan al mercado en sus funciones de asignador de recursos. Se trata, en otras palabras, de una estrategia para asegurar la continuidad de la política económica que articule el modelo en los países capitalistas periféricos. Esta estrategia se fundamenta en la realidad y define, con un marco más flexible que puede revisarse o reajustarse, las acciones y medidas que se van a implementar, en un determinado período de corto o mediano plazo, de acuerdo a la viabilidad política de aquella, por lo que se estaría ante una modalidad de planificación sin la existencia formal de un plan. ${ }^{535}$

A fines del siglo pasado y en lo que va del presente siglo, los mismos organismos financieros internacionales, como el Banco Mundial y el BID frente a las consecuencias

\footnotetext{
${ }^{534}$ Carlos A de Matos, "Planes versus planificación en la experiencia latinoamericana", Revista de la CEPAL Agosto 1979, 79-96.

${ }_{535}$ Carlos A de Matos, "Planes versus planificación en la experiencia latinoamericana", Revista de la CEPAL Agosto 1979, 79-96
} 
negativas, económicas y sociales de sus ajustes radicales, del deterioro en la distribución del ingreso y el limitado efecto de sus reformas estructurales, así como frente a nuevas realidades por los efectos y peligros del cambio climático, las transformaciones producidas por la sociedad del conocimiento y el desarrollo de la información y las comunicaciones, plantearon la necesidad de limitar los excesos del sistema, revalorizar la importancia del gasto social en el desarrollo productivo, y la recentralización y la participación proactiva del Estado para asegurar la competencia y la corrección de fallas en el mercado y la importancia de la política fiscal y monetaria con la finalidad de lograr estabilidad de precios y seguridad a los agentes económicos.

Esto es, se discute, en el nivel académico, si un papel activo y adecuado del Estado puede contribuir significativamente a alcanzar una nueva "gobernanza" participativa y no autoritaria con actores públicos y privados, para sortear las crisis, controlar los excesos del capital financiero y apoyar el desarrollo de todos los países.O' Donnell considera que el Estado es "pieza clave para la gobernabilidad democrática y que "es un error asociar al Estado con el aparato estatal o el sector público, o la suma de burocracias públicas, que indudablemente son parte del Estado, pero no constituyen el todo". Esther del Campo llega a la conclusión de que el Estado debe ampliar la participación social, estabilizar las instituciones y ser el soporte de la democracia, resolviendo problemas de desigualdad social y contribuyendo con medidas eficaces para impulsar el crecimiento económico. ${ }^{536}$

Se plantea, desde los organismos internacionales, que el Estado, como impulsor del desarrollo y del crecimiento, no es agente principal de la economía como en la etapa desarrollista, sino socio eficaz de los actores privados, tanto del capital transnacional como de los grupos de poder económico nacional, jugando un papel protagónico para expedir políticas públicas e incentivar a las empresas a corto, mediano y largo plazo; impulsar el comercio internacional, acceder a nuevos y más amplios mercados y la explotación racional y sustentable de los recursos naturales; crear nuevas ventajas comparativas con procesos de producción con mayor valor agregado y alto contenido tecnológico; asegurar la provisión de bienes públicos de calidad (infraestructura, educación, salud) para el funcionamiento eficiente de los mercados y proteger los derechos de propiedad, la seguridad jurídica y la seguridad social. ${ }^{537}$

El Banco Mundial, en contraposición a sus anteriores políticas de desmantelamiento estatal, en su informe de Desarrollo Mundial de 1997, manifestó: "El Estado es fundamental para el proceso de desarrollo económico y social..."; "pero no como agente directo de crecimiento sino como socio, elemento catalizador e impulsor de ese proceso". Para subrayar el papel actual de las instituciones públicas dijo: para "elevar el nivel de bienestar de la población, tendrá que ampliarse la capacidad del Estado, es

\footnotetext{
${ }^{536}$ Esther del Campo, Del por qué al cómo: el sentido último de las reformas en América Latina, Quorum: Revista del pensamiento iberoamericano, 2008, 139-150.

${ }^{537}$ Jorge Leiva Lavalle, "Pensamiento y práctica de la planificación en América Latina", serie gestión pública, CEPAL - ILPES, Santiago, 2012.
} 
decir, su capacidad de emprender y promover acciones de interés colectivo de forma eficiente". 538

El FMI estableció a la vez, en el año 2000, lineamientos generales para las economías de transición. Los principales elementos para que opere la transición fueron: la liberalización, como proceso para "permitir que la mayoría de los precios se determinen en mercados libres", reduciendo "las barreras comerciales que habían aislado a las economías en transición de la estructura de precios de las economías de mercado del resto del mundo"; la estabilización macroeconómica,que "en esencia, es el proceso mediante el cual se contiene y se reduce la inflación a lo largo del tiempo, tras un estallido inicial de alta inflación después de la liberalización y la reaparición de la demanda reprimida. Este proceso exige disciplina en cuanto al presupuesto público y al crecimiento del dinero y el crédito (es decir, disciplina en la política fiscal y monetaria), así como avances hacia el logro de una balanza de pagos sostenible"; la reestructuración y la privatización, como "proceso mediante el cual se crea un sector financiero viable y se reforman las empresas de estas economías para que puedan producir bienes comerciables en mercados libres y transferir su propiedad a manos privadas" y las jurídicas e institucionales que "son necesarias para redefinir el papel del Estado en la economía, establecer el imperio de la ley, e introducir políticas de competencia apropiadas". 539

En esencia, el neoestructuralismo no se opone a mantener las denominadas reformas estructurales, sino a ampliarlas, y por lo tanto, se trata de una variante del neoliberalismo y no un modelo económico totalmente opuesto, lo que ha dado lugar a que algunos prefieran denominar al nuevo modelo o política pública posneoliberal, y si bien se denomina al modelo como neodesarrollista, esa identificación no reproduce los planteamientos iniciales del desarrollismo. En realidad, los modelos y políticas económicas actuales del capitalismo en América Latina no son sino una combinación entre el neoliberalismo y el desarrollismo.

En el informe de la CEPAL, Gobierno y planificación, ${ }^{540}$ este organismo detalla que la planificación de un Gobierno es útil solo en la medida en que la acción sea un proceso práctico que permita ejecutar sus promesas y roles en los objetivos. En Latinoamérica existe poca sintonía entre la planificación y las promesas que ha hecho cada Gobierno. Parte de una buena planificación es el carácter previsor que deben tener las políticas públicas. Esto permite tener mejores resultados en el cumplimiento de los fines y objetivos del Gobierno y del Estado y en la conducción y ejecución de las finanzas públicas que son el instrumento para alcanzar aquellos.

\footnotetext{
${ }^{538}$ Banco Mundial, El Estado un mundo en trasformación, 1997, http://documentos. bancomundial.org/curated/es/973681468778813985/pdf/341310spanish.pdf

${ }^{539}$ FMI, Economías en transición: Análisis del FMI sobre los avances y las perspectivas, Noviembre de 2000. www.imf.org/external/np/exr/ib/2000/esl/110300s.htm\#II

540 Revista de la CEPAL, Gobierno y planificación, Santiago de Chile, 1987. https://www.cepal.org/es/publications/list/publication-type.
} 
Agrega la CEPAL que "la planificación puede ser un instrumento de gran utilidad a disposición del Estado para coordinar el proceso hacia un desarrollo con igualdad, que necesariamente es de largo plazo. En esos términos, distinguimos a la planificación para el desarrollo de la planificación del desarrollo, término que se ajusta al ejercicio de la disciplina en las décadas de los sesenta y setenta, cuando se planificaba el desarrollo desde las oficinas de planificación, sin procesos de consulta o discusión con el resto de los actores sociales, políticos y económicos y con un enfoque económico y escasa consideración de lo social y ambiental". ${ }^{441}$

Según Jorge Máttar, Director del ILPES, la planificación en el presente siglo puede contribuir y ser un instrumento poderoso para que los países tengan una visión de futuro, de largo plazo, para alcanzar un desarrollo "sostenido e incluyente" como lo plantea la CEPAL en su documento La hora de la igualdad: Brechas por cerrar, caminos por abril, ${ }^{542}$ pues puede articular tanto los intereses de sus actores como Estado, sociedad, Gobierno y los del entorno externo, como los de los espacios nacional y local y las políticas públicas y fiscales expresados en los planes y programas nacionales y locales. ${ }^{543}$

Los organismos internacionales regionales (CEPAL - ILPES) plantean que en la actualidad, en la etapa del neoestructuralismo y del neodesarrollismo, se hable de una nueva planificación para que el Estado se fortalezca ejecutando o apoyando transformaciones estructurales, coordine a todos los actores económicos; permita la participación regional y local en las finanzas públicas y en la construcción de objetivos y para que en sus etapas de ejecución incorpore concepciones estratégicas y participativas, acordes con el contexto de predominio de las actividades económicas mundiales de los mercados y de las empresas transnacionales, por medio de las "alianzas público-privadas", sin dejar de definir políticas públicas para alcanzar una "sostenibilidad ambiental" y el logro de los valores esenciales de las sociedades democráticas, en cuanto a equidad, igualdad, transparencia y lucha anticorrupción. ${ }^{544}$

La planificación económica normativa adoptada de manera común en América Latina fue una camisa de fuerza impotente para enfrentar a las realidades sociales de cada país, por lo que se pasó luego a la planificación estratégica flexible con la adopción de políticas económicas que estructuraron a los problemas del mundo y de la región y, ya en este siglo, a una reactivación de la planificación indicativa y estratégica que vincula el espacio nacional con los locales en un proceso de recuperación del papel del Estado en la economía y en el proceso de desarrollo y de una cierta redistribución de la riqueza

\footnotetext{
${ }^{541}$ Jorge J. Máttar y Daniel E. Perrotti, La planificación como instrumento de desarrollo con igualdad en América Latina y el Caribe: Tendencias y desafíos, (Chile: CEPAL, 2014), 13.

542 CEPAL, La hora de la igualdad: Brechas por cerrar, caminos por abrir, Brasilia, 2010. http://repositorio.cepal.org/bitstream/handle/11362/13309/S2010986_es.pdf.

543 Jorge Máttar Director del ILPES en presentación al documento de Jorge Leiva Lavalle, "Pensamiento y práctica de la planificación en América Latina”, serie gestión pública, CEPAL - ILPES, Santiago, 2012. ${ }_{544}$ Jorge Leiva Lavalle, "Pensamiento y práctica de la planificación en América Latina", serie gestión pública, CEPAL - ILPES, Santiago, 2012.
} 
nacional. Otro elemento para una buena planificación es la democracia. Si un Gobierno no es eficaz para gobernar mediante una planificación que permita alcanzar los fines del Estado, entonces la democracia disminuye.

Otros elementos importantes, asociados a la planificación y a la ampliación de la democracia, son los procesos de descentralización y luego los de participación que se han implementado desde hace varias décadas en América Latina con diferentes enfoques, con la finalidad de reconocer el papel que cumplen y pueden desarrollar los gobiernos locales y, más tarde, las organizaciones sociales y los ciudadanos, en la definición y ejecución de políticas públicas nacionales, regionales y locales. Todo lo cual exige expedición o modificación de la normativa jurídica nacional y local y un acceso y distribución más equitativos de los recursos públicos.

En los estados unitarios latinoamericanos y aún en los federales, como lo observa la profesora Esther Del Campo, el desarrollo político-administrativo, desde la fundación de las repúblicas hasta fines del siglo XIX, se fundamentó en la centralización para consolidar los estados-nación y su control oligárquico, subsumiendo los intereses y poderes regionales. Los primeros intentos de descentralización propiamente dicha se presentaron en la década de los sesenta del siglo XX, con el desarrollismo y el proceso de industrialización por sustitución de importaciones mentalizados por la CEPAL. Se planteó entonces que en la planificación centralizada del Estado se incluyeran primero "polos de desarrollo regional" y más tarde proyectos de carácter rural, para lo cual se crearon corporaciones o centros de desarrollo regional que se convirtieron en instrumentos eficaces de una descentralización territorial y funcional. ${ }^{545}$

En los años ochenta del siglo pasado, en la parte final del modelo desarrollista, se fortalecieron los procesos de descentralización política-administrativa en beneficio de las instituciones locales pero bajo control estatal. Ya en los años noventa, con la influencia del neoliberalismo, se pretendió debilitar la autoridad y competencias del Estado central para que fueran asumidas por los gobiernos locales mediante procesos de modernización, privatización y autonomía, para optimizar el uso y la eficiencia de los recursos públicos. Finalmente, ya en este siglo, en algunos países como en Ecuador, (2007-2017) se adoptó una recentralización de los procesos de desarrollo mediante un neointervencionismo o neodesarrollismo estatal que reconoce ciertas competencias exclusivas y la asignación de recursos a los gobiernos locales, pero que en todo caso los subordina a los objetivos y presupuestos del Plan Nacional de Desarrollo.

Si bien se reconocen los beneficios de gobernabilidad y de mejora en la participación democrática que ocasionan los procesos de descentralización, en el modelo neoliberal y aún en el neointervencionista, favorecen la competitividad, una mayor inserción en el mercado regional y mundial y la apertura económica al capital transnacional,

\footnotetext{
${ }^{545}$ Esther del Campo García, Gobernabilidad y descentralización político-administrativa en los países
} andinos. El caso de Bolivia, Ecuador y Perú en los años noventa, (Barcelona: CIDOB ediciones, 2006). 
especialmente financiero, y el Estado asume un cierto papel regulador y promotor de la vinculación de la economía nacional y de sus actores a la globalización capitalista mundial.

\section{LA PLANIFICACIÓN: SU PROCESO HISTORICO Y LEGISLACIÓN EN ECUADOR HASTA 1990}

La planificación y los planes de desarrollo en Ecuador tienen sus antecedentes históricos en la tercera década del siglo XX, cuando el sistema económico y político transitaba de una modernización del liberalismo agroexportador acoplado a la economía mundial capitalista, a un modelo intervencionista inspirando en el keynesianismo que pretendía superar las irracionalidades del sistema y la gran crisis de los años treinta.

En esa transición, luego de la Primera Guerra Mundial y de las revoluciones rusa de 1917 y mexicana de 1919, fue preocupación principal de los EE UU como nueva potencia mundial que, en su área de influencia, los países latinoamericanos modernizaran sus instituciones, especialmente las económicas, monetarias y financieras para su mejor integración al mercado mundial y a los mecanismos de reproducción del capital internacional.

En el final del primer cuarto de siglo (1900-1925), Ecuador enfrentó una profunda crisis económica, política y social, como resultado de la crisis del cacao y sobre todo porque su sistema bancario y monetario se desenvolvía en el ámbito privado, sin control público. El Estado no controlaba la emisión monetaria, y dependía del crédito y la emisión inorgánica de dinero por parte de los banqueros de la Costa y de la Sierra.

Estos hechos ocasionaron que un grupo de militares y sectores emergentes de la burguesía dieran un golpe de Estado el 9 de julio de 1925 bajo la proclama: "la revolución persigue la igualdad de todos y una protección del hombre proletariado", dando origen a la "revolución juliana". Tal como indica José Moncada: "la revolución no tenía características caudillistas sino institucionales, para combatir el predominio plutocrático representado por el Banco Comercial Agrícola de Guayaquil y no necesariamente para terminar con la oligarquía comercial - financiera sino para limitar su poder". ${ }^{546}$ Por ello, a pesar de que el Gobierno adoptó una serie de medidas para enfrentar a la banca privada y a la oligarquía agroexportadora, estas, sin embargo, se ingeniaron para conseguir y afianzar concesiones que siguieran beneficiando sus privilegios.

Los militares julianos facilitaron la modernización del país al adoptar las reformas económicas e institucionales que sugirió la comisión norteamericana de expertos

\footnotetext{
546 José Moncada, Historia Económica, Planificación y socialismo, Colección pensamiento Socialista, Nro. 9. (Quito: Edit. La Tierra, 2008), 81.
} 
financieros presidida por Edwin Walter Kemmerer. ${ }^{547}$ El 9 de octubre de 1928 el presidente provisional Isidro Ayora inauguró las sesiones de la convención que elaboró una nueva constitución el 29 de Marzo de 1929. SegúnRamiro Borja "la Constitución de 1929 introdujo grandes innovaciones en el derecho constitucional ecuatoriano, estableció "un régimen presidencial mitigado por matices parlamentarios tan subidos que le hacen casi intermedio entre el presidencial puro y el parlamentario"548 e inició un periodo de preocupación por los aspectos sociales y económicos relativos al derecho laboral, la seguridad social y la reforma agraria y por una participación activa del Estado en la economía.

En el contexto de la crisis capitalista mundial de los años treinta, de la creciente influencia del keynesianismo, del desorden en la economía nacional, en concreto en el manejo monetario ${ }^{549}$ y de las nuevas normas constitucionales, durante su primer Gobierno, el presidente José María Velasco Ibarra, con la motivación de reconstruir el país, pidió a su ministro de Hacienda y connotado banquero guayaquileño, Víctor Emilio Estrada, que preparara un plan económico con la finalidad de alcanzar la anhelada estabilidad económica.

Estrada parte de constatar que las leyes de emergencia dictadas en esos años habían destruido "la confianza y la lógica" y que era necesario recuperarlas elaborando un plan con esos valores, pues "no importa para el caso cual sea el régimen social económico tanto colectivista como el capitalista". Dentro de los principales aspectos que acogió "el plan Estrada de reconstrucción económica", para conseguir levantar el poder de compra de los ciudadanos, crear demanda y fomentar la producción agrícola e industrial, constaban: "la atención preferente del Estado en el aspecto financiero; la necesidad de una moneda estable; el aumento de salarios, la exportación libre y la colonización de tierras incultas". Estrada procuró metodizar cada sugerencia de manera que cada una de ellas contenía tres aspectos: "un estudio del caso y la necesidad de reforma; un proyecto de ley y finalmente un comentario sobre las principales bases y razones que amparan cada prescripción esencial de aquel". 550

El referido plan Estrada cuestionó también a quienes estiman que el presupuesto es el eje de la vida nacional y aseguró que "la vida nacional constituye el eje del presupuesto del Estado" y que, por lo tanto, se debe estimular "el restablecimiento de la confianza en los negocios y el trabajo". Se trata pues de una crítica liberal temprana a las teorías

547 BANCO CENTRAL SOBRE KEMMERER EN LOS ANDES, http://biblioteca.bce.ec/cgibin/koha/opac-detail.pl?biblionumber=1820\&query_desc $=$ su\%3A\% $\quad 22 \mathrm{KEM}$ MERER\%2C\%20EDWIN\%20 WAL TER\%22. JUAN PAZ Y MINO SOBRE REVOLUCION JULIANA. En Paz y Miño Cepeda, Juan J. Revolución juliana. Nación, ejército y bancocracia, Quito, EC: Abya-Yala, 2000.

${ }_{548}$ Ramiro Borja (1950) "Derecho Constitucional Ecuatoriano". Quito - Ecuador, Tomo 2. Ed. Cultura Hispánica, 676.

${ }^{549}$ Leonardo Vicuña, Estudio introductorio a la Planificación en el Ecuador, Biblioteca Básica del Pensamiento Ecuatoriano, No.27, Banco Central del Ecuador, 1987.

${ }^{550}$ Leonardo Vicuña, Estudio introductorio a la Planificación en el Ecuador, Biblioteca Básica del Pensamiento Ecuatoriano, No.27, Banco Central del Ecuador, 1987, 21. 
posteriores del "presupuesto funcional", como instrumento ordenador y dinámico de la economía nacional y el desarrollo. ${ }^{551}$

A la par de esta iniciativa liberal pionera de planificación, en los años treinta y cuarenta del siglo pasado se intentó conformar una institucionalidad para que promoviera la planificación y la expedición de políticas económicas por medio de un Consejo Nacional de Economía en 1935, 1937, 1943 o de una Corporación de Fomento. En la revolución del 28 de Mayo de 1994, su promotora Alianza Democrática Ecuatoriana planteó "la necesidad urgente de adoptar la planificación como mecanismo idóneo para aplicar medidas que condujeran a la población a condiciones de vida más elevadas y al país a un proceso de desarrollo económico y social integral", y el 2 de enero de 1945 el Gobierno organizó una Comisión Técnica de Economía "para coordinar y planificar la política económica del Estado" que a la vez puso en vigencia un Plan de Fomento Inmediato de la Economía Nacional. En los meses siguientes, en el marco de la Constitución de 1945 se creó la Comisión Nacional de Economía y dispuso en su artículo 146 que "para encausar la economía nacional, el Estado dictará los planes adecuados, a los que se someterán las actividades privadas, sin perjuicio de los establecido sobre el régimen de propiedad". La Constitución de 1946 erigió nuevamente el Consejo Nacional de Economía, restringiendo sus actividades al estudio de la realidad económica y a la orientación de las finanzas públicas y en 1949 se estructuró un Instituto de Fomento de la Producción, que fue el antecedente para la creación del Banco Nacional de Fomento en 1953. ${ }^{552}$

Después de la Segunda Guerra Mundial y de la acción de los organismos financieros que se crearon para monitorear la economía y consolidar el sistema capitalista internacional liderado por Estados Unidos, los países latinoamericanos se articularon activamente al comercio internacional y promovieron su desarrollo interno, dentro de un modelo intervencionista, en el que el Estado jugaba un papel preponderante en la creación de las condiciones básicas para aquel.

La CEPAL inició sus actividades en Ecuador con un informe sobre el desarrollo económico del país $(1951$ - 1953) y conjuntamente con el BIRF y el Banco Central platearon en 1954 estructurar un organismo nacional de planificación: la Junta Nacional de Planificación y Coordinación Económica, que fue creada en la tercera administración del presidente José María Velasco Ibarra. Se integró inicialmente con seis funcionarios públicos y tres ciudadanos de prestigio, con las finalidad de formular planes nacionales y regionales de desarrollo y coordinar las políticas económicas y el endeudamiento públicos. $^{553}$

551 SILEC, Introducción a la LOAFYC, http://portal.uasb.edu.ec:2165/WebTools/eSilec Pro/DocumentVisualizer/DocumentVisualizer.aspx?id=HISTORIC-LEY_ORGANICA_DE_ADMINIS TRA CION_FINANCIERA_Y_CONTROL_1977 \&query =LOAFYC\#I_DXDataRow1.

${ }_{552}$ Marco Antonio Guzmán, Derecho Económico Ecuatoriano I, (Quito: Corporación Editora Nacional UASB, 1996).

${ }_{553}$ Ecuador, Presidencia de la República, Decreto Ley de Emergencia N ${ }^{\circ} 19$, Registro Oficial No. 527, 29-mayo-1954 
Como bien señala José Moncada, los orígenes y la necesidad de implementar la planificación en el Ecuador se deben analizar en virtud al tiempo económico en que vive el país. Así, "el periodo en el cual fue creada la Junta, se caracterizó por una relativa estabilidad económica que tuvo su fundamento en un mejoramiento notable de las exportaciones (volúmenes y valores) con toda su secuela en la generación de ocupación y de ingresos privados y públicos". El valor de nuestras exportaciones, que entre 1930 1940 fue de un promedio anual de 7,4 millones de dólares, llegó entre 1950 - 1955 a 78,6 millones de dólares. ${ }^{554}$

En aquella etapa económica de Ecuador se observa una tranquilidad económica en virtud que la economía se mantenía con estándares muy aceptables para nuestro país. Por lo tanto, la planificación surge justamente para que esos recursos sean adecuadamente planificados y destinados para el desarrollo productivo del Ecuador y que se mantenga el nivel de crecimiento económico. Debemos resaltar que la planificación no nace como remedio ante dificultades económicas, sino más bien, se origina en afán de que la economía se mantenga equilibrada y dé buena rentabilidad para el país.

La planificación entendida como un proceso en el que se estructura un "plan general, metódicamente organizado y frecuentemente de gran amplitud, para obtener un objetivo determinado, tal como el desarrollo armónico de una ciudad, el desarrollo económico, la investigación científica, el funcionamiento de una industria» ${ }^{, 555}$ y en el que se establece una consolidada institucionalidad para formularlo e implementarlo, surge de manera pionera en Ecuador. Los gobiernos que sucedieron al del presidente Velasco, que adoptó las dos iniciativas indicadas, refrendaron y continuaron esta decisión, que dio como resultado una evidente consolidación institucional. ${ }^{556}$

La Junta Nacional de Planificación y Coordinación Económica tuvo desde 1961 la finalidad de "asesorar al poder público en la formulación de planes para el desarrollo económico del país y en la coordinación de la política económica". ${ }^{557}$ Mediante Decreto-Ley de Emergencia No. 40 de agosto de 1961 se estableció el Sistema Nacional de Planificación, que incorporó al directorio de la Junta a todos los ministros con voz y voto en los asuntos concernientes a su área; diferenció con claridad las atribuciones del directorio con las de la Secretaría General de Planeación Económica que dirigía los departamentos técnicos y administrativos y a la que se confirió la atribución de revisar las proformas presupuestarias nacionales y locales y se estableció en todos los ministerios y en el sector público departamentos de programación para que con la Junta

\footnotetext{
554 José Moncada, Historia Económica, Planificación y socialismo, Colección pensamiento Socialista, Nro. 9. (Quito: Edit. La Tierra, 2008), 177.

555 Diccionario de la Real academia Española. http://dle.rae.es/?id=TJwPLbdfecha de consulta 21 de mayo de 2017.

556 Patricio Moncayo, La planificación estatal en el inter juego entre desarrollo y democracia, (Quito: Atrio, 2017), 91.

${ }^{557}$ Luis Luna, Ecuador Sociedad Limitada, $1^{\circ}$ Ed. (Quito: Promoser, 1989), 69.
} 
definan programas de acción, presupuestos y planes de desarrollo. ${ }^{558}$ Debemos recordar que la Constitución vigente en aquella época, la del año 1946, establecía la existencia de un Consejo Nacional de Economía pero no contemplaba normativa explícita respecto a la planificación y a los manejos de los planes y objetivos económicos del Estado. ${ }^{55}$

Si bien con la Constitución de 1967 se consolidaron los conceptos sobre planificación y planes considerados como obligatorios para el sector público e indicativos y orientadores para el sector privado, ${ }^{560}$ en 1970 se debilitaron las atribuciones de la Junta, cuya institucionalidad no constaba en la referida carta política y se recortó significativamente el personal que había alcanzado un alto nivel de calificación y tecnificación, por un impase con el Gobierno de Velasco Ibarra, que se negó a aprobar el Plan de Desarrollo 1970 - 1973 y, proclamada su dictadura, dispuso la reorganización de la Junta mediante decreto supremo en octubre de $1970 .^{561}$

En 1972, la Junta Nacional de Planificación se fortaleció gracias al Gobierno "nacionalista y revolucionario" presidido por el general Guillermo Rodríguez, quien planteó la Filosofía y Plan de Acción de las Fuerzas Armadas para introducir cambios profundos en la estructura económica y social del país. Con este propósito formuló un Plan de Desarrollo inspirado en las doctrinas desarrollistas de la CEPAL, en las reflexiones que el propio organismo había formulado en sus bases para una Estrategia de Desarrollo en el Contexto de la Integración Subregional (1969-1991) y en las proclamas reformistas de los militares en el ámbito agrario, tributario, financiero y social, que permitieron además formular los Lineamientos Fundamentales del Plan Integral de Transformación y Desarrollo en junio de 1972. ${ }^{562}$ En 1975 se estableció también el Sistema Nacional de Proyectos como parte del Sistema Nacional de Planificación que fue el antecedente directo para la creación del Banco de Desarrollo en 1976.

El Plan de Desarrollo, que finalmente se expidió en diciembre de 1977, no tenía su contenido original, pues el jefe militar fue derrocado el año anterior y sustituido por un triunvirato de orientación derechista, que modificó las políticas de desarrollo iniciales y emprendió en una agresiva política de endeudamiento externo y represión a los sectores sociales, con la expedición de numerosos decretos anti-obreros, con la matanza de trabajadores de Aztra y el asesinato del dirigente político Abdón Calderón. ${ }^{563}$

\footnotetext{
558 Ecuador, Presidencia de la República, Decreto Ley de Emergencia No. 40, 2-agosto-1961. Registro Oficial Nro. 281, 4-Agosto-1961.

${ }^{559}$ Ecuador, Constitución Política del Ecuador de 1946, Registro Oficial Nro. 773, 31-diciembre-1946.

${ }^{560}$ Ecuador, Constitución Política del Estado de 25 de mayo 1967 (arts. 94 -97)

${ }^{561}$ Ecuador, Presidencia de la República, Decreto Supremo 595,13-octubre-1970, Registro Oficial No.81, 16-octubre-1970.

${ }^{562}$ Leonardo Vicuña Izquierdo, Estudio introductorio a la Planificación en el Ecuador, Biblioteca Básica del Pensamiento Ecuatoriano, No.27, Banco Central del Ecuador, 1987.

563 Víctor Granda Aguilar, la Masacre de Aztra, (Cuenca: Facultad de CCEE de la Universidad de Cuenca, 1979).
} 
En 1979 culminó un escabroso proceso de retorno al régimen constitucional, al aprobarse en referéndum una nueva Constitución de la República ${ }^{564}$ que instituyó, en sustitución de la Junta de Planificación, el Consejo Nacional de Desarrollo (CONADE) (Artículos 89 y 91), que "fija las políticas generales económicas y sociales del Estado y elabora los correspondientes planes de desarrollo; que son aprobados por el presidente de la República para su ejecución”. Su directorio estaba presidido por el vicepresidente de la República e integrado por cuatro ministros de Estado, un delegado del Congreso Nacional, el presidente de la Junta Monetaria, un representante de los alcaldes y prefectos, un representante de los trabajadores organizados, un representante de las Cámaras de la Producción y un representante de las universidades y escuelas politécnicas. Se mantuvo la estructura técnica y la Secretaría de Planeación Económica y formalmente se organizó el Banco de Desarrollo del Ecuador.

La conformación del Consejo, según Patricio Moncayo, fue vista de manera positiva por sectores públicos y privados, en virtud de que "el plan ya no sería obra exclusiva del poder central o del Gobierno nacional, al menos así lo entendieron los representantes incorporados al directorio como vocales, lo que contrastaba con el estilo vertical de planificación del régimen de facto". 565 En esta Constitución el órgano de planificación que tenía más un carácter técnico se sustituyó por un órgano político. Literalmente no consta en este texto la palabra planificación, pero se mantiene una cierta conceptualización de ella en las referidas competencias otorgadas al CONADE.

Sobre las políticas de planificación se estableció que una vez que estas fueran determinadas por el Consejo, al igual que los planes económicos y sociales que se elaboraran, debían ser puestos a consideración del presidente de la República para que una vez aprobados fueran ejecutados y cumplidos de forma inmediata. Esta ejecución es obligatoria para los respectivos ministros y por las distintas entidades públicas, siendo sus directivos responsables de su aplicación. Se dispuso también que cuando esas políticas y planes requirieran de modificación, reforma o expedición de leyes, el residente de la República presentaría al Congreso Nacional o al Plenario de las Comisiones Legislativas los correspondientes proyectos.

El Consejo Nacional de Desarrollo estructuró el Plan Nacional de Desarrollo Económico y Social 1980-1984 que se sustentó en la necesidad de contar en la planificación con un instrumento para la acción gubernamental orientada a la consecución de tres fines específicos: afianzamiento del sistema democrático, desarrollo económico y justicia social, a los que en 1981 se agregó defensa nacional. Como estrategia principal el Plan formulaba la confluencia entre Estado, empresa privada y capital extranjero en calidad de promotores de la industrialización y articuladores de la economía nacional. Sustituía la política de reforma agraria de la década anterior por la de fomento agropecuario; sostenía la necesidad de implementar ciertas "reformas

\footnotetext{
${ }^{564}$ Ecuador, Constitución Política de 1979, Registro Oficial 800, 27-Marzo-1979.

${ }^{565}$ Patricio Moncayo, La planificación estatal en el inter juego entre desarrollo y democracia, 120.
} 
básicas" tributaria, administrativa, educacional y política y la ejecución de "41 proyectos fundamentales" para diferentes provincias y regiones del país.

Sin que se cumplieran las metas y proyectos indicados se formuló luego el Plan General de Desarrollo 1985-1988 y como estrategia de mediano plazo se expidió un documento denominado El Ecuador del Futuro 1988.

En 1984 se expidió la Ley Orgánica del Consejo Nacional de Desarrollo; su reglamento en 1985 y el Reglamento Orgánico Funcional de la institución varios años más tarde en 1992. ${ }^{566}$ Como observa Marco Antonio Guzmán, los preceptos jurídicos sobre planificación son "ambiguos e imprecisos", pues según nuestro criterio, a los grupos dominantes del país no les interesaba el uso racional de los recursos públicos. La referida Ley del CONADE no derogó todas las normas de 1961 sobre la Junta Nacional de Planificación y Coordinación, sino en cuanto se opusieran a aquella, por lo que algunas de ellas subsisten por ser convenientes a la referida ambigüedad normativa. ${ }^{567}$

Si se hace un balance sobre la década del ochenta se debe reconocer que se mantuvieron y adecuaron a la nueva Constitución (1979) las principales instituciones y transformaciones económicas y sociales implementadas en la dictadura militar progresista del general Guillermo Rodríguez y que se desmontó parcialmente la legislación represiva expedida por el triunvirato militar que le sucedió en el poder. Sin embargo, no prosperó el modelo de industrialización del país; los grupos de poder trasladaron a su favor la renta petrolera; el regionalismo entre la sierra y la costa se profundizó y el sostenimiento del Estado y de las políticas clientelares de los gobiernos de turno, para favorecer intereses locales, ocasionaron un masivo endeudamiento público y una nueva configuración territorial del Estado, con procesos de descentralización políticos y administrativos, que se expresan en los planes de desarrollo antes indicados y en la normativa jurídica que se expidió al respecto. ${ }^{568}$

Como ya hemos manifestado anteriormente, el modelo económico intervencionista y burocrático, agobiado por la deuda externa, colapsó en los inicios de la década del noventa, por lo que el Gobierno socialdemócrata de Borja (1988-1992), además de suscribir cartas de intención con el FMI para ajustar gradualmente la economía, inició un proceso de liberalización del comercio y de reforma de las finanzas públicas, especialmente de simplificación y expedición de un nuevo régimen tributario interno; de flexibilización laboral que vulneró los derechos individuales y colectivos de los

\footnotetext{
${ }^{566}$ Ecuador, Ley 002, aprobada por el Congreso Nacional el 28 de noviembre de 1984, sancionada el 12 de diciembre y publicada en el Registro Oficial No. 102, 10-enero-1985; Decreto Ejecutivo No.724, Registro Oficial No.185, 14-mayo-1985 y Acuerdo No. 249-A, 5-julio-1993, Registro Oficial de 9 de agosto de 1993.

${ }^{567}$ Marco Antonio Guzmán, Derecho Económico Ecuatoriano I, Corporación Editora Nacional - UASB, Quito, 1996.

${ }^{568}$ Esther del Campo García, Gobernabilidad y descentralización político-administrativa en los países andinos. El caso de Bolivia, Ecuador y Perú en los años noventa, (Barcelona: CIDOB ediciones, 2006).
} 
trabajadores y adoptó nuevas formas contractuales para promover la inversión extranjera, la capitalización y privatización de las acciones de las empresas estatales.

\section{LA PLANIFICACIÓN EN LAS NORMAS CONSTITUCIONALES Y LEGALES EN EL MODELO NEOLIBERAL (1990 - 2006)}

Desde los años ochenta del siglo pasado en Ecuador y con la introducción de las reformas liberales en Inglaterra, EEUU y aún en nuestra región con la dictadura de Pinochet y otros gobiernos autoritarios, se fueron adoptando paulatinamente políticas que cuestionaban al desarrollismo, al estructuralismo y en especial a la participación activa del Estado en la Economía. En Ecuador, el modelo económico y político neoliberal se introdujo con mayor fuerza en la década del noventa, en la parte final del gobierno de Borja, en concreto, en el gobierno de Sixto Durán-Alberto Dahik y en los que lo sucedieron hasta 2006.

En ese contexto, en la década del noventa se intensifica un proceso de disminución de la importancia institucional de la planificación y de los efectos de los planes de desarrollo y de otros instrumentos de ordenamiento y control estatal, promoviendo a la vez la modernización del Estado, las privatizaciones, el equilibrio fiscal y los esquemas de descentralización y desconcentración para debilitar el papel concentrador e interventor del Estado, sin que ello signifique que a la vez se desmantele el modelo autoritario en el ejercicio del Gobierno y de la Administración, ya que resultaba necesario y útil para acelerar las reformas liberales.

Las reformas neoliberales se adoptaron abiertamente, como lo hemos dicho desde antes de la vigencia de la Constitución de 1998, durante el gobierno de Sixto Durán, al aprobar la Ley de Presupuestos (1992), nuevas reformas tributarias, la Ley de Modernización del Estado para promover privatizaciones y concesiones (1993) y la expedición del ERJAFE que sustituyó la legislación administrativa y otorgó al Ejecutivo las atribuciones necesarias, para acelerar los procesos económicos liberales y el pago de la deuda externa.

En la implementación del modelo neoliberal en Ecuador nos referiremos al cuestionamiento al centralismo del Estado y a la promoción de la descentralización; a la reforma del Estado para impugnar su intervención en la economía y el desarrollo y a la disminución progresiva del papel de la planificación en la gestión pública.

La impugnación del centralismo, la burocratización y la función intervencionista del Estado en la economía no tienen solo fundamento ideológico-político neoliberal ni son resultado exclusivo de las presiones o imposiciones de los organismos financieros internacionales, en representación del capital transnacional y de las potencias mundiales, sino que obedecen principalmente a las contradicciones existentes, en la realidad y en el territorio del país, entre el poder nacional, ejercido por las élites 
económicas y políticas que controlan los gobiernos, y las élites regionales y locales autónomas, que representan a la vez los intereses de los grupos de poder subnacionales que gestionan los consejos provinciales, los concejos municipales, las juntas parroquiales rurales y otros órganos de poder local establecidos en la Constitución.

La descentralización tiene una dimensión política, una administrativa y otra físcal. Hasta las reformas de 1996 la Constitución de 1979 no incluía como características de identidad del Gobierno ser "descentralizado, pluricultural y mutiétnico". Pues bien, desde el inicio de la vigencia de aquella se dictaron normas legales específicas para regular las competencias del "régimen seccional autónomo" y el reconocimiento de su descentralización política y de su autonomía funcional, económica y administrativa.

Entre 1989 y 1998, con reformas constitucionales presionadas por grupos de poder regional y local, se profundiza en el modelo descentralizador, ya que los gobiernos municipales más representativos (Quito, Guayaquil, Cuenca), diputados provinciales pertenecientes a organizaciones políticas a ellos vinculados y las asociaciones nacionales de consejos provinciales y municipales y luego de las juntas parroquiales exigen una descentralización no solo política, sino fiscal y administrativa, para participar obligatoriamente en la distribución de las rentas nacionales y asumir competencias y recursos demandados por ellos.

Desde 1989 a 2004 se emitieron veinte disposiciones de transferencias de financiamiento del Gobierno central a los gobiernos seccionales autónomos. En 1996, mediante reforma constitucional se dispuso que para hacer efectiva la autonomía de los "gobiernos seccionales autónomos" se les destine el 15\% del presupuesto del Gobierno Central y en 1997 se expidió la ley sobre esa participación obligatoria, a la que se suma el 5\% de ingresos no permanentes excepto el endeudamiento público, para constituir un Fondo de Descentralización. La Ley de Descentralización y Participación Ciudadana, aprobada en octubre de 1997 y luego la Constitución de 1998, establecieron un sistema de transferencias de competencias y recursos denominado "a la carta", puesto que se accede a ellas obligatoriamente siempre que no sean exclusivas del Estado, por voluntad de la entidad solicitante y demuestre tener la capacidad operativa para asumirla (Art. 226). El panorama jurídico de esta descentralización se completa con la expedición de la Constitución de 1998, que recoge todas las disposiciones antes indicadas además de establecer como nuevo Gobierno autónomo: la Junta Parroquial Rural y una renovada estructura para los consejos provinciales. ${ }^{569}$

Como se puede observar, el proceso de descentralización en Ecuador durante la vigencia del modelo neoliberal contribuyó a la dispersión y debilitamiento del Estado central y a un fortalecimiento de los gobiernos seccionales autónomos que asumieron nuevas competencias conforme a sus preferencias, dentro de los límites establecidos en

\footnotetext{
${ }^{569}$ Ana Isabel Molina Morte, Relaciones Intergubernamentales en la descentralización del Ecuador, tesis doctoral dirigida por Esther del Campo García, Madrid, 2015.
} 
la Constitución y siempre que justifiquen su capacidad para ejercerlas, además de contar de manera directa, permanente y predecible con mayores recursos provenientes del Presupuesto General del Estado.

Sobre la reforma del Estado y las privatizaciones, la acción gubernamental se orientó inicialmente en la construcción de una estructura burocrática (CONAM) destinada a identificar las áreas, empresas y actividades públicas más importantes para acelerar los procesos de modernización del Estado, de privatización y de establecer un régimen de concesiones para favorecer en todas ellas la inversión y la participación de los sectores privados extranjeros y nacionales.

El contenido de la Ley de Modernización del Estado expedida por el presidente Sixto Durán en 1993 se oponía a la Constitución de 1979 entonces vigente, que impedía que los recursos naturales y los servicios públicos mediante acciones administrativas pudieran ser transferidos a la iniciativa privada. Así y todo se dictó la ley y su reglamento para favorecer los procesos de descentralización, desconcentración y en especial la denominada "desmonopolización y privatización de los servicios públicos y de las actividades económicas asumidas por el Estado u otras entidades del sector público" (Art.5). ${ }^{570}$

Para cumplir con los objetivos antes indicados, la Ley de Modernización creó el Consejo de Modernización del Estado como organismo adscrito a la Presidencia con régimen especial. La estructura del CONAM contaba con un Consejo Nacional, una Presidencia y una Dirección Ejecutiva. El Consejo estaba integrado por el delegado del presidente de la República que a la vez será su presidente, tres funcionarios públicos, un representante de los trabajadores y servidores públicos y un representante de las cámaras de la producción. El director ejecutivo era nombrado por el presidente de la República como representante legal del Consejo y tenía amplias atribuciones para celebrar en su nombre los contratos.

Si bien la Ley de Modernización incluye varias normas de racionalización y eficiencia administrativa, que son positivas para el ejercicio de los derechos ciudadanos y adopta regulaciones para promover la descentralización, desconcentración y delegación de competencias y atribuciones, lo esencial de la norma, para la implementación del nuevo modelo económico y político, se encuentra en las regulaciones de "desmonopolización, delegación de servicios públicos a la iniciativa privada y privatización”, para lo cual se establecen las modalidades de "aporte total o parcial al capital de sociedades por acciones; arrendamiento mercantil, concesión de uso, de servicio público o de obra pública, licencia, permiso u otras figuras reconocidas por el derecho administrativo; venta, transformación, fusión, escisión y liquidación de empresas estatales o mixtas, y

${ }^{570}$ Ecuador, Ley 50, de Modernización del Estado, Registro Oficial 349, 31-dic-1993. 
cualquier otra modalidad que mediante decreto determine el Ejecutivo y que esté amparada en la ley ecuatoriana". 571

Según Marco Antonio Guzmán, en el Gobierno de Sixto Durán se puso como "preocupación y pasión centrales", "la participación del sector empresarial altamente capitalizado en áreas reservadas al Estado y se dejó de lado la solidaridad social y la participación de sectores comunitarios o la autogestión", sin dar atención prioritaria a la protección del usuario y del público y al interés nacional, en abierta contraposición con las normas constitucionales vigentes (1978-79) que establecían como requisito la expedición de una ley para otorgar concesiones a particulares de las actividades económicas reservadas al Estado. ${ }^{572}$

La Ley se complementó con un Reglamento expedido en marzo de 1994, que luego fue sustituido el 2 de diciembre de 1994 y reformado el 22 de julio de 1996, en el que se amplían las normas, procedimientos e instituciones sobre la desmonopolización, privatización, delegación al sector privado, ampliación de inversiones y el régimen de concesiones con normas especiales para la obra pública, el servicio público, el sector eléctrico, el agua potable y saneamiento ambiental, obras y servicios portuarios. ${ }^{573}$

La Ley de Modernización y las acciones del Consejo de Modernización sustituyeron en la práctica los estudios que efectuaron los organismos de planificación desde los años ochenta hasta finales de 2006, momento en el que formalmente se inicia un renovado modelo neointervencionista y neodesarrollista. La Ley de alto contenido autoritario se mantuvo vigente hasta 2017 para todas las operaciones de modernización y concesiones implementadas, tanto en el modelo neoliberal como en el neoestatista y neodesarrollista en la actualidad.

En cuanto a la planificación, como observa Marco Antonio Guzmán, las actuaciones del Ejecutivo en el neoliberalismo son contrarias al mantenimiento de un sistema de planificación y su política al respecto es contradictoria entre esa tendencia y el contenido del Reglamento Orgánico Funcional del CONADE expedido en agosto de 1993, pues mientras “decaía sensiblemente la actividad planificadora nacional”, el Vicepresidente Dahik, por razones políticas y personales, "configuraba una ampulosa estructura orgánica para la Secretaría General de Planificación” que él dirigía, ${ }^{574}$ con la finalidad de acumular poder al interior del Gobierno.

\footnotetext{
${ }^{571}$ Ecuador, Ley 50, de Modernización del Estado, Registro Oficial 349, 31-dic-1993.

${ }^{572}$ Marco Antonio Guzmán, Derecho Económico Ecuatoriano II, Corporación Editora Nacional - UASB, Quito, 1996, 260.

${ }^{573}$ Ecuador, Reglamento General de la Ley de Modernización del Estado del 31 de marzo de 1994, Registro Oficial 1623; Reglamento Sustitutivo del Reglamento General de la Ley de Modernización del Estado, Registro Oficial 581, 2-dic-1994 y reformas al reglamento anterior publicadas en el suplemento del Registro Oficial de 22 de julio de 1996.

${ }^{574}$ Marco Antonio Guzmán, Derecho Económico Ecuatoriano I, Corporación Editora Nacional - UASB Quito, 1996.
} 
Las reformas a la Constitución de la República, en su segundo bloque, adoptadas en el Congreso Nacional en mayo de $1995,{ }^{575}$ oficializaron la tendencia regional y local de quitar fuerza a la planificación y a los planes de desarrollo, aprovechando y utilizando las contradicciones que existían al respecto, en la Ley y Reglamento del CONADE, vigentes desde 1984. Las reformas constitucionales disponían, en sus artículos 17 y 18, que en las atribuciones y deberes del presidente de la República (Art. 79) se incluyeran las mismas que la carta política preveía para el CONADE, esto es, la de fijar "las políticas generales económicas y sociales del Estado", la de "aprobar los correspondientes planes de desarrollo" y "la política poblacional del país, dentro de las directrices sociales y económicas para la solución de los problemas nacionales, de acuerdo a los principios de respeto a la soberanía del Estado y de autodeterminación de los pueblos" y, en lo relativo al vicepresidente, se sustituía el Art 83 por la siguiente norma: "El vicepresidente ejercerá las funciones que le asigne el presidente de la República" suprimiendo expresamente la obligación que tenía de ser "presidente nato del Consejo Nacional de Desarrollo".

Con estas reformas, al asignar al Ejecutivo las mismas funciones que antes tenía el CONADE y la obligación de que este sea presidido por el vicepresidente de la República, se anulaban en la práctica las competencias relacionadas con el desarrollo y el ordenamiento económico y social del país, que tenía independientemente el organismo técnico de planificación y su ejercicio colectivo con la participación de representantes de importantes sectores de la sociedad civil. Son reformas que cuando menos generan incertidumbre y desconcierto en el funcionamiento del organismo de planificación y debilitan la eficacia de los planes generales y operativos, a las que se suman varias deficiencias de la Ley, todas ellas orientadas a relativizar esta importante actividad estatal.

La ley y el reglamentos vigentes desde 1994 se acoplaron perfectamente a la intención política y a la conveniencia económica de anular los efectos del sistema de planificación y de los planes nacionales, pues no demandaban una regularidad en el funcionamiento del Consejo y limitaban sus atribuciones al cumplimiento de las instrucciones presidenciales sobre las distintas políticas económicas y sociales y aún sobre los proyectos a ejecutarse.

Sin embargo, las normas daban atribuciones similares a las del Consejo cuando este no se encontraba reunido, al presidente del CONADE y a la Secretaría de Planificación, como su órgano técnico y administrativo, con atribuciones legales que podían contraponerse a las del Ejecutivo y sus ministros, con lo que se creaba un conflicto de poder. El vicepresidente de la República, como presidente del CONADE o por medio de la Secretaría Técnica o sus subsecretarías, podía ejercer atribuciones otorgadas por la Ley (Art. 4) en la ejecución y control de proyectos, en la relación con los organismos

\footnotetext{
575 Ecuador, Segundo Bloque de Reformas Constitucionales, adoptadas el 17 de mayo de 1995 y publicadas en el Registro Oficial No. 863, 16-enero-1996.
} 
locales, en la emisión de dictámenes para ciertas operaciones financieras y administrativas del Estado, en la priorización del gasto y en la definición de políticas para regular la asistencia y cooperación externas.

De igual manera, observa Marco Guzmán, en los gobiernos conservadores, adversarios por principio a la planificación y de su obligación de proveer recursos a los proyectos nacionales prioritarios que constaban en los planes nacionales de desarrollo, se adoptaron una serie de medidas financieras y legales para boicotearlos y disponer de dichos recursos para otras obras, según su conveniencia política y clientelar.

Si a eso se suma, según el autor antes indicado, las imprecisiones en la ley y las normas sobre planificación; las debilidades y falta de transparencia en los sistemas de información y estadísticas del Estado; la concentración burocrática de funciones en la elaboración y adopción del Plan por parte de la Secretaría de Planificación del CONADE, limitando la participación de los ministerios y los organismos regionales, locales y sociales; la no existencia clara de períodos de duración del plan; el no aseguramiento del financiamiento y coordinación necesarios con otros funcionarios y con las políticas indispensables para la ejecución eficiente y eficaz del plan y la falta de mecanismos jurídicos efectivos para el control en la ejecución, en la consecución de las metas y la revisión, hacen de los planes de desarrollo y de la planificación, en este período, una simple "manifestación de buena voluntad" o de "una declaración insustancial", sin mayor trascendencia en el desarrollo y en el quehacer nacional sometidos a la voluntad de los grupos de poder y de su incidencia directa en las decisiones de quienes gobiernan. ${ }^{576}$

La política neoliberal de bloquear institucionalmente la planificación y los planes que otorgaban protagonismo al Estado central para favorecer especialmente a los actores privados internacionales y locales y para reorganizar la economía como "social de mercado", culminó su propósito con la expedición de la Constitución Política de la República del Ecuador promulgada el 10 de agosto de $1998 .{ }^{577}$

La nueva carta política (1998) extinguió expresamente el Consejo Nacional de Desarrollo CONADE, estableciendo retóricamente en sus artículos 254 y 255 que la planificación económica y social del país sería implementada por un Sistema Nacional de Planificación que estableciera los objetivos nacionales permanentes en materia económica y social; fijara las metas de corto, mediano y largo plazo, que deberían alcanzarse en forma descentralizada, y orientara la inversión con carácter obligatorio para el sector estatal y referencial para el sector privado. Dicho "Sistema Nacional de Planificación estará a cargo de un organismo técnico dependiente de la Presidencia de la República, con la participación de los gobiernos seccionales autónomos y de las organizaciones sociales que determine la ley. En los organismos del régimen seccional

\footnotetext{
${ }^{576}$ Marco Antonio Guzmán, Derecho Económico Ecuatoriano I, Corporación Editora Nacional - UASB, Quito, 1996.

${ }^{577}$ Ecuador, Constitución Política del Ecuador, Registro Oficial 567, 02-mayo-2002.
} 
autónomo podrán establecerse departamentos de planificación responsables de los planes de desarrollo provincial o cantonal, en coordinación con el sistema nacional”.

La participación de varios sectores de la economía (como los representantes de los trabajadores, sectores empresariales, universidades que integraron antes el Consejo Nacional de Desarrollo) quedaron marginados en la formulación de los planes de desarrollo y en la definición de las políticas económicas del país, salvo el caso de los gobiernos seccionales y organizaciones sociales cuya participación debía ser establecida posteriormente en una Ley que no se expidió en los años siguientes.

De acuerdo con este mandato constitucional se disolvió el CONADE y se liquidó a su personal y mediante Decreto Ejecutivo No. 120, publicado en el Registro Oficial No. 27 de 16 de septiembre de 1998, se estableció en la Presidencia de la República una Oficina de Planificación Nacional, ODEPLAN, con una secretaría técnica responsable de liderar y coordinar el Sistema Nacional de Planificación.

Pero antes de organizar el nuevo Sistema Nacional de Planificación subordinado al Ejecutivo, los interesados en radicalizar el modelo neoliberal y de profundizar los procesos de reforma estructural impulsaron la reactivación del instrumento destinado a la modernización del Estado y las privatizaciones y las concesiones, el Consejo Nacional de Modernización del Estado, CONAM, que se reforzó con una amplia estructura burocrática y trabajos de consultoría para continuar con el análisis institucional del sector público y para diseñar un proceso agresivo destinado a trasladar al sector privado internacional y nacional, mediante las vías establecidas en la Ley de Modernización del Estado, las instituciones, empresas y actividades estatales, relacionadas con la actividad económica, los recursos naturales y los servicios públicos. El 29 de marzo de 1999, mediante Acuerdo, el Consejo Nacional de Modernización del Estado (CONAM) definió una nueva estructura orgánica funcional para ampliar las actividades de asesoría en el país y en la región de litoral, para la realización de estudios, planes y proyectos de modernización; profundizar las actividades de la unidad de reforma del Estado con la redistribución y racionalización de competencias, facultades y recursos para acelerar en todo el país los procesos de descentralización, desconcentración, lucha contra la corrupción y rendición de cuentas; ampliar las actividades de la unidad de empresas públicas para lograr eficiencia e impulsar la participación del sector privado en los sectores manejados tradicionalmente por el Estado. En la unidad de infraestructura del CONAM, así mismo, se plantea desarrollar la infraestructura básica y productiva del país con la participación del sector privado y fortalecer la función reguladora del Estado, tanto del sector oficial como de los operadores privados. También el Consejo de Modernización pretende acelerar los procesos de descentralización de competencias hacia el régimen seccional autónomo y 
hacia entidades regionales y en el nivel administrativo fortalecer las atribuciones de las direcciones jurídica, administrativa y financiera, de tecnología y de comunicación. ${ }^{578}$

En mayo del año 2000 se expidió el Reglamento Orgánico Funcional de ODEPLAN, que en su Título II, artículo 6 señala, la Oficina de Planificación de la Presidencia, tendrá las siguientes funciones: a) Procesar, armonizar, conciliar, formular y actualizar permanentemente el conjunto de políticas públicas, el Plan de Desarrollo y el Programa Anual de Inversiones para someterlos a la aprobación del presidente de la República; b) Formular los Planes de Desarrollo Económico y Social con sus respectivas metas; c) Evaluar el cumplimiento de las metas derivadas de las políticas generales, económicas y sociales del Estado y de sus respectivos planes; d) Coordinar con los diferentes niveles y actores que conforman el Sistema de Planificación; e) Cumplir y hacer cumplir los objetivos y metas programados, estableciendo indicadores de rendimiento y estándares de servicio que coadyuven al mejoramiento de la gestión institucional; f) Coordinar con la Agencia de Cooperación Externa, la formación y ejecución de la Política de Cooperación y Asistencia Técnica provenientes de las fuentes bilaterales y multilaterales, para el fortalecimiento de la administración central e institucional; y, g) Las que por mandato de la Constitución Política de la República, leyes, normas, reglamentos y demás disposiciones legales correspondan ejecutar y las asignadas por el presidente Constitucional de la República. ${ }^{579}$

Para cubrir el vacío de Ley sobre la organización del Sistema Nacional de Planificación el presidente Gustavo Noboa emite en enero de 2001 un Decreto Ejecutivo con el que se establece de manera obligatoria para el sector público y se dispone que guarde armonía con las políticas y procesos de descentralización y desconcentración. La Oficina de Planificación de la Presidencia (ODEPLAN) se convierte en el órgano técnico y de coordinación del Sistema que contará con una dirección de responsabilidad y dos subsistemas de planificación nacional y provincial.

El subsistema de planificación nacional se integrará por la ODEPLAN que dirige y coordina la Secretaría del Consejo de Seguridad Nacional y las unidades de planificación de las instituciones de la función ejecutiva que tienen como cometido elaborar el Plan Nacional de Desarrollo integrando las políticas definidas por el Ejecutivo y asesorar e integrar la planificación provincial a nivel nacional.

El subsistema de planificación provincial queda bajo la dirección y coordinación de los prefectos provinciales, de los gobernadores para asegurar la participación de los representantes institucionales de la función ejecutiva, los alcaldes, los presidentes de las juntas parroquiales y los representantes de las entidades de desarrollo regional, de las circunscripciones indígenas y afroecuatorianas y de las organizaciones sociales y productivas. Este subsistema contará con una Secretaría Técnica que tiene la

578 Ecuador, Consejo Nacional de Modernización del Estado, Acuerdo Nro. 0004, Registro Oficial No.158, 29-marzo-1999.

${ }^{579}$ Ecuador, Presidencia de la República del Ecuador, Acuerdo 0032, Registro Oficial 72, 8-mayo-2000. 
responsabilidad de elaborar los planes de desarrollo provincial para identificar proyectos, programas, acciones y recursos necesarios y fuentes de financiamiento para implementarlos. El plan provincial debe ser presentado a la ODEPLAN, para que se los considere en la proforma presupuestaria que elabora el Ministerio de Economía y Finanzas y su posterior trámite ante el Congreso Nacional. ${ }^{580}$

Como se puede advertir, extinguido el CONADE, la Constitución de 1998 propuso un nuevo esquema de planificación en el país, controlado directamente por el presidente de la República, con la participación referencial de los gobiernos provinciales, acorde con el nuevo rol de Estado y por tanto enmarcada en los procesos de modernización, globalización y apertura económica mundial, con observancia de las diversidades pluriculturales y multiétnicas, regionales y locales existentes, así como los aspectos de género y desarrollo sustentable, a ser implementadas a través de un Sistema Nacional de Planificación, que incorporando una acción eficiente, eficaz y permanente de todos los actores públicos, privados y de la sociedad civil, en los niveles nacional, regional, provincial y local, tenía como objetivo el desarrollo integral y equitativo nacional. En este sentido podemos indicar, que a las administraciones seccionales del Estado se les asigna un rol protagónico.

En el gobierno de Lucio Gutiérrez en febrero de 2003, mediante Decreto Ejecutivo, amparado en el ERJAFE, instrumento jurídico que concentra en el Ejecutivo la potestad "organizatoria" de la administración pública, se conforma la Secretaría de Diálogo Social y Planificación para impulsar la conformación del Sistema Nacional de Planificación y en febrero de 2004 el régimen crea la Secretaría Nacional de Planificación y Desarrollo (SENPLADES) que sustituye a la ODEPLAN y a la reciente Secretaría de Diálogo y Planificación, con la particularidad de definirla como un organismo técnico responsable de la Planificación Nacional dependiente de la Presidencia y que estará dirigida por un Secretario Nacional con rango de Ministro de Estado, que puede emitir acuerdos y resoluciones y nombrar y remover personal de acuerdo con la Ley, lo que evidencia una inicial decisión política de reactivar la planificación en las actividades públicas, pues se le confieren atribuciones similares a las que antes ejercían la Junta de Planificación y el CONADE y nuevas en el diálogo con actores sociales, políticos e institucionales. ${ }^{581}$

En esta etapa económica del país entre 1998 y 2008 se dictaron discretamente varios planes de desarrollo desde la ODEPLAN y luego desde la SENPLADES. Entre las estrategias de largo plazo y los planes de desarrollo de mediano plazo, más relevantes, podemos indicar: Ecuador Siglo XXI: Estrategia de Desarrollo Económico y Social 1992-2012; Agenda para el Desarrollo 1992. Plan de Acción del Gobierno 1993-1996; Plan Nacional de Desarrollo Social 1996-2005; Plan de Acción Inmediata del Gobierno

\footnotetext{
${ }^{580}$ Ecuador, Decreto Ejecutivo 1133 del presidente Gustavo Noboa, Registro Oficial 253, 26-ene.2001.

${ }^{581}$ Ecuador, Presidencia de la República, Decreto Ejecutivo 6-A del presidente Lucio Gutiérrez, Registro Oficial 14, 4-feb-2003 y Decreto Ejecutivo 1372, Registro Oficial 278, 20-feb-2004.
} 
Nacional, 1997; Plan Operativo del Gobierno Nacional, 1998; y, Ecuador 1999: Objetivos, Políticas y Lineamientos Estratégicos.

\section{LA PLANIFICACIÓN EN LAS NORMAS CONSTITUCIONALES Y LEGALES EN EL MODELO NEOINTERVENCIONISTA $Y$ NEODESARROLLISTA (2006 - 2017)}

Los procesos de descentralización y planificación aplicados en América Latina y en Ecuador desde 1990 hasta el momento, coinciden y difieren en sus contenidos y propósitos según el contexto económico mundial y regional. Pero además en ellos resulta más evidente identificar como los modelos neoliberal (1990-2006) o neointervencionista (2007-2017) impuestos o recomendados por los organismos internacionales se acoplan a los intereses económicos inmediatos de los grupos de poder nacional y local y de los sectores sociales que presionan, negocian o se acomodan con quienes ejercen el poder político para que emitan las política públicas, la planificación, las leyes y en general las normas que les resulten más convenientes, para concentrar a su favor o participar así sea marginalmente en la distribución de la renta nacional.

La descentralización y la limitada planificación en la etapa neoliberal en Ecuador favorecieron decisiones administrativas y fiscales que reconocieron autonomía política a los gobiernos y grupos de poder locales, legitimidad a instancias asociativas nacionales o locales y un acceso definido en el presupuesto del Estado, a un porcentaje importantes de los recursos nacionales a favor de los gobiernos locales, que no afectaran el pago de las obligaciones internacionales. En el nuevo modelo neointervencionista que se va gestando desde fines del siglo anterior e inicios del presente con las reflexiones de académicos y de los organismos financieros internacionales, se reacomodan las relaciones territoriales, políticas, administrativas económicas y financieras entre los gobernantes progresistas y los tradicionales y nuevos grupos económicos y sociales de poder nacional que los apoyan, con los grupos económicos y sociales tradicionales y nuevos que inciden en la acción de los gobiernos locales.

Las circunstancias internacionales y la aplicación de los modelos económicos, la intervención de las agrupaciones políticas y sociales y las negociaciones entre el Gobierno nacional y los gobiernos o poderes locales definen el grado y orientación de la descentralización. En el caso de Ecuador la descentralización en la década del noventa y en los inicios del presente siglo fue principalmente fiscal, dejando a los gobiernos locales que definan sus prioridades. Por su parte, en la década 2007-2017 se produce una reformulación de la relación para tener una "descentralización ordenada", ya que si bien se mantienen los privilegios fiscales obtenidos, ahora se controla su destino con la aprobación de planes de desarrollo local sometidos a la planificación nacional y el ejercicio de las competencias delimitados en la Constitución en ciertos ámbitos específicos que no alteren las amplias y rectoras atribuciones del Gobierno nacional. Por ello se dice acertadamente que se habría producido una "centralización por debajo de la 
descentralización" o un cambio en el "modelo de descentralización", tanto más que las instancias de negociación en Ecuador, entre 2007 y 2017, Gobierno, Asamblea, Consejo de Competencias o asociaciones de los gobiernos locales, se encuentran copadas por el partido dirigido por el presidente Correa. ${ }^{52}$

Coincidiendo con todo el proceso de recuperación del papel del Estado en la economía, formulado por el neoestructuralismo desde fines del siglo XX y en especial desde inicios del presente y con el establecimiento de gobiernos progresistas en América Latina y sus formulaciones neodesarrollistas, la actual Constitución de la República del Ecuador, aprobada en referéndum por el pueblo ecuatoriano en 2008, tiene normas novedosas sobre la descentralización, la autonomía, la participación y la estructura económica y jurídica del Estado que corresponden a la nueva etapa histórica. ${ }^{583}$

Como hemos señalado, se "asigna al Estado un papel protagónico en el campo económico, no solo en la recuperación de las actividades económicas relacionadas por la explotación de los recursos naturales y en especial en materia petrolera y minera, sino también en el campo de la prestación de servicios públicos y la preservación del medioambiente...".584

La Constitución de 2008, en el contexto antes indicado, articula el sistema nacional descentralizado de planificación participativo, la planificación y el Plan Nacional de Desarrollo, al nuevo Régimen de Desarrollo y al Régimen del Buen Vivir que se propone construir, fundamentados en un sistema económico social y solidario para tener al ser humano como sujeto y fin y propender a una relación dinámica y equilibrada entre sociedad, Estado y mercado en armonía con la naturaleza. (Art. 283).

Por ello, la planificación y el Plan Nacional de Desarrollo se vinculan estrechamente a los procesos de descentralización y en especial a las finanzas públicas y a la formulación y ejecución del Presupuesto General del Estado (Art. 293 CRE). El sistema de Planificación se conforma con un Consejo Nacional que está facultado para definir sus lineamientos y políticas y presidido por el presidente de la República, si bien se prevén además consejos de planificación en los gobiernos autónomos descentralizados y consejos ciudadanos como formas de descentralización y participación, pero sometidos a las decisiones nacionales. (Art. $179 \mathrm{CRE}$ ).

Las indicadas normas constitucionales y las legales que constan en el Código de Planificación y Finanzas (2010) y en los decretos presidenciales sobre la materia prevén

\footnotetext{
${ }^{582}$ Carlos Rocabado, Escenarios de negociación intergubernamental: intereses partidarios y territoriales en los procesos de descentralización fiscal en Bolivia y Ecuador, Revista Latinoamericana de Desarrollo Económico (LAJED) $\mathrm{N}^{\circ}$ 28, abril-noviembre, 2017; Ana Isabel Molina Morte, Relaciones Intergubernamentales en la descentralización del Ecuador, tesis doctoral dirigida por Esther del Campo García, Madrid, 2015

${ }^{583}$ Ecuador, Constitución de la República del Ecuador, Registro Oficial 449, 20-oct-2008.

${ }^{584}$ Víctor Granda, "Contenido económico de las Constituciones de Bolivia y Ecuador"1ra Edición. (Quito: Ediciones Legales - UASB: 2015), 27.
} 
un sistema concentrado con el mando absoluto del titular de la función ejecutiva, lo que refuerza el sistema hiperpresidencialista propio del modelo económico y político establecido a partir de 2008.

El Título VI de la Constitución vigente dispone imperativamente: "el Estado planificará el desarrollo del país para garantizar el ejercicio de los derechos, la consecución de los objetivos del régimen de desarrollo y los principios consagrados en la Constitución" y define sus principios, cuando agrega: "la planificación propiciará la equidad social y territorial, promoverá la concertación y será participativa, descentralizada, desconcentrada y trasparente".

Según la carta política, además, el goce de derechos y ejercicio de responsabilidades de las personas, pueblos y nacionalidades se da en el régimen de desarrollo y en el régimen del buen vivir, que se construyen en el contexto de la interculturalidad, del respecto a sus diversidades y de la convivencia armónica con la naturaleza (Art. 275 CRE).

Los objetivos del régimen de desarrollo planificado persiguen: mejorar la calidad y esperanza de vida y aumentar las capacidades y potencialidades de la población; construir un sistema económico justo, democrático, productivo, solidario y sostenible basado en la distribución igualitaria de los beneficios del desarrollo, de los medios de producción y en la generación de trabajo digno y estable; fomentar la participación y el control social, con reconocimiento de las diversas identidades y promoción de su representación equitativa, en todas las fases de la gestión del poder público; recuperar y conservar la naturaleza y mantener un ambiente sano y sustentable; garantizar la soberanía nacional, la integración latinoamericana y la inserción estratégica en el contexto y sistema internacionales; promover un ordenamiento territorial equitativo y equilibrado para lograr la unidad del Estado y promover y proteger la diversidad cultural, la memoria social y el patrimonio cultural (Art. 276 CRE).

Y, para la consecución del buen vivir son deberes del Estado: garantizar los derechos de las personas, colectividades y la naturaleza; dirigir, planificar y regular el proceso de desarrollo; generar, ejecutar y controlar la ejecución de políticas públicas; producir bienes, crear y mantener infraestructura y proveer servicios públicos; impulsar el desarrollo de las actividades económicas y promover la ciencia, la tecnología, los saberes ancestrales e iniciativas creativas comunitarias, asociativas, cooperativas y privadas. Y a las personas, organizaciones y colectividades les corresponde participar en la gestión y planificación del desarrollo nacional o local; en la ejecución y control del cumplimiento de los planes de desarrollo y en la producción, intercambio y consumo de bienes y servicios con responsabilidad social y ambiental (Artículos 277 y 278 de CRE).

En cuanto a los planes de desarrollo, la carta política de 2008 diferencia entre el Plan Nacional de Desarrollo y los planes de desarrollo de los gobiernos autónomos descentralizados, si bien estos quedan supeditados al primero bajo diversas formas y disposiciones. El Plan Nacional de Desarrollo, según la Constitución, “es el instrumento 
al que se sujetarán las políticas, programas y proyectos públicos; la programación y ejecución del presupuesto del Estado; y la inversión y la asignación de los recursos públicos; y coordinará las competencias exclusivas entre el Estado central y los gobiernos autónomos descentralizados". La norma correspondiente puntualiza que "su observancia será de carácter obligatorio para el sector estatal e indicativo para los demás sectores" (Art. 280 CRE).

El Plan, por sus efectos obligatorios en los ámbitos indicados del sector público, tiene un carácter de ley material o de instrumento obligatorio reglamentario o de acto administrativo general, si bien no es ley porque no es tramitado o aprobado formalmente como tal por la función legislativa, pero sí lo es expresamente por el Consejo Nacional de Planificación por iniciativa y como propuesta del titular de la función ejecutiva.

En el informe a la Nación 2007 - 2017 el presidente Correa dice, sobre el Sistema y la Secretaría Nacional de Planificación y Desarrollo: la planificación en el Ecuador parte de un nuevo marco normativo que garantiza un Estado de derechos, de justicia social y territorialmente equitativo. La Constitución (Asamblea Nacional Constituyente, 2008), el Código Orgánico de Planificación y Finanzas Públicas (2010), el Código Orgánico de Organización Territorial, Autonomía y Descentralización (2010), entre otros, han marcado por iniciativa del Ejecutivo las bases legales para la planificación nacional y descentralizada. Según el presidente Correa: "este marco normativo contribuyó a la recuperación de la rectoría por parte del Estado y el fortalecimiento de las capacidades institucionales de las entidades para liderar y gestionar nacionalmente". 585

Mediante decreto ejecutivo Nro. 878, publicado en el Registro oficial nro. 268 de fecha 08 de febrero de 2008, el presidente ratificó la existencia del Sistema Nacional de Planificación a cargo de la secretaria técnica denominada SENPLADES, cuya finalidad es "impulsar el desarrollo integral del país sobre la base de los principios de integración, participación, descentralización, desconcentración, transparencia y eficiencia". ${ }^{586}$ En este decreto ejecutivo se dictaron lineamientos generales de actuación de la SENPLADES, y se definió su estructura funcional y orgánica.

Tomando como base al decreto ejecutivo anterior, se publicó con fecha 26 de febrero de 2009 y mediante Registro Oficial Nro. 535, el decreto ejecutivo Nro. 1577, con la finalidad de normar temporalmente, el Sistema Nacional Descentralizado de Planificación Participativa. En este decreto se creó el Consejo Nacional de Planificación y se establecieron sus funciones, entre las cuales están: “ejercer la rectoría del Sistema

585 Informe a la Nación, 2007-2017, Presidencia del Eco. Rafael Correa Delgado, http://www.planificacion.gob.ec/wp-content/uploads/downloads/2017/04/Informe-a-la-Nacion.pdf. Fecha de consulta 5 de junio de 2017.

${ }^{586}$ Ecuador, Presidencia de la República, Decreto Ejecutivo Nro. 878, Registro Oficial 268, 08-febrero2008. art. 2. 
Nacional Descentralizado de Planificación Participativa" y "conocer y aprobar el Plan Nacional de Desarrollo", en sus artículos 2 y 3 respectivamente.

Las normas que constaban sobre el Sistema de Planificación y sobre la secretaría, desde 2004 y luego desde 2008 y 2009, en decretos ejecutivos, se amplían en 2010 y se elevan formalmente al rango de Ley en el Código Orgánico de Planificación y Finanzas Públicas, con lo que se pone en evidencia la prioridad e importancia que el Gobierno de Rafael Correa otorgó a la planificación tanto en el proceso de desarrollo como en la asignación de recursos del país.

El Código planteó que su finalidad era, según el Art. 1: “organizar, normar y vincular el Sistema Nacional Descentralizado de Planificación Participativa con el Sistema Nacional de Finanzas Públicas, y regular su funcionamiento en los diferentes niveles del sector público, en el marco del régimen de desarrollo, del régimen del buen vivir, de las garantías y los derechos constitucionales". 587

Este Código tiene la particularidad de unir la planificación nacional, que es de exclusiva responsabilidad del Gobierno central, es decir del presidente de la República, que es la máxima autoridad para expedir políticas de desarrollo a través del Plan Nacional de Desarrollo, y los planes de desarrollo y los de ordenamiento territorial de los GADS (gobiernos autónomos descentralizados), al Sistema Nacional de Finanzas Públicas y en especial a la programación presupuestaria cuatrianual, al Presupuesto General del Estado y a los presupuestos de las entidades públicas. De esta manera, en todos los niveles de Gobierno la planificación debe guardar concordancia con la necesidad de mantener sostenibilidad fiscal y estabilidad económica en el funcionamiento del Estado.

Por ello, el Código estableció principios comunes y responsabilidades conjuntas entre las entidades rectoras de la planificación y las de las finanzas públicas para observar principios comunes y en el cumplimiento del Plan Nacional de Desarrollo, en todas las etapas del ciclo presupuestario, así y en la sujeción a la planificación, coordinación, transparencia y acceso a la información, participación ciudadana y descentralización y desconcentración. De igual manera, se deben realizar, conjuntamente, evaluaciones de la sostenibilidad fiscal, de sus actividades de coordinación, de la programación de la inversión pública y del seguimiento de sus actividades y responsabilidades específicas.

Respecto de la sostenibilidad fiscal, el Reglamento General del Código Orgánico de Planificación y Finanzas Públicas (Art. 3) dispone que la SENPLADES, el Ministerio de Finanzas y el Ministerio Coordinador de la Política Económica y otras instituciones relacionadas elaborarán la programación macroeconómica preliminar plurianual tomando en cuenta los objetivos y metas del Plan Nacional de Desarrollo, con la finalidad de que el Ministerio de Finanzas revise la programación fiscal que incide en el

\footnotetext{
587 Ecuador, Código Orgánico de Planificación y Finanzas Públicas, Segundo Suplemento del Registro Oficial 306, 22-octubre-2010.
} 
escenario fiscal anual y plurianual y la SENPLADES pueda elaborar, con dicha información, el plan anual y plurianual de inversión de las instituciones del Presupuesto General del Estado y de otras que requieran recursos.De igual manera la norma establece que las dos instituciones indicadas deben definir los mecanismos de vinculación entre el Plan Nacional de Desarrollo y todos los presupuestos del sector público. ${ }^{588}$

El Sistema Nacional Descentralizado de Planificación organiza y coordina la planificación del desarrollo y el régimen del buen vivir, en todos los niveles de gobierno, mediante procesos, entidades y políticas que involucran a los actores institucionales y sociales del país para el logro de resultados en el cumplimiento de sus fines. El sistema está conformado por el Gobierno central y los gobiernos autónomos descentralizados en el que participan adicionalmente: el Consejo Nacional de Planificación; la Secretaría Técnica del Sistema; los consejos de Planificación de los Gobiernos Autónomos Descentralizados; los consejos sectoriales de Política Pública de la Función Ejecutiva; los consejos nacionales de Igualdad y otras instancias de participación como los consejos ciudadanos; los consejos consultivos; las instancias de participación de los GADS y regímenes especiales y otras que se conforman para efecto del ejercicio de la planificación participativa (Art. $21 \mathrm{COPF}$ ).

El Consejo Nacional de Planificación está conformado por el presidente de la República que lo preside y tiene voto dirimente; cuatro representantes de los niveles de gobierno de los GADS; siete delegados de la función ejecutiva; el secretario nacional de Planificación y Desarrollo que será el vicepresidente del Consejo; cuatro representantes de la sociedad civil elegidos de conformidad con la ley y el presidente del Consejo de Educación Superior. El Consejo, en el que tiene mayoría absoluta y eventualmente voto dirimente el presidente, aprueba el Plan Nacional de Desarrollo que es propuesto por el mismo Ppresidente de la República.

La Secretaría Técnica del sistema la desempeña el Secretario Nacional de Planificación y Desarrollo, que es designado por el presidente; tiene rango de ministro de Estado; firma contratos y convenios; es el representante legal, judicial y extrajudicial de la Secretaría; puede delegar sus facultades y las responsabilidades al funcionario delegado; prepara la propuesta del Plan Nacional de Desarrollo; integra y coordina la planificación nacional con la sectorial y territorial descentralizada; propicia la coherencia de las políticas públicas y la inversión con el Plan Nacional de Desarrollo; realiza el seguimiento y evaluación en el cumplimiento del Plan Nacional de Desarrollo; asegura la articulación y complementariedad de la cooperación internacional no reembolsable con el Plan Nacional de Desarrollo; dirige el sistema nacional de información para relacionarlo con el Sistema Nacional de Planificación; acuerda y define con el ente rector de las finanzas públicas las orientaciones de política general y cumplimiento

\footnotetext{
588 Ecuador, Reglamento General del Código Orgánico de Planificación y Finanzas Públicas, Decreto Ejecutivo 489, Registro Oficial-2S 383, 26-nov-2014.
} 
obligatorio para las finanzas públicas; coordina con el sector público las políticas de descentralización en función del Plan Nacional de Desarrollo; promueve y realiza estudios relevantes para la planificación, etc. (Artículos 26 y $27 \mathrm{COPF}$ ).

Los consejos de planificación de los GADS se integran por la máxima autoridad del ejecutivo local, un representante del legislativo local, el funcionario responsable de la planificación en el Gobierno autónomo, tres funcionarios designados por la máxima autoridad, tres delegados de las instancias de participación y un representante de los niveles de Gobierno inferior a nivel territorial. Son funciones de estos consejos: participar en la formulación de sus planes; emitir resoluciones sobre prioridades estratégicas para la aprobación ante el órgano legislativo correspondiente; velar por la coherencia del plan de desarrollo local y de ordenamiento territorial con los planes de otros niveles de Gobierno y con el Plan Nacional de Desarrollo, sus lineamientos y políticas; verificar la coherencia de la programación presupuestaria y los planes de inversión con el plan de desarrollo y de ordenamiento territorial; velar por la armonización de la gestión de cooperación internacional no reembolsable con los planes locales; conocer los informes de seguimiento y evaluación de los planes del respectivo nivel de gobierno, etc. (Art. $29 \mathrm{COPF}$ ).

El Código establece también los instrumentos del Sistema Nacional de Planificación entre los que se encuentran; el Sistema Nacional de Información para la planificación, cuyos datos deben ser oficiales y públicos que estarán a cargo de la Secretaría Nacional de Planificación y Desarrollo; el Sistema Estadístico y Geográfico Nacional que está a cargo de los organismos establecidos en la Ley y que ofrecerán sus datos y análisis para la construcción y evaluación de la planificación; el Plan Nacional de Desarrollo; los lineamientos y políticas públicas y los instrumentos complementarios como: la programación presupuestaria cuatrianual; los presupuestos de las entidades públicas; la Estrategia Territorial Nacional; los planes institucionales con acciones, programas y proyectos en sus competencias y que sean compatibles con los objetivos del Plan Nacional de Desarrollo; los planes de inversión y sus instrumentos y la gestión, aprobación, registro y control de la cooperación internacional no reembolsable.

El principal instrumento del Sistema Nacional de Planificación, y que tiene efecto vinculante en todas las instituciones del sector público, incluyendo a la Asamblea Nacional e indicativo para los otros sectores de la economía, es el Plan Nacional de Desarrollo. El Código lo define como "la máxima directriz política y administrativa para el diseño y aplicación de la política pública y todos los instrumentos dentro del ámbito definido en este Código". La norma dispone también que el Plan articule "la acción pública de corto y mediano plazo con una visión de largo plazo en el marco del régimen de desarrollo y del régimen del buen vivir previstos en la Constitución de la República"; que se sujeten a él "las acciones, programas y proyectos públicos, el endeudamiento público, la cooperación internacional, la programación, formulación, aprobación y ejecución del Presupuesto General del Estado y los presupuestos de la banca pública, las empresas públicas de nivel nacional y la Seguridad Social” y que los 
presupuestos de los gobiernos locales y sus empresas públicas se sometan a sus propios planes en el marco del Plan Nacional de Desarrollo que articula el ejercicio de sus competencias de cada nivel de Gobierno (Art. $34 \mathrm{COPF}$ ).

El Plan Nacional de Desarrollo es formulado por la SENPLADES para cuatro años, en correspondencia con el programa de gobierno del Presidente electo, tomando en cuenta los planes de las otras funciones del Estado, los de los GADS y las sugerencias de instancias de participación. Su contenido debe integrar: contexto histórico y diagnóstico de la realidad nacional actual; visión de largo y mediano plazo; políticas de gobierno, estrategias, metas e indicadores de cumplimiento; criterios para asignar recursos e inversión pública; el plan plurianual de inversiones; lineamientos de planificación territorial e instrumentos complementarios. El Plan que es aprobado por el Consejo a propuesta del presidente de la República es, además, un requisito para presentar la programación presupuestaria plurianual y la proforma presupuestaria. Si el Plan no es aprobado en noventa días entra en vigencia por ministerio de la ley y será conocido por la Asamblea Nacional. El seguimiento y evaluación del Plan es de atribución de la SENPLADES y su informe es presentado por el presidente de la República a la Asamblea Nacional (Artículos 36-39 COPF).

En cuanto a los planes de desarrollo y de ordenamiento territorial de los gobiernos autónomos descentralizados, que son aprobados mediante ordenanza por el órgano legislativo de los GADS, siguen los lineamientos anteriores generales del Plan Nacional de Desarrollo en cuanto a su contenido, diagnóstico, propuesta y modelos de gestión. Se diferencia el plan de desarrollo local con el de ordenamiento territorial que tiene por objeto regular, compatibilizar y armonizar las decisiones estratégicas de desarrollo respecto de los asentamientos humanos, las actividades económico-productivas y el manejo de los recursos naturales para el cumplimiento de la función social y ambiental de la propiedad. Estos planes deben definir el modelo económico productivo y ambiental, de infraestructura y de conectividad para la asignación y regulación del uso y ocupación del suelo, en concordancia con las normas del COOTAD y con la participación ciudadana. El seguimiento y la evaluación de estos planes los realizan los GADS aplicando los lineamientos que al respecto formule la SENPLADES, organismo al que se reporta el cumplimiento de las propuestas y metas de aquellos. (Artículos 41$51 \mathrm{COPF})$.

El reglamento al Código antes señalado, en el artículo 5, expresa además que la Secretaría Nacional de Planificación y Desarrollo, en su calidad de ente rector de la planificación nacional y el ordenamiento territorial, y como ente estratégico del país, emitirá directrices y normas para la formulación, articulación, coordinación y coherencia de los instrumentos de planificación y de ordenamiento territorial, de manera que se asegure la coordinación de las intervenciones planificadas del Estado en el territorio, así como la verificación de la articulación entre los diferentes sectores y niveles de gobierno". 
Como resulta evidente, en la normativa principal y reglamentaria del Código de Planificación y Finanzas, en lo relacionado con la planificación de los gobierno autónomos descentralizados, ésta queda de una u otra manera supeditada al Plan Nacional de Desarrollo y a la aplicación de la metodología y del control que sobre ellos ejerce las SENPLADES, desde su formulación, planificación, asignación de recursos, ejecución y evaluación. De allí que la autonomía de los GADS, en un asunto tan importante como este, se evidencia cada vez más como relativa y resulta más declarativa que real.

Si durante el período en el que se impuso el modelo neoliberal en Ecuador, la planificación y su institucionalidad se relativizaron al punto de convertirse en actividades marginales en la acción del Gobierno, si bien las asumió formalmente por medio de una oficina y de una Secretaría de la presidencia (ODEPPLAN), durante el modelo neoestructural y neodesarrollista a partir de 2007, a la misma Secretaría, denominada SENPLADES desde 2004, se le otorgó un rango más elevado y se la convirtió en un poderoso ministerio, eje de la política y de la acción del régimen.

Los difusores en el cambio de ésta política han manifestado reiteradamente que el Gobierno del Presidente Correa y la Constitución de 2008 sustituyeron una concepción centrada en el mercado y en los individuos, que propiciaba la existencia de un "Estado mínimo" deformante del concepto de lo público, por una que permite la recuperación del Estado democrático y de su papel en la sociedad y en la economía mediante la planificación, para que el Estado responda a la ciudadanía en su conjunto y a cada uno de los territorios del país y se establezca un nuevo modelo de desarrollo en la distribución y redistribución de la riqueza. ${ }^{589}$

Durante los gobiernos sucesivos del presidente Correa se expidieron tres planes: el Plan Nacional de Desarrollo (2007 - 2010) en el que se recuperan las facultades de planificación y de rectoría del Estado en todo el territorio; el Plan Nacional para el Buen Vivir (2009 - 2012) y el Plan Nacional para el Buen Vivir (2013 - 2017), en los que se impone supuestamente, mediante el lema "El Estado a tu lado", un nuevo concepto de desarrollo, mediante mecanismos desconcentrados y descentralizados de los servicios, pero en todo caso definidos e implementados verticalmente.

La SENPLADES sustituyó, durante la vigencia de los referidos planes, los organismos de Desarrollo Regional (ODR) existentes hasta 2007, por unidades territoriales horizontales de planificación en 9 zonas, 140 distritos y 1.134 circuitos para ejecutar y optimizar la prestación de los servicios públicos a cargo de varios ministerios.

\footnotetext{
589 Pabel Muñoz, Secretario Nacional de la Secretaría Nacional de Planificación y Desarrollo, en la presentación del libro La desconcentración del Ejecutivo en el Ecuador. El Estado en el territorio y la recuperación de lo público, (Quito: SENPLADES, primera edición, 2014); Eulalia Flor Recalde, compiladora, Construcción de un Estado Democrático para el Buen Vivir. Análisis de las principales transformacionesdel Estado ecuatoriano 2007 - 2012, (Quito: SENPLADES, 2014).
} 
El primer Plan Nacional de Desarrollo (2007-2010), expedido antes de la vigencia de la Constitución de Montecristi (2008), se fundamentó en la concepción de "desarrollo humano" (ONU), en otras visiones progresistas sobre la economía y el medioambiente y, por sobre todo, en la recuperación del papel del Estado en la economía, sin dejar de reconocer la preeminencia de la economía privada.

El Plan del Buen Vivir (2009-2013), influenciado por el contenido progresista de la Constitución, ponía énfasis en la necesidad de construir un sistema económico alternativo para construir un "igualitarismo republicano moderno" para el "Buen Vivir", mediante la estructuración de una "sociedad del bioconocimiento", la agroecología y los "servicios ecoturísticos comunitarios".

El Plan del Buen Vivir (2013-2017) sustituye o disminuye la visión anterior, para priorizar esta vez el "cambio de la matriz productiva", con la finalidad de satisfacer la demanda nacional e impulsar las exportaciones de productos industrializados y servicios de alto valor agregado que están relacionadas con la consolidación de las relaciones privadas o estatales de producción capitalista y que se constituyen ahora en el motor de cambio y de modernización del sistema. ${ }^{590}$

Existe pues, como afirma Silvia Vega, un "desplazamiento conceptual en los dos últimos planes" para concentrar la acción del gobierno de la "revolución ciudadana", según nuestra opinión, en la modernización de la economía nacional, mediante la negociación con el capital transnacional y los grupos económicos de poder interno, con la finalidad de consolidar el capitalismo local asociado mucho más a la globalización del sistema mundial.

Por otro lado, si comparamos la estructura productiva del país durante el período de aplicación de los tres planes antes referidos (2007-2017), se puede constatar que no se han modificado la composición y la dinamia de las actividades económicas del país. Según el Banco Central del Ecuador, los sectores económicos son los mismos al inicio y final de la década correísta, sin que haya cambiado su porcentaje de participación en la renta nacional, salvo un leve crecimiento en el sector de electricidad, construcción, administración pública y enseñanza y se registra penosamente un leve descenso en agricultura, petróleo, manufactura y comercio. ${ }^{591}$

No se han fortalecido ni han mejorado tampoco la productividad y competitividad de los sectores económicos tradicionales afectados cada vez más por la dolarización y las innovaciones tecnológicas. No han aparecido, como se esperaba, nuevos sectores en la economía nacional asociados al turismo, a la biodiversidad y a la tecnología digital publicitados por el Gobierno e identificados en las planes de desarrollo. Por lo tanto, los datos oficiales y la percepción ciudadana comprueban y coinciden en que los planes

\footnotetext{
${ }^{590}$ Silvia Vega Ugalde, La Economía solidaria y comunitaria en Ecuador y Bolivia, interpelaciones a la experiencia de los gobiernos de Rafael Correa y Evo Morales, (Quito: FLACSO, 2017).

${ }^{591}$ Ecuador, Banco Central del Ecuador, 2016.
} 
"para cambiar la matriz productiva" no tuvieron éxito significativo en la aplicación definición adecuada de las políticas públicas y en los proyectos de inversión. Existe, sin embargo, una cierta sensación de bienestar de determinados sectores medios de la sociedad que aumentaron su capacidad de consumo y empleo al trabajar en las dependencias públicas y de sectores populares que también se beneficiaron de ciertos subsidios y evidentes mejoras en los sistemas de salud, educación y seguridad social.

En el caso de la nueva orientación de la descentralización, de la autonomía y de la planificación se reafirma la apreciación de la existencia de un modelo autoritario y personalista del presidente de la República: "hiperpresidencialista" (2007-2017), que le permitió el control institucional de las instancias de negociación del Estado como la Asamblea y las asociaciones de los gobiernos autónomos descentralizados, de igual manera como ocurrió con los organismos de control jurisdiccional o administrativo, con lo que se debilitó la democracia y la participación establecidas en la Constitución de Montecristi.

De igual manera se ha observado acertadamente la manipulación de la participación ciudadana, que en lugar de promover debates y consensos, se limitó a ratificar o respaldar las decisiones oficiales y socializar las políticas gubernamentales mediante diferentes mecanismos. Así mismo se creó un clima de intolerancia, excluyendo y persiguiendo la crítica, criminalizando la lucha social y con el uso de un discurso agresivo y ofensivo. ${ }^{592}$

La proyectada relación entre los planes de desarrollo, el gasto público y el presupuesto para mantener el equilibrio y la sostenibilidad fiscal, al final de la década de Gobierno del Presidente Correa registra un creciente déficit que no ha podido ser cubierto con el aumento reiterado de la carga fiscal, la recuperación de los precios internacionales del petróleo y la gran deuda externa que ha superado a fines de 2016 las barreras establecidas en el Código Orgánico de Planificación y Finanzas y suma más de sesenta mil millones de dólares.

Al final del ciclo neointervencionista se llega a la misma situación de crisis en la que desembocaron los modelos económicos y políticos anteriores, a la que se suman los escándalos de corrupción que han roto todo récord en un período en el que el país contó como nunca antes, con cuantiosos recursos económicos no utilizados racional y equitativamente en beneficio de la mayoría de la población.

\footnotetext{
592 Ana Isabel Molina Morte, Relaciones Intergubernamentales en la descentralización del Ecuador, tesis doctoral dirigida por Esther del Campo García, Madrid, 2015
} 


\section{CAPITULO VII: EL DERECHO DE CONTROL Y SU RELACIÓN CON LAS MODIFICACIONES CONSTITUCIONALES Y JURÍDICAS EN LOS MODELOS POLÍTICOS Y ECONÓMICOS EN ECUADOR (1990-2015)}

Este capítulo se refiere a los cambios en los tipos y sistemas de control del Estado y de las administraciones públicas en el período de análisis para organizar tanto en el ámbito del control externo, especialmente político, económico-financiero y social, como en el de control interno, relativo a los recursos, la gestión y la lucha anticorrupción.

El capítulo realiza también un examen del control y de las responsabilidades en las reformas constitucionales y legales adoptadas antes y después de la vigencia de las dos cartas políticas de 1998 y 2008 hasta las enmiendas aprobados en diciembre de 2015, para explicar su articulación con los modelos económicos y políticos aplicados por los gobiernos de turno en Ecuador.

\section{LOS MODELOS ECONÓMICOS Y LAS CATEGORÍAS DE CONTROL Y RESPONSABILIDAD}

La evolución del control está relacionada con los sistemas y modelos económicos y el desarrollo de la democracia. Fernández Ajenjo dice, adecuadamente, que en las democracias constitucionales del modelo liberal, el control se desarrolló a partir del Estado abstencionista, cuyo control público se asentó sobre la doctrina de la división de poderes; luego, con el Estado de partidos, ya en el modelo intervencionista que difuminó dicha división, surgió una red compleja de controles institucionales y con la implementación del Estado providencia se incorporaron el gerencialismo, las técnicas de control por objetivos y los controles de calidad del campo privado. ${ }^{593}$

Abundando en esta percepción, creemos que en la etapa de la democracia liberal el control en general se restringía al "formalismo" de la legalidad entre los poderes estatales, asignándose al poder legislativo la facultad de ejercer de manera amplia la potestad de control y de establecer responsabilidades en los poderes ejecutivo y judicial. En la etapa de la democracia intervencionista o representativa, al control político tradicional se agregó el control técnico contable y financiero, fiscalizador, ejercido por los tribunales de cuentas o por órganos independientes unipersonales como las contralorías, en virtud del crecimiento de las operaciones del Estado en los servicios y en el manejo de importantes recursos públicos.

En los modelos neoliberales y luego en los neointervenionistas y en la denominada democracia participativa o democracia de resultados, se perfeccionan los instrumentos públicos de control interno y externo y se reconoce también el derecho de los ciudadanos, en forma individual o colectiva, para ejercer además "el control popular de

\footnotetext{
593 José Antonio Fernández Ajenjo, El control de las administraciones públicas y la lucha contra la corrupción, (Pamplona: Civitas - Thomson Reuters, 2011).
} 
las instituciones del Estado y la sociedad y sus representantes", pues tienen la potestad de "fiscalizar los actos del poder público"; "combatir los actos de corrupción" y ejecutar dicho control a las "entidades públicas y privadas que presten servicios públicos, "a través de los órganos del poder público y de las formas de participación directa previstas en la Constitución" (transparencia, rendición de cuentas, control social) utilizando "todas las formas de organización como expresión de la soberanía popular" (Art. 96). ${ }^{594}$

Debemos considerar también que en los diversos momentos históricos del Estado moderno y contemporáneo y del régimen democrático, sea en su fase liberal, intervencionista, neoliberal o neointervencionista o en las formas mixtas que se adaptan actualmente en las realidades concretas de cada país, las categorías control y responsabilidad resultan esenciales para el funcionamiento del sistema y la transformación de la administración, al igual que la división de poderes o funciones, el respeto irrestricto a los derechos, libertades y garantías ciudadanas, la participación, la seguridad jurídica, etc.

La estrecha relación entre control y responsabilidad surge de la concepción y convicción democrática de que la administración es medio y no fin para el cumplimiento de sus funciones y en especial para satisfacer los derechos colectivos, para lo cual tiene que ser eficiente y eficaz. Para tal propósito, la Administración tiene necesariamente que ajustarse en todas sus actuaciones y eventos que deba enfrentar -y aún en el ejercicio de cierta potestad discrecional de la que se encuentra investida- a las normas constitucionales y legales establecidas. El control administrativo interno o autocontrol y el control externo, en todas sus manifestaciones (el político, el económico-financiero, el jurisdiccional y el social o ciudadano) estarán siempre sometidos al principio de legalidad, para que las normas de todo el ordenamiento partiendo de la Constitución sean el límite o el horizonte en la actuación de la autoridad pública.

El control como principio democrático se asocia a otro principio de igual relevancia, la responsabilidad, que es otro de los pilares de la democracia y del Estado de derecho en sus diferentes momentos históricos. Existen diferentes tipos de responsabilidad por acción u omisión, según la doctrina y la legislación de cada país: la política, administrativa o disciplinaria, la civil, la contable y la penal.

La responsabilidad política se refiere a altos funcionarios del Estado señalados en la Constitución por sus decisiones relacionadas con la violación de la Constitución y la ley. La responsabilidad administrativa gestora o disciplinaria se asigna exclusivamente a funcionarios cuando estos transgreden sus deberes $\mathrm{u}$ obligaciones o incurren en las prohibiciones establecidas en la ley y en las normas o procedimientos que regulan su actividad y desempeño en las instituciones públicas.

${ }^{594}$ Constitución del Ecuador de 2008 (arts. 1, inciso 2; 61.5; 83.8; 95; 96; 100.5). 
La responsabilidad civil, que también se identifica como contable-financiera, está dirigida a indemnizar o a reparar económicamente, por un daño o perjuicio causado a la administración o a un tercero y puede involucrar al Estado o a las instituciones que lo representan (responsabilidad extracontractual) o a cualquier funcionario que ocasiona directamente el daño o el perjuicio a la administración o a un tercero o a quien coparticipe en los mismos.

La responsabilidad penal se establece por un delito o una infracción penal y debe ser resuelta por el juez competente. Le corresponde a la autoridad administrativa o de control entregar a la fiscalía o a la autoridad jurisdiccional competente los indicios o las pruebas de la inculpación al funcionario y a terceros que se encuentren involucrados. ${ }^{595}$

En la actualidad también se puede agregar la responsabilidad ciudadana, que es más de carácter moral y político, pues el ejercicio pleno de la democracia implica participación, iniciativa legislativa y control y si bien no entraña sanción objetiva alguna, constituye un castigo inexorable de conciencia o de opinión por parte de la comunidad a los infractores y corruptos.

Respecto de la responsabilidad del Estado, esta puede ser solo de carácter civil o indemnizatoria y tiene un origen contractual, al ser producto de una obligación bilateral incumplida o extracontractual cuando los funcionarios estatales ocasionan a uno o varios ciudadanos un daño por su actuación o por la mala calidad o por la no prestación de un servicio, sea en el ámbito legislativo, judicial o administrativo.

Según Eduardo Silva Cimma, la responsabilidad extracontractual del Estado, citando a Rolando Pantoja, "se basa en una teoría pública objetiva que se configura por el daño causado por los órganos administrativos con su actuar lícito o ilícito, jurídico o de hecho... o por la falta de un servicio que sirve a un demandante de causa para pedir". Se produce, dice el primero -citando esta vez a Patricio Aylwin- una "responsabilidad objetiva" que se origina por el "daño" causado, "sin que sea necesario individualizar a la persona que causó el daño o la omisión que causó el perjuicio, ni probar la culpa o dolo de su conducta ni discernir si la actuación de la Administración fue lícita o ilícita o si se materializó en un hecho material o en un acto administrativo". 596

Estos conceptos sobre responsabilidad extracontractual del Estado fueron introducidos en la legislación ecuatoriana en la Constitución de 1969 (Art. 27) y en la Constitución de 1998 (Art. 20) y la Constitución vigente de 2008 (Art. 11 numeral 9, 53, 54, 97, 172, 233), en los que se dispone que el Estado, los concesionarios y todos los que actúen ejerciendo potestad pública tienen la obligación de reparar violaciones de derechos por

\footnotetext{
${ }^{595}$ Alberto Palomar Olmeda, "El control de las administraciones públicas desde una perspectiva general. Insuficiencias del sistema actual" en La Gestión de los Fondos Públicos: Control y Responsabilidades, Alberto Palomar, Mario Garcés (Directores) y otros, (Pamplona: Thomson Reuters Aranzadi, 2013).

${ }^{596}$ Enrique Silva Cimma, Derecho Administrativo Chileno y Comparado, el Control Público, (Santiago: Editorial Jurídica de Chile: 1994), 217.
} 
falta o deficiencia en servicios públicos y por acciones u omisiones de funcionarios en el desempeño de sus cargos. De igual manera se establece que el Estado es responsable por error judicial, detención arbitraria, retardo o inadecuada administración de justicia, violación de derecho a tutela judicial y violación a reglas del debido proceso. También se incluye el derecho de repetición a favor del Estado por parte de los funcionarios que hayan ocasionado el pago de indemnizaciones.

La potestad de control y de fiscalización interna (ad intra) y externa (ad extra) es esencial para todos los órganos del Estado. Para ejercerla a plenitud se ha creado una estructura de órganos al interior de cada una de las funciones del Estado y otros, que formando parte de este, como órganos extra poderes o funciones independientes especializadas, realizan, de manera externa e interna a las entidades y funcionarios controlados, actividades preventivas y de asesoramiento para alcanzar eficiencia y eficacia en el desempeño de sus funciones y una actividad técnica de control permanente especializado en lo administrativo y financiero, que se encuentra regulada por leyes y normas nacionales e internacionales, especialmente dictadas para ese propósito.

El Estado de derecho contemporáneo ha establecido también, luego de un largo proceso histórico, que una de sus funciones, la judicial, de manera definitiva y con efectos obligatorios mediante sentencias, realice el más importante de los controles sobre la administración y el gobierno. ${ }^{597}$ Se trata de un control integral de efectos obligatorios, jurisdiccionales, sobre la legalidad y la desviación en el ejercicio del poder, en los actos y decisiones que las autoridades públicas adopten en su quehacer, para que se establezcan sus responsabilidades y las de los funcionarios en el desempeño de sus atribuciones, en los actos, contratos hechos y consecuencias que se deriven por su acción u omisión.

Existen, además, en la actualidad, como lo desarrollaremos más adelante, el control político, el control interno, el control externo técnico y el control ciudadano o popular, por medio de los cuales, al margen de los órganos del Estado, la sociedad civil y los propios ciudadanos, desarrollan iniciativas independientes de fiscalización y control, constituyendo órganos autónomos para vigilar los recursos y bienes públicos y para combatir la corrupción, el abuso de poder y la violación de sus derechos y garantías por parte de las autoridades públicas.

Como hemos señalado, las dos categorías, el control y la responsabilidad, son básicas para el derecho administrativo y para esta materia jurídica especializada. Las dos tienen indudables connotaciones propias de la ciencia y la filosofía políticas por estar

\footnotetext{
597 Ricardo Rivero Ortega, Derecho administrativo económico, (Madrid: Marcial Pons, sexta edición,
} 2013). 
asociadas al ejercicio del poder y a las reflexiones teóricas que existen sobre la democracia y el ejercicio pleno de los derechos. ${ }^{598}$

El profesor venezolano Armando Rodríguez nos recuerda que las dos categorías en referencia, esenciales a la estructura del derecho administrativo y al derecho público, están asociadas a los conceptos de deber, subordinación y obligación y vinculadas al concepto de poder político, que a su vez nos remiten a las ideas de gobierno, autoridad, imperio, potestad, prerrogativa o supremacía. La relación conceptual, enfatiza, es más relevante en la época actual, "marcada por la primacía del ser humano como centro de atención, origen y destino de las instituciones que administran el ejercicio del poder público de manera vicarial, con sometimiento al derecho, pero además, a través de las manifestaciones democráticas y el más absoluto respeto a la libertad y las situaciones jurídicas subjetivas de los ciudadanos, dentro de un contexto de eficiencia en la gestión pública, de buena administración"; todo esto frente a la tendencia actual en algunos países, como Venezuela o Ecuador, en los que, quienes se encuentran en ejercicio del poder pretenden "evadir, reducir o neutralizar la presencia efectiva de la responsabilidad y el correlativo control, mediante artilugios y figuras aparentemente avanzadas y progresistas que, en definitiva, resultan retrógradas y regresivas, a más de mantener la ineficiencia y elevar los costos de transacción en el desenvolvimiento de la vida social". 599

Aunque el concepto obligación tiene su origen en el derecho civil y en el derecho romano -en el que el vínculo entre el acreedor y el deudor podía dar como resultado inicialmente la entrega física del deudor (esclavitud) o luego la entrega de bienes para liberar los iniciales poderes despóticos del primero-, adquiere una connotación especial en el actual derecho público, administrativo, financiero y de control, en los que el Estado tiene a la vez una situación de poder y de deber frente a los ciudadanos, pues se encuentra sometido al derecho y es su deber primordial el respeto y promoción de los derechos humanos. Por tanto, el Estado y la administración no ejercen ni son titulares de derechos como sí lo son los ciudadanos, pues cumplen y deben responder por el ejercicio de sus funciones al servicio de todos.

José Antonio Fernández Ajenjo nos recuerda que el vocablo control es un neologismo importando de las lenguas francesa e inglesa, que tiene en sus tradiciones jurídicas connotaciones particulares y que en la actualidad las dos, de una u otra manera más los aportes de la doctrina italiana, se encuentran incorporadas en la doctrina actual del control en todos los países del mundo.

\footnotetext{
598 Enrique Silva Cimma, Derecho administrativo chileno y comparado, el control público, (Santiago: Editorial jurídica de Chile, 1994).

599 Armando Rodríguez García y otros, en El control y la responsabilidad en la Administración Pública, VI Congreso Internacional de Derecho Administrativo Margarita 2012, (Caracas: Editorial Jurídica Venezolana, 2012), 20 y 21.
} 
El control como concepto, argumenta el profesor español, recoge actualmente: de la doctrina iuspublicista francesa una connotación de "comprobación y fiscalización" por la que el sujeto controlador especializado "emitirá una declaración crítica sobre la actividad del sujeto controlado"; de la doctrina anglosajona la de ser una "manifestación del poder", con una "función normativa" tanto para la actuación de la organización como para una "función correctiva", que permita corregir las desviaciones de las normas; y de la doctrina italiana, una relación más estrecha con la exigencia de responsabilidades "sin la cual no pudiera hablarse en propiedad de una auténtica actividad fiscalizadora", subrayando la relación estrecha entre el control y la exigencia de establecer responsabilidades como su consecuencia. ${ }^{600}$

Por ello, alejándonos de una concepción restringida sobre el control, considero que resulta pertinente, para el propósito de este trabajo, precisar el contenido de las transformaciones en el derecho de control en los últimos años en Ecuador, otorgándole al concepto una dimensión más amplia, que no solo ponga énfasis en sus aspectos de ejercicio de una potestad estatal o derecho ciudadano, en cuanto control económicofinanciero de verificación y fiscalización de los recursos públicos, por parte de la sociedad y de los órganos del Estado que cumplen esa función, sino también como un instrumento de análisis de la gestión y de los resultados administrativos, pues la introducción obligatoria de modificaciones y de correcciones, en la administración pública, impedirá todo brote o manifestación de corrupción para el cumplimiento cabal de sus obligaciones y fines.

\section{SISTEMAS Y TIPOS DE CONTROL}

En las democracias contemporáneas, los sistemas de evaluación, control y responsabilidades, se diferencian de manera general en función del sujeto que los realiza y de los ámbitos en los que se ejecutan, conforme a su composición unipersonal o pluripersonal o de su ubicación o papel que ocupan en la estructura organizativa del Estado y la sociedad. También se diferencia a aquellos, según los momentos $\mathrm{u}$ oportunidad en los que se efectúan sus actividades en el tiempo o por la naturaleza y órganos que intervienen en el control o por los fines que persiguen, etc. ${ }^{601}$

Como dice Juan Martín Queralt y otros, no es factible establecer una clasificación con validez universal en los diferentes tipos de control, que varían en los distintos ordenamientos jurídicos con los más variados criterios. ${ }^{602}$ También se puede explicar la modificación de sus categorías, como dice Mario Garcés San Agustín, por "las nuevas

\footnotetext{
600 José Antonio Fernández Ajenjo, El control de las administraciones públicas y la lucha contra la corrupción, (Pamplona: Civitas - Thomson Reuters, 2011), 136-137.

${ }^{601}$ Fernando Pérez Royo, Derecho Financiero y Tributario Parte General, Madrid: Novena edición, Civitas, 1999); Yolanda Gómez Sánchez, El Tribunal de Cuentas: el control económico y financiero externo en el ordenamiento constitucional, (Madrid: Marcial Pons, 2001).

${ }^{602}$ Juan Martín Queralt, Carmelo Lozano, José Tejerizo, Gabriel Casado, Curso de Derecho Financiero y Tributario, (Madrid: Tecnos, 2011).
} 
técnicas funcionales que se van incorporando al sistema de controles a lo largo de los últimos años". ${ }^{603}$

En este trabajo, de contenido fundamentalmente administrativo-financiero, utilizaremos la clasificación de control externo e interno que recoge la legislación en Ecuador para diferenciar los espacios institucionales en los que se realiza y a los sujetos que intervienen en un sistema integral de control, fiscalización y auditoría del Estado. ${ }^{604}$

Complementariamente utilizaremos, según la naturaleza del control y de los órganos o personas intervinientes, la clasificación histórica de control político, control jurisdiccional, control técnico-financiero en los distintos ámbitos del Estado, control interno o de gestión y control social y ciudadano, si bien no es nuestro propósito referirnos en esta ocasión al control jurisdiccional o de constitucionalidad y legalidad, con el cual el Estado garantiza a los ciudadanos, de manera definitiva y obligatoria, el respeto a la ley y a la democracia con la finalidad de detener cualquier forma de abuso, corrupción y autoritarismo.

Otras clasificaciones que también nos sirven de referencia diferencian con mayor detalle el momento o tiempo en el que se efectúan las actividades de control: previo, inicial, preventivo o a priori (exante o pre-audit), si se realiza antes o al inicio de producirse el hecho o actividad que se va a examinar; concurrente, simultáneo o concomitante si se lo hace a la par de la actividad u operación que se fiscaliza o si "es un requisito en la perfección del acto o en la consumación del mismo"; y, posterior o a posteriori de las operaciones efectuadas (expost o post-audit), si se lo ejecuta luego de la realización del acto, para establecer si se procedió correctamente o si se cometieron irregularidades en ellos. $^{605}$

Según los fines de la actividad de control se diferencian: controles preventivos para evitar actos irregulares; correctivos si se trata de enmendar las acciones incorrectas y represivas si su propósito es sancionar actos irregulares. Los controles según la materia pueden ser: de legalidad si se refiere al cumplimiento de la normativa reguladora; de oportunidad o racionalidad económica si su atención se centra en la valoración y mérito de la gestión en lo político, social, económico o de justicia y de eficacia si se realiza un análisis de los resultado respecto de los objetivos propuestos con los medios utilizados con criterios de rentabilidad, funcionalidad, etc. ${ }^{606}$

\footnotetext{
${ }^{603}$ Mario Garcés San Agustín, "El control económico-financiero en el ámbito de la Administración General del Estado", 483, en La Gestión de los Fondos Públicos: Control y Responsabilidades, Alberto Palomar, Mario Garcés (directores) y otros, (Pamplona: Thomson Reuters Aranzadi, 2013).

${ }^{604}$ Ecuador, art. 6 de la Ley Orgánica de la Contraloría General del Estado (Ley N²002-73).

${ }^{605}$ M. Caballer Dura, "El Control de la Actividad Financiera: concepto, clases y ámbito. Órganos de control”, en VVAA, Nociones de Derecho Financiero, Madrid, EHP, 1993; Carlos GiulianiFonrouge, Derecho Financiero, Volumen I, obra actualizada por Susana Navarrine y Rubén Asorey, $7^{\mathrm{a}}$ edición, (Buenos Aires: Depalma, 2001).

${ }^{606}$ José Antonio Fernández Ajenjo, El control de las administraciones públicas y la lucha contra la corrupción, (Pamplona: Civitas - Thomson Reuters, 2011); Juan Martín Queralt, Carmelo Lozano, José Tejerizo, Gabriel Casado, Curso de Derecho Financiero y Tributario, (Madrid: Tecnos, 2011).
} 
Para Enrique Silva, el control externo persigue fiscalizar a los órganos de la administración en sus diversos aspectos legales, políticos, administrativos, financieros, económicos, de gestión, de resultados, etc., y lo ejercen órganos unipersonales o pluripersonales distintos e independientes de los examinados; de manera previa o $a$ posteriori de acuerdo a los objetivos que se persigan con las acciones de control y mediante actos generales o específicos de fiscalización, con diversas modalidades como la de legalidad; de mérito o conveniencia; de gestión; de verificación de los aspectos jurídicos y financieros; de examen de las pérdidas y ganancias y solvencia de las empresas públicas, privadas o mixtas; de inspección y auditoría y de control de rendimientos, resultados, bondades, inconvenientes y medios de solución.

El mismo autor dice también que el control interno o autocontrol es jerárquico; se ejerce de oficio o a requerimiento de la autoridad o por reclamación ciudadana al interior de la propia administración y su fundamento se encuentra en el ejercicio de los principios de auto tutela y tutela administrativas, que obligan a las estructuras de poder y a sus funcionarios a controlarse a sí mismos y garantizar el cumplimiento y observancia de la ley para el cumplimiento de sus fines. ${ }^{607}$

Es necesario observar que, históricamente, primero surgieron los sistemas de control externo como producto de la organización del estado moderno en poderes y funciones. Luego el control externo se diversificó, con la estructuración y surgimiento de órganos especializados de carácter técnico, en calidad de instrumentos de apoyo al control político y parlamentario que más tarde se independizaron, como órganos extrapoderes o como función independiente del Estado, puesto que su ámbito de control también cubrió a todas las instituciones que manejen recursos públicos, incluyendo a aquellas que están relacionadas con los servicios públicos propios e impropios y con los productos de consumo masivo y a las actividades administrativas de la función legislativa y de la judicial. Finalmente, en la actualidad, el control integral implica el seguimiento de un sistema de control interno o de autoevaluación de las actividades de la propia Administración, especialmente financieras, para corregir sus defectos y evidenciar eficiencia, eficacia y economía en el uso de recursos incluyendo su gestión y los sistemas de control externo: político general, a los más altos dignatarios del Estado; técnico-financiero en los diferentes ámbitos administrativos y de la gestión pública y en aquellos en los que estén involucrados intereses colectivos; social o ciudadanos, como expresión de la participación y democratización de los regímenes constitucionales en todos los países del mundo; y jurisdiccional para establecer violaciones legales y sancionar responsabilidades y delitos que se puedan presentar en la actividad y gestión de la administración, en la del Estado o en un ámbito de interés público o colectivo.

Más allá de las clasificaciones que permiten organizar la identificación de las diferentes formas de control administrativo y financiero, es necesario reafirmar la convicción

\footnotetext{
${ }^{607}$ Enrique, Silva Cimma, Derecho Administrativo Chileno y Comparado, el Control Público, (Santiago: Editorial Jurídica de Chile, 1994).
} 
democrática de que el control es una potestad pública estatal y a la vez un derecho y garantía ciudadana. Como potestad es manifestación de la soberanía, que se adjudica a los órganos del Estado para ejercer un equilibrio en el ejercicio del poder e impedir cualquier forma de abuso o autoritarismo, y como derecho y garantía, los ciudadanos, los medios de comunicación y la organización social no solo ejercen los procesos y procedimientos habilitados por el orden jurídico para el efecto, sino que directamente, bajo diversas modalidades, intervienen, observan, participan y actúan en todos aquellos asuntos que son de su interés y están relacionados con el buen uso de los recursos públicos, con la gestión y la Administración pública y la vida social.

Fernández Ajenjo nos recuerda también la naturaleza jurídica de la función de control que como potestad pública se basa en el principio de legalidad y no en la autonomía de voluntad. El control como potestad, dice, es un "atributo o capacidad jurídica asignado ex lege a una institución pública que la habilita para ejercer vigilancia de la actividad pública" y que le confiere además "competencia" para "dictar actos con valor jurídico". Manifiesta también que si bien las "potestades de control originarias" están asignadas a los poderes clásicos, "el ordenamiento jurídico atribuye potestades de control derivadas por delegación, desconcentración o descentralización a diversos órganos e instituciones públicas", por lo que existen también otros controles "de segundo rango jurídico como derechos subjetivos, atribuidos a sujetos que no ostentan una potestad sobre el ente público controlado" (como organizaciones sociales o ciudadanos particulares) que "pueden tener su origen en la atribución legal o en los negocios jurídicos". ${ }^{608}$

Para nosotros, en las democracias contemporáneas en las que se incluye el principio de participación, tanto el control público como el ciudadano sobre los recursos y su buen uso, son fundamentales y complementarios. Los dos tienen rango constitucional y convencional y sus técnicas se han desarrollado significativamente. El control social y ciudadano, siempre que no sea manipulado por el propio Estado o por intereses económicos y políticos hegemónicos, podría complementar la eficacia y eficiencia de las acciones, técnicas y sistemas públicos de control, en una época en la que ha crecido la corrupción, la impunidad y el autoritarismo, siempre resistentes a toda forma de control.

\section{El control interno}

Los sistemas de control interno o de autocontrol se desarrollan dentro de las instituciones administrativas. Históricamente surgieron como parte de la misma Administración, luego se trasladaron parcialmente a los órganos de control externo y en la actualidad se han especializado en la propia administración, sin que sean excluyentes sino complementarios con el control externo que debe incluir gestión, pues esta es parte fundamental de la auditoría y la evaluación.

\footnotetext{
608 José Antonio Fernández Ajenjo, El control de las administraciones públicas y la lucha contra la corrupción, (Pamplona: Civitas - Thomson Reuters, 2011), 150.
} 
Según la legislación ecuatoriana, los sistemas de control interno implican una serie de procesos que implementan las máximas autoridades de dichas instituciones para tener la seguridad razonable de que se usan adecuadamente los recursos públicos y se alcanzan "los objetivos institucionales" (Art. 9 de LOCGE).

En la mayoría de países existen estructuras de control interno asociadas al ciclo presupuestario de las instituciones estatales, que en algunos casos dependen directamente del Ministerio de Finanzas o de Hacienda o de otros entes de gestión pública en la propia Administración o de aquellos que ejercen control de legalidad y de eficiencia de la Administración y que, siendo nombrados por el Ejecutivo, deberían tener independencia funcional y autonomía, respecto a las autoridades o funcionarios que controlan, como ocurre con el interventor general del Estado en España o la Fiscalía Nacional de Investigación Administrativa en Argentina, etc. ${ }^{609}$

En Ecuador, el control interno en la función ejecutiva que dirige la mayoría de órganos administrativos del Estado, se encuentra asignado por el presidente de la República a la Secretaría General (Ministerio) de la Administración pública o, en la actualidad a la Secretaría de la Presidencia; a la Secretaría de Planificación y Desarrollo Social; al Ministerio de Finanzas en el seguimiento, evaluación y control del presupuesto; a la Procuraduría General del Estado y a cada una de las propias entidades públicas, conforme lo dispone la propia Constitución. Lo propio ocurre también en otras administraciones públicas como las de los gobiernos autónomos descentralizados, en las que existen dependencias propias de control interno, además del control de legalidad que ejerce sobre todas ellas la Procuraduría General del Estado.

Además, en todas las dependencias públicas, la Ley Orgánica de la Contraloría General del Estado dispone que el control interno esté organizado mediante la aplicación de la contabilidad gubernamental, que ofrece información gerencial para los requerimientos operacionales de sus máximas autoridades y que en aquellas se conformen sistemas de control especial, además de las auditorías internas que son órganos directos de asesoría y evaluación técnica-financiera de la Contraloría que, bajo su vigilancia y encabezadas por un funcionario o auditor y su personal, desarrollan de manera permanente en la institución: exámenes especiales y auditorias de legalidad, de buen uso y destino eficiente de bienes y recursos, humanos, materiales y económicos-financieros y elaboran informes sobre la observación de normas técnicas, administrativas y medioambientales y sobre la eficiencia, eficacia y resultados de los programas y actividades que ejecutan en dichas dependencias pública el personal a su cargo.

Los departamentos de evaluación y control interno y los de auditoría interna o de evaluación institucional, a nivel general de la Administración pública, son parte de la estructura de las diferentes instituciones estatales que asumen sus gastos y organización;

${ }^{609}$ Fernando Pérez Royo, Derecho Financiero y Tributario Parte General, novena edición, Madrid, Civitas, 1999; Patricia Martínez, "Organización Administrativa" en Manual de Derecho Administrativo, Ismael Farrando y otros, Buenos Aires, Ediciones Depalma, 1996. 
pero, en el ámbito técnico y administrativo, las auditorías internas dependen, en cuanto a la planificación y a las instrucciones y orientaciones de coordinación, del órgano técnico de control externo que, en el caso del Ecuador y de otros países de la región, corresponde a la Contraloría General del Estado. Por lo general, las acciones de control interno y, en especial, las auditorías internas son el punto de partida para las operaciones técnicas y de auditoría integral o especializada, que realiza simultáneamente o $a$ posteriori el órgano de control externo, la Contraloría General del Estado. ${ }^{610}$

El control interno siempre ha estado asociado jerárquicamente al ejercicio del poder administrativo de cada uno de los órganos e instituciones del Estado que tienen la obligación constitucional de autovigilar sus procedimientos y los de todas las dependencias a su cargo, para que estén sometidos a la ley y para que en sus acciones permitan el cumplimiento de sus objetivos y atribuciones.

Las actividades de control y evaluación internas no se limitan a aquellas que planifica y coordina el órgano de control externo, sino que incluyen otras iniciativas y procedimientos de evaluación y control adoptados por la propia institución o por la función estatal a la que pertenecen. En el control moderno, con el apoyo de la informática y de la técnica contable y de la auditoría, se han introducido nuevos procedimientos de evaluación de los procesos administrativos y los de gestión, para introducir la planificación y medir además la eficiencia y la eficacia en el uso de los recursos y en el logro de las metas y objetivos institucionales. Estas autoevaluaciones no son incompatibles con las que realiza el órgano de control externo, sino más bien contribuyen a que cuando este realice su propia evaluación, constate que desde el inicio o de manera concurrente se realizaron las correcciones y ajustes necesarios, para el buen uso y buen resultado en el manejo de los recursos públicos.

El control interno debe poner énfasis, por tanto, en el control inicial y en la intervención y evaluación concurrentes sobre el uso de recursos para asegurar los resultados de la gestión y evaluación de los funcionarios y de las dependencias públicas y para generar un aumento de su capacidad gerencial y el cumplimiento de sus fines sociales. En las legislaciones de varios países este tipo de control lo realizan las mismas instituciones y se ha ido eliminando la obligatoriedad de que estas evaluaciones preliminares las efectúen los órganos de control externo, pues su uso excesivo podría ocasionar limitaciones en la gestión y demoras innecesarias en la ejecución, convirtiéndose en algunos casos en una especie de cogobierno o coadministración. ${ }^{611}$

Ello no significa, como ya hemos enfatizado, que en una auditoría externa sea imprescindible realizar también el análisis de toda la gestión institucional interna, incluyendo el desempeño y los resultados, por lo que no se justifica suprimir

\footnotetext{
${ }^{610}$ Ecuador, Ley Orgánica de la Contraloría General del Estado (Ley N ${ }^{\circ}$ 2002-73), Sistema de Control Interno (arts. 9-17),

${ }^{611}$ Carlos Alberto Cepeda Ortiz, El sistema de control interno del Estado", (Bogotá: Ediciones Librería del Profesional, 2001).
} 
precipitadamente el control de gestión o del cumplimiento de los objetivos institucionales en las atribuciones de la Contraloría, como lo dispuso, de manera absurda, la última enmienda constitucional en Ecuador a fines de $2015 .{ }^{612}$

Asimismo, es necesario reconocer que si hay decisión política, el control interno es clave para combatir con eficacia el crecimiento de la corrupción en la Administración pública o también para disimularla o esconderla. Fernández Ajenjo señala que el Gobierno tiene una situación de predominio en la lucha contra aquella por razones de jerarquía y por la serie de instrumentos y órganos de los que dispone para hacerlo, ya que puede dirigir la inspección de las actividades fraudulentas, dirimir discrepancias entre órganos fiscalizadores y fiscalizados, emitir opiniones de legalidad y conveniencia, resolver recursos sobre actos presuntamente ilegales adoptados por órganos administrativos, descubrir más fácilmente prácticas corruptas por su jerarquía y control diario o permanente de los trámites de mayor importancia económica, etc. En efecto, podría ser, como dice Ximena Lazo Vitoria, "un primer filtro para detectar posibles irregularidades o inobservancias del orden establecido"613 y también para adoptar sanciones administrativas drásticas y hacer conocer los ilícitos, en caso de haberlos, a las autoridades judiciales.

El problema principal que se advierte en la eficacia del control interno es que sus órganos de control deber ser independientes, lo cual es imposible esperar de gobiernos concentradores de poder que prefieren la opacidad y el ocultamiento de las corruptelas, para evitar el desgaste de su imagen pública. En todo caso, en algunos países como en España se han creado para el efecto la Agencia Estatal de Evaluación de las Políticas Públicas y la Calidad de los Servicios y la Intervención General de la Administración del Estado, entes a los que se les reconocen autonomía para sus acciones de control, lo cual no resulta suficiente para que cumplan a cabalidad con su cometido. Con mayor razón, el resultado es deficiente y desalentador si las numerosas instituciones que se crean para realizar evaluación y seguimiento económico-financiero, control interno de gestión y aún para tramitar denuncias de corrupción son dependencias directas del Ejecutivo totalmente burocratizadas, como ocurre en Ecuador, en dónde las denuncias o sanciones sobre el mal manejo de recursos públicos jamás provienen directamente de esas instancias de control como precisaremos más adelante.

No obstante, se debe reconocer que en la Administración pública moderna, mediante departamentos financieros, de personal, presupuestarios y otros órganos de control interno, ayudados por sistemas informáticos, se han mejorado sustancialmente el manejo presupuestario, tributario, contable, en el uso de bienes, captación directa de recursos monetarios, etc. Los actos de corrupción en la actualidad no se concentran ya en esos asuntos que pueden ser eficazmente monitoreados y controlados; se refieren más bien a los que ocurren a propósito de las más importantes decisiones administrativas y

${ }^{612}$ Ecuador, Enmiendas a la Constitución de la República del Ecuador, Suplemento del Registro Oficial 653 de 21 de diciembre de 2015.

${ }^{613}$ Ximena Lazo Vitoria, El control interno del gasto público estatal... (Madrid: Tecnos, 2008). 
financieras en la contratación de grandes obras públicas y en otras decisiones económicas y financieras de gran volumen, que obviamente no son controladas por funcionarios subalternos.

El control financiero-presupuestario de las administraciones públicas se ejecuta mediante sistemas de control interno y externo. A nivel interno se ejerce la función interventora por medios de los órganos e instrumentos (auditorías) creados mediante ley o por los órganos y procedimientos que estime necesarios la máxima autoridad de la función ejecutiva. Dicha función interventora permanente tiene por objeto verificar de forma continua la situación y funcionamiento de las entidades públicas en el aspecto económico-financiero y presupuestario, para comprobar el cumplimiento de las normas y analizar y verificar la gestión financiera, la estabilidad y el equilibrio financiero.

A nivel externo, la Contraloría, facultada por la ley, ejercerá concomitantemente el control en materia presupuestaria mediante auditorías internas o externas sobre los diferentes momentos del ciclo presupuestario, en los que se pueden dictar recomendaciones y establecer responsabilidades en el campo administrativo, civil y presunciones o indicios de responsabilidad penal, conforme lo dispone la Constitución y la ley. Estas atribuciones pretenden ser limitadas y aún eliminadas con las últimas enmiendas constitucionales de 2015 en Ecuador, que seguramente impondrán nuevas reglas para el control económico y financiero del ciclo presupuestario.

\section{El control externo}

Los principales sistemas de control y evaluación externos se refieren: al control político, al control técnico-financiero especializado, al control ciudadano o social y al control jurisdiccional.

El primero, el más antiguo, es el control político. Está asignado en las constituciones de los estados al Congreso, Parlamento o Asamblea Nacional, para controlar actividades transcendentales de la Administración como la aprobación del presupuesto del Estado, recibir y pronunciarse sobre los informes de las funciones del Estado y procesar o enjuiciar al presidente de la República, a los ministros del Gobierno y a los más altos dignatarios del Estado, incluyendo en su tiempo a los jueces o magistrados de la función judicial. El control político también involucra la actividad de las comisiones parlamentarias conformadas de manera permanente o transitoria y de los legisladores que individualmente tienen facultades para requerir información y fiscalizar la ejecución del presupuesto y las actividades administrativas y financieras de otras dependencias y órganos de la estructura estatal.

Asimismo, realizan control externo y de fiscalización permanente, órganos de carácter técnico-administrativo-financiero, como la Contraloría, las superintendencias, la Defensoría del Pueblo o las agencias de Regulación, que surgieron inicialmente como auxiliares del Congreso, Asamblea o Cortes y que posteriormente actúan con independencia de las funciones del Estado o conforman una función destinada al control 
y a la fiscalización y, en la actualidad, otras estructuras estatales o de la sociedad civil o de iniciativa ciudadana destinadas al control social y popular como nueva formas de participación en el régimen democrático.

No nos referiremos en este estudio al control jurisdiccional externo propiamente dicho, desempeñado por los órganos comunes y especializados de la función judicial o por tribunales de lo Contencioso Administrativo dependientes o independientes de la misma $\mathrm{y}$ por los tribunales o cortes constitucionales, que de manera definitiva y mediante sentencias realizan el control de legalidad y constitucionalidad sobre las acciones u omisiones de las instituciones públicas y de sus funcionarios, con la finalidad de establecer las diferentes responsabilidades que tienen en el desempeño de sus competencias.

Tampoco nos referiremos en este estudio a las potestades de control de legalidad, que la Constitución ha asignado a la Procuraduría General del Estado; al control en cuanto al respeto de los derechos humanos que ejerce la Defensoría del Pueblo ni a las actividades y potestades que cumplen otros órganos de control técnico externo que existen en nuestro ordenamiento jurídico para vigilar actividades privadas o de interés social o público, como son las superintendencias de bancos, de compañías, de telecomunicaciones, de control del mercado y de las numerosas agencias de regulación. Nuestra atención se concentrará a continuación en el control externo político; el técnicoadministrativo-financiero y el social, relacionado especialmente con el manejo, gestión y destino de los recursos públicos.

\subsection{El control político}

Los estados a partir de las tres grandes revoluciones de la modernidad: inglesa (1688), norteamericana (1776) y la francesa (1789), se inspiraron para su estructuración en la doctrina política de la división de poderes, formulada inicialmente por John Locke en su Ensayo sobre el Gobierno Civil (1690), ${ }^{614}$ como una racionalización entre los mismos, para establecer límites al ejercicio del poder absoluto. Posteriormente, Montesquieu, de manera más directa, en su obra El Espíritu de las Leyes (1784), planteó la misma tesis con la finalidad de introducir "frenos" y "contrapesos" entre los poderes estatales. ${ }^{615}$ Rousseau y quienes dirigieron las revoluciones antes indicadas reforzaron la necesidad obvia de que quien ejecuta la ley debe subordinarse a ella, lo que constituye el fundamento del principio de legalidad y del Estado de derecho. ${ }^{616}$

Con fundamento en el pensamiento político antes indicado, en la organización de los estados, la soberanía del pueblo se expresa en el poder legislativo que aprueba leyes y

\footnotetext{
${ }^{614}$ John Locke, Ensayo sobre el Gobierno Civil, (México: Aguilar, 1983).

${ }^{615}$ Luis de Montesquieu, El Espíritu de las Leyes, (Madrid: Colegio de Abogados de Madrid, 1999).

${ }^{616}$ Felipe Rotondo Tornaría, Manual de Derecho Administrativo, tomo I, (Montevideo: Ediciones "Del Foro", 2002).
} 
controla a los otros poderes; en el judicial que administra justicia entre los particulares mediante sentencias y en el ejecutivo que, ejerciendo la coacción, aplica las leyes y los fallos judiciales, garantizando el orden interno y su independencia exterior y atendiendo las necesidades sociales y servicios públicos mediante una creciente estructura y las correspondientes normas administrativas.

Esta división de poderes, conjuntamente con el reconocimiento de los derechos de los ciudadanos y el principio de legalidad, se convirtieron en la esencia del Estado de derecho moderno y contemporáneo, que incluye el concepto de lo que hoy se denomina Constitución, ya sea escrita o consuetudinaria, pues en la Declaración de los derechos del hombre y del ciudadano, de 26 de agosto de 1789, se reconoció en su artículo 16 que: "Una sociedad en la que no esté asegurada la garantía de derechos ni determinada la separación de poderes, carece de Constitución". ${ }^{617}$ Por lo que se puede afirmar que lo esencial del Estado moderno, organizado como república y sometido a un ordenamiento jurídico, radica en el reconocimiento y ejercicio de los derechos de sus ciudadanos y en el control del poder, para impedir que su ejercicio, por parte de los mandatarios o de las autoridades, atente contra aquellos y especialmente contra la libertad, la igualdad y la solidaridad humanas.

Posteriormente, la escuela alemana de Derecho Público, al desarrollar la teoría única de la personalidad estatal, sostuvo que hay una sola persona jurídica que ejerce el poder: el Estado y que lo distribuye entre sus órganos como funciones, por medio de las cuales se ejercen las potestades públicas de las que se encuentra investido.

La doctrina administrativa actual estima de manera generalizada que no hay en el Estado poderes independientes sino funciones, y que los órganos del poder público que es uno solo, están dotados de potestades: unas que son de su especialidad y otras que se ejercen residualmente, conforme a las actividades que desempeñan y al ordenamiento jurídico y constitucional. ${ }^{618}$ Por ello, para algunos autores se pueden identificar en la actualidad siete o más funciones del Estado: ejecutiva, legislativa, judicial, pre constituyente, constituyente, de gobierno, de control, etc. ${ }^{619}$

En los dos enfoques públicos iniciales, de los poderes o de las funciones, el control es una potestad estatal que se ejerce en diversas dimensiones: por medio del poder o función legislativa, que además de aprobar leyes tiene la potestad de ejercer la vigilancia política y de legalidad de las actuaciones u omisiones de los titulares del Estado del máximo nivel o por medio de otros órganos especializados y otras funciones

\footnotetext{
${ }^{617}$ Francia, Declaración de Derechos del Hombre y del Ciudadano, 26 de agosto de 1789.

${ }^{618}$ Jorge Zavala Egas, El Estatuto del Régimen Jurídico Administrativo de la Función Ejecutiva en el ordenamiento jurídico, (Quito: Corporación Latinoamericana para el Desarrollo (CLD), 1995).

619 Dardo Pérez Guilhou, Responsabilidad política y control en la reforma de las constituciones provinciales, (Córdova: Banco Social de Córdova, 1985); José Luis Martínez Peroni, Algunas consideraciones acerca de las funciones del poder, en Dardo Pérez Guilhou y otros, Atribuciones del presidente argentino, Instituto Argentino de Estudios Constitucionales y Políticos, (Buenos Aires: Depalma, 1987).
} 
del Estado, de manera interna o externa, para controlar la legalidad, el ejercicio o la gestión de sus operaciones administrativas, técnicas o financieras, ambientales y de otras, conforme a la complejidad que va asumiendo históricamente el Estado y sus fines.

Las constituciones ecuatorianas, desde 1830 hasta la de 1945, estructuran la organización del Estado mediante el establecimiento de tres poderes: Legislativo, Ejecutivo y Judicial y desde la Constitución de 1946 hasta la actualidad se sustituye el concepto de poder por el de función. ${ }^{620}$ Las constituciones siguientes de 1967, 1978 y 1998 establecían la existencia de tres funciones del Estado: legislativa, ejecutiva y urisdiccional - judicial- y órganos extrapoderes, mientras que la Constitución vigente desde 2008 organiza el Estado en cinco funciones: legislativa; ejecutiva; judicial y justicia indígena; transparencia y control y electoral, incluyendo en ellas a los órganos extrapoderes que constaban en las constituciones anteriores.

El control político o de fiscalización de los congresos o asambleas en Ecuador, organizados bajo el sistema presidencialista, se ha ejercido a lo largo de la historia mediante dos mecanismos principales: el juicio o enjuiciamiento político al presidente y vicepresidente de la República y contra los ministros de Estado y altos funcionarios; los informes que deben rendir los titulares de las funciones del Estado y que deben ser analizados por el pleno de la función legislativa y los documentales oficiales o informes personales que demandan a los funcionarios públicos, las comisiones parlamentarias y, en especial, la comisión de trámite y control presupuestario en el ámbito financiero estatal.

Enrique Ayala nos recuerda que en Ecuador, desde 1830 hasta la actualidad, se estableció en la Constitución la obligación de los mandatarios máximos del país y de los ministros de informar de su gestión a la legislatura y de someterse a enjuiciamiento político en el Congreso, pudiendo ser censurados y destituidos. Sin embargo, anota, que no siempre a lo largo de la historia esa facultad tuvo las mismas características: así "en las constituciones que dieron grandes atribuciones al Ejecutivo con un sesgo autoritario, como la Carta de Esclavitud (1843) o la Carta Negra (1869), la posibilidad de fiscalización y censura se redujo o desapareció", mientras que "en las cartas políticas que dieron mucho peso a la legislatura, en cambio, la remoción de ministros se facilitó, a tal punto que en la Constitución de 1929 se estableció que podían ser destituidos sin Juicio político, con un simple 'voto de desconfianza' resuelto por la mayoría del Congreso". 621

Históricamente, los juicios políticos han estado dirigidos principalmente contra los ministros de Estado para cuestionar las políticas y decisiones trascendentes de los gobiernos de turno, sin embargo, en los últimos años, con la aplicación de los modelos económicos neo liberal o neointervencionista y la concentración del poder económico

${ }^{620}$ Federico Trabucco, Constituciones de la República del Ecuador, (Quito: Editorial Universitaria, 1975).

${ }^{621}$ Enrique Ayala Mora, ¿ Por qué la Asamblea Constituyente?, (Quito: Ediciones La Tierra, 2015), 47. 
en el Ejecutivo, se eliminó la posibilidad de enjuiciar y destituir a jueces y se pretendió eliminar los efectos de la destitución y remoción de los ministros de Estado, para evitar negociaciones políticas gravosas y la inestabilidad en las decisiones políticas y económicas, como lo estableció la Constitución de 1998, que imposibilitó la sanción y destitución de los ministros o como consta en la Constitución de 2008 en la que se exigen para ello requisitos especiales de procedencia y votaciones calificadas de difícil acceso.

Es verdad que el control político de los congresos o asambleas legislativas en Ecuador se convirtió muchas veces en un mecanismo retórico y publicitario de sectores políticos parlamentarios para impugnar al Gobierno de turno, o de negociación o corrupción entre los interpelantes y el régimen, sin mayor efecto en la corrección de errores, y mucho menos en la sanción de irregularidades o corruptelas de los más altos funcionarios del Estado. Sin embargo, la obligación de informar y enjuiciar políticamente a los mandatarios, ministros y altos funcionarios del Estado, también constituye un ejercicio democrático; un espacio de transparentar sus actuaciones para vigilar el uso de los recursos públicos y combatir la corrupción en sus casos más connotados y una instancia que hace evidente, de alguna manera, que no puede haber en un Estado de derecho, funcionario alguno, así sea de la más alta jerarquía, exento de responsabilidad en el ejercicio de sus competencias o en el abuso de sus atribuciones. En este sentido, eliminar o limitar el control externo y el control político es propio de regímenes autoritarios que temen a la transparencia, a la fiscalización y al control.

De manera general, los parlamentos, congresos o asambleas tienen la atribución de intervenir en las diferentes fases del ciclo presupuestario y en el control de las más importantes decisiones políticas, económicas y financieras de la función ejecutiva. En la época inicial liberal de las repúblicas modernas las posibilidades de control parlamentario eran amplias y formales, especialmente a la hora de establecer los ingresos y autorizar los gastos. Durante el Estado social de derecho la intervención parlamentaria creció en importancia en materia económica y financiera, por lo que, sin renunciar totalmente a sus atribuciones, delegó su vigilancia constante y el establecimiento de responsabilidades, a órganos como el Tribunal de Cuentas o a la Contraloría. En la época actual se ha reducido el control parlamentario a ciertos formalismos en la aprobación del presupuesto; se ha restringido el control político conforme se ha ampliado el presidencialismo y los órganos autónomos de control externo, en algunos casos, han perdido, limitado o fortalecido sus potestades en el control simultáneo y posterior de los recursos públicos y su gestión.

\subsection{El control técnico económico-financiero y sus sistemas}

El control externo de las administraciones públicas surge, según constatación histórica, mediante sistemas o instrumentos institucionales auxiliares de la función de control de los congresos, asambleas o parlamentos, que en algunos casos, adquirieron luego 
autonomía relativa o total de aquellos, como órganos extrapoderes del Estado o conformando una nueva función estatal, como ocurre actualmente en Venezuela, Bolivia y Ecuador.

Estos sistemas técnicos de control externo incluyen varios procedimientos y modalidades de distinta naturaleza. A día de hoy los preferentes son las auditorías, que pueden concentrarse en asuntos relacionados con: la legalidad y el cumplimiento de las normas; el uso de los recursos y los aspectos económico-financieros; la eficiencia y eficacia en la gestión administrativa para analizar los procesos, los procedimientos y sus resultados; el impacto medioambiental en las diferentes actividades y proyectos que se realicen y el examen de las obras públicas que se encuentran en ejecución, en las cuales se analiza su tecnología y las aplicaciones científicas adoptadas en ellas, además de sus costos e impacto económico-financiero.

Al control técnico global algunos lo denominan control gubernamental o control integral y cuando se refiere a uno solo de sus aspectos se lo identifica de manera específica con el asunto o dimensión a los que se refiere. Se diferencia, también, en la legislación ecuatoriana, auditoria y examen especial: la primera incluye un análisis integral o especializado del asunto o actividad que se examina para establecer las conclusiones y correctivos institucionales que se estimen necesarios y el segundo se limita a una operación específica de los mismos. ${ }^{622}$

El control financiero propiamente dicho, que tiene una connotación especial en el ámbito estricto del derecho financiero, está relacionado con mayor precisión en la formulación, ejecución y evaluación del presupuesto, el endeudamiento público y la naturaleza de los ingresos y los gastos públicos. Se trata de un concepto más general, relacionado con el control administrativo, que permite determinar si la gestión económica-financiera de las instituciones se ajusta a los principios de legalidad, economía, eficiencia y eficacia. Fernando Pérez Royo dice que el control de eficacia es una subespecie del control económico y financiero, que se ejerce "mediante el análisis del coste de funcionamiento y del rendimiento o utilidad de los respectivos servicios o inversiones, así como del cumplimiento de los objetivos de los correspondientes programas". ${ }^{623}$ Una auditoría financiera integral tiene que referirse necesariamente a la eficacia y eficiencia de la gestión de la administración y sus resultados.

Existen, de manera general, dos sistemas o estructuras principales de control: unipersonales o pluripersonales para el ejercicio técnico del control externo, especialmente administrativo y financiero y de gestión de los presupuestos y de la actividad administrativa: el sistema europeo y pluripersonal de tribunales de Cuentas y el sistema externo unipersonal de Contraloría de origen norteamericano.

\footnotetext{
${ }^{622}$ Ecuador, Ley Orgánica de la Contraloría General del Estado (Ley $N^{\circ}$ 2002-73), Del Sistema de Control Externo (arts. 18-28).

${ }^{623}$ Fernando Pérez Royo, Derecho Financiero y Tributario Parte General, Novena edición, (Madrid: Civitas, 1999), 394.
} 


\subsubsection{Sistema pluripersonal (o europeo) de Tribunal de Cuentas}

El Tribunal de Cuentas tiene una larga historia en los países europeos. En el caso español existió previamente la figura del Contador y de la Contaduría Mayor de Cuentas para llevar y registrar las cuentas de la hacienda real, y desde 1718, Felipe V, utilizó por primera vez la designación Tribunal de Cuentas, que se conserva, con ciertos intervalos, hasta nuestros días y cuyo nombre se ha extendido a otros países de Europa, de la Unión Europea y del mundo, si bien sus funciones y atribuciones no son las mismas, pues se han modificado a lo largo de la historia, de acuerdo con las circunstancias de cada país.

A este sistema se lo conoce también como sistema francés o de control jurisdiccionaladministrativo para referirse a la Corte de Cuentas, creada en 1807 por Napoleón I, que posee una estructura y competencias similares a las del Consejo de Estado y ejerce, además de sus potestades jurisdiccionales y de fiscalización, un intenso control administrativo que se ha incrementado, en las últimas décadas con reformas en los sistemas de contabilidad y de gestión. ${ }^{624}$

Desde sus orígenes hasta la actualidad, con ciertas modificaciones en el tiempo, el Tribunal y las Cortes de Cuentas conservan un doble carácter gubernativoadministrativo y jurisdiccional, si bien la influencia del sistema de control anglonorteamericano, de gran difusión en la globalización capitalista contemporánea, ha reforzado sus atribuciones administrativas de fiscalización de la actividad económicafinanciera. En algunos países se crearon además otros órganos, agencias o departamentos que realizan, exclusivamente en el ámbito administrativo-financiero, control externo.

El control que efectuaba inicialmente el Tribunal de Cuentas en España, desde su creación se refería al registro de ingresos, gastos y a la distribución y comprobación de las operaciones realizadas por los funcionarios de la Hacienda Real, por lo que la fiscalización esencialmente tenía una naturaleza contable y personal. Con la implantación del sistema constitucional, se estableció la obligación de que la Contaduría y luego el Tribunal de Cuentas presenten a las Cortes un finiquito anual de las mismas para su aprobación y, si bien inicialmente la jurisdicción contable se trasladó a la Función Judicial, desde 1931 se definió al Tribunal de Cuentas de la República como un "órgano fiscalizador de la gestión económica", que "dependerá directamente de las Cortes y ejercerá sus funciones por delegación de ellas en el conocimiento y aprobación de las cuentas del Estado". ${ }^{625}$ Durante el régimen franquista (1936 - 1975) el Tribunal de Cuentas mantuvo su carácter administrativo y jurisdiccional pero bajo la tutela y control total del Jefe de Estado.

\footnotetext{
${ }^{624}$ Carlos Giuliani Fonrouge, Derecho Financiero, Volumen I, obra actualizada por Susana Navarrine y Rubén Asorey, $7^{\mathrm{a}}$ edición, (Buenos Aires: Depalma, 2001).

${ }^{625}$ España, Constitución de la II República de 1931, art. 120.
} 
El sistema de control pluripersonal externo, de cinco, siete o nueve jueces, ejercido por medio de un Tribunal de Cuentas de carácter económico-administrativo y jurisdiccional, para examinar el uso correcto y eficiente de los recursos públicos y establecer, si fuere del caso, responsabilidades administrativas y civiles, se encuentra reconocido en las constituciones de varios países europeos (Alemania, Italia, Bélgica, Grecia, Austria, Portugal, etc.); latinoamericanos (Brasil, Argentina, Colombia, Uruguay, Paraguay, etc.) y también en sistemas regionales de integración como la Unión Europea. Se trata de órganos de relevancia constitucional o convencional, independiente de las otras estructuras de poder o relacionados con los parlamentos, para ejercer control externo a las estructuras administrativas, con obligación de informarlos de sus actividades y de los resultados de aquel y que se homologan a las Entidades Fiscalizadoras Superiores (EFS) que están estructuradas a nivel internacional.

En el caso de la Unión Europea, en 1975, mediante el Tratado de Bruselas se creó el Tribunal de Cuentas Europeo, que inició sus actividades en Luxemburgo en 1977 y se perfeccionó, como institución de pleno derecho, con el Tratado de Maastricht el 1 de noviembre de 1993, con la finalidad de controlar los ingresos y gastos que se manejan en la Comunidad, en los países miembros y en cualquier organismo creado por esta, así como su uso y la gestión que con ellos se realice. El control que efectúa es externo, $a$ posteriori, permanente y se concreta en actos de fiscalización y auditorías sobre la legalidad, las reglas contables y una evaluación de una "buena gestión financiera", de su economía y de su eficacia y eficiencia administrativas, aplicando las normas básicas de fiscalización de la INTOSAI y en coordinación y colaboración con los tribunales de Cuentas de los países miembros. ${ }^{626}$

Este sistema de control de legalidad y oportunidad por medio del Tribunal de Cuentas ha recibido en España una serie de reparos sobre su falta de independencia y, por lo tanto, de su ineficacia como órgano fiscalizador de las cuentas y de conocidos casos de corrupción y de su impotencia en el control de la gestión económica de las administraciones públicas, como resultado del origen de su nombramiento por parte de las mayorías partidistas que controlan las Cortes Generales y el Gobierno. De igual manera, se cuestiona su incompetencia para controlar asuntos económicos-financieros de trascendencia, como la estabilidad presupuestaria y el equilibrio de las finanzas públicas de un país o de la región, lo que ha dado lugar al surgimiento de nuevas iniciativas como las de crear, tanto a nivel nacional como regional, nuevos organismos de supervisión externa de las reglas fiscales, como la Autoridad Independiente de Responsabilidad Fiscal en España, cuyo propósito es el de evitar colapsos económicos y bancarios, como los ocurridos luego de la reciente crisis financiera de $2008 .{ }^{627}$

\footnotetext{
${ }^{626}$ Yolanda Gómez Sánchez, El Tribunal de Cuentas: el control económico y financiero externo en el ordenamiento constitucional, (Madrid: Marcial Pons, 2001).

${ }^{627}$ España, Ley Orgánica 6/2013, de 14 de noviembre, de creación de la Autoridad Independiente de Responsabilidad Fiscal.
} 
El profesor Fernández Ajenjo expone dos criterios sobre esta controversia: algunos autores estiman que dada la dependencia del Tribunal de Cuentas a la función de control parlamentario sobre la legalidad y eficacia en la gestión de los recursos públicos, por parte de las administraciones públicas y dado que carece de facultades suficientes en las labores de fiscalización y enjuiciamiento, su papel en la lucha anticorrupción es limitado ya que se reduce a "detectar y denunciar los denominados por Nieto de Alba 'riesgos morales', correspondiendo a las autoridades del orden penal y administrativo su represión y a las autoridades legislativas su corrección normativa". Otros, dice, consideran, en cambio, que dicho órgano máximo de control externo es clave para la lucha anticorrupción ya que los "actos defraudatorios de los intereses colectivos suponen, en la mayor parte de las ocasiones, un perjuicio a los intereses financieros públicos", lo que le permite "detectar, en primera instancia, las actividades irregulares producidas a través de sus unidades de control en el ejercicio de la función fiscalizadora, a ser objeto, en segunda instancia, de enjuiciamiento contable, cuando se deba resarcir económicamente al erario público". ${ }^{628}$

De los cuestionamientos y controversia anteriores, se le reconocen aciertos al Tribunal de Cuentas en el trámite de los procedimientos jurisdiccionales-contables por medio de salas que examinan "las cuentas que deben rendir quienes recauden, intervengan, administren, custodien, manejen o utilicen bienes, caudales o efectos públicos". ${ }^{629} \mathrm{Y}$ también por su labor fiscalizadora, que no se refiere únicamente a la legalidad sino a la eficacia de la actividad administrativa; al uso de la técnica de la auditoría, pero con debilidades en el establecimiento de indicios de responsabilidad; al cumplimiento de su función de asesoramiento al parlamento y al aporte en la fiscalización forense que contribuye al enjuiciamiento contable y aún judicial, etc.

Martín Queralt y otros sostienen que la función fiscalizadora de los tribunales de Cuentas tienen un contenido "más amplio" que la que se realiza como "control interno", ya que no se restringe al control de legalidad sino también al de oportunidad en la gestión económica-financiera presupuestaria del sector público, para evaluar la "buena gestión", esto es, a la "eficiencia, racionalidad y aprovechamiento máximo de los recursos que el legislativo mismo puso a disposición del Ejecutivo". Igualmente afirman que su cobertura es "ilimitada", porque su control puede extenderse a todas las administraciones públicas y a todos los órganos que dispongan de recursos públicos y resaltan los efectos de la fiscalización del Tribunal que se expresan en la censura conforme o disconforme de las cuentas, en cuyo caso las irregularidades o delitos se someten a la jurisdicción contable o penal, según sea el caso. ${ }^{630}$

\footnotetext{
628 José Antonio Fernández Ajenjo, El control de las administraciones públicas y la lucha contra la corrupción, (Pamplona: Civitas - Thomson Reuters, 2011), 409 y 410.

${ }^{629}$ Miguel Ángel Martínez Lago y otros, Lecciones de Derecho Financiero y Tributario, undécima edición, (Madrid: Iustel, 2015), 227.

${ }^{630}$ Juan Martín Queralt, Carmelo Lozano, José Tejerizo, Gabriel Casado, Curso de Derecho Financiero y Tributario, (Madrid: Tecnos, 2011), 794-795.
} 
Es necesario precisar que la jurisdicción que ejercen los tribunales de Cuentas, no es la ordinaria sino una jurisdicción contable especial destinada a reparar o restituir o indemnizar daños (responsabilidad civil) ocasionados al Estado o a las administraciones públicas, en materia económica y presupuestaria y de gestión, por parte de funcionarios, autoridades y personas que perjudiquen lo recursos y bienes públicos locales, nacionales y regionales, sin que esta atribución sea incompatible con otras que corresponden a la jurisdicción penal, disciplinaria y contencioso administrativa, dependiendo de la naturaleza de las infracciones, delitos y de las responsabilidades que se establezcan sobre ellas.

Al tener calidad jurisdiccional, los tribunales de Cuentas, sus procedimientos y enjuiciamientos en los tradicionales juicios de cuentas, deberán observar las garantías comunes constitucionales de todo proceso judicial, si bien para algunos tratadistas como Pérez Royo, dicha función jurisdiccional contable permanece, en esos términos, más como un "residuo histórico". 631

Según nuestra opinión, la restitución económica por daños y perjuicios o pagos en exceso de los funcionarios o de terceros a las administraciones públicas, bien pueden ser solventados con mayor agilidad con procedimientos administrativos no jurisdiccionales, sin mantener ritualidades tradicionales en asuntos que contablemente se pueden determinar con celeridad, claridad y exactitud.

En el caso ecuatoriano, desde su origen republicano en 1830 hasta 1863, en las sucesivas leyes de Hacienda, se establecieron, siguiendo el modelo colonial, primero una Contaduría General y luego contadurías departamentales para examinar y finiquitar cuentas de funcionarios, cuyas decisiones podían ser apeladas en el Ministerio de Hacienda. Desde 1863, la nueva Ley de Hacienda trasladó las atribuciones de las contadurías al Tribunal de Cuentas, concebido como un órgano jurisdiccional para conocer y resolver sobre las cuentas que obligatoriamente debían presentar funcionarios públicos nacionales y municipales, luego de llevar estrictamente los correspondientes registros contables.

El Tribunal de Cuentas, organizado en dos salas, era designado de manera mixta por el Congreso Nacional y el presidente, de igual manera que la Corte Suprema de Justicia; los expedientes de cuentas concluían en sentencia o "vista" que se debía publicar con la finalidad de que el rindente o su apoderado o los ministros o los "revisores" pudieran solicitar formalmente su revisión a la otra sala que no conoció el asunto para expedir la sentencia de "revista" correspondiente y para que esta, finalmente, se pudiera impugnar ante la Corte Suprema mediante los recursos de queja o de nulidad.

\footnotetext{
${ }^{631}$ Fernando Pérez Royo, Derecho Financiero y Tributario Parte General, Novena edición, (Madrid: Civitas, 1999).
} 
El Tribunal de Cuentas podía establecer, en sus decisiones, responsabilidades pecuniarias a ser cobradas al funcionario involucrado, y legales a quien infringiera las normas, pudiendo ser sancionado con la destitución, suspensión de derechos y aún con prisión para que él o sus sucesores presentaran las cuentas. Si el Tribunal encontraba indicios de la comisión de un delito, cometido por el funcionario, la Sala debía trasladar el expediente al juez competente. ${ }^{632}$

El Tribunal de Cuentas se mantuvo en Ecuador mientras estuvo vigente la Ley de Hacienda de 1863, expedida en el Gobierno de Gabriel García Moreno hasta 1928, por 65 años con ciertas modificaciones en 1912 y 1924. Su conformación constó en las constituciones de 1878, 1883, 1897 y 1906. El control se limitó fundamentalmente a aspectos contables en la ejecución presupuestaria y al manejo de los recursos asignados y desembolsados en Quito, Guayaquil y Cuenca.

\subsubsection{Sistema externo unipersonal de evaluación y auditoría o Contraloría.}

El sistema externo de control unipersonal tiene origen anglo-norteamericano, pues en Gran Bretaña se inició como control parlamentario que, al no poder realizarse a plenitud de manera directa, desde 1832 se delegó a organismos técnicos como el Departament of Exchequer and Audit, dirigido por un Comptroller y Auditor General, que realizaba sus test audit o fiscalizaciones intensivas efectuadas mediante inspecciones sorpresivas que obligaban a las instituciones a mantenerse en orden y en permanente regularidad.

Este sistema de control se adoptó luego en Estados Unidos, en especial en las primeras décadas del siglo XX, como resultado de la crisis económica en la economía y en sus empresas, luego de la Primera Guerra Mundial. En 1921 se estableció la estructura actual de control norteamericano, mediante el Budget and Accountig Act que creó el General Accounting Office y frente al cual se designó a un Comptroller General, nombrado primero por el presidente por quince años y luego por el Congreso (1946), que es responsable directo de sus acciones de control administrativo, contable y de fiscalización, tanto de las dependencias administrativas como de las corporaciones estatales. ${ }^{633}$

Este sistema que tiene como máxima instancia directiva autónoma de control y de auditoría un órgano unipersonal, el Contralor, que se encuentra supeditado inicialmente al Congreso o Asamblea Nacional como auxiliar técnico de control externo a sus labores de control político, si bien su designación depende una vez del Congreso, otra del presidente o de los dos a la vez. Esta modalidad de control se impuso también en varios países latinoamericanos y luego sus técnicas se fueron adaptando paulatinamente a otros países de tradición jurídica continental, modificando las atribuciones de los

\footnotetext{
${ }^{632}$ España, Ley de Hacienda de 21 de octubre de 1863.

${ }^{633}$ Carlos Giuliani Fonrouge, Derecho Financiero, Volumen I, obra actualizada por Susana Navarrine y Rubén Asorey, $7^{\mathrm{a}}$ edición, (Buenos Aires: Depalma, 2001).
} 
tribunales de Cuentas, o creando nuevos órganos de control y auditoría financieroadministrativos externos independientes.

De manera acelerada, en la época actual de globalización, que "ha extrapolado" el modelo administrativo, regulador y de control estadounidense, se ha ido generalizando en todo el mundo para desarrollar e incluir en la Administración pública, los sistemas de eficiencia y eficacia de las empresas privadas y para ejercer "nuevos de derechos sociales, ambientales, de minorías, de riesgos laborales, derechos civiles y de discriminación positiva, etc". ${ }^{634}$

En la estructuración de este sistema de control, que se introdujo tempranamente en Ecuador y otros países de la región, tuvo una presencia activa una comisión asesora de expertos académicos financieros norteamericanos presidida por Edwin Walter Kemmerer, entre 1923 y 1931, que además de consolidar un nuevo sistema monetario, bancario y financiero, asesoraron y supervisaron la estructuración de órganos de control, Contraloría, superintendencias y direcciones generales, mediante la designación de funcionarios extranjeros para el control de los bancos, las aduanas y la contabilidad nacional. En ese contexto, se creó en Ecuador en 1928, mediante una nueva la Ley de Hacienda, la Contraloría General de la Nación para la vigilancia del comportamiento fiscal y la contabilidad del gobierno, en sustitución de los tribunales de Cuentas que funcionaban en Quito y Guayaquil y se designó como primer contralor general al norteamericano James H. Edwards, quien fue sustituido en 1929 por un Contralor de nacionalidad ecuatoriana. ${ }^{635}$

Los sistemas de contabilidad y control externo en EE.UU se desarrollaron también, como una respuesta estatal a los efectos desastrosos de la crisis del capitalismo moderno y del crac de la bolsa Nueva York en 1929 y como resultado de la irracionalidad del mercado y la falta de transparencia en las empresas. En1933, mediante Ley, se estableció en Estados Unidos un nuevo modelo regulador de las empresas y de transparencia en sus cuentas, mediante la intervención de técnicos auditores.

Este sistema de control, con técnicas originadas en el ámbito privado y gerencial, se impuso de manera inicial en Estados Unidos por parte de la administración de Woodrow Wilson para el control de las empresas, luego de la Primera Guerra Mundial y antes de la crisis capitalista de 1930. Durante los gobiernos de Franklin Delano Roosevelt se insistió en un eficiente control de las empresas y del sistema financiero para superar el descalabro económico generalizado y, mediante reformas administrativas y mecanismos de información y transparencia, las nuevas técnicas de garantía de calidad se trasladaron a la Administración pública: incluían auditoría, evaluación, acreditación y certificación, en el ámbito de las instituciones estatales.

\footnotetext{
${ }^{634}$ Pilar Jiménez Tello, Regulación a través de la evaluación: auditoría y calidad en las Administraciones Públicas, Cursos de Especialización en Derecho, Universidad de Salamanca, 2015, 3.

${ }^{635}$ Paul W. Drake, Kemmerer en los Andes, (Quito: Banco Central del Ecuador, 1995).
} 
Más tarde, en 1960, en Estados Unidos se conformó la Corporate Social Responsability, que incluía el control de la seguridad social y laboral, los derechos ambientales y los asuntos de raza y género, que luego fueron afinados con las reformas administrativas del Presidente John F. Kennedy en 1970. El sistema de control se perfeccionó, en los años siguientes con las modificaciones implementadas por las administraciones de Johnson, Nixon y, recientemente, con las políticas del presidente Barak Obama, siguiendo los sugestivos planteamientos de los administrativistas norteamericanos Cass Sunstein y Richard Thaler. ${ }^{636}$

Los sistemas de auditoría y evaluación, tanto en el sector privado como en el público, dan como resultados positivos para el mercado, la sociedad y el Estado, transparencia y seguridad. Si no funcionan, resulta evidente que crece la corrupción, la desconfianza y estallan escándalos, como ocurre en la actualidad con los capitales de dudosa procedencia que se encuentran en paraísos fiscales y catástrofes económicas y sociales como la crisis internacional de 2008 provocada por la falta de control del mercado hipotecario, de futuros y derivados.

En el sistema de control en Ecuador que ejerce la Contraloría General de la Nación primero y luego del Estado, desde 1928 hasta la actualidad, se pueden identificar tres momentos importantes: el inicial, entre 1928 y 1974, en el que el control combina primero procedimientos internos y externos, centrando su vigilancia en los aspectos contables del ejercicio de las actividades de los funcionarios públicos sobre las que se establecen responsabilidades administrativas principalmente, a las que se agregan las reformas administrativas y de fiscalización adoptadas por el Gobierno de Galo Plaza, con asesoría del Punto IV Norteamericano sobre el buen uso de los recursos públicos, involucrando no solo a funcionarios sino también a las instituciones estatales.

Un segundo momento que va desde 1974 hasta 1998-2002 en el que se expide una ley moderna en materia de control y administración financiera, la LOAFYC, ${ }^{637}$ que contiene las normas que rigen la actividad financiera gubernamental (contabilidad, tesorería, presupuesto, etc.) a cargo del Ministerio de Finanzas y las que corresponden a la Contraloría General del Estado para regular los sistemas de control interno y externo y de gestión mediante auditorías; el establecimiento de responsabilidades y los recursos administrativos y contenciosos que los ciudadanos pueden interponer frente a sus decisiones. Estas innovaciones no se recogieron a plenitud en la Constitución de 1979, como sí lo hace la Constitución de 1998, que es el antecedente para la expedición de la vigente Ley Orgánica de la Contraloría General del Estado (LOCGE) en junio de 2002.

Un tercer momento se inicia con la expedición de la ley vigente desde 2002 y se consolida con el contenido de la Constitución de 2008 que amplía las funciones, atribuciones y autonomía de la Contraloría, cuyo titular es designado para cinco años,

\footnotetext{
${ }^{636}$ Pilar Jiménez Tello, Regulación a través de la evaluación: auditoría y calidad en las Administraciones Públicas, Cursos de Especialización en Derecho, Universidad de Salamanca, 2015.

${ }^{637}$ Ecuador, Ley Orgánica de Administración Financiera y Control, Registro Oficial 337, 16-mayo-77.
} 
mediante un concurso promovido por una comisión especial de selección, sin una aparente intervención directa del Ejecutivo o de la función legislativa. La ampliación de funciones y atribuciones incluye un concepto integral de control, el análisis de la gestión y la eficacia y eficiencia en el uso de los recursos públicos y se ve complementada con un mayor desarrollo del control interno en las instituciones administrativas, mediante el uso creciente de la tecnología y del control por procesos y resultados.

Sin embargo, este proceso progresista se ve interrumpido por las reformas constitucionales aprobadas mediante enmiendas en diciembre de 2015, y que se podría calificar como el inicio de un nuevo momento de incertidumbre y de solapado retroceso de la función de control, pues se elimina del ámbito de la Contraloría el análisis del cumplimiento de objetivos institucionales y se pretende reducir su actividad a un simple control económico a posteriori en el uso de los recursos públicos, manteniendo la posibilidad de que se puedan establecer sobre los funcionarios, responsabilidades administrativas y civiles y trasladar los indicios de responsabilidad penal a la Fiscalía para el correspondiente enjuiciamiento penal, todo ello en relación con el manejo de recursos más no por la gestión, como originalmente lo disponía la Constitución.

En el primer momento, cuando se sustituye el sistema de control jurisdiccional pluripersonal del Tribunal de Cuentas por el sistema unipersonal en 1928, la Contraloría no actúa exclusivamente en el ámbito administrativo externo bajo un régimen de auditorías ni tampoco sus decisiones quedan sometidas al control contenciosoadministrativo o jurisdiccional. En este período la Contraloría ejerció atribuciones de control de los recursos presupuestarios y otras de lo que actualmente se encontraría en el ámbito del control interno, pues emitía pronunciamientos previos o concurrentes para la derogación de recursos públicos y manejo de bienes; certificaciones de disponibilidades de fondos, transferencia de partidas, etc.

En cuanto al control externo propiamente dicho, referente a los exámenes de cuentas, la Contraloría mantenía para sus decisiones el tradicional carácter de jurisdicción contable que caracterizaron al Tribunal de Cuentas, para tener una mayor vigilancia sobre los funcionarios y el uso de los recursos públicos sin tomar en cuenta el desempeño institucional y de sus actividades administrativas. Su atribución se limitaba pues al examen contable y a finiquitos de la información financiera y de la ejecución del presupuesto que obligatoriamente los funcionarios debían hacerle conocer, para que se declare si el uso de los recursos fue el correcto. En cuanto a responsabilidades, la ley autorizaba al contralor a trasladar a los jueces competentes los asuntos de carácter penal, además de destituir a funcionarios de sus cargos e imponer multas o anotarlas cuando eran impuestas por otras autoridades administrativas.

En la Constitución de 1946 consta (Art. 149) que el contralor general, designado por el Congreso, desempeñaba función jurisdiccional cuando se conocían y sentenciaban cuentas que manejaban los funcionarios públicos. Esta norma distorsionaba totalmente 
el carácter administrativo de este tipo control y el ámbito propio de la jurisdicción contenciosa administrativa, que se encontraba en formación en Ecuador desde las constituciones de 1906, 1929 y 1945.

En 1951 se actualiza la legislación presupuestaria ${ }^{638}$ y en 1958 y 1961 se dictan normas para regular de mejor manera los asuntos contables, administrativos y financieros públicos, con asesoría del Punto IV de EEUU y la consultora Affaires Institute. En 1963 la Junta Militar, con fuerte influencia norteamericana y frente al impacto de la Revolución cubana en América Latina, planteó su proyecto regional de Alianza para el Progreso que incluía la ejecución de tres reformas radicales: administrativa, tributaria y agraria. En la modificación administrativa se plantearon nuevos sistemas y estructuras administrativas para el sector público, como la Secretaría Técnica de la Administración y más tarde otras dependencias que tenían la finalidad de reformar la estructura y los procedimientos administrativos, para ejecutar las reformas económico-sociales propuestas y "mantener una evaluación permanente del grado de eficiencia con que se prestan los servicios públicos". 639

En la ley que creó el Tribunal Fiscal (1959) y luego el Código Fiscal (1963) se le otorgaban competencia al primero para conocer recursos y emitir sentencias sobre resoluciones de la Contraloría General, relativas a responsabilidad económica en las instituciones públicas. ${ }^{640}$ En la Constitución de 1967 se modificó el nombre de Contraloría General de la Nación por Contraloría General del Estado y cuando se dictó la Ley de la Jurisdicción Contencioso Administrativa (1968) y, en especial, con la expedición del Decreto 1077 en 1973, quedó claro que correspondía al Tribunal Contencioso Administrativo conocer y resolver las resoluciones de la Contraloría. ${ }^{641}$ Pero es en 1975, con la expedición del Decreto 611 y del Código Tributario (1975) que se completó el tránsito definitivo de la etapa jurisdiccional a la etapa propiamente administrativa del control externo ejercido por la Contraloría. ${ }^{642}$

El segundo momento en la evolución de la Contraloría y su legislación se inicial durante la dictadura militar del general Guillermo Rodríguez Lara en la que, siguiendo las innovaciones administrativas y de control provenientes en especial de EE.UU, se dictaron varios decretos para organizar adecuadamente el control y la administración financiera de las instituciones públicas en Ecuador. La Contraloría propuso en 1974 la expedición del Decreto 1065-A, para implantar en el país un "control gubernamental moderno" mediante el cual se establecieron dos sistemas: el control interno y la

\footnotetext{
${ }^{638}$ Ecuador, Ley Orgánica de Presupuesto, Decreto de Emergencia № 538, Registro Oficial 769, 21 marzo-1951.

${ }^{639}$ Ecuador, Presidencia de la República, Decreto-Ley 240, Registro Oficial 33, 20-agosto-1963, quinto considerando.

${ }^{640}$ Ecuador, Ley 10, Registro Oficial 847, 19-junio1959; Ecuador, Código Fiscal de 1963, Registro Oficial 490, 25-junio-1963.

${ }^{641}$ Ecuador, Ley 035-CL, Registro Oficial, Número 338, 18-marzo-1968; Decreto 1077, Registro Oficial 392, 17-Septiembre-1973.

${ }^{642}$ Ecuador Presidencia de la República, Decreto 611, Registro Oficial 857, 31-julio-1975.
} 
auditoría externa, los cuales reformaron radicalmente la Ley de Hacienda de 1960. De acuerdo con este Decreto, a la Contraloría le correspondió "poner en funcionamiento en el sector público, un sistema integrado de administración financiera y control, capaz de servir al desarrollo del país y al empleo de los recursos humanos, materiales y financieros, de manera eficiente, efectiva y económica, evaluando periódicamente y velando en forma permanente por la correcta aplicación del mismo". ${ }^{643}$

Todos los cambios, antes indicados y otros, resultado de la necesidad de agilizar la prestación de servicios públicos y el desarrollo socio económico del país, constan en la nueva Ley Orgánica de Administración Financiera y Control de $1976^{644}$ que establece un sistema integrado de presupuesto, de determinación y recaudación de recursos, de tesorería, contabilidad y control.

Las reformas y la nueva ley no solo autorizaron legalmente al contralor, desde 1974 y 1976, a establecer un sistema más ágil, que permitiera a las instituciones un control contable interno más eficaz de los recursos públicos, sino que a la naturaleza tradicional del control le agregaron la innovación de ejercer un control integral para asociar los asuntos financieros con los operacionales y de resultados en la gestión de la entidades públicas, además de la potestad de control en la determinación de ingresos y en el control interno y en el ejercicio de sus potestades normativa, asesora y correctiva.

Se trata de un sistema de control distinto al instaurado en el país en 1928 con la asesoría de Kemmerer, pues ahora el sistema tiene por objeto "las operaciones administrativas y financieras de la institución y no solo las "cuentas" y, a la vez, "el sujeto del control es la entidad y, por consiguiente, sus gestores empezando por los máximos ejecutivos, lo que contrasta con el sistema anterior, en el que el sujeto de control era únicamente el rindente", ${ }^{645}$ sobre el cual se partía de una cierta presunción de que había cometido alguna “incorrección”.

Por ello, vale enfatizar que el nuevo sistema de control establecido se fundamenta en "la presunción de corrección" y en las "auditorías" y "exámenes especiales" financieros, operacional o de cualquier índole, que tienen la finalidad de promover reformas en la gestión administrativa de cada entidad u organismo, con "recomendaciones" que se convierten luego en obligaciones para ser cumplidas por los gestores de las entidad pública, independientemente de trasladar los indicios de responsabilidad penal a la Fiscalía y a los jueces competentes y de establecer las responsabilidades que se hayan fijado contra ellos o sus antecesores, en el ámbito administrativo y civil. Las auditorías

\footnotetext{
${ }^{643}$ Ecuador, Presidencia de la República, Decreto Nro. 1065-A, Registro Oficial, Número 668, 28octubre-1974.

${ }^{644}$ Ecuador, Ley Orgánica de Administración Financiera y Control, LOAFYC, Registro Oficial 337, 16mayo-77.

645 Estudio introductorio a la Ley Orgánica de Administración Financiera y Control, SILEC, http://portal.uasb.edu.ec:2165/WebTools/eSilecro/DocumentVisualizer/DocumentVisualizer.aspx?id=HIS TORICLEY_ORGANICA_DE_ADMINISTRACION_FINANCIERA_Y_CONTROL_1977\&query=LO AFYC\#I_DXDataRow1
} 
se efectúan aplicando las normas "generalmente aceptadas", provenientes de conferencias de contabilidad y en general por los contadores públicos a nivel internacional.

El sistema de control financiero y control previsto en la LOAFYC se mantuvo en Ecuador hasta 2002 a cargo del Ministerio de Finanzas y de la Contraloría, que debían actuar coordinadamente pues en varios casos se requerían informes previos e iniciativas conjuntas.

Finalmente, el tercer momento en la historia de la legislación de la Contraloría comienza en 2002 cuando se expide la Ley Orgánica de la Contraloría General del Estado, ${ }^{646}$ dejando la administración financiera y presupuestaria y los otros asuntos de su organización y control financiero interno en manos del Ejecutivo y del Ministerio de Finanzas, que en la actualidad están regulados por el Código de Planificación y Finanzas expedido en $2010^{647}$ y los asuntos de control externo en el ámbito de la Contraloría a la que, con las enmiendas constitucionales de diciembre de 2015, se pretende despojar del control operacional o de gestión, sobre lo que nos referiremos más extensamente más adelante.

La nueva Ley Orgánica de la Contraloría General del Estado de 2002, como exclusivamente lo disponía la Constitución de 1998 y de 2008 hasta las enmiendas de fines del 2015, asignan a la Contraloría competencia administrativa del control externo total o gubernamental, en sus diferentes dimensiones, contable, financiera, económica, administrativa, de operación, de gestión, ambiental, etc., sobre todas las entidades del sector público y de otros sectores que perciben fondos públicos, facultándole a la vez a ejercer potestades normativas, de asesoría en el ejercicio de sus funciones y a establecer las presunciones de responsabilidad administrativa y civil, que están sometidas al control jurisdiccional contencioso administrativo en la función judicial, y los indicios de responsabilidad penal para que sean trasladados a la Fiscalía General y se dé inició a las acciones penales correspondientes.

Desde 2015, al eliminar competencia de la Contraloría, el control de gestión y la posibilidad de que como resultado de ella se establecieran responsabilidades, se inicia una situación de incertidumbre legislativa, ya que se encuentra impugnada la constitucionalidad de las enmiendas y la potestad de que el órgano de control realice auditorías de gestión que aún constan en la ley pero que al contradecir la Constitución quedan de hecho insubsistentes.

\subsection{El control popular o ciudadano}

\footnotetext{
${ }^{646}$ Ecuador, Ley Orgánica de la Contraloría General del Estado. Ley № 2002-73, Registro Oficial 595, 12-junio-2002.

${ }^{647}$ Ecuador, Código Orgánico de Planificación y Finanzas, Registro Oficial 306, 3-octubre-2010.
} 
El derecho de participación tiene su origen en los inicios de la democracia moderna, ya que es un sistema que permite participar a los ciudadanos en su Gobierno por medio de mandatarios o representantes. Fundamentalmente, la democracia se convirtió en delegativa o representativa, a tal nivel que los mandatarios, luego de la elecciones, no se encontraban obligados a rendir cuentas a sus electores ni a asumir responsabilidades por sus acciones u omisiones, si bien teóricamente estaban sometidos al control político de la función legislativa.

La participación ciudadana en el control de la Administración pública, de manera individual o colectiva, se fundamenta, además, en el artículo 21.1 de la Declaración Universal de Derechos Humanos de las Naciones Unidas, aprobada el 10 de diciembre de 1948, que dice: "Toda persona tiene derecho a participar en el Gobierno de su país, directamente o por medio de representantes libremente escogidos" que luego fue incluido, de una u otra manera, en todas las constituciones del mundo. ${ }^{648}$

En la última década del siglo XX y con el desarrollo del concepto de democracia participativa, fundamentada en la transparencia y acceso a la información y en la noción del derecho a un "buen gobierno", se ha relievado el papel que puede desempeñar, con reconocimiento expreso en la esfera constitucional, la sociedad civil, entendida como el conjunto de relaciones culturales, ideológicas, religiosas, etc., que involucra a todos ciudadanos que, solos, en grupo o de manera colectiva organizada, se sienten impulsados para actuar, defender y hacer respetar sus derechos frente a cualquier estructura de poder, más allá del reconocimiento formal de su capacidad de intervención en las elecciones. Entre esos derechos se encuentran también los de participación y de control, sobre las estructuras, funcionarios o personajes estatales, políticos, sociales o de cualquier tipo, que se ejercen directamente o por medio de la organización social o no gubernamental, o mediante la actuación de los medios de comunicación o formando parte, como representantes ciudadanos, en órganos de las instituciones públicas o como consultores de ellos.

En el caso de Ecuador, desde la Constitución liberal de 1906 se reconoció como derecho expreso de los ciudadanos "acusar o denunciar las infracciones de la Constitución, sea ante el congreso, el Ejecutivo o cualquier autoridad competente, según los casos". ${ }^{649}$ Las constituciones siguientes ampliaron el derecho de control autónomo de los ciudadanos sobre los órganos de poder y los funcionarios públicos y por último se incluyó como una de las actividades en el ejercicio del derecho de participación.

A nivel internacional, en cada uno de los países están creciendo las exigencias ciudadanas de una evaluación y calificación de la calidad, tanto de los productos que se ofrecen y circulan en el mercado, como de los servicios públicos propios que prestan las

\footnotetext{
${ }^{648}$ Pablo Gallego Rodríguez, "Organismos de control y participación en la gestión. La participación ciudadana y representativa", en La Gestión de los Fondos Públicos: Control y Responsabilidades, Alberto Palomar, Mario Garcés (Directores) y otros, (Pamplona: Thomson Reuters Aranzadi, 2013).

${ }^{649}$ Ecuador, Constitución Liberal de 1906, Ecuador, art. 21.
} 
administraciones públicas y aún de los impropios que ofrecen entes mixtos o privados, todos los cuales están sometidos a órganos de control público o social, creados por los estados, los organismos internacionales y de integración, por organizaciones no gubernamentales y por los propios ciudadanos.

La discusión jurídica y política se ha centrado en si esas estructuras de control o acción popular o ciudadana deben formar parte del Estado o si deben mantenerse por fuera de él para cumplir a cabalidad con su misión. Los convenios internacionales de lucha contra la corrupción (para erradicarla o controlarla) reconocen e impulsan las dos posibilidades y en sus normas plantean el respeto, apoyo y auspicio de los estados y de la comunidad internacional, a la labor que pueden cumplir, independientemente del poder público, la sociedad civil y sus instituciones.

En varios países latinoamericanos, en las constituciones de Venezuela (2000), Ecuador (2008) y Bolivia (2009), se dispuso conformar como función del Estado de control y participación social, la unión de varios órganos existentes, como la Contraloría, las superintendencias y la Defensoría del Pueblo, creando uno nuevo: el denominado Consejo de Participación Ciudadana y Control Social. En otros países y en el mismo Ecuador en 1997 y en la Constitución de 1998, se autorizó la conformación de una Comisión de Control Cívico de la Corrupción, integrada por representantes de organizaciones representativas de la sociedad, no dependientes de las funciones del Estado, que contando con recursos públicos, desarrollaban actividades de investigación de denuncias de corrupción y de emisión de informes inculpatorios, que sirvieran de antecedente para la actuación e intervención de los órganos de control y de la función judicial.

La estatización de la función de transparencia y control ha producido una subordinación total a los intereses políticos dominantes, no solo de la institucionalidad de control que tradicionalmente estaba estructurada como "órganos extrapoderes", sino también del nuevo Consejo de Participación Ciudadana y Control Social. La manipulación de la organización y representación social, empeñada en el control y la participación, se expresa en un control vertical del Ejecutivo a sus estructuras, que necesitan de autonomía e independencia total del poder político gobernante para cumplir con eficiencia y eficacia su labor.

En los últimos años han surgido varias iniciativas ciudadanas y de organizaciones sociales para organizar "veedurías ciudadanas", observatorios y conformar comisiones de control de la corrupción, con la finalidad de que estos organismos ciudadanos reciban e investiguen denuncias; emitan pronunciamientos y presenten acciones legales en contra de funcionarios involucrados en contrataciones irregulares de importantes obras públicas nacionales o locales. ${ }^{650}$ Los ciudadanos, ejerciendo un derecho constitucional,

\footnotetext{
${ }^{650}$ En Ecuador, las organizaciones sociales del país decidieron conformar el 30 de mayo de 2015 una Comisión Nacional Anticorrupción.
} 
están facultados para presentar denuncias o hacer uso de lo que se denomina "acción popular" contra la corrupción.

En algunos países, la presentación de denuncias fundamentadas que luego son comprobadas y permiten recuperar bienes o recursos públicos, reciben reconocimientos y premios por parte del Estado. En Ecuador, sin embargo, los más altos funcionarios del Estado denigran las denuncias ciudadanas y plantean el enjuiciamiento penal de los denunciantes, contando con el apoyo político e institucional de la Fiscalía General, de la Contraloría y de jueces, que sirven a los intereses del régimen, con lo cual se atemoriza a los posibles denunciantes, se impide la fiscalización de origen social y se mantienen en la impunidad hechos dolosos que ocasionan enormes perjuicios a los recursos y economía del país.

También es importante la actitud de los organismos públicos de control y de investigación y en general de los burócratas sobre las denuncias que formulan los ciudadanos y las organizaciones sociales sobre corrupción. En España, por ejemplo, según indica Fernández Ajenjo, la Intervención General de Administración del Estado, órgano interno de investigación y de prevención de manejos irregulares administrativos y financieros, es reacia a atender demandas ciudadanas al respecto y prefiere realizar sus averiguaciones mediante sus atribuciones y con sus propios medios. No así el Tribunal de Cuentas, que se considera un organismo más abierto a las denuncias, ya que se reconoce la acción popular para poner en su conocimiento manejos irregulares de fondos, aunque el denunciante puede también ser condenado en costas. En Ecuador, las normas reglamentarias de los órganos anticorrupción dependientes de la función ejecutiva y del Consejo de Participación Ciudadana y Control Social exigen que las denuncias sean reconocidas formalmente y ha ocurrido, en varias ocasiones, que los denunciantes terminan siendo procesados y sancionados. La Contraloría General del Estado ha establecido, según señala su último informe, un sistema abierto de denuncias al que frecuentemente recurren los ciudadanos. ${ }^{651}$

El autor español en referencia recuerda también en su texto, que en 1996, el informe NOLAN evidenció que en ciertas ocasiones tiene gran trascendencia la denuncia anónima, originada en los propios órganos públicos en los que se produjo el acto fraudulento, por lo que sugería el uso de un sistema de denuncias confidencial y hotline; que sean personas ajenas a la estructura jerárquica las que las conozcan; además de la responsabilidad de los ministros para que las denuncias de prácticas irregulares se puedan investigar de forma rápida y eficaz. Al mismo tiempo manifiesta que en la actualidad es una recomendación habitual de los organismos internacionales incentivar la participación ciudadana en la lucha contra conductas ilícitas y se refiere a las recomendaciones del Libro Blanco sobre Gobernanza Europea de 2011, del XVI Congreso de la INTOSAI de 1998, de los firmantes de la Convención de la Naciones Unidas contra la Corrupción de 2003, de la OLAF (Oficina Europea de Lucha contra el

${ }^{651}$ Ecuador, Contraloría General del Estado, Rendición de Cuentas, marzo de 2016. 
Fraude) que otorgan facilidades, mediante sistemas especiales, para procesar las denuncias ciudadanas. Menciona también las iniciativas del Banco Mundial con programas como el de Revelación voluntaria de información, Línea directa de denuncias internacional o el envío de denuncias e informes por correo electrónico (investigations_hotline@worldbank.org) e internet al departamento correspondiente (www.worldbank.org/integrity), que incluyen el trámite de denuncias anónimas sobre delitos de corrupción, en los que se otorgan, a quienes las formulan, garantías de atención inmediata, confidencialidad y ausencia de sanciones. De igual manera la GAO (Government Accountability Office) en Norteamérica se ha sumado a la iniciativa de líneas directas y ha establecido el proyecto Fraudnet para tramitar denuncias públicas, anónimas o reservadas sobre fraudes, derroches, abusos o mala gestión de fondos federales. $^{652}$

El ejercicio ciudadano y social de denunciar y combatir la corrupción se encuentra asociado a la exigencia de acceso libre y sin cortapisas a la información, a la transparencia en las decisiones y en la gestión y uso de los recursos públicos. La falta de información ocasiona dolorosas crisis económicas y otros impactos sociales en las que sus principales perjudicados son los ciudadanos que confían en las instituciones públicas y privadas. Por ello en EEUU se dictó primero Freedom of Information Acty y luego la Sunshine Acty. Posteriormente, en los diferentes países se han promovido, especialmente en las dos últimas décadas, la discusión y aprobación de leyes de transparencia y acceso a la información pública en las que se reconoce como derecho ciudadano acceder a los detalles en la asignación y utilización de los recursos públicos y a las rendiciones de cuentas por parte de los funcionarios de todas las instituciones y entidades que manejen recursos públicos. En la Comunidad Europea se aprobó una norma sobre Transparencia, Acceso a la Información Pública y Buen Gobierno el 18 de julio de 2006. Más tarde se promovió en el Consejo de Europa un Convenio sobre Acceso a los Documentos Oficiales el 18 de junio de 2009 y en España se expidió la Ley de Transparencia, Acceso a la Información Pública y Buen Gobierno el 9 de diciembre de 2013 (Ley 19/2013).

En Ecuador se aprobó primero la Ley Orgánica de Responsabilidad, Estabilización y Transparencia Fiscal el 4 de junio de 2002, en la que se estableció inicialmente el "control ciudadano de la gestión pública" por medio del libre acceso a los documentos e información presupuestaria y contable y de las operaciones y contratos de crédito de todas las entidades del sector público y más tarde, en mayo de 2014, la Ley de Transparencia y Acceso a la Información Pública, por la que el ciudadano puede recurrir a la justicia para acceder, dentro de un plazo razonable, a la información que requiera para ejercer sus derechos y fiscalizar la actividad pública.

\footnotetext{
652 José Antonio Fernández Ajenjo, El control de las administraciones públicas y la lucha contra la corrupción, (Pamplona: Civitas - Thomson Reuters, 2011).
} 
Se debe enfatizar también el gran impacto que en la actualidad tiene en todos los países del mundo el papel revolucionario de las nuevas tecnologías para facilitar y promover la comunicación y la movilización social. ${ }^{653}$ Individualmente o como organización social se puede acceder a datos, realizar investigaciones, formular denuncias y realizar campañas frente a abusos de poder, mala calidad de obras y servicios públicos y actos de corrupción. El control ciudadano y social de la Administración y en general de los servicios y bienes que afectan a la población, son cada vez más accesibles y se requiere una normativa que no vulnere los derechos de participación y control sino que garantice su ejercicio.

Deben rescatarse finalmente las dos iniciativas ciudadanas de conformar órganos de control de la corrupción: la de 1997 cuando se constituye la Comisión de Control Cívico de la Corrupción (CCCC) y la constitución de la Comisión Anticorrupción en 2015, la primera impulsada por varias organizaciones de la sociedad civil y la segunda por iniciativa de las organizaciones sociales para denunciar y combatir la corrupción.

\section{EL CONTROL EN LAS CONSTITUCIONES Y EN LA LEGISLACIÓN DE ECUADOR EN LOS MODELOS ECONÓMICOS (1990-2017).}

En las diferentes etapas económicas, políticas y jurídicas del país, a partir de la fundación de la República en 1830 hasta la actualidad, se puede advertir una evolución y organización de las instancias y tipos de control adoptados a la realidad económica y política del país y conforme a las sucesivas cartas políticas que han regido al Estado.

Haciendo un intento inicial de clasificación tenemos primero las normas de control que corresponden a la economía y al Estado liberal que se fueron forjando durante todo el siglo XIX, desde la expedición de la primera Constitución en 1830, si bien en las tres primeras décadas de la República se mantuvo sin mayores modificaciones el ordenamiento jurídico colonial, hasta la de 1929; luego, las que se expidieron desde la Constitución de 1929 hasta las reformas constitucionales de 1992 mientras estuvo vigente un modelo económico, político y jurídico de intervencionismo estatal o de Estado social; posteriormente las adoptadas por el neoliberalismo, que culminaron con la expedición de la Constitución de 1998 y extendieron su influencia hasta el 2005-2006 y finalmente las de la actual etapa o el actual modelo neointervencionista o neoestatista que tiene su mejor expresión en la Constitución de 2008, si bien las políticas de los dos últimos modelos económicos y políticos se encuentran combinados, respondiendo a factores externos de la globalización y de los problemas internos del desarrollo del capitalismo en Ecuador.

\footnotetext{
${ }^{653}$ Pablo Gallego Rodríguez, Organismos de control y participación en la gestión. La participación ciudadana y representativa", en La Gestión de los Fondos Públicos: Control y Responsabilidades, Alberto Palomar, Mario Garcés (Directores) y otros, (Pamplona: Thomson Reuters Aranzadi, 2013).
} 
En el surgimiento y consolidación del Estado liberal, el control hasta 1927 se mantuvo en la esfera del control político por parte del Congreso o Asamblea Nacional y, siguiendo la herencia colonial, se restringió al registro y rendición de cuentas de los funcionarios públicos por medio de contadurías, conforme consta en el Art 55 de la Constitución de 1830 y luego, desde 1863, en la Ley de Hacienda y de la Constitución desde 1868, por los tribunales de cuentas y tribunales de rentas (Constitución de 1906), cuyas resoluciones tenían carácter administrativo y jurisdiccional. Las cuentas debían declararse fenecidas al año siguiente de su ejecución, establecerse responsabilidades (penal, pecuniaria y legal) de los funcionarios y tramitar los recursos que entonces se podían plantear.

Durante ese lapso, el Congreso o Asamblea Nacional (1830 - 1929) estaba facultado para ejercer el control político y deponer o destituir al presidente y vicepresidente de la República, ministros, legisladores, miembros del Consejo de Estado o de Gobierno y jueces de la Corte Suprema. En algunas constituciones se le confería, de manera general, la atribución de examinar directamente cuentas, rentas, recursos, producto de bienes y gastos del país por parte del presidente o de sus ministros. En todas ellas, sin embargo, se otorgaba al presidente de la República la atribución de cuidar la recaudación, administración e inversión de los fondos y rentas públicos y de nombrar, remover o suspender a empleados públicos.

Durante la transformación del Estado liberal al Estado social (1929 a 1992) las constituciones mantuvieron el control político a las otras funciones del Estado, como una de las atribuciones del Congreso Nacional. En cuanto al control financiero, se pueden distinguir dos subperíodos: el inicial que comienza en 1927 y 1928, cuando, con la asesoría de la misión norteamericana Kemmerer, se expidió una nueva ley de Hacienda en la que se creó en lugar de los tribunales de cuentas, la Contraloría General de la Nación, como órgano descentralizado de control externo, de carácter eminentemente contable (ingresos - gastos) de la ejecución presupuestaria, de control de legalidad y formalidad (fiscalización) de los recursos públicos y de establecimiento de responsabilidades personales en el manejo de estos, en un momento en el que se inició la ampliación de las actividades y servicios del Estado. La Contraloría General de la Nación consta como órgano autónomo del Estado desde la Constitución de 1944 (Art. 137). El segundo subperíodo se inicia en 1975 - 1976, cuando se expidió la Ley Orgánica de Administración Financiera y Control. La Constitución de 1967 modifica el nombre de Contraloría General de la Nación por Contraloría General del Estado, e introduce conceptos modernos de control gubernamental, análisis, gerencia y auditoría financiera empresarial, para perfeccionar el control público de un Estado en expansión.

En ese contexto histórico y con la adopción de los modelos económicos neoliberal, neointervencionista y mixto y de los correspondientes sistemas de control y de responsabilidades de los recursos públicos y su incidencia en la gestión administrativa en Ecuador, analizaremos, en los últimos treinta años, las reformas expedidas antes y después de las constituciones de 1998 y 2008 y realizaremos, a la vez, una revisión 
analítica y comparativa de las diferentes normas y políticas de control interno y externo, en los ámbitos político, técnico financiero, social y ciudadano.

\subsection{El control en la transición al modelo neoliberal 1990-1998.}

Desde inicios de la década del noventa hasta la expedición de la Constitución de 1998, se adoptaron algunos ajustes al modelo de control del Estado tanto en lo político como en lo económico financiero.

\section{Control político}

En cuanto al control político, hasta 1995 se mantuvo lo dispuesto en la Constitución de 1978: el Congreso Nacional tenía formalmente la atribución de fiscalizar a los órganos de poder del Estado mediante el conocimiento de los informes que le presentaran los altos funcionarios del Estado, y de tramitar el enjuiciamiento político, hasta un año después, a los más altos dignatarios del Estado, incluyendo presidente y vicepresidente de la República, sus ministros y los ministros de la Corte Suprema de Justicia, por infracciones cometidas en el ejercicio de sus funciones y de encontrarlos culpables, censurarlos y destituirlos. Ya en 1984 se agregó, en el caso del presidente y vicepresidente, que solo podrían ser enjuiciados "por traición a la patria, cohecho o cualquier otra infracción que afectare gravemente el honor nacional” y que además de la destitución se los debía inhabilitar para ejercer cargos públicos durante el mismo período. En las reformas constitucionales de 1995 a 1996 se incluyó en la Constitución que si la acusación política implicaba responsabilidad penal, y se hallare fundamento para ello, se podría ordenar que el asunto pase a conocimiento del juez o tribunal competente.

Hasta 1992, mientras estuvo vigente el modelo económico desarrollista, el control político que podía ejercer el Congreso Nacional no tenía una regulación legal u obstáculo especial y se sometía a un reglamento interno, que no imponía al legislador fiscalizador ninguna exigencia previa para el trámite de una interpelación a un ministro o dignatario de los órganos de control del Estado. Se expidió, en la parte final del Gobierno de Rodrigo Borja, en enero de 1992, iniciada la implementación del modelo neoliberal, una Ley Orgánica de la Función Legislativa que regulaba la actividad del Congreso y en especial el control político, pero se autorizaba la petición de información por parte de los diputados y se obligaba a los funcionarios a entregarla, en un término de 15 días, abriéndose la posibilidad de realizar, cuando fuere del caso, enjuiciamientos políticos.

Los juicios políticos de entonces diferenciaban requisitos cuando se trataba de ministros y otros altos funcionarios del Estado o del presidente o vicepresidente de la República. En el caso de ministros y altos funcionarios del Estado se estableció un trámite previo en la Comisión de Fiscalización y Control Político para desarrollar la acusación, con 
posibilidad de entregar y pedir pruebas por parte de los legisladores acusadores y de ejercer la defensa oral o escrita por parte del inculpado. Vencidos los plazos, la Comisión dentro de cinco días debía remitir todo lo actuado al presidente del Congreso y en cinco días adicionales, debían presentar los acusadores la moción de censura que si no era formulada oportunamente se declaraba concluido el enjuiciamiento. El presidente del Congreso debía convocar, dentro de un plazo que podía dilatarse en sesenta días a petición de 10 legisladores, a la sesión del pleno para escuchar la defensa del inculpado hasta por ocho horas, a los acusadores por dos horas cada uno y una réplica del acusado hasta por cuatro horas. Finalmente se abría el debate a todos los legisladores y se procedía a la votación nominal a favor o en contra de la censura, la misma que se consideraba aprobada si obtenía la mayoría absoluta del total de los miembros del Congreso Nacional.

En cuanto al enjuiciamiento al presidente y vicepresidente, la Ley exigía que las acusaciones se fundamentaran en causales constitucionales "por traición a la patria, cohecho o cualquier otra infracción que afectare gravemente el honor nacional", que fueran formuladas al menos por 20 diputados y que sus firmas se reconocieran judicial o notarialmente. En este caso, la acusación se sustanciaba por una "Comisión Especialísima de Juicio Político que debía emitir en cinco días un informe de admisibilidad para ser aprobado por el pleno del Congreso Nacional. Si se admitía la acusación se tramitaba de manera similar a los otros juicios políticos y la moción de censura se formulaba por cuando menos 20 diputados, los que debían designar a tres para que sostuvieran los cargos en la sesión plenaria. La moción de censura necesitaba el voto favorable de las dos terceras partes de los miembros del Congreso Nacional. ${ }^{654}$

Durante este período 1990 - 1997, en el que se sustituyó el modelo político y económico intervencionista por el neoliberal, se agudizó el conflicto partidista y se realizaron en el Congreso Nacional 29 juicios políticos a ministros de Estado, de los cuales 12 fueron censurados y destituidos, 1 absuelto y 16 enjuiciamientos fueron archivados o se quedaron en amenaza. Los procesados y destituidos lo fueron en acusaciones por actos de corrupción, en la contratación de la gran obra pública nacional y por adoptar medidas económicas de negativo impacto social, como el aumento de los precios de los combustibles y las tarifas de servicios. ${ }^{655}$

En el contexto de las reformas económicas de corte neoliberal y de una "modernización del Estado entre 1992-1996, además de los juicios políticos a ministros de Estado, se realizó uno al vicepresidente Alberto Dahik, por uso abusivo en gastos reservados, que no culminó en su destitución, pero que creó las condiciones para que el presidente de la Corte Suprema de Justicia ordenara su detención por peculado, lo que ocasionó de

\footnotetext{
654 Ecuador, Ley $\mathrm{N}^{\circ}$ 139, Suplemento del Registro Oficial 862, 28-enero-1992, reformada en 1996 y 1998.

${ }^{655}$ En el gobierno de Borja, entre 1990-1992, se efectuaron 7 juicios políticos en los que los Ministros fueron censurados y destituidos; En el Gobierno de Sixto Durán (1992-1996), se realizaron 22 juicios políticos a Ministros de los cuales 5 fueron censurados y 17 fueron archivados o se quedaron en amenazas. Julio Teodoro Verdugo Silva, El Juicio Político, (Quito: Asamblea Nacional, 2009).
} 
inmediato su abandono del cargo y su asilo en el exterior. ${ }^{656}$ Estos hechos, sumados a la destitución parlamentaria posterior de los presidentes Bucaram (1997) y Mahuad (2000), son el antecedente para que en el ejercicio del poder y en la implementación de las reformas económicas de corte liberal primero y luego neoestructural, los grupos políticos hegemónicos de Ecuador inicien un proceso para establecer obstáculos constitucionales y legales al control político de los más altos dignatarios de los gobiernos, que son los principales ejecutores de las políticas económicas respaldadas por organismos financieros internacionales.

En cuanto al control político financiero, el modelo económico exigía restringir las atribuciones presupuestarias del Congreso Nacional y de los legisladores, para garantizar el equilibrio fiscal y el pago oportuno de la abultada deuda externa. La Comisión de Presupuesto del Congreso Nacional, desde 1978 hasta 1995, estaba autorizada para negociar con el Ejecutivo el contenido y el control de ejecución del presupuesto del Estado, mediante un monto de asignaciones definidas y asignadas por los legisladores y la propia Comisión, pues tenía la atribución constitucional, "con el asesoramiento del organismo técnico del Ejecutivo" de "conocer y discutir la proforma e informar y en caso de discrepancia al Congreso Nacional, para que la resuelva en un solo debate".

Luego de la consulta popular, en enero de 1995, se reformó el artículo 71 de la Constitución, para que la Comisión se limitara a conocer la proforma presupuestaria; a aprobarla por sectores de gasto y a informar si existieran discrepancias para resolverla en el pleno del Congreso, en un solo debate hasta el 31 de diciembre de cada año. Se reformó también el artículo 63 de la Constitución, agregando una disposición para que los legisladores no pudieran manejar fondos del presupuesto del Estado. ${ }^{657}$

A eso se suman las normas de la Ley de Presupuestos, expedida a fines de 1992, al inicio del Gobierno de Sixto Durán, que trasladaron el manejo casi absoluto del ciclo presupuestario en manos del Ejecutivo. El Congreso Nacional, con dichas normas legales y constitucionales posteriores, fue despojado en los hechos de una de sus principales funciones de larga tradición histórica de aprobar a plenitud el presupuesto del Estado y de controlar su ejecución por intermedio de una comisión especializada o por el pleno del mismo. ${ }^{658}$

\section{El control financiero externo e interno y el control ciudadano}

En lo relacionado con el control financiero externo ejercido por la Contraloría, se mantuvo el texto de la Constitución de 1978 hasta 1996. En él se disponía que la Contraloría era un órgano "técnico y autónomo"; "que controlará el manejo de los

\footnotetext{
${ }^{656}$ Pablo Cuvi, Historia del Congreso Nacional, República del Ecuador, (Quito: Mariscal, 2004).

${ }^{657}$ Ecuador, Reformas Constitucionales, primer bloque, arts. 10 y 11, Registro Oficial-S 618, 24-enero1995.

${ }^{658}$ Ecuador, Ley General de Presupuestos del Estado, Registro Oficial-S 76, 30-nov-1992.
} 
recursos públicos" y los "bienes públicos"; "la normatividad y consolidación contable de los mismos" y ejercía "la asesoría y reglamentación" de sus actividades (Art. 113), por lo que el control gubernamental externo según la Constitución no incluía el control de gestión y de resultados, que sin embargo era autorizado, al igual que la determinación de responsabilidades, por la Ley Orgánica de Administración Financiera y Control (LOAFYC) vigente sin mayores modificaciones desde 1977.

La Ley de Presupuestos del Sector Público y su reglamento autorizaban a la Contraloría a realizar el control externo del presupuesto de manera previa, concurrente y posterior y le permitían ejecutar controles aleatorios económicos y financieros a las instituciones públicas. La ley, a la vez, autorizaba al Ministerio de Finanzas para emitir las normas técnicas para el control y evaluación del Sistema Nacional de Presupuestos Públicos y para evaluar, directamente o mediante firmas independientes, el cumplimiento de los fines y la obtención de las metas establecidas en aquel (Artículos 46-53).

En el segundo y tercer bloque de reformas constitucionales, que entraron en vigencia en enero de 1996, se modificó el artículo 116 codificado (antes 113) relativo a la Contraloría General del Estado y se ampliaron sus atribuciones para controlar no solo los ingresos y gastos, sino la administración e inversión de los recursos y bienes públicos, sea que estos se gestionaran por funcionarios del Estado o por entidades de derecho privado. Se incluyó también un nuevo artículo en la carta olítica, que decía: "De conformidad con la Ley, y sin perjuicio del correspondiente derecho de defensa, tendrá potestad para determinar responsabilidades administrativas y presunciones de responsabilidad civil y penal”. Curiosamente, el 16 de julio de 1997 esta norma fue declarada inconstitucional por la forma por el Tribunal Constitucional, ${ }^{659}$ para satisfacer intereses políticos del alcalde de Quito, Jamil Mahuad, quien sostenía que ese artículo había sido modificado arbitrariamente por el plenario de las comisiones legislativas y no por el pleno del Congreso Nacional al anteponer, sin competencia, la palabra presunciones en los casos de las responsabilidades civil y penal que podía establecer la Contraloría. ${ }^{660}$

Como resultado de la consulta popular que se realizó el 25 de junio de 1997, luego del derrocamiento del presidente Abdalá Bucaram, para legitimar la designación de un Presidente interino y la convocatoria a una Asamblea que modificara de manera íntegra las normas constitucionales vigentes para ponerlas a tono con el modelo económico neoliberal, se modificó también, con reforma constitucional del 31 de julio de 1997, que los titulares de los organismos de control y entre ellos el contralor, no fuera elegido por el Congreso de una terna enviada por el presidente de la República, sino que lo hiciera por su propia iniciativa, contando para ello con el apoyo de las dos terceras partes de sus integrantes. $^{661}$

\footnotetext{
${ }^{659}$ Ecuador, Resolución del Tribunal Constitucional 056-1-97, Registro Oficial 109, 16-julio-1997.

${ }^{660}$ Ecuador, Reformas a la Constitución, tercer bloque, Registro Oficial 863, 16-enero- 1996; Resolución del Tribunal Constitucional 056-1-97, Registro Oficial 109, 16-julio-1997.

${ }^{661}$ Ecuador, Reformas a la Constitución, Registro Oficial 120, 31-julio-97.
} 
Con estas modificaciones, en nuestro Derecho constitucional se perfecciona, en principio, el control técnico externo mediante auditorias, llamadas a superar el nivel tradicional de la fiscalización, pues con ellas se debía evaluar también la administración y la inversión, lo que necesariamente implica un control de la gestión efectuada por los diferentes órganos de la Administración pública y de las instituciones que reciben recursos estatales. Pero como queda indicado, la autonomía de la Contraloría se mantiene en entredicho, pues se evidencia una disputa por su manipulación por parte del Ejecutivo y del Congreso, ya que inicialmente se designaba al contralor enviando por parte del presidente una terna al Congreso y, luego de la reforma, se lo designaba directamente por parte del Congreso, sin intervención del Ejecutivo y mucho menos de la ciudadanía o la sociedad civil, pero con una mayoría calificada de dos terceras partes de aquel. ${ }^{662}$

En cuanto a la Ley Orgánica de Administración Financiera y Control, expedida el 16 de mayo de 1977 por la dictadura militar ${ }^{63}$ y que se mantuvo vigente, con algunas reformas hasta 2002, introdujo en nuestro ordenamiento jurídico un sistema de control integral interno y externo, tanto de las instituciones públicas, como de aquellas que recibieran asignaciones estatales, mediante auditorías gubernamentales que examinaban los asuntos de legalidad, administrativos y financieros; control interno; planificación y evaluación; eficiencia, efectividad y economía con que se utilizaban los recursos humanos, materiales y financieros y de revisión y evaluación de los resultados de las operaciones programadas, a fin de determinar si se habían alcanzado las metas propuestas (Arts. 257 y 258).

El control interno, según dicha ley, comprende un plan de organización y un conjunto de medios para proteger los recursos públicos, verificando su información financiera, técnica, contable y administrativa de las instituciones públicas; promover la eficacia en sus operaciones y lograr en la gestión el cumplimiento de sus metas y objetivos (Art. 252).

En 1979 se reformaron las normas de control interno que eran de responsabilidad exclusiva de las instituciones públicas para compartirlas y otorgarle mayor protagonismo a la Contraloría, a la que se le asignó la atribución de establecer las auditorías internas de acuerdo a las "necesidades y recursos que deban controlarse" y de designar al auditor interno jefe y al personal de auditoría requerido. Mediante Ley 18 (R.O.-S 76) de 30 de noviembre de1992 se derogaron esas normas pero se mantuvieron otras que exigían a la Contraloría planificar y vigilar las actividades y los resultados de las auditorías internas, que se convirtieron en el soporte de sus actividades posteriores de control.

\footnotetext{
${ }^{662}$ Luis Hidalgo López, "Organismos de Control” en Nueva justicia y revocatoria del mandato, (Quito: programa de Apoyo al Sistema de Gobernabilidad Democrática, Colección Reforma Política 3, Gobierno del Ecuador-BID, 1997).

${ }^{663}$ Ecuador, Presidencia de las República, Decreto Supremo 1429, Registro Oficial 373, 16-mayo-1977.
} 
En 1992, la Ley de Presupuestos, como lo indicamos anteriormente, estableció un control paralelo a las diferentes fases del ciclo presupuestario, otorgándole al Ministerio de Finanzas que dictara las normas técnicas para el control financiero interno y que esa actividad la realizara directamente o por medio de consultorías o firmas privadas independientes.

En cuanto a responsabilidad, la LOAFYC parte de una presunción de corrección de las operaciones y actividades desempeñadas por los funcionarios públicos y asigna al contralor la potestad de pronunciarse sobre el movimiento financiero, el control de obras y las operaciones y sus resultados de las entidades públicas; vigilar e informar sobre el cumplimiento de requisitos legales y las condiciones de los contratos más importantes de las obras públicas y establecer, luego de las correspondientes auditorías y exámenes especiales, "las responsabilidades de carácter administrativo y civil y las presunciones de responsabilidad penal” (Art. 326).

La responsabilidad administrativa, "sin perjuicio de las responsabilidades civil y penal a que hubiere lugar", la pueden establecer las entidades y funcionarios por inobservancia a las disposiciones legales y el incumplimiento de sus atribuciones y deberes, debidamente detalladas en la ley, y se prevén sanciones de multas y destitución del cargo, impuestas por las autoridades nominadoras o por el contralor o informadas al presidente de la República o a la legislatura, según los casos. Las sanciones administrativas son definitivas en la vía administrativa y solo pueden ser impugnadas en la vía jurisdiccional ante el Tribunal Contencioso Administrativo (Art. 378).

La responsabilidad civil la determina en forma privativa la Contraloría, mediante glosas, "previo estudio del movimiento financiero o del proceso de contratación y ejecución de estudios o proyectos de obras públicas, cuando por la acción u omisión de los servidores respectivos, se haya producido perjuicio económico a la entidad u organismo". Si las glosas son confirmadas y se agota el recurso administrativo de revisión, el afectado puede impugnarlas en el Tribunal Contencioso Administrativo. También, si se comprueba la existencia de sumas indebidamente desembolsadas, la responsabilidad y la exigencia de su devolución se establece mediante oficio fundamentado del contralor, que debe ser notificado al o los interesados, sin que se requiera de estudio previo del movimiento financiero (Art. 341); se dispone también, creando un injustificado privilegio, que si los implicados son "funcionarios cuyo juzgamiento corresponde a la legislatura, el contralor se limita a participar documentadamente de los hechos al presidente de la República y a referirse a ello en su informe a la función legislativa, sin perjuicio del trámite de las demás responsabilidades respecto de otros servidores implicados" (Art. 345).

En cuanto a la presunción de responsabilidad penal sobre peculado, la LOAFYC reformó el tipo penal, dándole una mayor cobertura y estableciendo sanciones más severas que incluían incapacidad perpetua para desempeñar cargos públicos y autorizaba al funcionario de la Contraloría que llevara adelante la auditoria o el examen 
especial, previo visto bueno del jefe del equipo de auditoría o supervisor, "ordenar la inmediata detención provisional del presunto responsable" y "dentro de las cuarenta y ocho horas siguientes, ponerlo a disposición del juez de lo penal correspondiente" para que se "inicie el enjuiciamiento" y para que emitida la sentencia se determinen también las responsabilidades civiles, proveyéndose incluso sanciones a los jueces que no actúen ágilmente conforme a las normas establecidas (Arts. 342 al 344). Estas disposiciones radicales fueron en corto tiempo modificadas en 1979, excluyendo primero de la aplicación de estas normas a los funcionarios cuyo juzgamiento corresponda a la Legislatura y posteriormente, con reformas al Código Penal para que las órdenes de detención provengan del juez y no de funcionarios administrativos de la Contraloría.

Sobre el control externo ciudadano o de las organizaciones sociales o de la "sociedad civil" hasta 1977, el derecho constitucional ecuatoriano y las leyes no contemplaban normativa alguna.

En el derrocamiento del presidente Abdalá Bucaram, entre el 5 y 6 de febrero de 1997, no solo confluyeron intereses políticos para violar la Constitución y asumir el control del poder ejecutivo por quienes habían sido derrotados en las elecciones generales, sino graves denuncias de corrupción formuladas por ciudadanos en los medios de comunicación y por fuentes extranjeras, todas ellas relacionadas con el abuso de fondos públicos en gastos reservados y en contratos de obras públicas y adquisiciones. Por ello se planteó, desde las organizaciones sociales y la opinión pública, la conformación de una Comisión de Control Cívico de la Corrupción.

El presidente interino de Ecuador, Fabián Alarcón, mediante decretos ejecutivos 107-A y 506, conformó el 4 de marzo de 1997 una comisión de ocho "ciudadanos ilustres" para que receptaran denuncias de corrupción del Gobierno derrocado y otros actos ilícitos en instituciones públicas, los investigaran, elaboraran informes fundamentados y los pusieran en conocimiento de la Contraloría y de la función judicial, para que estas establecieran responsabilidades y las correspondientes sanciones.

Esta comisión realizó investigaciones sobre los casos de corrupción más difundidos en el año de su conformación, como el uso de gastos reservados en el Gobierno de Sixto Durán y la contratación irregular de la mochila escolar y el dispendio de recursos destinados a la seguridad nacional y a la estabilidad democrática en el régimen de Abdalá Bucaram, sobre los que se emitieron informes inculpatorios que fueron corroborados por la Contraloría y dieron origen a procesos penales en contra de un exvicepresidente y un expresidente, que culminaron en sentencias condenatorias contra varios de su colaboradores y en su orden de detención, lo que ocasionó que fugaran del país y se exiliaran para evitar la culminación de aquellos. ${ }^{664}$

\footnotetext{
664 http://www.ecuadorinmediato.com/index.php?module=Noticias\&func=news_user_view\&id=165678; http://www.ecuavisa.com/articulo/noticias/actualidad/50800-abdala-bucaram-pide-anular-accionproteccion-presentada-hace-4
} 


\subsection{El control en la Constitución y la legislación de 1998-2007}

La constitución de 1998 y la legislación de control que se expidió o reformó en consonancia con ella, respondiendo a los políticos neoliberales, limitaron el control político a los más altos funcionarios del Gobierno, ejecutores principales del modelo y que ampliaron de manera más simbólica que efectiva el control técnico y ciudadano dirigido principalmente a funcionarios de mediana y baja jerarquía.

\section{Control político del Congreso Nacional}

El control político asignado al Congreso Nacional en la Constitución de 1998 permite de manera general "la fiscalización de los actos de la función ejecutiva y del Tribunal Supremo Electoral; solicitar a los funcionarios públicos las informaciones que consideren necesarias; conocer y pronunciarse sobre el informe anual que debe presentar el presidente de la República y proceder al enjuiciamiento político del presidente y vicepresidente, de los ministros de Estado, del procurador y contralor, del defensor del pueblo, del fiscal general, de los superintendentes, y de los vocales del Tribunal Constitucional y Tribunal Supremo Electoral, durante el ejercicio de sus funciones y hasta un año después" (Artículo 130, numerales 3, 8 y 9).

En las normas antes indicadas se pueden advertir las siguientes restricciones en el control político que tradicionalmente realizaba el Congreso Nacional: limitar su potestad, existente desde los inicios de la República, de enjuiciar políticamente y destituir a los ministros de la Corte Suprema de Justicia y establecer requisitos adicionales para dificultar el trámite y los efectos de los juicios políticos a los más altos dignatarios del Gobierno, que son los principales ejecutores de las políticas económicas y a aquellos que finalmente podrían a ser sancionados por delitos de peculado y de corrupción junto a personas privadas internacionales o nacionales.

Los juicios políticos solo se podrán iniciar si son solicitados por al menos una cuarta parte de los integrantes del Congreso Nacional, lo cual constituye un incremento en el número de legisladores para ejercer esa potestad que antes no tenía ese requisito; los funcionarios pueden ser enjuiciados políticamente por infracciones constitucionales y legales en general, mientras que el presidente y vicepresidente de la República solo por "la comisión de delitos contra la Seguridad del Estado o por delitos de concusión, cohecho, peculado y enriquecimiento ilícito". El presidente y vicepresidente podían ser censurados o destituidos con el voto de las dos terceras partes de los integrantes del Congreso Nacional, mientras que los funcionarios que no sean ministros de Estado podían ser censurados y destituidos, con el voto de la mitad más uno de los miembros del Congreso Nacional, a excepción de los ministros de Estado, cuya permanencia en el cargo dependerá de la voluntad del presidente de la República, pues se anula la destitución como efecto lógico, político y administrativo, del juicio y de esa potestad de control. En todos los casos, si en el juicio político existieran indicios de responsabilidad penal se los pondría poner en conocimiento del juez competente. 
La Ley Orgánica de la Función Legislativa entre 1998 y 2008 no introdujo modificaciones importantes a las normas de procedimiento del control político, que ya constaban en la ley original dictada en 1992 por el Gobierno del presidente Borja. En cuanto a la información documentaria, las reformas establecieron la obligación del funcionario de entregarla o de comparecer ante el Congreso o la Comisión, para exponer la información, contestar las preguntas de los legisladores y permanecer, personalmente o por medio de su delegado, en el recinto mientras se debata lo expuesto. En 1996 se reformó la ley para establecer también que, además de la censura y destitución cuando cabe, se plantearán las acciones civiles, administrativas y penales en caso de que se encontrare fundamento para ello.

En cuanto al control político, en lo estrictamente financiero y fiscal, por parte del Congreso Nacional, las modificaciones constitucionales y legales entre 1992 y 1998 lo debilitan y lo reducen a declaraciones ineficaces de tipo general. La Constitución de 1998 confiere la responsabilidad de formular y ejecutar la proforma del presupuesto general del Estado al presidente de la República, sin perjuicio del control que tienen los organismos pertinentes. Dicha proforma es elaborada por la función ejecutiva de acuerdo a su Plan de Desarrollo y presentada al Congreso Nacional, que la conocerá y la aprobará en un solo debate hasta el 30 de noviembre, por sectores de ingresos y gastos; si no lo hace hasta esa fecha, la proforma elaborada por el presidente entra en vigencia. Se exige contar en el proceso de aprobación de la misma con un informe del Banco Central; el Congreso no queda facultado para incrementar el monto estimado de ingresos y egresos y durante su ejecución deberá contar con su aprobación formal para incrementar gastos más allá del porcentaje establecido en la ley, si bien esta limitación puede ser eludida con modificaciones separadas que realice el Ministerio de Finanzas. Las disposiciones que regulan la ejecución y control de los presupuestos son teóricamente obligatorias y, por mandato de la ley, deben constar como obligatorias en el Presupuesto General del Estado, y están destinadas principalmente al cumplimiento de obligaciones convencionales o contractuales provenientes de compromisos internacionales y por servicio de amortización y pago de intereses de la deuda pública. $^{665}$

La Constitución de 1998 dispuso también que no se podrán financiar gastos corrientes mediante endeudamiento público, que ningún organismo público será privado del presupuesto necesario para cumplir con sus fines y objetivos para los que fue creado y que el Ejecutivo informará semestralmente al Congreso Nacional sobre la ejecución del presupuesto y su liquidación anual (Art. 259) y ratificó y amplió las normas que prohíben a los diputados "ofrecer, tramitar, recibir o administrar recursos del presupuesto del Estado"; que "no podrán percibir dietas u otros ingresos de fondos públicos", "ni integrar directorios de otros cuerpos colegiados de instituciones o empresas en las que tenga participación el Estado" (Art. 145).

${ }^{665}$ Ecuador, Ley Orgánica de Administración Financiera y Control, art. 76. 
La Constitución aprobada el 5 de junio de 1998 no identifica, finalmente, a las comisiones especializadas permanentes y faculta a la Ley Orgánica de Función Legislativa a que ella determine su número, conformación y competencias. La reforma aprobada a esta ley, el 31 de julio de 1998, identifica entre las comisiones a la "de lo tributario, fiscal y bancario", eliminando las palabras "y de presupuesto", para no darle a ninguna de ellas la connotación especial de control, como sí la tenía en las constituciones anteriores y en las codificaciones de la constitución de 1978, por lo que resulta evidente que se otorga al Congreso, de manera general, indeterminada y declarativa, una cierta potestad de control financiero, sin definir los instrumentos ni la institucionalidad para ejercerla.

\section{El control externo técnico y social}

En el contexto de la implementación de un nuevo modelo económico en el país y frente a las denuncias y hechos de corrupción, el sistema político dio una respuesta de mejorar la normativa relativa al control externo. En la Constitución de 1998 se amplían y complementan en su texto las reformas efectuadas hasta 1997 sobre el control técnicofinanciero externo, asignado a la Contraloría General del Estado que ya constaban en la Ley Orgánica de Administración Financiera y Control y se introduce simbólicamente en la carta política el ejercicio del control ciudadano y popular, por medio de la Comisión de Control Cívico de la Corrupción, como respuesta a una exigencia social, nacional e internacional, expresada en la movilización popular, los medios de comunicación y en la expedición de la Convención Interamericana contra la Corrupción, suscrita el 29 de marzo de 1996.

Se reconoce en esta Constitución, por primera vez, que la Contraloría es "el organismo técnico superior de control", con "autonomía administrativa, presupuestaria y financiera", "dirigido y representado por el contralor general del Estado, quien desempeñará sus funciones por cuatro años" y será designado por el presidente de la República de la terna, conformada por el Congreso Nacional, con la votación de las dos terceras partes de sus miembros. Para ser elegido contralor se requiere "cumplir los requisitos establecidos en la Constitución" (Art. 213) y "no encontrarse incurso en las incompatibilidades o inhabilidades establecidas en la ley, especialmente la de no tener contratos con el Estado bajo ninguna modalidad, no ser representante o apoderado de personas jurídicas nacionales o extranjeras y no tener intereses o representar a terceros que los tuvieren en las áreas que vayan a ser controladas o reguladas" (Art. 34 de la LOCGE).

A la Contraloría, según la Constitución, se le asignan atribuciones "para controlar ingresos, gastos, inversión, utilización de recursos, administración y custodia de bienes públicos"; extender su acción a las entidades de derecho privado "exclusivamente respecto de los bienes, rentas u otras subvenciones de carácter público de que dispongan"; realizar "auditorías de gestión a entidades y organismos del sector público y sus servidores"; pronunciarse "sobre la legalidad, transparencia y eficiencia de los 
resultados institucionales"; dictar "regulaciones de carácter general para el cumplimiento de sus funciones"; dar obligatoriamente asesoría cuando se lo solicite en las materias de su competencia"; examinar las declaraciones patrimoniales juramentadas antes y después del ejercicio de los funcionarios públicos para investigar los casos en los que se presuma "enriquecimiento ilícito"; ejercer la "potestad exclusiva para determinar responsabilidades administrativas y civiles culposas e indicios de responsabilidad penal" y hacer "el seguimiento permanente y oportuno para asegurar el cumplimiento de sus disposiciones y controles" (Artículos 211, 212 y 122).

Como se puede constatar, la Constitución de 1988 confiere a la Contraloría el carácter de órgano técnico y superior de control para otorgarle mayor jerarquía frente a otros órganos de control como las superintendencias, la Procuraduría y el Ministerio Público y modifica el procedimiento para designar contralor, pues este funcionario era nombrado antes de una terna enviada al Congreso por el Ejecutivo y ahora se dispone que la terna sea conformada por el Congreso, con el voto de las dos terceras partes de sus integrantes, pero que el Ejecutivo sea el que finalmente designe a quien lo estime conveniente, reforzando el presidencialismo y contradiciendo lo dispuesto en la consulta popular del 25 de junio de 1997. De cualquier forma, según los tres procedimientos de designación, la independencia del contralor queda totalmente relativizada o "partidizada", pues sigue siendo asunto de negociación entre las dos funciones del Estado y sus actores políticos. Así el órgano de control utilice técnicas de auditoría moderna, si su dirección sigue siendo objeto de reparto y se convierte, por tanto, en instrumento político, privilegiadamente del Ejecutivo, para "combatir a los dirigentes y líderes políticos de oposición" y en un "poderoso instrumento para las luchas partidistas" tanto a nivel nacional como en los gobiernos locales. ${ }^{666}$

Resulta trascendente, en todo caso, que la carta política de 1998 incluya en su texto normas compatibles con las que ya se encontraban vigentes en la LOAFYC y que no fueron incluidas en la Constitución de 1978 y en las siguientes cuatro codificaciones y numerosas reformas, con lo que en la carta política se incorporaron los conceptos actuales de auditoría financiera y de gestión. Es importante también que en la Constitución conste que el control técnico de la Contraloría sobre los recursos públicos, se plantee como integral y no se limite a asuntos contables, sino que se fundamente en las auditorias de gestión para que el contralor esté habilitado a pronunciarse "sobre la legalidad, transparencia y eficiencia de los resultados institucionales". Sin embargo, frente a los procesos de privatización de las actividades estatales mediante empresas privadas, la Constitución y la ley limitan exclusivamente el control a los bienes, rentas y subvenciones públicas que ellas dispongan.

Si bien con la Constitución de 1998 las normas de la LOAFYC cobraron fundamento jurídico pleno, durante su vigencia se adoptaron una serie de reformas para perfeccionar

\footnotetext{
${ }^{666}$ Carlos Pólit Faggioni, La Contraloría General del Estado en el ordenamiento jurídico constitucional, (Quito: NINA Comunicaciones, 2009).
} 
las instituciones de control, las mismas que culminaron con la expedición de la Ley Orgánica de la Contraloría General del Estado (LOCGE) el 12 de junio de 2002, ${ }^{667}$ diferenciando e interrelacionando las instituciones de la administración y del control financieros internos a cargo de las instituciones públicas, con las actividades superiores de control externo, técnico-financiero, que son de responsabilidad de la Contraloría y el ejercicio pleno de sus potestades constitucionales.

Con la expedición de la LOCGE (2002), se inicia, como hemos afirmado en esta investigación, una tercera fase en la organización del sistema de control unipersonal de Contraloría en la historia de Ecuador, pues se pasa de la vigilancia contable inicial y a la posterior de fiscalización-financiera, a una integral que diferencia y combina los referidos tipos de control, con el de gestión y de resultados, con la finalidad de transformar la Administración pública y prevenirla no solo de la corrupción y de los abusos de fondos públicos, sino de la ineficacia, ineficiencia, mala calidad de servicios y desperdicio de recursos.

En la LOCGE, partiendo de las referidas normas constitucionales, se pueden identificar o subrayar algunas modificaciones que las consideramos cruciales en la legislación de control que regula la Contraloría General del Estado, sobre su objeto, ámbito de aplicación, concepto de recursos públicos, control de la auditoría interna, reconceptualización de la auditoría de gestión, autonomía del órgano de control y atribuciones del contralor y las precisiones en lo relativo al establecimiento de responsabilidades y a los recursos administrativos.

En cuanto al objeto de la ley, esta cubre no solo sus atribuciones de fiscalización y auditoría de las instituciones del Estado sino, de manera amplia y actualizada, la de regular su funcionamiento para "examinar, verificar y evaluar" el cumplimiento de su "visión, misión y objetivos" y la "utilización de recursos, administración y custodia de bienes públicos" (Art. 1).

Sobre a su ámbito de aplicación, la LOCGE involucra a todas las instituciones estatales y a las "entidades de derecho privado, exclusivamente respecto de los bienes, rentas $\mathrm{u}$ otras subvenciones de carácter público de que dispongan" (Art. 2). Sin embargo de manera confusa inicialmente, el artículo 4 de la Ley establecía que "están sometidas al control de la Contraloría General del Estado las personas jurídicas de derecho privado, con fines sociales o públicos, cuyo capital social, patrimonio, fondo o participación tributaria esté integrado en el 50\% o más con recursos públicos" y que "las demás personas jurídicas de derecho privado, que no tengan finalidad social o pública, aun cuando su capital este integrado en más del $50 \%$ con recursos públicos, y aquellas cuyo capital social, patrimonio, fondo o participación tributaria este integrado con recursos públicos en un porcentaje menor al $50 \%$, estarán sometidas a la vigilancia y control de las superintendencias de compañías, de bancos y seguros o del respectivo órgano de

${ }^{667}$ Ecuador, Ley 2002-73, Registro Oficial-S 595, 12-jun-2002. 
control, en cuyo caso la Contraloría realizaría la vigilancia de los recursos públicos de manera indirecta por medio de socios o accionistas del sector público, luego de finalizar el ejercicio económico y coordinando su labor con los respectivos órganos de control. De esta manera se pretendía evitar o relativizar el control de la Contraloría sobre las empresas o corporaciones privadas o sociedades anónimas que utilizaban fondos públicos y que habían sido privatizadas. Esta norma se sustituyó, luego de dos años, mediante Ley 2004-42, en la que se dispuso que el control de los recursos públicos de personas jurídicas de derecho privado, por parte de la Contraloría, se realizará cualquiera sea su monto y las distintas modalidades contractuales que las instituciones delegantes haya celebrado con empresas privadas o delegatarios. (Art. 4 reformado).

Para efectos de las acciones de control que realice la Contraloría, la Ley precisa también que se entienden por recursos públicos todos los bienes, fondos, títulos, acciones, participaciones, activos, rentas, utilidades, excedentes, subvenciones y todos los derechos que pertenecen a las instituciones estatales, sea cual fuere la fuente de la que procedan, inclusive los provenientes de préstamos, donaciones y entregas que a cualquier otro título realicen a favor del Estado o de sus instituciones, personas naturales o jurídicas u organismos nacionales o internacionales" (Art. 3), lo cual involucra acciones de control a todo tipo de recursos públicos, en cuanto a su modalidad y origen.

Sobre las clases de auditorías y examen especial que realiza el órgano de control, la LOAFYC preveía, además de la auditoría gubernamental y financiera, la denominada auditoría operacional, concebida como "un examen y evaluación que se realiza con respecto a una entidad u organismo, para establecer el grado de eficiencia, efectividad y economía en su planificación, organización, dirección, control interno y uso de sus recursos", así como un instrumento para "verificar la observancia de las disposiciones pertinentes $\mathrm{y}$ formular conclusiones y recomendaciones tendientes a mejorar las actividades y materias examinadas" y para "dirigir su atención en forma selectiva a las actividades y materias consideradas como críticas" (Art. 263).

La LOCGE regula, en cambio, de manera integral, conforme al avance de la ciencia y normas internacionales de la materia, las clases o tipos de auditoría gubernamental y examen especial: financiera, ambiental, de obras públicas o de ingeniería y la denominada "auditoría de gestión", que viene a ser como "la acción fiscalizadora dirigida a examinar y evaluar el control interno y la gestión, utilizando recursos humanos de carácter multidisciplinario, el desempeño de una institución, ente contable, o la ejecución de programas y proyectos, con el fin de determinar si dicho desempeño o ejecución, se está realizando, o se ha realizado, de acuerdo a principios y criterios de economía, efectividad y eficiencia"; o para "examinar y evaluar los resultados originalmente esperados y medidos de acuerdo con los indicadores institucionales y de desempeño pertinentes". La norma también establece que "constituirán objeto de la auditoría de gestión: el proceso administrativo, las actividades de apoyo, financieras y operativas; la eficiencia, efectividad y economía en el empleo de los recursos humanos, 
materiales, financieros, ambientales, tecnológicos y de tiempo; $\mathrm{y}$, el cumplimiento de las atribuciones, objetivos y metas institucionales". De allí que, a diferencia de la auditoría financiera, el resultado de la fiscalización mediante "auditoría de gestión" no implica la emisión de una simple opinión profesional, sino la "elaboración de un informe amplio con los comentarios, conclusiones y recomendaciones pertinentes" (Arts. 18 - 28). Son evidentes y notorias las diferencias de los dos conceptos para el ejercicio eficiente y eficaz del control externo.

En cuanto al control de las auditorías internas y a su relación con las actividades del control externo, habíamos indicado más arriba que las reformas a la LOAFYC modificaron el manejo más directo de la Contraloría a dichas auditorías a una coordinación de trabajo sin un control directo sobre el personal que las ejecuta. La LOCGE establece de manera categórica que las "unidades de auditoría interna" dependerán "técnicamente" de la Contraloría General del Estado y que el personal auditor será "nombrado, removido o trasladado" por el contralor, mientras que las remuneraciones y gastos de aquellas serán cubiertos por las instituciones públicas involucradas (Art. 14).

Sobre la autonomía de la institución de control, la LOAFYC establecía de manera general, que la Contraloría es "autónoma en sus funciones", pero no detallaba el ejercicio de dicha autonomía, más bien, en lo económico y en su presupuesto, la entidad estaba supeditada a las decisiones del Gobierno y del Ministerio de Finanzas, entes sometidos a su control. La LOCGE, en cambio, ratifica el contenido de la norma constitucional que la Contraloría, para el cumplimiento de sus funciones, tiene "autonomía administrativa, presupuestaria y financiera"; le otorga la calidad de "persona jurídica de derecho público" y le asegura el financiamiento de las actividades de control con el aporte del cinco por mil de todas las instituciones públicas y de las que manejen recursos públicos con ciertas excepciones, estableciendo además obligaciones gubernamentales para la recaudación de ese aporte y la capacidad reglamentaria de la Contraloría para dicho propósito.

En la LOCGE constan también, de manera minuciosa, las más importantes atribuciones y competencias y funciones del contralor sin que ellas se agoten en su texto, pues agrega en la parte final que ejercerá las demás conferidas por la Constitución, la Ley y los reglamentos. Dichas funciones se podrían clasificar en potestades para el ejercicio integral de control; de transparencia e información; normativas y consultivas; administrativas y de delegación. (Arts. 7, 31 y siguientes).

El ejercicio de las competencias de control las ejerce el contralor mediante el antes explicado sistema integral de auditorías y de fiscalización sobre recursos y bienes públicos y de prevención de actos de corrupción, incluyendo sus atribuciones sobre declaraciones patrimoniales juramentadas, operaciones de financiamiento y deuda, presupuestos, gastos reservados, consultorías, informes y opinión profesional sobre estados financieros consolidados de las instituciones públicas, sobre contratos públicos 
cuando se lo solicitare y de legalidad sobre los procesos de delegación o concesión al sector privado; registro de contratistas incumplidos y adjudicatarios fallidos; determinación de responsabilidades administrativas, civiles culposas e indicios de responsabilidad penal, además de sus potestades para recaudar mediante coactiva recursos públicos establecidos en las actividades de control; resolver los recursos administrativos de revisión y ser parte procesal en los procesos que se tramitan sobre control en la función jurisdiccional.

Las potestades de transparencia e información obligan al contralor a informar y rendir cuentas en el momento oportuno, y por todos los medios posibles, de todas sus actividades y su gestión, a los ciudadanos, a los medios de comunicación, al presidente de la República y a la Asamblea Nacional, a la que además se atenderá en sus requerimientos de información y en los procedimientos de enjuiciamiento político.

Las competencias administrativas le permiten a la máxima autoridad de la Contraloría definir la estructura organizativa de la institución y todo el régimen del personal, incluyendo el ejercicio de las potestades disciplinarias y de capacitación para el eficiente y eficaz desempeño de los funcionarios.

Las potestades normativas autorizan al contralor a expedir, aprobar, actualizar y verificar normas de control interno, políticas y normas de auditoría gubernamental de carácter local e internacional, normas de control y fiscalización adaptadas de las normas emitidas por la Organización Internacional de Entidades Fiscalizadoras Superiores, reglamentos, regulaciones, manuales generales y especializados, guías metodológicas, instructivos y otras disposiciones para aplicar los sistemas de control y la determinación de responsabilidades. Las potestades de delegación autorizan ampliamente al contralor a delegar con la misma fuerza y efecto el ejercicio de sus funciones y atribuciones a los funcionarios de la institución, conforme al reglamento que se expida, sin que estos lo puedan hacer a sus subalternos.

Sobre responsabilidades, la LOCGE trae varias innovaciones a las establecidas en la LOAFYC sobre el régimen de responsabilidades: las responsabilidades administrativas y civiles culposas y las antes denominadas presunciones y ahora indicios de responsabilidad penal. Se reconoce en la nueva ley, vigente desde 2002, como punto de partida, la "presunción de legitimidad de operaciones y actividades de instituciones del estado y sus servidores" y se desarrolla con mayor claridad lo que se entiende y ocasiona la responsabilidad administrativa culposa y la responsabilidad civil culposa.

En cuanto a la responsabilidad administrativa culposa, esta surge no solo por la inobservancia de las disposiciones legales, especialmente financieras, de contabilidad, planificación, inversión, administración de recursos humanos y de control interno o externo, sino por el incumplimiento de atribuciones y obligaciones y por la acción u omisión al contraer compromisos y obligaciones por cuenta de las instituciones del Estado, o por no efectuar ingreso oportuno de recursos recibidos, no establecer ni 
aplicar indicadores de gestión, cometer abuso en el ejercicio o desempeño del cargo, disponer o ejecutar cambios de planes, programas y estipulaciones en la ejecución de contratos y estar involucrado o participar en actos que constituyan delitos contra la administración, sin perjuicio de la responsabilidad penal o civil. La sanciones por faltas administrativas pueden ser: multas que se incrementan entre una y diez remuneraciones mensuales unificadas, y además, de acuerdo a la gravedad de la falta, la destitución del cargo. La sanción de destitución es definitiva en la vía administrativa y se puede impugnar hasta en el término de 30 días, luego de su notificación, ante el Tribunal de lo Contencioso Administrativo.

En lo relacionado con la responsabilidad civil culposa, se mantiene lo establecido en la Ley anterior respecto de las órdenes de reintegro y con las predeterminaciones o glosas a funcionarios o a terceros que se establecen en las auditorías o examen especial respecto de actos administrativos, que sin tomar las precauciones necesarias ocasionen perjuicios directos e indirectos a bienes y recursos públicos; lo que implica una obligación indemnizatoria del perjuicio económico ocasionado a las instituciones públicas. Se establece en la LOCGE un trámite administrativo interno para la reconsideración de la orden de reintegro y para la notificación, contestación y resolución de la glosa. En los dos casos se pueden impugnar las decisiones del contralor en el Tribunal Contencioso Administrativo y una vez ejecutoriadas las decisiones o la sentencia, se emiten los títulos de crédito que se los recauda mediante la jurisdicción coactiva ejercida, según los casos, por la propia Contraloría o la institución pública respectiva. En el caso de las predeterminaciones, las resoluciones originales pueden ser revisadas por la Contraloría de oficio o a petición de parte, fundamentadas en la ley o interpuestas por parte del afectado, el recurso de revisión dentro del plazo de 60 días, luego de la notificación de la resolución original. En plazo de 30 días la Contraloría decide si otorga o no el recurso, y en 60 días adicionales, si aceptó el trámite, dictará la resolución motivada en la que se confirma, revoca, modifica o sustituye la resolución revisada. Luego de ello, cabe la posibilidad de impugnar, dentro del término de 60 días, la resolución definitiva en el Tribunal Contencioso Administrativo.

Las presunciones de responsabilidad penal que se establecen en la LOAFYC se sustituyen por los indicios de responsabilidad penal, ya que la acción penal desde hace varios años es de iniciativa de la Fiscalía y ya no la puede iniciar directamente el juez. El procedimiento, según la LOCGE, parte de actas o informes que evidencian indicios de responsabilidad penal en delitos de peculado, enriquecimiento ilícito, cohecho, concusión y otros contra la Administración pública y que son de conocimiento de los funcionarios de la Contraloría o de la auditoría interna, luego de efectuar una auditoría o examen especial. El auditor jefe de equipo, previo visto bueno del supervisor, hace conocer el particular al contralor o delegado, quien luego de aprobar el informe, lo remite con la evidencia acumulada a la Fiscalía, para que esta proceda conforme lo establece la ley a la correspondiente acción o proceso penal. 
También la LOCGE ratifica las normas constitucionales que disponen la responsabilidad de autoridades, funcionarios y servidores por acción u omisión. Establece un régimen para las órdenes superiores que deben ser por escrito para que los funcionarios ejecutores no asuman sus consecuencias; la responsabilidad directa de los funcionarios encargados de la gestión financiera, administrativa, operativa o ambiental hasta por culpa leve; la principal y subsidiaria en el pago indebido y la solidaria en caso de coautoría de acción, inacción u omisión administrativa que la origine (Arts. 40-44).

En ese contexto, en el mismo mes de junio de 2002, con la expedición de la Ley Orgánica de Responsabilidad, Estabilización y Transparencia Fiscal, ${ }^{668}$ que exige la planificación estratégica y la introducción de indicadores de gestión institucional y de desempeño en las instituciones públicas, la Contraloría expidió el Acuerdo Nro. 002 de 6 de septiembre de 2002, para adoptar un sistema integrado de gestión y modelos de excelencia y de autoevaluación que permitan generar productos y servicios que satisfagan las necesidades y expectativas de la comunidad. Complementariamente, para cumplir con la nueva y más amplia dimensión integral del control, la Contraloría expidió también nuevas guías y manuales de auditoría financiera externa, interna y de gestión y normas técnicas y regulaciones administrativas de control interno, de personal, de bienes, presupuestos públicos, reserva monetaria, deuda externa, ambiental, etc.

Según informó la Contraloría, en ese período de gestión también se adoptaron sistemas integrados de control, cruce de información, capacitación y procedimientos de desconcentración de las auditorías externas, absolución de consultas, patrocinio y emisión de informes sobre contratación pública. ${ }^{669}$

A pesar de las indicadas innovaciones constitucionales, legales y de la visión optimista de sus personeros sobre la actividad de la Contraloría, existen serios cuestionamientos, formulados en ese período, sobre la eficacia de su gestión, y en la utilización de los instrumentos jurídicos de la que está dotada, para impedir actos irregulares y, una vez ocurridos, para investigarlos y sancionarlos, como ocurrió en la crisis bancaria (19992003), con el descomunal abuso de fondos públicos del Banco Central, del Ministerio de Finanzas y la Corporación Financiera Nacional en el feriado bancario y en el congelamiento de fondos.

Igualmente se cuestiona la mala calidad e insuficiente motivación en las resoluciones de la Contraloría, que ocasiona que muchas de ellas sean desestimadas por los tribunales contencioso-administrativos y el problema de la real y evidente dependencia de sus autoridades frente a los intereses políticos y económicos presentes en la sociedad. ${ }^{670}$

\footnotetext{
${ }^{668}$ Ecuador, Ley 2002-72, Registro Oficial 131, 24-oct-2005.

${ }^{669}$ Carlos Pólit Faggioni, La Contraloría General del Estado en el ordenamiento jurídico constitucional, (Quito: NINA Comunicaciones, 2009).

${ }^{670}$ Juan Pablo Aguilar, "Compromiso político y organismos de control" en FORO, Revista de Derecho de la UASB, No. 7, I semestre 2007.
} 


\section{Control ciudadano y social}

En cuanto al control externo social o ciudadano, la Constitución de 1998, de manera expresa, incluyó, como una de las definiciones del gobierno el ser "participativo" y dispuso que la soberanía "radica en el pueblo" y se la ejerce por medio "de los órganos del poder público y de los medios democráticos previstos en esta Constitución" (Art. 1).

Siendo dicha Constitución "garantista de derechos" y entre ellos los políticos, individuales y sociales, incorporó en ella como un derecho de los ciudadanos el de "fiscalizar los actos de los órganos del poder público" (Art. 26) y, en sus deberes y responsabilidades: "administrar honradamente el patrimonio público"; "asumir las funciones públicas como servicio a la colectividad; rendir cuentas a la sociedad y a la autoridad, conforme a la ley" y "denunciar y combatir los actos de corrupción" (Art. 97).

Entre los organismos de control, más de manera simbólica que con fuerza legal eficaz para combatir la impunidad frente a los crecientes casos y escándalos de corrupción, la Constitución de 1998 oficializó la conformación de un órgano de control ciudadano: la Comisión de Control Cívico de la Corrupción (CCCC), constituida inicialmente por el Presidente de la República, por exigencia de las fuerzas sociales del país en 1997, para impulsar la lucha contra ese flagelo, presente cada vez con mayor fuerza en la vida nacional, si bien se ha objetado su existencia por considerarla que duplica las funciones de la Contraloría y por su integración "corporativa" que distorsiona una representación ciudadana directa. ${ }^{671}$

La Comisión, de acuerdo con la Constitución, se conforma como una "persona de derecho público", con "autonomía e independencia económica, política y administrativa". Su finalidad es la de "promover la eliminación de la corrupción" en representación de la ciudadanía y se integrará por "representantes de las instituciones de la sociedad civil" para recibir "denuncias sobre hechos presuntamente ilícitos cometidos en las instituciones del Estado, investigarlos y solicitar su juzgamiento y sanción" (Art. 220).

La misma Carta Política estableció que la Comisión, luego de sus investigaciones, pondrá en conocimiento del Ministerio Público y de la Contraloría los indicios de responsabilidad que hubiere encontrado y dispuso que la Comisión no interfiera con las atribuciones de la Función Judicial que deberá tramitar sus pedidos; que los organismos y funcionarios del Estado remitan la información que se considere necesaria para sus investigaciones, pudiendo ser sancionados legalmente si se niegan a hacerlo y que se otorgue protección legal, a las personas que colaboren para establecer los hechos de corrupción.

${ }^{671}$ Ibídem. 
Cumpliendo con el mandato constitucional, el Congreso Nacional aprobó el año siguiente la Ley Orgánica de Control Cívico de la Corrupción ${ }^{672}$ en la que se puso como antecedente que el Ecuador es suscriptor de la Convención Interamericana Contra la Corrupción de $1996^{673}$ y que el crecimiento de la misma, en el sector público y privado, "pone en riesgo la estabilidad y la credibilidad del sistema democrático, posterga la satisfacción de las necesidades del pueblo ecuatoriano, limita la inversión y afecta al desarrollo económico y humano".

La Ley enfatiza que la Comisión "actuará en representación dela ciudadanía” y por ello estará integrada por siete miembros, designados por entes de la sociedad civil, para lo cual, se conforman colegios electorales integrados por: el Consejo Nacional de Universidades y Escuelas Politécnicas; gremios profesionales representativos de cada sector y de carácter nacional; Asociación Ecuatoriana de Editores de Periódicos, Canales de Televisión, de Radiodifusión y de la Federación Nacional de Periodistas; las Federaciones Nacionales de las Cámaras de la Producción; Centrales Sindicales y Organizaciones Indígenas, afroecuatorianas y campesinas de carácter nacional legalmente reconocidas; Organizaciones Nacionales de Mujeres legalmente reconocidas y Organizaciones de Derechos Humanos y de Defensa de los Consumidores legalmente reconocidas. Los integrantes de la Comisión, según la ley, no serán dirigentes de las organizaciones que los elijan; sus candidaturas pueden ser objetadas o recibir la oposición de cualquier ciudadano; gozan de fuero de Corte Suprema y deben presentar al inicio y final de sus funciones una declaración patrimonial juramentada, guardar reserva absoluta de las investigaciones que se realicen y excusarse si hay conflicto de intereses personales o de sus parientes. También la Ley estableció la forma de organización de la Comisión, su financiamiento, la posibilidad de impugnar sus resoluciones ante el Tribunal Constitucional y el proceso de investigación, juzgamiento y destitución de los miembros de la misma (Art. 4, 8-23 de la Ley).

La Ley amplió además el objeto de la comisión ciudadana inicial, no sólo para recibir e investigar denuncias de actos de corrupción de mandatarios y representantes de elección popular, magistrados, dignatarios, autoridades, funcionarios y empleados de los organismos del Estado y por personas particulares involucrados en los hechos que se investigan, sino para realizar las acciones necesarias para la prevención de aquellos con programas y campañas y la difusión de valores y principios de transparencia en el manejo de los asuntos públicos para crear una cultura de legalidad y honestidad. La Comisión tenía la obligación de diseñar un plan nacional de prevención para ser puesto en conocimiento de las funciones del Estado. La Ley estableció también que la Comisión se ocupará preferentemente de las denuncias sobre peculado, cohecho, extorsión, concusión, agiotismo, fraudes en el sistema financiero y acciones fraudulentas en general y otras similares que afecten los recursos de las instituciones públicas (Art. 2 y 7).

\footnotetext{
${ }_{672}$ Ecuador, Ley 99-39, Registro Oficial 253, 12-ago-1999.

${ }^{673}$ Convención Interamericana Contra la Corrupción, Caracas, 29 de mayo de 1996, ratificada por Ecuador y publicada en el Registro Oficial 70, 23-mayo-1977.
} 
Se otorgaron amplias facultades a la Comisión para investigar las denuncias; y se establecieron obligaciones de los funcionarios para entregar la información con documentos en veinte días y, frente al desacato, la Comisión podía solicitar a la autoridad nominadora la remoción del funcionario que se niegue o incumpla su obligación de informar. También podía otorgar protección legal para su seguridad personal a los denunciantes mediante las autoridades pertinentes; recibir declaraciones extraprocesales; designar peritos y personas especializadas para realizar investigaciones; ordenar a los miembros de la fuerza pública que presten protección oportuna e irrestricta a los miembros de la Comisión o sus delegados, con una sola petición verbal y la identificación oficial y remitir los informes finales de investigación a la Contraloría y al Ministerio Público para que actúen conforme a la Ley (Art. 7).

La Comisión cumplió una gran labor de investigación. Entre el 2000 y 2003, la CCCC recibió más de 2.560 reportes, de los cuales el $21 \%$ se iniciaron de oficio por iniciativa de la Comisión y el $79 \%$ a través de denuncias. Sin embargo, sus conclusiones e informes frecuentemente no fueron aceptadas por la Contraloría y, al no ser parte procesal en las acciones penales que se iniciaron, tampoco los juicios iniciados por casos de corrupción, investigados por la Comisión, prosperaron de manera eficaz, manteniéndose el tradicional clima de impunidad en los delitos de corrupción. La Comisión, no obstante, designó una Unidad Administrativa de Seguimiento que, entre 2000 y 2004, reportó haber vigilado 737 recomendaciones. ${ }^{674}$ Por ello, el 25 de febrero de 2003, se presentó un proyecto de reforma a la Ley para que la Comisión fuera considerada como parte procesal en los procesos penales que se originaron en denuncias de la Comisión; a pesar de haber sido aprobada en el Congreso Nacional fue objetada por el Ejecutivo. ${ }^{675}$

Entre las investigaciones más conocidas y difundidas por la propia Comisión (2005), por su impacto en la opinión pública nacional se encuentran las que se realizaron sobre el salvataje bancario entre 1999 y 2001, en el que importantes bancos del país colapsaron como resultado de créditos vinculados, especulación cambiaria, abuso de fondos públicos provistos por el Gobierno de turno y fuga de recursos a otros países. Los banqueros fueron parcialmente procesados, algunos excepcionalmente sentenciados y prófugos, mientras el Estado asumió el costo mayoritario del saqueo de recursos públicos y de particulares para proteger la estabilidad del sistema financiero privado nacional

También se investigaron, entre otros escándalos: los aportes a la campaña electoral de Jamil Mahuad; peculado en la AGD; créditos otorgados irregularmente en la Corporación Financiera Nacional; irregularidades en Petroecuador y en la contratación del proyecto hidroeléctrico San Francisco; irregularidades en varios gobiernos locales y organismos estatales como el Registro Civil, Ministerio de Salud, FISE, INDA,

${ }^{674}$ Ecuador, Comisión de Control Cívico de la Corrupción, Memorias 2000-2004, Cuenca, Monsalve Moreno.

${ }^{675}$ Víctor Granda Aguilar, Diputado, Proyecto de Ley No. 24-026, 25-febrero-2003. 
Aviación Civil, Fuerzas Armadas, etc.; la comercialización de materiales y equipos de oficinas (Red Peñaranda); irregularidades en la Defensoría del Pueblo en el cobro de indemnizaciones de migrantes; contratos de personal innecesario en el Congreso Nacional; abusos en las aduanas con donaciones destinadas a los damnificados por el fenómeno del Niño. Varias de las investigaciones motivaron informes de la Contraloría y en la mayoría de casos se iniciaron procesos penales, algunos de los cuales culminaron en sentencias condenatorias y otros permanecen en la impunidad, como el relacionado por el feriado bancario y abuso de fondos públicos contra el expresidente Mahuad, cuyo juicio se inició en los inicios del 2000 y aún no culmina el proceso, que se encuentra tramitando recursos para impedir una sanción definitiva. ${ }^{676}$

\section{El control interno}

Si bien, como lo hemos señalado, las actividades de control interno o de vigilancia de las actividades de la Administración y en especial de los recursos públicos, representan una tarea permanente del Gobierno en todos los tiempos, establecida tradicionalmente en las normas constitucionales, que le confieren al Ejecutivo la vigilancia de los ingresos y del buen uso de los bienes y recursos del Estado, su institucionalización ha seguido un proceso progresivo en todos los países del mundo.

El control externo político, técnico-financiero y jurisdiccional es una responsabilidad democrática del Estado y el control social un derecho y obligación de los ciudadanos, fundamentados en la división de poderes y funciones y en el derecho de participación y en la creciente exigencia ciudadana de exigir y gozar de los beneficios de un buen gobierno y de una excelente administración, que respeten sus derechos y les ofrezcan servicios y bienes públicos y privados de calidad.

Las actividades de control interno y externo administrativo-financiero y jurisdiccional constituyen un sistema de control global que se encuentra interrelacionado y en el que las funciones del Estado se complementan. Por tanto, las normas constitucionales y legales definen y regulan sus campos de acción y de vinculación y complementación para el perfeccionamiento, eficacia y eficiencia de la Administración y del buen y honesto uso de los recursos públicos.

En el tránsito del modelo económico intervencionista o estatista, que en Ecuador finalizó en los inicios de la década del 90, al modelo neoliberal o mercado céntrico hasta el 2007, se produjo una aguda crítica al exceso burocrático del Estado, a la mala calidad de los servicios públicos e ineficiencia de las empresas estatales, por lo que se plantearon, por iniciativa de los organismos financieros internacionales, "reformas estructurales" que no solo promovían las privatizaciones de las actividades económicas estatales y los servicios públicos, sino modificaciones sustanciales en cuanto a la

\footnotetext{
${ }^{676}$ Ecuador, Consejo de Participación Ciudadana y Control Social, Informe del 2016 y Juicio Nro. 442000 (actualmente $\mathrm{N}^{\mathrm{o}}$ 167-2009) contra Jamil Mahuad, reiniciado el 13 de junio de 2007 por petición presentada por Jorge Rodríguez y Víctor Granda el 14 de diciembre de 2006.
} 
organización y eficiencia del Estado, con la descentralización, la desconcentración y la delegación y con mejores sistemas de control externo e interno. El "adelgazamiento" del Estado no estaba acompañado con el debilitamiento del Gobierno, sino con el reforzamiento de su autoridad y de su eficiencia en el ámbito administrativo y financiero. Según esto, el proceso de transformaciones económicas estaban acompañadas por el fortalecimiento del autoritarismo gubernamental y el presidencialismo para una imposición exitosa de las reformas, pues estas ocasionaron importantes reacciones y movilizaciones sociales frente a sus fatales consecuencias en la mayoritaria población de escasos recursos y a la manifiesta corrupción con la que ciertas autoridades procedían a disponer alegremente de los recursos públicos.

La pregonada modernización del Estado redujo las potestades y atribuciones económicas, políticas, legislativas y de control del Congreso Nacional para trasladarlas preventivamente a la propia función ejecutiva, a la que se le otorgó no solo el control total del ciclo presupuestario, de las finanzas públicas y del endeudamiento, sino de su propia organización interna y de sus procedimientos. Aparentemente, se ampliaron las atribuciones de los órganos técnicos de control externo, se inició un proceso paulatino para trasladar el control interno y de gestión y la investigación de denuncias de corrupción a las propias instituciones públicas, mediante crecientes atribuciones otorgadas por el Ejecutivo a la Secretaría de la Administración Pública, que si bien tiene rango ministerial, oficialmente no se le reconoce esa denominación para evitar que sea objeto de fiscalización política externa.

El ERJAFE expedido por el presidente de la República en 1994, para sustituir solapadamente a la Ley de Régimen Administrativo y despojar al Congreso Nacional de su potestad legislativa organizatoria de la Función Ejecutiva, contenía normas básicas sobre la estructura de la Administración pública central e institucional; los procesos administrativos, su actividad jurídica, la responsabilidad patrimonial del Estado y los procedimientos y recursos administrativos. ${ }^{677}$

En el Estatuto se disponía que el presidente de la República tiene la potestad de "controlar y evaluar los logros y resultados de carácter fundamental alcanzados por los organismos, entidades y empresas de la función ejecutiva" y que estará asistido por el secretario general de la Administración, con rango de ministro de Estado, que será la máxima autoridad de la Secretaría General de la Administración pública, para facilitar la adopción de decisiones presidenciales, despachar los asuntos administrativos de la Presidencia y coordinar las actividades de la función ejecutiva y más funcionarios públicos. Entre las atribuciones de la referida dependencia se establecían las relativas a nombrar personal, celebrar contratos, certificar decretos ejecutivos, emitir acuerdos y resoluciones y reglamentos sobre la dependencia, dirigir todas los organismos de la Presidencia, aprobar el presupuesto, etc.

\footnotetext{
677 Víctor Granda Aguilar, Proyecto de Código Administrativo (I), Boletín Electrónico Spondylus,
} U.A.S.B., Quito, 30 de junio de 2016. 
En Agosto de 1998, el presidente Jamil Mahuad creó la Secretaría General de la Presidencia de la República a cargo de un funcionario, también con rango de ministro de Estado, con similares atribuciones a las del secretario general de la Administración pública, que luego se redujeron a la coordinación con ministerios y entidades de derecho público, para conferir delegaciones adecuadas para el buen funcionamiento de su dependencia y tener una Secretaría de Prensa. En noviembre del mismo año, el presidente creó, adicionalmente, una oficina de control de la función ejecutiva, tanto de la Administración central como institucional, para conocer las denuncias escritas de los ciudadanos plenamente identificados sobre los casos cuya investigación se considere necesaria y que se "relacionen con la honestidad y corrección en el desempeño de los funcionarios, empleados o trabajadores en el funcionamiento de los organismos o entidades; o en el manejo de los recursos públicos", para lo cual dispuso el apoyo económico del Ministerio de Finanzas, con las reformas presupuestarias que fueran del caso, y que todos los funcionarios y empleados públicos obligatoriamente colaboraran con la oficina para el cumplimiento de sus funciones. ${ }^{678}$

De esta forma, en los últimos diecisiete años se inició la estructuración de nuevas unidades de control interno en la función ejecutiva para conocer y tramitar denuncias de corrupción, y para controlar la gestión de las entidades públicas en cuanto a su eficacia y eficiencia, proceso que avanzó más significativamente en los años siguientes.

El presidente Gustavo Noboa amplió en 2002 las normas del ERJAFE para regular más extensamente, con un segundo libro, el procedimiento administrativo y la posibilidad de los ciudadanos de impugnar las resoluciones y decisiones de los órganos públicos en sede administrativa. En dichas reformas mantuvo como atribución presidencial "controlar y evaluar los logros y resultados de carácter fundamental alcanzados por los organismos, entidades y empresas de la función ejecutiva" y las de la Secretaría General de la Administración, por medio de una oficina de su Subsecretaría General, para conocer y tramitar las denuncias de corrupción. Se agregaron posteriormente varias normas para su trámite y se reconoce el derecho ciudadano a vigilar y fiscalizar los actos del poder público, por lo que todo funcionario tiene la obligación de permitir el acceso a la documentación y archivos que se hallen en su poder excepto los que la ley haya declarado reservados. Se dispuso también que las denuncias de actos corrupción, formuladas por ciudadanos u organizaciones gremiales, cívicas y populares, deberían constar por escrito, sus suscriptores estar debidamente identificados y que pudieran presentarse en cualquier dependencia pública y contra cualquier funcionario para que ser remitidas de inmediato a la Secretaría General de la Administración Pública, la que

\footnotetext{
${ }^{678}$ Ecuador, Presidencia de la República, Decreto Ejecutivo 2, Registro Oficial 3, 13-ago-1998 y Decreto Ejecutivo 302, Registro Oficial 69, 18-nov-1998, Ministerio de Finanzas, Acuerdo Ministerial 10, Registro Oficial 31, 8-mar-2000.
} 
reconocerá a los denunciantes el derecho de acceso al expediente y a ser parte del proceso investigativo, para ser notificados con sus resultados finales. ${ }^{679}$

\subsection{El control en la Constitución y la legislación de 2008 - 2017}

Con el advenimiento del neointervencionismo económico se fortalece el autoritarismo presidencial para promover las reformas propuestas por el socialismo del siglo XXI, para lo cual se realizaron ajustes en el control político para dificultar mucho más ese control, se procedió a debilitar paulatinamente el control técnico-financiero de la Contraloría hasta despojarla de su autonomía y de su competencia de control de gestión para trasladarlo a organismos dependientes directamente del presidente de la República y se estatizó el control social para neutralizar la denuncias e investigaciones de corrupción y controlar el mecanismo de designación de las autoridades de control para ubicar a funcionarios incondicionales del Gobierno.

\section{El control político}

En cuanto al control político, la nueva Constitución de 2008 incrementó la tendencia de la anterior de restringirlo en los procedimientos, si bien se reconocen formalmente las atribuciones de la Asamblea Nacional, para conocer los informes que debe presentar el presidente de la República y pronunciarse al respecto con el fin de fiscalizar los actos de las otras funciones del Estado y otros órganos del poder público, a excepción de la función judicial, y para "requerir a los servidores públicos las informaciones que considere necesarias".

Sobre el informe anual del presidente ante el pleno de la Asamblea Nacional, la Ley Orgánica de la Función Legislativa estableció que se referirá al cumplimiento del Plan Nacional de Desarrollo y a los objetivos que el Gobierno se propone cumplir. La Asamblea debe designar una comisión de análisis del informe para ser conocido en un solo debate antes de su pronunciamiento, sin que se prevea que se puedan exigir rectificaciones o aclaraciones y mucho menos establecer sanciones.

En cuanto al enjuiciamiento político del presidente y vicepresidente de la República, la Constitución dispone que solo se puede plantear durante su ejercicio, eliminando la norma que permitía el enjuiciamiento hasta un año después de terminado el mandato, "a solicitud de al menos una tercera parte de sus miembros" y "por delitos contra la seguridad del Estado, por delitos de concusión, cohecho, peculado o enriquecimiento ilícito". Además del incremento en el número de proponentes, ahora para iniciarlo se exige un "dictamen de admisibilidad de la Corte Constitucional" y para "la censura y destitución se requerirá el voto de las dos terceras partes de los miembros de la

\footnotetext{
${ }^{679}$ Ecuador, Secretaría General de la Administración Pública, Acuerdo Ministerial 10, Registro Oficial 31, 8-mar-2000; Decreto Ejecutivo 2428, Registro Oficial 536, 18-mar-2002; Presidencia de la República, Decreto Ejecutivo 122, Registro Oficial 25, 19-febrero-2003.
} 
Asamblea Nacional" (Art. 129), con lo cual el control político a las máximas autoridades del Estado resulta imposible y no se diga si a la vez se implementa un sistema de manipulación en las designaciones de los altos funcionarios del Estado y de las Cortes, mediante una supuesta meritocracia, en manos de comisiones de selección bajo la vigilancia y decisión del Consejo de Participación Ciudadana y Control Social y del Gobierno, en la que finalmente resultan beneficiados y designados personajes allegados al régimen, con lo que se anula el sistema de división democrática de poderes y funciones del Estado.

En cuanto al enjuiciamiento político de los más altos dignatarios del Estado y los ministros del Gobierno, la carta política dispone, a diferencia de un posible enjuiciamiento al presidente y vicepresidente de la República, que se puede realizar durante el ejercicio de sus cargos y hasta un año después de ejercerlos, "por incumplimiento de las funciones que les asignan la Constitución y la ley"; a solicitud de al menos una cuarta parte de los miembros de la Asamblea Nacional y su censura, destitución y un posible enjuiciamiento penal requiere de mayoría absoluta de sus miembros, con excepción de los ministros de Estado y miembros de la función electoral y del Consejo de la Judicatura, para los que se exige una votación calificada de dos terceras partes (Art. 131), que resulta casi imposible o muy difícil de conseguir.

Sobre la fiscalización y el control político, la Ley Orgánica de la función legislativa aprobada el 8 de julio de $2009^{680}$ regula la información documental y el enjuiciamiento político de los funcionarios públicos según establece la Constitución. A diferencia de la ley anterior, que facultaba al legislador pedir la comparecencia del funcionario a una comisión para que explicara la información enviada, esa atribución ahora se burocratiza y pasa a conocimiento del presidente de la Asamblea; este a su vez la traslada al Consejo de Administración Legislativa para que la remita a una comisión especializada, la que nuevamente pedirá información al funcionario para que la complete y entonces se fije su comparecencia, para que conteste en 40 minutos los cuestionamientos previamente planteados por escrito. Las preguntas se formularán en un máximo de diez minutos, habrá una réplica del funcionario de 20 minutos y sin que esté presente se analizarán las respuestas: si son satisfactorias se procederá al archivo de la petición o la mayoría de la comisión podrá solicitar al presidente de la Asamblea el inicio de un juicio político. También la ley prevé lo que se denomina investigación de oficio, cuando el Pleno o el Consejo de Legislatura disponen una investigación de las comisiones sobre las actuaciones de funcionarios en actos de interés ciudadano que causen conmoción o crisis política.

De igual manera, el trámite mismo del enjuiciamiento político se complica y burocratiza. En el caso de enjuiciamiento político a funcionarios se exige que la solicitud cuente con las firmas verídicas de una cuarta parte de los miembros titulares de la Asamblea y que se incluya el anuncio de la totalidad de pruebas que se presentarán,

${ }^{680}$ Ecuador, Ley Orgánica de la Función Legislativa, Registro Oficial-S 642, 27-jul-2009. 
acompañando la prueba documental que se disponga. Luego el presidente de la Asamblea la pone en conocimiento del Consejo de Administración Legislativa para que verifique si se cumplen los requisitos y disponga el inicio del trámite, entregándosela al presidente de la Comisión de Fiscalización y Control Político con la finalidad de que lo avoque y sustancie. La Comisión, nuevamente en cinco días, avocará conocimiento de la petición; verificará si se cumplen los requisitos constitucionales y se pronunciará sobre su archivo o el inicio del subsiguiente paso que comprende la notificación al inculpado con la petición y documentos entregados y el otorgamiento de un plazo de 15 días para que ejerza su derecho de defensa y presente las pruebas de descargo. En el mismo lapso, los solicitantes pueden presentar pruebas y la Comisión solicitarlas de oficio. Vencido el último plazo, la Comisión debe informar motivadamente, en los siguientes cinco días, que pueden ser prorrogados, las razones por las que se archivó la petición o se recomendó el trámite del juicio político. Entonces, el presidente de la Asamblea incorporará en el orden del día el juicio político y dispondrá, con notificación al inculpado, que los solicitantes designen dos asambleístas para realizar la interpelación. El funcionario ejercerá ante el pleno su derecho de defensa por tres horas; los interpelantes dispondrán de dos horas y se otorgará una hora adicional para la réplica; luego, en ausencia del funcionario, se abrirá el debate y, si no existiera moción de censura y destitución, se archivará la petición. La destitución requiere de mayoría absoluta, salvo en el caso de los ministros de Estado y de los miembros de la función electoral o del Consejo de la Judicatura, para la que se exige la casi imposible votación de las dos terceras partes de los miembros de la Asamblea.

Si el enjuiciamiento es al presidente o vicepresidente de la República, la petición debe referirse a las causales constitucionales; estar acompañada de la prueba documental de que se disponga y reunir la firma verídica de una tercera parte de los miembros totales de la Asamblea. En este caso, luego del trámite en el Consejo de Administración Legislativa, que puede ordenar que se lo complete o archive, se remite la petición a la Corte Constitucional para que, luego de un trámite especial, emita el dictamen previo de admisibilidad, que si es negativo retornará al primero para el archivo, y si es positivo al presidente de la Asamblea para que envíe el expediente al presidente de la Comisión de Fiscalización y Control Político para que avoque conocimiento e inicie un trámite adicional, con el que se notificará al inculpado para que ejerza su derecho de defensa personal o por medio de procuradores en cinco días, plazo en el cual los peticionarios también pueden presentar pruebas. Después de los referidos trámites, se envía el informe al presidente de la Asamblea, para que, luego de su difusión, incorpore el juicio en el orden del día para conocimiento del pleno. En este, el presidente o vicepresidente ejerce su derecho de defensa sin límite de tiempo, igual que sus dos interpelantes, y habrá derecho de réplica para el inculpado. Finalizadas las intervenciones, se abre el debate y luego de cinco días de concluido, se convoca a sesión para que motivadamente y sin debate, el pleno de la Asamblea resuelva. Si no hay moción de censura y destitución se archiva la solicitud. La moción de censura requerirá de la votación de las dos terceras partes de sus integrantes para que proceda la destitución. 
Durante la vigencia de la actual Constitución, más de ocho años, ningún grupo de legisladores ha podido tramitar hasta el final un juicio político a un ministro de Estado y mucho menos al presidente o vicepresidente de la República, con excepción del enjuiciamiento y censura a la exsuperintendente de bancos, Gloria Sabando, que se distanció del Gobierno y renunció. Su juicio político fue iniciativa del Ejecutivo y tramitado por los asambleístas afines al régimen. ${ }^{681}$ De la veintena de solicitudes de juicio político a ministros y otros altos funcionarios del Estado, entre 2008 y 2016 se archivaron un total de 19 por el Consejo de Administración Legislativa o por la Comisión de Fiscalización y Control Político, conocida también en las esferas políticas como la Comisión de Archivo. ${ }^{682}$

La Ley Orgánica de la Función Legislativa asigna además a una comisión especializada permanente de Régimen Económico y Tributario y su Regulación y Control, sin establecer para ella competencias específicas, por lo que se entiende que el control financiero parlamentario y en especial sobre el presupuesto le correspondería a ella, sin embargo, para diluir competencias, se incluye una norma general por la que se atribuye a todas las comisiones, "recibir, analizar, procesar y tramitar las peticiones de fiscalización y control político a las funciones Ejecutiva, Electoral y de Transparencia y Control Social, y los otros órganos del poder público y requerir a los servidores públicos la información que considere necesaria" (Arts. 21 y 26).

Dicha ley contempla también algunas normas relativas a la competencia de la Asamblea para aprobar la proforma presupuestaria anual, la programación presupuestaria cuatrienal y el límite del endeudamiento público. El trámite que se prevé para el análisis de la proforma presupuestaria en la comisión correspondiente es sumario: en 10 días debe elaborar un informe para que pase a consideración del Pleno, que en 30 días, en un solo debate y con mayoría absoluta de sus miembros, la pruebe o la observe, solo por sectores de ingresos y gastos, "sin alterar el monto global de la proforma"; si hay alguna observación parlamentaria, el Ejecutivo puede modificar o insistir en su propuesta original; si la Asamblea insiste en sus observaciones requiere del voto de dos tercios de sus integrantes, caso contrario entra en vigencia la proforma o programación enviadas en segunda instancia por la función ejecutiva. El aumento de gastos durante la ejecución presupuestaria debe ser aprobado por la Asamblea si supera los límites establecidos en la ley, lo que finalmente resulta inoficioso, ya que las modificaciones se hacen en tiempos distintos. Adicionalmente, la Ley dispone que la información sobre el ciclo presupuestario sea pública, por intermedio del portal web de la Asamblea, que en cada semestre el Ejecutivo envíe un informe sobre la ejecución presupuestaria, y que si no lo hace se podría solicitar la comparecencia del ministro del ramo (Arts. 102 - 107).

\section{Control externo: técnico financiero y social o ciudadano}

\footnotetext{
${ }^{681} \mathrm{http}: / /$ www.eluniverso.com/2011/01/08/1/1356/juicio-gloria-sabando-entra-recta-final.html

${ }^{682}$ El Universo, 1 de agosto de 2016, 2.
} 
En cuanto al control técnico-administrativo externo y el social o ciudadano, la Constitución de 2008 crea como nueva función del Estado la de transparencia y control social, en la que se incluyen el Consejo de Participación Ciudadana y Control Social, que sustituye a la Comisión de Control Cívico de la Corrupción; la Contraloría General del Estado, las Superintendencias y la Defensoría del Pueblo. Se proclama que "el pueblo es el mandante y primer fiscalizador del poder público, en ejercicio de su derecho de participación" (Art. 204), y, en virtud, de ello se institucionalizan o estatalizan, con evidentes fines de manipulación política, todas las instituciones de control y en especial las iniciativas de control social, popular o ciudadano.

Según la actual carta constitucional, los órganos de la Función de Transparencia y Control tienen autonomía administrativa, financiera, presupuestaria y organizativa y sus titulares ejercerán sus funciones por cinco años, un año más que el período presidencial y de los legisladores, tienen fuero de Corte Nacional, están sujetos a enjuiciamiento político y son seleccionados mediante un concurso de oposición y méritos, en los casos que proceda.

La nueva Función del Estado tiene como finalidad "promover e impulsar el control de las entidades y organismos del sector público y de personas que presten servicios o actividades de interés público" y para ello conforman una instancia de coordinación, con un presidente elegido cada año para formular políticas públicas y otras iniciativas sobre "transparencia, control, rendición de cuentas, participación ciudadana y prevención y lucha contra la corrupción"; coordinar un plan de acción de entidades sin afectar su autonomía; formular el plan nacional de lucha contra la corrupción; presentar reformas legales en su ámbito e informar a la Asamblea Nacional sobre sus actividades (Arts. $204-206$ ).

Nos referiremos a la Contraloría y al control social, que son los dos espacios desde los que se pueden realizar acciones de fiscalización y control de los recursos estatales y su buen uso. La Defensoría del Pueblo y las superintendencias ejercen el control del respeto de los derechos de los ciudadanos y la vigilancia de actividades de interés público, pero lo realizan fundamentalmente entes privados y por lo tanto no son objeto del presente estudio.

\section{La Contraloría}

En cuanto a la Contraloría General del Estado, la Constitución elimina su carácter de órgano superior de control que le otorgaba la carta política de 1998 al conformar la Función de Transparencia y Control Social. Ahora la define "como un órgano técnico encargado del control de la utilización de los recursos estatales y la consecución de los objetivos institucionales del Estado y de las personas jurídicas de derecho privado que dispongan de recursos públicos" (Art. 211). 
A la Contraloría se le otorgan las funciones de dirección del sistema de control técnico administrativo "que se compone de auditoría interna, auditoría externa y del control interno de las entidades del sector público y de las entidades privadas que dispongan de recursos públicos"; la potestad de "determinar responsabilidades administrativas y civiles culposas e indicios de responsabilidad penal"; la facultad "normativa (reglamentaria) para el cumplimiento de sus funciones" y la potestad de "asesorar a los órganos y entidades del Estado cuando se le solicite" (Art. 212).

Como se puede advertir, las potestades de control financiero externo que se otorgan a la Contraloría son integrales y se refieren no solo a la fiscalización posterior de los recursos, sino al control interno y externo y, simultáneamente, al control de gestión y de resultados de los objetivos de las instituciones públicas o privadas que dispongan de bienes y recursos públicos.

Cuando se expidió la Constitución de 2008, el contralor general del Estado de Ecuador, Carlos Pólit, enfatizó, en declaraciones públicas, que la nueva carta política garantizaba la independencia de la Contraloría para el ejercicio de sus funciones y que no solo facultaba a la entidad controlar "la utilización de recursos estatales, sino también, la consecución de los objetivos, tanto de las instituciones del Estado, como de las personas jurídicas de derecho privado que dispongan de recursos públicos".

Según el funcionario, con esa normativa, la Contraloría "ha adquirido la potestad de comparar en sus exámenes los objetivos previstos y los objetivos alcanzados, es decir, medir la eficiencia de las organizaciones". Relievaba que las indicadas normas constitucionales concebían "al control dentro de una concepción sistémica integrada por el control interno, la auditoría interna y el control externo" y conservaban la atribución de asesorar a los órganos públicos que lo solicitaran y la expedición de la normativa necesaria para cumplir con sus funciones.

El contralor consideraba también la conformación de la función de Transparencia y Control Social como una innovación positiva para que los organismos de control coordinen sus actividades y sostenía que la autonomía de la entidad se veía ampliada de lo administrativo, financiero y presupuestario a lo organizativo. De igual manera, apoyaba la decisión de que el contralor se designara mediante concurso de oposición y méritos y que se extendiera su período en el cargo a cinco años, para que el ejercicio de sus funciones no coincidiera con el período presidencial. Resaltaba, finalmente, que como el proceso planificador está sometido al examen de la Contraloría, esta puede también controlar los procesos de endeudamiento y los presupuestos públicos. ${ }^{683}$

Las auditorías gubernamentales y exámenes especiales, regulados por la Ley (LOCGE), son instrumentos de control externo e interno efectuados por la Contraloría a las

683 Carlos Pólit Faggioni, La Contraloría General del Estado en el Ordenamiento Jurídico Constitucional, (Quito: Nina Comunicaciones, 2009), 175 - 179. 
instituciones públicas o a las entidades que perciban recursos públicos, sea en la adquisición de bienes, como en la construcción de obras y prestación de servicios, partiendo del análisis del cumplimiento de sus objetivos en el marco de sus competencias.

Según la ley y la práctica moderna de las Entidades Fiscalizadoras Superiores de la región y el mundo, la auditoria y el control no son un conjunto aislado de actividades, sino un sistema complejo que incluye necesariamente el análisis de la utilización de los fondos públicos, conjuntamente con la gestión y la consecución de los objetivos institucionales. Por ello, la Contraloría puede formular a los funcionarios e instituciones, en sus acciones de control y en la ejecución de los proyectos, recomendaciones obligatorias que deben ser cumplidas por aquellos inmediatamente, ya que están sometidas a una constante verificación; y establecer, a la vez, responsabilidades administrativas, civiles culposas e indicios de responsabilidad penal, con la finalidad de fortalecer el control integral sobre la Administración en el manejo eficiente y correcto de los fondos públicos. ${ }^{684}$

La Contraloría está organizada en la actualidad con siete unidades de control de carácter nacional, 23 delegaciones provinciales y 345 unidades de auditoría interna en las instituciones más importantes del país.

Desde enero de 2007 hasta marzo de 2016, la Contraloría informó que ha recuperado para el Estado 350 millones de dólares y no ha podido recuperar 854 millones de dólares de sus múltiples acciones de control a casi seis mil entidades del país, en nueve años de gestión de sus actuales autoridades. En este período, la Contraloría ha realizado más de 440 auditorías de gestión y "ha establecido 39.409 responsabilidades civiles, de las cuales 26.280 fueron glosas, 12.129 órdenes de reintegro, mientras que los casos en los que se estableció indicios de responsabilidad penal llegaron a 1.939, de los cuales 1.859 fueron remitidos a la Fiscalía". ${ }^{65}$

Adicionalmente, la Contraloría informó que de los casos referidos con indicios de responsabilidad penal, 412 pasaron a instrucción fiscal, esto es, fueron acusados ante un tribunal penal; el 34\% restantes, o sea cerca de 700 casos, siguen en investigación y más de 700 fueron archivados o desestimados por falta de evidencias, lo que da una visión del alto grado de impunidad y baja credibilidad que el Estado otorga a los informes de la Contraloría. ${ }^{686}$

En la rendición de cuentas de la Contraloría, correspondiente a 2011, se informó que se han ejecutado 3.297 auditorías y exámenes especiales, sin incluir los informes aprobados con indicios de responsabilidad penal, de los cuales se han emitido 683 informes aprobados, 747 acciones que se encuentran en ejecución y 1.465 informes en

\footnotetext{
${ }^{684}$ Ecuador, Contralor General del Estado Carlos Pólit, Rendición de Cuentas, 17 de marzo de 2016.

${ }^{685}$ El Comercio de 24 de marzo de 2016, 2.

${ }^{686} \mathrm{El}$ Comercio de 3 de noviembre de 2016.
} 
proceso de control previo. El monto de recursos públicos examinados en ese año asciende a más de 36 mil millones de dólares y las responsabilidades administrativas y civiles culposas ascienden a casi 55 millones de dólares y los indicios de responsabilidad penal en 157 informes superan los 15 millones de dólares. ${ }^{687}$

La Contraloría General del Estado de Ecuador realizó en 2015 la suma de 2.128 auditorías externas gubernamentales y exámenes especiales y 1.421 auditorías internas, sumando más de 300 a las efectuadas el año anterior; se elaboraron en su totalidad 3.549 informes y se establecieron 314 informes con indicios de responsabilidad penal. De las 2.128 acciones de control externo a un monto de recursos examinados que supera los 155 mil millones de dólares, 17 corresponden a auditorías de gestiones propiamente dichas y 1.243 a exámenes especiales con contenido financiero y enfoques de gestión. Del total de 2.128 informes, 1.187 son generales y 257 contienen indicios de responsabilidad penal y en las 1.421 auditorías internas, 1.364 tienen informes generales y 57 con indicios de responsabilidad penal. En este año de gestión, la Contraloría estableció también 1320 responsabilidades civiles culposas por un monto de 122`233.878,22 dólares; 413 responsabilidades civiles con orden de reintegro por 10`953.200,91 dólares y 14.802 responsabilidades administrativas culposas por un monto de $15^{\prime} 870.529,00$ dólares. Todo lo cual da un total de 16.535 predeterminaciones por un monto de $149^{`} 057.608,13$ dólares. ${ }^{688}$

Durante la vigencia de la Constitución de 2008 se han realizado varias reformas a la Ley Orgánica de la Contraloría General del Estado, que siendo preconstitucional se consideraba inicialmente que sus normas eran compatibles con aquella, pero las reformas dictadas posteriormente, a nuestro juicio, disminuyen en lo fundamental algunos avances que en materia de control se incluyeron en el texto original de la LOCGE (2002). Sin embargo, también se expidieron algunos cambios que agilizan el tiempo de duración para la presentación de los informes de auditoría, pues se redujo de un año a 180 días, mientras que el de aprobación por parte del contralor o su delegado, a un término de 30 días, ${ }^{689}$ y se amplió a siete años el plazo para la caducidad en el ejercicio de las facultades de la Contraloría. ${ }^{690}$

Las reformas que implican un retroceso para las atribuciones que tenía la Contraloría se refieren a limitar sus atribuciones en el control de los grandes contratos públicos, a modificar el régimen jurídico de los gastos reservados, a eliminar sus potestades de control externo de las fases del ciclo presupuestario y a reducir su autonomía económica.

\footnotetext{
${ }^{687}$ Ecuador, Contraloría General del Estado, Rendición de Cuentas 2011.

${ }^{688}$ Ecuador, Contralor General del Estado Carlos Pólit, Rendición de Cuentas 17 de marzo de 2016.

${ }^{689}$ Ecuador, Código Orgánico Integral Penal, disposiciones reformatoria, décimo segunda que sustituye artículo 26 de la Ley Orgánica de la Contraloría General del Estado, Registro Oficial-S 180, 10-feb-2014. ${ }^{690}$ Ecuador, Ley s/n, Ley Orgánica Reformatoria a la Ley Orgánica de la Contraloria General del Estado, Registro Oficial-S 1, 11-ago-2009.
} 
En la Ley sobre el nuevo Sistema de Contratación Pública, aprobada en la Asamblea Constituyente, se derogó expresamente la norma que autorizaba a la Contraloría a emitir informes razonados previos a la celebración de contratos de las instituciones del Estado y que implicaran egresos por un monto igual o mayor al del concurso público de ofertas. $^{691}$

De igual manera y mediante ley, en 2009 se modificó el concepto de fondos reservados que antes solo se destinaban a la defensa nacional y ahora a la seguridad nacional. Si se recuerda que hace algunos años se enjuició y se separó de sus funciones a un vicepresidente de la República por el uso abusivo de fondos reservados en asuntos políticos y personales, el cambio no es inocente, ya que por esa razón se legisló antes que se podían utilizar fondos públicos reservados solo en la defensa nacional y al destinarlos ahora a la seguridad nacional se abre todo un espacio de discrecionalidad favorable a la conveniencia del Gobierno. ${ }^{692}$

En el Código Orgánico de Planificación y Finanzas (2010) se derogó implícitamente la Ley de Presupuestos, en la que se confería a la entidad de control de manera expresa el control previo, concurrente y posterior del Presupuesto General del Estado. Al referirse a la fase de seguimiento y evaluación, el código dice que comprende la medición de resultados físicos y financieros obtenidos y los efectos producidos y que de dicha evaluación y resultados que incluyen, según el Reglamento, el cumplimiento de metas y objetivos, eficiencia y eficacia del gasto en programas, proyectos y actividades institucionales, son responsables los titulares administrativos de cada entidad, que enviarán, periódicamente, los informes al respecto al ente rector de las finanzas públicas, que es el presidente y el Ministro de Finanzas, y a la SENPLADES, para luego ser difundidos a la ciudadanía. Esto es, en dicho código se excluye totalmente a la Contraloría de sus labores de control al presupuesto general del Estado, anticipando la intención que expresó el Ejecutivo con el impulso de las enmiendas constitucionales de 2015, para eliminar como competencias constitucionales de la Contraloría el examen del cumplimiento de los objetivos institucionales y la posibilidad de establecer responsabilidades en los asuntos de gestión administrativa. ${ }^{693}$

El financiamiento que otorgaba autonomía financiera a la Contraloría, con el aporte del cinco por mil de los ingresos de las instituciones sometidas a su control, se sustituyó en 2014 con la antigua norma de que su presupuesto se financiará "con la asignación que se le entregue a través del presupuesto general del Estado", instrumento en el que la

\footnotetext{
${ }^{691}$ Ecuador, Ley s/n, Ley Orgánica del Sistema de Contratación Pública, Registro Oficial-S 395, 4-ago2008.

${ }^{692}$ Ecuador, Ley s/n, Ley Orgánica Reformatoria a la Ley Orgánica de la Contraloria General del Estado Registro Oficial-S 1, 11-ago-2009.

693 Ecuador, Código Orgánico de Planificación y Finanzas Públicas, Registro Oficial 306, 22-oct-2010; Reglamento General del Código Orgánico de Planificación y Finanzas Pública, (DE-489) Registro Oficial 329, 26-nov-2010.
} 
función ejecutiva tiene manejo absoluto sobre todo el ciclo presupuestario, si bien se agregó que la Contraloría puede obtener "recursos de autogestión". 694

En el informe de rendición de cuentas de 2015 que presenta el contralor general del Estado, consta también la activa relación internacional del principal órgano de control externo del Estado con la INTOSAI (Organismo Internacional de Entidades Fiscalizadoras Superiores) al formar parte de su Comisión Financiera y Administrativa; con la OLACEFS (Organización Latinoamericana y del Caribe de las Entidades Fiscalizadoras Superiores) y con las Entidades Fiscalizadoras Superiores del MERCOSUR y EFSUR. En dichas entidades prospera también el concepto de que las auditorías y las acciones perfeccionadas que realizan en la actualidad los entes superiores de fiscalización, implican un sistema complejo en el que no solo se examinan los recursos estatales utilizados, sino la consecución de los objetivos institucionales.

Respecto de la gestión de la Contraloría en los últimos diez años existe una percepción social de ineficacia en las acciones de control, no solo por el resultado en la recuperación de fondos que es ínfima en relación con el monto total de recursos auditados, sino por la falta de acción oportuna de la Fiscalía cuando le han remitido indicios de responsabilidad penal, como lo ha manifestado en varias oportunidades el mismo contralor del Estado. Pero además existe la sensación, pese a las declaraciones de las autoridades, que la gestión del organismo de control en la última década no es independiente ni del Gobierno ni de sectores políticos poderosos, ya que en las obras más grandes del primero y en las enormes inversiones de entidades como el municipio de Guayaquil no se han realizado oportunamente auditorías sobre la gestión y la calidad del gasto en las que se establezcan responsabilidades en las modificaciones de precio desde el inicio de grandes obras públicas hasta su culminación.

\section{El Consejo de Participación Ciudadana y el control social estatizado}

El Consejo de Participación Ciudadana y Control Social que crea la actual Constitución de 2008 pretende estatalizar o estatizar, a favor de los intereses del régimen, la participación ciudadana y el control anticorrupción, pues a nombre del pueblo ecuatoriano se realiza, por medio de dicho ente público, la selección y designación de autoridades de los órganos de poder que antes eran nombrados por el Congreso o la Asamblea Nacional y el control de las veedurías ciudadanas, los mecanismos de rendición de cuentas y la lucha anticorrupción, tanto en el trámite e investigación de denuncias, como en su actuación como parte procesal "en las causas que se instauren como consecuencia de sus investigaciones" (Art. 208). Atribuciones que antes no tenía la Comisión de Control Cívico de la Corrupción que era eminentemente de carácter social y no gubernamental.

${ }^{694}$ Ecuador, Código Orgánico Monetario y Financiero, Registro Oficial-2S 332, 12-sep-2014. 
Según la Constitución de 2008, el Consejo de Participación Ciudadana y Control Social tiene por objeto: promover el ejercicio de derechos de participación; impulsar mecanismos de control social en los asuntos de interés público y designar autoridades de las instancias de control que le correspondan. El Consejo se conforma con siete consejeros principales y suplentes y un presidente que se elige entre ellos y será su representante legal. La selección de los consejeros se realiza entre postulantes propuestos por organizaciones sociales y ciudadanía, por concurso de méritos y oposición organizado por el Consejo Nacional Electoral, con veeduría y derecho de impugnación ciudadana.

Entre los deberes, atribuciones y medios de acción más relevantes del CPCCS, la Constitución establece: formar a los ciudadanos en valores, transparencia y lucha anticorrupción; establecer mecanismos de rendición de cuentas y veedurías; investigar denuncias sobre actos que generen corrupción o afecten la participación; elaborar informes que determinen indicios de responsabilidad; formular recomendaciones para impulsar acciones legales; ser parte procesal en causas investigadas; proteger a quienes denuncien actos de corrupción y organizar procesos de selección mediante la conformación de comisiones ciudadanas para designar a las autoridades establecidas en Constitución, como el procurador del Estado y superintendentes de las ternas propuestas por el presidente de la República; defensor del pueblo, defensor público, fiscal general, contralor general, miembros del Consejo Electoral, Tribunal Contencioso Electoral y Consejo de la Judicatura, luego de los correspondientes procesos de selección. ${ }^{695}$

La Ley Orgánica del Consejo de Participación Ciudadana y Control Social, en lo relacionado con sus finalidades y competencias, establece medios y acciones financieros, jurídicos y técnicos para incentivar, mediante fondos concursables y otros apoyos: la participación, el control social, la transparencia la lucha contra la corrupción; el acceso a archivos de información y la capacitación. Asimismo provee y apoya técnicamente el control social, las veedurías, los observatorios y demás espacios de control social; regula los procesos de revocatoria y consulta popular y establece mecanismos de evaluación y exigencias en la rendición de cuentas anual y pública, con información precisa, suficiente y lenguaje asequible.

En cuanto a la transparencia y lucha anticorrupción se dispone crear una Secretaría Técnica que promueva políticas de transparencia, ética pública y acceso a la información; requiera información para investigaciones y procesos, pida sanciones y emita informes con validez probatoria y que determinen indicios de responsabilidad además de recomendar e impulsar acciones legales como parte procesal y de solicitar a la Fiscalía protección a quienes denuncien o testifiquen en investigaciones del Consejo.

Según la ley, las denuncias de corrupción se deben receptar de forma oral o escrita y tendrán que ir acompañadas de la correspondiente documentación. Se califican si

${ }^{695}$ Ecuador, Constitución de la República 2008, (arts. 207 al 210). 
cumplen los requisitos y si no existe proceso judicial en curso. Las denuncias sobre actos u omisiones que generen corrupción se tienen que tramitar e investigar según un reglamento. Durante la investigación se pueden solicitar medidas cautelares a los jueces y se guardará reserva y protección del denunciante. Se elaborarán, finalmente, informes escritos, motivados y concluyentes por parte del Pleno del CPCCS y se adoptarán medidas para resguardar los archivos y la información. El CPCCS está obligado además a dar seguimiento a los procesos judiciales o administrativos que se inicien con sus informes y de acuerdo a las recomendaciones formuladas. El Consejo es parte procesal en juicios y está autorizado para la presentación de acusación particular cuando se determinen indicios de responsabilidad penal. ${ }^{696}$

El reglamento de trámites de las denuncias de corrupción contempla, a la vez, las normas generales sobre la materia; la forma de presentación; la admisión y sustanciación de las mismas; la asignación del expediente; el desarrollo de la investigación de las denuncias siguiendo el debido proceso; la duración del trámite y el tiempo para la emisión de la resolución. Dentro del trámite se puede requerir información; presentar recurso de acceso a información; formular petición de medidas cautelares para impedir actos de corrupción o suspender hechos o actos que perjudiquen la investigación; realizar investigaciones de campo; incorporar pruebas, etc. Se considerarán también, antes de resolver, los informes de la secretaría de transparencia y de las veedurías ciudadanas y se elaborará un proyecto de informe motivado para conocimiento del pleno, en el que se decidirá el archivo o la aprobación del informe con indicios de responsabilidad. Se puede solicitar, finalmente, ampliación o aclaración y remisión a la Subcoordinación de Patrocinio para definir estrategias e iniciar las acciones legales correspondientes.

El reglamento se refiere al trámite de pedidos y solicitudes ciudadanas no atendidas por autoridad o personas que prestan servicios públicos, en el que se establece un tiempo de admisión y la definición al respecto de acciones y diligencias realizadas en los siguientes 30 días, luego de lo cual, se deberá elaborar un informe sobre lo pedido o solicitado. El reglamento impone también la obligación de la Secretaría Técnica de presentar un informe al pleno del Consejo, cuatrimestral sobre el trámite de las denuncias de corrupción y trimestral sobre el registro y reporte de los pedidos admitidos o archivados. 697

Luego de revisar las normas relativas a las atribuciones y competencias de la nueva función del Estado de Transparencia y Control Social y del Consejo de Participación Ciudadana y Control Social en Ecuador, nos parece conveniente observar que la

\footnotetext{
${ }^{696}$ Ecuador, Ley Orgánica del Consejo de Participación Ciudadana y Control Social, Registro Oficial-S 22, 9-sep-2009.

697 Ecuador, Consejo de Participación Ciudadana y Control Social, Reglamento para el trámite de denuncias y pedidos sobre actos u omisiones que afecten la participación o generen corrupción. Resolución 005-242- CPCCS- 2013. Registro Oficial 21, 24-jun-2013; El 26 de noviembre de 2015, se dictó un nuevo Reglamento de Gestión de pedidos y denuncias sobre actos u omisiones que afecten la participación o generen corrupción No. PLE-CPCCS-022-26-11-2015.
} 
iniciativa y la decisión constitucional en lo jurídico, político y doctrinario, tiene varios aspectos sobre lo que es necesario reflexionar.

Agrupar a los órganos del poder público que realizan control técnico externo, pues resulta inviable sumar también a los que realizan, histórica y funcionalmente, control político y control interno, es evidentemente conveniente y útil, para un eficaz funcionamiento del Estado, ya que permite que dichos órganos puedan coordinar y hacer eficaces sus tareas específicas de control, destinadas a fortalecer la democracia y el equilibrio y control mutuo entre las funciones estatales, para evitar el autoritarismo, el abuso de poder y el mal uso y corrupción en la utilización de los recursos públicos. La coordinación permite, sin duda, definir de manera conjunta políticas, planes y acciones y promover una legislación de control más avanzada y perfeccionada, que enfrente y disminuya los efectos nocivos de la corrupción, adoptando medidas que sobre este flagelo son acordes con la realidad actual del mundo y del desarrollo científico y tecnológico.

Sin embargo, si las funciones del Estado ejercen potestades específicas otorgadas soberanamente por el pueblo por medio de la Constitución, se debe garantizar que su origen y su designación surjan democráticamente de órganos directamente elegidos por el mismo. La manifestación soberana del pueblo se expresa genuinamente en una Asamblea Nacional o en un Congreso de diputados o de representantes, integrada plural y proporcionalmente con todas las expresiones políticas de la decisión popular. Ese órgano máximo de la soberanía que dicta la Constitución y las leyes, debería ser el único autorizado para conformar y controlar otros órganos unipersonales o colectivos que ejerzan otras actividades especializadas de la función pública, como la administrativa, la jurisdiccional y el control técnico. En los regímenes parlamentarios los titulares de las funciones del Estado son designados por el órgano máximo de la soberanía popular. En los regímenes presidencialistas, el pueblo no solo elige a los integrantes de la función legislativa a los que les da también la potestad del control político sobre las otras funciones y órganos máximos del Estado, sino al titular de la función ejecutiva y administrativa, que es la más numerosa y compleja en la estructura del Estado, pues abarca sus mismas actividades. De manera conjunta, la función legislativa y la ejecutiva generalmente ejercen la potestad de elegir a los titulares de otras actividades especializadas del Estado como son las de juzgar y la de controlar.

En Ecuador, la designación de los órganos de control y de la función judicial, por parte de la Asamblea o del Congreso Nacional o del Ejecutivo o de manera mixta por los dos, como resultado de pactos políticos, desprestigió su nombramiento y desempeño, pues era manifiesto su ejercicio al servicio de intereses personales-partidistas. Por ello, en la sociedad primero y luego en la Asamblea Constituyente de 2007, se planteó que la designación se realizara mediante procedimientos meritocráticos, por medio de concursos dirigidos y controlados por comisiones ciudadanas o por un Consejo de Participación Ciudadana, que sin tener origen democrático en elecciones generales asumieran la representación social para, en su nombre y luego de las impugnaciones a 
los candidatos si las hubiere, proceder a la designación de los titulares de los órganos de control y aún de los magistrados o jueces de la Corte Nacional de Justicia o de la Corte Constitucional.

Este proceso de selección y de designación de los titulares de la función judicial, función de transparencia y control y de la función electoral, hubiera mejorado el sistema de selección de los titulares de los órganos jurisdiccionales y de control, si los referidos consejos o comisiones tuvieran un origen democrático y si no fueran resultado de una selección controlada e indebidamente dirigida por el poder Ejecutivo, para que solo sus allegados fueran los que triunfaran finalmente en dichos concursos, designados para tan altas funciones, con lo que se desvirtuó el procedimiento y se arribó a un mayor estado de deterioro institucional, pues es evidente el control autoritario por parte del Ejecutivo de la función judicial, del Consejo de la Judicatura, de la función electoral y de todos los órganos de control como la Contraloría, la Fiscalía General, las superintendencias, etc. El remedio resultó peor que la enfermedad, pues antes los órganos de control y las Cortes y Tribunales se repartían por cuotas políticas de los partidos que tenían representación parlamentaria y que en todo caso garantizaban una representación plural, con el nuevo sistema y la manipulación de los concursos, los triunfadores en su totalidad pertenecen al partido oficial o son allegados al régimen, destruyendo su naturaleza plural y consolidando la concentración de poderes por parte de la función ejecutiva.

Por ello, en la actualidad se discute si en Ecuador es un avance o un retroceso la creación de una función de transparencia y control social y del Consejo de Participación Ciudadana y Control Social y de haberle otorgado a este la potestad de designación de los más altos funcionarios de control del Estado y el combate a la corrupción.

Juan Pablo Aguilar, al analizar la creación de una Cuarta Función del Estado de Control, en la nueva Constitución de Ecuador, dice que se trata de una ficción sobre la representación y la participación. Manifiesta que el supuesto poder popular no está pensado desde la sociedad sino como una función del Estado en manos de quien tiene el poder, ya que en ella la sociedad no controla la actividad pública sino que es la misma institucionalidad del Estado la que se adjudica su propio control. Asegura también que con la nueva función, quien tiene en sus manos el poder popular no es el pueblo, sino un grupo de funcionarios que asume su representación, que surgida del voto, se sustituye por un sistema de selección cercana del corporativismo que crea una instancia intermedia para designar máximas autoridades de los organismos estatales. Sostiene que la supuesta designación apolítica de las autoridades es una quimera, pues ese discurso se convierte en máscara del poder, ya que el Estado no es espacio de participación sino de ejercicio del poder y sigue conservando su esencia de instrumento de dominación y control social. El Estado, dice finalmente, asume la participación como propia para 
matarla o volverla inofensiva; la participación exige no un aparato burocrático sino una sociedad civil organizada. ${ }^{698}$

Enrique Ayala, refiriéndose tanto a la nueva función del Estado como al Consejo de Participación Ciudadana y Control Social especialmente, manifiesta que dichas estructuras son un retroceso grave que "no tiene sustentación jurídica ni necesidad real" pues su integración no es producto de una elección ciudadana y por lo tanto no tienen representación. Argumenta que es un "poder sin base"; que "no profundiza la democracia"; que es una "instancia burocrática", no representativa; que los concursos que promueve el Consejo son una "farsa" y que no termina habiendo ni meritocracia por el abuso en el papeleo ni democracia real; que las críticas al sistema de representación y a los métodos de elección anterior no justifican un "remedio peor que la enfermedad"; que la organización de la sociedad debe ser promovida y respetada y no suplantada por el Estado y que el "corporativismo o gremialismo" es diferente a la organización y representación social cuando se encuentra presente en la institucionalidad pública. Ayala cuestiona a las atribuciones conferidas al Consejo de Participación Ciudadana y Control Social que lo considera, además, "un mecanismo de concentración de poder de un caudillo", si bien dice que, tergiversando y manipulando la historia, sus mentores lo justifican afirmando que la idea se inspira en el pensamiento de Bolívar cuando planteó en Venezuela crear un poder moral" o "moderador" de dos cámaras para promover la moral y la educación, y en Bolivia la creación de un poder de "censores" para controlar al presidente, pues los Congresos se reunían cada dos años. ${ }^{699}$

En el escueto informe presentado a la Asamblea Nacional por la Función de Transparencia y Control Social el 11 de abril de 2016, su propio presidente relata la amplia labor de difusión del Plan Nacional de Prevención y Lucha contra la Corrupción 2013 - 2017 y del Pacto Social Nacional propuestos para el efecto, que contienen una serie de acciones e iniciativas conjuntas para la promoción de los organismos de control, mediante talleres y otros eventos. También se da cuenta de una serie de reuniones preparatorias, con expertos extranjeros y con actores nacionales, para la expedición en diciembre de 2015 de las políticas generales de protección de datos personales que protegen los derechos de los ciudadanos y de las entidades que conforman la función de transparencia y control social. Con esa misma finalidad, los personeros de la nueva función estatal participaron en el XIII Encuentro Iberoamericano de Protección de Datos en Lima (2015) y en el seminario internacional denominado Los nuevos retos de la privacidad y los tratamientos masivos de los datos personales, promovido por la Agencia Española de Cooperación Internacional para el Desarrollo (AECID). ${ }^{700}$

\footnotetext{
${ }^{698}$ Juan Pablo Aguilar, "La cuarta función del Estado. Análisis de una ficción” en La nueva Constitución de Ecuador, Santiago Andrade y otros, editores, (Quito: Universidad Andina Simón Bolívar, Sede Ecuador-Corporación Editora Nacional, 2009).

${ }^{699}$ Enrique Ayala Mora, Porque la Asamblea Constituyente, (Quito: Ediciones La Tierra, 2015).

${ }^{700}$ Ecuador, Informe de labores 2015 de Carlos Ochoa, presidente de la Función de Transparencia y Control Social a la Asamblea Nacional, 21 de enero de 2016.
} 
De igual manera, en el informe de 2015 del Consejo de Participación Ciudadana y Control Social, se puede constatar que la entidad consume su presupuesto y su tiempo en orientaciones sobre rendición de cuentas; modelos de transparencia, participación y control social; organización de veedurías y observatorios y en la organización de eventos y encuentros para socializar y difundir las metas que persigue sobre los mismos temas y sobre la lucha anticorrupción, en el marco de los convenios internacionales suscritos por Ecuador sobre la materia.

Dicho informe reconoce que de los 364 expedientes, heredados por el CPCCS en el 2008-2009 de la excomisión de Control Cívico de la Corrupción y de la ex Secretaría Anticorrupción, organizada inicialmente por la Presidencia de la República, se tramitaron apenas 132, de los cuales en 17 se ha dispuesto recuperar información mediante acciones administrativas y judiciales y 115 fueron enviadas al archivo por haber culminado su trámite, mientras otros 120 se cerraron por la negativa de ciertas instituciones de entregar información pública.

El informe registra también que en 2015, en el principal órgano ciudadano-estatal de combate a la corrupción, se han receptado apenas 88 denuncias; de las cuales 44 se encuentran en investigación y 37 han culminado con informes concluyentes. Se difunde, como un extraordinario éxito, el haber aprobado recientemente, en noviembre de 2015 , un nuevo "Reglamento de Gestión de pedidos y denuncias sobre actos u omisiones que afecten la participación o generen corrupción" que contiene adicionalmente nuevos protocolos para garantizar la reserva del nombre del denunciante, de la documentación, del caso denunciado y del proceso de admisibilidad, investigación y patrocinio, así como la atención en la orientación jurídica a la ciudadanía. ${ }^{701}$

\section{El control social y popular autónomo}

Retomando la experiencia de 1997, en la que la sociedad movilizada, frente a numerosos casos y denuncias de corrupción, exigió al presidente de la República la conformación de una Comisión de Control Cívico de la Corrupción integrada por representantes de entidades sociales y ciudadanas, y luego de la experiencia frustrante e ineficaz de conformar órganos de control agrupados en una nueva función del Estado, en la que, supuestamente se ha reforzado sus atribuciones y a uno de ellos se le ha otorgado la potestad de combatir la corrupción y de escoger y seleccionar a los más altos funcionarios de Control del Estado, del Consejo Electoral y de los órganos jurisdiccionales que antes eran elegidos por la Asamblea o el Congreso Nacional, en el 2015, algunos ciudadanos constituyeron primero un Observatorio Electoral y las organizaciones populares, sindicales, campesinas, indígenas, de maestros, estudiantes y profesionales, agrupados en el Comité Unitario de Organizaciones Sociales y Populares, decidieron conformar, con personajes representativos de la sociedad por su trayectoria de vida, una Comisión Anticorrupción para ocuparse de la labor de fiscalización y

${ }^{701}$ Ecuador, Informe del Consejo de Participación Ciudadana y Control Social, 2015. 
control popular de proyectos de infraestructura de gran costo económico, que los titulares de las dos nuevas funciones del Estado, la de Control y la Electoral, no la realizan por haberse convertido en instrumentos incondicionales de la función ejecutiva. $^{702}$

Para el impulso de esta iniciativa social se partió del reconocimiento de las convenciones internacionales contra la corrupción, aprobadas en el marco de las Naciones Unidas (2003) y a nivel interamericano (1996), que apoyan y exigen a los estados miembros que respeten y fomenten la organización social independiente de lucha contra la corrupción. La decisión de las organizaciones sociales y populares también se fundamentó en las normas pertinentes de la carta política vigente de 2008.

En efecto, la Constitución reconoce como derechos ciudadanos individuales y colectivos y no estatales: el control, la lucha anticorrupción y la participación. Por ello autoriza expresamente a los ecuatorianos: "Fiscalizar los actos del poder público" (Art. 61); "el control popular de las instituciones del Estado y la sociedad y de sus representantes en un proceso permanente de construcción de poder ciudadano" (Art. 95); "el control social de todos los niveles del Gobierno así como de las entidades públicas y privadas que presten servicios públicos" (Art. 96); el derecho a demandar por "daños ocasionados por los entes públicos y privados" y a "formular propuestas y reivindicaciones económicas, políticas, ambientales, sociales y culturales y las demás iniciativas que contribuyan al buen vivir" (Art. 97); y "el pueblo es el mandante y primer fiscalizador del poder público en ejercicio de su derecho a la participación" (Art. 204).

Estos derechos y garantías permiten que la ciudadanía y a los entes sociales que puedan organizar, sin supeditación estatal o gubernamental, iniciativas transitorias o permanentes para su ejercicio, tanto más que esa protección y derechos se encuentran consignados en los convenios internacionales sobre la materia a los que hemos hecho referencia.

La Constitución permite también instaurar "en todas los niveles de Gobierno instancias de participación" para "fortalecer la democracia con mecanismos permanentes de transparencia, rendición de cuentas y control social", mediante "audiencias públicas, veedurías, asambleas, cabildos populares, consejos consultivos, observatorios y demás instancias que promueva la ciudadanía" (Art. 100) y la posibilidad de participación directa en la gestación de las leyes, de las políticas públicas y en las decisiones administrativas como la iniciativa de la "silla vacía" en los gobiernos autónomos descentralizados (Art. 101).

${ }^{702}$ En Quito, el 13 de abril de 2015 se conformó un Observatorio Electoral Ciudadano y el Comité Unitario de Organizaciones Sociales y Populares en su Convención de Riobamba de 30 de Mayo de 2015 conformó una Comisión Nacional Anticorrupción que se estructuró con su propio estatuto y realiza denuncias sobre irregularidades en la gran obra pública nacional contratada durante el gobierno de Rafael Correa. 
Para manipular los referidos espacios de participación y control social establecidos en la Constitución, el régimen promovió la expedición de la Ley de Participación Ciudadana con la que se controla su designación, ${ }^{703}$ desconociendo la aplicación directa y sin supeditación a ninguna norma de los derechos constitucionales, y cuando aquella no se la logra, se promueve la criminalización de quienes realizan observaciones que incomodan o cuestionan las acciones de gobierno sometidas a veeduría, como ocurrió con quienes examinaron los contratos del hermano del presidente. ${ }^{704}$

El Gobierno, la Fiscalía y la propia Contraloría han cuestionado y denostado públicamente las iniciativas ciudadanas de control que no se sometan a las disposiciones verticales de la Ley de Participación ciudadana y han sido los primeros en presentar y tramitar denuncias en contra de los ciudadanos y aún legisladores que hicieron conocer a la ciudadanía los documentos relativos a actos de corrupción, como ocurrió con la sentencia por calumnia en contra de la Comisión Anticorrupción conformada en 2015 por su denuncia de sobreprecio en la construcción de la Central Hidroeléctrica Manduriacu y con el legislador Cléver Jiménezy su asesor Fernando Villavicencio, quienes fueron despojados primero del fuero y de su representación, para ser luego procesados y sentenciados por calumnia y enjuiciados por utilizar información confidencial de las máximas autoridades del Estado. ${ }^{705}$

\section{Control interno}

La actual Constitución, vigente desde 2008, caracterizada por instaurar un reforzado presidencialismo para la ejecución más efectiva del modelo económico neointervencionista, al que se le han agregado recientemente políticas de corte neoliberal, autoriza y promueve mayores actividades de control interno por parte de la función ejecutiva sobre todas las instituciones y órganos que conforman la Administración Pública Central e Institucional y otras administraciones públicas, las cuales se rigen por los principios constitucionales de "eficacia, eficiencia, calidad, jerarquía, desconcentración, descentralización, coordinación, participación, planificación, transparencia y evaluación", ${ }^{706}$

A diferencia de las cartas políticas anteriores, la actual Constitución otorga expresamente al presidente de la República, entre sus potestades (Art. 145), la de regular mediante los decretos necesarios no solo "la integración, organización y regulación" de la Administración pública sino también su "control” $y$, concomitantemente con ello, le autoriza a "crear, modificar y suprimir ministerios,

\footnotetext{
${ }^{703}$ Ecuador, Ley 0, Ley Orgánica de Participación Ciudadana, Registro Oficial Suplemento 175, 20-abr2010.

${ }_{704}$ http://www.elcomercio.com/tag/pablo-chambers

${ }^{705}$ Remitido de la Contraloría General del Estado, publicado en Diario El Comercio, 2 de marzo de 2016; http://www.eluniverso.com/2013/04/17/1/1355/abogado-correa-confirma-sentencia-asambleista-cleverjimenez.htmlhttp://www.eluniverso.com/noticias/2016/10/28/nota/5878258/juez-ordena-prisionpreventiva-clever-jimenez-fernando

${ }^{706}$ Ecuador, Constitución del Ecuador 2008, art. 227.
} 
entidades e instancias de coordinación" y "expedir los reglamentos necesarios...que convengan a la buena marcha de la administración”. Esto es, el Ejecutivo dispone de una amplia potestad normativa para ejercer la "potestad organizatoria", que corresponde a la función legislativa, y el control interno de las actividades de la Administración pública mediante las instituciones, regulaciones y normas que él defina.

El Ejecutivo, luego de expedida la actual Constitución, introdujo de inmediato reformas en el régimen jurídico de la SENPLADES (Secretaría Nacional de Planificación y Desarrollo Social) y en el ERJAFE, con la finalidad, entre otros objetivos, de fortalecer sus atribuciones de control interno de la Administración pública bajo su responsabilidad, por medio de la Secretaría Nacional de la Administración Pública y otras instancias burocráticas.

La SENPLADES es un órgano de la Presidencia de la República que dirige y gestiona el Sistema Nacional de Planificación en coordinación con los organismos del régimen seccional autónomo y organizaciones sociales. Entre las acciones de control que se asignan a esta Secretaría, por medio de un Subsistema de Seguimiento y Evaluación, constan la de realizar el seguimiento a la ejecución de los planes, programas y proyectos ejecutados por el Gobierno central y efectuar estudios de evaluación de impacto de los planes, programas y proyectos. ${ }^{707}$

En el ERJAFE, además de las referidas competencias presidenciales y la de "controlar y evaluar los logros y resultados de carácter fundamental alcanzados por los organismos, entidades y empresas de la función ejecutiva", norma que consta en dicho instrumento desde 1994, en el Gobierno del presidente Correa se crean, mediante decretos ejecutivos (2008), un Consejo Nacional de Administración Pública para dictar políticas y regulaciones así como nuevas y más amplias atribuciones a la Secretaría Nacional de la Administración Pública, cuyo titular tiene rango de ministro, si bien se mantiene esa denominación para impedir el control político que pueda ejercer sobre sus actuaciones la Asamblea Nacional.

Con la misma finalidad, el presidente decidió erigir adicionalmente las agencias de regulación y control, definidas como organismos técnicos que regulan las actividades específicas de un sector y de los agentes que operan en él, de acuerdo con la normativa establecida en la ley. Dichas agencias estarán adscritas a un Ministerio o Secretaría Nacional y contarán con un directorio como máxima instancia de dirección. Autorizó también la creación de nuevas entidades y organismos públicos, para el control administrativo propio, como las secretarías técnicas, adscritas a la Presidencia, Vicepresidencia, Ministerio sectorial o Secretaría Nacional, con facultades de coordinación, gestión, seguimiento y evaluación en la implementación de las políticas públicas; luego autorizó la conformación del denominado servicio, como organismo

\footnotetext{
${ }^{707}$ Ecuador, Presidencia de la República, Decreto Ejecutivo 1372, Registro Oficial 278, 20-feb-2004; DE 878, Registro Oficial 268, 8-feb-2008.
} 
público, con personalidad jurídica y autonomía administrativa, operativa y financiera, para la administración y provisión de bienes y/o servicios destinados a la ciudadanía o a la administración pública central o institucional y para ejercer facultades de regulación, gestión y control, y finalmente erigió las secretarías nacionales y las secretarías, con titulares con rango de ministro, para el ejercicio adicional de facultades de rectoría, planificación, regulación, gestión y control sobre temas intersectoriales o de un sector de la Administración pública. ${ }^{708}$

Estas nuevas estructuras institucionales que ejecutan potestades de control interno, de gestión y evaluación a nombre del Ejecutivo, están relacionadas con las nuevas atribuciones asignadas (2008) a la Secretaría General de la Administración pública con la finalidad de que establezca "políticas, metodologías de gestión e innovación institucional y herramientas necesarias para el mejoramiento de la eficiencia, calidad y transparencia de la gestión en las entidades y organismos de la función ejecutiva, con quienes coordinará las acciones que sean necesarias para la correcta ejecución de dichos fines" y para que realice "el control, seguimiento y evaluación de la gestión de los planes, programas, proyectos y procesos de las entidades y organismos de la función ejecutiva que se encuentren en ejecución, así como el control el seguimiento y evaluación de la calidad en su gestión". Para el cumplimiento de dichas funciones, el presidente otorgó luego a dicha Secretaría: "personalidad jurídica, patrimonio propio y autonomía presupuestaria, financiera, económica y administrativa". 709

El secretario nacional de la Administración pública preside, por tanto, el Consejo Nacional de la Administración Pública, que está integrado también por el secretario nacional de Planificación y Desarrollo, los ministros coordinadores, el secretario nacional Jurídico y el secretario de Comunicación y tiene como atribuciones, además de las indicadas, las de conocer, analizar y deliberar sobre los informes de gestión de los ministerios coordinadores sectoriales, que a la vez tienen otras funciones como las de: evaluar la gestión y la ejecución de las agendas y políticas sectoriales; dar seguimiento y controlar la ejecución de los procesos y proyectos y definir, conjuntamente con la Secretaría de Planificación y Desarrollo, las evaluaciones de impacto de los programas de su área.

La Secretaría Nacional de la Administración pública es uno de los ministerios más importantes de la función ejecutiva en la actualidad. Cuenta con varias subsecretarías y entre ellas, en relación con nuestro estudio, la de Organización, Métodos y Control y la de Transparencia de Gestión responsable de la lucha anticorrupción.

\footnotetext{
${ }^{708}$ Ecuador, Presidencia de la República, Decreto Ejecutivo- 918, Registro Oficial 286, 3-mar-2008; DE 109, Registro Oficial-S 58: 30-0ct-2009; DE-726, Registro Oficial 433: 25-abr-2011; DE-720, Registro Oficial 468,13-jun-2011; DE-62, Registro Oficial 63, 21-ago-2013; DE-338, Registro Oficial-S 263, 9jun-2014.

${ }_{709}$ Ecuador, Presidencia de la República, DE-726, Registro Oficial 433, 25-abr-2011; DE 3, Registro Oficial-S 14, 13-jun-2013.
} 
La Subsecretaría de Organización, Métodos y Control tiene como atribuciones y responsabilidades principales: coordinar con la SENPLADES (Secretaría Nacional de Planificación y Desarrollo) y el Ministerio de Finanzas y los organismos de planificación de todas las entidades de la Administración pública los planes operativos anuales; elaborar lineamientos metodológicos y coordinar con las dependencias públicas de la función ejecutiva el control de gestión cotidiana y a corto plazo, así como los sistemas de información sobre los resultados obtenidos en el ejercicio de su gestión; coordinar el seguimiento a los compromisos de los gabinetes itinerantes; elaborar informes de cumplimiento o desviaciones de resultados de la gestión y formular recomendaciones y liderar la información oportuna, sobre la ejecución de programas y proyectos, al presidente, autoridades y a los ciudadanos (Art. 2). ${ }^{710}$

El presidente de la República dispuso también en ese contexto (2011) la implementación obligatoria del Proyecto Gobierno por Resultados-GPR, en todas las instituciones públicas de la función ejecutiva, como responsabilidad de la Secretaría General de la Administración pública, a la que autorizó expedir las normas para su implementación. ${ }^{711}$ La Secretaría de la Administración pública emitió a la vez una Norma Técnica de Administración de Procesos mediante Acuerdo Ministerial 00001573 de 4 de abril de 2016, dando cumplimiento a la Carta Iberoamericana de Calidad de la Administración Pública para obtener un "buen Gobierno democrático", 712 y otra norma técnica de implementación y operación de la metodología y herramienta del "Gobierno por resultados".

El Gobierno por resultados" (GPR) es un conjunto de conceptos, metodologías y herramientas para orientar al Gobierno y a sus instituciones en una gestión eficiente de sus planes estratégicos, operativos, riesgos, proyectos y procesos en sus distintos niveles organizacionales, mediante el control y seguimiento de sus elementos y resultados obtenidos. La principal herramienta del GPR es un instrumento informático que permite sistematizar y gestionar los planes estratégicos y operativos, programas, proyectos, procesos y monitorear sus resultados. Para ello, es fundamental la calidad, veracidad, pertinencia y actualización de la información que se ingrese y administre por medio del portal GPR; realizar el seguimiento o el monitoreo oportuno de la gestión pública para diagnosticar su estado actual y generar alertas de prevención y corrección para tomar decisiones acertadas y efectuar el control preventivo o de resultados de la gestión pública, mediante auditorías de gestión, que permitan verificar, comprobar y constatar que las acciones de las instituciones se ajustan a la planificación estratégica y operativa.

La norma de Administración de Procesos establece que la Administración por procesos tiene la finalidad de mejorar la eficacia y eficiencia de las operaciones y gestiones de las

\footnotetext{
${ }^{710}$ Ecuador, Ministerio de Finanzas, Acuerdo Ministerial 323, de 11 de abril de 2008, Registro Oficial 323, 24-abril-2008.

${ }^{711}$ Ecuador, Presidencia de la República, Decreto Ejecutivo 726, Registro Oficial 433, 25-abr-2011.

$712 \mathrm{http} / / /$ old.clad.org/documentos/declaraciones/carta-iberoamericana-de-calidad-en-la-gestion-publica
} 
instituciones públicas de la función ejecutiva para que sus servicios sean de calidad y satisfagan las exigencias ciudadanas. Con esa premisa la Secretaría adoptará normas, guías metodológicas, manuales, cuadernos de trabajo, etc.

La dos normas de gestión y control se complementan entre sí y con los sistemas de gestión de la calidad, que contienen, a la vez, conceptos, metodologías y herramientas que orientan las acciones del Gobierno y sus instituciones para el cumplimiento de sus objetivos, con mejores prácticas de gestión, control y evaluación de los resultados y de la calidad de los productos. Tanto en la toma de decisiones como en la ejecución y en la evaluación se realiza un monitoreo, medición e información permanentes, mediante el Sistema o Portal GPR, para adoptar medidas correctivas que aseguren la eficiencia y eficacia en el desempeño de la administración, la consecución de los objetivos de Gobierno y la más alta calidad del servicio. Con estos sistemas el ciudadano podría estar informado y constatar el estado de un proceso, de un trámite o de una obra y sus resultados, así como el impacto de los proyectos de mejora y la calidad y cobertura de los servicios.

La administración por procesos implica compromisos institucionales y de las autoridades para implementarlos, definiendo roles y responsabilidades o conformando los comités de Calidad de Servicio y de Desarrollo Institucional; proveyendo los recursos necesarios para el funcionamiento del sistema y el personal capacitado para su ejecución y seguimiento, evaluación y estableciendo los mecanismos de participación o involucramiento de los ciudadanos o de los clientes del servicio. La norma define, finalmente, los responsables, las actividades y los lineamientos para la administración institucional de procesos y en procesos; la identificación y priorización de los procesos a mejorar; la gestión de la calidad, análisis y mejora de los procesos y la gestión y control de los mismos.

En cuanto al control, mediante la utilización del Sistema y Técnicas del GPR se establecen lineamientos de acción para ser monitoreados mensualmente por los responsables: la recolección de datos para el cálculo de los resultados; la actualización de estos para evaluar implicaciones y tomar acciones correctivas o preventivas y eliminar o prevenir desviaciones; la determinación de acciones para la mejora continua y la evaluación y ajustes a las metas de los objetivos operativos propuestos. ${ }^{713}$

En la Rendición de Cuentas de marzo de 2016, la Secretaría Nacional de la Administración pública informa que en 2015 ha monitoreado 4.049 procesos de contratación pública, ha elaborado 1.448 informes y revisado dichos procesos en 39 entidades de un total de 90 que conforman la Función Ejecutiva, si bien el catastro de entidades, según la Defensoría del Pueblo, registra 164 unidades administrativas que están obligadas a entregar informes anuales de sus actividades. La Dirección Nacional

${ }^{713}$ Ecuador, Secretaría de la Administración Pública, Acuerdos Ministeriales 784 de 28 de julio de 2011, Registro Oficial 501, 28-julio-2011 y 1580 de 13 de febrero de 2013, Registro Oficial-S 895: 20-feb2013. 
de Control de la Gestión identificó en el mismo año 238 alertas en 163 instituciones que utilizaron el registro de "gobierno por resultados" y en seis entidades promovió auditorías administrativas y de trabajo, con la finalidad de optimizar los recursos humanos, financieros, materiales y tecnológicos para alcanzar mayor eficiencia en la gestión, identificando planes de mejoras frente a los hallazgos encontrados. ${ }^{714}$

Por su parte, la Subsecretaría de Transparencia de Gestión pretende asumir la lucha anticorrupción en la Administración pública, que se propuso como política de Estado en la campaña electoral y así declarada una vez que se inició el Gobierno del presidente Correa en 2007 y que luego se hizo constar en la Constitución de 2008. Esta Subsecretaría adscrita a la Presidencia de la República y a la SNAP, financiada con fondos públicos y que inicialmente se denominó Secretaría Nacional Anticorrupción; está dirigida también por un subsecretario con rango de ministro; dotada de personalidad jurídica propia; tiene gestión desconcentrada en el ámbito nacional y cubre a todas las entidades públicas de la función ejecutiva, incluyendo a aquellas que forman parte de estas como accionistas o socias y, además, a las corporaciones, fundaciones, sociedades civiles, compañías mercantiles y empresas públicas en las que el Estado tenga participación mayoritaria.

La Subsecretaría de Transparencia de Gestión tiene como atribuciones: promover una administración gubernamental transparente que coadyuve a establecer un sistema integral de control de la corrupción; investigar y denunciar actos de corrupción de las instituciones públicas señaladas, siguiendo el correspondiente instructivo, para poner en conocimiento del Consejo de Participación Ciudadana y Control Social el resultado de sus investigaciones; fortalecer la coordinación y cooperación entre las instituciones de gobierno, organismos de control, entidades judiciales y todos los involucrados en la investigación, juzgamiento y sanción de actos de corrupción; generar instrumentos y manuales operativos para la investigación de denuncias receptadas; vigilar el cumplimiento de la Ley Orgánica de Transparencia y Acceso a la Información Pública en todas las instituciones del sector público y dar seguimiento y prosecución de los procesos legales y administrativos que se sigan como resultado de sus investigaciones y que fueron puestos en conocimiento de las autoridades competentes. ${ }^{715}$

En el Informe de la SNAP (2016) se indica que la Subsecretaría de Prevención revisó procesos de contratación pública en 39 entidades de la función ejecutiva y que realizó 304 acompañamientos a dichos procesos en sus diferentes etapas. En 2015 la Subsecretaría de Investigaciones conoció 166 denuncias de corrupción, de las cuales se investigaron 70 para las que se elaboraron los correspondientes informes técnico-

\footnotetext{
${ }^{714}$ Ecuador, Rendición de Cuentas, Informe de la Secretaría Nacional de Administración Pública, marzo de 2016.

${ }^{715}$ Ecuador, Presidencia de la República, Decreto Ejecutivo 1511, Registro Oficial-3S 498, 3-dic-2008. Instructivo de trámites, 20 de octubre de 2014, Registro Oficial 465: 24-mar-2015.
} 
legales concluyentes. La Dirección Nacional correspondiente registra un cuadro de seguimiento de apenas 22 de dichos informes desde $2012 .^{716}$

Finalmente, entre 2007 y 2019 el presidente Correa actualizó y reformó la gestión y administración del ya existente Sistema de Información para la Gobernabilidad Democrática (SIGOB), creado en 2002 para "fortalecer la capacidad de gestión estratégica y operacional de la Presidencia de la República" y para "generar y mantener condiciones de gobernabilidad democrática", garantizando derechos y cumpliendo las metas y compromisos del Gobierno.

El SIGOB es un proyecto de gestión y control de la Presidencia, con metodologías de trabajo en procesos eficientes y soportes informáticos, adscrito al Programa de Naciones Unidas para el desarrollo (PNUD). Lidera un proceso de información oportuno y permanente al presidente de las acciones de las autoridades e instituciones de la función ejecutiva, elabora informes de control, gestión, seguimiento y monitoreo de los programas prioritarios del régimen. Con dichos documentos, el presidente y otras autoridades como la Secretaría de la Administración Pública y su subsecretario de Organización, Métodos y Control, se apoyan para realizar la evaluación del estado de gestión de las instituciones que forman los diferentes órganos de la función ejecutiva. El referido subsecretario debe presentar periódicamente informes de gestión del sistema a su superior, en los que "se determinarán el estado de cada módulo, los avances, las dificultades y recomendaciones orientadas a la toma de decisiones que apoyen el funcionamiento adecuado del SIGOB". ${ }^{717}$

Como resulta evidente, las labores de control interno y de evaluación de los procesos y de la gestión de los órganos mayoritarios de la Administración pública, más los nuevos sistemas informáticos de los procesos de contratación pública, que se encuentran bajo la dirección de la función ejecutiva, cuentan con una amplia normativa y sistema técnicos para su monitoreo y evaluación, con la finalidad de realizar los correspondientes correctivos y evaluar sus resultados y su impacto en la satisfacción de los derechos y de los servicios eficientes y de calidad que reclaman los ciudadanos. Sin embargo, pese al amplio aparato burocrático creado y los sistemas técnicos implementados por el Gobierno del presidente Correa con esta finalidad, los resultados son insatisfactorios no sólo por los límites de su cobertura, sino por la mala calidad final de los servicios públicos y administrativos en general y por el crecimiento de la corrupción en los numerosos contratos de la gran obra pública y en general en la gestión administrativa nacional. Sin embargo, se debe reconocer que algunos de los servicios y procedimientos administrativos tutelados por la función ejecutiva, como los del Registro Civil y los del Servicio de Rentas Internas, han mejorado en agilidad y eficiencia como resultado de la

\footnotetext{
${ }^{716}$ Ecuador, Rendición de Cuentas, Informe de la Secretaría Nacional de Administración Pública, marzo de 2016.

717 Ecuador, Presidencia de la República, Decreto Ejecutivo 387, Registro Oficial 110, 21-jun-2007; DE 1052, Registro Oficial 337, 15-may-2008.
} 
introducción de la tecnología informática en los trámites, declaraciones, formularios y autorizaciones.

\subsection{El control y las enmiendas constitucionales de 2015}

Entre las enmiendas a la Constitución de 2008 propuestas por el Ejecutivo y los legisladores allegados al Gobierno del presidente Correa en 2015, constan dos modificaciones a los artículos 211 y 212 de la Constitución, relativas a la Contraloría General del Estado, en las que se evidencia la decisión política del régimen no solo de restringir el control político sino también el control externo técnico-financiero, para trasladar el control de gestión y de resultados de los entes que reciben fondos públicos, a la propia administración nacional dirigida por la función ejecutiva, por medio de la SENPLADES y la Secretaria General de la Administración pública y otras dependencias del Ministerio de Finanzas, que son los que asumen de manera total el control absoluto de la gestión financiera del Estado y de los procesos de inversión, concesión, privatización y ejecución de los grandes activos en los que se encuentra empeñado el régimen.

En el artículo 211 se elimina del texto constitucional la competencia de la Contraloría de perseguir "la consecución de los objetivos de las instituciones del Estado" y se limita a controlar "la utilización de los recursos estatales", lo que significa un retroceso histórico en la función y papel de la entidad, ya que la orientación actual de los procesos de auditoría en el mundo y en la región incluyen, necesariamente, una valoración no solo de la utilización de los recursos sino también de la gestión y de los resultados de la administración, tomando en consideración los principios de eficiencia, eficacia y economía.

Ratificando la referida decisión política gubernamental, la reforma del artículo 212 elimina también la potestad de la Contraloría de determinar responsabilidades administrativas y civiles culposas e indicios de responsabilidad penal en los asuntos de gestión. En otras palabras, la auditoría integral de uso de recursos y de gestión eficaz de los mismos queda limitada a una fiscalización posterior sobre aquellos, eliminando la finalidad de poder determinar si esos recursos fueron bien, ética y eficientemente utilizados por la Administración.

En el dictamen emitido por la Corte Constitucional sobre las enmiendas a los referidos artículos de la Constitución se afirma que "al delimitarse las competencias de las instituciones se fortalece la institucionalidad", pues se determinan sus funciones y se evitan interferencias con otras entidades, como la Secretaría Nacional de Planificación y Desarrollo Social. Manifiesta también el dictamen que las modificaciones propuestas a 
los artículos 211 y 212 de la Constitución, no menoscaban, reforman o modifican las atribuciones de la Contraloría General del Estado. ${ }^{718}$

La Comisión Ocasional de Enmiendas de la Asamblea Nacional, en su informe para segundo debate, argumenta que la Secretaría de la Administración pública es la encargada de realizar el control de las entidades del Ejecutivo "para la consecución del Plan Nacional del Buen Vivir" y que "los productos del control de la gestión que realiza la Secretaría son insumos para que el presidente de la República rinda cuentas al Legislativo subsecuentemente, el Legislativo ejerce su atribución constante de fiscalizar los actos del Ejecutivo". Y, agrega que "el rol primigenio de la Contraloría es el de ser juez de cuentas". 719

Concordante con este informe, una de las vicepresidentas de la Asamblea Nacional dijo: "las enmiendas a las atribuciones de la Contraloría tienen que ver con antecedentes históricos y de derecho comparado", según los cuales el órgano de control "ha sido y debería ser el de realizar una auditoría financiera del uso de recursos públicos”, pues "otros órganos se especializan en otro tipo de auditorías", como las superintendencias que controlan actividades y servicios que prestan entidades públicas y privadas, o la Secretaría Nacional de la Administración pública que controla la gestión de los organismos de la función ejecutiva, por lo que, las "enmiendas contribuirán a la eficacia y eficiencia en el desempeño del servicio público". 720

Es insólito que la Corte Constitucional y los asambleístas que aprobaron las referidas enmiendas invoquen como argumento jurídico la supuesta contradicción entre las atribuciones que se confieren, mediante un reglamento de la función ejecutiva, a las secretarías de la Administración pública y a la SENPLADES, frente a una competencia asignada a la Contraloría General del Estado por la Constitución. Las referidas enmiendas, violatorias de la carta política en cuanto a su trámite y contenido, pues se trata de reformas, alteran las atribuciones del órgano de control y su estructura, para retornar a una concepción arcaica de vigilancia de cuentas, que no toma en consideración la integralidad de las auditorías que analizan, en la actualidad, simultáneamente la gestión, los resultados y el cumplimiento de los objetivos de las instituciones públicas.

Según manifestó el contralor Carlos Pólit, dichas enmiendas "debilitan un control moderno y eficaz de los recursos públicos"; "alteran las competencias de la Contraloría"; "implican una inentendible contradicción con el entorno (internacional)" y convierten a órganos de la Administración pública, como la SENPLADES que no es órgano de control según la Constitución y la ley, en fiscalizadores de ellos mismos. Por

\footnotetext{
${ }^{718}$ Ecuador, Dictamen de Constitucionalidad sobre las Enmiendas N ${ }^{\circ}$ 001-14-DRC-CC de 31 de octubre de 2014, Gaceta Constitucional No 009 de 10 de noviembre de 2014.

${ }^{719}$ Ecuador, Comisión Ocasional de Enmiendas Constitucionales, Informe para segundo debate, 23 de noviembre de 2015, www.asambleanacional.gob.ec/sites/default/files/field/image/enmienda8.jpg

${ }^{720}$ Marcela Aguiñaga, Segunda vicepresidenta de la Asamblea Nacional, réplica, El Universo, 4 de diciembre de 2015.
} 
ello, el contralor anunció que "planteará impugnaciones a dichas enmiendas ante la Corte Constitucional y a las instancias legales, hasta agotar todos los caminos que la ley prevé para impugnar tal decisión". 721

En la rendición de cuentas de la Contraloría General del Estado, presentada en marzo de 2016, el contralor manifestó, de manera categórica: "La Constitución de Montecristi es una síntesis del proceso histórico de construcción de la República, condensa la evolución de la Contraloría General del Estado, plasmada en una concepción moderna y eficaz en el control de los recursos públicos. Hasta diciembre de 2015 la Constitución atribuía a la entidad fiscalizadora superior una obligación de control integral de los recursos públicos, en dos vías: primero, sobre su utilización en la adquisición de bienes, construcción de obras y prestación de servicios, individualmente considerados; y, en segundo lugar, en base del análisis del cumplimientos de los objetivos, planteados en el marco de sus competencias, de todas las instituciones públicas. En varias ocasiones, las autoridades de la institución expresaron sus argumentos respecto a las enmiendas e indicaron que modifican las competencias del organismo de control. La oposición a los cambios aprobados por el legislativo se justifica ante la ausencia de otra institución, designada constitucionalmente, que asuma la competencia de auditar la gestión y la consecución de los objetivos de los organismos del Estado. Las facultades actuales de la CGE reflejan el perfeccionamiento continuo de la auditoría en el país y concuerdan con el trabajo que realizan las EFS de la región y del mundo. Desde el punto de vista técnico, el control de los recursos públicos no es un conjunto aislado de actividades. Se trata de un sistema complejo y el análisis de la consecución de los objetivos institucionales, que requiere la utilización de fondos estatales, es una parte esencial del proceso, por lo que la defensa de la institucionalidad responde a la necesidad de sostener un adecuado control, a través de medios técnicos que permiten fiscalizar con resultados correctos". 722

Hacia el futuro, queda clara la decisión del régimen, que no será alterada por la Corte Constitucional que previamente emitió informe favorable para la violación de la Constitución con estas enmiendas, que la evaluación de gestión de los órganos de la función ejecutiva será realizada por la propia administración, por medio de la Secretaría Nacional de la Administración pública, la Secretaría Nacional de Planificación de Desarrollo Social y algunas dependencias del Ministerio de Finanzas, todas con competencias asignadas por el presidente de la República, mediante simple decreto ejecutivo y sin jerarquía de ley, y no por un órgano técnico externo y especializado, como lo es la Contraloría General del Estado, que de acuerdo con la Constitución puede establecer responsabilidades personales, no sólo por el manejo de los recursos públicos sino por la calidad de la gestión y el cumplimiento de objetivos en las actividades y proyectos de la Administración.

\footnotetext{
${ }^{721}$ Carlos Pólit: "Hay una equivocación total y profunda", El Universo de 4 de diciembre de 2015, 4.

${ }^{722}$ Ecuador, contralor General del Estado, Rendición de Cuentas, marzo de 2016, www.contraloria.gob.ec
} 
Esto es, con las enmiendas constitucionales se consagra un retroceso importante en el derecho de control en Ecuador y en la lucha anticorrupción, pues se pretende retornar en cuanto a las atribuciones que se asignan a la Contraloría General del Estado, como órgano de control externo, a las que en 1863 otorgó la Ley de Hacienda al entonces Tribunal de Cuentas, en el Gobierno del presidente Gabriel García Moreno. 


\section{CONCLUSIONES}

Finalizamos esta investigación sobre la incidencia de los modelos y políticas económicas implementados en Ecuador, desde 1990 hasta 2017, en su legislación económica constitucional, financiera $\mathrm{y}$ administrativa relativa al contenido $\mathrm{y}$ modificaciones jurídicas sobre los ingresos tributarios y crediticios, los gastos $\mathrm{y}$ presupuesto, la planificación y el control. Exponemos algunas conclusiones que sintetizan nuestras reflexiones y aportes y formulamos, a la vez, varias inquietudes y temas que se podrían desarrollar en el futuro por el autor o por quienes compartan nuestro enfoque o se sientan motivados a estudiar, desde otras perspectivas, el referido ordenamiento legal.

1. La globalización capitalista actual en su fase de financiarización del sistema y la crisis histórica mundial del sistema que provoca incertidumbre son el entorno en el que se inscriben los modelos o políticas económicas neocompetitivas o neoliberales o neointervencionistas o neodesarrollistas, que de manera sucesiva, alternada o combinada, sirven de sustento al sistema capitalista mundial desde inicios de la última década del siglo XX hasta la actualidad y que se expresan en las normas constitucionales $\mathrm{y}$ en las normas jurídicas administrativas $\mathrm{y}$ financieras vigentes en este período histórico.

Esta realidad se manifiesta tanto en los países dependientes o subdesarrollados como en los países industriales y desarrollados de Norteamérica, Europa y el mundo, azotados por las recurrentes crisis e irracionalidades del sistema, sin dejar de advertir, a la vez, la enorme resistencia y malestar social que provocan sus desastrosos efectos en el creciente desempleo, la concentración acelerada de la riqueza y el incremento de la pobreza y la corrupción.

Para enfrentar los fenómenos antes indicados se puso en cuestionamiento las políticas de desregulación que se promovieron especialmente en las dos últimas décadas del siglo XX a nivel internacional y nuevamente los organismos internacionales y regionales y los estados nacionales reaccionaron activando o creando nuevas instancias de vigilancia e instrumentos legales y regulaciones que les permitieran estabilizar el sistema y trasladar su enorme costo a los sectores laborales, populares y a amplias capas de la sociedad, tanto en los países desarrollados como, en especial, en los países periféricos o subdesarrollados.

De allí que las políticas neoliberales o neocompetitivas se modificaron desde inicios del presente siglo para reconocer la necesidad de introducir o recomendar un nuevo intervencionismo estatal (neokeynesiano o neodesarrollista) que combinara su papel regulador con las cuestionadas iniciativas de mercado del pasado reciente y que se siguen promocionando y aplicando conjunta o combinadamente en la actualidad, como lo sugieren en su informe anual en 2008 
el FMI, el BM en 2013 y la CEPAL en varios documentos y estudios desde 2000 hasta hoy.

En este contexto internacional de transición se suman nuevos acontecimientos sorprendentes como el Brexit, la política de Donald Trump, la emergencia y liderazgo de China y la creciente resistencia social a nivel mundial que cuestionan el papel y las políticas de los estados, de la comunidad internacional y del derecho internacional o revalorizan sus funciones, todo lo cual tiene incidencia directa en las modificaciones que se realizan en las normas constitucionales, administrativas y financieras de todos los países del mundo y entre ellos, Ecuador.

Para nosotros resulta feliz la figura difundida en el ámbito académico para describir el momento actual en el que va concluyendo en el campo jurídico y político el ordenamiento de Westfalia y se transita a un nuevo orden mundial identificado como Worldfalia, en el que es pertinente hablar de una acelerada globalización del derecho internacional, constitucional, administrativo y financiero y de las múltiples instituciones que los ejecutan, generadas por una pluralidad de sujetos, la creciente transformación o reconceptualización del principio de soberanía y una conciencia cada vez más universal de los seres humanos que se consideran ciudadanos para ejercer ampliamente sus derechos humanos y no se resignan a ser considerados como habituales súbditos de los estados. $^{723}$

Sin embargo, ya en el presente siglo XXI y con más fuerza en los últimos años, resurgen, como lo hemos analizado, las tesis proteccionistas que se resisten a la globalización, a la deslocalización productiva, a una extrema liberalización comercial y a sus efectos sociales adversos, tanto en los países capitalistas dependientes del sur como en los países desarrollados del norte, poniendo en peligro los procesos de integración y la estabilidad de los tratados de libre comercio, a la vez que se anuncian procesos de reindustrialización y renegociaciones bilaterales entre Europa y Estados Unidos y se mantienen estancados y aún en retroceso procesos de integración como el latinoamericano.

Es evidente también que el cuestionamiento a la viabilidad de los estados nacionales se relativizó en los últimos años, frente a la crisis y a las medidas y ajustes económicos, financieros y jurídicos que se adoptaron a partir del 2008 para sortear el colapso de entidades especuladoras a nivel internacional, regional y local y trasladar sus efectos mediante medidas monetarias a la mayoría de la población mundial. No se puede dejar de reconocer que fue imprescindible para

\footnotetext{
${ }^{723}$ Nuris Bouza, Caterina García y Angel Rodrigo, ¿Hacia Worldfalia? otros, La gobernanza política jurídica del interés público global, en La gobernanza del interés público global, XXV Jornadas de las Asociación Española de Profesores de Derecho Internacional y Relaciones Internacionales, Universitat Ponpeu Fabra, Tecnos, Barcelona, 2013.
} 
ello, de una activa intervención de los organismos internacionales, especialmente financieros y de un Gobierno de factode la globalización que ejercen, para universalizar los correctivos de control, imponer la denominada lex mercatoria y desarrollar mecanismos de resiliencia a la agresiva financiarización de la economía mundial.

En la actualidad, enfrentamos un escenario económico y político complejo y en movimiento, en el que la globalización dejó de ser un objetivo idílico y fácil de alcanzar, ya que se encuentran presentes y activos los intereses contradictorios transnacionales; el resurgimiento del proteccionismo y de los populismos y una renovada lucha social por universalizar los derechos y en especial los económicos y sociales de los seres humanos.

2. Si bien los modelos económicos liberal, intervencionista, neoliberal y neointervencionista se han ensayado a nivel mundial, regional y nacional, a lo largo de la historia, ninguno de ellos han podido consolidarse y mantenerse en el tiempo, pues las necesidades de acumulación, las crisis internacionales del sistema y la lucha social y política producen hechos inesperados.

El modelo y las políticas neocompetitivas que se sugirieron e impusieron a países como Ecuador, por los organismos internacionales (FMI, BM, OMC, ONU, OCDE, CEPAL, BID), siguiendo el consenso de Washington, solucionaron temporalmente las irracionalidades del modelo intervencionista anterior expresadas en una inflación y burocratización incontroladas y un asfixiante endeudamiento externo.

Sin embargo, las reformas estructurales, la descentralización, las políticas de estabilización y ajuste y las privatizaciones de recursos y servicios públicos ocasionaron, además de modificaciones en las normas de la Constitución económica y en la legislación administrativa y financiera, un amplio rechazo social, nuevos desequilibrios macroeconómicos, mayor concentración de la riqueza y enorme corrupción.

Por ello, desde fines del siglo pasado y en los inicios del presente, los mismos organismos internacionales y regionales promovieron una nueva forma de articulación de nuestras economías a la globalización capitalista, mediante un neointervencionismo estatal o neodesarrollismo, para regular los excesos neoliberales y garantizar, mediante la negociación y una limitada redistribución, la seguridad y estabilidad del sistema mundial y en especial los intereses de las empresas transnacionales y del capital financiero mundial.

Las reformas neoliberales, conforme a la realidad de cada país, en la actualidad se encuentran combinadas con las políticas neointervencionistas, en todos los países del mundo, mediante la intervención de nuevas instancias institucionales 
públicas y privadas -como el Consejo de Estabilidad Financiera (FSB,2009)- que se desarrollan en el marco de las Naciones Unidas o como necesidad del mercado mundial. Dichas instituciones promueven reformas constitucionales, administrativas y financieras internacionales y locales para asegurar estabilidad macroeconómica, la observancia de reglas fiscales para controlar el déficit y el endeudamiento y la expedición de regulaciones comunes para manejar la agresividad del capital y los productos y derivados financieros internacionales.

La acción y orientación de los organismos internacionales, especialmente financieros, los requerimientos políticos y económicos de las agrupaciones que ejercen y se benefician del poder y la fuerza cambiante de los sectores sociales populares, que soportan la dominación, conforman un pacto social que modula el contenido de la legislación y de las normas internacionales e internas constitucionales, administrativas y financieras. Dicho acuerdo se expresa además de manera explícita o implícita en los procesos y resultados electorales de cada país o a nivel regional, para la conformación de gobiernos de diferente signo y con diversa representación social.

El ordenamiento jurídico, en todo caso, no solo refleja los cambios señalados, sino que expresa los intereses, equilibrios o desequilibrios sociales y políticos, si bien tiene también un papel activo en promoverlos o adecuarlos a las necesidades internacionales, locales y del conflicto social.

Se debe observar que si bien los modelos económicos y las políticas públicas tienen su propia identidad y coherencia teórica y doctrinaria, no se aplican de manera radical y homogénea en ningún país. En el caso de Ecuador en casi tres de las últimas décadas, como lo hemos señalado en este estudio, se han ensayado, por parte de los gobiernos de turno, el modelo intervencionista, neoliberal y neointervencionista, pero jamás se los ha aplicado de manera absoluta cada uno de ellos, pues en la práctica se han combinado, si bien en determinado momento las políticas de uno de ellos innegablemente fueron las dominantes.

En Ecuador, entre 1992 y 1998 se sustituyeron las políticas intervencionistas por las neoliberales; entre 1998 y 2007 se priorizó inicialmente el modelo neoliberal matizándolo con ciertas políticas intervencionistas adoptadas luego de la crisis financiera y la dolarización del 2000; entre 2008 y 2015, se establecieron al principio políticas neo estatistas y tras la crisis de las materias primas, especialmente del petróleo, de los problemas monetarios internacionales y locales y la falta de liquidez, en los últimos tres años el Gobierno combinó las políticas neodesarrollistas con reformas estructurales e iniciativas neoliberales, formas disimuladas de privatización, aumentos en la tributación indirecta y un agresivo endeudamiento, para tratar de equilibrar el presupuesto y enfrentar los agudos problemas económicos. 
3. Las políticas públicas neodesarrollistas del último período no sustituyeron radicalmente a las recetas o a las políticas neocompetitivas, sino que las acomodaron a las necesidades del sistema y al momento económico y político del país. No solo en Ecuador sino en América Latina, desde fines del siglo pasado e inicios de presente, se plantea, con diferentes matices teóricos, un nuevo intervencionismo estatal en la gestión, fomento, participación y control o regulación de la economía que es negociado o renegociado con las empresas transnacionales, para la explotación y aún sobreexplotación de los recursos naturales, sin afectar radicalmente las reformas estructurales de la fase neoliberal.

Como se puede advertir no se trata de aplicar modelos o políticas públicas totalmente distintas, sino complementarias, ni tampoco de restablecer el Estado controlado por burócratas privilegiados, sino un proyecto abierto a las fuerzas del mercado y a la sociedad civil y sus principales actores, para renovar las bases económicas e institucionales de la sociedad, lo que se conoce como neoinstitucionalismo.

Se tiene presente también que los ajustes estructurales tradicionales, impuestos inicialmente por el FMI y el BM, provocaron malestar y masivas protestas sociales en la década del noventa del siglo pasado, por lo que los gobiernos prefirieron adoptar ajustes graduales para tratar de restablecer los equilibrios macroeconómicos y sostener una precaria estabilidad política e institucional para garantizar los intereses de los regímenes de turno y los globales del sistema.

El neodesarrollismo latinoamericano propone que el Estado impulse: una estructura productiva heterogénea y competitiva, insertada en el ordenamiento comercial mundial, mediante un "desarrollo desde adentro" con estímulos a la microempresa, la generación de empleo y la diversificación de exportaciones; corrección de ciertas distorsiones abusivas en la concentración del ingreso y la renta mediante una adecuada política fiscal y una política ambiental sustentable que mitigue la sobreexplotación de recursos naturales. También se plantea que se impulse un régimen eficiente y eficaz de "economía mixta" que armonice el mercado con la naturaleza, para promover el desarrollo y una descentralización controlada, mediante la planificación nacional y regional, debidamente coordinadas y una dirección discreta de la economía que otorgue responsabilidades y participación a los sectores privados para optimizar sus ganancias y aliviar los problemas y desequilibrios fiscales del país.

La Hacienda neodesarrollista contemporánea replantea ciertos mecanismos para alcanzar justicia social y una limitada redistribución del ingreso con la finalidad de impulsar el desarrollo en el contexto de una estabilidad macroeconómica. En países como Ecuador, que tuvo ingresos extraordinarios por los altos precios de sus materias primas en la primera década de este siglo, plantea: un mayor acceso 
de su población al consumo y al empleo mediante el aumento de los servicios y un incremento significativo de la inversión pública; mejores salarios para los trabajadores públicos y privados con un respeto restringido de los derechos laborales individuales en desmedro de los derechos colectivos; el fortalecimiento de las grandes y medianas empresas y de los agentes financieros; una incorporación vigilada a la economía de la economía popular y solidaria, entre otras iniciativas.

La continuidad entre los modelos o políticas neoliberales o neocompetitivas con los neointervencionistas o su combinación ha llevado a que algunos los identifiquen con mayor precisión posneoliberal, pues incluso el supuesto modelo alternativo de socialismo del siglo XXI en América Latina, no es sino una variación del neo-, que sus propios protagonistas, Lula da Silva en Brasil y Rafael Correa en Ecuador, identifican como un proceso en construcción, destinado a mejorar u optimizar el funcionamiento del sistema capitalista, con ciertos correctivos redistributivos, con la finalidad de ampliar las ganancias de los poderosos grupos económicos dominantes transnacionales, regionales y locales.

Se debe enfatizar en que los modelos y políticas antes señalados se implementaron por medio de un Estado inicialmente desahuciado y ahora rehabilitado como instrumento útil y eficiente para trasladar los efectos de la crisis a la mayoría de la sociedad y en especial a los sectores medios y a los más empobrecidos del mundo. Se les reconoce a los estados nacionales sus potestades de mando para apuntalar al sistema aumentando su carácter conservador, regulador y autoritario. Neoliberales y neokeynesianos reconocen el papel crucial que juegan la autoridad estatal y la institucionalidad de la comunidad internacional organizada en las épocas de crisis, para la conservación y reproducción del sistema capitalista mundial, regional y local.

4. En el contexto de la globalización se afinan los instrumentos jurídicos a nivel internacional, regional y local, con la transformación y publicización del derecho internacional y de los instrumentos privados y financieros de regulación internacional, que se transforman de inicial derecho blando (soft law) o de recomendaciones discrecionales a derecho obligatorio (hard low) en materia constitucional, administrativa y financiera.

Si bien el derecho financiero económico tiene en la actualidad una connotación más amplia para cubrir las actividades públicas y privadas, también se encuentra relacionado en el ámbito público, de manera cada vez más estrecha, con las actividades de planificación y control que tienen una connotación especial y los involucra en el derecho administrativo económico, como rama más genérica y originaria de nuevas disciplinas jurídicas o de nuevos enfoques regulatorios. 
Todos los asuntos indicados tienen sustento, obviamente a nivel interno, en el derecho constitucional y más precisamente en lo que se conoce como Constitución económica - financiera para luego desarrollar sus instituciones y normativas en el derecho administrativo económico y en el financiero, entre los cuales existe una estrecha e indisoluble relación, para regular la planificación, las finanzas públicas y en particular los ingresos, gastos, presupuesto y la actividad de control que por su amplitud tienen también dimensiones políticas, administrativas y financieras. La transformación de la hacienda clásica a la hacienda moderna y a la actual o contemporánea, requiere de la confluencia y complementación de las indicadas ramas del derecho.

Las normas administrativas y financieras del Estado y de control de los recursos públicos en Ecuador se han modernizado y el marco jurídico es más coherente y eficiente al respecto. Sin embargo, hace falta voluntad social y política para asegurar que esas regulaciones sirvan al interés nacional y al de las mayorías, para mejorar radicalmente los servicios públicos y el ejercicio efectivo de los derechos económicos, sociales y culturales, para evitar que de una u otra manera se conviertan en políticas de ajuste y restricción de derechos, para seguir beneficiando a la concentración de la riqueza y a los intereses del capital internacional y a sectores de la propia oligarquía ecuatoriana que se acomodan fácilmente a las modificaciones políticas en la conducción del país.

Como hemos demostrado en esta investigación, en los últimos treinta años se transformó nuestra economía y nuestra legislación para hacer operativo en el país el modelo neoliberal y la internacionalización comercial y financiera del capital primero y, en la actualidad, la introducción de un nuevo modelo neoestructuralista y neodesarrollista o su combinación, para lo cual se adoptaron las normas jurídicas, inspiradas en la nueva Constitución del 2008, tanto para las finanzas públicas, la planificación y el control, como para la intermediación financiera privada y la que ejecutan los agentes de la economía popular y solidaria.

Según nuestros estudios, en los diferentes capítulos anteriores se puede constatar que las principales categorías actuales del derecho administrativo económico y del derecho financiero público se encuentran fundamentadas en el derecho internacional público, el derecho constitucional y en el derecho administrativo en general y en las normas de los organismos financieros internacionales conocidos como lex mercatoria.

Estas normas nos permiten identificar a la vez el papel que cumplen esas modificaciones o propuestas jurídicas externas, en las regulaciones de las actividades económicas, financieras, de planificación y de control de cada país, definidas y negociadas finalmente por los gobiernos locales. Las normas aprobadas en Ecuador con ese contenido se tramitaron con procedimientos 
abreviados como los establecidos en las leyes de urgencia económica, que permiten, a la vez, establecer las responsabilidades directas de quienes las proponen, las aprueban y las ejecutan y ser un referente para la actuación de los ciudadanos, en cuyas manos y movilización se encuentra la consolidación de las normas establecidas o el cuestionamiento de los intereses a los que responden los mecanismos de corrupción que involucran.

En este contexto se requiere espíritu crítico y convicciones solidarias y nacionales para defender los intereses del país, las demandas de los depositantes y recursos públicos y privados que no pueden ser festinados por grupos externos e internos de poder, afectando a la gran mayoría de la población. Por ello es necesario crear instituciones financieras alternativas y sólidas de origen comunitario o social, con sistemas eficientes de control y que observen profundos valores éticos, para favorecer el desarrollo y la inversión en actividades y empresas que sean fuente de empleo y trabajo para la mayoría de ecuatorianos, con la finalidad de limitar la migración, el desempleo, el subempleo, la pobreza y la extrema miseria que se han extendido a capas cada vez más numerosas de la población.

Es imprescindible también un conocimiento cabal del funcionamiento, de la regulación y de los productos de las instituciones financieras públicas y privadas, incluyendo las de la economía popular y solidaria, para enfrentar los problemas que ocasionan los productos financieros especulativos, el creciente endeudamiento interno y externo, la desmedida ambición de grupos de poder que pretenden seguir saqueando al Estado con nuevos salvatajes o accediendo inescrupulosamente al ahorro de los afiliados de la seguridad social o beneficiarse de las rigideces de la dolarización y de su posible sustitución.

5. La Constitución económica y financiera de Ecuador, tanto en el modelo o en las políticas neoliberales como en las intervencionistas, aseguran un desarrollo legislativo para la modernización del Estado y para imponer una economía social de mercado en el primer caso (Constitución de 1998) o un sistema económico social y solidario en el segundo (Constitución de 2008), en el que supuestamente se busca una relación equilibrada y dinámica entre sociedad, Estado y mercado con el ser humano y en armonía con la naturaleza, pero que en los dos casos, finalmente -si bien en el segundo se invoca la soberanía nacional-, representan un acomodo o mejor acoplamiento al sistema mundial y a los requerimientos del capital financiero internacional y de las empresas transnacionales, expresados en las políticas y en la legislación y normas que impulsaron e impulsan los organismos financieros y de regulación como el FMI, el Banco Mundial, la OMC y los nuevos acuerdos y pactos adoptados para prevenir crisis y desajustes económicos-financieros mundiales. 
Las reformas constitucionales en la década del noventa del siglo pasado y las dos constituciones (1998 y 2008) y sus reformas en Ecuador, así como las sucesivas modificaciones y expedición de nuevas leyes y códigos sobre política fiscal, planificación y control, respondieron finalmente a los requerimientos de los modelos económicos internacionales o a su combinación, teniendo en su propósito y contenido diferentes connotaciones: el primero estaba centrado en el mercado para alcanzar el adelgazamiento del Estado y las privatizaciones y concesiones y el segundo en la recuperación del poder estatal, para la ampliación en la provisión de servicios y de infraestructura pública y la absorción de varias actividades económicas por parte de las instituciones y empresas públicas, con un supuesto privilegio normativo y financiero al sector de la economía popular y solidaria.

Ahora bien, en la ejecución de los dos modelos económicos y su combinación, para la reestructuración y dinamización del capitalismo mundial, regional y local, se utilizan la descentralización y la planificación otorgándole connotaciones distintas nivel nacional y local; un fuerte control de las finanzas públicas para establecer el equilibrio presupuestario y el cumplimiento de las obligaciones internacionales; una política comercial sometida al mercado mundial; una creciente concentración de poder en el Ejecutivo y una manifiesta disminución de los instrumentos de control político, técnico y social. La reestructuración económica y política en los dos modelos y en las normas constitucionales $(1998,2008)$ se apoyan en el autoritarismo y la concentración de poder y en la disminución o anulación del control democrático y la evaluación, dosificando el impacto de las grandes decisiones y proyectos económicos y concentrando su atención en asuntos menores de la administración o en instancias burocráticas internas intermedias.

Desde que en Ecuador formamos parte de los organismos multilaterales, desde la década del cincuenta del siglo pasado y en especial a partir de los años setenta hasta la actualidad, las condicionalidades, imposiciones y sugerencias del FMI y del BM y otros entes de desarrollo mundial y regional se han impuesto de manera directa o indirecta en la conducción, políticas y modelos económicos que se han desarrollado en el país. Las principales normas y políticas públicas en lo relativo a lo monetario, financiero, tributario, presupuestario, gasto, planificación, recortes sociales, subsidios, medidas de control y las que rigen el crédito público fueron sugeridas, promocionadas o impuestas por los organismos internacionales antes indicados y cuando los gobiernos han pretendido hacer gala de su nacionalismo o de la soberanía han adoptado las medidas y han manifestado que son producto de su propia iniciativa o que son resultado de una coincidencia con las sugerencias o recomendaciones extranjeras.

En las dos constituciones que caracterizan los modelos neoliberal (1998) y neointervencionista (2008) los sectores sociales y progresistas de Ecuador se 
limitaron a exigir el reconocimiento de todos los derechos humanos posibles incluyendo en la última los derechos de la naturaleza, a la pluralidad, la interculturalidad y a la resistencia. Sin embargo, en las cartas constitucionales no se demandaron ni se concretaron modificaciones estructurales e institucionales que permitan hacer efectivos los derechos, por lo que finalmente, en las dos versiones del neoconstitucionalismo no se superaron la tradicional exclusión y marginación de las mayorías sociales en el ejercicio del poder.

Se debe reconocer que en la Constitución de 2008 existen definiciones y elementos de participación y opciones alternativas para que los sectores mayoritarios de la población puedan decidir y ser consultados, ejerciendo su poder constituyente en asuntos de trascendencia económica, social y política o para hacer efectivos los derechos económicos, sociales y culturales de la mayoría de la población. Esas opciones progresistas (neoconstitucionalismo andino) fueron anuladas por el autoritarismo y el caudillismo del presidente de la República, que desarticuló la organización social y manipuló las consultas y las enmiendas de la Constitución (2011 y 2015) para relativizar las conquistas y los derechos sociales, tergiversando su alcance y cobertura y afianzando su control autoritario del poder para fortalecer la corrupción de sus allegados y la reproducción del sistema dominante.

6. La Hacienda pública contemporánea es esencialmente política y económica y está articulada a los modelos y políticas económicas internacionales y locales, convenientes a la mantención y reproducción del sistema y a la satisfacción de los intereses y privilegios de sus principales actores extranjeros y nacionales.

En la política fiscal ecuatoriana relativa a los ingresos tributarios, las políticas neoliberales en 1999 pretendieron reducir y aún eliminar los tributos directos como el impuesto a la renta, para priorizar e incrementar los tributos indirectos, considerando que de esa manera se impulsaba un protagonismo empresarial en la inversión y la generación de empleo, mientras que en las políticas intervencionistas (2002-2017) se ampliaron los tributos directos, se restableció y amplió el impuesto a la renta personal y se estableció un límite a la contribución de empresas (25\% a $20 \%$ ) con la finalidad de propender a una redistribución de la riqueza y ampliar el gasto social.

Los principios fiscales en cuanto a los ingresos se mantuvieron con formulaciones similares, si bien en las políticas neoliberales se puso énfasis en la igualdad, unidad y generalidad, mientras que las políticas neointervencionistas se basaron en la equidad, proporcionalidad eficiencia y transparencia.

En los dos modelos o políticas económicas se combinaron los principios antes indicados, de acuerdo a las coyunturas y a los requerimientos sociales y locales y en los dos casos se coincidió en la necesidad de mejorar los sistemas de 
recaudación y de control de la evasión y de la elusión tributaria. El fortalecimiento de órganos administrativamente autónomos nacionales, pero controlados políticamente por el Ejecutivo, como el SRI y el SNA, han mejorado y perfeccionado la recaudación tributaria, especialmente en lo relacionado con los tributos indirectos y la incorporación de sectores sociales más amplios.

En la actual Hacienda pública, tanto en la fase neoliberal como en la intervencionista, se adoptaron inicialmente o en principio políticas similares de control del gasto y de restricciones en el Presupuesto del Estado, en cuya formulación, reforma y ejecución se otorga control total al Ejecutivo en franco desmedro de las potestades que tradicionalmente tenía el Congreso o Asamblea Nacional. En los dos modelos se asegura el pago de la deuda externa y su servicio estableciéndose como una obligación imprescindible que debe constar en el presupuesto anual y en la programación presupuestaria estimada de más largo plazo.

En los dos modelos, la descentralización asegura, además, una participación económica fija en el Presupuesto del Estado de los gobiernos locales, si bien en el modelo neoliberal, con esos y otros recursos preasignados, se pretendía debilitar las potestades económicas del Estado central. En el modelo neointervencionista se mantiene la obligación de asignar en el Presupuesto del Estado porcentajes importantes de recursos a los gobiernos autónomos descentralizados, pero a la vez el Gobierno central controla su destino y ejecución por medio de una planificación local subordinada totalmente a la definida por el presidente de la República. Respecto del endeudamiento público, este se incrementó descontroladamente y a tasas de interés especulativas entre 2014 y 2016, violando normas constitucionales y legales y reglas de equilibrio fiscal, con la finalidad de sostener un modelo neointervencionista dispendioso, burocrático, plagado de corrupción, en la contratación de enormes inversiones en obras públicas de gran dimensión, en las que jamás se realizaron auditorias serias de gestión y gasto.

7. La legislación de las finanzas públicas, especialmente la tributaria y la del gasto y presupuesto, se analizó en su contexto histórico para concentrar la atención en las características propias, continuidades y diferencias de las políticas o modelos económicos neoliberales y neointervencionistas en Ecuador.

Los fines fiscales y extra fiscales de los tributos y de las reformas tributarias están asociados a la obligación de contribuir de los ciudadanos al pagar tributos. En nuestro estudio diferenciamos las reformas y ajustes rutinarios o coyunturales a los tributos, de las reformas o transformaciones de magnitud que impactan en el sistema tributario, tanto en su administración como en el ejercicio de derechos de los ciudadanos. 
En los dos modelos se priorizó la reorganización de la administración tributaria para hacer eficiente y eficaz la recaudación y perseguir la evasión y elusión, fortaleciendo la institucionalidad y capacidad recaudatoria del SRI (Servicio de Rentas Internas) y de otras administraciones tributarias, pero se puso menos énfasis en identificar a todos los grupos económicos más poderosos del país, si bien en la última década se avanzó parcialmente en su identificación e incorporación en el pago de tributos.

En los dos períodos se amplió también la base de contribuyentes, pero no mejoró la redistribución de la riqueza ni la equidad, pues el objetivo de las políticas neoliberales y neointervencionistas era mantener el equilibrio fiscal, restringir el incremento del gasto público nacional y garantizar el pago puntual de la amortización de la deuda externa y su servicio.

Sin embargo, las reformas tributarias inspiradas en el neointervencionismo crearon nuevos tributos directos e indirectos. En los diez años de Gobierno del presidente Correa se introdujeron más de 20 reformas, con fines principalmente recaudatorios y limitados matices redistributivos y medioambientales, como exigencia necesaria para solventar parcialmente el gran incremento del gasto y el deterioro de los ingresos petroleros.

En los dos modelos existe coincidencia también en la prerrogativa exclusiva del Ejecutivo para plantear iniciativas tributarias; en ofrecer y garantizar seguridad jurídica como incentivo y protección de la inversión, especialmente extranjera, y en la relación estrecha entre tributos y gastos para obtener equilibrio presupuestario y alcanzar los objetivos económicos y sociales que los dos modelos plantean.

En los dos modelos políticos económicos aplicados entre 1990 y 2017 se modernizaron también los procedimientos y el proceso contencioso tributarios para agilizar y simplificar las impugnaciones y proteger los derechos de los contribuyentes.

En ambos modelos, la concentración de poder o el hiperpresidencialismo, inspira una estructura centralizada de la administración tributaria y arancelaria. Mediante reformas a la ley, propuestas por el Ejecutivo, se eliminaron los directorios que ejercían ciertas potestades administrativas y estaban conformados con representación de los contribuyentes, para sustituirlos por comités de política tributaria y arancelaria, de carácter consultivo, conformados y controlados totalmente por representantes del Gobierno, mientras todo el poder regulatorio administrativo, normativo y sancionatorio quedó concentrado en los directores designados por el presidente de la República. 
8. Las normas constitucionales y legales en materia tributaria son bastante similares desde la expedición del Código Tributario en 1976 y luego de más de cincuenta años de vigencia, si bien han soportado varias modificaciones durante el modelo intervencionista y en la sucesión y combinación de los modelos recientes neoliberal y neointervencionista. Incluso principios como los de justicia y capacidad contributiva, se aplican dúctil y hábilmente en el tiempo conforme a los propósitos y objetivos de dichos modelos.

Durante el Gobierno del presidente Correa (2007-2017) se modificó la legislación tributaria para ampliar las prerrogativas estatales y la utilización de los recursos constitucionales de garantías de derechos que corresponden a los ciudadanos para impugnar los abusos de la autoridad, con la finalidad de proteger las potestades del Estado y muchas veces los atropellos de la autoridad tributaria.

Luego de la dolarización, con la que Ecuador perdió la potestad monetaria, la política tributaria y fiscal fue de trascendencia crucial, pues por medio de ella se debía garantizar, en los dos modelos o políticas económicas (2000- 2017), la estabilidad macroeconómica, el desarrollo y la justicia redistributiva.

Es cierto que se produce cercana identidad en los modelos, sistemas y políticas públicas tributarios en Ecuador y se pueden diferenciar los énfasis en sus discursos y advertir ciertos cambios significativos que no son sustanciales, pues la relación entre impuestos directos e indirectos entre 1997 y 2006 correspondían al $34.34 \%$ y al $65.7 \%$ respectivamente de la totalidad de la recaudación, mientras que entre 2007 y 2016, los directos fueron del 43,3\% y los indirectos del 56,6\% de la recaudación. En ambos períodos son mayoritarios los impuestos indirectos de naturaleza regresiva, si bien en el neointervencionismo se acortan las distancias.

Además, en el sistema de mercado, como todos conocemos, los tributos que pagan las empresas se trasladan a los costos de sus productos o se absorben mediante la inflación y la especulación en los precios, perjudicando a los sectores sociales, medios y populares de la población. Existe también la convicción social, ratificada por datos oficiales, de que los "esfuerzos tributarios" no se imponen finalmente a los grupos de poder, sino a la mayoría de la población.

Como señalamos en el capítulo tercero de esta investigación, el sistema tributario en el modelo neoliberal reduce la progresividad de los impuestos personales y sostiene, no sin fundamento, que el régimen intervencionista tampoco alcanzó los efectos redistributivos y de justicia propuestos, porque además de ser ineficiente en el control del fraude y de la elusión tributarios, produjo efectos recesivos y nocivos sobre la población más necesitada, pues 
incrementó el desempleo. Por ese motivo, se plantearon mecanismos para aliviarlo, fijando un límite máximo y creando estímulos en caso de generación de empleo. Se trata, por tanto, de aplicar con flexibilidad, de acuerdo a las condiciones históricas, los principios tributarios de proporcionalidad, no confiscatoriedad, capacidad económica, etc.

En el capítulo séptimo sobre el derecho de control dijimos que el modelo neoliberal, en todo caso, no pretende eliminar totalmente el valor de la solidaridad y de la justicia en el que se fundamenta el Estado social, sino reformular el sistema tributario y del gasto público para que aquellos operen eficientemente en el sostenimiento del sistema, manteniendo los servicios esenciales para los más pobres, pero sin afectar la sobreacumulación productiva $\mathrm{y}$ financiera de los monopolios y de las empresas transnacionales.

Y, afirmamos también, en lo relativo a la asignación equitativa de los gastos públicos se establece una conexión con el principio de igualdad material y medidas de discriminación positiva, para superar las desigualdades de origen y proveer los gastos sociales más significativos. Pero además, el modelo exige, en el campo de las finanzas públicas y de la actividad financiera, alcanzar permanentemente el equilibrio presupuestario, para lo cual los principios que regulan los ingresos y los gastos públicos deben estar íntimamente relacionados, pues se conectan con los efectos redistributivos del conjunto de la actividad financiera, para mitigar las diferencias y asegurar una sociedad más justa y solidaria.

El Gobierno de Correa (2007-2017) incorporó un número alto de nuevos contribuyentes, la mayoría provenientes de sectores medios y populares y más reducidamente de grandes contribuyentes, sin que por ello haya cambiado representativamente la estructura tributaria tradicional, ni se hayan incrementado significativamente los porcentajes de impuesto a la renta ni establecido un impuesto al patrimonio, por lo que la distribución del ingreso en Ecuador sigue siendo una de las más inequitativas de la región.

En los primeros siete años del Gobierno del presidente Correa disminuyó ligeramente la pobreza y no se alteró la polarización económica y social. Los datos demuestran que en los diez años del régimen neointervencionista los grupos de poder económico, comercial y financiero acumularon más riqueza que en períodos anteriores.

La CEPAL registra que los incrementos en la recaudación tributaria en América Latina se deben a la ampliación de la base tributaria, mediante "sistemas duales" en los que se diferencian los ingresos del trabajo de los del capital. Se limitan incentivos y deducciones y se establecen tributos mínimos a los ingresos societarios para obtener una recaudación más segura. Si bien los impuestos 
directos disminuyeron en el modelo neoliberal y en el neointervencionista se incrementaron del 3.4\% del PIB a 5.7\% del PIB, entre 2000-2014 no se alteró significativamente el rendimiento de los impuestos indirectos en los dos modelos ni la concentración de la riqueza en los mismos grupos de poder.

Al igual que en otros países, en Ecuador se introdujeron nuevos tributos en los precios de transferencia, en inversiones realizadas en paraísos fiscales, en las transferencias de rentas de no residentes, se crearon gravámenes "poco convencionales" por razones de emergencia y se establecieron regímenes simplificados de recaudación para estimular el pago de tributos de los pequeños contribuyentes.

Se introdujo también en este país el "anticipo" de impuesto a la renta, tanto a personas como a sociedades, tomando como base la estimación de activos, el monto total de ingresos brutos de las empresas, etc., con la finalidad de que se convirtiera en un pago mínimo de dicho impuesto, pues es casi imposible que fuera devuelto luego en su liquidación definitiva. De igual manera se establecieron otros tributos adicionales sobre la propiedad rural y urbana y a los vehículos y un impuesto del 5\% a la salida de divisas (ISD), para "sostener" la dolarización y controlar las importaciones, reconociendo a la vez algunas exoneraciones de carácter personal o para el fomento de las exportaciones.

Una real transformación tributaria fundamentada en un "pacto fiscal" entre Estado y contribuyentes, que dé como consecuencia alcanzar la equidad y redistribución de la riqueza para promover el desarrollo, todavía es una tarea pendiente en Ecuador al igual que en otros países de la región y el mundo.

9. El derecho del gasto y del presupuesto se encuentra fundamentado en las normas constitucionales y desarrollado en las normas legales que se han expedido tanto en el período 1990-2006 como en el 2007-2017. Sobre el presupuesto y gasto, las políticas neoliberales impusieron un control a su crecimiento y destino, procurando que varios servicios públicos pudieran ser autofinanciados por los ciudadanos. También se establecieron, en la década del noventa del siglo pasado, normas regulatorias y de prudencia financiera sobre la materia para que el Gobierno controlara todas las fases del ciclo presupuestario; se limitaron las posibilidades que tenían los legisladores para incluir nuevos egresos en el momento de aprobación o reforma del presupuesto y se incluyeron preasignaciones para educación, salud y gobiernos locales y para asegurar el pago de la amortización y servicio de la deuda, especialmente externa.

En el modelo neodesarrollista se mantuvieron similares y rigurosos mecanismos de control sobre el gasto y el presupuesto y aún se los llegó a ampliar, si bien se aumentó la intervención y participación estatal sobre los recursos naturales y los servicios públicos, con la finalidad de cubrir y subsidiar el gasto social, 
aprovechando además la bonanza de los precios internacionales de las materias primas y particularmente del petróleo. En cuanto a los gastos públicos, en el neoliberalismo se recomendaba que estos atendieran a las necesidades básicas del Estado y especialmente a las financieras, mientras que en el neointervencionismo se los articuló a la planificación y a una supuesta satisfacción y ampliación de derechos de los ciudadanos para el buen vivir.

En la evolución del Estado se diferencia entre el gasto neutro y esencial de la hacienda clásica con el gasto público activo propio de la hacienda moderna, neoliberal y actual, en la que su incremento o disminución impacta en la economía total y se los adopta para obtener determinados resultados macroeconómicos, articulados a la racionalidad y reproducción del sistema mundial.

En los principios del derecho del gasto tienen, en la actualidad, especial significación los criterios de equidad, eficiencia, estabilidad, solidaridad y planificación, pues se persigue que el gasto y las políticas públicas, relacionadas con los dos modelos o políticas económicas, presten eficientes servicios públicos y satisfagan los derechos de los ciudadanos con buenos parámetros, según la connotación que les otorgan los dos enfoques o su combinación.

Existe controversia sobre la justiciabilidad y responsabilidad de las autoridades que vulneren derechos fundamentales de los ciudadanos, en cuanto a su cobertura con los gastos y si se impugnan políticas de gasto y presupuesto que supediten o limiten su ejercicio, a la existencia y asignación insuficientes de los recursos económicos necesarios para su satisfacción.

Durante la ejecución de las políticas neocompetitivas en Ecuador (1990-2005) se cuestionó la activa participación estatal en la actividad económica y su eficiencia en la prestación de servicios públicos, por lo que se trató de limitar el gasto y las inversiones en ellos, para que sea el sector privado el que los financie o para que, con los aportes adicionales de los ciudadanos, el Estado asuma dichas competencias, mientras que en el período neointervencionista (2006-2017) se enfatizó en la recuperación del Estado en dichos campos, para que dinamice la economía con la inversión y el fomento de consumo y el bienestar de la población.

Se diferencian los conceptos de presupuesto financiero y de presupuesto económico y político del Estado, introducido ya en la etapa intervencionista, que se ha mantenido posteriormente tanto en el modelo neoliberal como en el neointervencionista, pues se pretenden alcanzar objetivos políticos claros que corresponden a los diferentes enfoques de los modelos que se implementan de manera sucesiva o combinada. 
Respecto de la obligatoriedad de las normas del gasto y del presupuesto y como consecuencia de ellas la posibilidad de establecer responsabilidades a funcionarios en cuanto a su incumplimiento, se ha preferido una cierta ambigüedad en los modelos económicos recientes, ya que si bien existen normas específicas que orientan y definen el gasto, muchas de las obligaciones y orientaciones del mismo constan en la planificación y en políticas públicas que no tienen la fuerza imperativa de la ley.

En las dos constituciones emblemáticas del modelo neoliberal y neointervencionista el presupuesto no se concibe ni se define ya como una ley formal, sino como un instrumento que debe cumplir determinados requisitos y cuya evaluación de cumplimiento que se encontraba inicialmente en manos de la Contraloría o de la Asamblea, desde la expedición del Código Orgánico de Planificación y Finanzas (2010), quedó finalmente como una atribución de la propia autoridad financiera. Ella define su contenido, ejecución y su propio control para proporcionarla luego al presidente de la República, quien discrecionalmente la puede incorporar o no en su informe anual a la Asamblea Nacional. De esta forma, en nuestra normativa vigente se diluyen una vez más las responsabilidades de las autoridades en el uso y gestión de los recursos públicos.

Si bien se reconoce una estrecha relación entre el derecho del gasto y el derecho presupuestario, es necesario diferenciarlos, ya que en si en este los egresos tienen validez formal, no se refieren a la legitimidad de su cobertura o satisfacción de los derechos de los ciudadanos consignados en el primero, tanto más que las autoridades tienen la obligación de cumplirlos. La naturaleza jurídica de los gastos-derechos es, sin duda, distinta a la de los egresos autorizados en el presupuesto, pues los primeros se fundamentan en la Constitución y la ley, mientras que los segundos son establecidos discrecionalmente por las autoridades, conforme la disponibilidad de recursos del erario nacional, al margen de las pretensiones y necesidades de sus beneficiarios.

El derecho presupuestario, por lo tanto, registra y autoriza los recursos asignados y es la normativa de su ciclo, mientras que el derecho del gasto regula los principios y normas constitucionales y legales destinados a reconocer la erogación de recursos públicos y la satisfacción de derechos económicos, sociales y culturales de los ciudadanos.

Durante el modelo neoliberal en Ecuador y con la aplicación de reglas fiscales recomendadas por el FMI y el BM, el presupuesto creció en la década del noventa del siglo pasado en porcentajes menores a la inflación, ya que no se lo estimaba como un instrumento de desarrollo. Antes de la dolarización, el déficit fiscal, el crecimiento de precios y el endeudamiento externo e interno y su 
amortización y servicio se salieron de control, por lo que se renovaron los programas de ajuste y reestructuración. Posteriormente a la dolarización, se expidieron leyes, reglas y medidas adicionales para convertir a la política fiscal en el principal instrumento de estabilización de la economía y de cumplimiento de las obligaciones internacionales.

En el modelo neointervencionista se combinaron las medidas anteriores con políticas neoestatistas y fiscales, también recomendadas por los organismos financieros y de desarrollo internacionales para reactivar la economía, elevar el consumo y cumplir con las obligaciones crediticias internacionales, aprovechando el auge de los precios internacionales del petróleo y de las materias primas. Si bien la deuda externa disminuyó al inicio del Gobierno de Rafael Correa (2008-2009) por el cese de pagos y la recompra en el mercado secundario, el régimen que contaba con cuantiosos recursos provenientes de los precios internacionales del petróleo se alejó temporalmente del mercado financiero tradicional para depender de los onerosos créditos de China y en los últimos años desde 2014, se vio obligado a colocar instrumentos financieros en el mercado internacional con altas tasas de interés, haciendo crecer descomunalmente la deuda externa e interna y superando artificial y dolosamente los límites establecidos en la legislación.

La economía ecuatoriana creció significativamente en la última década y se construyeron grandes proyectos de infraestructura, especialmente en el sector eléctrico. Se hace evidente la mala calidad del gasto por la corrupción generalizada, producto en buena parte de las modificaciones jurídicas que propiciaron una significativa disminución de controles en toda la estructura del Estado. La política fiscal contracíclica, sustentada en el gasto, dio como resultado el crecimiento del déficit y la iliquidez, llegando a situaciones críticas similares a las que en su tiempo llegaron los modelos económicos anteriores, por lo que una vez más se exhiben propuestas similares a las de antaño, para recortar los gastos, el incontrolado endeudamiento externo e interno y la reiterada corrupción, con la finalidad de alcanzar nuevos equilibrios, la sostenibilidad de la economía y la menor afectación a los sectores populares.

10. Como lo indicamos en el capítulo sexto de esta investigación, la planificación y la descentralización en América Latina y en Ecuador, más allá de su naturaleza jurídica, son un importante instrumento de desarrollo que están asociados, mucho más en la actualidad, a los modelos económicos implementados en nuestra región desde los años treinta del siglo pasado. Desde 1945 hasta 1975 tuvimos una importante etapa de despliegue institucional de la planificación; luego se dio un repliegue hasta el punto de que casi desaparecen sus instituciones y los planes de desarrollo en las dos últimas décadas del siglo XX y finalmente tenemos un proceso de revalorización institucional y de sus instrumentos, desde el 2000 hasta la actualidad. 
A lo largo de la historia de nuestros países ha existido una constante polarización entre centralización y descentralización que expresa las contradicciones económicas y la distribución de la renta nacional entre quienes controlan el poder del Estado nacional y los gobiernos regionales y locales. En los años sesenta del siglo pasado, en el modelo desarrollista, se planteó que la planificación centralizada reconozca polos de desarrollo regional y proyectos rurales y cantonales, para lo cual y se creó una institucionalidad y se dictó una legislación y normas administrativas que los promueva como instrumentos de descentralización funcional y territorial. En los años noventa el neoliberalismo, para debilitar al Estado central en sus atribuciones económicas y competencias, promovió una descentralización para fortalecer a los gobiernos locales con nuevas competencias y recursos para facilitar las privatizaciones y las transferencias de los recursos naturales y servicios públicos a las empresas privadas transnacionales y locales. En la década neointervencionista 2007-2017 se impulsó una recentralización, que si bien reconoce competencias exclusivas y recursos a los gobiernos provinciales y locales, los subordina con la planificación central y el control autoritario de la función ejecutiva. ${ }^{724}$

Los organismos financieros internacionales, como el BM y el FMI y los de desarrollo como la CEPAL, plantearon a fines del siglo pasado y ya en el presente la necesidad de limitar los excesos del modelo neoliberal y de revalorizar el papel que el gasto social produce en el desarrollo productivo y la necesidad de reintroducir en la Hacienda pública las técnicas de descentralización, planificación y asignación racional de los recursos públicos, convirtiendo al Estado en socio o elemento catalizador del desarrollo.

Los organismos multilaterales enfatizan que, en la actualidad, la nueva planificación o la estratégica-flexible puede ser un instrumento de gran utilidad en manos del Estado, para impulsar reformas estructurales y coordinar el desarrollo con procesos de consulta con los actores sociales, políticos y económicos internacionales y locales o mediante alianzas público-privadas, sin dejar de definir políticas públicas para alcanzar la sostenibilidad ambiental y el lograr valores esenciales en las sociedades democráticas como equidad, igualdad, transparencia y lucha contra la corrupción.

En cuanto a las normas administrativas y jurídicas relativas a la planificación en Ecuador, en el primer momento se produjo una evolución negativa (1990-2006) de este análisis, pues las políticas neoliberales fueron limitando y eliminando la estructura autónoma de planificación nacional y de control, en la asignación de recursos heredada del intervencionismo anterior a los años noventa y la sustituyeron por un Consejo Nacional de Modernización (CONAM) y una oficina de planificación adscrita a la Presidencia de la República que priorizaron,

\footnotetext{
${ }^{724}$ Esther del Campo García, Gobernabilidad y descentralización política-administrativa en los países
} andinos. El caso de Bolivia, Eciador y Perú en los años noventa, (Barcelona: CIDOB ediciones, 2006). 
mediante planes y estrategias de desarrollo, el equilibrio fiscal, la descentralización, la modernización del Estado, las privatizaciones, el cumplimiento de las preasignaciones presupuestarias y la creación de partidas extrapresupuestarias para fortalecer gobiernos y proyectos locales.

En la fase neointervencionista y con la expedición de la Constitución de 2008 se ampliaron las potestades y estructuras de planificación nacional, regional y local subordinadas a la SENPLADES, como instancia única del Ejecutivo para orientar el gasto y el presupuesto según sus decisiones autoritarias, relativizando la autonomía de los gobiernos locales y de otras entidades autónomas de seguridad social y de educación superior.

En este período (2006-2017) y según se proyecta para los años siguientes, la planificación y los planes de desarrollo se vincularon estrechamente a las finanzas públicas, a la programación macroeconómica para la sostenibilidad fiscal y a la formulación y ejecución del Presupuesto General del Estado y a la programación presupuestaria cuatrianual, para lo cual se requiere el aporte del Sistema Nacional de Información, del Sistema Estadístico y Geográfico Nacional, de los planes de inversión, etc.

El Plan Nacional de Desarrollo es el principal instrumento del sistema y tiene efectos vinculantes para todas las instituciones del sector estatal e indicativos para los otros sectores de la economía. El Código Orgánico de Planificación y Finanzas (2010) establece que el Plan Nacional de Desarrollo es la "máxima directriz política y administrativa" del Estado, que debe articular las acciones públicas de corto, mediano y largo plazo, por lo que se deben someter a él las acciones, programas y proyectos públicos, el endeudamiento público, la cooperación internacional, todas las fases del ciclo presupuestario nacional y local y los presupuestos de la banca pública, empresas públicas y la seguridad social.

Por ello, los defensores de la política neointervencionista sostienen que el nuevo ordenamiento jurídico, desde el 2007, sustituyó una concepción del Estado centrada en el mercado y en los individuos, por una que lo recupera en su papel activo en la economía y en la sociedad, para lo cual se requiere convertir a la planificación en el eje de la acción pública de un nuevo modelo de desarrollo.

Durante la última década se expidieron tres planes de desarrollo; el primero con ese nombre entre 2007-2010; el Plan del Buen Vivir 2009-2010 y el Plan Nacional para el Buen Vivir 2013-2017, que contienen un nuevo concepto de desarrollo mediante mecanismos desconcentrados y descentralizados y la conformación de unidades territoriales horizontales de planificación para la ejecución y optimización de los servicios públicos. 
Los dos primeros planes (2007-2013) se centraron en el objetivo de recuperar el papel del Estado en la economía, de promover un modelo alternativo para construir "igualitarismo republicano moderno para el buen vivir" fundamentado en la "sociedad del conocimiento, la agroecología y los servicios ecoturísticos comunitarios", sin dejar de reconocer la preeminencia de la economía privada. El Plan de Desarrollo del 2013-2017 disminuyó o sustituyó la visión anterior y plantea la necesidad de la modernización del sistema económico vigente para lo que propone el "cambio de la matriz productiva", para cubrir la demanda nacional, impulsar las exportaciones de productos industrializados y servicios de alto valor agregado. Como se puede observar existe un "desplazamiento conceptual" en los contenidos de los planes para concentrarse en la modernización del capitalismo local, mediante una negociación con el capital transnacional y los grupos económicos de poder interno para una mayor articulación hacia la actual globalización del sistema mundial.

11. Nuestras reflexiones y estudios sobre el derecho de control y responsabilidades, nos permiten hablar de él como una rama o disciplina especializada del derecho administrativo y del financiero económicos, en cuanto su campo de regulación objetiva y académica es la vigilancia o auditoría de aquella parte de la actividad económico-financiera, que se refiere a las decisiones previas en el uso correcto de los recursos públicos, a las actividades de gestión en todas sus fases y al cumplimiento de los objetivos y fines institucionales de los órganos que los administran. El derecho de control tiene su propia identidad, pues utiliza categorías específicas y está dotado de técnicas y procedimientos propios para el cumplimiento de su labor reguladora.

Como hemos indicado en varios estudios anteriores, existen numerosas clasificaciones sobre los tipos de control conforme a la naturaleza de su objeto y finalidad. En este trabajo privilegiamos el análisis del control económico y financiero vinculado a la lucha anticorrupción, pues está articulado al buen uso y gestión de los recursos públicos que permite corregir desviaciones ex ante y ex post en caso de haberlas y establecer las correspondientes responsabilidades administrativas y civiles o contables culposas y los indicios de responsabilidad penal, para que el órgano de control administrativo externo establezca las primeras o los ponga en conocimiento de la fiscalía y del juez competente, según los correspondientes cuerpos jurídicos.

Aclaramos una vez más que no nos hemos referido en este trabajo al control de legalidad, al jurisdiccional ni al control de los derechos individuales 0 colectivos, que son regulados por leyes especiales y tienen su propia institucionalidad $y$ propósitos de naturaleza diferente al financiero $y$ administrativo relacionados con el buen uso y buena gestión de los recursos públicos. 
Aceptando la diferenciación que hace nuestra legislación entre control interno y control externo, el control interno se lo realiza al interior de las propias instituciones públicas o de las que utilizan recursos públicos, como control económico, financiero y de legalidad, si bien dicho control, en la actualidad, se lo diferencia con el control de gestión de la actividad administrativa que siempre requiere del uso y gestión de recursos de todo tipo. Un eficiente control interno necesariamente debe tener un contenido y una repercusión económica que se tiene que vigilar de una forma permanente para establecer los correctivos adecuados oportunos y para detectar irregularidades que si son graves o delictivas tienen que ser tramitadas y sancionadas administrativa, civil o penalmente, siguiendo los procedimientos establecidos en el ordenamiento jurídico.

El control externo de los recursos y la gestión públicos, en cambio, puede ser: político si interviene el parlamento, Asamblea Nacional o Congreso, sus comisiones o los legisladores; técnico económico y financiero si en él participan los órganos externos, establecidos en la Constitución o en la ley, como órganos "auxiliares" o "autónomos" de la función legislativa, como son el Tribunal de Cuentas o la Contraloría, que están sometidos a un régimen jurídico administrativo especial, tanto para el ejercicio de sus labores de fiscalización y auditoría, como para adoptar resoluciones administrativas o jurisdiccionalescontables cuando se establecen las responsabilidades que son de su competencia. También forman parte del control externo los órganos o actividades realizadas o promovidas por los ciudadanos o las organizaciones sociales por medio de la institucionalidad estatal o fuera de ella.

El control externo e interno y social o ciudadano forman parte de un control integral y por lo tanto deberían estar interrelacionados y coordinados, ya que son complementarios y no son incompatibles, garantizando en todos ellos su independencia y autonomía como exigencias básicas para la eficiencia y eficacia de su labor.

En Ecuador, en la actualidad, se desvinculó a la Contraloría del control externo e interno de gestión, con las enmiendas constitucionales de diciembre de 2015, pues en la legislación hasta entonces vigente participaba en el control interno y externo integral, mediante auditorías en las fases del ciclo presupuestario, el cual, mediante normas expresas del Código de Planificación y Finanzas (2010), fueron asignadas desde entonces, en cuanto a su seguimiento, evaluación e informes, a las máximas autoridades de las entidades públicas y al órgano rector de las finanzas públicas, que es el mismo presidente de la República y el ministro de Finanzas en su representación, excluyendo a la Contraloría y a cualquier órgano de control externo.

El control político externo que la Asamblea Nacional o el Congreso puede constitucionalmente ejercer contra las máximas autoridades de la 
Administración Pública y del Estado, durante los modelos y políticos estudiados entre 1990 y 2017, se restringió manifiestamente, con creciente obstáculos y requisitos.

En los dos modelos se pretende impedir o hacer imposible el control político y la destitución del presidente, vicepresidente, ministros y máximas autoridades de control por violaciones constitucionales y legales en las que incurrieron frecuentemente para implementar los referidos modelos económicos. El control político, tradicionalmente relacionado con la violación de derechos individuales o colectivos o de intereses regionales, se trasladó al campo económico con denuncias de corrupción en el manejo de fondos públicos, en las privatizaciones y en la contratación de la gran obra pública nacional, y por ello, se introdujeron una serie de limitaciones constitucionales y legales y exigencias burocráticas de trámite casi imposibles de cumplir, para obstaculizar el trámite de los juicios políticos y para impedir la censura y destitución de los máximos dignatarios del gobierno, ministros y altos funcionarios del Estado. De igual manera, el control financiero sobre el presupuesto y el endeudamiento, que tradicionalmente era vigilado por la Asamblea o Congreso, fue trasladado por la Constitución y las leyes, a las propias esferas internas del gobierno, como resultado de la aplicación de las cartas de intención y los informes y recomendaciones de los organismos financieros internacionales FMI, BM, etc.

12. Respecto de la gestión y atribuciones de la Contraloría también se advierten modificaciones, tanto en la implementación del modelo neoliberal (1990-2006) como en el modelo neointervencionista (2007-2017). En el primero aparentemente se ampliaron sus atribuciones en la Constitución de 2008 al modificar y luego sustituir la LOAFYC, aprobada por la dictadura militar en 1977, por la Ley Orgánica de la Contraloría General del Estado (LOCGE) en 2002.

En los últimos diez años, para aparentar la autonomía de las instituciones de control, la Constitución de 2008 conformó una nueva función del Estado, la de Transparencia y Control Social. Dispuso que los titulares de los órganos que la conforman no sean designados ni por el Ejecutivo ni por la Asamblea como se hacía tradicionalmente, sino por un concurso promovido por comisiones especiales de selección y por el Consejo de Participación Ciudadana y Control Social por un período de cinco años, que finalmente se convirtió en un solapado instrumento de la función ejecutiva para controlar las designaciones de los titulares de los órganos de control y de otras instancias máximas del Estado con sus allegados, desvirtuando los procedimiento de selección meritocráticos.

La falta de autonomía que deberían tener las instancias de control y las jurisdiccionales con relación a quienes son las autoridades controladas o procesadas, crea finalmente una crisis institucional irreversible. Será necesario 
para restablecer la independencia real de funciones y desterrar el sometimiento a una de ellas que la elección y designación de los órganos técnicos de control se realice por parte de las otras funciones estatales con origen democrático en su elección o que se originen en procesos electorales directos, como ocurre en Bolivia para conformar la función judicial. Debería exigirse, además, a los personeros de los órganos técnicos y jurisdiccionales de control, el cumplimiento de requisitos severos de idoneidad para el desempeño de sus competencias, con períodos más extensos a los establecidos para sus electores y la posibilidad de estar sometidos a instancias políticas y jurisdiccionales de control sobre el ejercicio de sus potestades para que su desempeño sea eficaz, honesto y no arbitrario.

En Ecuador se ha constatado la ineficacia de las acciones e instituciones de control en asuntos y obras de mayor trascendencia económica. Casi no se han recuperado los fondos y recursos dilapidados y es notoria la falta de acción oportuna y eficaz de la Fiscalía, cuando le han remitido indicios de responsabilidad penal, como se ha denunciado en varias oportunidades, incluso por las autoridades de la Contraloría General del Estado.

Como consta en nuestras investigaciones sobre la gestión de la Contraloría, la mayoría de responsabilidades establecidas en los últimos diez años (2007-2017) en las acciones de control involucran principalmente a autoridades de gobiernos autónomos descentralizados que no tienen influencia ni relaciones políticas con las autoridades de control y las acciones tampoco involucran a los máximos representantes de las instituciones nacionales, sino a funcionarios de mediano y bajo nivel. Informes inculpatorios de la Contraloría en grandes obras o escándalos de corrupción en los que estén involucradas autoridades nacionales solo se han emitido inevitablemente cuando ya son de conocimiento público y es imposible disimular sus evidencias.

A la ineficiencia de la Contraloría se suma de manera definitiva la actitud complaciente y aún justificativa de los gobiernos de turno y en especial el de la última década (2007-2017) frente a casos de corrupción que se expresan en las "enmiendas" constitucionales (artículos 211 y 212 de la CRE) y legales que ha promovido para eliminar atribuciones, flexibilizar el control en la contratación público, descartar el control externo en la ejecución presupuestaria y autorizar a los personeros de las instituciones públicas para que organicen y resuelvan los informes de seguimiento y evaluación en la utilización de los recursos públicos y en la gestión y resultados de los proyectos ejecutados.

13. Las manifiestas falencias del control político y del control técnico asignado a los tribunales de cuentas o a la Contraloría, la lucha social y la exigencias de participación de la ciudadanía son el fundamento para incorporar, en las democracias contemporáneas, el control ciudadano o el control social como un 
derecho y una obligación para participar de manera directa en las decisiones del gobierno, en la elaboración de los presupuestos, la fiscalización de los recursos públicos y en el análisis y valoración de la calidad de la gestión realizada por las instituciones y órganos que disponen de ellos.

El desarrollo tecnológico y la revolución en las comunicaciones pueden facilitar el control social o ciudadano de manera directa, sea de manera individual o colectiva. Las leyes de transparencia, el acceso libre a la información pública y los convenios internacionales de lucha contra la corrupción y otras instancias institucionales mundiales, en las que se discuten los principales problemas de la democracia y de la participación, alientan para que se apoyen las iniciativas ciudadanas, que sin autorización ni regulación previa de la autoridad pública puedan contribuir a un control eficiente y eficaz de los recursos y bienes públicos.

Para evitar la participación social y manipular sus decisiones en el control independiente democrático y de la corrupción, gobiernos autoritarios han pretendido estatizarla para legitimar sus decisiones. En nuestra investigación pudimos constatar que transcurridos varios años desde que se conformara la Función de Transparencia y de Control Social y constituido el Consejo de Participación y Control Social (2008) en Ecuador, los resultados evidencian que si bien se han formulado políticas, planes y acciones conjuntos entre los organismos de control que no dejan de ser positivos y se ha definido un Plan de Prevención y Lucha contra la Corrupción 2013-2017, estos esencialmente son instrumentos retóricos, pues ha mejorado, de manera muy relativa, la calidad del control técnico sobre la Administración pública. En cuanto a las actividades del Consejo de Participación Ciudadana y Control Social (2009-2017), el órgano estatalizado fue muy diligente en promover y tramitar concursos de selección de altos funcionarios estatales, que en su totalidad fueron personas allegadas políticamente al Gobierno. Resultó totalmente ineficiente en el control anticorrupción, tanto es así, que no existen casos significativos que hayan sido judicializados.

En las denuncias e investigaciones de corrupción, la participación ciudadana y social es muy perceptiva y si bien se han presentado en esferas oficiales y de la Contraloría, muchas de estas no han prosperado y no han faltado casos en los que los denunciados o veedores sobre casos de corrupción han sido procesados, perseguidos y sancionados. Por ello, frente al silencio de los organismos de control y la fiscalía sobre irregularidades, sobornos y denuncias en grandes obras públicas, que han ocasionado un cuantioso endeudamiento externo, las organizaciones sindicales y sociales conformaron por su propia iniciativa y sin autorización estatal, el 30 de mayo de 2015, una comisión anticorrupción, integrada por profesionales de trayectoria intachable, para examinar y presentar 
denuncias de sobreprecios y presuntos casos de corrupción debidamente fundamentados.

14. En cuanto al control interno, como se ha evidenciado en esta investigación, se introdujo paulatinamente en nuestra legislación, si bien constaba en forma general y declarativa, en todas las constituciones republicanas, como una atribución implícita del Ejecutivo, especialmente en lo relacionado con el registro de cuentas y en el ámbito financiero. Es en la LOAFYC primero en 1977 y luego en la LOCGDE en 2002, que se regula el control interno como atribución propia de la Administración y como una labor complementaria de la Contraloría en el control externo, mediante auditorías internas que de una u otra manera están supeditadas al control y programación de la Contraloría.

Durante la ejecución de los dos modelos neoliberales y a los tres primeros años del neointervencionista (1990-2010) se reconoció la potestad de la Contraloría de organizar y de utilizar las auditorías internas como actividades previas o coordinadas con su labor de control externo, incluyendo, conforme lo disponía la Ley de Presupuestos del Sector Público (1992), que aquella era la responsable del control externo de todas las fases del ciclo presupuestario y que el control interno debía ser normado por el Ministerio de Finanzas.

Conforme se consolidó el proceso de concentración de poder y se adoptaron por parte del Ejecutivo medidas centralizadoras de la planificación y del control financiero y operativo internos por medio de la Secretaría Nacional de Planificación y Desarrollo (SENPLADES) y la Secretaría Nacional de la Administración Pública (SNAP) y con la expedición del Código Orgánico de Planificación y Finanzas (2010) se excluyó a la Contraloría del control externo e interno del ciclo presupuestario y se trasladó esa atribución al ente rector del Sistema Nacional de Finanzas Públicas, que es el propio presidente de la República y su ministro de Finanzas. Esta decisión se ve corroborada y ampliada para las otras instituciones de la Administración pública central con las enmiendas constitucionales de 2015, a los artículos 211 y 212 de la carta política, que despoja a la Contraloría de su competencia de auditar el cumplimiento de los objetivos de las instituciones y le priva de la capacidad de establecer responsabilidades en sus auditorías de gestión.

El control interno, siendo parte de un control técnico integral, debería emplearse para que el control externo constate las desviaciones detectadas y le sirva de precedente para obtener conclusiones más exactas y valederas en las labores finales de auditoría. En el régimen de Correa se argumentó que el control interno de gestión, en lugar de apoyar a la auditoria externa, debe ser solo un instrumento de evaluación para informar al presidente y para que este, a su vez, notifique anualmente sobre la gestión a la ciudadanía por medio de la Asamblea Nacional. 
Sin embargo, incluso para garantizar la eficacia del control interno, especialmente financiero, los órganos que lo realicen deberían ser independientes de la Administración y no ejercidos por órganos que formen parte de su la línea jerárquica, lo cual es imposible esperar de gobiernos concentradores de poder que prefieren el ocultamiento y la opacidad para evitar el desgaste de su imagen pública.

15. Las reflexiones y políticas comunes que hemos formulado en nuestros estudios sobre el derecho de control, relativas a la crisis de gobernabilidad a nivel global, nos llevan a la convicción y a la necesidad de fortalecer la institucionalidad democrática internacional, para que los gobiernos nacionales y sus coaliciones, mediante medidas de gobernanza involucren a todos los actores sociales, económicos y políticos; y permitan alcanzar estabilidad y sostenibilidad frente a los abusos del capital financiero internacional con el uso incontrolado e incontrolable de derivados y a la acción de la delincuencia internacional que, mediante el tráfico de drogas y la corrupción, han estructurado redes internacionales de difícil vigilancia, como ocurre con los paraísos fiscales y la manipulación de los derechos individuales de inversionistas y propietarios para satisfacer su ilimitada sed de lucro, perjudicando los derechos de la mayoría y aún de los propios estados.

De allí que los asuntos financieros públicos, de control, responsabilidad, anticorrupción, transparencia, acceso a la información, uso adecuado de la información y la tecnología, así como la exigencia creciente de una participación ciudadana directa en las decisiones y en la gestión de los asuntos y actividades principales de los órganos públicos y de aquellos que satisfacen o atienden intereses colectivos, son temas cruciales para fortalecer la democracia y sus instituciones.

16. Revisadas las normas constitucionales y legales que se han adoptado en el país sobre las finanzas públicas, la planificación y el control, conforme a los modelos y políticas económicas impulsadas por los organismos internacionales que responden a las necesidades de consolidar y reproducir el sistema económico y social vigente, cabe plantearnos, finalmente, si las normas actuales que constan en la Constitución de 2008 en Ecuador podrían permitir la construcción de un modelo económico, político y jurídico alternativo que no sean un instrumento para atender los requerimientos del sistema como ha ocurrido con los modelos vigentes incluido el denominado socialismo del siglo XXI para construir un sistema democrático social más justo, equitativo, libre de discriminaciones, exclusiones y corrupción y que satisfaga de manera creciente los derechos económicos sociales y culturales de sus ciudadanos.

Si consideramos el papel activo del derecho e identificamos en este estudio las cuestiones constitucionales y legales que por su ambigüedad fortalecen la 
articulación de la economía nacional a los intereses dominantes internos y de la globalización regional y mundial, también podrían abrir la posibilidad de una opción alternativa, popular, solidaria y pluralista, para ser estudiada y formulada por una coalición de fuerzas sociales y políticas que se propongan la real transformación del país.

En el caso ecuatoriano, en la nueva Constitución de 200, el Gobierno contaba en principio con un amplio respaldo social para impulsar transformaciones democráticas, lo que implicó contar inicialmente con un activo y movilizado poder constituyente de amplio espectro social, que no solo se expresaba en las normas y garantías que se consignaron en ella, sino que aseguraba, que se podían reformar o introducir nuevas normas constitucionales y legales y reformas institucionales dirigidas a la progresiva transformación del país. Sin embargo, el régimen impuso en la parte orgánica de la Constitución un esquema autoritario y populista que terminó absorbiendo y disolviendo a la representación y organización social y sustituyendo el ejercicio democrático del poder ejecutivo por un caudillismo personalista, puesto al servicio de la modernización del capitalismo local y disminuyendo y cortando derechos y garantías mediante el electoralismo, la propaganda y la división y persecución de las organizaciones sociales interpelantes de las principales políticas del régimen.

Las organizaciones sociales más importantes del Ecuador y sectores alternativos discuten en la actualidad sobre la necesidad de impulsar, partiendo de la Constitución vigente, que establece como posibilidad para su reforma integral, la reunión de una Asamblea Constituyente o la convocatoria de consultas populares para que se dicte una nueva carta política o se aprueben reformas democráticas progresivas y progresistas inspiradas en un pluralismo jurídico transformador, que mantengan las garantías ciudadanas, restablezcan las que fueron reducidas y recortadas por el Gobierno de Correa, impulsen de manera eficaz la unión de los pueblos latinoamericanos y reformulen la conformación de las instituciones republicanas, para que exista una real participación democrática y social sin exclusiones y se alcance un equilibrio en el ejercicio del poder, sin autoritarismo ni persecución y criminalización social.

Esto es, se requiere reconocer y ejecutar eficazmente un nuevo ordenamiento jurídico y político transformador, los derechos individuales y colectivos, especialmente los económicos, sociales y culturales de los diversos sectores sociales y de los pueblos que conforman el Ecuador, para forjar democráticamente una amplia participación social, el prometido proyecto alternativo plural que se frustró por las contradicciones e inconsistencias del régimen autoritario de Correa.

De igual manera, nos parece relevante referirnos también, a propósito de esta investigación, a la necesidad de formular en el ámbito teórico, político y 
jurídico, en el campo económico del derecho constitucional, administrativo y financiero incluyendo la descentralización, planificación y control, propuestas alternativas que se podrían desarrollar en futuras investigaciones, partiendo de conceptos y categorías provenientes de un marxismo renovado y de otras escuelas o corrientes actuales del pensamiento crítico-jurídico, como: la propuesta de un neoconstitucionalismo andino formulado por Ramiro Ávila o de la teoría del discurso; el feminismo jurídico y el derecho de minorías que propone Carlos del Cabo Sanmartín y otros o la investigación del contenido y desarrollo del derecho, poniendo como eje los derechos humanos y en especial los económicos, sociales y culturales de los ciudadanos, según plantea Jorge Witker.

El neoconstitucionalismo andino enfatiza en la importancia de desarrollar la teoría para guiar la transformación de la realidad injusta y conformar un nuevo pacto social, que teniendo como eje los derechos de los excluidos, el sistema jurídico no se convierta en un instrumento de dominación para consolidar las instituciones tradicionales al servicio de los sectores financieros $y$ transnacionales más agresivos que lideran el capitalismo mundial, sino en un camino para su democratizarlas y reformuladas en beneficio de las mayorías populares. $^{725}$

Por su parte, la teoría del discurso propone tomar en cuenta en la investigación jurídica las normas, sentencias y las relaciones jurídicas negociables; la práctica teórica doctrinal de los juristas y el derecho producido relativo a las creencias, percepciones y ficciones de los usuarios. Esta teoría podría ser útil para establecer las reglas de producción del discurso jurídico y las percepciones individuales y sociales de las normas económicas constitucionales, administrativas y financieras vigentes, pues dicho discurso jurídico es producto de la interrelación de otros (económico, social, ideológico, etc.) presentes en un determinado momento de la sociedad en conflicto y es finalmente con el cual el poder económico y político emite las normas destinadas a satisfacer sus intereses y controlar a los sectores sociales dominados. Esta teoría nos facilitaría, por tanto, no solo analizar las ideas dominantes sino la construcción de un discurso pluralista, convocante de la mayoría social para promover transformaciones necesarias y profundas.

El feminismo jurídico aportaría también, con un enfoque especial para analizar la realidad actual, pues parte de que el patriarcalismo se perfecciona en el capitalismo y se inserta en las relaciones de producción y es preciso introducir, en los análisis jurídicos contemporáneos y en este caso en las normas económicas, administrativas y financieras que tienen un impacto total en la

${ }^{725}$ Ramiro Ávila Santamaría, El neo-constitucionalismo andino, Universidad Andina Simón Bolívar, Quito 2016; Carlos De Cabo Sanmartín, Dialéctica del sujeto, dialéctica de la Constitución, Editorial Trotta, Madrid, 2010. 
sociedad y en los ciudadanos y en la satisfacción de sus derechos, especialmente económicos, sociales y culturales, la dimensión de género, la promoción de la igualdad, la eliminación de discriminaciones y el reconocimiento de esas diferencias. ${ }^{726}$ En cuanto al derecho de minorías, generalmente no escrito o consuetudinario, permite incluir dentro del pluralismo jurídico también, en los estudios y en la estructura del derecho y del Estado, el derecho de las comunidades, de los pueblos indígenas, de los guetos y de los grupos y movimientos sociales que funcionan como espacios extrasistema, en los que se reconoce la presencia y la acción de un sujeto colectivo en el ejercicio de derechos. $^{727}$

La investigación jurídica para implementar propuestas alternativas -en cuanto a las normas económicas administrativas y financieras públicas, incluyendo la descentralización, la planificación y el control-, es una propuesta válida para la creación de normas y doctrinas jurídicas transformadoras que se puedan asumir por los sectores sociales mayoritarios que luchan por una real transformación democrática del sistema, poniendo como eje la satisfacción y el control judicial de los derechos económicos sociales y culturales de la mayoría de la población, ${ }^{728}$ con un enfoque pluralista que reconozca la realidad existente y que en ella privilegie el impulso de relaciones sociales comunitarias, cooperativas y solidarias.

Del mismo modo, estas formulaciones teóricas son compatibles con la filosofía latinoamericana del siglo XX, ya que como lo señala el profesor Juan Camilo Salas, en una investigación jurídica se presenta lo que se denomina el "conflicto de interpretación", para lo cual se requiere estar dotado de una teoría que permita una mejor comprensión y explicación de la realidad, para formular una alternativa, o identificar propuestas innovadoras que tienen que surgir del análisis y conocimiento certeros del asunto investigado ${ }^{729}$. Para lo cual es preciso asumir el aporte de varios maestros latinoamericanos que han promovido una filosofía y soluciones propias de raigambre latinoamericana en las que ya han aportado los estudios de José Carlos Mariátegui, Manuel Agustín Aguirre, además de los teólogos de la liberación y cientistas sociales y politólogos como Agustín Cueva, Aníbal Quijan, Boaventura Sousa dos Santos entre otros, y juristas como Ricardo Gargarella, Jorge Witker, Carlos Wolkmer, Ramiro Avila, etc.

\footnotetext{
${ }^{726}$ M.L. Balaguer, Mujer y Constitución, Cátedra, Madrid, 2005; Igualdad y Constitución Española, Tecnos, Madrid, 2010; A. Facio y L. Fries (compiladoras y selección), Género y Derecho, La Morada, Santiago de Chile, 1999.

${ }^{727}$ Carlos de Cabo Martín, Dialéctica del sujeto, dialéctica de la Constitución, Editorial Trotta, Madrid, 2010.

${ }^{728}$ Jorge Witker, Los derechos humanos: nuevo escenario de la investigación jurídica, Boletín Mexicano de Derecho Comparado, nueva serie, año XLX, núm. 149, mayo-agosto 2017, pp. 979-1005.

729 Juan Camilo, Salas Cardona, conferencia "La Filosofía Española del siglo XX en América Latina", Salamanca, septiembre 2015.
} 
En el momento actual de funcionamiento sofisticado del capitalismo, especialmente con las persistentes crisis y la financiarización de la economía mundial, no resulta fácil identificar siempre el conflicto y la contradicción, pues se utilizan diversos mecanismos y técnicas para ocultar la situación real del sistema capitalista y la posibilidad de modificarlo y cambiarlo. Carlos de Cabo, subrayando el fenómeno anterior, observa que hoy en día se produce un extrañamiento de lo humano reducido a funcionalidad sistémica, una configuración cosificada de las relaciones sociales entre los hombres, por lo que puede concluirse que el capitalismo supone un bloqueo histórico de la razón ${ }^{730}$.

Por ello es necesario que el pensamiento crítico como el que proponemos y coincidimos, en sus diferentes vertientes debe contribuir al desbloqueo de aquella, para posibilitar la explicación y el conocimiento profundo y objetivo de la realidad y sus conflictos y encontrar los procedimientos y alternativas para su transformación.

Nuestra perspectiva de análisis jurídico, en este caso, no se inscribe en separar lo objetivo de lo subjetivo o en el necesario privilegio permanente de uno de ellos, sino en su presencia simultánea y en su interrelación con la totalidad, en la que, en algunos momentos o circunstancias, se privilegia uno a lo otro y viceversa, sin descartar que las instituciones y conceptos económicos del derecho constitucional, administrativo y del financiero sean un instrumento directo y eficaz de conocimiento y explicación de la realidad en ése ámbito, descartando una limitada aplicación legalista y positivista .

Un nuevo enfoque de los estudios jurídicos, en el ámbito económico constitucional, administrativo y financiero, pone en evidencia las contradicciones de su interior y transparenta los intereses en conflicto, lo que de por sí es movilizador de la opinión y acción de las mayorías y fundamenta los objetivos humanistas de la lucha social para que el ser humano sea el eje de acción del derecho. Solo con este enfoque se pueden adoptar, por lo tanto, decisiones progresivas y soberanas del poder constituyente con la finalidad de que sean un eficaz instrumento en la transformación de la realidad y la satisfacción integral de los derechos.

El pacto fiscal democrático, más allá de invocaciones ambiguas, debe conducir hacia una tributación justa y solidaria de todos los ciudadanos; a una asignación del gasto y de los créditos públicos que satisfagan progresivamente todos los derechos, priorizando, en la gestión del Estado, los económicos, sociales y culturales para una eficaz redistribución de la riqueza y la explotación racional y sustentable de los recursos naturales; a una planificación nacional, regional y

${ }^{730}$ Carlos, De Cabo Martín, Dialéctica del sujeto, dialéctica de la Constitución, Madrid, Editorial Trotta, Madrid, 2010, página 33. 
local democrática que supere desequilibrios y desigualdades y al ejercicio de un control directo, eficiente y permanente de la población, en el uso óptimo de los recursos públicos, erradicando la corrupción y el aprovechamiento ilegal en el ejercicio arbitrario y autoritario de las funciones del Estado.

También es evidente que en el presente se plantean exigencias de los actores sociales tradicionales y de los nuevos para revalorizar la estructura jurídica y política de los estados y de sus procesos regionales de integración y de articulación a la globalización, para demandar ampliación y progresividad de los derechos y la vigencia plena de la democracia y de las garantías ciudadanas y en especial en la creciente satisfacción de los derechos económicos, sociales y culturales y para que se pueda reclamar jurisdiccionalmente su creciente satisfacción y cumplimiento.

Todas esas teorías jurídicas y doctrinas transformadoras y el desarrollo de la conciencia y movilización social, pueden abrir el campo de formulaciones alternativas eficaces que sean el fundamento para una verdadera y profunda transformación de todas las estructuras económicas, sociales y jurídicas vigentes en Ecuador, la región y el mundo. 


\section{BIBLIOGRAFÍA}

Acosta, Alberto y otros. El correismo al desnudo, Quito: Arcoiris Producción Gráfica, 2013.

Acosta, Alberto, La restauración conservadora, Quito: Arcoiris Producción Gráfica, 2014.

Acosta, Alberto. "A modo de prólogo. El correísmo. Un modelo de dominación burguesa", Quito: Montecristi Vive, 2013.

Acosta, Alberto. Breve Historia Económica del Ecuador, Quito: Corporación Editora Nacional, 2012.

Acosta, Alberto. La deuda eterna, ALOP, CAP, CECCA, CERG, Quito: CIUDAD, 1990.

Aguirre, Manuel Agustín. Dos Mundos dos Sistemas, Quito, Colección Pensamiento Socialista Volumen 1, estudio introductorio de Víctor Granda Aguilar, Ediciones La Tierra, 2006.

Alberich Nistal, Tomás y Otros, Planificación y gestión: manual para la acción social, 1ra Edi. Madrid: Dykinson, 2014.

Albertí Rovira, Enoch. "Criterios constitucionales de la intervención pública en la economía" en La Constitución económica, Madrid: Asociación de Letrados del Tribunal Constitucional, 2012.

Alfaro, Eloy. Deuda Gordiana, Quito: Imprenta Nacional, 1896.

Alfaro, Eloy. Historia del Ferrocarril, Quito: Editorial Nariz del Diablo, 1931.

Alli Aranguren, Juan-Cruz. Derecho Administrativo y Globalización, Madrid: Universidad de Navarra, Aranzadi, 2004.

Amatucci, Andrea. "La enseñanza del derecho financiero en Italia y España", Quito, Revista de Derecho N 1, UASB-CEN, 2003.

Amin, Samir. Transnacionalización de la economía, el reto de la mundialización en Globalización, mundialización y modernización capitalista, Dakar: Third World Forum, 1999.

Anderson, Perry. "Neoliberalismo: un balance provisorio" y "Más allá del neoliberalismo", en La Trama de Neoliberalismo, Emir Sader y otros, Buenos Aires: CLACSO, 2da edición, 2013.

Anderson, Peter V.N. "La Constitución ecuatoriana de 1861”. Enrique Ayala Mora, editor, Historia Constitucional, estudios comparativos, Biblioteca de Historia/36, Universidad Andina Simón Bolívar - Corporación Editora Nacional, Quito, 2014. 
Arnáez Arce, María. La potestad planificadora de las administraciones públicas, Bilbao: Gomylex, 2013.

Ávila Santamaría, Ramiro. El neoconstitucionalismo andino, Quito: Universidad Andina Simón Bolívar, 2016.

Ávila, Ramiro y Luis Fernando Torres, "Debate dos visiones diferentes sobre la Constitución", en La Nueva Constitución del Ecuador, S. Andrade, A. Grijalva, C. Storini, editores, Quito: Universidad Andina Simón Bolívar / Corporación Editora Nacional, 2009.

Ayala Mora, Enrique. Ecuador en el "Capitalismo del Siglo XXI", Quito, Ediciones La Tierra, 2015; ¿Por qué la Asamblea Constituyente?, Quito, Ediciones la Tierra, 2015 .

Ayala Mora, Enrique. Edit. Historia Constitucional, estudios comparativos, Biblioteca de Historia/36, Quito: Universidad Andina Simón Bolívar - Corporación Editora Nacional, 2014.

Barber, William J. Historia del Pensamiento Económico, Madrid: Alianza Editorial, 1980.

Barnes, Javier. "Reforma e innovación del procedimiento administrativo", en La Transformación del procedimiento administrativo, J. Barnes, editor, Sevilla: Global Law Press, 2008.

Blanes Climent, Miguel. La transparencia informativa de las Administraciones públicas, Aranzadi: Editorial Thomson-Reuters, 2014.

Bobbio, Norberto. Contribución a la Teoría del Derecho, Valencia: Editorial Fernando Torres-Editor, 1980.

Bobbio, Norberto. Liberalismo y Democracia, México: Fondo de Cultura Económica, 1997.

Borja, Ramiro. Derecho Constitucional Ecuatoriano. Quito - Ecuador, Tomo 2. Ed. Cultura Hispánica, 1950.

Borrero Veintimilla, Antonio. Derecho Bancario Ecuatoriano, Cuenca: Indugraf, 1982.

Bouza, Nuria. Caterina García y Angel Rodrigo. ¿Hacia Worldfalia? La gobernanza política jurídica del interés público global, en La gobernanza del interés público global, XXV Jornadas de la Asociación Española de Profesores de Derecho Internacional y Relaciones Internacionales, Universitat Ponpeu Fabra, Tecnos, Barcelona, 2013.

Burgaya Riera, Josep. El Estado de bienestar y sus detractores: A propósito de los orígenes y la encrucijada del modelo social europeo en tiempos de crisis, 1ra Edi., Octaedro, 2013. 
Caballer Dura, M. "El Control de la Actividad Financiera: concepto, clases y ámbito, Órganos de control", en VVAA, Nociones de Derecho Financiero, Madrid, EHP, 1993.

Calonge Velázquez, Antonio. La "nueva" institución de la Unión: El Consejo Europeo, en Derecho Administrativo y Regulación Económica Liber Amicorum Gaspar Ariño Ortiz, coordinadores Juan Miguel de la Cuétara Martínez y otros, España: La Ley, 2011.

Casanovas, Ariel. "La dimensión pública del Derecho Internacional actual" en la Gobernanza del interés público global, XXV Jornadas de la AEPDIRT, Universitat Pompeo Fabra y Tecnos, Barcelona, 2013.

Castillo Calle, Manuel Arnaldo. El Derecho Constitucional Económico, Lima: CLDC, 2012.

Cazorla Prieto, Luis María. Derecho Financiero y Tributario, Parte General, Navarra: Editorial Aranzadi, 2001.

Cepeda Ortiz, Carlos Alberto. El sistema de control interno del Estado", Bogotá: Ediciones Librería del Profesional, 2001.

Colección pensamiento Socialista $\mathrm{N}^{\mathrm{o}}$ 9, José Moncada. Historia Económica, Planificación y socialismo, Quito: Edit. La Tierra, 2008.

Cornago, Noe. "De la Filosofía político a la Gobernanza Global: un acercamientos crítico a la noción del interés público global", en XXV Jornadas de AEPDIRT, Universitat Pompeu Fabra, Tecnos, Barcelona, 2013.

Cotarelo García, Juan. "El concepto de Constitución económica y su aplicación a la Constitución española de 1978" en El Sistema Económico en la Constitución Española, Madrid: Ministerio de Justicia 1994.

Cueva, Agustín. "Problemas y perspectivas de la teoría de la dependencia" en Teoría social y procesos políticos en América Latina, México: Editorial Edicol, 1979.

Cueva, Agustín. El desarrollo del capitalismo en América Latina, México: Siglo XXI, 1979; Autoritarismo y fascismo en América Latina, Quito: Centro de Pensamiento Crítico, 2da edición, 2013.

Cuvi, Pablo. Historia del Congreso Nacional, República del Ecuador, Quito: Mariscal, 2004.

Dávalos, Pablo. La democracia disciplinaria, el proyecto posneoliberal para América Latina, Quito: Graficas Iberia, 2010.

David Held y otros, Transformaciones globales, México: University Press, Oxford, 2002 . 
De Cabo Martín, Carlos. Dialéctica del sujeto, dialéctica de la Constitución, Madrid: Editorial Trotta, 2010.

De la Garza, Sergio Derecho Financiero Mexicano, México: Porrúa, 1985.

De la Guerra, Eddy. El deber de contribuir al gasto público, principios que lo informan y derechos del contribuyente, México: Editorial Porrúa, 2017.

De la Guerra, Eddy. El régimen tributario ecuatoriano, Quito: CEP, 2012.

De la Torre, "Carlos. Asamblea Constituyente y Economía", Constituciones en Ecuador, Quito: Abya-Yala, 2007.

Del Campo García, Esther. Gobernabilidad y descentralización político-administrativa en los países andinos. El caso de Bolivia, Ecuador y Perú en los años noventa, Barcelona: CIDOB ediciones, 2006.

Doanto Gianini, Achille. Instituciones de Derecho Tributario. Traducción y estudio preliminar de Sainz de Bujanda, Madrid: Giuffre Editores, 1957.

Drake, Paul W. Kemmerer en los Andes, Quito: Banco Central del Ecuador, 1995.

Durango, Washington. Legislación Tributaria Ecuatoriana, Quito: Editorial Universitaria, 1979.

Edwards, Sebastián y Rudiger Dornsbusch. eds, Macroeconomía del populismo en América Latina, México: Fondo de Cultura Económica, 1992.

Embid Irujo, Antonio. La Constitucionalización de la crisis económica, Madrid: Iustel, 2012.

Endara Osejo, Ximena. Modernización del Estado y Reforma Jurídica, Ecuador 19921996, Quito: UASB, 1999.

Fabra Valls, Modesto. "Solidaridad y Derecho Financiero en una sociedad neocompetitiva", en Revista Española de Derecho Financiero, Nro. 120, 2013.

Fernández Ajenjo, José Antonio. El control de las administraciones públicas y la lucha contra la corrupción, Pamplona: Civitas - Thomson Reuters, 2011.

Fernández Lamela, Pablo. El impacto de las redes transgubernamentales en la evolución del Derecho Administrativo Internacional, en Benedit Kingsbury y otros, El Nuevo Derecho Administrativo Global en América Latina, Buenos Aires: Ediciones Rap S.A.,2009.

Fernández, Tascón y Otros. Una visión eurocéntrica de la actividad económica, del Neolítico al siglo XXI, 1era Ed. Madrid: Biblioteca Nueva, 2012. 
Flor Recalde, Eulalia. Comp. Construcción de un Estado Democrático para el Buen Vivir. Análisis de las principales transformaciones del Estado ecuatoriano 2007 - 2012, Quito: SENPLADES, 2014.

Flores Jijón, Antonio. La conversión de la deuda anglo.ecuatoriana, Biblioteca básica del pensamiento ecuatoriano, Banco Central del Ecuador, Quito: CEN, 1979.

Gallego Rodríguez, Pablo. Organismos de control y participación en la gestión. La participación ciudadana y representativa", en La Gestión de los Fondos Públicos: Control y Responsabilidades, Alberto Palomar, Mario Garcés (Directores) y otros, Pamplona: Thomson Reuters Aranzadi, 2013.

Garcés San Agustín, Mario. "El control económico-financiero en el ámbito de la Administración General del Estado", 483, en La Gestión de los Fondos Públicos: Control y Responsabilidades, Alberto Palomar, Mario Garcés (Directores) y otros, Pamplona: Thomson Reuters Aranzadi, 2013.

Garcés, Diego. Intendente del Mercado de Valores, oficio $N^{\circ} 10529$ de 16 de junio de 2003.

Gargarella, Roberto. Los fundamentos de la desigualdad, Madrid: Siglo XXI, 2008.

Gargarella, Roberto. Pensando sobre la Reforma Constitucional en América Latina, en El derecho en América Latina, César Rodríguez Garabito, coordinador, Buenos Aires: Siglo Veintiuno Editores, 2011.

Garzón, Carlos Licto y otros. En Comentarios a la Ley Reformatoria para la Equidad Tributaria del Ecuador, Ediciones Processum, Quito, 2008.

Giuliani Fonrouge, Carlos. Derecho Financiero, Volumen I, obra actualizada por Susana Navarrine y Rubén Asorey, $7^{\text {a }}$ edición, Buenos Aires: Depalma, 2001.

Gómez Sabaini, Juan Carlos y otros. Consensos y conflictos en la política tributaria de América Latina, Santiago: CEPAL, Naciones Unidas, Cooperación Española, 2017.

Gómez Sánchez, Yolanda. El Tribunal de Cuentas: el control económico y financiero externo en el ordenamiento constitucional, Madrid: Marcial Pons, 2001.

Gordillo, Agustín. Derecho administrativo de la economía, Buenos Aires: Ed. Macchi, 1967.

Gorospe Oviedo, Juan Ignacio. Derecho Financiero y Tributario, Madrid: Dykinson, 2010.

Granda Aguilar, Víctor. Contenido económico de las Constituciones de Bolivia y Ecuador. Reflexiones jurídico-políticas, Quito: Ediciones Legales y Universidad Andina Simón Bolívar, 2015. 
Granda Aguilar, Víctor. Derecho Económico Financiero Ecuatoriano, Quito: Universidad Central del Ecuador, 2016.

Granda Aguilar, Víctor. Didáctica Activa del Derecho", Quito: Editorial UniversitariaUCE, 2009.

Granda Aguilar, Víctor. La Masacre de Aztra, Cuenca: Facultad de CCEE de la Universidad de Cuenca, 1979.

Granda Aguilar, Víctor. Los principales desafíos del Derecho Administrativo en el Ecuador de hoy, Salamanca, Curso de Especialización en Derecho, 2015.

Grijalva, Agustín. "La Constitución Económica del Ecuador" en Estado, Derecho y Economía, Quito: UASB sede Ecuador y Corporación Editora Nacional, 2013.

Grizziontti, Benvenutto. Principios de la ciencia de las finanzas, Buenos Aires: Depalma, 1949.

Guitian, Manuel y Félix Varela. Sistemas financieros ante la globalización, Madrid: Ed. Pirámide, 2000.

Guzmán, Marco Antonio. Derecho Económico Ecuatoriano, Tomos I y II, Quito: Universidad Andina Simón Bolívar y Corporación Editora Nacional, 1996.

Harnecker, Marta. El Capital: conceptos fundamentales DEL CAPITAL, México: Siglo XXI, 1971.

Hayek, Friedrich A. von. Camino de la servidumbre, San José: Libro Libre, 1989.

Hidalgo López, Luis. "Organismos de Control" en Nueva justicia y revocatoria del mandato, Quito: programa de Apoyo al Sistema de Gobernabilidad Democrática, Colección Reforma Política 3, Gobierno del Ecuador-BID, 1997.

Hobsbawm, Eric. Historia del Siglo XX, Barcelona: Editorial Crítica, 2003.

Iglesias, Enrique V. Reflexiones sobre el desarrollo económico", Washington: BID, 1992.

Ingrosso, Gustavo. Derecho Financiero, Nápoles 1956.

Jara, María Elena. "Constitución económica ecuatoriana y desarrollo" en Estado, Derecho y Justicia, Ramiro Ávila, compilador, Quito: Universidad Andina Simón Bolívar / Corporación Editora Nacional, 2013.

Jiménez Tello, Pilar. "Valores de la auditoria y la evaluación en las administraciones Públicas", en Nuevas formas de control de las administraciones públicas y su repercusión sobre consumidores y usuarios", Enrique Rivero Ysern y M. Dolores Calvo Sánchez, (Coord.), Salamanca: Ratio Legis, 2013. 
Jiménez, Juan Pablo y Andrea Podestá. La tributación sobre la renta en América Latina: desafíos y perspectivas, en Consensos y conflictos en la política tributaria de América Latina, Santiago: CEPAL, Naciones Unidas, Cooperación Española, 2017.

Keynes, John Maynard. Teoría general de la ocupación, el interés y el dinero, traducción de Eduardo Homedo, México: Fondo de Cultura Económica, 1992.

Kingsbury, Benedict, NicoKrisch y Richard Stewart. "El Surgimiento del Derecho Administrativo Global" en BenedictKingsbury y otros, El Nuevo Derecho Administrativo Global en América Latina, Buenos Aires: Ediciones Rap S.A.

Kresalja Baldo y César Ochoa, Derecho constitucional económico, Lima: Fondo editorial de la Universidad Católica del Perú, 2009.

Lange, Oskar. Objeto de la economía política: nociones preliminares. Moderna economía política, 2da edición, Río de Janeiro: Fondo de Cultura, 1963.

Lazo Vitoria, Ximena. El control interno del gasto público estatal, Madrid: Tecnos, 2008.

Leguizamón Acosta, William. Derecho Constitucional Económico, Ediciones Jurídicas Gustavo Ibáñez, 2002.

Locke, John. Ensayo sobre el Gobierno Civil, México: Aguilar, 1983.

López, Manuel."La protección de la estabilidad financiera como bien público global”, en La Gobernanza del Interés Público Global, XXV jornadas de la AEPDIRI, Barcelona: UniversitatPompeuFabra, Tecnos, 2013.

Luna, Luis. Ecuador Sociedad Limitada, $1^{\circ}$ Ed. Quito: Promoser, 1989.

Mancero Samán, Alfredo. La Constitución económica del Estado ecuatoriano y las nuevas condiciones de la economía mundial, Quito: UASB-E / CEN / Fundación Jonrad Adenauer (FKA), 1997.

Martín Queral, Juan y otros. Curso de Derecho financiero y tributario, Tecnos, 22 edición, Madrid 2011.

Martínez Lago, Miguel Ángel y otros. Lecciones de Derecho Financiero y Tributario, undécima edición, Madrid: Iustel, 2015.

Martínez Neira, Néstor. Sistemas financieros, fundamentos jurídicos y económicos para la iniciación de su estudio en América Latina, Bogotá: Biblioteca Felaban, 1994.

Martínez Peroni, José Luis. Algunas consideraciones acerca de las funciones del poder, en Dardo Pérez Guilhou y otros, Atribuciones del presidente argentino, Instituto Argentino de Estudios Constitucionales y Políticos, Buenos Aires: Depalma, 1987. 
Martínez, Patricia. "Organización Administrativa" en Manual de Derecho Administrativo, Ismael Farrando y otros, Buenos Aires, Ediciones Depalma, 1996.

Martín-RetortilloBaquer, Sebastián. Derecho administrativo económico, Madrid: La Ley, 1991.

Marx, Carlos. Prólogo de la Contribución a la Crítica de la Economía Política, Berlín: ErstesHelft, 1859.

Máttar Jorge J. y Daniel E. Perrotti. La planificación como instrumento de desarrollo con igualdad en América Latina y el Caribe: Tendencias y desafíos, Chile: CEPAL, 2014.

Matus, Carlos. Estrategia y Plan, Santiago: Editorial universitaria, 1972; La planificación posible en la prospectiva socio política de América Latina, Caracas: CENDES, 1980.

Meireles, Monika y Mateo Martínez. En El correismo al desnudo, Alberto Acosta, editor, Quito: Montecristi vive, 2013.

Mejía Salazar, Álvaro. Diccionario de derecho tributario, Quito: Corporación de Estudios y Publicaciones, 2012.

Mogrovejo, Juan Carlos. El poder tributario municipal en el Ecuador, Ediciones AbyaYala, Quito, 2010.

Moncayo, Patricio. La planificación estatal en el inter juego entre desarrollo y democracia, Quito: Atrio, 2017.

Monsalve, Claudio. Legislación Monetaria y Bancaria, Loja: Universidad Técnica Particular de Loja, 1999.

Montaño Galarza, César. La obligación de contribuir y los primeros de la tributación en las constituciones de los estados miembros de la Comunidad Andina, en Tópicos fiscales contemporáneos, México: Universidad de Guadalajara, 2004.

Montaño Galarza, César. Manual de Derecho Tributario Internacional, Quito: UASB CEN, 2006.

Montesquieu, Luis. El Espíritu de las Leyes, Madrid: Colegio de Abogados de Madrid, 1999.

Muñoz, Pabel. Secretario Nacional de la Secretaría Nacional de Planificación y Desarrollo, la desconcentración del Ejecutivo en el Ecuador. El Estado en el territorio y la recuperación de lo público, Quito: SENPLADES, primera edición, 2014.

Nieto García, Alejandro. Derecho administrativo sancionador, Madrid: Tecnos, 2009. 
Ocampo, José Antonio. "Una visión amplia de la estabilidad macroeconómica", en Narcis Serra y J. Stiglitz (eds), El consenso de Washington reconsiderado. Hacia una nueva gobernanza global, Oxford New York: UniversityPress, 2008.

Ocampo, José Antonio. América Latina frente a la turbulencia económica mundial, en Neo estructuralismo y corrientes heterodoxas en América Latina y el Caribe a inicios del siglo XXI, Alicia Bárcena, Antonio Prado, Santiago de Chile: CEPAL - IDRC - CDRI, 2015.

Pacheco Prado, Lucas. Política Económica, sus fundamentos en la economía política, Quito: Pontificia Universidad Católica del Ecuador, quinta edición, 2015.

Palomar Olmeda, Alberto. "El control de las administraciones públicas desde una perspectiva general. Insuficiencias del sistema actual" en La Gestión de los Fondos Públicos: Control y Responsabilidades, Alberto Palomar, Mario Garcés (Directores) y otros, Pamplona: Thomson Reuters Aranzadi, 2013.

Parejo Alfonso, Luciano. Antonio Jiménez Blanco, Luis Ortega Álvarez. Manual de Derecho Administrativo, vol. I, 5ta edición, Barcelona: Ariel, 1998.

Patiño Ledesma, Rodrigo. El cobro de la deuda tributaria y la vía judicial, Quito: Instituto Ecuatoriano de Derecho Tributario, 2004.

Paz y Mino Juan y Carlos De la Torre. En Asamblea Constituyente y Economía, Quito, THE, 2007 y Agustín Grijalva, en Estado, Derecho y Economía, Quito: UASB, 2013.

Paz y Mino, Juan Pablo. Revolución Juliana: Nación, Ejército y bancocracia, Quito: Abya-Yala, 2000.

Paz y Miño Cepeda, Juan. "Constituyentes, Constituciones y Economía" en Asamblea Constituyente y Economía, Taller de Historia Económica, ADHILAC, Quito: ABYA YALA, 2007.

Paz y Miño, Juan Pablo. Cepeda, Historia de los impuestos en Ecuador, Quito: SRI, CEFI, THE, 2015.

Pérez Guilhou, Dardo. Responsabilidad política y control en la reforma de las constituciones provinciales, Córdova: Banco Social de Córdova, 1985.

Pérez Royo, Fernando. Derecho Financiero y Tributario Parte General, Madrid: Editorial Civitas. 9na. edición, 1999.

Pérez Royo, Javier. Las Fuentes del Derecho, Madrid: Tecnos, 5ta edición, 2008.

Piketty, Thomas. La Crisis del Capital en el siglo XXI, Anagrama, Colección Argumentos, Barcelona: Siglo XXI editores, 2015.

Plazas Vega, Mauricio. Derecho de la hacienda pública y Derecho tributario, las ideas políticas de la hacienda pública, Bogotá: Editorial Temis, 2000. 
Pólit Faggioni, Carlos. La Contraloría General del Estado en el ordenamiento jurídico constitucional, Quito: NINA Comunicaciones, 2009.

Prado Mario y otros. Comentarios a la Ley Reformatoria para la Equidad Tributaria del Ecuador, Ediciones Processsum, 2008, Quito, Ecuador.

Prebisch, Raul. "La teoría económica, el monetarismo y los países periféricos”, en Los modelos de la crisis, compilación SohelRiffka, Quito: Editorial El Conejo, 1983.

Prebisch, Raúl. El capitalismo periférico, México: Fondo de Cultura Económica, 1981.

Queralt, Juan Martín. Carmelo Lozano, José Tejerizo, Gabriel Casado, Curso de Derecho Financiero y Tributario, Madrid: Tecnos, 2011.

Rawls, Jhon. Liberalismo Político, México: Fondo de Cultura Económica, 1996.

Riofrío Villagómez, Eduardo. Estudios de Derecho Financiero, 1949, CCE, Quito.

Riofrío Villagómez, Eduardo. Manual de Ciencia de hacienda, Tomos I-IV, Quito: Casa de la Cultura Ecuatoriana, 1977.

Riofrío Villagómez, Eduardo. Manual de Hacienda Pública Tomos I, II y III, Quito, Casa de la Cultura, Ecuatoriana, 1957.

Riofrío Villagómez, Eduardo. Tratado de Finanzas Públicas, CCE, Quito, 1968.

Rivero Ortega Ricardo y Víctor Granda Aguilar. Derecho Administrativo, Quito: Universidad Andina Simón Bolívar, Sede Ecuador, Corporación Editora Nacional, 2017.

Rivero Ortega, Ricardo. (ed.), "Reforma del Estado en América Latina... en A. Ferraro, En busca del buen gobierno: Nuevas perspectivas sobre política y gestión del Estado en América Latina, Barcelona: Ediciones Bellaterra, 2007.

Rivero Ortega, Ricardo. "El derecho a la buena administración en Europa y el procedimiento administrativo de la Comunidad Autónoma de Castilla y León", Revista de Administración y Función Pública de Castilla y León, $\mathrm{N}^{\circ}$ 1, abril 2004.

Rivero Ortega, Ricardo. "La necesaria innovación de los medios de control administrativo" en Nuevas formas de control de las administraciones públicas y su repercusión sobre consumidores y usuarios, Enrique Rivero Ysern y María Dolores Calvo Sánchez, coordinadores, Salamanca, Ratio Legis, 2013.

Rivero Ortega, Ricardo. Derecho administrativo económico, Madrid: Marcial Pons, sexta edición, 2013.

Rodríguez Arana, Jaime. Aproximación al Derecho administrativo constitucional, México: Editorial LiberJurisNovum, 2011. 
Rodríguez Bereijó, Álvaro. Introducción al estudio del Derecho Financiero. Un ensayo sobre los fundamentos teóricos del Derecho Financiero, Madrid: IEF, 1976.

Rodríguez Bereijó, Álvaro. La Constitución fiscal de España, Bilbao: Centro de Estudios Políticos y Constitucionales, 2015.

Rodríguez Garavito, César. Un nuevo mapa para el pensamiento jurídico latinoamericano, en El derecho en América Latina, César Rodríguez Garavito, coordinador, Buenos Aires: Siglo Veintiuno Editores, 2011.

Rodríguez García, Armando y otros. En El control y la responsabilidad en la Administración Pública, VI Congreso Internacional de Derecho Administrativo Margarita 2012, Caracas: Editorial Jurídica Venezolana, 2012.

Rodríguez Rodríguez, Libardo. El Derecho Administrativo Transnacional o Global: Un nuevo capítulo del Derecho Administrativo", en Derecho Administrativo, en homenaje a Jorge Fernández Ruiz, México: Universidad nacional Autónoma de México y Asociación Mexicana de Derecho Administrativo, 2013.

Rodríguez, Linda Alexander. Estudio introductorio al Pensamiento Fiscal Ecuatoriano, volumen 41, Banco Central del Ecuador - Corporación Editora Nacional, Quito, 1996.

Rodríguez, Linda Alexander. Las Finanzas Públicas en el Ecuador (1830-1940), Quito: Banco Central del Ecuador, 1992.

Rodríguez-Arana Muñoz, Jaime. El derecho a la buena administración en las relaciones entre ciudadanos y administración pública, en Aportes para un Estado eficiente, ponencias del V Congreso Nacional de Derecho Administrativo, Lima: Palestra Editores, 2012.

Rojo, Angel. El Derecho Económico como categoría sistemática, Buenos Aires: Editorial Depalma, 1982.

Roldós, León. Banca y Crédito, Guayaquil: Escuela Superior Politécnica del Litoral, 1998.

Vicuña Izquierdo, Leonardo. Estudio introductorio a la Planificación en el Ecuador, Biblioteca Básica del Pensamiento Ecuatoriano, No.27, Banco Central del Ecuador, 1987.

Rossetti, José Paschoal. Introducción a la economía, enfoque latinoamericano, séptima edición, México: Harla, 1985.

Rotondo Tornaría, Felipe. Manual de Derecho Administrativo, tomo I, Montevideo: Ediciones "Del Foro", 2002.

Ruiz Almendral, Violeta. "Estabilidad Presupuestaria y Gasto Público en España, Madrid: Ed. La Ley, 2008. 
Saavedra, Ruth y Otros. Planificación del Desarrollo, Bogotá: EDIT. JORGE TADEO, 2003.

Sáinz de Bujanda, Fernando. Hacienda y derecho, volumen I, Madrid: Instituto de Estudios Políticos, 1975.

Sáinz de Bujanda, Fernando. Hacienda y derecho, volumen II, Madrid: Instituto de Estudios Políticos, 1962.

Selowsky, Marcelo. Stages in the Recovery of Latin América's Growth", Finance and Development. Banco Mundial, junio de 1990.

Silva Cimma, Enrique. Derecho Administrativo Chileno y Comparado, el Control Público, Santiago: Editorial Jurídica de Chile, 1994.

Smith, Adam. Investigación sobre la naturaleza y la causa de la riqueza de las naciones, traducción de José Alonso Ortiz, Barcelona: Casa Editorial Bosch, 1983.

Stallings, Bárbara y otros. En La crisis latinoamericana de la deuda desde la perspectiva histórica, CEPAL, Santiago de Chile: Cooperación Alemana y Banco de Desarrollo de América Latina, 2014.

Stiglitz, Joseph. Caida Libre, Buenos Aires, Taurus, 2010.

Stiglitz, Joseph. El malestar de la globalización, Buenos Aires, Taurus, 2003.

Stolowicz, Beatriz. El "posneoliberalismo" y la reconfiguración del capitalismo en América Latina", Universidad Nacional de Colombia, Bogotá, 2010.

Storini, Claudia. Pluralismo popular como paradigma de un constitucionalismo de la diferencia, en Constitucionalismo nuevos saberes jurídicos. Construcciones desde las diversidades, Quito: Corporación Editora Nacional-Universidad Andina Simón Bolívar, 2017.

Terán Suárez, José Luis. Principios Constitucionales y Jurídicos de la Tributación, Quito: Editorial Jurídica Cevallos, 2014.

Tinbergen, Jan. Planificación del Desarrollo, Biblioteca para el Hombre Actual, Madrid: Ediciones Guadarrama, 1967.

Torres, Luis Fernando. Presidencialismo constituyente, Quito, Cevallos, 2009.

Trabucco, Federico. Constituciones de la República del Ecuador, Quito: Editorial Universitaria, 1975.

Troya Jaramillo, José Vicente "El Sistema Tributario en el Ecuador", Libro del Sesquicentenario, IV, Economía, Segunda Parte, CEN, 1983.

Troya Jaramillo, José Vicente. "El modelo económico, financiero y tributario de la Constitución de 2008" en La nueva Constitución del Ecuador, Estado, derechos 
e instituciones, Quito: Universidad Andina Simón Bolívar - Corporación Editora Nacional, 2009.

Troya Jaramillo, José Vicente. "Finanzas Públicas y Constitución” en La estructura constitucional del Estado ecuatoriano, Santiago Andrade y otros, editores, Centro de Estudios Políticos y Sociales de España, Quito: UASB, CEN, 2005.

Troya Jaramillo, José Vicente. Derecho del Gasto Público, Bogotá: Editorial Temis, 2015.

Troya Jaramillo, José Vicente. et al, Estudios de Derecho Económico, Quito: CENUASB, 1998.

Troya Jaramillo, José Vicente. Lecciones de Derecho Tributario con las últimas reformas, Quito: Ediciones Fausto Reinoso, 2015.

Uckmar, Víctor. Principios Comunes del Derecho Constitucional Tributario, Bogotá: Editorial Temis S.A., 2002.

Vega Ugalde, Silvia. La Economía solidaria y comunitaria en Ecuador y Bolivia, interpelaciones a la experiencia de los gobiernos de Rafael Correa y Evo Morales, Quito: FLACSO, 2017.

Verdugo Silva, Julio Teodoro. El Juicio Político, Quito: Asamblea Nacional, 2009.

Villar Palasí, José Luis. Apuntes de Derecho administrativo, Madrid: Villar Palasí, 1977.

Villegas, Héctor B. Curso de Finanzas, Derecho Financiero y Tributario, Buenos Aires: Editorial Depalma, 1980.

Villegas, Héctor. Manual de finanzas públicas, Buenos Aires: Ediciones de Palma, 2001.

Vivares, Ernesto. El Banco Interamerican o de Desarrollo en la década neoliberal, Quito: FLACSO sede Ecuador, 2013.

Witker, Jorge. Introducción al Derecho Económico, México: FCE, edición del 2000.

Witker, Jorge. Los derechos humanos nuevo escenario de la investigación jurídica, Boletín Mexicano de Derecho Comparado, nueva serie, año XIX, núm. 149, mayo-agosto de 2017. UNAM, Instituto de Investigaciones Jurídicas.

Wolkmer, Carlos Antonio. Teoría crítica del derecho desde América Latina, México: Ediciones Akal, 2017.

Wray Espinosa, Alberto. Estudio introductorio a Pensamiento Jurídico Ecuatoriano, Biblioteca Básica del Pensamiento Ecuatoriano, Banco Central del Ecuador Corporación Editora Nacional N 42, Quito, 1997. 
Ycaza, Patricio, Silvia Vega, Marco Velasco. Historia crítica de la República, Quito: 1989, CONUEP, UCE, 1989.

Zavala Egas, Jorge. El Estatuto del Régimen Jurídico Administrativo de la Función Ejecutiva en el ordenamiento jurídico, Quito: Corporación Latinoamericana para el Desarrollo (CLD), 1995.

\section{Publicaciones, Prensa}

Aguilar, Juan Pablo. "Compromiso político y organismos de control" en FORO, Revista de Derecho de la UASB, No. 7, I semestre 2007.

Aguilar, Juan Pablo. "La cuarta función del Estado. Análisis de una ficción" en La nueva Constitución de Ecuador, Santiago Andrade y otros, editores, Quito: Universidad Andina Simón Bolívar, Sede Ecuador-Corporación Editora Nacional, 2009.

Albuja, Fabián. Superintendente de Compañías, entrevista del 22 de julio de 2003.

Amoroso, Ximena. Directora del SRI, Entrevista a Revista Vistazo, 21 de mayo de 2015.

Amoroso, Ximena. Directora del SRI, Entrevista, Diario El Comercio, 3 de octubre de 2014.

Anderson, Perry. "Globalización y Desarrollo", Conferencia dictada en FLACSOEcuador el 14 de diciembre de 2007.

Ayala Mora, Enrique. "Hacia el Capitalismo del Siglo XXI", ponencia al Congreso Nacional de la CEDOCUT, Quito: diciembre de 2013.

Ayala Mora, Enrique. Hacia el Capitalismo del Siglo XXI, Quito, Periódico Opción Socialista, Junio 2014.

Banco Central del Ecuador. "Cartas de Intención suscritas por el Gobierno del Ecuador con el Fondo Monetario Internacional”. Quito. s/e. 1990.

Cantuña Castillo, Fabián. La política fiscal como instrumento de estabilidad y crecimiento bajo un esquema de dolarización, caso Ecuador 2000-2012, Tesis de maestría en Relaciones Internacionales, mención economía y finanzas, UASB, Quito, 2015.

Carrasco, Carlos Marx. Director del SRI, entrevista a la Revista Vanguardia, 17febrero-2012.

Carta de Intención del Gobierno del Ecuador (Presidente Sixto Durán) al FMI, Quito, 31 de marzo de 1994 y cartas de intención del Gobierno de la República del Ecuador (Presidente Gustavo Noboa), Quito, 2000, Publicación del Banco Central del Ecuador. 
Comisión de Control Cívico de la Corrupción, Memorias 2000-2004, Cuenca, Monsalve Moreno.

Conclusiones y acuerdos del seminario taller, de partidos y movimiento de izquierda de América Latina, Lima: 26 al 29 de febrero de 1992, "Proyecto Propio frente al Proyecto Ajeno".

De la Guerra Zuñiga, Eddy. Presupuesto, gasto público y compra pública responsable en Ecuador, en Revista de Derecho Foro, UASB-CEN 25, I semestre 216, Quito.

De Matos, Carlos A. "Planes versus planificación en la experiencia latinoamericana", Revista de la CEPAL Agosto 1979.

Del Campo, Esther. Del por qué al cómo: el sentido último de las reformas en América Latina, Quorum: Revista del pensamiento iberoamericano, 2008.

Ediciones Legales, guía práctica, 81 .

Ediciones Legales, Régimen Tributario Ecuatoriano, Tomo 1, Guía Práctica, Quito, 2009.

Ediciones Legales, Régimen Tributario Ecuatoriano, Tomos II y III.

Ediciones Legales, Régimen Tributario, IV tomos, última edición, Quito, 2017.

El Comercio, 3 de noviembre de 2016.

El Comercio, 28 de julio de 2017.

El Comercio, 29 de enero de 2012.

El Comercio, Enfoque Económico, fascículo 5, sobre impuestos y recaudación tributaria, 29 de junio de 2015; Valeria Heredia, redactora de El Comercio de Quito, 22 de septiembre de 2016.

El Comercio, Enfoque Económico, fascículo 5, sobre impuestos y recaudación tributaria, 29 de junio de 2015

El Comercio, Jorge Gallardo Zavala. "Impuestos”, 29 de enero de 2012.

El Comercio, jueves 24 de marzo de 2016.

El Comercio, Revista Líderes, 14 de diciembre de 2009.

El Comercio, Revista Lideres, Estudio "La carga tributaria en el Ecuador", publicado por la Cámara de Industrias y Producción en noviembre de 2011, 24 de diciembre de 2012.

El Comercio, Revista Líderes, informe del 31 de agosto de 2009. 
El Telégrafo, 15 de enero de 2011, entrevista a Rafael Correa.

El Telégrafo, 21 de diciembre de 2017.

El Telégrafo. Entrevista a Lula, Página 12, el 17 de mayo de 2013.

El Telégrafo. Entrevista a Rafael Correa, 15 de enero de 2011.

El Universo, Carlos Pólit. "Hay una equivocación total y profunda", 4 de diciembre de 2015.

El Universo, Jorge Gallardo Zavala. Impuestos, 29 de enero de 2012.

El Universo, Pablo Lucio Paredes. 22 de octubre de 2011.

El Universo, réplica Marcela Aguiñaga, Segunda Vicepresidenta de la Asamblea Nacional, 4 de diciembre de 2015.

Fabra Valls, Modesto. "Solidaridad y Derecho Financiero en una sociedad neocompetitiva", en Revista Española de Derecho Financiero, Nro. 120, 609 680, Madrid, 2003.

Ferrer, Aldo y Raul Prebisch y el dilema del desarrollo en el mundo global, Revista de la CEPAL 101, Agosto de 2010.

Galilea, Sergio. Los desafíos metodológicos en la planificación latinoamericana: algunas cuestiones básicas. Memorias XVI del Congreso Interamericano de Planificación, Políticas y estrategias. Universidad de Puerto Rico, San Juan, 1988, citado en Ruth Saavedra Y Otros, Planificación del Desarrollo, Bogotá: Edit. Jorge Tadeo, 2003.

Gordillo Pérez, Luis Ignnacio y José Ramón CanedoArrillaga. "La constitución económica de la Unión Europea. Bases de un modelo en constante evolución”, en Cuadernos de Derecho Transnacional Marzo 2013, Vol.5, $\mathrm{N}^{\circ}$ 1. ISSN 19894570 - www.uc3m.es/cdt

Granda Aguilar, Víctor. "Los Gobiernos Progresistas y la Alternativa Socialista", Quito: Opción Socialista, edición especial No. 39-40, Julio de 2013.

Granda Aguilar, Víctor. "Los principales desafíos del Derecho administrativo hoy", Universidad de Salamanca, 2015.

Granda Aguilar, Víctor. La situación actual y la alternativa socialista en América Latina, Brasilia, 2011.

Granda Aguilar, Victor. Proyecto de Código Administrativo (I), Boletín Electrónico Spondylus U.A.S.B., Quito, 30 de junio de 2016. 
Haro C, María Elena. La política Fiscal ecuatoriana a partir de la dolarización. 20022002, Tesis de maestría en relaciones internacionales, mención en economías y finanzas, U.A.S.B., Quito, 2002.

Heredia, Valeria. Redactora de El Comercio de Quito, 22 de septiembre de 2016, 5.

Huesa, Rosario. "La protección del interés público global" y Pedro A. de Miguel, "Desarrollo y eficacia de reglas transnacionales con participación de actores no estatales”, Ministerio de Ciencia e Innovación, Barcelona, 2011-2014.

Jiménez Tello, Pilar. Regulación a través de la evaluación: auditoría y calidad en las Administraciones Públicas, Cursos de Especialización en Derecho, Universidad de Salamanca, 2015.

Katz, Claudio. Interpretación de la crisis, Buenos Aires, 6 de octubre de 2010.

Katz, Claudio. Qué es el neo-desarrollismo: Una visión Crítica, Argenpress, 17 de julio de 2014.

Leiva Lavalle, Jorge. "Pensamiento y práctica de la planificación en América Latina", serie gestión pública, CEPAL - ILPES, Santiago, 2012.

Llanos, Oscar Olmedo. "Bolivia: Modelos económicos y sistema político". Santa Cruz, Revista Perspectivas, No. 31, abril de 2013.

Loza Tellería, Gabriel. Intervención sobre "El Modelo Económico Plural de Bolivia" en el Foro Andino Amazónico de Desarrollo Rural, La Paz, 18 de septiembre de 2013.

Martínez Lago, Miguel Angel y Leonardo García de la Mora, Lecciones de derecho financiero y tributario, Editorial Iustel, Madrid, 2016.

Martínez Lago, Miguel Angel. "Crisis Fiscal, Estabilidad Presupuestaria y Reforma de la Constitución" en El Cronista del Estado Social y Democrático de Derecho, núm. 24, 2011.

Martín Retortillo, Lorenzo. "Actos administrativos generales y reglamentos. Sobre la naturaleza de la convocatoria de oposiciones", Revista de Administración Pública, No 40, 1963.

Molina Morte, Ana Isabel. Relaciones Intergubernamentales en la descentralización del Ecuador, tesis doctoral dirigida por Esther del Campo García, Madrid, 2015.

Navarro Yáñez, Clemente. La nueva gobernanza local, en IX Congreso Internacional de la CLAD sobre Reforma del Estado y la Administración Pública, Madrid, 2004.

Nemiña, Pablo. "El nuevo FMI”, informe en Página 12, Buenos Aires, 20 de septiembre de 2009. 
Olano Alor, Aldo. "Desarrollo y Planificación en América Latina. Teorías e instrumentos”. Revista de Economía Institucional 18, Bogotá, 2016, 135-150.

Oleas, Julio. La banca central: una historia de cambio, Revista del Banco Central Cuestiones Económicas Nº19, Quito, 1994.

Parra Maldonado, Germán. Las condicionalidades de las Cartas de Intención con el Fondo Monetario Internacional y su influencia en la Modernización del Estado Ecuatoriano", Tesis de Maestría, UASB, 2005.

Rivadeneira, Francisco. Delegado del Ecuador ante el FMI, entrevista Diario El Comercio, 3 de diciembre de 2017.

Rocabado, Carlos. Escenarios de negociación intergubernamental: intereses partidarios y territoriales en los procesos de descentralización fiscal en Bolivia y Ecuador, Revista Latinoamericana de Desarrollo Económico (LAJED) $\mathrm{N}^{\circ} 28$, abrilnoviembre, 2017.

Sala Cardona, Juan Camilo. Conferencia en la Universidad de Salamanca sobre "La Filosofía española del siglo XX en América Latina, 2 de noviembre de 2016.

Secretaría Técnica de Administración, Manual de Presupuesto por Programas, Casa de la Cultura Ecuatoriana. 1964, Quito.

Tamariz, Oswaldo. Gerente de la AGD, entrevista del 25 de julio de 2003.

Trujillo, Julio César. "La Constitución económica más allá del neoliberalismo", en Foro: revista de derecho, No. 7, Quito, Universidad Andina Simón Bolívar, Sede Ecuador (UASB-E) / Corporación Editora nacional (CEN), 2007.

Valarezo, Jorge. Carlos Licto y otros, Comentarios a la Ley Reformatoria para la Equidad Tributaria del Ecuador, Ediciones Processsum, 2008, Quito, Ecuador.

Vega, Silvia. ¿Es la Economía Social y Solidaria una Alternativa a la Economía Capitalista?, monografía, FLACSO, 2013.

\section{Documentos internacionales}

Arias, Marta y José María Vera. Banco Mundial y Fondo Monetario Internacional ¿una ayuda para los países pobres?, Departamento de Estudios de Intermón-Oxfan, Barcelona, 2002.

Banco Mundial. Finanzas para el crecimiento económico: Opciones de política en un mundo volátil, Gerard Caprio, Patrick Honohan, 2010.

Banco Mundial. Índices de desarrollo humano, PNUD, Barcelona, 2000.

Banco Mundial. Informe sobre el desarrollo mundial, 1997. El Estado en un mundo en transformación. Washington, 1997. 
Banco Mundial: Informe Helping Countries Combat Corruption: The Role of de World Bank, Poverty Reduction an Economic Management Network, 1997.

Carta de Intención del Ecuador con el Fondo Monetario Internacional, marzo 31 de 1994.

CEPAL. Cambio estructural para la igualdad: una visión integrada del desarrollo, 2012.

CEPAL. Panorama Fiscal de América Latina y el Caribe. Reformas Tributarias y renovación del Pacto Fiscal, 2013.

CEPAL. Panorama Social de América Latina, 2015.

CEPAL/OCDE. Estadísticas tributarias en América Latina y el Caribe 1990-2014, Paris, 2016.

Constitución de la II República de 1931, España.

Constitución española, Reforma del art. 135 del 2 de septiembre de 2011.

Convención de las Naciones Unidas Contra la Corrupción, Naciones Unidas, Nueva York, 2004.

Convención Interamericana Contra la Corrupción, Caracas, 29 de mayo de 1996, ratificada por Ecuador y publicada en el Registro Oficial 70, 23-mayo-1977.

Convención Interamericana contra la Corrupción, suscrita en Caracas, Venezuela, 29 de marzo de 1996.

Declaración de Derechos del Hombre y del Ciudadano, 26 de agosto de 1789.

FMI. Código de buenas prácticas de transparencia en las políticas monetarias y financieras, 1999.

FMI. Código de buenas prácticas de transparencia fiscal, 1998.

FMI. Economías en transición: Análisis del FMI sobre los avances y las perspectivas, Noviembre de 2000. www.imf.org/external/np/exr/ib/2000/esl/110300s.htm\#II

FMI. Informes anuales, 2006 y 2008.

Fondo Monetario Internacional: Aspectos teóricos del diseño de los programas de ajuste respaldados por el Fondo, documento interno del FMI, SM/86/162 (S), 1987.

Fondo Monetario Internacional: por una economía mundial para todos: Informe anual 2008, www.imf.org

Informe a la asamblea de primavera del FMI y el Banco Mundial, en el Foro Estratégico Mundial reunido en Miami, 19 de abril de 2017. 
Jiménez, Juan Pablo y Andrea Podestá La tributación sobre la renta en América Latina: desafíos y perspectivas, en "Evasión y Equidad en América Latina", CEPAL, Naciones Unidas, Cooperación Española, Santiago, 2017.

Ley de Hacienda de 21 de octubre de 1863, España.

Ley Fundamental de Bonn.

Ley Orgánica 6/2013, de 14 de noviembre, de creación de la Autoridad Independiente de Responsabilidad Fiscal, España.

Ley Orgánica de Estabilidad Presupuestaria y Sostenibilidad Financiera de España 2/2012 de 27/04, España.

López, Manuel. "La protección de la estabilidad financiera como bien público global", en La Gobernanza del Interés Público Global, XXV Jornadas de la AEPDIRI, UniversitatPompeuFabra, Tecnos, Barcelona, 2013.

Panorama Social de América Latina 2000 - 2001, CEPAL, Santiago de Chile, 2001.

Resolución del Consejo Europeo, Ámsterdam, 17 de junio 1997.

Tratado de Estabilidad, Coordinación y Gobernanza de la UE, 2 de marzo de 2012.

\section{Constitución y Reformas}

Constitución de la República del Ecuador, 2008, Registro Oficial 449 del 20 de octubre de 2008.

Constitución Liberal de 1906, Ecuador.

Constitución Política de Ecuador 1979, Registro Oficial 800, 27-Marzo-1979.

Constitución Política de la República del Ecuador 1998.

Constitución Política de la República del Ecuador de 1929, Registro Oficial 138, 26mar-1929.

Constitución Política del Ecuador de 1946, Registro Oficial Nro. 773, 31-diciembre1946.

Constitución Política del Estado de 25 de mayo 1967.

Enmiendas a la Constitución de la República del Ecuador, Suplemento del Registro Oficial 653 de 21 de diciembre de 2015.

Enmiendas, Dictamen de Constitucionalidad sobre las Enmiendas $\mathrm{N}^{\circ}$ 001-14-DRC-CC de 31 de octubre de 2014, Gaceta Constitucional No 009 de 10 de noviembre de 2014. 
Reformas a la Constitución 2do y 3er bloque: Registro Oficial 863,16-ene-96.

Reformas a la Constitución, Primer bloque: Registro Oficial-S 618: 24-ene-95.

Reformas a la Constitución, Registro Oficial 120, 31-julio-97.

Reformas a la Constitución, tercer bloque, Registro Oficial 863, 16-enero- 1996.

Reformas Constitucionales, primer bloque, arts. 10 y 11, Registro Oficial-S 618, 24enero-1995.

\section{Códigos, leyes orgánicas y leyes}

Código de Organización Territorial, Autonomía y Descentralización, Registro Oficial Suplemento 303, 19-oct.-2010.

Código Fiscal Ecuatoriano, Registro Oficial 490, 25-junio-1963.

Código Orgánico Administrativo, Registro Oficial 31, Quito, viernes 7 de julio de 2017.

Código Orgánico de la Producción, Comercio e Inversiones, Artículos reformados mediante Ley s/n, Registro Oficial 150-2S, 29 de diciembre de 2017.

Código Orgánico de Planificación y Finanzas Públicas Registro Oficial 306, 22 de octubre de 2010.

Código Orgánico Integral Penal, disposiciones reformatoria, décimo segunda que sustituye artículo 26 de la Ley Orgánica de la Contraloría General del Estado, Registro Oficial-S 180, 10-feb-2014.

Código Orgánico Monetario y Financiero, publicado en el Registro Oficial, Quito, 12 de septiembre de 2014.

Código Tributario, suplemento, Registro Oficial 958, 23-diciembre-1976.

Ley 002, aprobada por el Congreso Nacional el 28 de noviembre de 1984, sancionada el 12 de diciembre y publicada en el Registro Oficial No. 102, 10-enero-1985.

Ley 035-CL, Registro Oficial, Número 338, 18-marzo-1968.

Ley 10, Registro Oficial 847, 19-junio1959.

Ley 2002-72, Registro Oficial 131, 24-oct-2005.

Ley 2002-73, Registro Oficial-S 595, 12-jun-2002.

Ley 41 de creación del Servicio de Rentas Internas - SRI-, Registro Oficial 206, 2diciembre-1997.

Ley 50, de Modernización del Estado, Registro Oficial 349, 31-dic-1993. 
Ley 99-39, Registro Oficial 253, 12-ago-1999.

Ley de Alianzas Público- Privadas, Registro Oficial Suplemento No. 652, 18 de diciembre de 2015.

Ley de Equidad Tributaria del Ecuador, Registro Oficial 242, Primer Suplemento $\mathrm{N}^{\mathrm{o}}$ 242,29 -diciembre-2007.

Ley de Incentivos a la producción del Fraude Fiscal, Registro Oficial 405, Suplemento, 29-diciembre-2014.

Ley de Modernización del Estado y su reglamento, 31 de diciembre de 1993, 29 de noviembre de 1994.

Ley de Presupuestos del Sector Público, 18-PCL, Registro Oficial-S 76, 30-nov-1992.

Ley de Régimen Del Distrito Metropolitano De Quito, Registro Oficial 345, 27-dic1993.

Ley de Reordenamiento en Materia Económica en el área Tributario-Financiera, Registro Oficial Suplemento Nº. 78, 01-diciembre-1998.

Ley de Transformación Económica, Registro Oficial Suplemento №. 34, 13-marzo2000.

Ley General de Instituciones del Sistema Financiero 1994.

Ley General de Presupuestos del Estado, Registro Oficial-S 76, 30-nov-1992.

Ley General de Presupuestos del Sector Público 1994.

Ley $\mathrm{N}^{\circ} 139$, Suplemento del Registro Oficial 862, 28-enero-1992, reformada en 1996 y 1998.

Ley No. 42-2006 Reformatoria a la Ley de Hidrocarburos, publicada en el Registro Oficial Suplemento Nro. 257, 25-abril-2006.

Ley Orgánica de Administración Financiera y Control (LOAFYC), Registro Oficial 337, 16-mayo-77.

Ley Orgánica de Hacienda Codificada, Registro Oficial 855 de 29-julio-1975.

Ley Orgánica de Incentivos a la Producción y Prevención del Fraude Fiscal, Suplemento del Registro Oficial 405, 29-diciembre-2014.

Ley Orgánica de la Contraloría General del Estado, Art. 6, Ley N²002-73.

Ley Orgánica de la Contraloría General del Estado, Registro Oficial Suplemento 595, 12-junio-2002. 
Ley Orgánica de la Función Legislativa, Registro Oficial-S 642, 27-jul-2009.

Ley Orgánica de Participación Ciudadana, Ley 0, Registro Oficial Suplemento 175, 20 abr-2010.

Ley Orgánica de Presupuesto, Decreto de Emergencia N 538, Registro Oficial 769, 21 marzo-1951.

Ley Orgánica de Redistribución de los Ingresos para el Gastos Social, Registro Oficial 847, Suplemento, 10-diciembre-2012.

Ley Orgánica de Responsabilidad, Estabilidad y Transparencia Fiscal, Registro Oficial 589, 4-junio-2002.

Ley Orgánica de Solidaridad y corresponsabilidad ciudadana para la reconstrucción y reactivación de las zonas afectadas por el terremoto de 16-abril-2016.

Ley Orgánica del Consejo de Participación Ciudadana y Control Social, Registro Oficial-S 22, 9-sep-2009.

Ley Orgánica del Sistema Nacional de Contratación Pública, Ley s/n, Registro Oficial-S 395, 4-ago-2008.

Ley Orgánica para evitar la elusión del impuesto a la renta sobre ingresos provenientes de herencias, legados y donaciones, Registro Oficial 802, 2do. Suplemento, 21julio-2016.

Ley Orgánica para evitar la especulación sobre el valor de las tierras y fijación de tributos, 7mo. Suplemento, 30 de diciembre de 2016.

Ley Orgánica para la Eficiencia en la Contratación Pública, Registro Oficial 906, 20marzo-1917.

Ley Orgánica para la Recuperación del Uso de los Recursos Petroleros del Estado y la Racionalización Administrativa de los Procesos de Endeudamiento, Registro Oficial 308, 03 de abril de 2008.

Ley Orgánica Reformatoria a la Ley Orgánica de la Contraloría General del Estado, Ley s/n Registro Oficial-S 1, 11-ago-2009.

Ley para la Reactivación Económica, Fortalecimiento de la Dolarización y Modernización de la Gestión Financiera, segundo suplemento Registro Oficial 150, 29-diciembre-2017.

Ley para la Reforma de las Finanzas Públicas, Disposición General Tercera, Registro Oficial Suplemento No 181,-30-abril-1999.

Ley Reformatoria a la Ley para la Transformación Económica del Ecuador, Registro Oficial 48, 31-mar-2000. 
Ley Reformatoria para la Equidad Tributaria del Ecuador s/n, Suplemento Registro Oficial 94, 23-diciembre-2009.

Leyes para la Transformación Económica del Ecuador: Trole I, Registro Oficial 34 de 13 de marzo de 2000 y Trole II, Registro Oficial 144 de 18 de agosto de 2000.

Reformas a la Ley Orgánica de Responsabilidad, Estabilidad y Transparencia Fiscal, L2005-4, Registro Oficial 69, 27-jul-2005.

\section{Reglamentos}

Reformas al reglamento publicadas en el suplemento del Registro Oficial de 22 de julio de 1996.

Reglamento a la Ley de creación del SRI.

Reglamento a la Ley de Presupuestos del Sector Público.

Reglamento General de la Ley de Modernización del Estado del 31 de marzo de 1994, Registro Oficial 1623.

Reglamento General del Código Orgánico de Planificación y Finanzas Públicas, Decreto Ejecutivo 489, Registro Oficial-2S 383, 26-nov-2014.

Reglamento para el trámite de denuncias y pedidos sobre actos u omisiones que afecten la participación o generen corrupción. Resolución 005-242- CPCCS- 2013, Registro Oficial 21, 24-jun-2013. Consejo de Participación Ciudadana y Control Social.

Reglamento Sustitutivo al Reglamento de la LOREYTF, Registro Oficial 131, 24-oct2005.

Reglamento Sustitutivo del Reglamento General de la Ley de Modernización del Estado, Registro Oficial 581, 2-dic-1994.

\section{Decretos ejecutivos}

Decreto 1077, Registro Oficial 392, 17-Septiembre-1973.

Decreto Ejecutivo 1015, Registro Oficial 953, 16-diciembre-1975.

Decreto Ejecutivo 1026 Registro Oficial Suplemento 231 08-ene-1998, art. 23.

Decreto Ejecutivo 1052, Registro Oficial 337, 15-may-2008.

Decreto Ejecutivo 109, Registro Oficial-S 58: 30-0ct-2009.

Decreto Ejecutivo 1133 del presidente Gustavo Noboa, Registro Oficial 253, 26ene.2001. 
Decreto Ejecutivo 1218, Segundo Suplemento Registro Oficial 869, 25-octubre 2016.

Decreto Ejecutivo 122, Registro Oficial 25, 19-febrero-2003.

Decreto Ejecutivo 1283, Registro Oficial 305, 8-septiembre-1971.

Decreto Ejecutivo 1372, Registro Oficial 278, 20-feb-2004.

Decreto Ejecutivo 1511, Registro Oficial-3S 498, 3-dic-2008.

Decreto Ejecutivo 2, Registro Oficial 3, 13-ago-1998.

Decreto Ejecutivo 201. Registro Oficial 38 de 7 de abril de 1997.

Decreto Ejecutivo 2218 de 20 de octubre de 2016 para autorizar otra forma de cálculo de la deuda externa y para que ésta pueda ser utilizada en gasto público.

Decreto Ejecutivo 2428, Registro Oficial 536, 18-mar-2002.

Decreto Ejecutivo 3, Registro Oficial-S 14, 13-jun-2013.

Decreto Ejecutivo 302, Registro Oficial 69, 18-nov-1998.

Decreto Ejecutivo 338, Registro Oficial-S 263, 9-jun-2014.

Decreto Ejecutivo 387, Registro Oficial 110, 21-jun-2007.

Decreto Ejecutivo 40, el Presidente Lenin Moreno, eliminó la Secretaria General de la Administración y transfirió sus amplias atribuciones a la Secretaría de la Presidencia y a la Secretaría Nacional de Planificación y Desarrollo, publicado en el Segundo Suplemento del Registro Oficial 16 de 16 de junio de 2017.

Decreto Ejecutivo 489 de 26 de noviembre de 2014 para autorizar otra forma de cálculo de la deuda externa y para que ésta pueda ser utilizada en gasto público.

Decreto Ejecutivo 529-A. Registro Oficial-2S 136, 26-feb-1993.

Decreto Ejecutivo 575, publicado en el Registro Oficial No. 207, 21-abril-1971.

Decreto Ejecutivo 611, Registro Oficial 857, 31-julio-1975.

Decreto Ejecutivo 62, Registro Oficial 63, 21-ago-2013.

Decreto Ejecutivo 685, 11-marzo-1999, Registro Oficial № 149, 16-marzo-1999.

Decreto Ejecutivo 6-A del presidente Lucio Gutiérrez, Registro Oficial 14, 4-feb-2003.

Decreto Ejecutivo 720, Registro Oficial 468,13-jun-2011.

Decreto Ejecutivo 724, Registro Oficial No.185, 14-mayo-1985. 
Decreto Ejecutivo 726, Registro Oficial 433, 25-abr-2011.

Decreto Ejecutivo 878, Registro Oficial 268, 8-feb-2008.

Decreto Ejecutivo 918, Registro Oficial 286, 3-mar-2008.

Decreto Ejecutivo 994, Registro Oficial 232-14 de diciembre-1976.

Decreto Ley de Emergencia N 19, Registro Oficial No. 527, 29-mayo-1954

Decreto Ley de Emergencia No. 40, 2-agosto-1961. Registro Oficial Nro. 281, 4Agosto-1961.

Decreto Nro. 1065-A, Registro Oficial, Número 668, 28-octubre-1974.

Decreto Supremo 1429, Registro Oficial 373, 16-mayo-1977.

Decreto Supremo 293, 21-marzo-1973.

Decreto Supremo 595,13-octubre-1970, Registro Oficial No.81, 16-octubre-1970.

Decreto-Ley 240, Registro Oficial 33, 20-agosto-1963, quinto considerando.

\section{Acuerdos Ministeriales}

Acuerdo Ministerial 1580 de 13 de febrero de 2013, Registro Oficial-S 895: 20-feb2013, Secretaría de la Administración Pública.

Acuerdo Ministerial 323, de 11 de Abril de 2008, Registro Oficial 323, 24-abril-2008, Ministerio de Finanzas.

Acuerdo Ministerial 784 de 28 de julio de 2011, Registro Oficial 501, 28-julio-2011, Secretaría de la Administración Pública.

Acuerdo Ministerial 10, Registro Oficial 31, 8-mar-2000, Ministerio de Finanzas.

Acuerdo 249-A, 5-julio-1993, Registro Oficial de 9 de agosto de 1993.

Acuerdo 0004, Registro Oficial No.158, 29-marzo-1999, Consejo Nacional de Modernización del Estado.

Acuerdo 0032, Registro Oficial 72, 8-mayo-2000, Presidencia de la República del Ecuador.

Acuerdo Ministerial MF-DJM-RD-2010-01, abril 2010, Ministerio de Finanzas.

Acuerdo Ministerial MF-MD-RD-2010-003 de abril 2010, Ministerio de Finanzas.

Acuerdo Ministerial MF-DM-RD-2010-002, octubre 2010, Ministerio de Finanzas. 


\section{Instructivos y resoluciones}

Instructivo de trámites, 20 de octubre de 2014, Registro Oficial 465: 24-mar-2015.

Resolución del Tribunal Constitucional 056-1-97, Registro Oficial 109, 16-julio-1997.

Resoluciones Ministeriales MF-DM-RD-2010-2001-2002-2003, 27-abril, 27-octubre y 1-noviembre-2010, Ministerio de Economía y Finanzas

\section{Informes, Juicios y Proyectos de Ley}

Contraloría General del Estado, Rendición de Cuentas 2011.

Contraloría General del Estado, Rendición de Cuentas, marzo de 2016.

Correa Delgado, Rafael. Presidente Constitucional de la República del Ecuador, Programación Presupuestaria Cuatrianual 2015-2018, Ministerio de Finanzas, Quito, 2014.

Granda Aguilar, Víctor y Jorge Rodríguez Torres. Petición de reapertura del sumario en el juicio $N^{\circ}$ 044-2000, audiencia extraprocesal en la Corte Suprema de Justicia el 14 de diciembre de 2006.

Granda Aguilar, Víctor. Diputado, Proyecto de Ley N. 24-026, 25-febrero-2003.

Informe de Ejecución Presupuestaria del Ejercicio Fiscal enero junio 2016, Comisión de Régimen Económico de la Asamblea Nacional, Oficio AN-CERET-329-16, Quito, 17 de noviembre de 2016.

Informe de la Comisión Especializada del Régimen Económico y Tributario de la Asamblea Nacional, CRET-443-2010, sobre la proforma presupuestaria 2011 y la Programación cuatrianual 2011-2014, Quito, 19 de noviembre de 2010.

Informe de labores 2015 de Carlos Ochoa, Presidente de la Función de Transparencia y Control Social a la Asamblea Nacional, 21 de enero de 2016.

Informe del Banco Central del Ecuador sobre la proformas del gobierno central y el límite del endeudamiento externo del año 2006, Congreso Nacional, Quito, 2005 .

Informe del Consejo de Participación Ciudadana y Control Social, 2015.

Informe final, resumen ejecutivo, Comisión para la Auditoría Integral del Crédito Público, Quito, diciembre de 2008.

Juicio Nro. 44-2000 (actualmente $N^{\circ}$ 167-2009) contra Jamil Mahuad, reiniciado el 13 de junio de 2007 por petición presentada por Jorge Rodríguez y Víctor Granda el 14 de diciembre de 2006.

Peña, Eduardo. Cámara de Comercio de Guayaquil, 25 de octubre de 2011. 
Rendición de Cuentas, Informe de la Secretaría Nacional de Administración Pública, marzo de 2016.

Resolución del Tribunal Constitucional 056-1-97, Registro Oficial 109, 16-julio-1997.

\section{Internet}

BANCO CENTRAL SOBRE KEMMERER EN LOS ANDES, http://biblioteca.bce.ec/cgibin/koha/opacdetail.pl?biblionumber=1820\&query_de $\mathrm{sc}=\mathrm{su} \% 3 \mathrm{~A} \% 22 \mathrm{KEMMERER} \% 2 \mathrm{C} \% 20 \mathrm{EDWIN} \% 20 \mathrm{WAL}$ TER\%22. JUAN PAZ Y MINO SOBRE REVOLUCION JULIANA. En Paz y Miño Cepeda, Juan J. Revolución juliana. Nación, ejército y bancocracia, Quito, EC: Abya-Yala, 2000.

Banco Mundial, El Estado un mundo en trasformación, 1997, http://documentos.

Banco Mundial, Informe Anual 2015, 7, http://www.bancomundial.org/es/about/annualreport-2015

Bancomundial.org/curated/es/973681468778813985/pdf/341310spanish.pdf

Canals, Jordi. La globalización después de la crisis financiera, 2003, https://www.bbvaopenmind.com/wpcontent/uploads/static/pdf/080_JORDI_CANALS.pdf

CEPAL. La hora de la igualdad: Brechas por cerrar, caminos por abrir, Brasilia, 2010.

http://repositorio.cepal.org/bitstream/handle/11362/13309/S2010986_es.pdf.

Comisión Ocasional de Enmiendas Constitucionales, Informe para segundo debate, 23 de noviembre de 2015, www.asambleanacional.gob.ec/sites/default/files/field/image/enmienda8.jpg

Contralor General del Estado, Rendición de Cuentas, marzo de 2016, www.contraloria.gob.ec

Correa Delgado, Rafael. Informe a la Nación 2007-2017, Quito, www.planificacion.gob.ec

Diccionario de la Real academia Española. http://dle.rae.es/?id=TJwPLbd fecha de consulta 21 de mayo de 2017.

Eric Hobsbawn, Después del siglo XX: Un mundo en transición, http://www.letraslibres.com/mexico-espana/despues-del-siglo-xx-un-mundo-entransicion

Estudio Introductorio a la Ley Orgánica de Administración Financiera y Control (LOAFYC), http://portal.uasb.edu.ec:2165/WebTools/eSilec ro/DocumentVisualizer/DocumentVisualizer .aspx?id=HISTORICLEY_ORGANICA_DE_ADMINIS TRA

CION_FINANCIERA_Y_CONTROL_1977 \&query =LOAFYC\#I_DXDataRow1 
FMI, Boletín del FMI, de febrero de 1999. http://www.imf.org/es/news/search?type=News+Article \&category\&datefrom $=1$ 994-01-01\&dateto $=2017-11$ $04 \&$ query=planificaci\%C3\%B3n+en+1990\&page $=7$

Fondo Monetario Internacional, http://www.imf.org/es/About/Factsheets/IMF-at-aGlance

http://old.clad.org/documentos/declaraciones/carta-iberoamericana-de-calidad-en-lagestion-publica

http://presupuestopublico.blogspot.com

http://www.ecuadorinmediato.com/index.php?module=Noticias\&func=news_user_view \&id=165678; http://www.ecuavisa.com/articulo/noticias/actualidad/50800abdala-bucaram-pide-anular-accion-proteccion-presentada-hace-4

http://www.elcomercio.com/tag/pablo-chambers

http://www.eluniverso.com/2011/01/08/1/1356/juicio-gloria-sabando-entra-rectafinal.html

http://www.eluniverso.com/2013/04/17/1/1355/abogado-correa-confirma-sentenciaasambleista-clever-

jimenez.htmlhttp://www.eluniverso.com/noticias/2016/10/28/nota/5878258/juezordena-prision-preventiva-clever-jimenez-fernando

https://www.eluniverso.com/2008/08/27/0001/8/97859FDB3F 774283ABE1 642 1F05A FB8 7.html

Informe a la Nación, 2007-2017, Presidencia del Eco. Rafael Correa Delgado, http://www.planificacion.gob.ec/wp-

content/uploads/downloads/2017/04/Informe-a-la-Nacion.pdf. Fecha de consulta 5 de junio de 2017.

Informe del presidente del T.S.E., Consulta Popular 1994 y Consulta Popular 1995, https://Repositories.lib.utexas.edu

Informe final, resumen ejecutivo, Comisión para la Auditoría Integral del Crédito Público, Quito, diciembre de 2008, www.tce.gob.ec/biblio/opac_css/index.php?lvl=notice_display\&id=2053...1

OEA, Carta de Punta del Este, 1961, https://dialnet.unirioja.es /descarga/articulo/ 2048 393.pdf

ONU, http://www.un.org.ec/?page_id=821

Pérez Soto, Olga. La Globalización, www.videotecamarxista.blogspot.com, 8 noviembre 2013. 
Ramonet, Ignacio. El fin de una era del capitalismo financiero: la crisis del siglo, en el periódico Le Monde Diplomatique de 7 de octubre de 2008, https://mondiplo.com/la-crisis-del-siglo-4024

Revista de la CEPAL, Gobierno y planificación, Santiago de Chile, 1987. https://www.cepal.org/es/publications/list/publication-type

Revista Lideres, Informe sobre las 10 Reformas Tributarias, www.revistalideres.ec/lideres/10-reformas-tributarias-impactos.html

Santana, Yesenia. El Rol del Fondo Monetario Internacional en la Economía del Ecuador,

http://repositorio.iaen.edu.ec/bitstream/24000/2603/1/EL\%20ROL\%20DEL\%20 FONDO $\% 20$ MONETARIO\%20INTERNACIONAL\%20EN\%20EL\%20DESA RROLLO\%20DE\%20LA\%20ECONOMIA\%20ECUATORIANA

SRI - CEF, Introducción a la Teoría General de la Tributación, https://cef.sri.gob.ec/virtualcef/mod/book/tool/print/index.phpid=1127

Introducción a la Teoría General de...

www.transparency.org 